\title{
Mechanisms of late Quaternary coastal uplift along the Raukumara Peninsula segment of the Hikurangi margin, North Island, New Zealand.
}

\section{Kathryn J. Wilson}

\author{
A thesis \\ submitted to the Victoria University of Wellington \\ in fulfilment of the requirements for \\ the degree of \\ Doctor of Philosophy \\ in Geology
}

Victoria University of Wellington

2006 


\section{Abstract}

The coastal geomorphology of the Raukumara Peninsula, North Island, New Zealand, is investigated with the aim of understanding the geodynamics of this segment of the Hikurangi subduction zone. There are few active faults on the Raukumara Peninsula and there have been no historical subduction earthquakes on this part of the margin. Geodetic and geologic evidence suggests the onshore forearc is extending and sliding trenchward. However, Holocene and Pleistocene terraces that have some of the highest uplift rates and elevation in New Zealand occur in this region. Sediment underplating has previously been suggested as a cause of coastal forearc uplift, yet the inferred gradualness of this process does not reconcile with the inferred episodic nature of uplift suggested by stepped Holocene marine terraces along the Raukumara Peninsula. This study focuses on resolving these apparent inconsistencies in the current knowledge of the Raukumara sector of the Hikurangi margin by using the mechanisms of coastal uplift to improve our general understanding of forearc deformation processes.

The mid to late Holocene marine terrace chronology and distribution at the Pakarae River mouth locality on the central Raukumara Peninsula eastern coastline is revised. The coverbed sediments and morphology of the terrace surfaces and straths there are consistent with abandonment of each terrace during a coseismic coastal uplift event. The terraces are offset across the Pakarae Fault, a normal fault, but tilt vectors of the terraces suggest the dominant structure driving uplift is instead an offshore reverse fault in the upper plate of the subduction zone. The highest Holocene marine terrace at the Pakarae River mouth is underlain by a transgressive fluvio-estuarine sequence that documents infilling of the Pakarae River paleo-valley from 10,000 - 7,000 cal. yrs B.P. prior to eustatic sea level stabilisation. This sequence is an example of a valley infill sequence modified by tectonic uplift. By comparing it with facies models developed from stable coastlines a new facies architecture model is developed for incised valley infilling during conditions of synchronous eustatic sea level rise and tectonic uplift. 
The sedimentology and biostratigraphy of the Pakarae River incised valley infill sequence is also used to reconstruct the paleoenvironmental evolution of the paleovalley during the early Holocene. Two estuarine units display sudden vertical transitions to floodplain sediments implying significant marine regressions. During the depositional period, however, eustatic sea level was rapidly rising. The marine regressions, and associated estuary abandonment, are therefore attributed to coseismic coastal uplift events, occurring at $\sim 9,000$ and $\sim 8,500$ cal. yrs B.P. A third uplift between 8,500 and $~ 7,350$ cal. yrs B.P. is inferred from a significant difference between the amount of sediment preserved and the predicted sediment thickness according to the eustatic SL curve. This study demonstrates the utility of the stratigraphic analysis of incised valley infill sequences for neotectonic investigations on active coasts. In practice the application of incised valley infill analysis allows extension of coastal paleoseismic histories back prior to the time of eustatic sea level rise culmination. The combination of the Pakarae River mouth marine terrace and sedimentary infill sequence data yields the longest record of coastal paleo-earthquakes yet constructed globally.

Along the northeastern coastline of the Raukumara Peninsula a variety of Holocene coastal features have been studied to determine the uplift mechanism of this region. Topographic and coverbed stratigraphic data from previously interpreted coseismic marine terraces at the Horoera and Waipapa localities, east of Te Araroa, indicate that, despite their stepped surface morphology, they are not of marine origin and thus cannot be attributed to coseismic coastal uplift events. Paleoenvironmental analysis of drill cores of early Holocene sediments underlying the Hicks Bay flats shows a typical incised valley infill sequence with gradual transitions from fluvial to estuarine and back to fluvial. However, there are significant differences between the thickness of preserved intertidal infill sediments and the amount of space created by eustatic sea level rise. Therefore, uplift did occur during early Holocene evolution of the Hicks Bay paleo-estuary, but at this location there is no evidence of any sudden or coseismic land elevation changes. The beach ridge sequence of Te Araroa slopes gradually toward the present day coast with no evidence of coseismic steps. It is inferred the evolution of the beach ridges was controlled by a variable sediment supply rate in the context of a background tectonic uplift rate that was geologically continuous rather than punctuated. Although no individual dataset from the Holocene coastal features of 
the northeastern Raukumara Peninsula can uniquely resolve the mechanism of uplift, a careful evaluation and integration of all available evidence indicates uplift of this region has been driven by a gradual and aseismic mechanism. Pleistocene marine terraces fringing the northern coastline of the Raukumara Peninsula, and overlapping with the northeastern Raukumara Peninsula study area, display a northwest tilt. The tilt vector steepens and rotates gradually northward on the eastern side of the Peninsula. As there are no upper plate active faults that can account for this geometry, it is concluded that the buoyancy of underplated sediment beneath the forearc drives aseismic uplift of this region.

The Holocene coastal uplift mechanism data from the Pakarae River mouth and the northeastern Raukumara Peninsula are integrated with other coastal geomorphic data from the Raukumara Peninsula in this thesis. Distinct spatial variations in the coastal uplift rates and mechanisms are seen. The main parameter controlling the distribution of aseismic and coseismic deformation processes is inferred to be the distance of the forearc from the Hikurangi Trough, and depth to the underlying plate interface. Three margin-parallel zones of forearc uplift mechanisms are identified: (1) a zone of coseismic uplift on upper plate contractional faults located within $20-80 \mathrm{~km}$ of the trench; (2) a passive inner forearc zone at a margin-normal distance of $~ 80-120 \mathrm{~km}$ from the trench, in which vertical tectonic movement is controlled by distal upper plate structures and or slip on the plate interface; and (3) a zone of aseismic uplift driven by sediment underplating located at a margin-normal distance of $\sim 120-180$ $\mathrm{km}$ of the trench, also encompassing the Raukumara Ranges. Each of the zones has specific seismic hazard implications. Reverse faults within the coseismic uplift zone pose a significant seismic and tsunami hazard to Raukumara Peninsula coastal communities, while seismic hazard in the zone of aseismic uplift is probably less than previously thought. The passive forearc zone probably experiences uplift or subsidence during plate interface rupturing earthquake and therefore it may be the only one of the three zones that has the potential to record past subduction earthquakes. This study demonstrates the value of coastal geomorphology and stratigraphic studies in subduction zone neotectonic and paleoseismology studies. Variances in coastal uplift mechanisms across the Raukumara Peninsula are related to spatial position within the Hikurangi subduction margin and this has implications for our understanding of forearc deformation processes along the length of the margin. 


\section{ACKNOWLEDGEMENTS}

My greatest thanks are to my supervisors, Kelvin Berryman and Tim Little. Kelvin, thank-you for the inspiration behind this project, your constant flow of ideas and encouragement, and an ever-ready enthusiasm for fieldwork! Tim, thank-you for always having made the time to discuss my work with me, for your challenging questions and the many things you have taught me about scientific writing. Warmest thanks also go to my two, perhaps, informal supervisors, Nicola Litchfield and Ursula Cochran. An aspiring young scientist could not get better role models than these two. Their interest, optimism, and willingness to help at anytime has been so greatly appreciated. Above all, the support, scientific discussion and friendship of Kelvin, Tim, Nicola and Ursula made this project successful and enjoyable.

I am grateful to have been funded by the Sarah Beanland Memorial Scholarship awarded by GNS Science. I would also like to acknowledge an Earthquake Commission Student Grant. Without such financial support this project would not have been possible. Additional funding from the VUW Science Faculty and a VUW PhD Completion Scholarship was appreciated.

I would like to thank the many people who helped me in the field: Matt Hill, Ruth Wightman, Marcus Fink, Vicente Perez, Mira Persaud and Hannu Seebeck. Peter Barker and, again, Matt Hill deserve a huge thank-you for undertaking the drilling and collection of the cores from Hicks Bay. They endured almost constant rain for a week and some interesting driving conditions but they were always calm and happy! Neville Palmer was frequently called from remote field locations and asked obscure questions about why the GPS was not working - it was usually my mistake so thank you for your patience. The help and generous advice that John Patterson gave me when I was using the electron microprobe is greatly appreciated. Help and discussion with John Carter in the Sedimentology Lab at VUW was also appreciated. I would like to thank Bruce Hayward and Ashwaq Sabaa of Geomarine Research for assistance and advice when identifying the foraminifera assemblages of Hicks Bay and Pakarae. Karyne Rogers is thanked for her assistance and sharing of knowledge during the stable isotope study of the Hicks Bay cores. The estuarine evolution advice of Craig Sloss from Massey University was appreciated, as was his review of Chapter 
Three. Discussions with Yoko Ota were invaluable at the later stages of writing up this project; I would like to thank her for her ideas and interest.

Many landowners along the East Coast contributed to this project by generously allowing access to their properties. In particular I would like to thank Don and Sheryl Green of Whangara B5 Station, Pat of Pakarae Station and Buddy of Matakaoa Station for frequently allowing me onto their land. The interest and help of many locals of the East Cape and Hicks Bay regions made fieldwork more enjoyable.

I would like to thank many people at GNS Science and VUW for their friendship and encouragement over the past few years: Laura Wallace, especially for a great combination of scientific discussion and laughter; Dan Barker, for kindly helping me out with maps and seismic lines at short notice in the last few weeks; Andy Nicol, Pilar Villamor and Rob Langridge for summer field work distractions; Dave Kennedy for his coastal geology advice; the $4^{\text {th }}$ floor geology students - Ruth, Matt, Doug, Susanne - for friendship, morning coffees and Friday drinks, and in recent months the SES road cyclists - Phil Morrison, Andrew Mackintosh and Bea - for brightening up my Thursday lunchtimes. Former geology lecturers at Massey University, Vince Neall and Alan Palmer, are warmly thanked for their continuing interest in my academic endeavours. My amazing friends over the years are thanked for sharing their laughter with me, providing mountain biking adventures when I needed them. James and Lisa are particularly thanked for their support and friendship. I have been fortunate to share this PhD journey with Beatrice Mare-Jones and Vasso Mouslopoulou, I will always remember Bea for her energy and Vasso for her passion.

My last and most heartfelt thanks is to my family, Mum, Dad and Ben. They have been unquestioningly supportive not only during my $\mathrm{PhD}$ but throughout my whole time at University. I am lucky to have a family such as this, thank you for your love and encouragement. 
Title page

Abstract

Acknowledgements $\quad \mathrm{V}$

Table of Contents vii

List of Figures

List of Tables $\quad$ xvii

List of Appendices $\quad$ xviii

CHAPTER ONE

Introduction: The Hikurangi margin, Seismic Hazard and Coastal Geomorphology

1.1. Introduction 1

1.2. Thesis Format 8

1.3. References 9

CHAPTER TWO

A revision of Mid to Late Holocene marine terrace distribution and chronology at New Zealand's most tectonically active coastal location, Pakarae River mouth, North Island, New Zealand. 12

$\begin{array}{lll}2.1 & \text { Introduction } & 12\end{array}$

$\begin{array}{lll}2.2 & \text { Methods } & 15\end{array}$

$\begin{array}{lll}2.3 & \text { Results } & 17\end{array}$

$\begin{array}{lll}\text { 2.3.1 Marine Terrace Characterisation } & 17\end{array}$

$\begin{array}{lll}2.3 .2 & \text { Terrace ages } & 19\end{array}$

$\begin{array}{llr}2.4 & \text { Discussion } & 19\end{array}$

$\begin{array}{lll}2.4 .1 & \text { Terrace correlation and chronology } & 19\end{array}$

2.4.2 Tectonic uplift rates 26

2.4.3 Pakarae terrace uplift and the role of the Pakarae Fault 28

2.5 Conclusions 32

$2.6 \quad$ References 33 


\section{CHAPTER THREE}

A facies architecture model for Holocene incised valley infill on a tectonically active coast: Pakarae River, New Zealand.

3.1 Introduction 36

3.1.1 Models of Incised-Valley infilling 37

3.1.2 Tectonic setting of the Pakarae valley 39

3.2 Methodology 41

3.2.1 Chronology 41

3.2.2 Stratigraphy and sedimentology $\quad 42$

3.2.3 Micropaleontological processing $\quad 45$

$\begin{array}{lll}3.3 & \text { Results } & 46\end{array}$

$\begin{array}{lll}\text { 3.3.1 Chronology } & 47\end{array}$

$\begin{array}{lll}\text { 3.3.2 Foraminifera } & 49\end{array}$

$\begin{array}{lll}\text { 3.3.3 } & \text { Bio-lithofacies } & 51\end{array}$

3.3.4 Paleoenvironmental facies associations and correlations between sections 56

3.4 Discussion 58

3.4.1 Comparisons of Pakarae stratigraphy to stable-coast models of incised valley infilling

3.4.2 Development of a facies architecture model for an incised valley infill sequence on a coastline undergoing coseismic uplift 65

$\begin{array}{lll}3.5 & \text { Conclusions } & 67\end{array}$

$\begin{array}{lll}3.6 & \text { References } & 78\end{array}$

\section{CHAPTER FOUR}

Early Holocene paleoseismic history at the Pakarae locality, eastern North Island, New Zealand, inferred from transgressive marine sequence architecture. 84

$\begin{array}{lll}4.1 & \text { Introduction } & 84\end{array}$

$\begin{array}{lll}4.2 & \text { Methodology } & 88\end{array}$

4.2.1 Reconstruction of the Pakarae locality paleoenvironments 88

4.2.2 Age control 92

4.3 Results: Paleogeographic evolution of the Pakarae locality paleo-estuary 94

4.3.1 Models of estuary evolution 95

$\begin{array}{lll}4.4 & \text { Discussion } & 107\end{array}$

$\begin{array}{lll}\text { 4.4.1 Chronology of relative SL change } & 107\end{array}$

$\begin{array}{lll}\text { 4.4.2 Uplift Rates } & 108\end{array}$ 
4.4.3 Tsunami events

4.4.4 The interpretation of transgressive sequences for paleoseismology

4.4.5 Practical limitations of neotectonic analysis of transgressive deposits

4.5 Conclusions

4.6 References

\section{CHAPTER FIVE}

Holocene coastal evolution and uplift mechanisms of the northeastern Raukumara

Peninsula, North Island, New Zealand.

$\begin{array}{lll}5.1 & \text { Introduction } & 117\end{array}$

$\begin{array}{lll}5.2 & \text { Tectonic setting } & 118\end{array}$

5.3 Previous studies of NE Raukumara Peninsula Quaternary coastal geology 120

$\begin{array}{lll}5.4 \text { Methods } & 121\end{array}$

5.4.1 Geomorphic analysis of the Horoera and Waipapa coastal terraces 121

5.4.2 Geomorphic analysis of the Te Araroa Beach Ridges 122

5.4.3 Stratigraphic study of the Hicks Bay Paleo-estuary 124

5.4.3.1 Micropaleontology study of the Hicks Bay paleo-estuary sequence 126

5.4.3.2 Stable isotope study of the Hicks Bay paleo-estuary sequence 129

$\begin{array}{lll}5.5 & \text { Results } & 129\end{array}$

$\begin{array}{lll}\text { 5.5.1 Horoera terrace stratigraphy and geomorphology } & 129\end{array}$

$\begin{array}{lll}\text { 5.5.2 Waipapa terrace stratigraphy and morphology } & 131\end{array}$

5.5.3 Evolution of the Te Araroa Beach Ridges 133

5.5.3.1 Beach ridge morphology and stratigraphy 133

5.5.3.2 Age control of the Te Araroa beach ridges 135

5.5.4 Hicks Bay Paleo-Estuary 136

5.5.4.1 Hicks Bay Flats Stratigraphy 136

5.5.4.2 Cores HB1 and HB2 137

5.5.4.3 Age control of Cores HB1 and HB2 143

5.5.4.4 Hicks Bay Cores Paleoenvironmental Zones 144

5.5.4.5 Paleoenvironmental evolution of the Hicks Bay Flats 147

5.6 Discussion: Uplift mechanisms of the northeastern Raukumara Peninsula 153

5.6.1 Horoera terrace formation 153

5.6.2 Waipapa terrace formation 154

5.6.3 Te Araroa Beach Ridges 155

$\begin{array}{lll}\text { 5.6.4 Hicks Bay Paleo-Estuary } & 158\end{array}$ 


\section{CHAPTER SiX}

Distribution, age and uplift patterns of Pleistocene marine terraces of the northern Raukumara Peninsula, North Island, New Zealand.

6.1 Introduction

6.2 Methodology

6.2.1 Terrace stratigraphy and distribution

6.2.2 Terrace elevations

6.2.3 Age Control

6.3 Results

$\begin{array}{lll}\text { 6.3.1 Terrace distribution } & 190\end{array}$

6.3.2 Terrace Stratigraphy 192

$\begin{array}{lll}\text { 6.3.3 OSL Results } & 194\end{array}$

$\begin{array}{lll}6.4 & \text { Discussion } & 195\end{array}$

6.4.1 Ages of the Raukumara Peninsula Pleistocene marine terraces 195

6.4.2 Modelling of possible terrace chronology combinations 201

6.4.3 Deformation of the marine terraces in the context of Hikurangi subduction margin tectonics 205

$\begin{array}{lll}6.5 & \text { Conclusions } & 208\end{array}$

$\begin{array}{lll}6.6 & \text { References } & 214\end{array}$

\section{CHAPTER SEVEN}

Relationships between late Quaternary coastal geomorphology and subduction zone geodynamics of the Raukumara Sector of the Hikurangi margin. 217

$\begin{array}{lll}7.1 & \text { Introduction } & 218\end{array}$

$\begin{array}{lll}7.2 & \text { Previous work } & 220\end{array}$

$\begin{array}{lll}\text { 7.3 Raukumara Peninsula coastal geomorphology and uplift mechanisms } & 224\end{array}$

7.3.1 Mahia-Wairoa region 225

$\begin{array}{lll}\text { 7.3.2 Pakarae region } & 226\end{array}$

$\begin{array}{lll}\text { 7.3.3 Northern Raukumara Peninsula region } & 229\end{array}$ 
7.4 A model of Raukumara Peninsula uplift: subduction margin-parallel uplift mechanism zones

7.4.1 Coseismic uplift zone 235

$\begin{array}{lll}\text { 7.4.2 Passive inner forearc } & 236\end{array}$

$\begin{array}{lll}\text { 7.4.3 Aseismic uplift zone } & 238\end{array}$

$\begin{array}{lll}7.5 & \text { Discussion } & 239\end{array}$

7.5.1 Relationships between Pleistocene marine terrace geometry, sediment underplating, and Raukumara Ranges uplift within the aseismic uplift zone

7.5.2 Uplift mechanism distribution in relation to geodynamic changes along the strike of the Raukumara Peninsula 244

7.5.3 Raukumara Peninsula forearc deformation and plate interface dynamics 245

7.5.4 Seismic hazard implications for the Raukumara sector of the Hikurangi margin 251

7.5.5 Onshore forearc deformation and offshore geology 253

7.5.6 Comparisons of the uplift mechanism model with other tectonic studies of the Raukumara Peninsula 254

7.5.7 Geodynamic changes along the strike of the Hikurangi margin 256

7.5.8 Comparison of Raukumara Peninsula forearc uplift to global subduction zones 259

$\begin{array}{lll}7.6 & \text { Conclusions } & 261\end{array}$

$\begin{array}{lll}7.7 & \text { References } & 262\end{array}$

\section{CHAPTER EIGHT}




\section{LIST OF FIGURES}

\section{CHAPTER ONE}

\section{Introduction: The Hikurangi margin, Seismic Hazard and Coastal Geomorphology}

Fig. 1.1 Major tectonic elements of New Zealand and the Hikurangi margin. .2

Fig. 1.2 Photo of the Pakarae River mouth with an overlay of significant coastal geomorphic features.................................................

Fig. 1.3 Photo of the Hicks Bay locality with an overlay of significant coastal geomorphic features...................................................

Fig. 1.4 Photo of the Te Araroa region with an overlay of significant coastal

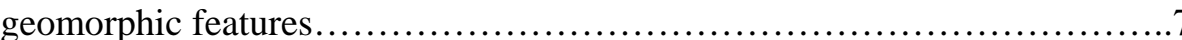

Fig. 1.5 Photo of the Waihau Bay coastline with an overlay of significant coastal geomorphic features......................................................

\section{CHAPTER TWO}

A revision of Mid to Late Holocene marine terrace distribution and chronology at New Zealand's most tectonically active coastal location, Pakarae River mouth, North Island, New Zealand.

Fig. 2.1 Location maps and aerial photographs of the Pakarae River mouth locality .14

Fig. 2.2 Topographic profiles and cover bed stratigraphy of the Pakarae River mouth marine terraces 18

Fig. 2.3 Photos of shells used for radiocarbon dating collected from the Pakarae River mouth marine terraces.................................................18

Fig. 2.4 Tilt directions of the Pakarae River mouth marine terraces..................22

Fig. 2.5 Correlation of marine terrace strath elevations and radiocarbon ages obtained from the terraces, and a revised map of marine terrace distribution and nomenclature at the Pakarae River mouth..................................23

Fig. 2.6 Graph of Pakarae locality marine terrace age and elevation .28

Fig. 2.7 Comparison of marine terrace topographic profiles on the up and downthrown blocks of the Pakarae Fault. .29

Fig. 2.8 Block models of combinations of slip on the Pakarae Fault and an offshore fault. 
CHAPTER THREE

A facies architecture model for Holocene incised valley infill on a tectonically active coast: Pakarae River, New Zealand.

Fig. 3.1 Location map of the Pakarae River mouth and the distribution of studied profiles along the Pakarae riverbank..................................38

Fig. 3.2 Sedimentology and biostratigraphy of the Pakarae riverbank stratigraphic profiles.

Fig. 3.3 Composition and distribution of benthic foraminifera assemblages of the Pakarae riverbank profiles.

Fig. 3.4 Bio-lithofacies and paleoenvironmental facies associations of the Pakarae riverbank profiles

Fig. 3.5 Comparisons between incised valley infill facies models of stable coasts and the facies architecture of the Pakarae riverbank, and a model of the distinguishing characteristics of incised valley infill sequences on tectonically active coasts.

\section{CHAPTER FOUR}

Early Holocene paleoseismic history at the Pakarae locality, eastern North Island, New Zealand, inferred from transgressive marine sequence architecture.

Fig. 4.1 Location map of the Raukumara Peninsula with on and offshore active faults, and the Pakarae River mouth locality with the distribution of studied profiles along the Pakarae riverbank............................................86

Fig. 4.2 Bio-lithofacies and paleoenvironmental facies associations of the Pakarae riverbank profiles.

Fig. 4.3 The present elevation of radiocarbon ages from the Pakarae riverbank sedimentary sections compared with the New Zealand eustatic sea level curve.

Fig. 4.4 Paleogeographic evolution of the Pakarae River incised valley

Fig. 4.5 Three palaeographic scenarios to explain the juxtaposition of non-marine and marine sediments within the Pakarae paleo-valley

Fig. 4.6 Photos of selected paleoenvironmental facies transitions in the Pakarae riverbank sedimentary sequence. .104

Fig. 4.7 Photos of radiocarbon dated shells from the Pakarae riverbank sedimentary sequence .105 
Fig. 4.8 Schematic illustration of the accommodation space deficit between Estuary units II and III in the Pakarae riverbank sedimentary sequence.

Fig. 4.9 A relative Holocene SL curve for the Pakarae locality.

Fig. 4.10 Photos of anomalous high-energy sedimentary units within the Pakarae riverbank sedimentary sequence....

\section{CHAPTER FIVE}

Holocene coastal evolution and uplift mechanisms of the northeastern Raukumara Peninsula, North Island, New Zealand.

Fig. 5.1 Location map of the northeastern Raukumara Peninsula region. 119

Fig. 5.2 Location of topographic profiles and auger holes on the Horoera terraces..122

Fig. 5.3 Geomorphology of the Te Araroa locality and locations of topographic profiles and auger holes.

Fig. 5.4 Geomorphology of the Hicks Bay locality with the locations of drill cores, probes and augers holes.

Fig. 5.5 Coverbed stratigraphy, topographic profiles and strath elevations of the Horoera terraces.

Fig. 5.6 Location map, coverbed stratigraphy and topographic profiles of the Waipapa terraces.

Fig. 5.7 Auger hole stratigraphy and topographic profiles of the Te Araroa beach ridge sequence, and of the modern storm beach ridge.

Fig. 5.8 Sedimentology, biostratigraphy and radiocarbon ages of Hicks Bay cores, HB1 and HB2 138, 139

Fig. 5.9 $\quad C$ and $N$ Stable isotope values from the upper $6 \mathrm{~m}$ of the HB1 core. 142

Fig. 5.10 Holocene paleogeographic evolution of the Hicks Bay Flats.... 148,149

Fig. 5.11 Cartoon of beach ridge development under different tectonic uplift mechanisms

Fig. 5.12 Radiocarbon ages from the Hicks Bay Flats plotted at their modern elevation and compared with the New Zealand eustatic sea level curve.

Fig. 5.13 Cartoon depicting the hypothetical development of a relative sea level curve for a location undergoing coseismic uplift during eustatic sea level rise....160

Fig. 5.14 Schematic illustration of accommodation space deficits with the Hicks Bay cores. 


\section{CHAPTER SiX}

Distribution, age and uplift patterns of Pleistocene marine terraces of the northern Raukumara Peninsula, North Island, New Zealand.

Fig. 6.1 Location map, tectonic setting and distribution of the Pleistocene marine terraces of the northern Raukumara Peninsula.

Fig. 6.2 Stratigraphic columns of terrace coverbeds at the OSL sample collection locations.

Fig. 6.3 Pleistocene terrace distribution and height correlations between Matakaoa Point and Te Araroa.

Fig. 6.4 OSL ages from the Pleistocene terrace coverbeds and a comparison with the Late Quaternary eustatic sea level curve. 198

Fig. 6.5 Comparison of Pleistocene terrace uplift rates at four locations around the Raukumara Peninsula under different terrace chronology scenarios........202

Fig. 6.6 Elevation contours on the Otamaroa and Te Papa Pleistocene terraces......206

Fig. 6.7 Uplift rates of the Otamaroa terrace around the northern Raukumara Peninsula and the elevation of the terrace surface projected to a northnorthwest line.

\section{CHAPTER SEVEN}

Relationships between Late Quaternary coastal geomorphology and subduction zone geodynamics of the Raukumara Sector of the Hikurangi margin.

Fig. 7.1 Location map, tectonic setting, coastal neotectonics and recent seismicity of the Raukumara sector of the Hikurangi margin

Fig. 7.2 Location map and summary of the coastal neotectonics in the Mahia-Wairoa region

Fig. 7.3 A summary of the coastal geomorphology and neotectonics of the Pakarae region.

Fig. 7.4 A summary of the Late Quaternary coastal geomorphology of the northern Raukumara Peninsula....

Fig. 7.5 Topography, major geomorphic elements and offshore structures of the Raukumara Peninsula and a model of Raukumara sector forearc uplift mechanism zones.

Fig. 7.6 Schematic cross-section of the structures accommodating uplift across the Raukumara Peninsula. 
Fig. 7.7 Seismic line from the Raukumara Peninsula continental shelf..

.237

Fig. 7.8 An illustration of the spatial offset between the zones of maximum aseismic uplift as estimated from the Raukumara Ranges and the Pleistocene marine

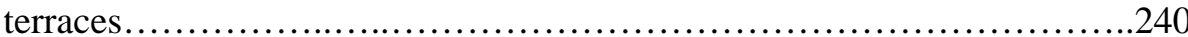

Fig. 7.9 Relationships between Raukumara Peninsula topography and bedrock

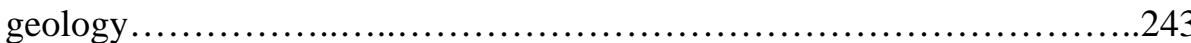

Fig. 7.10 Major geomorphic features and active faults of the Hikurangi margin, gravity anaomalies and GPS-measured interseismic plate coupling.

Fig. 7.11 Elastic dislocation model of coseismic surface displacements during a 1 per 100 year plate interface rupture event................................250 


\section{LIST OF TABLES}

\section{CHAPTER TWO}

Table 2.1 Radiocarbon age data collected during this study from the Pakarae marine terraces............................................................. 20

Table 2.2 Age-elevation relationships between the Pakarae River marine terraces including average uplift rates...........................................27

\section{CHAPTER THREE}

Table 3.1 Pakarae River mouth incised valley infill sedimentary sequence radiocarbon ages. .48

Table 3.2 Major element glass chemistry and heavy mineral chemistry of the Pakarae riverbank section.......................................................

Table 3.3 Distribution and sedimentary characteristics of the bio-lithofacies of the Pakarae infill sequence. ...............................................52

CHAPTER FOUR

Table 4.1 Pakarae River mouth incised valley infill sedimentary sequence radiocarbon

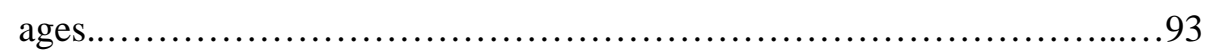

Table 4.2 Uplift rate calculations from the Pakarae River mouth incised valley infill sequence.

\section{CHAPTER FIVE}

Table 5.1 Palynological results from Hicks Bay cores, HB1 and HB2................127

Table 5.2 Diatom results from Hicks Bay cores, HB1 and HB2....................128

Table 5.3 Radiocarbon ages from the Hicks Bay Flats and the Te Araroa beach

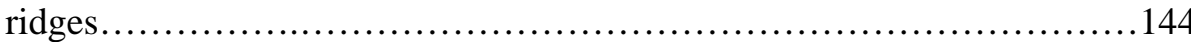

Table 5.4 Tectonic uplift rate calculations from Hicks Bay........................152

Table 5.5 Uplift rates calculations from the Te Araroa beach ridges sequence.........156

\section{CHAPTER SIX}

Table 6.1 OSL sampling locations, modern elevations and stratigraphic context of the samples...............................................................190

Table 6.2 OSL results: Radionuclide and water contents, measured a-value and equivalent dose, doserate and luminescence age. 


\section{LIST OF APPENDICES}

\section{CHAPTER THREE}

Appendix 3.1 Diatom and palynology study of the Pakarae River incised valley infill sequence.

Appendix 3.2 Foraminifera census of the Pakarae incised valley infill sedimentary sequence. .73

CHAPTER FIVE

Appendix 5.1 Stratigraphic columns of exposures and augers on the Hicks Bay Flats.....165

Appendix 5.2 Cone pentrometer resistance logs from the Hicks Bay Flats................166

Appendix 5.3 Hicks Bay cores stable isotope study................................167

Appendix 5.4 Major element glass geochemistry of tephras collected from the Te Araroa beach ridge sequence..............................................169

Appendix 5.5 Foraminifera census data from the Hicks Bay cores, HB1 and HB2.........170

Appendix 5.6 Hicks Bay core foraminifera data statistical correlation analysis............174

Appendix 5.7 Scanning electron microscope images of representative foraminifera from the Hicks Bay cores, HB1 and HB2

CHAPTER SIX

Appendix 6.1 Stratigraphic columns of Pleistocene marine terraces cover sequences. 209

Appendix 6.2 Laboratory Procedures of Optically Stimulated Luminescence Measurements 


\section{Chapter ONe}

InTRODUCTION: THE HikURANGI MARGIN, SEISMIC HAZARD AND COASTAL GEOMORPHOLOGY

\subsection{Introduction}

Plate convergence at the Hikurangi subduction margin directly controls the geomorphology, structure and seismicity of the East Coast of the North Island, New Zealand. Because no large subduction earthquakes have taken place historically, the plate interface represents potentially the most significant, yet least well-constrained seismic hazard in New Zealand. Until recently, there has been a comparative underappreciation of how the geomorphology of the margin can yield information on the geodynamics of the subduction zone. This thesis contributes to our understanding of the Hikurangi subduction zone specifically by using coastal geomorphology and stratigraphy to document rates, styles and mechanisms of forearc uplift mechanisms, and I aim to relate this to plate boundary processes and seismic hazard.

The focus of this thesis is the Raukumara Peninsula sector of the Hikurangi margin (Fig. 1.1). This northeastern coastline has some of the most spectacular uplifted Holocene and Pleistocene marine terraces of anywhere in New Zealand (Figs. 1.2 1.5, Yoshikawa et al., 1980; Ota et al., 1988; Ota et al., 1992; Berryman, 1993a, b). A key observation that was initially identified was that these marine terraces are geomorphically similar to other marine terraces of the Wairarapa and Wellington regions, at the southwestern end of the Hikurangi margin (Fig. 1.1), but despite the this apparent similarity, geophysical studies of seismicity and geodesy, and structural geology, indicate there are significant changes in how plate convergence is accommodated along the strike of the margin between these two regions (Collot et al., 1996; Beanland and Haines, 1998; Reyners, 1998; Wallace et al., 2004). Thus, a paradox of similar coastal geomorphology under different tectonic regimes appears to exist along the Hikurangi margin. Therefore, one of the main questions addressed in this thesis is what is the mechanism of coastal uplift of the Raukumara Peninsula and is it different from that farther to the south? 


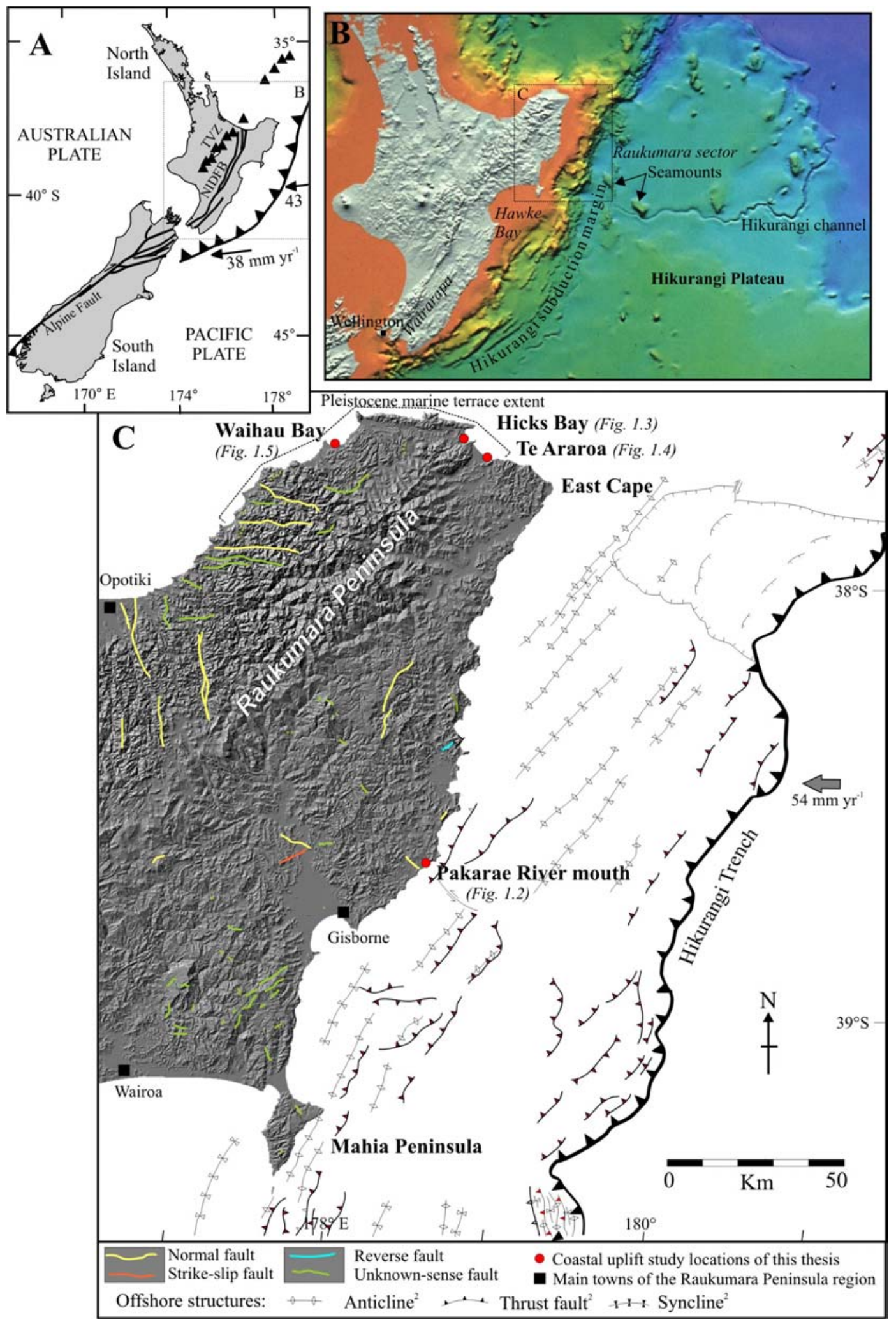

Fig. 1.1. (A) Major tectonic elements of New Zealand. The major fault lines (black lines) and the volcanic arc (black triangles) are shown (NIDFB: North Island dextral fault belt, TVZ: Taupo Volcanic Zone).Plate motions rates after De Mets et al. (1994). (B) Geographic regions, bathymetry and offshore geologic features of the Hikurangi subduction margin (map source: CANZ Group, 1996). (C) Shaded relief image of the Raukumara sector of the Hikurangi subduction zone. Active faults are shown (onshore faults source: New Zealand Active Faults Database, http://data.gns.cri.nz/af/, offshore faults source: Lewis, 1997) as are the coastal geomorphology study locations of this thesis and the main settlements of the region. Plate motion rate of Pacific-Kermadec convergence after Collot et al. (2001). 
On the southern margin, the prevalence of active contractional faults and historical records of coseismic coastal uplift results in a widely held acceptance that terraces here are uplifted in discrete events and this deformation is accommodated by upper plate reverse faults. On the Raukumara Peninsula, the virtual absence of recognised active faulting and proposed trenchward gravitational collapse and expansion of the forearc (Thornley, 1996; Arnadottir et al., 1999) beg the question of what structures control the uplift of these terraces? Are they uplifted by aseismic or coseismic mechanisms? Is the deformation accommodated by the plate interface, upper plate faults or, as yet, unidentified structures?

A variety of tools are used in this project to understand the coastal geomorphic evolution and its relationship to neotectonism. At several sites previously-used methods such as surveying, radiocarbon dating and stratigraphic studies are applied. At two locations biostratigraphy and facies architecture of incised valley infill sedimentary sequences are used to document paleoenvironmental evolution of valleys under conditions of rising eustatic sea level and tectonic uplift. Biostratigraphic studies of marginal marine sediments have been used extensively in New Zealand (for example, Hayward et al., 2004; Hayward et al., 2006; Cochran et al., 2006) and globally (for example, Atwater, 1987; Darienzo et al., 1994; Hemphill-Haley, 1995; Nelson et al., 1996; Clague, 1997) to infer coastal paleoseismic events. At some subduction margins, such as Cascadia, tidal wetland biostratigraphy provides the key evidence for past great earthquakes (Atwater, 1987; Hemphill-Haley, 1995). Thus, the value of marginal marine biostratigraphy has been proven. However, a common theme of these previous studies has been their use, firstly, in regions dominated by coseismic subsidence events and, secondly, during Late Holocene time periods when sea level has been approximately stable. In this study the biostratigraphic technique is used at locations on the Raukumara Peninsula that are undergoing tectonic uplift and applied to the early Holocene period when eustatic sea level was rapidly rising. Therefore while the primary aim of this thesis is to understand relationships between coastal geomorphology and subduction zone geodynamics, I also aim to develop a new methodology that uses the stratigraphy of incised valleys as a tool to constrain the rate and tempo of coastal uplift, and to reconstruct the paleoseismic history at such sites. 
In Chapter Two I present a timely revision of the marine terrace distribution and chronology at the Pakarae River mouth, one of the most well-documented coastal uplift locations of the Raukumara Peninsula (Fig. 1.1, 1.2). Here seven mid-late Holocene marine terraces were identified by Ota et al. (1991) and uplifted early Holocene estuarine sediments were described by Berryman et al. (1992). This location provided an opportunity to test whether rapid uplift at this site is driven by coseismic uplift on faults or whether other, more gradual processes operate here. Utilising modern methods of surveying and AMS radiocarbon dating, I constrain the timing and magnitude of coastal uplift at this location to a higher degree of precision than previously, and assess the tilt vectors on the terraces to estimate the probable location of the fault accommodating uplift.

The main focus of the Pakarae River mouth study is on the early Holocene uplifted incised valley infill sequence, now exposed along the Pakarae River banks (Fig. 1.2). This sequence was first identified by Berryman et al. (1992) when the sediments were dated and shown to have been deposited within the Pakarae River paleo-valley when sea level was still rising due to post-glacial melt. In Chapter Three the sequence is revisited and I present a detailed examination of the sedimentology, biostratigraphy and chronology of the sediments at multiple riverbank exposures. Biostratigraphy yields excellent paleoenvironmental control and several alternations between estuarine and fluvial environments can be seen. However, to understand the tectonic significance of how the paleoenvironmental facies are distributed in this paleo-valley exposure the sequence must be placed in a context that enables comparisons with equivalent deposits on stable coastlines. Several facies models have been developed for incised valley infill sequences on stable coasts due to their applicability in recording past eustatic sea level and climate changes. In Chapter Three a facies model is presented for incised valley infill sequences on tectonically active coastlines, based upon the Pakarae River mouth stratigraphic sequence.

With a context established for incised valley infill sequences on active coasts, in Chapter Four I identify which paleoenvironmental facies transitions at the Pakarae River mouth are part of a predictable valley infilling sequence under rising eustatic sea level and which transitions are anomalous, hence more likely to be related to tectonic events. Models of palaeographic evolution of the Pakarae River paleo-valley 


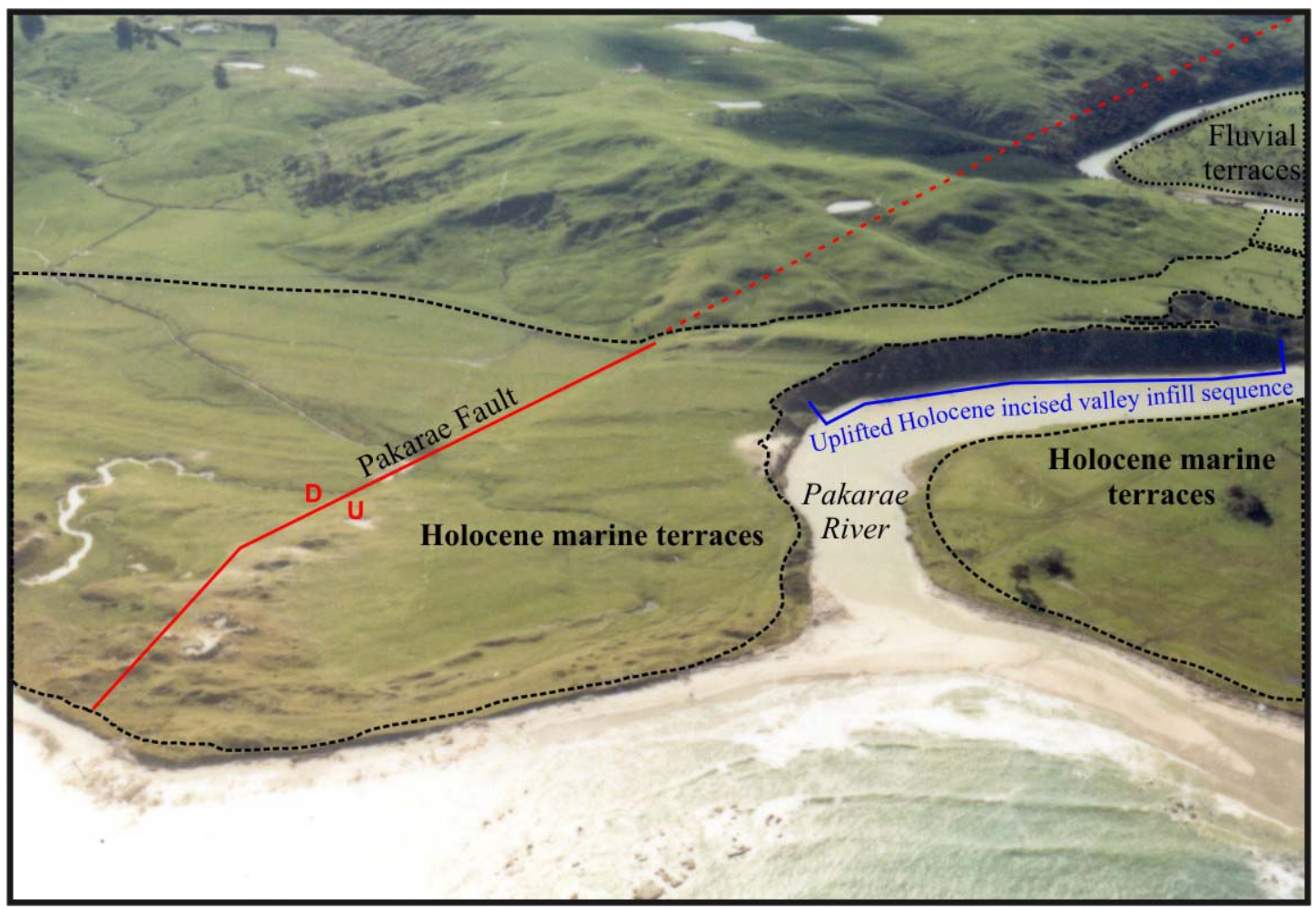

Fig. 1.2. The Pakarae River mouth site on the Raukumara Peninsula with significant coastal geomorphic features. View looking to the northwest, photo by Lloyd Homer.

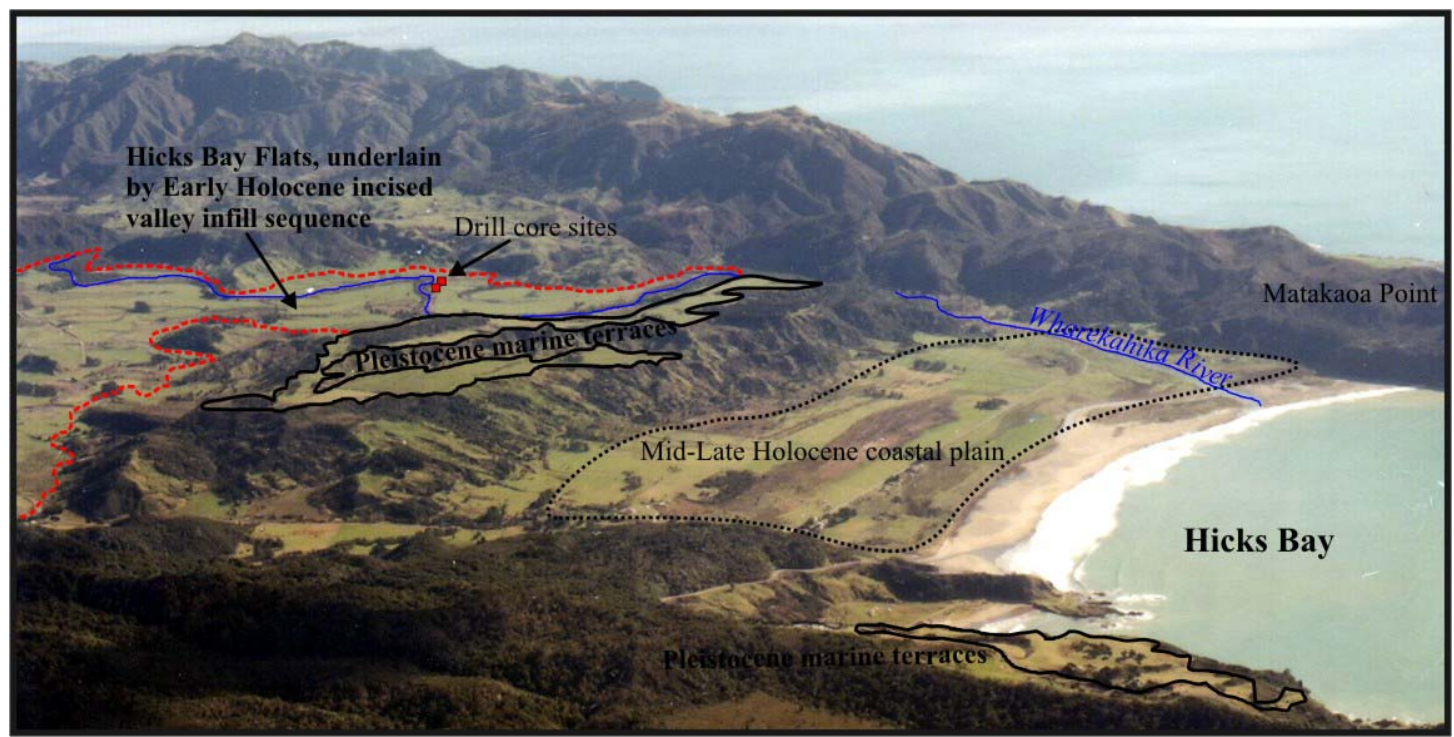

Fig. 1.3. The Hicks Bay locality on the northeastern Raukumara Peninsula with significant coastal geomorphic features. View looking toward the north-northwest, photo by Lloyd Homer. 
have been developed and the timing and magnitude of uplift events that occurred during infilling of the valley have been assessed. This chapter demonstrates that incised valley infill sequences can be used as a new approach or tool in paleoseismic investigations of coastal locations, and biostratigraphy of these sequences can constrain the rate at which tectonic processes took place.

The other coastal region of the Raukumara Peninsula studied is the northeastern portion (Fig. 1.1); here there is a rich record of both Holocene and Pleistocene uplifted marine deposits (Figs. 1.3, 1,4). In Chapter Five two marine terrace sequences near East Cape that were previously thought by Ota et al. (1992) to have been coseismically uplifted are re-evaluated. Coverbed stratigraphy and topographic surveying are used to determine the origin of the terraces. The remarkable uplifted beach ridge sequence at Te Araroa is also revisited. Here additional age control and ridge topography are used to re-assess the mechanism of beach ridge uplift (Fig. 1.4). A study of the transgressive marine sediments infilling the Hicks Bay paleo-valley is also presented in Chapter Five (Fig. 1.5). This study uses a similar methodology to the Pakarae River mouth study, except at Hicks Bay drill cores of the transgressive sediments rather than outcrop are the primary data source. Biostratigraphy is used to constrain the sediment depositional environments, and paleogeographic models of the infilling valley are developed. Again, the utility of transgressive marine sediments in coastal neotectonic studies is demonstrated.

At Te Araroa, the Pleistocene marine terraces of the northern Raukumara Peninsula reach their maximum elevation of $\sim 300 \mathrm{~m}$ (Fig. 1.4). Although previously studied by Yoshikawa et al. (1980), age constraints on these terraces are poor. In Chapter Six the dating results obtained from the terraces and discussion of terrace geometry in relation to active faults and forearc structures are presented. The continuity of these Pleistocene terraces, along approximately $90 \mathrm{~km}$ of coastline (Fig. 1.1, 1.5), provides an opportunity to extend the spatial and temporal scale of the coastal geomorphic study.

The Holocene coastal geomorphology at the Pakarae River mouth and around the northeastern part of the Peninsula has been studied in detail and yields evidence of coseismic Holocene uplift mechanism at the Pakarae locality and aseismic, apparently continuous uplift at the northeast tip of the Peninsula. In Chapter Seven data from the 


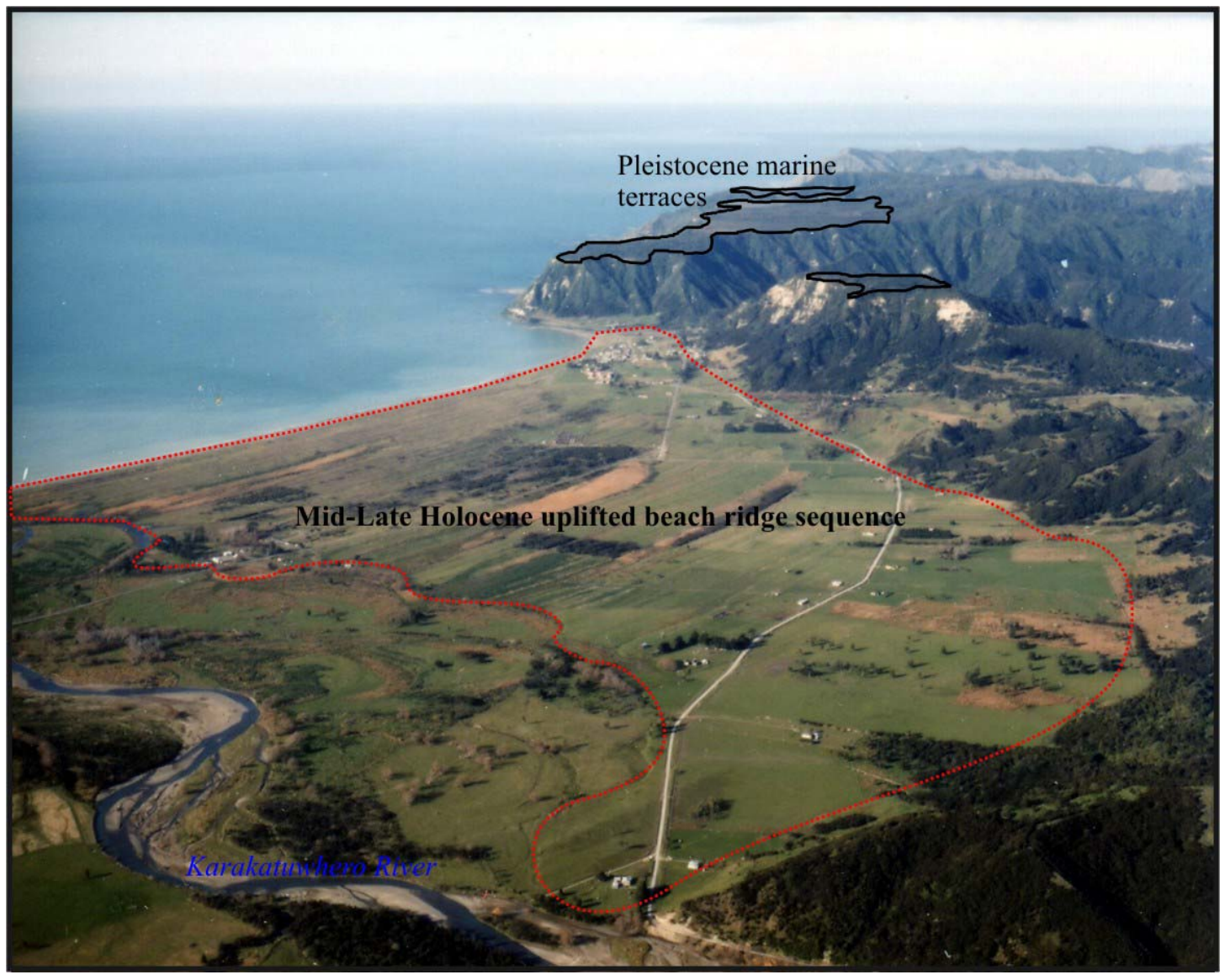

Fig. 1.4. The Te Araroa locality on the northeastern Raukumara Peninsula with significant coastal geomorphic features. View looking towards the southeast, photo by Lloyd Homer.

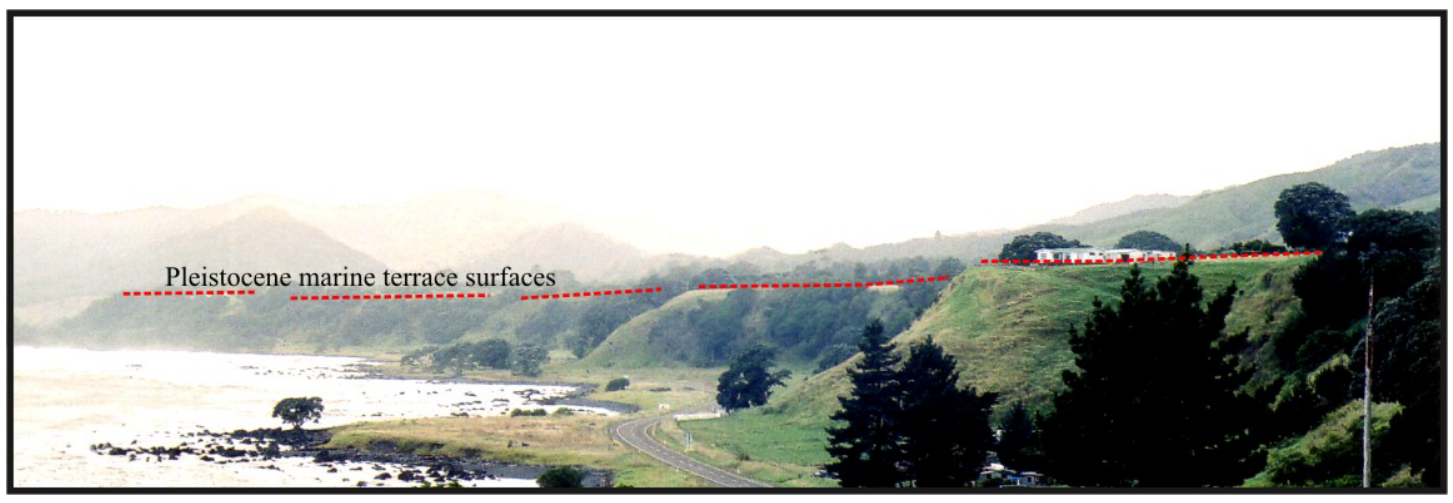

Fig. 1.5. The Waihau Bay coastline, located at the northwestern edge of the Raukumara Peninsula with uplifted Pleistocene marine terrace surfaces. View looking towards the north. 
previous chapters are integrated with other regional coastal geomorphic studies. Reconnaissance level studies of many other coastal locations on the Raukumara Peninsula have been presented by Ota et al. (1988), and Ota et al. (1992). Uplift rates presented in those studies are valuable data, although the interpretation of coseismic uplift mechanisms in those areas is not proven. The only other coastal reach where detailed coastal uplift mechanism studies have been undertaken is from Mahia Peninsula to Wairoa (Fig. 1.1). Studies of vertical deformation along this, southernmost portion of the Raukumara Peninsula have been presented by Berryman (1993a, b) and Cochran et al. (2006). This information is integrated with the new data of this study to provide insights into the mechanics of deformation of the Hikurangi subduction margin from three locations evenly spaced $\sim 80-100 \mathrm{~km}$ apart along the strike of the Raukumara sector.

The final discussion, presented in Chapter Seven, assesses how the spatial pattern of coastal deformation across the Raukumara Peninsula can be related to the Hikurangi subduction zone. Major questions, such as: do uplift mechanisms vary along the Raukumara sector, what parameters control the distribution of uplift mechanisms, and importantly, how does this study of coastal uplift mechanisms relate to other sources of information about Raukumara Peninsula deformation, are addressed. Other sources of information include seismicity (earthquake focal mechanisms and seismic velocity modelling), GPS-measured deformation, structural geology, and Late Quaternary fluvial terrace uplift studies. The contribution of coastal geomorphology to constraining seismic sources and seismic hazard in the Raukumara sector of the subduction margin is also discussed.

\subsection{Thesis format}

This thesis is presented in six chapters with brief introductory and concluding chapters. Five main chapters are written as papers suitable for publication in scientific journals. Therefore, they have been deliberately written so that they can be read as stand-alone, independent papers. I have tried to minimise repitition between chapters, but there some is unavoidable to ensure completeness, particularly regarding sections that describe regional settings and previous work. Appendices are included at the end of the relevant chapter, as are references. 
To date five papers have been submitted to journals and these are currently under published, in press, or under review. Chapter Two has been published in the New Zealand Journal of Geology and Geophysics (Wilson et al., 2006), Chapter Three is in press in Sedimentary Geology and Chapter Five is in press in Quaternary Science Reviews. Chapter Four has been submitted to Tectonics, and Chapter Six has been submitted to the New Zealand Journal of Geology and Geophysics. Most chapters include cross-references to other chapters. For simplicity, chapter numbers are used when cross-referencing rather than the submitted, or otherwise, state of the chapter.

All chapters have been written in first-person style. The term "we" is used extensively, and this refers to the co-authors and myself. My supervisors Kelvin Berryman and Tim Little will be co-authors on all papers published from this thesis, and Nicola Litchfield and Ursula Cochran are each co-authors on several of the papers. However, all work presented in this thesis is my own, and the term "we" reflects the work and opinions of myself as the primary author, but that I have benefited from discussions with my co-authors.

\subsection{References}

Arnadottir, T., S. Thornley, F. Pollitz, F. and D. J. Darby (1999). "Spatial and temporal strain rate variations at the northern Hikurangi margin, New Zealand." Journal of Geophysical Research 104(B3): 4931-4944.

Atwater, B. F. (1987). "Evidence for great Holocene earthquakes along the outer coast of Washington State." Science 236: 942-944.

Beanland, S. and J. Haines (1998). "The kinematics of active deformation in the North Island, New Zealand, determined from geologic strain rates." New Zealand Journal of Geology and Geophysics 41: 311-323.

Berryman, K. R. (1993a). "Age, height, and deformation of Holocene terraces at Mahia Peninsula, Hikurangi subduction margin, New Zealand. 1." Tectonics 12(6): 1347-1364.

Berryman, K. R. (1993b). "Distribution, age, and deformation of Late Pleistocene marine terraces at Mahia peninsula, Hikurangi subduction margin, New Zealand." Tectonics 12(6): 1365-1379.

Berryman, K. R., Y. Ota and A. G. Hull (1992). "Holocene evolution of an estuary on a tectonically rising coast: the Pakarae River locality, eastern North Island, New Zealand." Sedimentary Geology 80: 151-162.

CANZ Group. (1996). "Undersea New Zealand" New Zealand region physiography, 1:4,000,000. NIWA Chart Series 74. 
Clague, J. J. (1997). "Evidence for large earthquakes at the Cascadia subduction zone." Reviews of Geophysics 35(4): 439-460.

Cochran, U., K. Berryman, D. Mildenhall, B. Hayward, K. Southall, C. Hollis, P. Barker, L. Wallace, B. Alloway and K. Wilson (2006). "Paleoecological insights into subduction zone earthquake occurrence, eastern North Island, New Zealand." Geological Society of America Bulletin, 118(9/10): 1051-1074.

Collot, J.-Y., J. Delteil, K. Lewis, B. Davy, G. Lamarche, J.-C. Andru, P. Barnes, F. Chanier, E. Chaumillon, S. Lallemand, B. M. De Lepinay, A. Orpin, B. Pelletier, M. Sosson, Toussaint and C. Uruski (1996). "From oblique subduction to intra-continental transpression: structures of the southern Kermadec-Hikurangi margin from multibeam bathymetry, side-scan sonar and seismic reflection." Marine Geophysical Researches 18(2-4): 357-381.

Collot, J.-Y., K. Lewis, G. Lamarche and S. Lallemand (2001). "The giant Ruatoria debris avalanche on the northern Hikurangi margin, New Zealand; results of oblique seamount subduction." Journal of Geophysical Research 106B(9): 19271-19297.

Darienzo, M. E., C. D. Peterson and C. Clough (1994). "Stratigraphic evidence for great subductionzone earthquakes at four estuaries in Northern Oregon, U. S. A." Journal of Coastal Research 10: 820876.

De Mets, C., R. G. Gordon, D. F. Argus and S. Stein (1994). "Effect of recent revisions to the geomagnetic reversal timescale on estimates of current plate motions." Geophysical Research Letters 21: 2191-2194.

Hayward, B. W., U. Cochran, K. Southall, E. Wiggins, H. R. Grenfell, A. Sabaa, P. R. Shane and R. Gehrels (2004). "Micropalaeontological evidence for the Holocene earthquake history of the eastern Bay of Plenty, New Zealand, and a new index for determining the land elevation record." Quaternary Science Reviews 23: 1651-1667.

Hayward, B. W., H. R. Grenfell, A. Sabaa, R. Carter, U. Cochran, J. H. Lipps, P. Shane and M. S. Morley (2006). "Micropaleontological evidence of large earthquakes in the past 7200 years in southern Hawke's Bay, New Zealand." Quaternary Science Reviews 25(11-12): 1186-1207.

Hemphill-Haley, E. (1995). "Diatom evidence for earthquake-induced subsidence and tsunami $300 \mathrm{yr}$ ago in southern coastal Washington." Geological Society of America Bulletin 107: 367-378.

Lewis, K. B., J.-Y. Collot, B. Davy, J. Delteil, S. Lallemand and C. Uruski (1997). "North Hikurangi GeodyNZ swath maps: depths, texture and geological interpretation 1: 500 000." National Institute for Water and Atmospheric Research miscellaneous series chart 72. Wellington.

Nelson, A. R., I. Shennan and A. J. Long (1996). " Identifying coseismic subsidence in tidal-wetland stratigraphic sequences at the Cascadia subduction zone of western North America." Journal of Geophysical Research 101: 6115-6135.

Ota, Y., K. R. Berryman, A. G. Hull, T. Miyauchi and N. Iso (1988). "Age and height distribution of Holocene transgressive deposits in eastern North Island, New Zealand." Palaeogeography, Palaeoclimatology, Palaeoecology 68: 135-151.

Ota, Y., A. G. Hull and K. R. Berryman (1991). "Coseismic uplift of Holocene marine terraces in the Pakarae River area, eastern North Island, New Zealand." Quaternary Research 35: 331-346.

Ota, Y., A. G. Hull, N. Iso, Y. Ikeda, I. Moriya and T. Yoshikawa (1992). "Holocene marine terraces on the northeast coast of North Island, New Zealand, and their tectonic significance." New Zealand Journal of Geology and Geophysics 35: 273-288.

Reyners, M. (1998). "Plate coupling and the hazard of large subduction thrust earthquakes at the Hikurangi subduction zone, New Zealand." New Zealand Journal of Geology and Geophysics 41: 343 354. 
Thornley, S. (1996). "Neogene tectonics of Raukumara Peninsula, Northern Hikurangi margin, New Zealand." Victoria University of Wellington Unpublished PhD thesis.

Wallace, L. M., J. Beavan, R. McCaffrey and D. Darby (2004). "Subduction zone coupling and tectonic block rotations in the North Island, New Zealand." Journal of Geophysical Research 109(B12406): doi:10.1029/2004JB003241.

Wilson, K.J., K.R. Berryman, N.J. Litchfield, and T.A. Little (2006). A revision of Mid to Late Holocene marine terrace distribution and chronology at New Zealand's most tectonically active coastal location, Pakarae River, North Island, New Zealand. New Zealand Journal of Geology and Geophysics, 49(4): 477-489.

Yoshikawa, T., Y. Ota, N. Yonekura, A. Okada and N. Iso (1980). "Marine terraces and their tectonic deformation on the northeast coast of the North Island, New Zealand." Geographical Review of Japan 53(4): 238-262. 


\title{
CHAPTER TWO
}

\section{A REVISION OF MID TO LATE HOLOCENE MARINE TERRACE DISTRIBUTION \\ AND CHRONOLOGY AT NEW ZEALAND'S MOST TECTONICALLY ACTIVE \\ COAStal location, Pakarae River mouth, North Island, NeW \\ ZEALAND.}

\begin{abstract}
The highest Holocene coastal uplift rates adjacent to the Hikurangi subduction zone are evidenced by a suite of seven marine terraces at the Pakarae River mouth, New Zealand. New elevation, cover bed stratigraphy and age data allows for a timely revision of the distribution, nomenclature and chronology of these terraces. Terrace correlation is primarily based on the elevation of the wave-cut strath. Terrace preservation either side of the river is more equal than previously proposed. The age of abandonment of each terrace is approximately $7 \mathrm{ka}$ (T1), $4.3 \mathrm{ka}$ (T2), $3.5 \mathrm{ka}$ (T3), $2.89 \mathrm{ka}$ (T4), $1.6 \mathrm{ka}$ (T5), 0.91 (T6), <0.91 ka (T7). The average Holocene tectonic uplift rate at the Pakarae River mouth is $3.2 \pm 0.8 \mathrm{~mm} \mathrm{yr}^{-1}$. The abandonment of each terrace, from T2 to T7, probably took place after discrete uplift events. The average time interval between these events has been $850 \pm 450 \mathrm{yrs}$ and the average uplift magnitude has been $2.7 \pm 1.1 \mathrm{~m}$ per event. It is inferred that uplift has been accommodated by slip on an offshore reverse fault. Normal slip on the Pakarae Fault, at right angles to the margin, occurs at a comparatively slower rate and has probably made little contribution to coastal uplift.
\end{abstract}

\subsection{Introduction}

The Pakarae River mouth locality (henceforth called Pakarae) has the greatest number of Holocene marine terraces of any location adjacent to the Hikurangi subduction zone (Berryman et al., 1989; Ota et al., 1991; 1992). Seven terraces elevated above modern mean sea level (MSL) provide evidence of past sudden coastal uplift since sea level (SL) stabilised in the mid-Holocene. This well-preserved record of coastal uplift distinguishes this location as one of the most tectonically active coastal areas of the Pacific Rim (Berryman et al., 1992; Ota and Yamaguchi, 2004). Accurate knowledge 
of the timing and magnitude of coastal uplift for each event at Pakarae provides a long record of tectonism in the subduction margin. The proximity of the study location to a subduction thrust, which has no historic record of slip during large or great earthquakes, and a normal fault offsetting the terraces locally at Pakarae begs the question of what fault, or faults, are driving the rapid coastal uplift rates along this part of the Hikurangi margin.

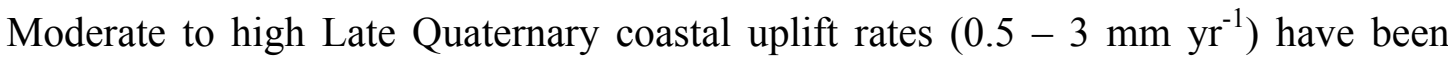
recorded by marine terraces at many locations along the Raukumara Peninsula, but the Pakarae region has the highest Holocene uplift rates recorded along this segment of the Hikurangi margin (Ota, 1987; Ota et al., 1988; Yoshikawa, 1988; Berryman et al., 1989; Ota et al., 1992; Berryman, 1993). Offshore of Pakarae, directly to the east, is the Hikurangi subduction zone (Fig. 2.1). The continental shelf has been deformed by strike slip, contractional and extensional faulting, and several margin indentations indicate previous seamount collisions (Lewis, 1980; Lewis and Pettinga, 1993; Collot et al. 1996). In the vicinity of Pakarae, Oligocene and Miocene marine siltstones and mudstones are juxtaposed across the Pakarae Fault, a north-striking structure on the western side of the Pakarae River (Kingma, 1964; Mazengarb and Speden, 2000). Several short segments of active normal faults have been mapped in the Pakarae region, including the Pakarae Fault and the Waihau Bay Fault, located 10km north of Pakarae (Mazengarb, 1984; Mazengarb, 1998; Mazengarb and Speden, 2000). Walcott (1987) and Thornley (1996) inferred that the Raukumara Peninsula is undergoing margin-normal extension due to uplift driven by sediment underplating. The character of active faulting at Pakarae is therefore of relevance to understanding the geodynamic relationships between onshore normal faults, offshore upper plate compressional structures and the subduction interface.

The Pakarae Holocene marine terraces were previously mapped, correlated, and dated by Ota et al. (1991). Seven terraces, named T1-T7, from oldest to youngest, were recognised at Pakarae. T1 corresponds to the maximum mid-Holocene marine transgression at c. 7,000- cal. yrs B.P. (calibrated radiocarbon years before present, Gibb, 1986). The terraces were correlated across the Pakarae River based on their age and height. Only terraces T4 and T5 were mapped on both sides of the river. Landward-tilting of the terraces was indicated by terrace height projections normal to 


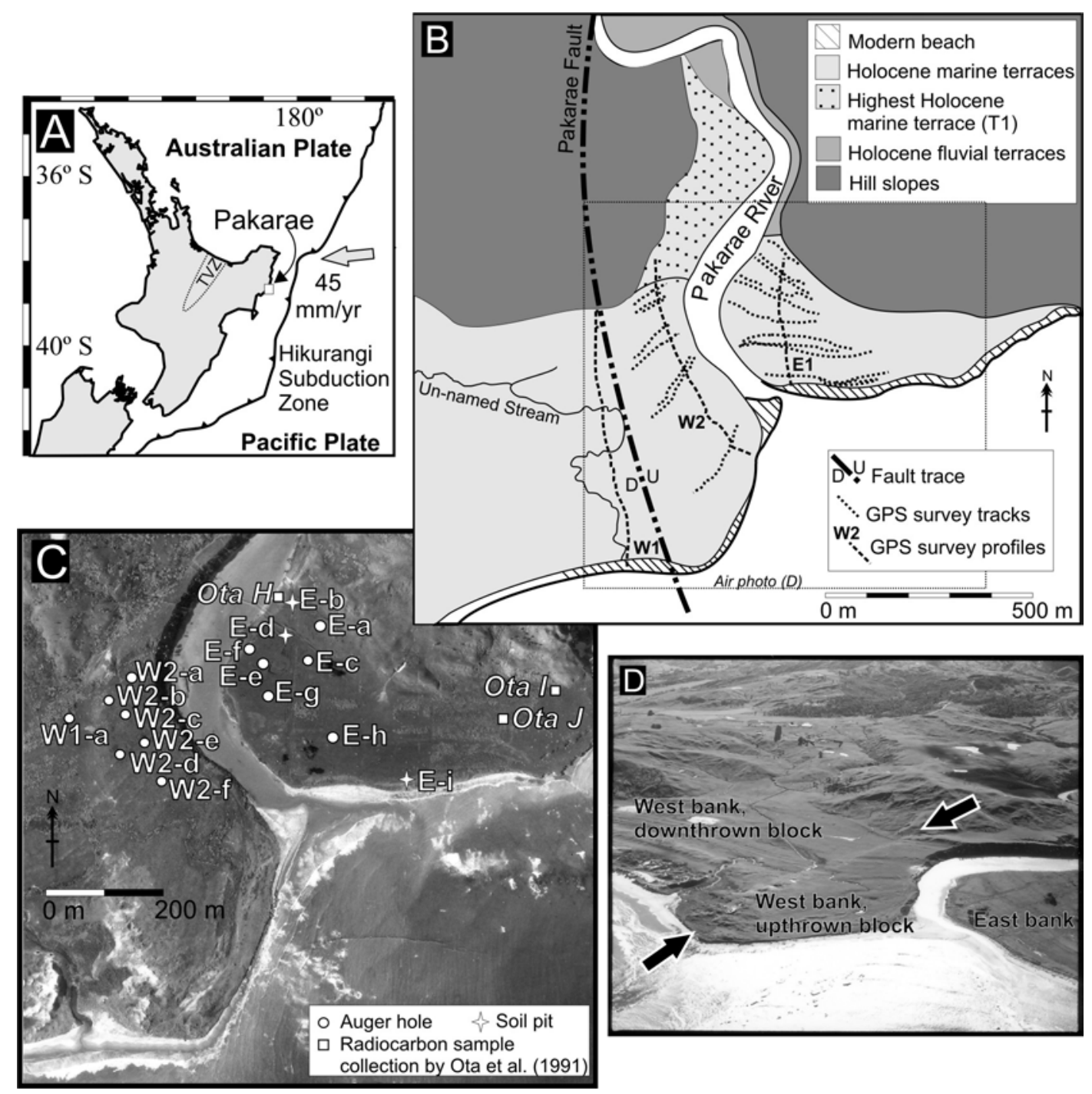

Figure 2.1: The Pakarae River mouth locality. (A) Location map and the Hikurangi subduction zone, North Island New Zealand. Arrow shows the relative plate motion vector from De Mets et al. (1994). (B) Major geomorphic features of the Pakarae River mouth and GPS survey lines referred to in text. (C) Locations of cover sediment profiles shown in Fig. 2.2. Points "Ota ..." are radiocarbon date collection locations of Ota et al. (1991) referred to in text. (D) Oblique aerial photo of the Pakarae River mouth showing the geomorphology of the Pakarae fault (arrowed). 
the coast (Ota et al. 1991). The timing of uplift of each terrace was estimated from tephra coverbed distribution and radiocarbon ages of shells collected close to the wave-cut strath. Shells from T1-T6 were collected for radiocarbon dating either from natural river bank exposures of the marine terrace cover beds on the west bank, or from soil pits excavated on the east bank. T7 was dated by correlation to the lowest terrace at Waihau Bay, $15 \mathrm{~km}$ north of Pakarae, which is overlain by sea-rafted Loisells Pumice. Originally thought to be uniformly <700 yrs B.P. (McFadgen, 1985), this pumice is now acknowledged to be diachronous at different sites around the New Zealand coastline (Shane et al., 1998).

As part of a broader study at Pakarae we collected new information on terrace elevation, cover bed stratigraphy, including tephra, and ages of fossils in the terrace deposits. These new data provide the basis for revising the correlation of the terraces across the Pakarae River and for re-considering the timing and rates of Holocene coastal uplift. In this study we use three GPS elevation profiles across the terraces, sixteen terrace cover sediment profiles and three new radiocarbon ages to revise the original terrace distribution and chronology detailed by Ota et al. (1991). The geomorphology and age of the raised terraces allow inferences to be made of the types of faults are most likely to have played a key role in the uplift of this coast.

\subsection{Methods}

In this study we use the following terminology: marine terraces refer to relict coastal erosion surfaces overlain by marine and non-marine cover sediments; risers separate the terraces. The term "wave-cut straths" refers to the surface cut by coastal erosion processes when the surface was approximately at MSL; the "terrace surface" refers to the modern surface of the terrace, which includes a certain thickness of cover sediments deposited since the sea abandoned the surface.

A microtopographic survey of the terrace surfaces was carried out using a Real Time Kinematic (RTK) GPS. The elevations have an uncertainty of $\pm 0.16 \mathrm{~m}$ at a $95 \%$ confidence interval. The perimeter of each terrace on the east bank and on the upthrown side of the fault on the west bank was surveyed. Linear profiles across all terraces were also made: one on the west bank on the downthrown side of the fault; two on the west bank, upthrown side of the fault; and three on the east bank (Fig. 
2.1B). Where multiple profiles were taken across the terraces the resultant profiles were so similar that we have adopted only one to use for further analysis - W2 and E1 (Fig. 2.1B).

The stratigraphy of the terrace sediment cover was determined at sixteen locations using a hand auger or soil pits (Fig. 2.1C). Cover bed sediments were described by a visual assessment of their colour and grain size (Fig. 2.2).

Our height correlations between the terraces are based on the elevation of the wavecut straths, which we obtained by subtracting the depth of cover sediment from the terrace surface elevation, as determined from the GPS. On approximately half of the terraces we had two measurements of the cover sediment thickness over the wave-cut strath, and there was always $<0.15 \mathrm{~m}$ difference between the two measurements (the average difference was $0.1 \mathrm{~m}$, Fig. 2.2). Given that $0.1 \mathrm{~m}$ is less than the elevation measurement uncertainty on each terrace, it was not deemed necessary to take more than one measurement of cover sediment thickness per terrace. To calculate the elevation of the wave-cut strath of the lowest terrace on the west bank we used the cover sediment thickness from the terrace above it as an approximate measure of the cover sediment thickness (Fig. 2.2). This assumption may result in a slight underestimation of the wave-cut strath elevation as there is a trend of decreasing cover sediment thickness with decreasing age. Therefore the lowest terrace probably has slightly less cover sediment than the one above it. Only one auger hole was taken on the downthrown side of the fault, this sampled the highest terrace. The auger hole reached the water table at $3 \mathrm{~m}$ and further sediment recovery was not possible. With the surface elevation of the terraces having an uncertainty of $\pm 0.16 \mathrm{~m}$ and the cover sediment thickness variation $<0.15 \mathrm{~m}$, we believe $\pm 0.5 \mathrm{~m}$ is a conservative estimate of the uncertainty at a $95 \%$ confidence interval for the elevation of each of the wave cut straths at the Pakarae River mouth.

Shell material was collected for radiocarbon dating from all auger holes and soil pits (Figs. 2.2 and 2.3). We always collected shells from as close as possible to the wavecut strath. These shells occur within coarse sand and mudstone-clast gravels that represent the paleo-beach deposits at the time the terrace was being cut. Whole shells were collected if present, otherwise well-preserved shell fragments were collected. The shell species have been identified when possible (Fig. 2.3). Accelerator mass 
spectrometer (AMS) radiocarbon ages of shells were provided by Rafter Radiocarbon Laboratory, GNS Science. We chose to only date terraces that had the highest age uncertainty, as most of the terraces have been previously dated by Ota et al. (1991). The radiocarbon ages of Ota et al. (1991) have been calibrated for use in this study using the marine calibrations of Hughen et al. (2004). All radiocarbon ages will be presented as the 2-sigma age estimate in calibrated years before present (cal. yrs B.P.). Tephra was identified by its physical characteristics, age relationships and comparison with tephra isopach maps of Vucetich and Pullar (1964).

\subsection{Results}

\subsubsection{Marine terrace characterisation}

RTK GPS profiles oriented approximately normal to the terraces show distinctive staircase topography with flat to gently sloping surfaces separated by steep risers (Fig. 2.2). From terrace profiles $\mathrm{W} 2$ and $\mathrm{E} 1$ we identified six terraces on the west bank and six terraces on the east bank of the Pakarae River. On the downthrown side of the Pakarae Fault (profile W1) separate terraces were not differentiated because they are covered by sand dunes (Fig. 2.2). Therefore, discussions of the west bank terraces refer to the upthrown side of the fault only.

Cover sediment thickness is greatest on the west bank; on both sides of the river there is a general decrease in cover sediment thickness with decreasing terrace elevation (Fig. 2.2). Cover sediment stratigraphy generally fines upwards. The basal deposits sit directly on the wave-cut strath and are everywhere coarse sand with shells (whole shells and shell hash) and mudstone-clast gravel (Fig. 2.2). Shell species in the beach deposits (Fig. 2.3) are mostly from rocky shore habitats and all are from intertidal environments (Morton and Miller, 1968; Marsden and Pilkington, 1995; Marsden, 2004; Morton, 2004). The beach deposits are overlain by well-sorted, massive medium sand barren of shells. This change from coarse shelly sand to medium unfossiliferous sand represents a transition between shoreface beach sands to aeolian sands. Dark brown topsoil has developed on the aeolian sand on all terraces. The depths of cover sediment that we measured on the east bank are similar to those of Ota et al. (1991). Both studies included the use of soil pits to measure sediment thickness above the wave-cut strath. On the west bank our measurements of cover 


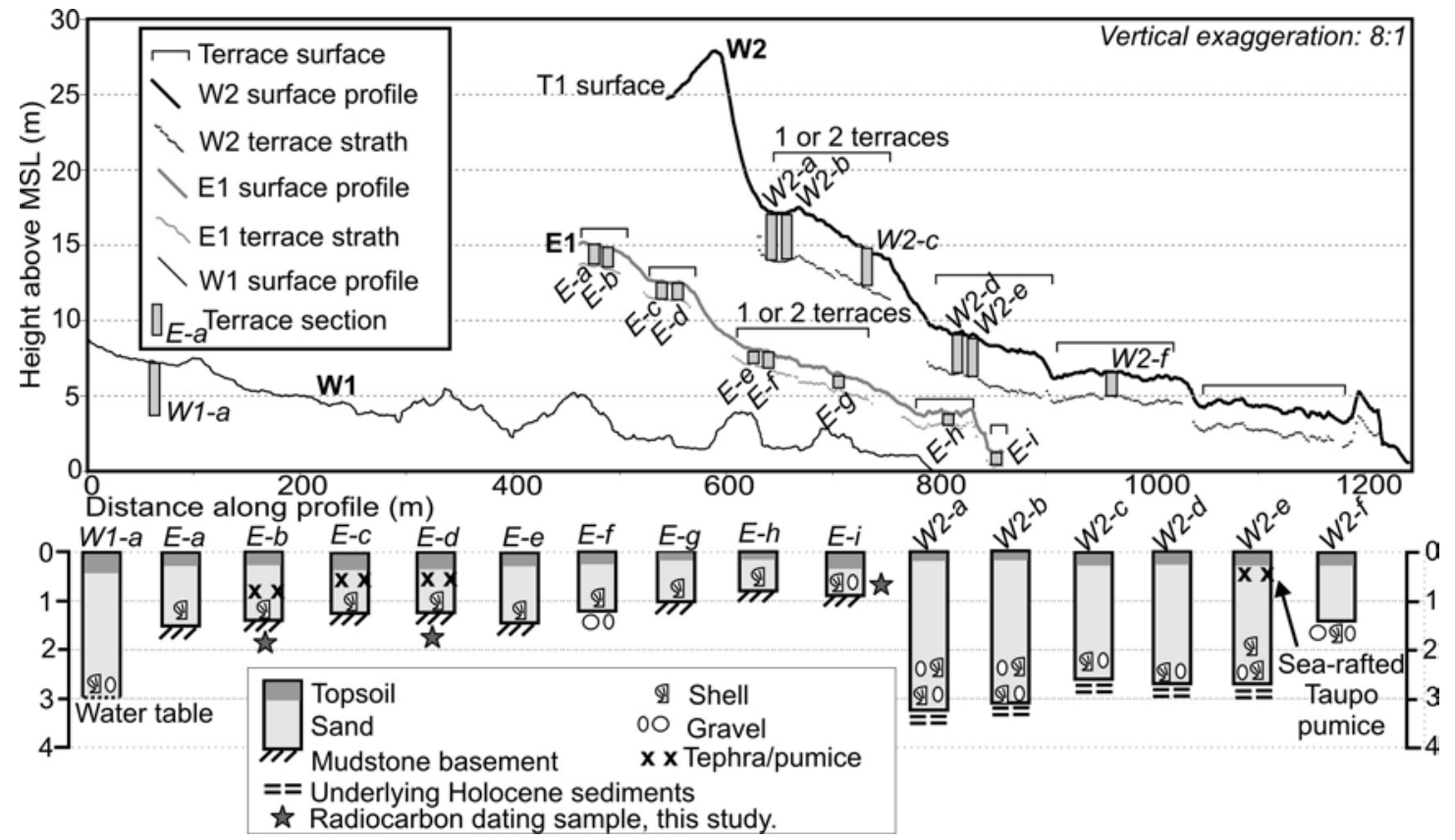

Figure 2.2: (Top) GPS height profiles across the Pakarae Holocene marine terraces, location of profiles shown on Fig. 2.2.1. Profiles W2 and E1 have the terrace straths plotted based on the amount of cover material on each terrace, location of the soil pits and auger holes shown. Profile E2 not shown as it is very similar to E1. See text for discussion of the GPS elevation uncertainties. (Below) Simplified cover bed stratigraphy on the Holocene marine terraces from soil pits and augering.
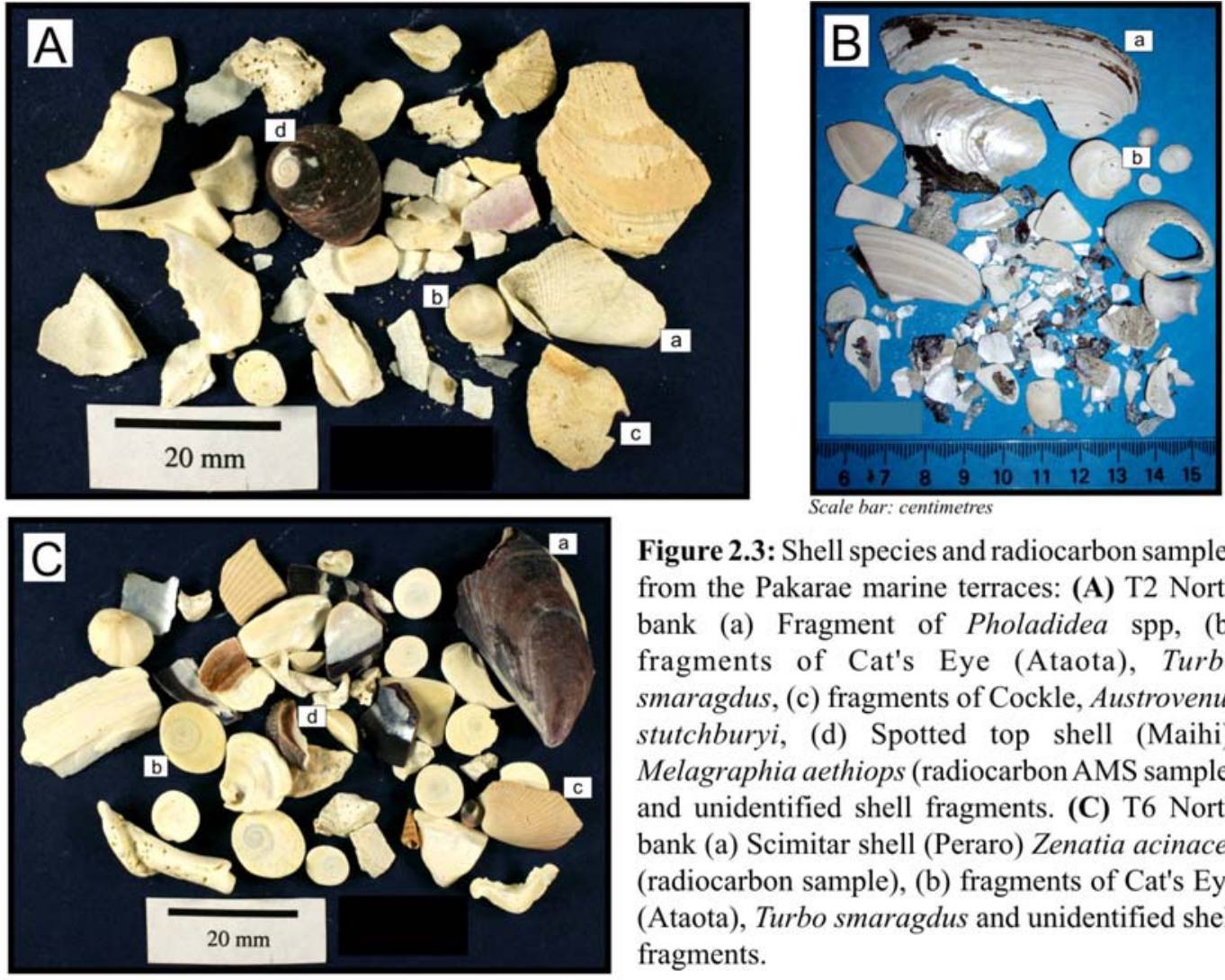

Figure 2.3: Shell species and radiocarbon samples from the Pakarae marine terraces: (A) T2 North bank (a) Fragment of Pholadidea spp, (b) fragments of Cat's Eye (Ataota), Turbo smaragdus, (c) fragments of Cockle, Austrovenus stutchburyi, (d) Spotted top shell (Maihi), Melagraphia aethiops (radiocarbon AMS sample) and unidentified shell fragments. (C) T6 North bank (a) Scimitar shell (Peraro) Zenatia acinaces (radiocarbon sample), (b) fragments of Cat's Eye (Ataota), Turbo smaragdus and unidentified shell fragments.

(B) T3 North bank (a) Blue mussel (Toretore), Mytilus edulis galloprovincialis, (radiocarbon AMS sample), (b) fragments of Cat's Eye (Ataota), Turbo smaragdus, (c) fragments of Cockle, Austrovenus stutchburyi, (d) Spotted top shell (Maihi), Melagraphia aethiops and unidentified shell fragments. 
sediment thickness are significantly less than Ota et al. (1991) (cf. second highest terrace: our study - $3.2 \mathrm{~m}$, Ota et al., $1991-5 \mathrm{~m}$ ). The difference is because we obtained sediment thickness in the middle of the terrace surface, whereas Ota et al. (1991) used outcrops along the riverbank. Our recent observations along the riverbank reveal that much of it has slumped and therefore these outcrops overestimate the thickness of sediment and underestimate the elevation of the wave-cut strath.

\subsubsection{Terrace ages}

Three new shell radiocarbon ages from the east bank were obtained: from the highest $(14 \mathrm{~m})$, second highest $(11.5 \mathrm{~m})$ and the lowest $(1 \mathrm{~m})$ terraces (Fig. 2.2, Table 2.1). The two highest terraces on the east bank have a mantle of Waimihia Tephra (3430 3470 cal. yrs B.P.; Froggatt and Lowe, 1990). This tephra is identified by its age relationship to the highest terrace (i.e. must be $<$ ca. 7,000 cal. yrs B.P., the time of eustatic SL stabilisation, Gibb, 1986) and its coarse lapilli texture. The middle terrace of the west bank has a layer of sea-rafted pumice clasts within the sand (section W2c). We identify this as the Taupo Pumice based on its age relationships to the terraces and other known occurrences of this pumice along the east coast of the North Island. These rounded pumice clasts are up to $5 \mathrm{~cm}$ in diameter; they are probably a stormdeposit and indicate that the terrace is older than the age of the Taupo eruption at 1718 cal. yrs B.P. (Sparks et al., 1995).

\subsection{Discussion}

\subsubsection{Terrace correlation and chronology}

Revised terrace correlations across the Pakarae River are primarily based on new data on the elevation of the wave-cut straths, and the additional age data presented here. We consider the elevation of the wave-cut strath is the most reliable feature for correlating the terraces because the point of maximum wave erosion would have been simultaneously at equal elevation on both sides of the river when the strath was cut. 
Table 2.1: Radiocarbon age data collected during this study from the Pakarae marine terraces.

\begin{tabular}{|c|c|c|c|c|c|c|c|c|}
\hline 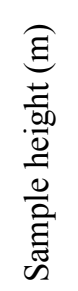 & 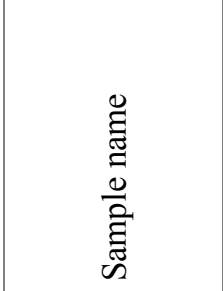 & 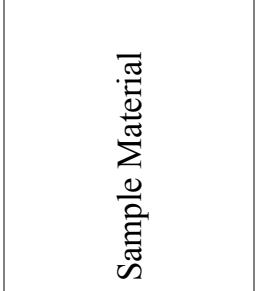 & 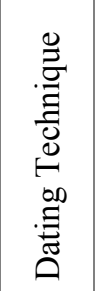 & $\underbrace{e_{0}^{d}}_{0}$ & 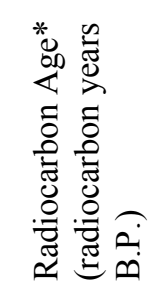 & 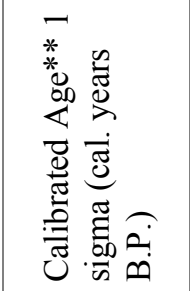 & 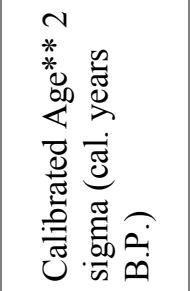 & 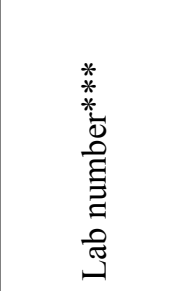 \\
\hline 14 & $\begin{array}{c}\text { East highest } \\
\text { terrace }\end{array}$ & $\begin{array}{c}\text { Shell, } \\
\text { Melagraphia } \\
\text { aethiops }\end{array}$ & AMS & 1.33 & $4148 \pm 30$ & $4337-4209$ & $4391-4138$ & NZA 22657 \\
\hline 11.5 & $\begin{array}{c}\text { East } 2^{\text {nd }} \\
\text { highest terrace }\end{array}$ & $\begin{array}{c}\text { Shell, Mytilus } \\
\text { edulis } \\
\text { galloprovincialis }\end{array}$ & AMS & 0.52 & $3582 \pm 30$ & $3558-3448$ & $3610-3403$ & NZA 22659 \\
\hline 1 & $\begin{array}{c}\text { East lowest } \\
\text { terrace }\end{array}$ & $\begin{array}{c}\text { Shell, Zenatia } \\
\text { acinaces }\end{array}$ & AMS & -8.48 & $2078 \pm 30$ & $1732-1629$ & $1802-1582$ & NZA 22658 \\
\hline
\end{tabular}

* Conventional radiocarbon age before present (1950 AD) after Stuiver and Polach (1977).

** Marine calibration in calendar years after Hughen et al. (2004). 1 sigma range (68\% probability) and 2 sigma range (95\% probability) reported.

*** NZA: Institute of Geological and Nuclear Sciences Rafter Radiocarbon Laboratory.

One potential problem with correlating wave-cut strath elevations across the river is the possible influence of tilting due to movement on the Pakarae or other faults. Projections of the terrace surface elevations to an east-west plane striking approximately normal to the Pakarae Fault show a small gradient $\left(0.19^{\circ}, 3.36 \mathrm{~m} / \mathrm{km}\right)$ of terrace tilt towards the west (Fig. 2.4A). This gradient is not steep enough to affect terrace correlations across the $\sim 100$ m wide Pakarae River. Ota et al. (1991) also documented westward tilt normal to the Pakarae fault. However, they interpreted this as evidence of landward tilt. We prefer to use a plane striking parallel to the Pakarae River and approximately normal to the Hikurangi subduction margin to detect landward tilt of the terraces (Fig. 2.4). Projections of the terrace surface elevations to this plane show $0.23^{\circ}$ of tilt (a gradient of $4.13 \mathrm{~m} / \mathrm{km}$ ) towards the northwest (Fig. 2.4).

Our terrace correlations indicate the presence of seven distinct terraces (Fig. 2.5). This is the same number as Ota et al. (1991); however, our terrace distribution and correlation is significantly different ( $c f$. Fig. $2.5 \mathrm{~B}$ and $2.5 \mathrm{C}$ ). In several cases there are 
conflicting radiocarbon ages from, what are interpreted to be, the same terrace. We resolve this by recognising that tephra provides an age constraint that can help distinguish which radiocarbon ages is more likely to be correct. We then consider from where the radiocarbon samples were collected. Some samples collected by Ota et al. (1991) are from areas where the terraces are indistinct and difficult to map and correlate. Lastly, we give preference to younger radiocarbon ages. We cannot see a mechanism for transporting young radiocarbon material into the basal beach deposits of higher terraces yet there are several mechanisms for older radiocarbon material to be recycled onto lower terraces. The following details the nomenclature, correlation and distribution of each terrace from oldest (T1) to youngest (T7):

T1: This terrace is present only on the west bank (Fig. 2.5B and 2.5C). Our interpretation is the same as that of Ota et al. (1991), being that this is the maximum Holocene SL transgression surface of $\sim 7$ ka (Gibb, 1986; Ota et al., 1992).

T2: This is the second highest terrace on the west bank and the highest terrace on the east bank (Fig. 2.5C). It was previously mapped as T3 on the east bank by Ota et al. (1991) because it had a younger radiocarbon age than the terrace of similar elevation on the west bank terrace $(6410-6138$ cal. yrs B.P. on the west bank vs. $4602-4130$ cal. yrs B.P. on the east bank, Ota et al., 1991). Our radiocarbon age of this terrace of $4391-4138$ cal. yrs B.P. on the west bank supports a younger terrace age of $\sim 4300$ cal. yrs B.P., this is also consistent with the presence of the Waimihia Tephra in the terrace cover sediments. We therefore revise the terrace correlation in spite of the age difference inferred by Ota et al. (1991) because the wave-cut straths are almost identical in elevation ( $\sim 14 \mathrm{~m}$ AMSL) on both sides of the river. We interpret the older ( $\sim 6.3 \mathrm{ka})$ radiocarbon age obtained by Ota et al. (1991) from the west bank as a reworked shell.

T3: This terrace is the second highest terrace on the east bank but is less distinct on the west bank (Fig. 2.2). On the west bank, T3 has a significant surface gradient; however, this gradient is considerably less than that of the other risers and we infer it to be a modified terrace surface. In the field the terrace on the west bank is sufficiently clear that its perimeter could be mapped. The seaward edge of the slope of the wave-cut strath on the west bank is the same elevation as the wave-cut strath of T3 on the east bank, so we correlate these terraces. The steeper terrace slope observed on 


\section{Terrace gradient approximately normal the Pakarae Fault}
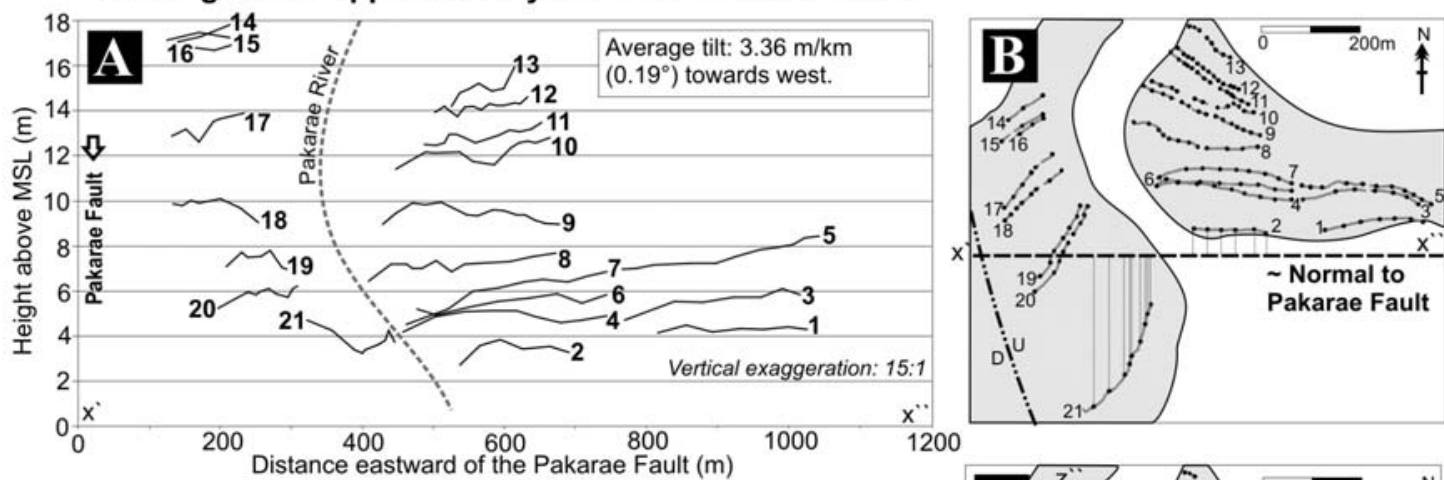

Terrace riser gradient approximately normal to subduction margin strike
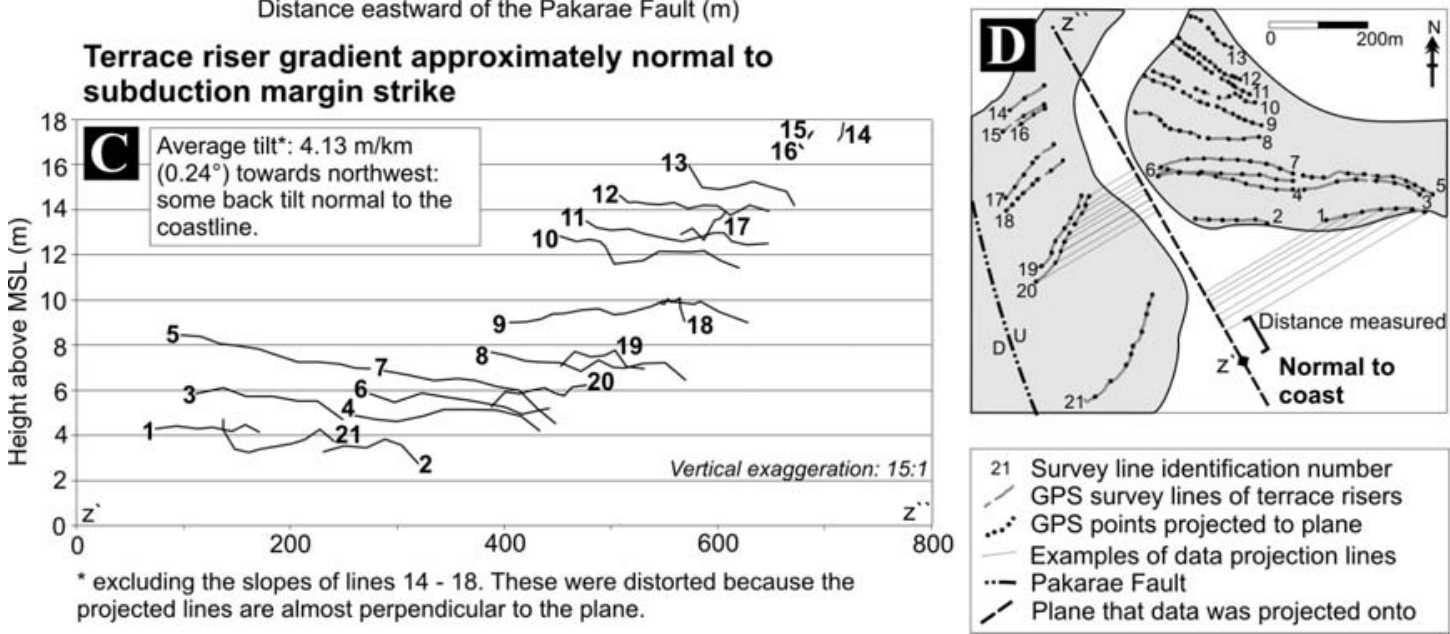

21 Survey line identification number GPS survey lines of terrace risers

$\therefore$ GPS points projected to plane Examples of data projection lines

Pakarae Fault

Plane that data was projected onto

Figure 2.4: Height profiles along the Pakarae terrace risers. Riser heights are projected to a plane approximately normal to the Pakarae Fault $(\mathbf{A}, \mathbf{B})$ and to a plane approximately normal to the Hikurangi subduction margin $(\mathbf{C}, \mathbf{D})$. This tests whether the terraces are back tilted relative to the Pakarae Fault of the subduction margin. 


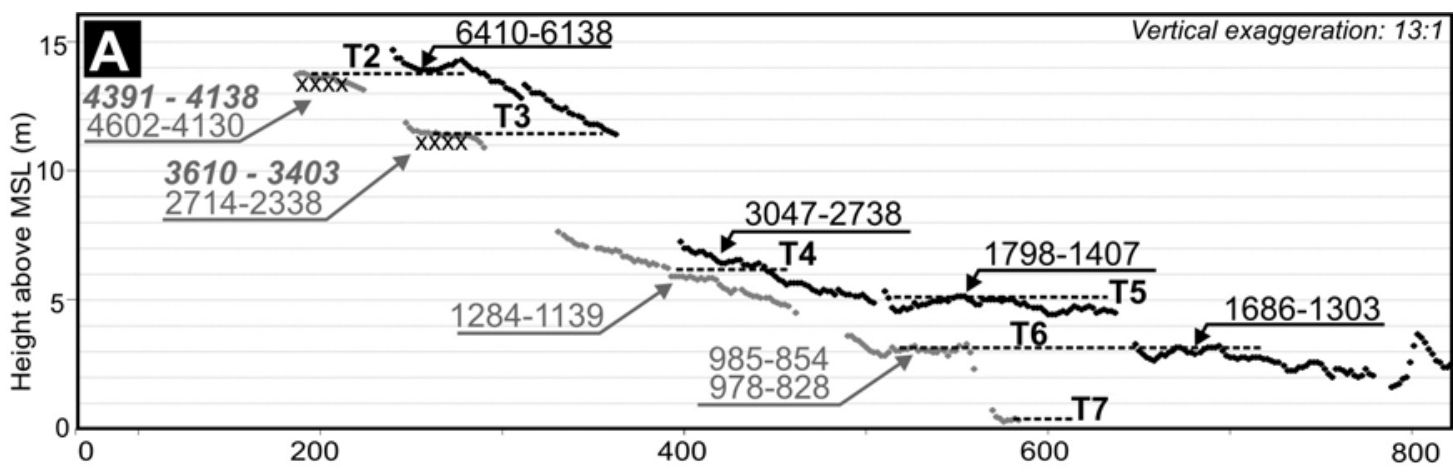

\begin{tabular}{|llll|}
\hline & W2 terrace strath & 6402 & Radiocarbon date of Ota et al., 1991 (cal. yrs B.P.) \\
Exxx & E1 terrace strath & 3610 & Radiocarbon date of this study (cal. yrs B.P.) \\
\hline
\end{tabular}
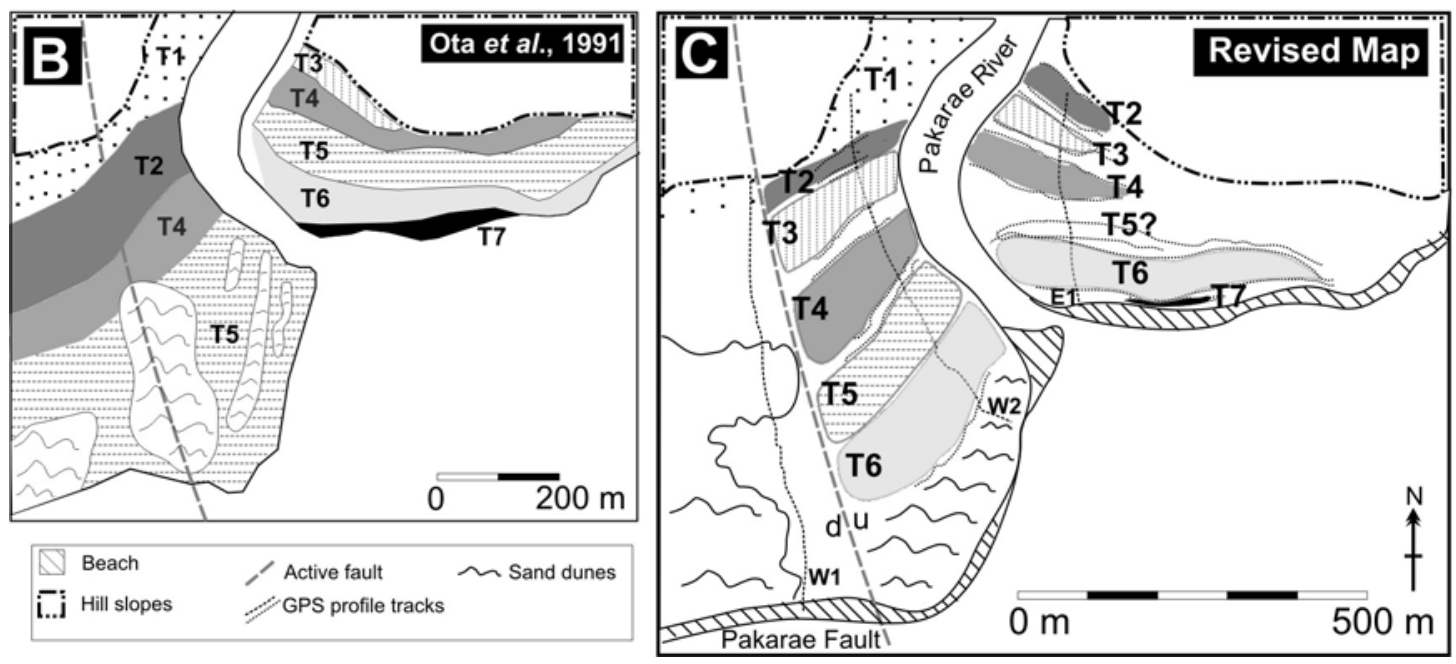

Figure 2.5: (A) Profiles showing wave-cut surface elevation with radiocarbon dates and surface correlation between the east and west banks of the Pakarae River. (B) Marine terrace distribution at Pakarae, original map by Ota et al., 1991. (C) Revised terrace distribution of this study. 
the west bank of T3 may result from either poor wave-cut strath planation or more likely due to aeolian sand accumulation towards the rear of the terrace, and this also explains why there is no riser separating T2 and T3 on the west bank. On the east bank T3 is mantled by the Waimihia Tephra (3430 - 3470 cal. yrs B.P) and we obtained a shell radiocarbon age of 3610 - 3403 cal. yrs B.P. An age of $2714-2338$ cal. yrs B.P. was obtained by Ota et al. (1991). We prefer our radiocarbon age as an estimate of the age of the second highest terrace because it is compatible with the presence of the overlying Waimihia Tephra. Also, the location of Ota et al.'s sample yielding the $2714-2338$ cal. yrs B.P. age is further away from the river mouth than our sample, therefore correlation of their sample to T3 has a higher uncertainty ( $c f$. points "E-d" and "Ota I", Fig. 2.1D). To the east the terrace morphology and location of terrace risers become less distincte. For this reason, we could not map the terrace distribution in this eastern area (Fig. 2.5C). It is possible the young age of Ota et al. (1991) is not from a correlative terrace of the second highest terrace as defined by us close to the river. Ota et al. (1991) previously mapped T3 only on the east bank where it was their highest terrace (Fig. 2.5B). We revise this in light of our new age estimates of the terrace and our data on the wave-cut strath elevations (Fig. 2.5C).

T4: This terrace is the middle terrace on both banks. Our mapping agrees with Ota et al. (1991) on the west bank but not on the east bank where they called it T5 (Fig. 2.5B and $5 \mathrm{C}$ ). We found scattered sea-rafted Taupo pumice clasts on this terrace on the west bank, as did Ota et al. (1991). They also found the same clasts on what we are calling T4 on the east bank, but despite this they mapped it as T5 on the east side. That Ota et al. (1991) mapped these as different terraces is plausible given that the sea-rafted pumice can be of diachronous age and deposited by storm waves some distance from the shoreface, but the simplest interpretation in our view is that these terraces are the same age. The terrace surface of $\mathrm{T} 4$ is relatively wide and gently sloping with the mid point of the wave-cut strath at $\sim 6 \mathrm{~m}$ AMSL on both banks. Another distinctive feature common to the T4 terrace on both sides of the river is that the riser on the landward side of the terrace is particularly high; $4 \mathrm{~m}$ compared to typical $2-2.5 \mathrm{~m}$ riser heights for other terraces (Fig. 2.2). Ota et al. (1991) obtained a radiocarbon date of $3047-2738$ cal. yrs B.P. from this terrace on the west bank and 1284 - 1139 cal. yrs B.P. on the east bank. The presence of Taupo pumice (erupted 1718 cal. yrs B.P., Sparks et al., 1995) as a storm beach deposit constrains the terrace 
age to the older date because pumice would occur as part of the basal beach deposit if the younger age were correct. The east bank radiocarbon sample was collected from a location far to the east of the river mouth (point "Ota-J", Fig. 2.1), where the terraces are indistinct and this sample may date a terrace younger than T3. For these reasons we prefer to use the older radiocarbon age of $3047-2738$ cal. yrs B.P. as the age of this terrace.

T5: This terrace is distinctive on the west bank but poorly developed or preserved on the east bank (Fig. 2.2, Fig. 2.5). On the west bank, T5 is wide and gently sloping with sharp $1-2 \mathrm{~m}$ risers above and below. Ota et al. (1991) also mapped this surface as T5 (Fig. 2.5B); however, their T5 is wider than our definition of T5 (Fig. 2.5C). This narrowing of T5 between interpretations is because we have subdivided Ota et al.'s T5 into T5 and T6 terraces. Both our profiles and that of Ota et al. (1991) show a step in the surface topography at our T5/T6 riser; however, Ota et al. (1991) did not split the terrace here apparently because the lower section yielded a similar radiocarbon date to the upper one (1783 - 1418 cal. yrs B.P. upper strath, 1680 - 1307 cal. yrs B.P. lower strath). We do not have any auger holes from the lower surface to verify that there is a step down in the wave-cut strath elevation but the surface topography is clearly stepped and therefore we have divided the terrace into two. The radiocarbon date of Ota et al. (1991) from the lower strath may have been derived from a reworked shell. On the east bank the profile of E1 between T4 and T6 is gently sloping with only a small riser at the front edge of T4. We do not map a terrace here because the morphological expression is indistinct; however, the wide gap between T4 and T6 suggests that significant time elapsed between the formation of these terraces. We therefore suggest that T5 is also present on the east bank where it was either weakly developed or has been poorly preserved as a result of aeolian deposition or riser scarp erosion. We retain the age of 1798- 1407 cal. yrs B.P. collected by Ota et al. (1991) for this terrace.

T6: As discussed above we have evidence from surface morphology for an additional terrace on the west bank that we call T6 (Fig. 2.5C). On the east bank our T6 is equivalent to that of Ota et al. (1991) (Fig. 2.5B). Two radiocarbon samples obtained by Ota et al. (1991) from the east bank, close to the river mouth, date the terrace at $985-854$ and $978-828$ cal. yrs B.P. 
T7: T7 occurs as a thin strip on the east bank. Our mapping of this terrace agrees with that of Ota et al. (1991) (Fig. 2.5B and 2.5C). The age of this terrace was previously estimated by correlation to a terrace $15 \mathrm{~km}$ north along the coast, which has the Loisells Pumice on it. The Loisells Pumice is no longer thought to be everywhere $<600$ years (Shane et al., 1998) so the age assigned to T7 needs to be re-considered. We obtained a shell sample from the mudstone platform and it was radiocarbon dated at 1802 - 1582 cal. yrs B.P. (Fig. 2.3, Table 2.1). Given the ages of $985-854$ and 978 - 828 cal. yrs B.P. for T6 we suspect that our shell sample was reworked. It is possible that $\mathrm{T} 7$ is also present on the west bank, however dune sands probably obscure its morphology (Figs. 1 and. 2).

\subsubsection{Tectonic uplift rates}

We agree with Ota et al. (1991) that each terrace was formed by a sudden uplift event that caused the abandonment of the wave cut surface by the sea (see Ota et al., 1991, for discussion). The New Zealand Holocene eustatic SL curve shows that, since the $\sim 7$ ka culmination, SL has remained near its modern position with only minor fluctuations of the order of $<0.5 \mathrm{~m}$ (Gibb, 1986). We can therefore assume that the present elevation of each terrace above modern mean SL is due almost entirely to tectonic uplift. We also agree with Ota et al. (1991) that radiocarbon ages of shells from the abrasion platform are likely to be (at least) slightly older than the timing of uplift and their abandonment, assuming that uplift caused the death of the organism. We use these ages to approximate the time of uplift.

Our revised terrace ages are summarised in Table 2.2. If the elevation of each terrace represents the amount of tectonic uplift since its formation and abandonment and we assume that the wave-cut strath approximately represents mean SL, we can use the terrace data to calculate mean coastal uplift rates through time at this site. The mean uplift rates appear to have been remarkably uniform since $\sim 7 \mathrm{ka}$. We calculate an average rate of $3.2 \pm 0.8 \mathrm{~mm} \mathrm{yr}^{-1}$ (Fig. 2.6, Table 2.2). From T2 to T7 each terrace probably represents one uplift event; the average time interval between events is 850 $\pm 450 \mathrm{yrs}$ and the average magnitude is $2.7 \pm 1.1 \mathrm{~m}$ per event (these are maximum values, it is possible that terraces produced by smaller events have not been 
preserved). It is clear that uplift at Pakarae is not as irregular, in timing or magnitude, as previously thought (Fig. 2.6).

Table 2.2: Age-elevation relationships between the Pakarae River marine terraces including average uplift rates.

\begin{tabular}{|c|c|c|c|c|c|c|c|c|}
\hline 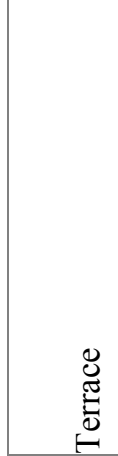 & 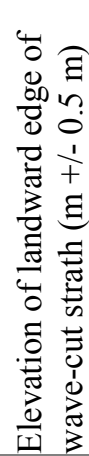 & 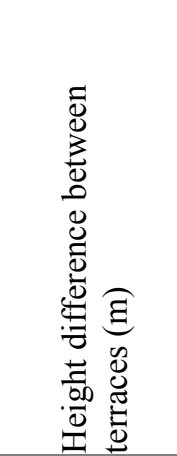 & 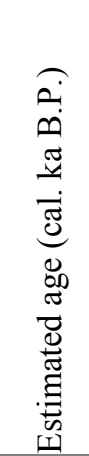 & 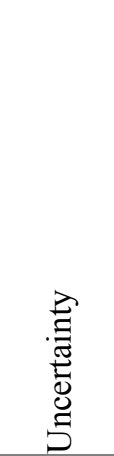 & 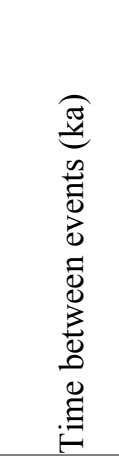 & 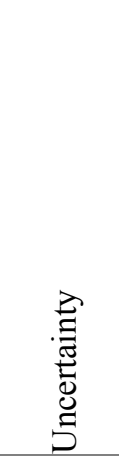 & 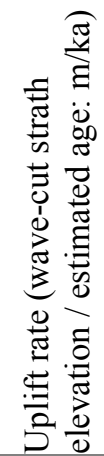 & 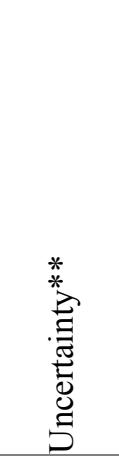 \\
\hline T1 & 24 & & $7^{a}$ & \pm 0.3 & & & 3.43 & \pm 0.14 \\
\hline T2 & 13.8 & 10.2 & $4.32^{\mathrm{b}}$ & \pm 0.24 & 2.68 & \pm 0.38 & 3.19 & \pm 0.19 \\
\hline T3 & 11.5 & 2.3 & $3.51^{\mathrm{c}}$ & \pm 0.1 & 0.81 & \pm 0.26 & 3.28 & \pm 0.16 \\
\hline T4 & 7.5 & 4 & $2.89^{\mathrm{d}}$ & \pm 0.15 & 0.62 & \pm 0.18 & 2.59 & \pm 0.23 \\
\hline T5 & 5 & 2.5 & $1.6^{\mathrm{e}}$ & \pm 0.2 & 1.29 & \pm 0.25 & 3.13 & \pm 0.47 \\
\hline T6 & 3 & 2 & $0.91^{\mathrm{f}}$ & \pm 0.07 & 0.69 & \pm 0.21 & 3.29 & \pm 0.59 \\
\hline T7 & 0.5 & 2.5 & - & & - & & & \\
\hline \multicolumn{2}{|l|}{ Average } & $2.66^{*} \pm 1.1^{+}$ & & & $0.85^{*}$ & $\pm 0.45^{+}$ & 3.15 & $\pm 0.83^{+}$ \\
\hline \multicolumn{2}{|c|}{ Standard deviation } & $0.78^{*}$ & & & $0.29 *$ & & 0.29 & \\
\hline
\end{tabular}

* $\quad$ Calculations do not include difference between T1 and T2.

** $\quad$ Uncertainty $=\sqrt{ }\left[(\% \text { elevation error })^{2}+(\% \text { age error })^{2}\right]$

$+\quad$ Uncertainty $=\sqrt{ }\left[\left(\right.\right.$ error $\left.^{2}\right)+\left(\right.$ error $\left.\left.^{2}\right)+\ldots.\right]$

a Eustatic SL stabilisation from Gibb, 1986, estimated uncertainty.

Radiocarbon dates from T2, this study and Ota et al, 1991: $(4391+4138+4602+4130) / 4$, uncertainty is the larger half difference between the 2 sigma calibrated age of the two samples. Mid point 3610-3403 cal. yrs B.P., this study, uncertainty is half the difference between the 2 sigma calibrated ages

Mid point 3047-2738 cal. yrs B.P., Ota et al, 1991, uncertainty is half the difference between the 2 sigma calibrated ages

Mid point 1798-1407 cal. yrs B.P., Ota et al, 1991, uncertainty is half the difference between the 2 sigma calibrated ages

Radiocarbon ages from T6, Ota et al, 1991: $(985+854+978+828) / 4$, uncertainty is the larger half difference between the 2 sigma calibrated age of the two samples.

One major difference between our terrace distribution interpretation and that of Ota et al. (1991) is the age of our T2. Ota et al. (1991) assigned an age of 6410 B.P. to 6138 cal. yrs B.P. to this terrace, whereas we revise this to $\sim 4300$ cal. yrs B.P. This means that there is more time between the formation of $\mathrm{T} 1$ and $\mathrm{T} 2$ in our revision. The age assignment of Ota et al. (1991) has an age difference of 1670 - 830 yrs between T1 and T2; this study has an age difference of 3210 - 2170 yrs. This change reconciles 
better with the very high riser height $(10.2 \mathrm{~m})$ between these two terraces. Between $\mathrm{T} 1$ and T2 we believe more than one uplift event occurred to account for the high terrace riser. It is unrealistic that a $10.2 \mathrm{~m}$ riser was created by a single event when the average riser height of all the younger terraces is $\sim 2.7 \mathrm{~m}$. Terraces may have formed in the period between T1 and T2 ( 7000 to 4300 cal. yrs B.P.), but were subsequently eroded.

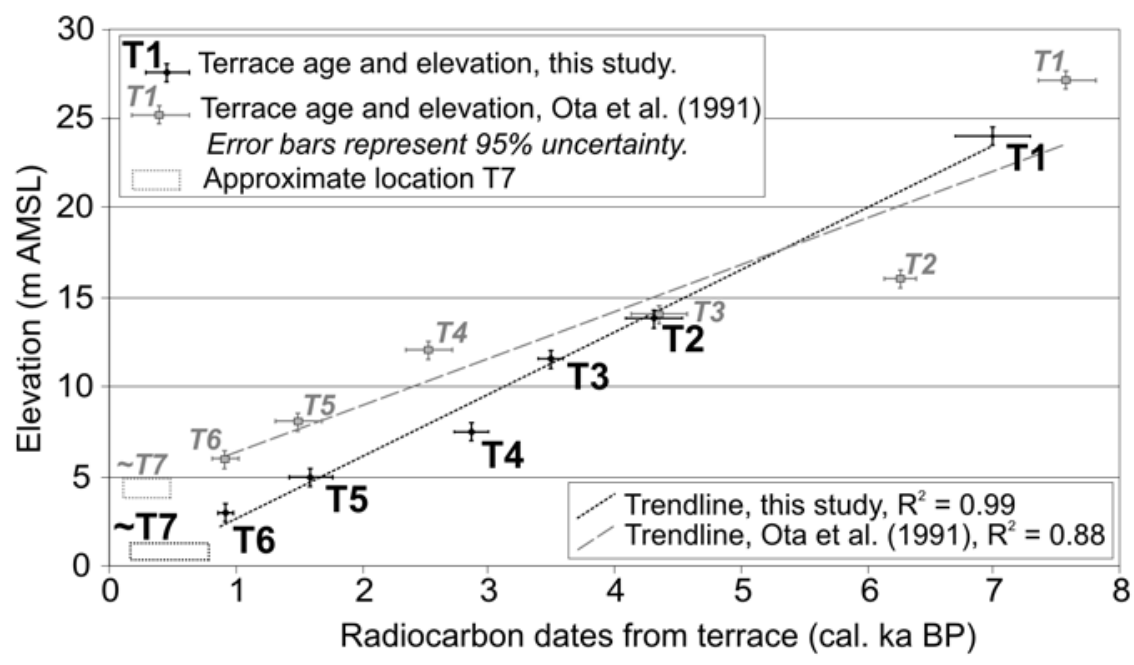

Figure 2.6. Radiocarbon dates from terraces $\mathrm{T} 1$ - T7 vs. elevation. Data from this study in black (see Table 2.2), data from Ota et al. (1991) in grey. Trendlines and R2 values shown. The ages of Ota et al. (1991) were calibrated (Hughen et al., 2004), the value shown here is the mid-point of the 2-sigma calibrated age.

\subsubsection{Pakarae terrace uplift and the role of the Pakarae Fault}

We seek to investigate the tectonic structures that have driven the coastal uplift at Pakarae. We can use the geomorphology and ages of the terraces and compare them with block models of how terraces would form under differenct faulting scenarios. The presence of the Pakarae Fault scarp across the $<7$ ka Pakarae terrace sequence is indisputable evidence that this fault has moved during the Holocene. However, the N$\mathrm{S}$ strike of the fault and the presence of terraces on either side of the fault indicate it is not the sole cause of uplift of the marine terraces. Instead, we infer that the main cause of coastal uplift on both sides of the Pakarae Fault was slip on a westwarddipping offshore reverse fault. Other than the Pakarae Fault the onshore region 
contains no other known active faults except for the Waihau Bay Fault; which is a normal fault located $\sim 15 \mathrm{~km}$ north of Pakarae. Fault scaling relationships imply that with the short surface trace of the Waihau Bay Fault and its distance from Pakarae, it is unlikely this fault causes uplift at Pakarae. Slip on the subduction interface is not discussed as a possible cause of uplift here; preliminary dislocation modelling has indicated an unrealistic amount of slip on the subduction thrust is required to produce uplift of $\sim 2.7 \mathrm{~m}$ at Pakarae (Litchfield and Wilson, 2005). Sixty kilometres southsouth-west of Pakarae, the offshore Lachlan reverse fault, dipping $15-20^{\circ}$ northwest, is known to have caused coseismic uplift of Holocene marine terraces approximately 5 km westwards on the Mahia Peninsula (Berryman, 1993; Barnes et al., 2002). Although no such structure has so far been seismically imaged offshore of Pakarae, we suggest a similar reverse fault structure may have caused coastal uplift at Pakarae. A reverse fault has been mapped offshore of Pakarae by Lewis et al. (1997) and Mazengarb and Speden (2000) however this was based on an estimated location by Ota et al. (1991).

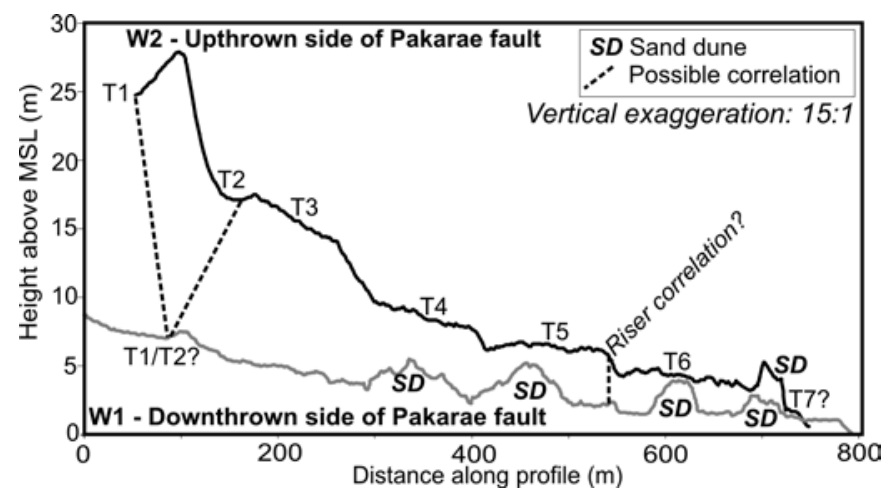

Figure 2.7. Comparison of the topographic profiles on the downthrown (W1) and upthrown (W2) sides of the Pakarae fault with possible correlation points.

Ota et al. (1991) also suggested the main fault driving the coastal uplift at Pakarae was a reverse fault located offshore. By correlation of terraces directly across the fault and comparison of riser heights, Ota et al. (1991) suggested the Pakarae Fault probably moved simultaneously with the uplift of the terraces, although not necessarily during every terrace uplift event, and that slip on this fault was not the 
primary cause of the regional coastal uplift. On the downthrown side of the Pakarae fault, our profile (W1, Fig. 2.2) does not show the "staircase topography" characteristic of the upthrown side of the fault; rather, it is characterised by gentle slopes and sharp sand dunes ridges (Fig. 2.2). Based on these data we cannot reliably correlate any terraces across the fault (Fig. 2.7) and suggest there are presently insufficient data to establish a relationship between Pakarae Fault movement and terrace formation; this differs from the observations of Ota et al. (1991). The terraces display a westward tilt, towards the Pakarae Fault, of $0.19^{\circ}$ (Fig. 2.4). This argues against significant involvement of the Pakarae Fault in terrace uplift because terraces in the footwall would be expected to have an eastward tilt away from the fault. The regional nature of the coastal uplift signal is corroborated by the similarity in the age of the marine terraces at Puatai Beach and Waihau Bay, 9 and $15 \mathrm{~km}$ north of Pakarae. Together these data sets imply a domal uplift pattern with a wavelength of uplift along the coast length of the coast of $>15 \mathrm{~km}$, as is consistent with slip on a major offshore fault striking parallel to the coast and dipping to the west-northwest (Ota et al., 1991).

We use a simple schematic block model with an offshore reverse fault striking parallel to the coastline and an onshore normal fault striking perpendicular to the coastline to assess the likely structures driving coastal uplift (Fig. 2.8). Flexural isostasy dictates that the majority of absolute movement during slip on normal faults occurs through subsidence of the hanging wall (e.g. Jackson et al., 1988). Under various combinations of fault movement our model shows that the Pakarae geomorphology is most compatible with an offshore fault as the primary driver of coastal uplift (Fig. 2.8), in agreement with the conclusions of Ota et al. (1991).

Slip on a NW-dipping offshore reverse fault would uplift both sides of the Pakarae Fault (Fig. 2.8A/1). Any synchronous or subsequent slip on the Pakarae Fault might be anticipated to cause subsidence of the downthrown block relative to MSL but not necessarily any significant vertical movement of the upthrown block relative to MSL (Fig. 2.8A/2). Vertical slip on the Pakarae Fault, in particular, subsidence of its downthrown block, must have been less than the regional uplift related to slip on the offshore reverse fault or else the western side of the fault would have been drowned due to net subsidence there, or be a flat coastal plain if coastal sedimentation rates 


\section{Starting configuration, terrace cross-section}

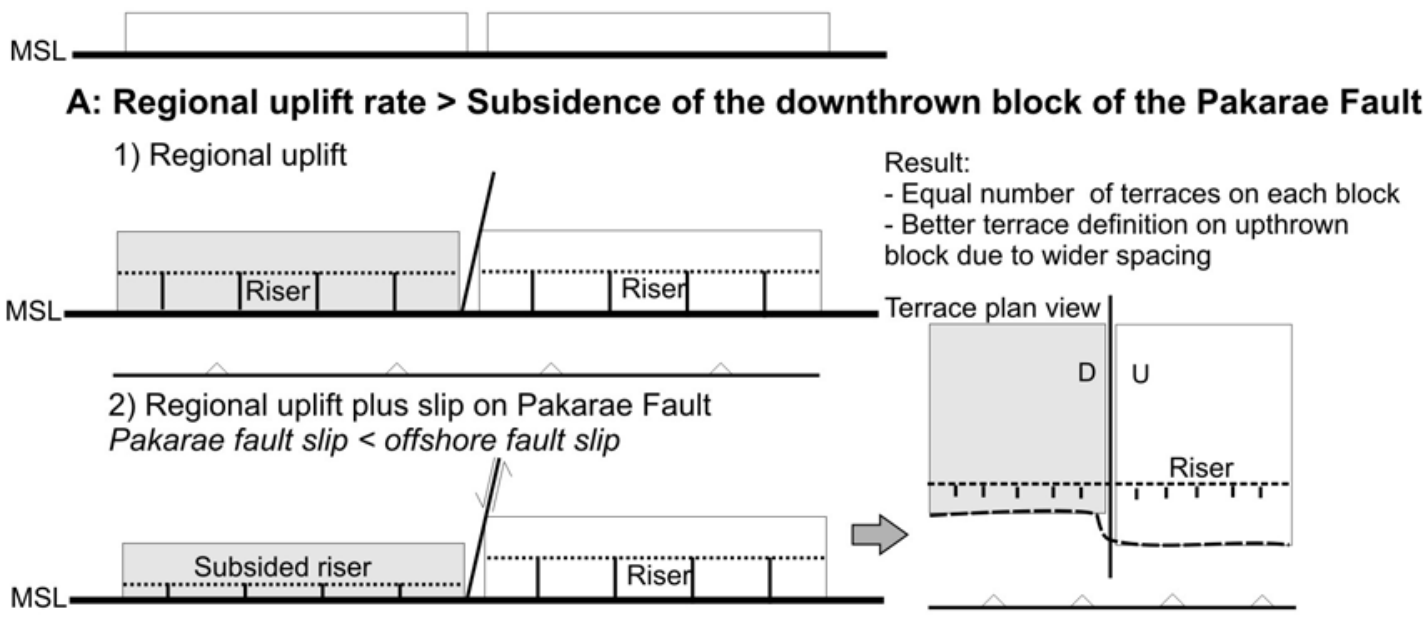

B: Regional uplift rate < Subsidence of the downthrown block of the Pakarae Fault
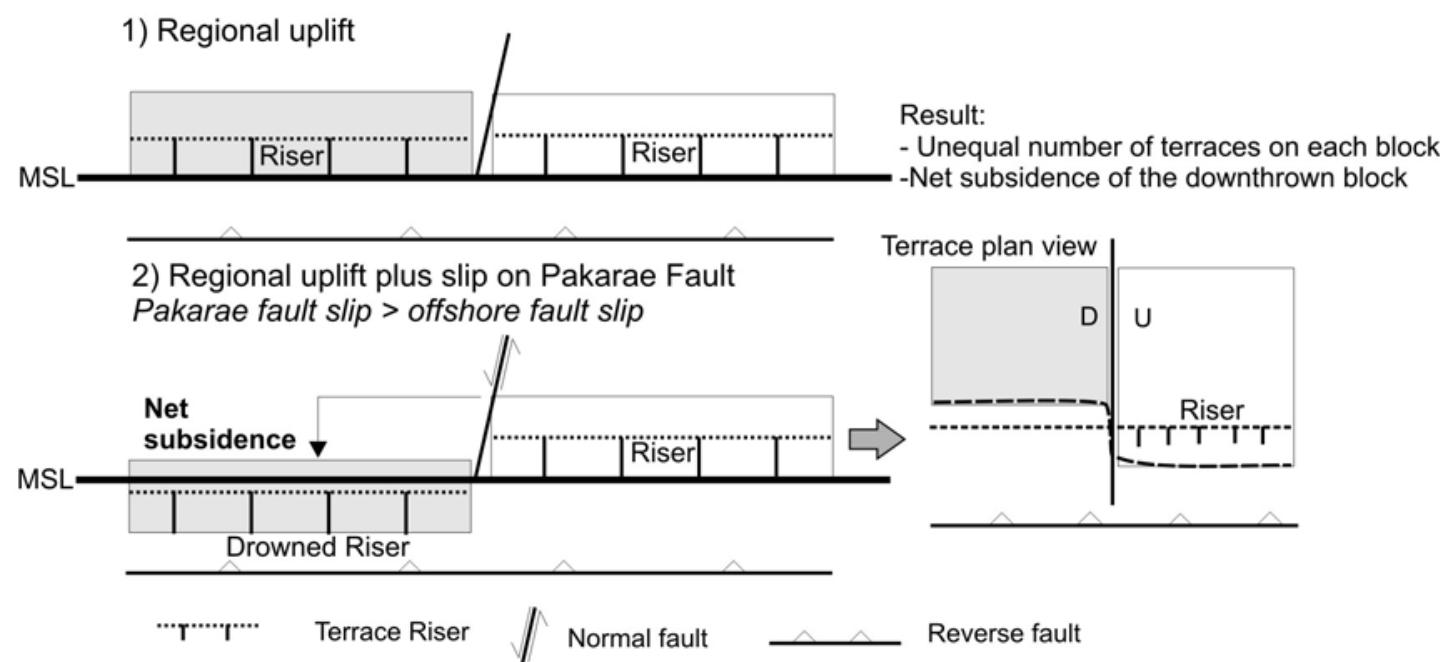

Figure 2.8: Block models of an offshore reverse fault parallel with the marine terraces causing regional uplift and a normal fault onshore perpendicular with the marine terraces. Two combinations of slip are shown, either regional uplift caused by the offshore fault is greater than dip-slip on the normal fault (A) or less than dip-slip on the normal fault (B). MSL = mean sea level. 
were high enough to infill the embayment created by such net subsidence (Fig. 2.8B). To produce a terrace flight geomorphology similar to that of Pakarae with a downthrown block raised above MSL, these models show that the coastal uplift rate related to slip on the offshore fault must have been greater than the dip-slip rate of the Pakarae Fault (Fig. 2.8). The landward tilt of the terraces is compatible with back-tilt on an offshore coast-parallel reverse fault (Fig. 2.4).

\subsection{Conclusions}

Our revision of the marine terrace distribution and chronology at Pakarae has shown that terrace formation and preservation on opposite sides of the Pakarae River are more uniform than previously described. Like Ota et al. (1991) we map seven terraces, from T1 (representing the maximum Holocene transgression, and present only on the west bank) to T7 (the youngest terrace, preserved only on the east bank). Terraces T2 - T6 are present on both sides of the river although T3 is indistinct on the west bank and T5 is indistinct on the east bank. New age data from the east bank indicates that T2 is $\sim 4300$ cal. yrs B.P., approximately 2000 yrs younger than the age of 6314 - 6195 cal. yrs B.P. assigned by Ota et al. (1991). Terrace uplift has been intermittent. Average time intervals between uplift events range from 1280 to $630 \mathrm{yrs}$ and incremental uplift ranges from $2-4 \mathrm{~m}$. Average Holocene uplift rates at Pakarae are relatively uniform over the past $7 \mathrm{ka}$ with a long term uplift rate of $3.2 \pm 0.8 \mathrm{~mm}$ $\mathrm{yr}^{-1}$.

This study illustrates the importance of using the wave-cut strath elevation for terrace correlation rather than relying upon surface morphology, which is subject to a range of post-formation changes, especially in the development of coverbeds. It also demonstrates how multiple ages from the same terrace are preferable to single ages, as we have several examples where shells used for radiocarbon dating gave different results from the same terrace and have probably, in part, been reworked from older terraces. Future work is needed at this site to refine the terrace chronology, particularly of $\mathrm{T} 7$, which is not yet satisfactorily dated. This is important because the elapsed time since the last coastal uplift event may be critical to assessing the current seismic hazard at this location. To evaluate the tectonic structure chiefly responsible for terrace formation we need to reliably correlate the terraces across the Pakarae 
Fault. Simplistic models indicates an offshore fault accommodates most or all of the coastal uplift with synchronous, or alternating smaller events on the Pakarae Fault causing relative subsidence of the western block of this normal fault.

\subsection{References}

Barnes, P. M., A. Nicol and T. Harrison (2002). "Late Cenozoic evolution and earthquake potential of an active listric thrust complex above the Hikurangi subduction zone, New Zealand." Geological Society of America Bulletin 114(11): 1379-1405.

Berryman, K. R. (1993). "Age, height, and deformation of Holocene terraces at Mahia Peninsula, Hikurangi subduction margin, New Zealand. 1." Tectonics 12(6): 1347-1364.

Berryman, K. R., Y. Ota and A. G. Hull (1989). "Holocene paleoseismicity in the fold and thrust belt of the Hikurangi subduction zone, eastern North Island, New Zealand." Tectonophysics 163: 185-195.

Berryman, K. R., Y. Ota and A. G. Hull (1992). "Holocene coastal evolution under the influence of episodoc tectonic uplift: examples from New Zealand and Japan." Quaternary International 15/16: 3145.

Collot, J.-Y., J. Delteil, K. Lewis, B. Davy, G. Lamarche, J.-C. Audru, P. Barnes, F. Chanier, E. Chaumillon, S. Lallemand, B. M. De Lepinay, A. Orpin, B. Pelletier, M. Sosson, Toussaint and C. Uruski (1996). "From oblique subduction to intra-continental transpression: structures of the southern Kermadec-Hikurangi margin from multibeam bathymetry, side-scan sonar and seismic reflection." Marine Geophysical Researches 18(2-4): 357-381.

De Mets, C., R. G. Gordon, D. F. Argus and S. Stein (1994). "Effect of recent revisions to the geomagnetic reversal timescale on estimates of current plate motions." Geophysical Research Letters 21: 2191-2194.

Froggatt, P. C. and D. J. Lowe (1990). "A review of late Quaternary silicic and some other tephra formations from New Zealand: their stratigraphy, nomenclature, distribution, volume and age." New Zealand Journal of Geology and Geophysics 33: 89-109.

Gibb, J. G. (1986). “A New Zealand regional Holocene eustatic sea-level curve and its application to determination of vertical tectonic movements, A contribution to IGCP-Project 200. Recent Crustal Movements of the pacific Region., Bulletin of the Royal Society of New Zealand”. 24: 377-395.

Hughen, K. A., M. G. L. Baillie, E. Bard, Beck, J. W. , C. J. H. Bertrand, P. G. Blackwell, C. E. Buck, G. S. Burr, K. B. Cutler, P. E. Damon, R. L. Edwards, R. G. Fairbanks, M. Friedrich, T. P. Guilderson, B. Kromer, G. McCormac, S. Manning, B. B. Ramsey, P. J. Reimer, R. W. Reimer, S. S. Remmele, J. R., M. Stuiver, S. Talamo, F. W. Taylor, J. van der Plicht and C. E. Weyhenmeyer (2004). "Marine04 Marine Radiocarbon Age Calibration, 0-26 Cal Kyr BP." Radiocarbon 46(3): 1059-1086.

Jackson, J. A., N. J. White, Z. Garfunkel and H. Anderson (1988). "Relations between normal-fault geometry, tilting and vertical motions in extensional terrains: an example from the southern Gulf of Suez." Journal of Structural Geology 10(2): 155-170.

Kingma, J. T. (1964). "Sheet 9, Gisborne (1st Ed.) Geological Map of New Zealand 1 : 250000 DSIR." Department of Scientific and Industrial Research, Wellington.

Lewis, K. (1980). Quaternary sedimentation on the Hikurangi oblique subduction and transform margin, New Zealand. Special Publication of the Institute of Professional Sedimentologists 4: 171-189. 
Lewis, K.B. and , J.R. Pettinga. (1993). The emerging, imbricate frontal wedge of the Hikurangi Margin, Ballance, P. F. (Editor). South Pacific Sedimentary Basins. Elsevier, pp. 225-250.

Lewis KB, Collot J-Y, Davy B, Delteil J, Lallemand S, Uruski C 1997. North Hikurangi GeodyNZ swath maps: depths, texture and geological interpretation 1: 500 000. National Institute for Water and Atmospheric Research Miscellaneous Series Chart 72. Wellington.

Litchfield N, Wilson K 2005. Holocene tectonic fluvial terraces at Pakarae River mouth, Gisborne region. Programme and Abstracts, Geological Society of New Zealand $50^{\text {th }}$ Annual Conference, Kaikoura New Zealand. Geological Society of New Zealand Miscellaneous Publication 119A, 45-46.

Marsden, I. D. (2004). "Effects of reduced salinity and seston availability on growth of the New Zealand little-neck clam Austrovenus stutchburyi." Marine Ecology Progress Series 266: 157-171.

Marsden, I. D. and R. Pilkington (1995). "Spatial and temporal variations in the condition of Austrovenus stutchburyi Finlay, 1927 (Bivalvia: Veneridae) from the Avon-Heathcote estuary, Christchurch." New Zealand Natural Sciences 22: 57-67.

Mazengarb, C. (1984). "The Fernside Fault: an active normal fault, Raukumara Peninsula, New Zealand." New Zealand Geological Survey Record 3: 98-103.

Mazengarb, C. (1998). "Late Neogene structural development of eastern Raukumara Peninsula: Implications for oil exploration." 1998 New Zealand Petroleum Conference Proceedings: 201 - 205.

Mazengarb, C. and I. G. Speden (Compilers) (2000). Geology of the Raukumara area, Institute of Geological \& Nuclear Sciences 1:250,000 Geological Map 6. Institute of Geological and Nuclear Sciences Limited, Lower Hutt, New Zealand.

McFadgen, B. G. (1985). "Late Holocene stratigraphy of coastal deposits between Auckland and Dunedin, New Zealand." Journal of the Royal Society of New Zealand 15: 27-65.

Morton, J. (2004). Seashore ecology of New Zealand and the Pacific, Hayward, B. W. (scientific editor), Bateman, Auckland.

Morton, J. and M. Miller (1968). The New Zealand sea shore. Collins, London.

Ota, Y., Ed. (1987). Holocene coastal tectonics of eastern North Island, New Zealand. A preliminary report on late Quaternary seismo-tectonic movement in the Circum Pacific area, 1st survery (1985/86).

Ota, Y and Yamaguchi. M 2004. Holocene coastal uplift in the western Pacific Rim in the context of Late Quaternary uplift. Quaternary International 120: 105-117.

Ota, Y., A. G. Hull and K. R. Berryman (1991). "Coseismic uplift of Holocene marine terraces in the Pakarae River area, eastern North Island, New Zealand." Quaternary Research 35: 331-346.

Ota, Y., K. R. Berryman, A. G. Hull, T. Miyauchi and N. Iso (1988). "Age and height distribution of Holocene transgressive deposits in eastern North Island, New Zealand." Palaeogeography, Palaeoclimatology, Palaeoecology 68: 135-151.

Ota, Y., A. G. Hull, N. Iso, Y. Ikeda, I. Moriya and T. Yoshikawa (1992). "Holocene marine terraces on the northeast coast of North Island, New Zealand, and their tectonic significance." New Zealand Journal of Geology and Geophysics 35: 273-288.

Shane, P., P. C. Froggatt, I. Smith and M. Gregory (1998). "Multiple sources for sea-rafted Loisels Pumice, New Zealand." Quaternary Research 49: 271-279.

Stuiver, M. and H. A. Polach (1977). "Discussion; reporting of C-14 data." Radiocarbon 19(3): $355-$ 363. 
Sparks, R.J., W.H. Meluish, J.W.A. McKee, J. Ogden and J.G. Palmer (1995). 14-C calibration in the southern hemisphere and the date of the last Taupo eruption: evidence from tree-ring sequences. Radiocarbon 37: 155-163.

Thornley, S. (1996). "Neogene tectonics of Raukumara Peninsula, Northern Hikurangi margin, New Zealand." Victoria University of Wellington Unpublished PhD thesis.

Vucetich, C. G. and W. A. Pullar (1964). "Stratigraphy of Holocene ash in the Rotorua and Gisborne districts. Part 2." New Zealand Geological Survey Bulletin 73: 43-63.

Walcott, R. I. (1987). "Geodetic strain and the deformation history of the North Island, of New Zealand during the late Cainozoic." Philosophical Transactions of the Royal Society of London A 321: 163-181.

Yoshikawa, T. (1988). "Pattern and rate of tectonic movement and Late Quaternary geomorphic development in the Raukumara Peninsula, northeastern North Island, New Zealand." Bulletin of the Department of Geography University of Tokyo 20: 1-28. 


\title{
CHAPTER THREE
}

\section{A FACIES ARCHITECTURE MODEL FOR HOLOCENE INCISED VALLEY INFILL ON A TECTONICALly active COASt: PAKARAE RiVER, NeW ZEALAND.}

\begin{abstract}
A sequence of fluvio-estuarine sediments exposed beneath the highest Holocene marine terrace at the Pakarae River mouth, North Island, New Zealand, records the early-mid Holocene infilling of the Pakarae River valley. This sequence was developed on an active, coseismically uplifting coastline and provides a valuable comparison to widely used facies models for estuaries, which were developed exclusively from stable coastal settings. We describe eight sedimentary sections, distributed along a $220 \mathrm{~m}$ stretch of riverbank and present twelve new radiocarbon ages. Sedimentology and benthic foraminifera are used to divide the sequence into eight bio-lithofacies. These units are grouped into four paleoenvironmental facies associations: barrier, estuarine, estuary-head delta and floodplain. We compare the distribution of the Pakarae River mouth paleoenvironmental facies associations to those in models of incised-valley infill sequence models and case studies of infilled valleys. These data allow us to modify existing models for infilling of valleys on tectonically active coasts. The distinctive characteristics of the latter include (1) part, or all, of the transgressive and lowstand sequences may now lie above modern sea level, (2) the transgressive sedimentary sequence is typically condensed relative to the coeval amount of eustatic sea level (SL) rise that occurred during that period, and (3) evidence of relative SL falls, such as transitions from estuarine to fluvial environments, despite conditions of rapid and continuous eustatic SL rise.
\end{abstract}

\subsection{Introduction}

A common feature of studies of sedimentary sequences that have accumulated as fill deposits in formerly incised valleys is their location on stable coastlines. Here we study a sedimentary sequence at the Pakarae River mouth locality (henceforth called Pakarae), North Island, New Zealand, to develop a facies architecture model for incised valley infill sequences that is applicable to active coseismically uplifting coastlines. Several conceptual models have been developed to explain the distribution 
of facies within drowned valleys (Roy, 1984; Dalrymple et al., 1992; Allen and Posamentier, 1994; Heap et al., 2004). These models have been useful for purposes such as assessing the petroleum potential of ancient transgressive estuarine sediments and the significance of these as sequence boundaries in oil exploration, and, more recently, for tracking Holocene post-glacial sea level (SL) changes. These models are now widely accepted and cited. However, taking into account that a large proportion of the world's coastlines are in regions of active tectonics, it is timely to consider how incised valley infill sequences differ according to tectonic setting. This, in turn, may improve interpretations of infill sequences for the purposes mentioned - of petroleum research and SL studies - and furthermore, allow utilisation of infill sequences in studies of past tectonic movements.

At the Pakarae River mouth a raised sequence of marine terraces attests to frequent ( 850 year recurrence interval, Ota et al., 1991) coseismic uplift events during the late Holocene (Fig 3.1). The highest terrace, which corresponds with the maximum Holocene flooding surface, is underlain by a sequence of estuarine, fluvial and marine sediments that were deposited under conditions of rising sea level (SL). These are now exposed above sea level due to continuing tectonic uplift (Berryman et al., 1992). These sediments provide an opportunity to study the stratigraphic development of incised valleys under conditions of rising eustatic SL and coseismic uplift. Our approach uses sedimentology, macropaleontology and micropaleontology (benthic foraminifera) to reconstruct the paleoenvironments that accompanied infilling of the Pakarae incised valley. In comparison with previous work on the incised valley infill sequences our study is unique as we are able to observe outcrop exposure of the Holocene sequences rather than cores or seismic images.

\subsubsection{Models of incised-valley infilling}

Models of incised-valley infill have been developed by Roy, (1984), Dalrymple et al. (1992) and Allen and Posamentier (1993; 1994). As mentioned above, these were all developed for stable coastlines. Here we summarise these models and compare their settings to that of Pakarae valley. 


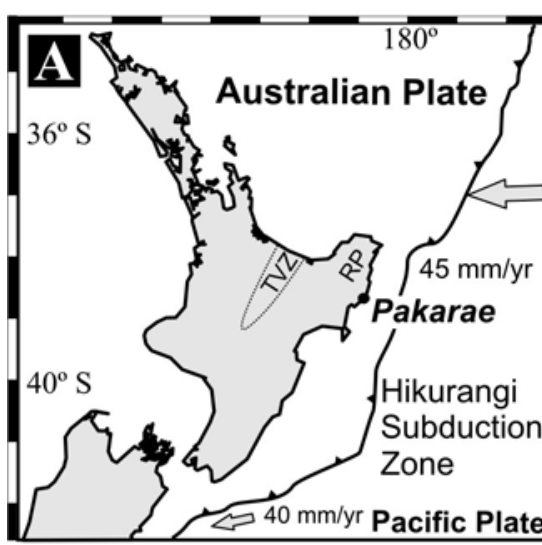

Hill slopes

Holocene marine terraces

$\square$ Holocene fluvial terraces

$\nabla$ Modern beach

\ Transgressive sequence sections 1 - 8

$\because$ Fault trace
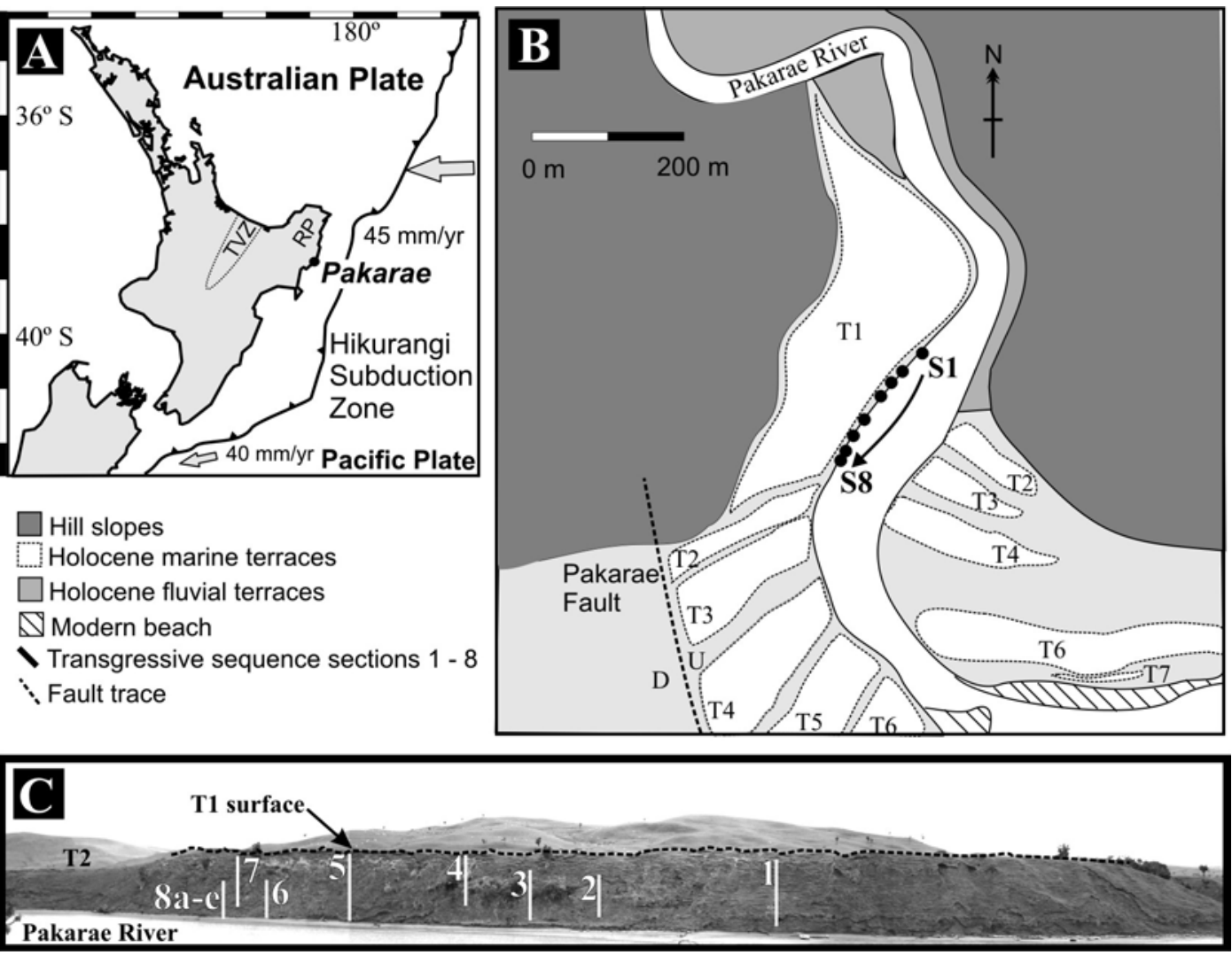

Figure 3.1. (A) North Island, New Zealand with major tectonic features. TVZ: Taupo volcanic zone, RP: Raukumara Peninsula. Continental-oceanic convergence at the latitude of the Raukumara Peninsula is oblique; the Pacific Plate has a velocity of $45 \mathrm{~mm} / \mathrm{yr}$ relative to the Australian Plate (Beavan and Haines, 2001; De Mets et al., 1994). Hikurangi subduction deformation front after Collot et al. (1996). (B) Pakarae River mouth with major geomorphic elements, marine terraces (after Wilson et al., submitted) and stratigraphic section locations (S1-S8). (C) The Pakarae riverbank, transgressive sedimentary sequence exposures beneath TI (highest Holocene marine transgression surface) with Sections 1 - 8e. Riverbank is $\sim 25 \mathrm{~m}$ high. 
The three incised-valley infill models are similar to one another in their recognition of three to four main sedimentary environments. All models recognise a fluvial/floodplain environment, a central estuary basin and a barrier environment. Dalrymple et al. (1992) also includes a fluvial delta environment at the head of the estuary, and Allen and Posamentier $(1993 ; 1994)$ include a shoreface environment. The models of valley infilling predict that these environments will translate landward under rising SL. Once the SL highstand (maximum flooding surface) is attained the estuary is subsequently infilled by fluvial sediments that prograde seaward.

The Pakarae valley is comparable to the drowned river valley estuary-type of Roy (1984), and is a wave-dominated estuary (as opposed to tide-dominated) according to the estuary-type classification of Dalrymple et al. (1992). The case studies of individual Holocene estuarine infill sequences, upon which the models are based, have commonly been of large estuaries at the mouths of major rivers with extensive catchment areas [for example, South Alligator River estuary: $>50 \mathrm{~km}$ length (Woodroffe et al., 1993); Miramichi River estuary: > 40 km length (Dalrymple et al., 1992); Gironde estuary, 100 km length (Allen and Posamentier, 1993); Daly River estuarine plains: $60 \mathrm{~km}$ length, and Sepik River floodplains: $70 \mathrm{~km}$ wide (Chappell, 1993)]. In contrast, the paleo-Pakarae estuary was $<0.5 \mathrm{~km}$ wide at the location of the studied sections (Fig 3.1), and we estimate the estuary would have been $<1 \mathrm{~km}$ in length. For this reason we must consider whether the facies models of Roy (1984), Dalrymple et al. (1992) and Allen and Posamentier (1993), based on studies of larger estuaries, are still applicable when scaled down to this extent. We begin by assuming that scaling is at least approximately valid as we can find no evidence presented in the literature to the contrary. Small estuaries are potentially more suitable for comparison to simplified facies models because multiple tributaries, as found in large estuaries, do not exist.

\subsubsection{Tectonic setting of the Pakarae valley}

Moderate to high late Quaternary coastal uplift rates have been recorded at many locations along the east coast of the North Island, an active continental margin inboard of the Hikurangi subduction zone (Fig 3.1). The Pakarae locality has the highest Holocene uplift rates yet recognised along this segment of the Australia- 
Pacific plate boundary (Berryman et al., 1989; Ota et al., 1988; Ota et al., 1991; Ota et al., 1992; Wilson et al., Ch. 2; Yoshikawa, 1988). The high uplift rate and evidence for a coseismic uplift process on this coast make Pakarae an ideal location for studying incised valley architecture on a tectonically active coast.

Uplifted forearc basin clastic sediments of Miocene to Pliocene age dominate the eastern region of the Raukumara Peninsula (Mazengarb and Speden, 2000). In the vicinity of Pakarae, Oligocene and Miocene marine siltstones and mudstones are juxtaposed across the Pakarae Fault, a normal fault, uplifted to the east and striking almost perpendicular to the trend of the subduction zone (Kingma, 1964; Mazengarb and Speden, 2000). This fault offsets the Holocene marine terraces but is not believed to be causing any significant coastal uplift. Rather, an unmapped offshore reverse fault is probably responsible for most of the coastal uplift (Ota et al., 1991; Wilson et al., Ch. 2). The Pakarae River has a catchment area of $\sim 230 \mathrm{~km}^{2}$. The modern river mouth has a small sand bar across the mouth, the prevailing longshore current is northerly and the spring tidal range is $1.7 \mathrm{~m}$.

The Pakarae marine terraces were first mapped, correlated, and dated by Ota et al. (1991). They recognised seven terraces, naming them T1-T7 from oldest and highest to youngest and lowest. T1 was recognised as corresponding with the maximum Holocene marine transgression. Wilson et al. (Ch. 2) have revised the distribution of these terraces and their age. These data indicate that uplift rates over the past $7 \mathrm{ka}$ have averaged $3.2 \pm 0.8 \mathrm{~mm} \mathrm{yr}^{-1}$, a process that has been achieved by sudden uplift events during which $2-2.5 \mathrm{~m}$ of coastal uplift has taken place every $\sim 850 \pm 450$ years.

Radiocarbon ages from the fluvio-estuarine sedimentary sequence underlying T1 were presented by Ota (1987) and Ota et al. (1988). These authors summarised the stratigraphy, but they did not make interpretations concerning the identification and timing of individual uplift events. The sequence was later studied in more detail by Berryman et al. (1992). They used stratigraphy, radiocarbon ages and tephrochronology from three riverbank sections to produce paleogeographic maps showing evolution of the river valley from ca. 9 to $1 \mathrm{ka}$. A relative sea level (RSL) curve for the period from $11 \mathrm{ka}$ to present was constructed for this site. Importantly these data showed that during the period $11,000-7,000$ calibrated years before 
present (cal. yrs B.P.), when eustatic SL in the New Zealand region was consistently rising, there were fluctuations in relative SL at Pakarae, including an apparent $4 \mathrm{~m}$ fall in RSL between 10.5 - 9.5 cal. yrs B.P. This short-term fall was attributed to a combination of tectonic and eustatic causes. A comparison between the amount of eustatic SL rise inferred to have taken place in New Zealand ( $34 \pm 2 \mathrm{~m}$, Gibb, 1986) from $11-7$ cal. yrs B.P. versus the amount of sediment deposited during that same period in the Pakarae valley $(12 \mathrm{~m})$ suggested that as much as $22 \pm 2 \mathrm{~m}$ of tectonic uplift may have taken place at Pakarae during this period (Berryman et al. 1992).

Of the three sections (Location A, B and Z) targeted in the Berryman et al. (1992) study, only Location A is in common with the sections that we will examine here. Their Location $\mathrm{Z}$ was revisited by us but will not be used in this study, as there are important unresolved inconsistencies in the ordering of radiocarbon ages at that site and also a lack of recognised marine deposits. The approximate site of their Location $\mathrm{B}$ was also revisited and again new sites were considered preferable because of uncertainty as to whether the riverbank section was in place or slumped. We believe that most of the section of their Location A has been encompassed by our new sections. However, we cannot exactly correlate our new data with the measured section of Berryman et al. (1992), at Location A, because that section was a composite of several nearby sections.

\subsection{Methodology}

To achieve our objective of developing a facies architecture model from the Pakarae sedimentary sequence we require information on the age and depositional environments of the sediments. To do this we used radiocarbon dating, tephrochronology, sedimentology, benthic foraminifera and shell assemblages. The collection and processing methods of these paleoenvironmental techniques are outlined below.

\subsubsection{Chronology}

Radiocarbon ages were obtained at significant sedimentary unit contacts to estimate times of paleoenvironmental change at Pakarae and to compare these changes with 
eustatic SL movements. Three radiocarbon samples were wood (2 small wood branches, one concentration of wood chips), for which the conventional radiocarbon techniques were used. Nine radiocarbon samples were marine shells. The accelerated mass spectrometry (AMS) technique was used for these. Well-preserved shells were preferentially selected for dating, particularly bivalves with articulated valves, in order to minimise the possibility of reworking. All radiocarbon ages are presented at the 2-sigma age range (95\% probability) and in units of calibrated radiocarbon years before present (cal. yrs B.P.), unless otherwise stated.

A tephra unit correlated within four sections (Sections $5-7$, and $8 \mathrm{~d}$ ) provided further age control. This tephra was identified on the basis of its glass chemistry and heavy mineralogy and in the context of its bounding radiocarbon ages. Glass shards of 63$250 \mu \mathrm{m}$ size were mounted in epoxy blocks, these were polished and carbon coated. Ten glass shards from the tephra were analysed with a JEOL-733 microprobe using a $10-\mu \mathrm{m}$-diameter beam of $8 \mathrm{nA}$ at $15 \mathrm{kV}$ accelerating voltage in the Analytical Facility of Victoria University of Wellington. Heavy mineral identification was done on selected grains using the electron microprobe.

\subsubsection{Stratigraphy and sedimentology}

Sections were chosen for study along the Pakarae riverbank on the basis of the quality and extent of their exposure and to maximise coverage along the strike of the river. A total of $90 \mathrm{~m}$ of vertical section was measured over eight sections $(1-8)$. Section 1 is the furthest upstream; ascending numbers correspond to sections located progressively further downstream (Fig. 3.2). Section 8 is subdivided into 5 small sections $(8 \mathrm{a}-8 \mathrm{e}$, Fig 3.2B). Horizontal bedding was used as the main criterion that a section was in place. At the base of Section 5 we used an auger to retrieve sediments $\sim 1 \mathrm{~m}$ deeper than the naturally exposed base of the section. We generally had near-continuous exposure vertically down the riverbank, though in some cases (Section 1, 3 and 5) we shifted horizontally along the bedding. The amount of horizontal offset was recorded in each case and was everywhere $<10 \mathrm{~m}$.

Each section was photographed, measured, described and sampled (Fig. 3.2). Estimates of sediment sorting were made by visual comparison to the charts of Anstey 


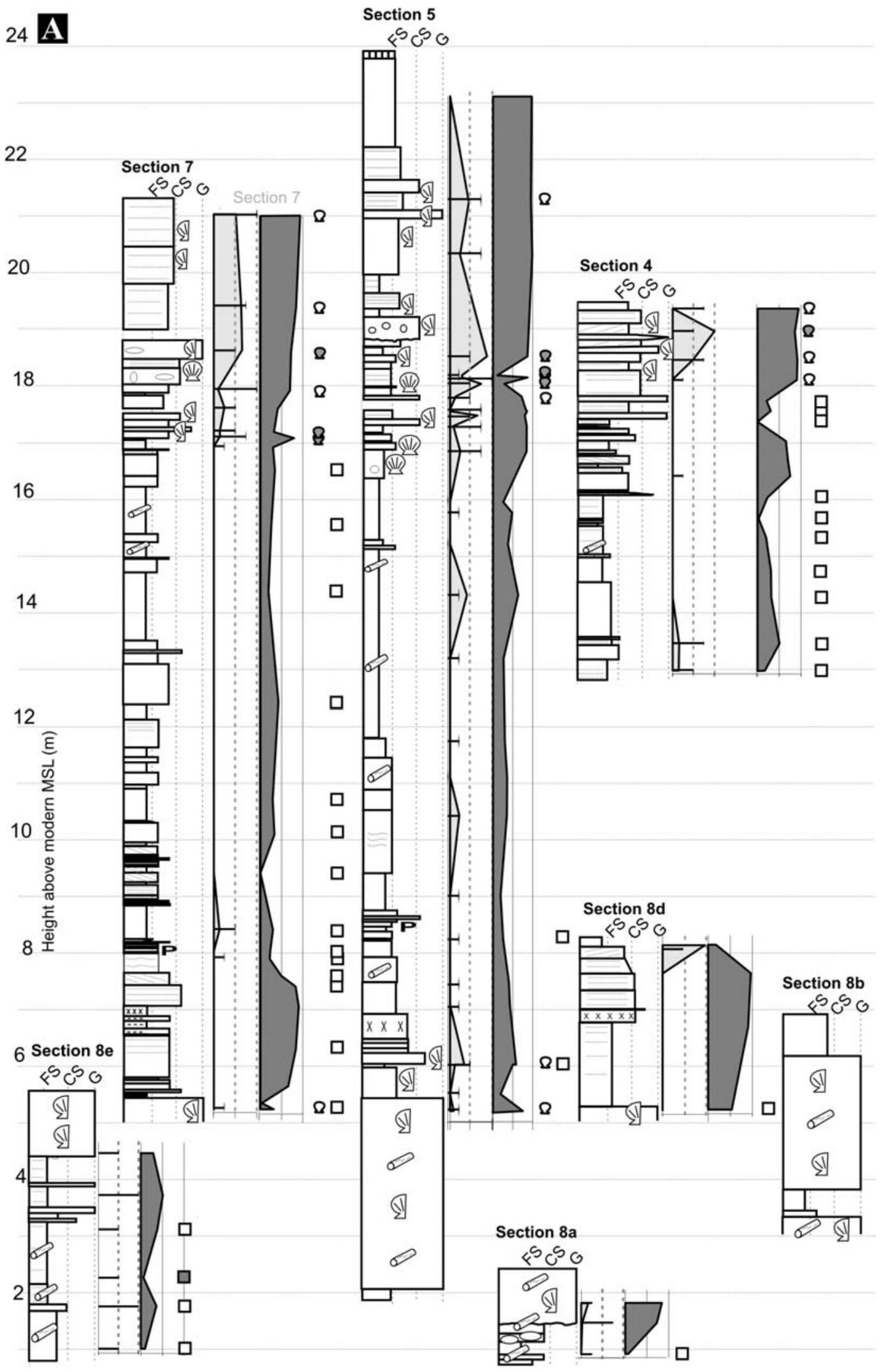

Figure 3.2. (A) Sedimentology of the Pakarae River incised valley infill sequence. Sedimentary units, grain size, bedding structures and presence of shells and wood are shown. The graphs alongside show the abundance of benthic foraminifera (columns), the percentage of intertidal foraminifera (light greyshaded line graph), and the percentage of sand in each sample collected for foraminifera analysis (dark grey-shaded line graph). (B) Location of sections along the Pakarae riverbank, note the vertical exaggeration. Shaded boxes encompass sections belonging to the same section number. 


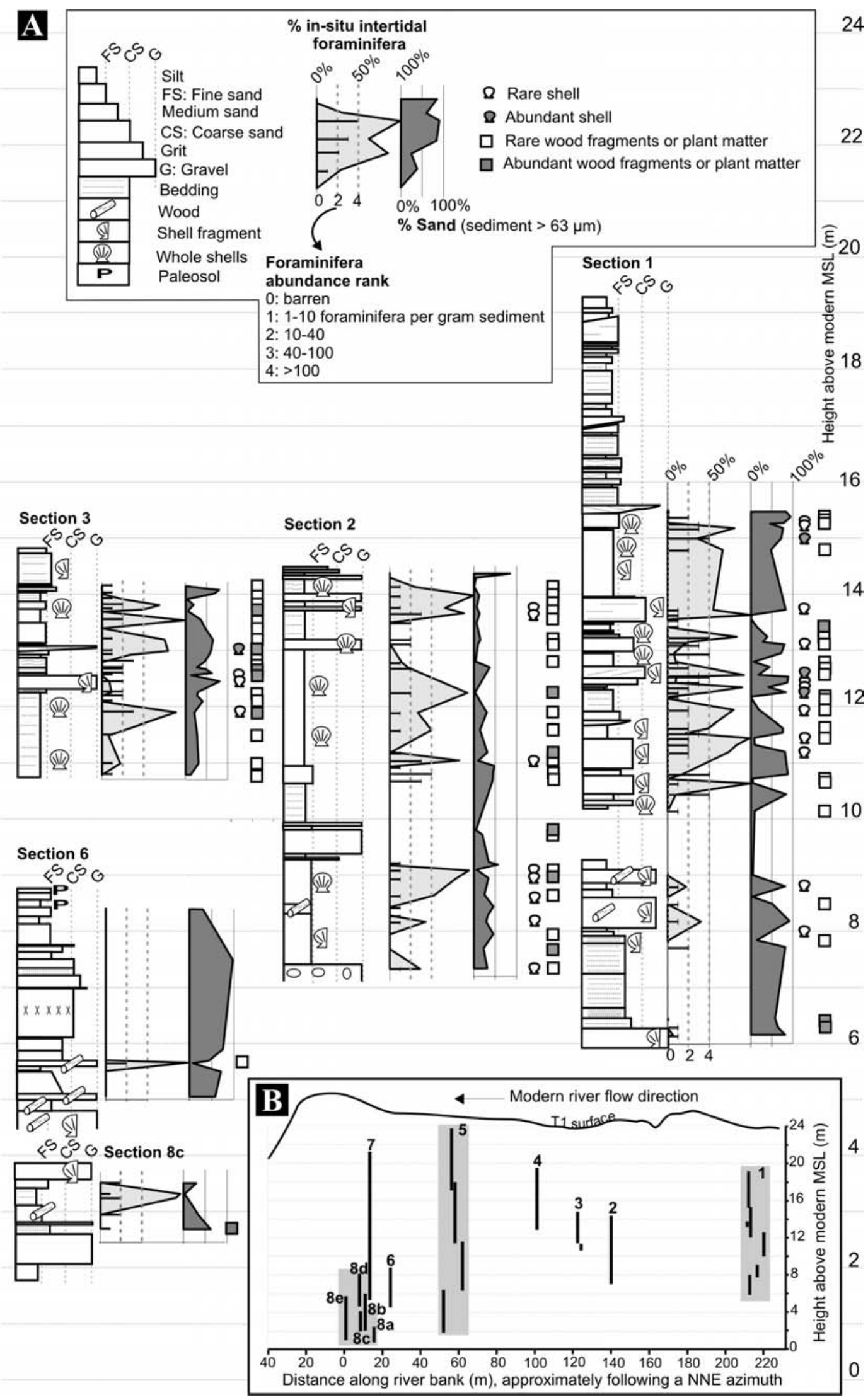

Fig. 3.2 continued. 
and Chase (1974). Estimates of clast angularity were made by visual comparison with the charts of Powers (1953). Samples of $\sim 80 \mathrm{~cm}^{3}$ were taken from almost every sedimentary unit that we described, larger samples were collected from gravely units. Where the beds were thicker than $2 \mathrm{~cm}$, samples were taken $4-10$ vertical cm apart; if the sediment was particularly homogenous samples were taken at up to $50 \mathrm{~cm}$ apart vertically.

The vertical distance of every sedimentary unit contact was measured relative to a reference datum fixed to the top of the exposed section. All heights were later calibrated to elevations in metres above mean sea level (m AMSL) by their relationship to one or more of the 58 elevation control points we had spanning all the sections. The elevation control points were measured with either a level or the RTKGPS. Levelling formed a closed circuit and was referenced to mean SL on Pakarae beach (MSL was located using high tide strand lines and tide levels at varying times). The elevations of Sections $1-3$ and 5, measured with the level, have uncertainties of $\pm 0.22 \mathrm{~m}$ at a $95 \%$ confidence interval (calculated by the square root of the sum of the squares of the errors). To calibrate the GPS elevations to mean SL we compared them with elevations of levelled horizons in Section 5, and with the high-tide mark and tide levels. The elevations of Sections 6 and $8 \mathrm{a}-8 \mathrm{e}$ have an uncertainty of $\pm 0.31 \mathrm{~m}$, and Sections 7 and 4 have an uncertainty of $\pm 0.22 \mathrm{~m}$, both at a $95 \%$ confidence interval. These uncertainties are based on the square root of the sum of the variances including: the GPS uncertainty, the levelled elevation measurements uncertainty and the uncertainty in our estimates of the high tide mark. On sloping sections all measurements were converted to elevations by taking two points where the elevation was measured (by level or RTK-GPS) and proportionally adjusting the elevation of every depth measurement in between. We predict the uncertainty from these elevation adjustments to be $<0.1 \mathrm{~m}$.

\subsubsection{Micropaleontological processing}

Selected sediment samples were processed for microfossil content to assist with paleoenvironmental interpretation. Microfossils have been demonstrated to be useful in differentiating coastal waterbody types (for example: Darienzo et al., 1994; Hayward et al., 1999b; Hayward et al., 2004a; Hemphill-Haley, 1995; Patterson et al., 
2000; Shennan et al., 1999). The preservation of diatom and pollen microfossils within the Pakarae sediments was very poor and the results were thus of no use in paleoenvironmental interpretation (Appendix 3.1). Benthic foraminifera are common in the Pakarae sediments and these were used in interpretation of the sediment depositional environment.

In total 199 samples were processed for the foraminiferal study, an average of one sample per $0.45 \mathrm{~m}$ of section (Appendix 3.2). However sampling was concentrated around significant stratigraphic contacts and in zones with high unit variability. Samples were processed using the standard techniques of Hayward et al. (1999a). Where possible 100 - 200 benthic foraminifera were picked, 100 tests being considered adequate for environmental assessment using brackish foraminifera (Hayward et al., 1996; 1999b; 2004a). In cases where well-preserved benthic foraminifera were rare we used a floating technique to concentrate the foraminifera. In total 29 samples were floated (Appendix 3.2). Approximately 5 grams of the $>0.063$ $\mathrm{mm}$ sediment fraction was stirred into sodium polytungstate with a specific gravity of 1.6; the fraction that floated contained the concentrated foraminifera. Identification of the well-preserved foraminifera was made with reference to Hayward et al. (1997) and Hayward et al. (1999a). For each sample the relative amounts of macro shell fragments and wood or plant matter were estimated and noted as either absent, scattered or abundant. The abundance of planktic foraminifera was noted for each sample, but we did not identify or count them as they yield no information about the paleo-elevation of the sediment.

\subsection{Results}

The sedimentology and micropaleontology studies at Pakarae were undertaken to facilitate interpretation of the depositional environments of the sedimentary sequence. Here we present the radiocarbon age results and the census results from the benthic foraminifera study. The foraminifera are grouped into assemblages with each assemblage providing some information about the depositional waterbody. We then present a combination of the foraminifera and shell assemblages and the sedimentology data to categorise the Pakarae sediments into bio-lithofacies. The biolithofacies form the basis of the depositional environment interpretation. The 
depositional environments and the chronology of the sequence finally allow delineation of the facies architecture at Pakarae.

\subsubsection{Chronology}

Ages of the infill sediment range from ca. 10230 cal. yrs BP at $1.1 \mathrm{~m}$ AMSL to ca. 7400 cal. yrs B.P. at 18.3 - 18.7 m AMSL (Table 3.1). The ages decrease upwards with the exception of two samples that occur out of chronological order at the $>2$ sigma level. In Section 5 the sample at $14.5 \mathrm{~m}$ AMSL is a large piece of wood that is not in growth position. Because this is detrital material, it must be older than the sediment that it is preserved within, hence the reversed chronology is not a significant concern. A shell sample from Section 4 at 18.9 m AMSL yielded an age of 8350-8170 cal. yrs B.P. and is older than the next sample below it (Section 5 at $18.3 \mathrm{~m} \mathrm{AMSL}$ ). This lower sample has an age of 7530-7280 cal. yrs B.P. The reason for this age reversal is unresolved, however, we will suggest that the higher sample may have been re-deposited.

The tephra layer at ca. $7 \mathrm{~m}$ AMSL in Sections, 5, 6, 7, and 8d has a major element glass chemistry characteristic of the Okataina volcanic centre and it contains the diagnostic heavy mineral cummingtonite (referenced to datasets in Stokes and Lowe, 1988, Lowe, 1988, and Froggatt and Rogers, 1990, Table 3.2, Appendix 3.3). Cummingtonite is a heavy mineral present in only three Okataina volcanic centre tephras: the Rotoehu ( 50,000 cal. yrs B.P.), the Rotoma (9464-9531 cal. yrs B.P) and the Whakatane (5465 - 5590 cal. yrs B.P.; Froggatt and Lowe, 1990). The bounding radiocarbon ages indicate this is the Rotoma tephra. Berryman et al. (1992) also identified this tephra as Rotoma, although their assignment was based only on bracketing radiocarbon ages. Our geochemical analyses confirm the Rotoma identification. Tephra isopach maps of Vucetich and Pullar (1964) suggest the Rotoma ash should be $<7.5 \mathrm{~cm}$ thick in the Pakarae region, consistent with our observations at the outcrop where the tephra appears to be largely reworked with only the thin fining-upwards layers at the base being a primary airfall deposit. 
Table 3.1: Pakarae River mouth incised valley infill sedimentary sequence radiocarbon ages.

\begin{tabular}{|c|c|c|c|c|c|c|c|c|}
\hline 莺 & 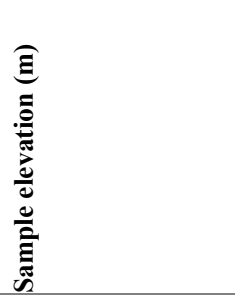 & 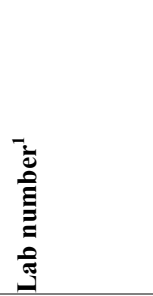 & 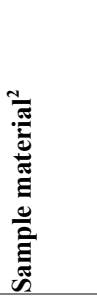 & 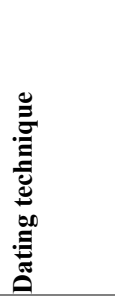 & 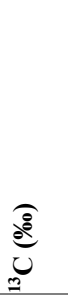 & 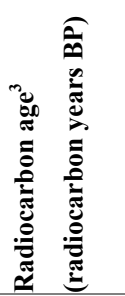 & 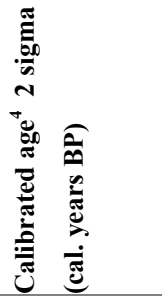 & 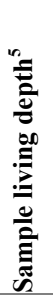 \\
\hline 1 & $15.2+/-0.22$ & NZA 21854 & A & AMS & -1.27 & $8056 \pm 30$ & $8590-8410$ & -0.2 \\
\hline 1 & $10.05+/-0.22$ & NZA 22529 & A & AMS & 1.05 & $8458 \pm 35$ & 9210-8980 & -0.2 \\
\hline 1 & $6.3+/-0.22$ & WK 16864 & Wood & Standard & -28.2 & $8420 \pm 59$ & $9530-9240$ & $?$ \\
\hline 1 & $6+/-0.22$ & NZA 21961 & A & AMS & -0.91 & $8868 \pm 30$ & $9600-9450$ & -0.2 \\
\hline 2 & $14.15+/-0.22$ & NZA 22528 & $\mathrm{~A}$ & AMS & 1.42 & $8082 \pm 35$ & $8640-8420$ & -0.2 \\
\hline 2 & $7.5+/-0.22$ & NZA 21852 & $\mathrm{~A}, \mathrm{~B}$ & AMS & -3.71 & $8338 \pm 30$ & $9010-8770$ & -0.2 \\
\hline 4 & $18.9+/-0.22$ & NZA 22526 & A, B & AMS & 0.98 & $7791 \pm 35$ & $8350-8170$ & -0.2 \\
\hline 5 & $18.3-18.7+/-0.22$ & NZA 21851 & A, B. C & AMS & -0.49 & $6847 \pm 30$ & $7430-7280$ & -0.2 \\
\hline 5 & $14.5+/-0.22$ & Wk 16454 & Wood & Standard & -27.2 & $8219 \pm 52$ & $9290-9000$ & $?$ \\
\hline 7 & $17.15+/-0.22$ & NZA 22527 & $\mathrm{~A}$ & AMS & 0.39 & $7981 \pm 35$ & $8540-8360$ & -0.2 \\
\hline $8 \mathrm{a}$ & $1.1+/-0.31$ & Wk 16453 & Wood & Standard & -28 & $9158 \pm 52$ & 10420-10180 & $?$ \\
\hline $8 b$ & $4.4+/-0.31$ & NZA 21853 & A & AMS & -2.9 & $9266 \pm 30$ & $10200-9990$ & -0.2 \\
\hline
\end{tabular}

${ }^{1}$ Wk: The University of Waikato Radiocarbon Dating Laboratory; NZA: Institute of Geological and Nuclear Sciences Rafter Radiocarbon Laboratory.

${ }^{2}$ Shell: A: Austrovenus stutchburyi, B: Paphies australis, C: Melagraphia aethiops.

${ }^{3}$ Conventional radiocarbon age before present (1950 AD) after Stuiver and Polach, 1977.

${ }^{4}$ Calibrated age in calendar years. Wood ages calibrated using Southern Hemisphere atmospheric data of McCormac et al. (2004); marine ages calibrated using data from Hughen et al (2004). Radiocarbon ages calibrated using OxCal v3.10. Reservoir correction of $-30 \pm 13$ yrs applied to all shell samples.

${ }^{5}$ Estimated based on Austrovenus stutchburyi living at mean sea level and burrowing to a depth of $0.2 \mathrm{~m}$ below the sediment surface.

Table 3.2: Major element glass chemistry and heavy mineral chemistry of the tephra within Sections 5 -8 at $\sim 7 \mathrm{~m}$ AMSL.

\begin{tabular}{|c|c|c|c|c|}
\hline \multirow[t]{2}{*}{ Element } & \multicolumn{2}{|l|}{ Glass } & \multicolumn{2}{|c|}{$\begin{array}{l}\text { Cummingtonite } \\
(n=4)\end{array}$} \\
\hline & Average & $1 \sigma$ & Average & $1 \sigma$ \\
\hline $\mathrm{SiO} 2$ & 78.37 & 0.30 & 52.63 & 1.41 \\
\hline $\mathrm{A} 12 \mathrm{O} 3$ & 12.44 & 0.17 & 0.29 & 0.08 \\
\hline TiO2 & 0.13 & 0.05 & 1.32 & 0.64 \\
\hline $\mathrm{FeO}$ & 0.96 & 0.06 & 21.30 & 2.79 \\
\hline $\mathrm{MnO}$ & 0.08 & 0.03 & 1.21 & 0.62 \\
\hline $\mathrm{MgO}$ & 0.12 & 0.02 & 21.62 & 2.17 \\
\hline $\mathrm{CaO}$ & 0.81 & 0.09 & 1.49 & 0.38 \\
\hline $\mathrm{Na2O}$ & 3.63 & 0.16 & 0.12 & 0.20 \\
\hline $\mathrm{K} 2 \mathrm{O}$ & 3.30 & 0.10 & 0.03 & 0.02 \\
\hline $\mathrm{Cl}$ & 0.17 & 0.04 & - & - \\
\hline
\end{tabular}




\subsubsection{Foraminifera}

Of the 199 samples analysed, 56 were barren of foraminifera and only 36 samples had sufficient foraminifera for $>100$ benthic specimens to be counted (Fig 3.3, Appendix 3.2). Two populations of foraminifers were recognised: one poorly-preserved and one well-preserved. The presence or absence of foraminifera and relative proportions of poorly- to well-preserved foraminifera formed the basis for identifying four foraminiferal assemblages. The assemblages are (1) barren, (2) reworked, (3) marginal-estuarine and (4) intertidal (Fig 3.3). The spatial distribution and composition of each assemblage are described in Fig 3.3.

The poorly-preserved tests are typically fragmented and encrusted; some are infilled with sediment or a chemical precipitate such as pyrite. Identification of some species proved the poorly preserved specimens to probably be reworked from the MiocenePleistocene sedimentary bedrock of the Pakarae River catchment (Mazengarb and Speden, 2000). These poorly preserved specimens make up the "Other" category of foraminifera in the census and in foraminifera assemblage descriptions (Fig 3.3).

The well-preserved benthic foraminifera are characterised by whole, clear and clean tests and provide a stark contrast to the reworked specimens (Fig 3.3). Ammonia parkinsonia f. aoetana is the dominant well-preserved species. Well-preserved tests of Elphidium excavatum $f$. excavatum were rare and only identified in nine samples. $A$. aoteana and E. excavatum are common species in brackish to very slightly brackish environments. A. aoteana is a dominant species in the intertidal and subtidal zones of lower estuaries and mid to inner areas of enclosed harbours (Hayward et al., 1999a). The well-preserved nature of these specimens indicates that they are in-situ fossils; i.e. they lived within the sediment in which they are now embedded and have not been transported far, if at all.

The foraminiferal assemblages tend to be clustered together at different elevations within the sections (Fig 3.3). Intertidal assemblages are notably clustered between $\sim 16$ $-10 \mathrm{~m}$ AMSL in the upstream Sections 1, 2, and 3, and at 17- $20 \mathrm{~m}$ AMSL in the downstream Sections 7 and 5 (Fig 3.3). 


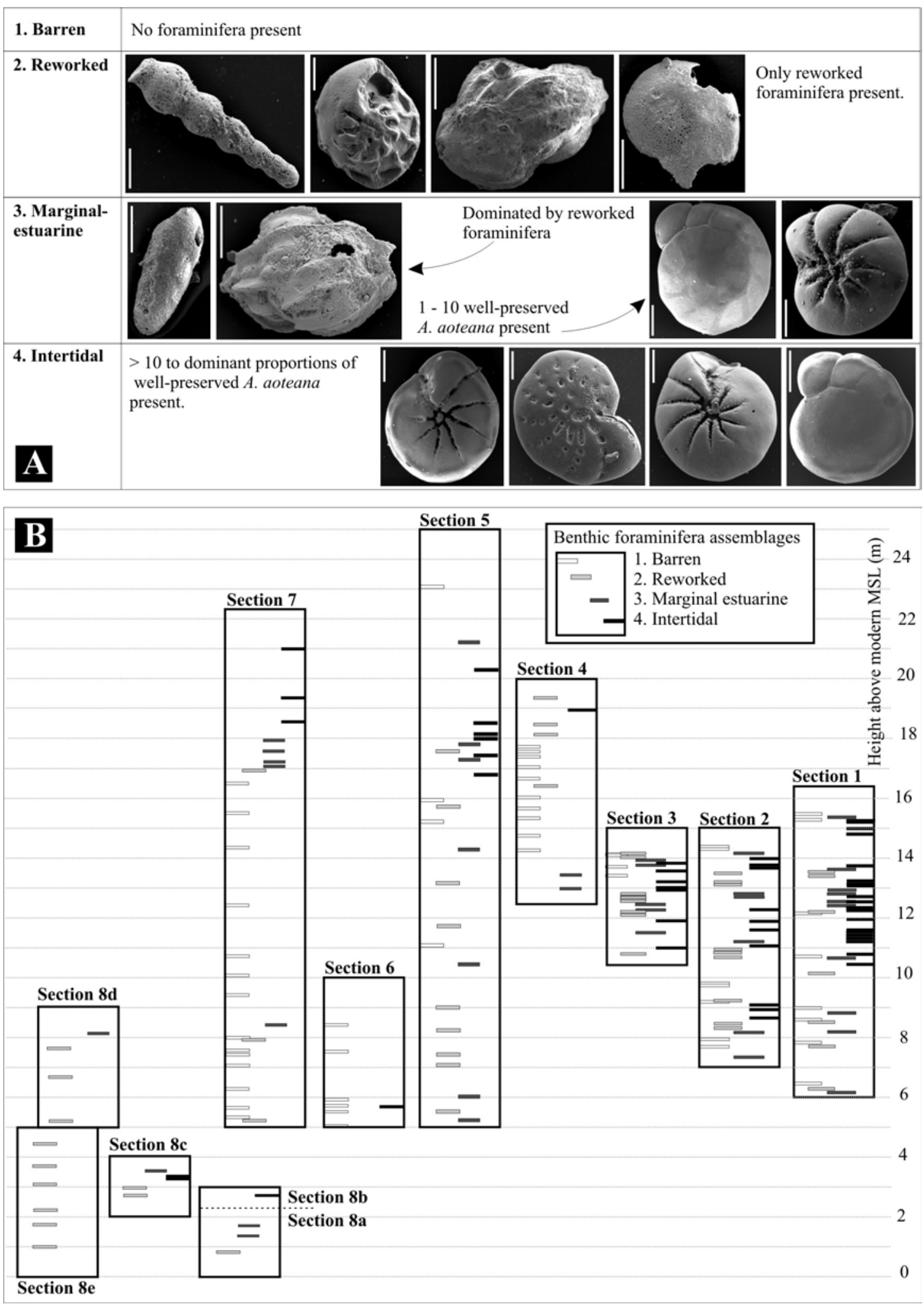

Figure 3.3. (A) Benthic foraminifera assemblages, with representative images of the specimens within each group. The difference between the marginal-estuarine and intertidal assemblages is based on the number of well-preserved ( $\sim$ in-situ) foraminifera picked from each sample. We do not use the percentage of in-situ tests as this can cause an artificial bias in those samples with extremely low abundances. Approximately equal sample sizes were scanned for foraminifera, therefore the numbers of foraminifera picked are comparable measures. The white bars in each image represent 100 microns. (B) Distribution of the foraminifera assemblages in the Pakarae sections. 


\subsubsection{Bio-lithofacies}

Ten bio-lithofacies are recognised within the studied sedimentary sequences ( $c f$. Fig. 3.2 and Fig. 3.4). We define a bio-lithofacies as a sedimentary unit with a characteristic lithology and biological assemblage. The sedimentary and faunal characteristics of each facies, and their distribution, are described in Table 3.3.

. Here we interpret the depositional environment of each facies.

- Unfossiliferous gravel beds 0.2-0.6 m thick.

The unfossiliferous gravel facies is probably a fluvial channel deposit because of the thin nature of the beds and high-energy currents implied by the large clast size. A non-marine environment is also consistent with the complete lack of shells in the gravel. The range of clast sizes and presence of angular clasts suggest the gravel has not been transported far, particularly since the clasts consist chiefly of mudstone, a soft lithology that would be quickly rounded during transport. The mudstone clasts are of identical lithology to that of the local outcrops of Neogene bedrock, thus supporting a nearby source. The poor sorting and angularity of clasts might suggest a colluvial depositional environment, but bedding indicates fluvial deposition of this proximally derived gravel.

- Thin shelly gravel units $<0.5 \mathrm{~m}$ thick.

The thin shelly gravel layers are interpreted as estuary tidal channel lags. The scoured bases, abundant fragmented estuarine shells (Austrovenus stutchburyi and Paphies australis) and large clast sizes indicate a high-energy depositional environment. The shell species and the foraminifera assemblages (dominantly estuarine to marginal) indicate a brackish-intertidal environment.

Table 3.3: Distribution and sedimentary characteristics of the bio-lithofacies of the Pakarae infill sequence. 


\begin{tabular}{|c|c|c|c|c|c|c|c|c|c|c|}
\hline . & & 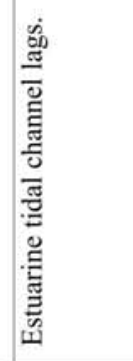 & 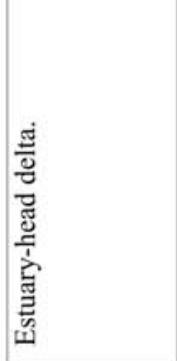 & 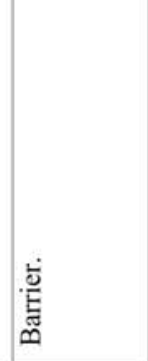 & 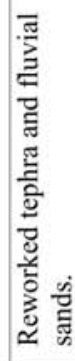 & 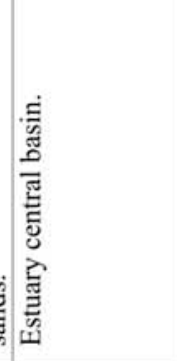 & 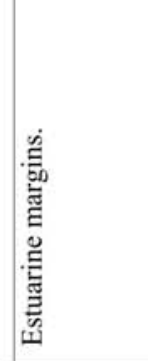 & $\frac{\vec{m}}{\frac{\vec{m}}{L}}$ & 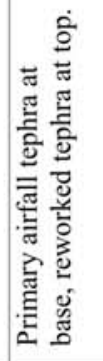 & 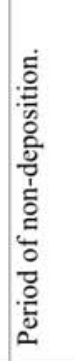 \\
\hline 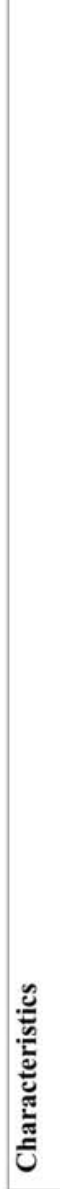 & 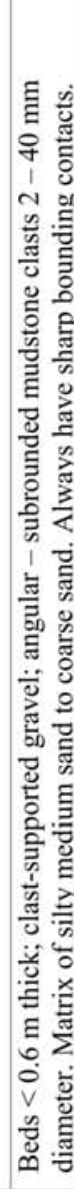 & 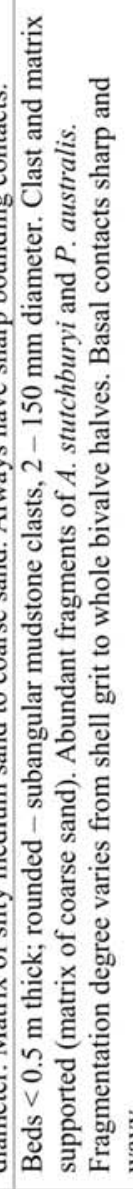 & 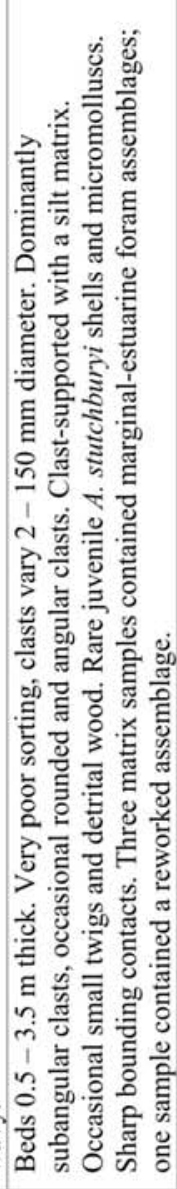 & 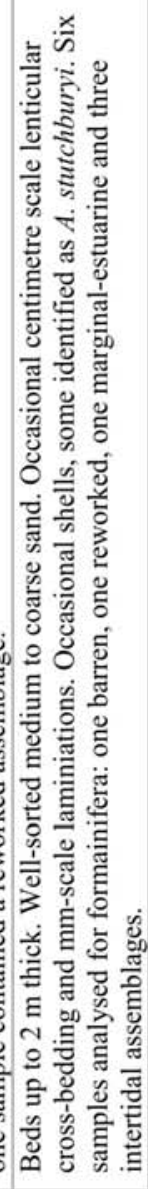 & 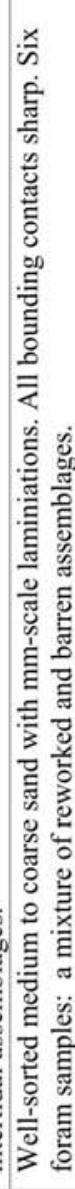 & 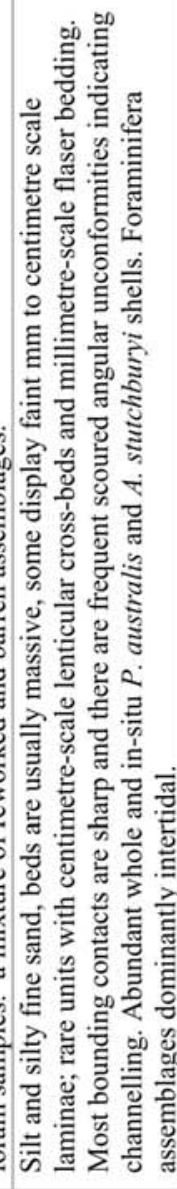 & 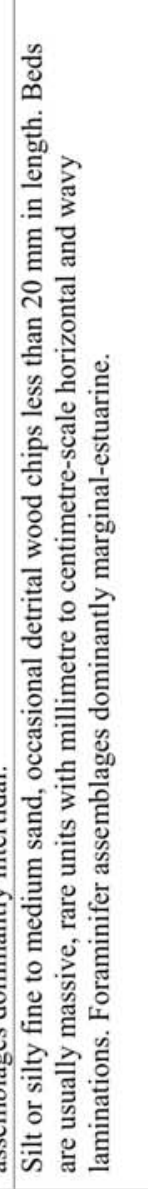 & 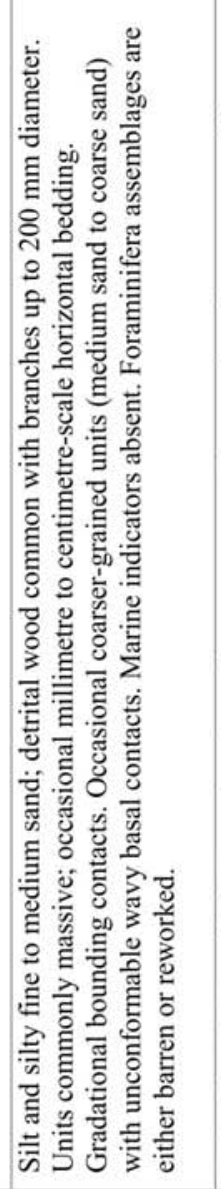 & 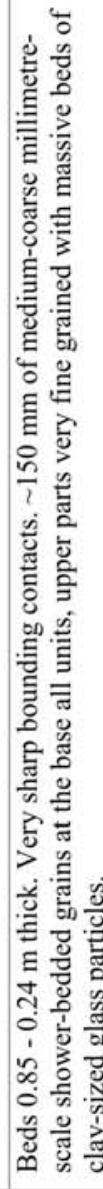 & 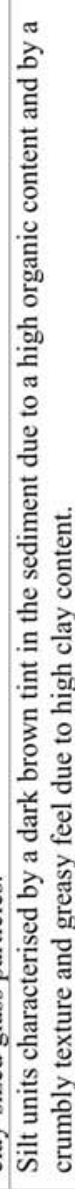 \\
\hline 产 & 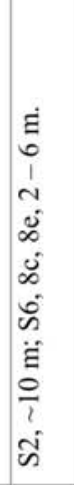 & 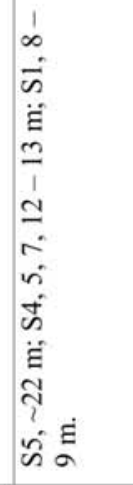 & 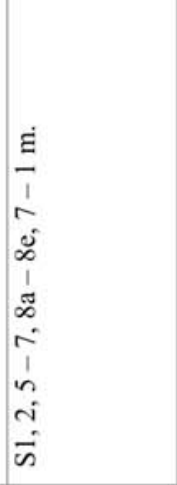 & $\begin{array}{l}\dot{E} \\
\hat{N} \\
\hat{n} \\
\dot{n} \\
\dot{n} \\
\dot{n}\end{array}$ & 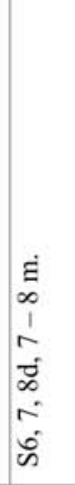 & 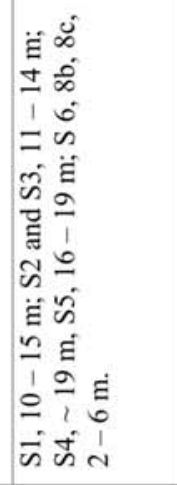 & 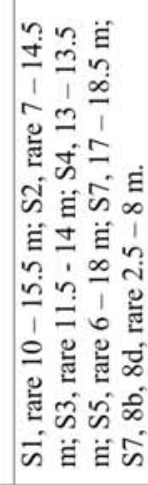 & 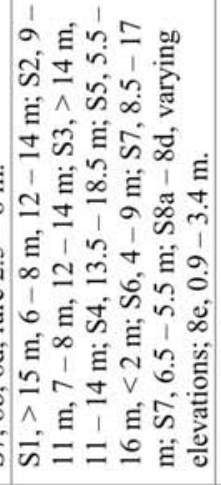 & $\begin{array}{l}\dot{E} \\
i \\
\vdots \\
b \\
\dot{0} \\
\dot{0} \\
i \\
\tilde{n}\end{array}$ & 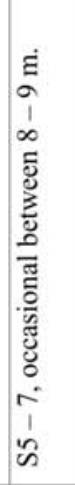 \\
\hline 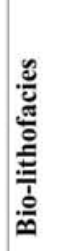 & 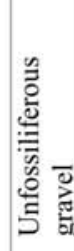 & 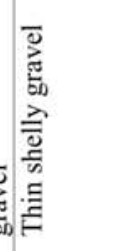 & 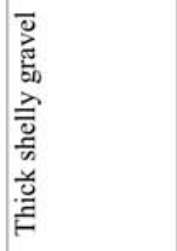 & 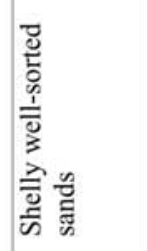 & 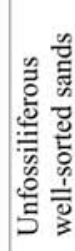 & 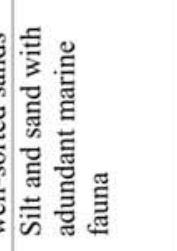 & 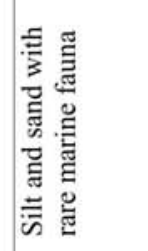 & 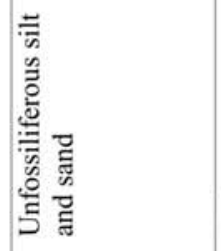 & 莺 & $\begin{array}{l}\frac{n}{0} \\
0 \\
\frac{d}{\pi} \\
\tilde{c}\end{array}$ \\
\hline
\end{tabular}




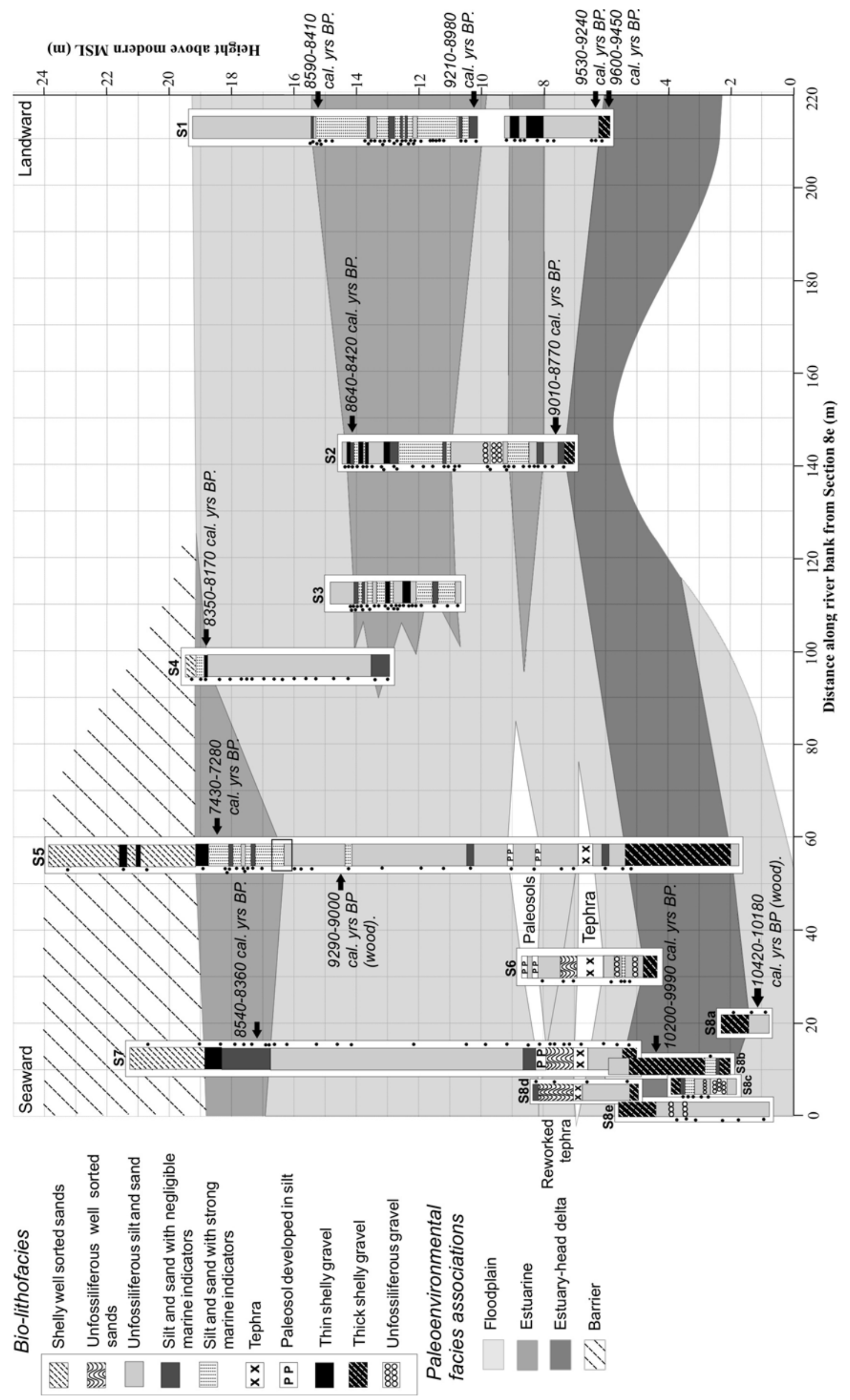


Figure 3.4. Bio-lithofacies and paleoenvironmental facies associations of the Pakarae River sections, correlations between the sections based on stratigraphy and paleoenvironmental interpretations. Tidal ravinement surface and transgressive surface after the terminology of Allen and Posamentier (1993).

- Thick shelly gravel units 0.5-3.5 m thick.

We interpret this facies to have been deposited in at the head of a paleo-estuary, henceforth called the estuary-head delta. The very poor sorting and clast angularity suggests short transport distances for the clasts. The marginal-estuarine foraminifera assemblages and juvenile intertidal shells indicate the sediment must have been deposited within reach of tidal flow. Radiocarbon ages from below and within the facies at the downstream end of the sections suggest rapid deposition of the gravel (Fig 3.4). The facies displays variable thicknesses along the riverbank; this may be because its distribution was controlled by proximity to the bedrock high (beneath Sections 1 and 2), which was the source of the gravels (Fig 3.4).

- Shelly well-sorted sand units up to $2.5 \mathrm{~m}$ thick.

We interpret the shelly well-sorted sand to have been deposited near the mouth of an estuary inside a wave-dominated barrier. The clean, well-sorted nature of the facies is characteristic of sediments sorted by waves and tidal currents (Allen and Posamentier, 1993; Roy et al., 1994), and cross-bedding can be a characteristic of barrier washover deposits (Dalrymple et al., 1992). The shell species and foraminifera assemblages are consistent with an intertidal environment.

- Unfossiliferous well-sorted sand units 0.4-1 m thick.

This sand was probably deposited in a fluvial environment as it contains no shells or foraminifera. Most of the grains consist of volcanic glass, suggesting reworking of the underlying Rotoma tephra or washing in of glass from the tephra-mantled catchment. . 
- Silt and sand units with abundant marine fauna, $0.1-1.5 \mathrm{~m}$ thick.

We interpret the depositional environment of this facies to be the central basin of an estuary. The primary evidence of this are abundant intertidal bivalve shells and foraminifera, species of which are common in estuaries (Morton and Miller, 1968; Hayward et al., 1999a; 1999b). The grain size variation between sand and silt and evidence of channelling is consistent with an estuarine environment subject to varying current energies and meandering tidal channels.

- Silt and sand units with rare marine fauna 0.1 - $1.5 \mathrm{~m}$ thick.

The distinguishing feature of this facies is the occurrence of marginal-estuarine foraminifera assemblages (Fig 3.3). The benthic foraminifer $A$. aoteana indicates this unit was probably deposited close to an estuary. However, the abundances are so low it is conceivable that either the depositional site was only inundated during extreme high tides or storm surges, or that the intertidal foraminifera could have been windblown up river. Sample contamination is also a possibility.

\section{- Unfossiliferous silt and sand units $0.2-8 \mathrm{~m}$ thick.}

Unfossiliferous silts and sands are the most widespread unit, the depositional environment of this bio-lithofacies is of critical importance to this study. We infer that the most likely depositional environment is fluvial. Evidence for this includes the complete absence of marine fauna, the silty nature of the sediments, channelling, and its content of scattered detrital wood.

Marine fauna could be absent from this unit for reasons other than the sediment having been deposited in a non-marine environment. For example (i) there could be poor marine fossil preservation because the calcareous shells and foraminifera tests may have been leached out by acidic ground water; (ii) the marine environment may not have suited the specific living preferences of the marine fauna; or (iii) sediment deposition rates could have been so high that the marine fauna are either highly "diluted" or could not survive under such rapid sedimentation. We considered quantitative grain size analysis as a depositional environment indicator. However, 
there are no quantitative data comparing sediment grain size and sorting between fluvial and estuarine environments and no modern analogue at Pakarae. With the available data we suggest that the unfossiliferous facies was deposited in a fluvial environment.

\section{- Tephra}

The lenticular shape of the tephra (correlations between the units suggests a horizontal top and curved concave-up base, Fig 3.4), and the considerable thickness of very fine reworked tephra suggest that the depositional environment may have been an abandoned oxbow of the Pakarae River. A low-energy paleoenvironment is required to preserve the tephra and allow the clay-sized glass particles to settle out of suspension.

\section{- Paleosol}

The paleosol units occur within silt, where they are characterised by a dark brown tint signifying a higher organic content. They have a crumbly texture with a greasy feel due to high clay content. Paleosols record a period during which the sediment surface was above water and not undergoing continuous sedimentation thereby allowing soil to develop.

\subsubsection{Paleoenvironmental facies associations and correlations between sections.}

With the exception of the paleosols and tephra facies, which can be correlated reliably between sections, the rest of the bio-lithofacies have highly variable distribution and correlation of individual units is not feasible. We thus simplify the stratigraphy further by adopting four basic paleoenvironmental facies associations to enable correlation between the sections (Fig 3.4). We define a paleoenvironmental facies association as a package of bio-lithofacies from a similar depositional paleoenvironment. Four paleoenvironmental facies associations are recognised within the Pakarae sequence: barrier, estuarine, estuary-head delta and floodplain. The composition of each of these is described below: 
- The floodplain paleoenvironmental facies association comprises the unfossiliferous silts and sand and unfossiliferous gravel bio-lithofacies.

- The estuarine paleoenvironmental facies association is composed mainly of silts and sand with abundant marine fauna and the thin shelly gravels. Both the floodplain and estuarine paleoenvironmental facies associations include occasional units of the silts and sand with rare marine fauna bio-lithofacies. As discussed above, it is difficult to conclusively determine the depositional environment of this bio-lithofacies so we typically package it within the paleoenvironmental facies association of the surrounding bio-lithofacies.

- The estuary-head delta paleoenvironmental facies association consists of the thick shelly gravel bio-lithofacies. With increasing distance from the bedrock high, these coarse gravelly sediments interfinger with the unfossiliferous silts and silts with abundant marine fauna.

- The barrier paleoenvironmental facies association contains the shelly wellsorted sands and some of the thin shelly gravels interpreted as tidal inlet channel lags.

These paleoenvironmental facies associations simplify the stratigraphic framework of Pakarae (Fig 3.4), allowing correlation of groups of bio-lithofacies from similar depositional environments. The spatial and chronological relationships between the paleoenvironmental facies associations form the basis of our comparisons with stable coast facies models of incised-valley infill.

The paleoenvironmental facies associations we identify have been developed on their own merits, but many have similarities with the facies divisions of Dalrymple et al. (1992), Roy (1984) and Allen and Posamentier (1993) (Fig 3.5A, B, D). Our barrier paleoenvironmental facies association is comparable to the barrier-shoreface facies of Dalrymple et al. (1992), the estuary mouth facies of Allen and Posamentier (1993), and the tidal delta sand of Roy (1984). The estuarine paleoenvironmental facies association of this study is similar to the central basin facies of Dalrymple et al. (1992), the tidal estuarine sand and mud facies of Allen and Posamentier (1993), and the estuarine mud facies of Roy (1984). The estuary-head delta paleoenvironmental facies association at Pakarae is similar to the bay-head delta facies of Dalrymple et al. (1992). Bay-head and estuary-head are interchangeable terms and refer to the same 
physiographic location within an estuary; we prefer the term "estuary-head". Our floodplain paleoenvironmental facies association corresponds to the alluvial package of Dalrymple et al. (1992) and the fluvial or floodplain packages of Allen and Posamentier (1993) and Roy (1984). The recognition of fluvial sediments in these studies is based on an absence of evidence of marine or tidal processes in the sediment deposition, similar to the criteria we have used at Pakarae.

\subsection{Discussion}

To characterise the facies architecture of an incised valley on a tectonically active coast, we compare the paleoenvironmental facies association distribution profile we have developed from Pakarae to facies models for stable coasts (Allen and Posamentier, 1993; Dalrymple et al., 1992) and case studies of infilled Holocene estuaries on stable coasts (for example, Chappell, 1993; Dabrio et al., 2000; Fletcher III et al., 1990; Lessa et al., 1998; Long et al., 1998; Nichol et al., 1996; Sloss et al., 2005; Woodroffe, 1996; Woodroffe et al., 1993). We then modify these models to better reflect the expected architecture of valley infill on tectonically active coasts.

\subsubsection{Comparisons of Pakarae stratigraphy to stable-coast models of incised valley infilling}

There are two elements of similarity between Pakarae facies distribution and the facies models of Dalrymple et al. (1992), Roy (1984) and Allen and Posamentier (1994) (Fig 3.5A, B, D): (1) the occurrence of floodplain sediments at the base of the sequence and the immediately overlying estuary-head delta facies; and (2) the occurrence of barrier sands at the top of the sequence. The major difference between Pakarae valley sequence and existing stable-coast models is within the middle part of the infill sequence where estuarine and fluvial facies alternate at Pakarae instead of displaying a deepening central estuary basin facies as predicted in the models. We discuss the similarities first, and then the important differences. 


\section{(A) STABLE COAST:}

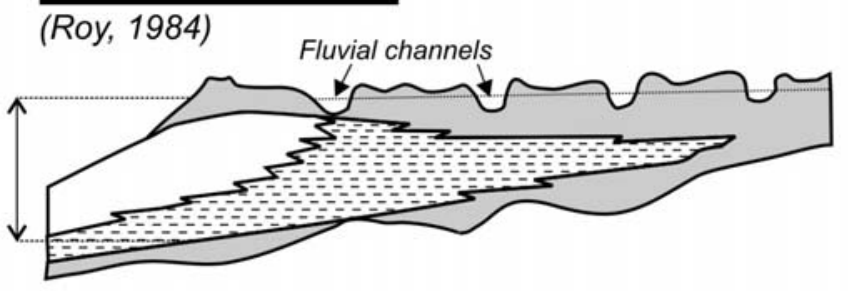

\section{(B) STABLE COAST:}

(Allen and Posamentier, 1993)

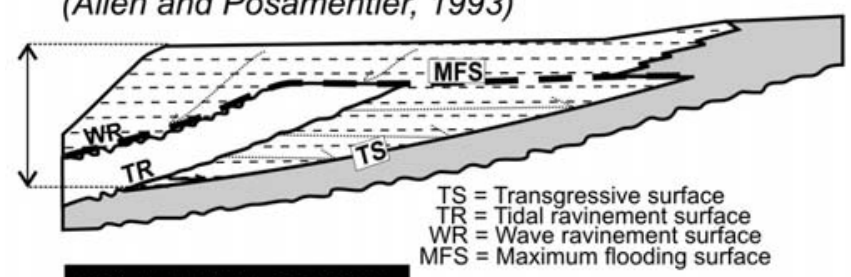

\section{(C) ACTIVE COAST:}

Pakarae River, this study.

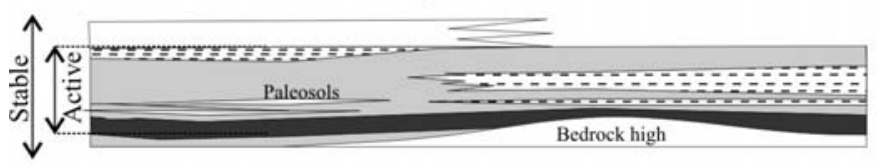

Paleoenvironmental facies associations

Estuary-head delta (C, D)

A: Bay-head delta

Floodplain (C, D)

A: Fluvial sand, muddy sand, floodplain silts and swamp deposits.

B: Coarse fluvial deposits

D: Alluvial deposits

Barrier (C, D)

A:Washover, tidal delta sand

B: Estuary mouth sand

$\mathrm{D}$ : Barrier shoreface

Z酒 Estuarine (C, D)

A: Estuarine mud

B: Tidal estuarine sand and mud

D: Central basin

Maximum infill
on a stable coast. $\downarrow \begin{aligned} & \text { Infill sequence } \\ & \text { thickness at Pakarae }\end{aligned}$

(D) STABLE COAST:

(Dalrymple et al., 1992)

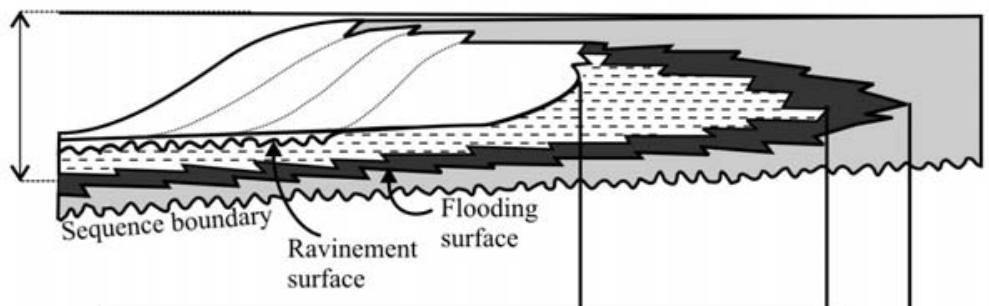

(E) DISTINGUISHING CHARACTERISTICS OF

INFILL SEQUENCES ON TECTONICALLY

ACTIVE COASTS

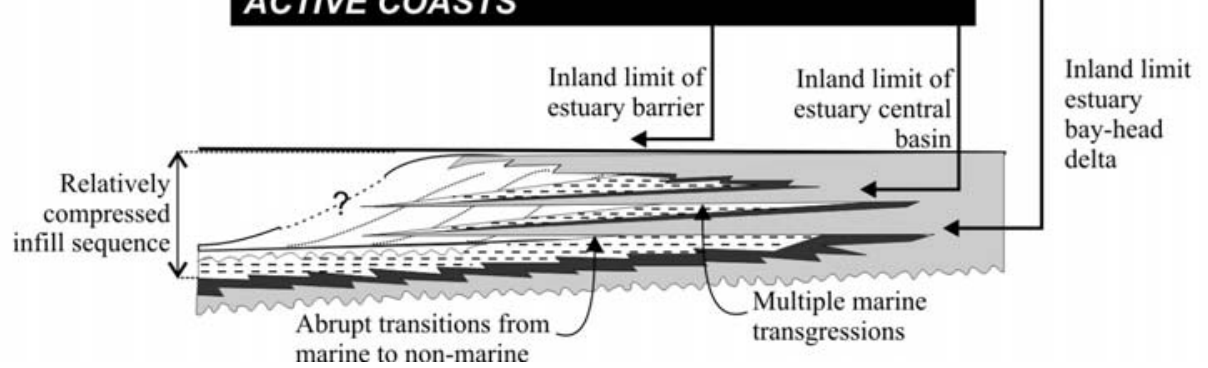

Figure 3.5. Comparisons between incised-valley facies models of stable coasts (A, B, D), and an active coast $(\mathbf{C})$, and a model for the distinguishing characteristics of an infill sequence on a tectonically active coast (E). All thicknesses (denoted by the vertical arrows) are relative. (A) Stable coast facies model Roy (1984), estuarine facies in the middle, thinning landward, underlain and overlain by fluvial sediments. (B) Stable coast facies model Allen and Posamentier (1993), thick estuarine facies in middle thinning landward. (C) Uplifting active coast, Pakarae River (this study), includes three estuarine paleoenvironmental facies associations, two of which pinch out seaward within a floodplain paleoenvironmental facies association. (D) Stable coast facies model Dalrymple et al. (1992), thick estuarine facies in middle thinning landward, underlain and overlain by fluvial sediments. (E) Modification of a stable coast infill model to better reflect the distinguishing characteristics produced by a tectonically active coast. 
It is significant that both the basal floodplain and capping barrier package are present at Pakarae because it suggests that the whole sequence of the Holocene valley infill is represented in the outcrop exposures. We infer there is no additional valley infill below the exposures we have documented at Pakarae. Shell from the lowest estuaryhead package is dated at 10200-9990 cal. yrs B.P. (Table 3.1). At this time eustatic SL was $\sim 23$ m below modern MSL. The present elevation of this shell sample at $4.4 \pm$ $0.31 \mathrm{~m}$ indicates an uplift rate of $2.7 \pm 0.5 \mathrm{~mm} \mathrm{yr}^{-1}$ since its deposition. This is within the uncertainty range of the Late Holocene uplift rate calculated at Pakarae from the elevation of marine terraces (3.15 $\pm 0.83 \mathrm{~mm} \mathrm{yr}^{-1}$, (Wilson et al., Ch. 2$)$. We infer the paleo-valley floor that was inundated at $\sim 10,000$ cal. yrs B.P. probably is now close to modern MSL, assuming that the average uplift rate has been constant for the past $10 \mathrm{ka}$. This supports our suggestion that there is no valley infill below the Pakarae riverbank exposures.

The presence of a laterally continuous layer of the bay-head delta paleoenvironmental facies association (extending the full $220 \mathrm{~m}$ length of the sections) deposited on top of the basal fluvial deposits at Pakarae is consistent with the Dalrymple et al. (1992), facies model (Fig 3.5D). The base of the bayhead paleoenvironmental facies association is termed the "flooding surface" by Dalrymple et al. (1992), and the "transgressive surface" by Allen and Posamentier (1994). This unit marks the start of the post-glacial marine transgression along this part of the incised valley. Radiocarbon ages from shell within this layer indicate that the estuary head shifted landward $\sim 200$ m between 10200-9990 cal. yrs B.P. and 9600-9450 cal. yrs B.P. (Fig 3.4).

The distribution of paleoenvironmental facies associations in the middle section at Pakarae, between the estuary-head delta package and the barrier sands, does not reconcile with the common stable-coast facies models (Dalrymple et al., 1992; Roy, 1984; Allen and Posamentier, 1994). In this part of the section sediments of the central estuary basin would be expected (Fig 3.5A, B, D). In contrast, the sediments at Pakarae between the basal estuary-head delta and capping paleoenvironmental facies associations show a complex alternation and interfingering of floodplain and estuarine paleoenvironmental facies associations (Figs. 4 and 5C). We consider this to be an important characteristic of the facies architecture of incised valley infill sequences on coseismically uplifting coastlines. 
There are three units of estuarine paleoenvironmental facies association sediments in the middle stratigraphic section. The highest and youngest estuarine paleoenvironmental facies association is at the seaward end of the sections. It overlies a floodplain facies, pinches out landward into floodplain sediments and grades upwards into estuary barrier sands. This paleoenvironmental facies association distribution can be likened to a typical transgressive estuarine sequence (Fig 3.4). The upper estuarine unit is thickest at the seaward end and its base is erosional above silts of the floodplain paleoenvironmental facies association (Fig 3.2). The basal unconformity represents a transgressive surface, after Allen and Posamentier (1994) (Fig 3.5B). The estuarine silts and sands contain in-situ intertidal foraminifera and intertidal brackish marine shells such as $A$. stutchburyi and $P$. australis. The estuarine unit coarsens upward into cross-bedded barrier sands. The thin gravel beds at $\sim 19 \mathrm{~m}$ AMSL in Sections 5 and 7 probably represent tidal channels at the estuary barrier (Fig 3.2), corresponding to a tidal ravinement surface (Fig 3.4, Fig 3.5B, Allen and Posamentier, 1994).

The lower and middle estuarine paleoenvironmental facies associations are located at the landward end of the sections (Fig 3.4). Both units appear to either pinch out or gradationally merge seaward into a fluvial facies which lies at the same elevation in the seaward sections, though the contact between the estuarine and floodplain paleoenvironmental facies associations is concealed (Fig 3.4). Floodplain sediments overlie both estuarine units. These lower two units of the estuarine paleoenvironmental facies association do not reconcile with existing models of incised valley infilling because in this section the marine environment should, if anything, become deeper due to rising eustatic SL. We have not conclusively resolved why this is so but can propose five possible scenarios:

(1) The floodplain paleoenvironmental facies association at the seaward end of the sections has been incorrectly identified.

(2) The non-marine sediments were deposited prior to estuary establishment. For example there may have been alluvial aggradation or colluvial fan deposition at the locations of Sections 5 and 7 before the estuarine sediments of Sections $1-4$ were deposited. 
(3) Birds-foot estuary-head delta morphology. A splayed fluvial delta front, in which there was switching between distributaries. Localised lobes of rapid sediment deposition that inhibited marine fauna colonisation, may account for the close juxtaposition of non-marine and marine-influenced sediments.

(4) The paleo-estuary wasn't oriented in the same direction as the modern river mouth. The former river mouth may have been in a different location therefore the paleo-seaward direction could have been different from the modern seaward.

(5) The estuarine paleoenvironmental facies associations were once continuous in the seaward direction, but have been removed by fluvial cut and fill subsequent to tectonic uplift, coastal emergence, and consequent river baselevel fall.

None of these scenarios are completely satisfactory to explain the juxtaposition of seaward non-marine sediments at equivalent elevations to landward estuarine sediments. For example, with regards to scenario (1), a mis-identification of the floodplain paleoenvironmental facies association has been previously discussed in the section regarding the paleo-depositional environment of the unfossiliferous silts and sands. In the stratigraphic position of the floodplain paleoenvironmental facies association, at the seaward end of an estuary, barrier sands are expected, but these are typically coarse, well-sorted sands. Therefore we are confident that this facies is not from a misidentified barrier paleoenvironmental facies association.

Deposition of the non-marine sediments prior to estuary establishment is possible (scenario 2), though colluvial fan deposition is inconsistent with the silty laminations and cross-bedding displayed by the seaward floodplain unit. A floodplain aggradation mechanism implies $\sim 7 \mathrm{~m}$ of floodplain sediment was deposited within $\sim 400 \mathrm{yrs}$ at a location very close to the coastline (cf. elevation of the $\sim 9500$ cal. yrs B.P. Rotoma tephra at $7 \mathrm{~m}$ and wood aged $\sim 9100$ cal. yrs B.P. at $14 \mathrm{~m}$ in Section 5), whilst leaving an area of lower elevation landward into which the middle estuarine paleoenvironmental facies association was deposited after $\sim 9100$ cal. yrs B.P. (indicated by shell age of 9210-8980 cal. yrs B.P. at $10 \mathrm{~m}$ elevation in Section 1). One might expect a river to grade to a consistent base level, and not form the significant topography implied by this scenario. 
A splayed delta-front is possible (scenario 3) but it implies the sediments barren of marine fauna (now identified by us as floodplain sediments) were deposited rapidly in an estuary seaward of locations inhabited by a rich estuarine fauna, without entraining any marine fauna. A different river mouth orientation (scenario 4) is unlikely because marine terraces on the east side of the river are underlain by mudstone bedrock. Therefore the paleo-river mouth cannot have flowed east, this only leaves a narrow valley width open to the west. And again, this was a narrow valley and it is doubtful that multiple splays could have formed.

The last scenario (scenario 5, post-uplift fluvial cut-and-fill) is preferred because it is known from the late Holocene marine terraces that tectonic uplift probably occurred during deposition of the infill sequence. River incision following a sudden base level fall caused coastal uplift during an earthquake is likely. The only problem with this scenario is that the floodplain paleoenvironmental facies association seaward of the middle estuarine unit is relatively uniform and there are no indications of an unconformity that may be equivalent to an incision event following abandonment of the middle landward estuarine unit. The paleosol layer near the base of the fluvial package at $\sim 9 \mathrm{~m}$ is interpreted as an unconformity because it indicates a hiatus in sedimentation. It is at approximately the same elevation as the lowest estuarine unit. The $\sim 2.5 \mathrm{~m}$ thickness of the floodplain sequence between the middle and upper estuarine units is significant and possibly represents rapid deposition of a large fluvial sediment pulse. The sediment pulse was probably due to catchment destabilisation triggered by an earthquake, probably the same event that caused abandonment of the middle estuarine unit.

The Pakarae stratigraphy is compared with other documented incised valley infills to check whether our interpretation of fluvial package in the middle section of the Pakarae stratigraphy is anomalous (for example: Chappell, 1993; Dabrio et al., 2000; Fletcher III et al., 1990; Heap et al., 2004; Heap and Nichol, 1997; Lessa et al., 1998; Long et al., 1998; Nichol et al., 1996; Sloss et al., 2005; Woodroffe, 1996; Woodroffe et al., 1993). While there are some detailed stratigraphic differences between these case studies and the facies models, there is a broad consistency between the examples and the stable coast models. The main signature is for a transgressive sequence of 
non-marine, followed by increasingly marine-influenced sediments, and then a reversion back to non-marine sediments.

The study of Dabrio et al. (2000) is particularly comparable to our Pakarae study as similar biostratigraphic tools were used at two river valleys in the south of Spain. Within the Guadalete River trangressive sequence the fauna (benthic foraminifera and shells) show a transition from a low-diversity, restricted-water assemblage to an increasingly diverse, open-water fauna as SL reached maximum flooding. The highstand sediments are represented by a transition back to low-diversity restricted water fauna as a result of estuary infilling (Dabrio et al., 2000). A comparable biostratigraphic sequence is not evident at Pakarae. The middle and lower estuarine units of Sections 1-3 show no apparent increase in marine influence or species diversity. The upper estuarine unit of Sections 4, 5 and 7 show some evidence of increasing marine influence: the foraminifera assemblages change from rare intertidal to dominant intertidal species between 16 - 20 m AMSL (Fig 3.3); however there is no change in species diversity.

A recent study by Sakai et al. (2006) addressed a similar issue to that of this study: to interpret the tectonic controls on incised valley infilling on an uplifting coastline in Japan. Evidence for three uplift events of the Isumi River lowlands was found. An early Holocene event at $\sim 9,000$ cal. yrs B.P., during the period of eustatic SL rise, was identified by an age gap in landward cores and a correlative period of very rapid sediment progradation within a marine silt sequence in the seaward cores. The rapid sedimentation and associated progradation were interpreted to be the result of intensified erosion, probably related to an earthquake (Sakai et al., 2006). Events at $\sim 6,400$ and $\sim 3,500$ cal. yrs B.P., younger than the culmination of eustatic SL rise, were identified by uplifted terraces and were associated with barrier establishment and enclosure of a lagoon. Our resolution of rapid deposition events is constrained by less age control relative to the Sakai et al. (2006) study, but it is possible that the middle, seaward floodplain paleoenvironmental facies association at Pakarae is an example of the rapid sedimentation and fluvial progradation event demonstrated at the Isumi River. Comparison of the Pakarae and Isumi River sequences illustrates that the preserved sedimentary signature of an uplift event within a transgressive estuarine sequence depends on the location of the preserved sequence within the incised valley. 
For example, the preserved Pakarae sequence was probably near the landward edge of the estuary and seaward of this point there were probably pulses of rapidly accumulating sediment corresponding to each coseismic event. The more landward parts of estuaries probably record hiatuses or unconformities, while seaward portions may respond with sediment progradation.

\subsubsection{Development of a facies architecture model for an incised valley infill sequence on a coastline undergoing coseismic uplift.}

Using the Pakarae valley data we present a model of how incised valley stratigraphy may be preserved if deposited synchronous with coseismic uplift (Fig 3.5E). On a coastline undergoing uplift synchronously with eustatic SL rise, we predict the transgressive estuarine sequence will be compressed and will not extend as far inland relative to that on a stable coastline (Fig 3.5E). If uplift occurred suddenly (i.e. by earthquakes) one might expect abrupt lateral shifts in the paleoenvironment, thus sharp facies boundaries. For example, the estuarine central basin sediments might slowly transgress landward during eustatic SL rise, suddenly retreat seaward synchronous with an uplift event, and then subsequently resume gradual landward movement under the continuing eustatic SL rise; a saw-tooth-type pattern of package interfingering might develop (Fig 3.5E). If coastal uplift occurred continuously and aseimically this would result in a compressed estuarine sequence with gradational facies transitions. No SL regressions would be recorded if the uplift was always less than the rate of eustatic SL rise rate.

We can demonstrate that the Pakarae valley infill sequence is compressed by comparing the preserved thickness of infill to the eustatic New Zealand SL curve (Gibb, 1986). To do this we have to assume that sedimentation rates in the paleovalley approximately kept pace with eustatic SL rise. This is testified to by the presence of intertidal foraminifera and bivalves throughout the estuarine paleoenvironmental facies associations. Taking two ages from near the base and top of the section: 10200-9990 cal. yrs B.P. at Section 8b/4.4 m AMSL and 7430-7280 cal. yrs B.P. at Section 5/18.3 - 18.7 m AMSL (we take the mid-point of $18.5 \mathrm{~m}$ ), there is $14.1 \pm 0.38 \mathrm{~m}$ between of sediment between them (Fig 3.4). According to the Gibb (1986) eustatic SL curve there was $\sim 21 \mathrm{~m}$ of eustatic SL rise between these two 
ages (we assign an uncertainty of $\pm 2 \mathrm{~m}$ to this value to reflect the uncertainty of the eustatic SL curve and the uncertainty of the radiocarbon age). SL rise creates accommodation space for sedimentation within incised valleys. If sedimentation within the Pakarae incised valley kept pace with the creation of accommodation space by SL rise then $21 \pm 2 \mathrm{~m}$ of sediment is expected to have been deposited between these two dated shells. The differential between the preserved sediment thickness $(14.1 \pm 0.38 \mathrm{~m})$ and the accommodation space created during this period $(21 \pm 2 \mathrm{~m})$ is $6.9 \pm 2.04 \mathrm{~m}$ (uncertainty calculated as the square root of the sum of the variances, Fig 3.4, Table 3.1). We call this residual the accommodation space deficit (Fig 3.5). The substantial deficit between the highest and lowest dated shells is an indicator that the transgressive sequence at Pakarae is compressed relative to that which would be expected on a stable coast. We cannot compare the inland extent of the marine sediments at Pakarae to other incised valleys because the geomorphology of Pakarae is unique. The initial depth and slope of the paleo-fluvial valley and rates of fluvial sediment delivery to the coast determine how far inland the maximum Holocene SL transgression reached and these differ with each valley.

Another distinguishing feature we identify for incised valley infills on coseismically uplifting coasts is saw-tooth pattern stratigraphy (Fig 3.5E). This is created by multiple cycles of sudden SL regressions (earthquakes) followed by gradual SL transgressions (eustatic SL rise). This is in contrast to an aseismic, gradual uplift mechanism, which might instead produce a compressed infill sequence with no reversals in the SL trend. While the paleoenvironmental package distribution of Pakarae has not produced an obvious saw tooth pattern (Fig 3.5C), the alternations of fluvial and estuarine packages indicates that more than one SL transgression occurred during the valley infilling. The three separate estuarine units indicate at least three periods of marine transgression into the Pakarae paleo-valley. The Pakarae stratigraphy actually indicates that a saw-tooth pattern stratigraphy is perhaps oversimplified and more complex sedimentation patterns are likely because of local circumstance, particularly with rapid fluvial sediment delivery due to catchment destabilisation following earthquakes. The problem of landward estuarine package juxtaposed at the same elevation with an apparently fluvial paleoenvironmental facies association in the seaward direction is evidence of this. Wilson et al. (Ch. 4) explores which package transitions within the stratigraphy represent uplift events and how the 
paleoenvironments at Pakarae changed during and after paleoseismic events. Evidence of SL reversals in the form of transitions from marine to fluvial environments despite continuous eustatic SL rise, is a remarkable stratigraphic feature at Pakarae and we believe it is an important characteristic of incised valley infills on coseismic tectonically active coasts.

It is possible that fluvial sedimentation pulses rather than uplift could produce sawtooth stratigraphic patterns and vertical transitions from estuarine to fluvial packages. Both would cause seaward movement of the shoreline and a marine regression stratigraphic signature. However, with SL rising at such fast rates during the early Holocene we believe that it is unlikely that fluvial sedimentation could have been rapid enough to cause seaward movement of the coastline, and this mechanism does not explain the accommodations space deficits recorded at Pakarae. Invoking fluvial sedimentation pulses is complicated because a likely cause of a sediment pulse is destabilisation of the catchment triggered by an earthquake. Offshore sediment cores have shown no evidence of sedimentation pulses during the early Holocene that could be related to earthquakes (Carter et al., 2002; Foster and Carter, 1997; Orpin, 2004), and sediment pulses are unlikely to be climate-related as this is a period of expanding vegetation and slope stabilisation (McGlone et al., 1994).

\subsection{Conclusions}

○ The stratigraphy preserved beneath the highest Holocene marine terrace represents infilling of the Pakarae incised valley during post-glacial SL rise.

- This example of infilling of an incised valley on a tectonically active coast provides a timely comparison with traditional facies models of incised valley infills, which have been developed exclusively for stable coasts (Allen and Posamentier, 1994; Dalrymple et al., 1992; Roy, 1984).

- At Pakarae the basal fluvial package, the immediately overlying estuary-head delta package, and the capping barrier package correlate well with models of incised valley infill and indicate that the complete sequence of incised valley infill is present within the Pakarae outcrops. 
- The middle section of the Pakarae stratigraphy displays complex alternations of estuarine and fluvial environments and thus differs from facies architecture models of stable coasts.

- The Pakarae sequence displays good evidence that the sequence is compressed relative to the amount of accommodation space that was created by eustatic SL rise. The middle section indicates there are complex sedimentary responses to uplift and a simple saw-tooth pattern is not seen. These stratigraphic complexities are probably related to rapid delivery of large volumes of earthquake-generated sediment in the catchment following uplift.

- Pakarae demonstrates that on coseismic uplifting coastlines distinctive sediment facies architecture is present. The distinguishing characteristics of the incised valley infill are:

- Part, or all, of the transgressive and lowstand sequences can be above modern SL.

- During the period of eustatic SL rise up to the culmination age (c. 7,000 cal. yrs B.P. in New Zealand) the infill sedimentary sequence is thinner than the amount of eustatic SL rise that occurred during that period.

- Evidence of relative SL falls (tectonic uplift), such as transitions from estuarine to fluvial environments, during periods of time when SL was constantly rising.

- Periods of rapid fluvial sedimentation may represent catchment destabilisation following earthquakes. 
Appendix 3.1: Diatom and palynology study

\section{Appendix 3.1.1 Summary}

Diatoms and palynomorphs have been frequently used in paleoenvironmental studies of coastal waterbody sedimentary sequences. The sensitivity of certain species of diatoms and plants to tidal inundation and salinity means they can be used to estimate paleo-elevations of sedimentary depositional environments with respect to mean SL (for example, Darienzo et al., 1994; Guilbault et al., 1995; Hemphill-Haley, 1995; Nelson et al., 1996; Shennan et al., 1996; Dawson and Smith, 1997; Long and Shennan, 1998; Hayward et al., 1999; Patterson et al., 2000; Sherrod et al., 2000; Hayward et al., 2004b; Cochran et al., 2006). As part of our paleoenvironmental study at Pakarae we tested the use of diatom studies and palynology. Our aim was to assess whether these microfossils could yield further paleoenvironmental data to compliment our foraminifera data, or be of use in sediment that was barren of foraminifera. This appendix outlines methodology employed and the results obtained. It was found that the diatom, pollen and spore assemblages were all characterised by very poor preservation. Rare lowland podocarp forest pollen was found, thus giving a regional vegetation signal rather than a localised depositional environment signal. The diatoms assemblages were very poorly preserved. In samples where identifiable species were found the interpreted depositional environment did not correlate well with the depositional environment interpreted from the foraminifera. Given the poor preservation of the diatoms and rarity of the diatoms, it was decided that the foraminifera were probably more reliable paleoenvironmental indicators.

\section{Appendix 3.1.2 Methods}

Seventeen samples from different sections were analysed for diatom content. Eight of the samples were fully processed in the following manner: diatom valves were concentrated from sediment samples (about $1 \mathrm{~g}$ dry weight) by chemical and physical processing. Samples were digested in hydrogen peroxide to remove organic matter and heated in hydrochloric acid to remove carbonates. Sand was removed by settling through a water column and retaining the fine fraction in suspension. Clay was removed by washing with dilute sodium hexametaphosphate and repeatedly decanting suspended fines. Microscope slides were prepared by drying aliquots of suspension onto coverslips and mounting them in Naphrax diatom mountant. Diatom species were identified at x1600 magnification with reference to standard floras (eg. Krammer and Lange-Bertalot, 1991; Hartley, 1996; Krammer and Lange-Bertalot, 1999a, b, 2000a, b; Witkowski et al., 2000). Where possible the species were assessed for their salinity and habitat preferences taken from van Dam et al. (1994), Round et al. (1990) 
and the above floras. The remaining nine samples were assessed by placing a wet smear of sediment on the slide and checking for the presence or absence of diatoms.

Only three samples were processed for a palynology study. The processing followed the standard technique of Moore and Webb (1978) and Moore et al. (1991). Bill McLea, VUW, identified the pollen species. The small number of samples reflects how we were testing the technique at Pakarae.

\section{Appendix 3.1.3 Results}

Abundance of diatoms in all samples was very poor and no samples had sufficient quantities of diatoms for full counts (of $\sim 300$ valves) to be undertaken. Of the eight samples fully processed, three had no diatoms, four were probably brackish-marine estuary and one was probably brackish or freshwater, but all had very few diatoms (Appendix 3.1, Table A). No diatoms were seen in any of the nine samples mounted on a smear slide. Each of the samples came from a location where the foraminifera were also studied. No correlation can be seen between the presence of diatoms and the foraminfera assemblages, for example of the four samples that had probable brackish-marine estuary diatoms, two had marginal-estuarine foraminifera assemblages one was intertidal and the other was barren of foraminifera (Appendix 3.1, Table A).

Hayward et al. (2004b) observed complementary preservation between diatoms and foraminifera: conditions for preserving the calcareous foraminifera may be unsuitable for the siliceous diatoms and vice versa. Based on this we were predicting that samples barren of foraminifera may contain diatoms if chemical dissolution was the reason for the absence of foraminifera. The evidence refutes this theory, there is no consistent complimentary relationship between diatom and foraminifera presence. Given the low abundance and poor preservation of the diatom assemblages we prefer to use the foraminifera assemblages in our paleoenvironmental interpretations.

We selected samples from three different foraminiferal zones to test whether palynological techniques could detect different paleoenvironments. One sample (Section 5: $11.7 \mathrm{~m} \mathrm{AMSL}$, in which we found reworked foraminifera) contained no pollen. The other two samples (Section 2: $14.14 \mathrm{~m}$ AMSL and Section 8b:2.75 m AMSL), which contained marginalestuarine and intertidal foraminifera assemblages, did contain pollen - the samples were dominated by Cyathea type pollen with minor amounts of Podocarpus type and Dacrydium cupressinum pollen (Appendix 3.1, Table B). These pollen types give information about the regional forest type at the time of deposition, which was probably a lowland podocarp forest, 
but yield no information about the environment in the immediate vicinity of the sample location. Pollen from plants such as rushes, sedges, saltwort and mangroves can be indicative of the local environment and have been used elsewhere as corroborative evidence of coastal waterbody change (eg. Goff et al., 2000; Cochran et al., 2006).

Our evidence implies the Pakarae pollen assemblages are not suitable for detecting localised paleoenvironmental change. This is consistent with Mildenhall (1994) who studied samples from Pakarae probably from the equivalent of the lower part of Section 5 based on stratigraphy matching and the grid references) and found most samples had few spore and pollen grains and large proportions of recycled pollen or very poor palynomorph preservation. Cyathea spores and podocarp pollen dominated the few samples that did contain in situ palynomorphs. Like the results of our test study, Mildenhall (1994) also did not make inferences about the local waterbody type based on the palynology.

Appendix 3.1, Table A: Diatom results from the Pakarae incised valley infill sequence.

\begin{tabular}{|c|c|c|c|c|}
\hline 苞 & 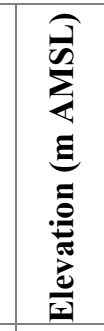 & 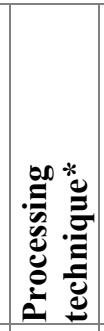 & 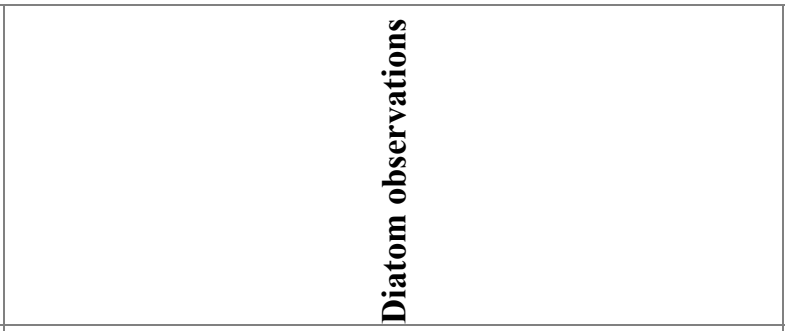 & 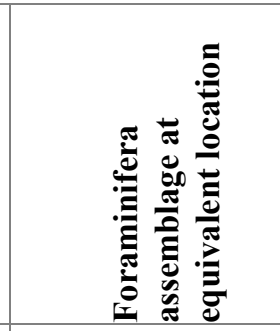 \\
\hline 1 & 15.48 & & No diatoms & Barren \\
\hline 1 & 15.18 & & Probably brackish marine estuary but very few diatoms & Intertidal \\
\hline 1 & 10.72 & & Probably brackish marine estuary but few diatoms & Barren \\
\hline 1 & 10.65 & $\mathrm{~F}$ & Probably brackish marine estuary but few diatoms & Marginal-estuarine \\
\hline 1 & 8.8 & $\mathrm{~F}$ & No diatoms & Marginal-estuarine \\
\hline 1 & 8.19 & $\mathrm{~F}$ & No diatoms & Marginal-estuarine \\
\hline 1 & 6.3 & $\mathrm{~F}$ & Possibly fresh water but almost no diatoms & Reworked \\
\hline 1 & 6.15 & $\mathrm{~F}$ & Possibly brackish or fresh water but almost no diatoms. & Marginal-estuarine \\
\hline 5 & 11.7 & SS & No diatoms & Reworked \\
\hline 7 & 5.65 & SS & No diatoms & Barren \\
\hline 7 & 9.4 & SS & No diatoms & Barren \\
\hline 7 & 12.42 & SS & No diatoms & Barren \\
\hline 7 & 16.5 & SS & No diatoms & Barren \\
\hline 7 & 17.08 & SS & No diatoms & Marginal-estuarine \\
\hline 7 & 17.91 & SS & No diatoms & Marginal-estuarine \\
\hline $8 \mathrm{a}$ & 0.8 & SS & No diatoms & Reworked \\
\hline $8 b$ & 2.75 & SS & No diatoms & Intertidal \\
\hline
\end{tabular}

* F: full processing, SS: slide scan. 
Appendix 3.1, Table B: Pollen results from the Pakarae incised valley infill sequence.

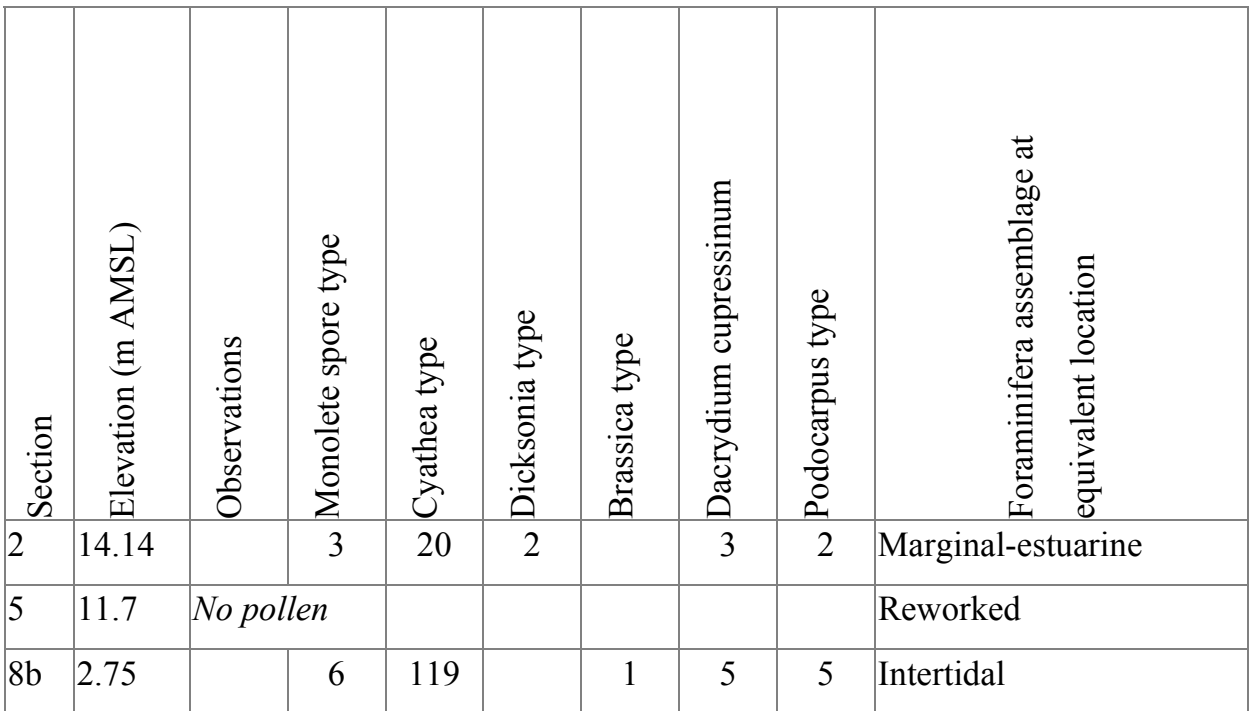


Appendix 3.2: Foraminifera census of the Pakarae incised valley infill sedimentary sequence.

Census data includes number of $A$. aoteana and E. excavatum picked, sample weight and fraction picked, percentage of sand in each sample, foraminifera abundance and rankings of the relative amounts of planktic foraminifera, macro shell fragments, mudstone chips and organic matter in each sample. ${ }^{1}$ Other foraminifera: all benthic foraminifera other than $A$. aoteana or E. excavatum, includes foraminifera that were too degraded for identification. ${ }^{2} \%$ sand: (weight of sediment $>63 \mu \mathrm{m}$ )/(sample dry weight). ${ }^{3}$ Abundance rank: 0: barren; 1: 1-10 benthic foraminifera per gram of sediment; 2: 10-40 benthic foraminifera per gram of sediment; 3: 40-100 benthic foraminifera per gram of sediment; 4: > 100 benthic foraminifera per gram of sediment. ${ }^{4} 0$ : not present; 1 : scattered presence; 2 : abundant presence.

\begin{tabular}{|c|c|c|c|c|c|c|c|c|c|c|c|c|c|c|c|}
\hline : & 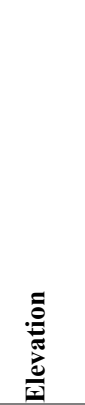 & 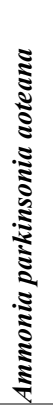 & 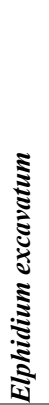 & ت & हีّ & 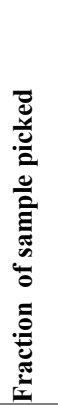 & 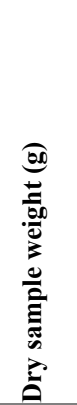 & 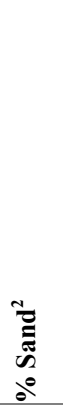 & 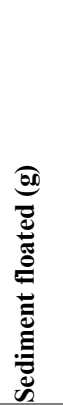 & 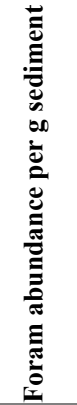 & 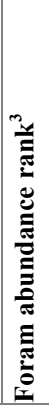 & 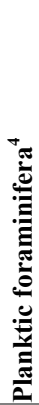 & 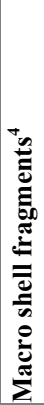 & 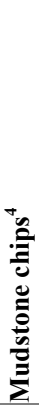 & 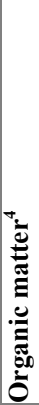 \\
\hline 1 & 15.48 & 0 & 0 & 0 & 0 & 0.02 & 10.06 & $84 \%$ & & 0.0 & 0 & 0 & 0 & 0 & 0 \\
\hline 1 & 15.38 & 1 & 0 & 107 & 108 & 1.00 & 7.43 & $96 \%$ & & 14.5 & 2 & 1 & 0 & 0 & 1 \\
\hline 1 & 15.27 & 0 & 0 & 0 & 0 & 0.05 & 9.33 & $79 \%$ & & 0.0 & 0 & 1 & 0 & 0 & 0 \\
\hline 1 & 15.26 & 16 & 0 & 84 & 100 & 0.19 & 12.28 & $46 \%$ & & 43.4 & 3 & 1 & 1 & 0 & 1 \\
\hline 1 & 15.18 & 139 & 6 & 36 & 181 & 0.38 & 10.92 & $77 \%$ & 4.11 & 44.1 & 3 & 1 & 1 & 0 & 1 \\
\hline 1 & 15 & 44 & 0 & 79 & 123 & 0.06 & 14.4 & $73 \%$ & & 136.7 & 4 & 1 & 2 & 0 & 0 \\
\hline 1 & 14.8 & 39 & 0 & 20 & 59 & 0.25 & 13.22 & $48 \%$ & 3.32 & 17.9 & 2 & 1 & 0 & 0 & 1 \\
\hline 1 & 13.73 & 18 & 0 & 15 & 33 & 0.38 & 12.48 & $84 \%$ & 4.72 & 7.0 & 1 & 1 & 1 & 0 & 0 \\
\hline 1 & 13.63 & 1 & 0 & 0 & 1 & 1.00 & 14.92 & $1 \%$ & & 0.1 & 1 & 0 & 0 & 0 & 0 \\
\hline 1 & 13.55 & 0 & 0 & 1 & 1 & 1.00 & 13.92 & $1 \%$ & & 0.1 & 1 & 0 & 0 & 0 & 0 \\
\hline 1 & 13.42 & 0 & 0 & 9 & 9 & 0.25 & 13.04 & $15 \%$ & & 2.8 & 1 & 1 & 0 & 0 & 2 \\
\hline 1 & 13.25 & 92 & 1 & 19 & 112 & 0.06 & 16.51 & $39 \%$ & & 108.5 & 4 & 1 & 0 & 0 & 1 \\
\hline 1 & 13.15 & 26 & 0 & 78 & 104 & 0.31 & 12.12 & $29 \%$ & & 27.5 & 2 & 1 & 0 & 0 & 0 \\
\hline 1 & 13.1 & 20 & 0 & 85 & 105 & 0.09 & 14.87 & $81 \%$ & & 75.3 & 3 & 1 & 1 & 0 & 1 \\
\hline 1 & 12.95 & 7 & 0 & 85 & 92 & 0.06 & 9.34 & $73 \%$ & & 157.6 & 4 & 2 & 0 & 0 & 0 \\
\hline 1 & 12.79 & 4 & 0 & 37 & 41 & 1.00 & 10.65 & $6 \%$ & & 3.8 & 1 & 1 & 0 & 0 & 1 \\
\hline 1 & 12.7 & 20 & 4 & 31 & 55 & 0.24 & 14.77 & $45 \%$ & 3.63 & 15.3 & 2 & 1 & 0 & 0 & 1 \\
\hline 1 & 12.56 & 114 & 1 & 11 & 126 & 0.13 & 17.78 & $18 \%$ & & 56.7 & 3 & 1 & 2 & 0 & 1 \\
\hline 1 & 12.54 & 10 & 0 & 84 & 94 & 0.06 & 9.95 & $90 \%$ & & 151.2 & 4 & 2 & 1 & 1 & 0 \\
\hline 1 & 12.43 & 10 & 0 & 99 & 109 & 0.22 & 7.99 & $88 \%$ & & 62.4 & 3 & 2 & 1 & 0 & 0 \\
\hline 1 & 12.34 & 132 & 0 & 16 & 148 & 0.50 & 17.36 & $42 \%$ & & 17.1 & 2 & 2 & 1 & 0 & 0 \\
\hline 1 & 12.25 & 13 & 0 & 14 & 27 & 0.25 & 26.32 & $84 \%$ & 6.55 & 4.2 & 1 & 1 & 2 & 1 & 0 \\
\hline 1 & 12.18 & 0 & 0 & 4 & 4 & 0.50 & 19.24 & $3 \%$ & & 0.4 & 1 & 1 & 0 & 0 & 1 \\
\hline
\end{tabular}




\begin{tabular}{|c|c|c|c|c|c|c|c|c|c|c|c|c|c|c|c|}
\hline : & 氕 & 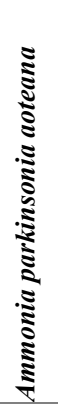 & 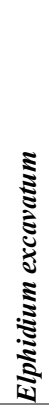 & 㐫 & हี & 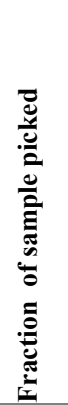 & 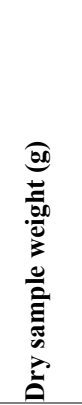 & 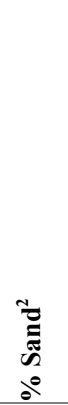 & 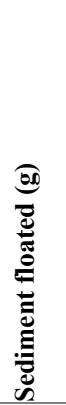 & 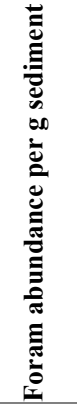 & 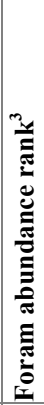 & 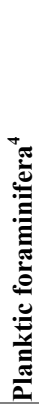 & 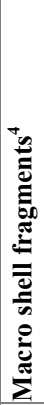 & 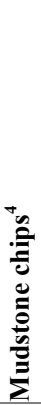 & 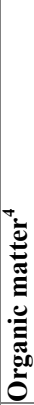 \\
\hline 1 & 12.14 & 0 & 0 & 0 & 0 & 1.00 & 19.48 & $1 \%$ & & 0.0 & 0 & 1 & 0 & 0 & 1 \\
\hline 1 & 11.94 & 79 & 1 & 21 & 101 & 0.16 & 22.45 & $19 \%$ & & 28.8 & 2 & 1 & 1 & 0 & 1 \\
\hline 1 & 11.62 & 28 & 0 & 30 & 58 & 0.40 & 10.41 & $77 \%$ & 4.24 & 13.8 & 2 & 1 & 0 & 0 & 1 \\
\hline 1 & 11.54 & 24 & 0 & 85 & 109 & 0.09 & 12.62 & $77 \%$ & & 92.1 & 3 & 1 & 0 & 0 & 0 \\
\hline 1 & 11.45 & 112 & 0 & 2 & 114 & 0.25 & 16.82 & $8 \%$ & & 27.1 & 2 & 1 & 1 & 0 & 1 \\
\hline 1 & 11.33 & 99 & 0 & 21 & 120 & 0.38 & 14.01 & $9 \%$ & & 22.8 & 2 & 2 & 0 & 0 & 0 \\
\hline 1 & 11.2 & 109 & 0 & 40 & 149 & 0.48 & 8.1 & $82 \%$ & 3.88 & 38.2 & 2 & 1 & 1 & 0 & 0 \\
\hline 1 & 10.8 & 19 & 0 & 95 & 114 & 0.09 & 10.67 & $89 \%$ & & 114.0 & 4 & 2 & 0 & 0 & 0 \\
\hline 1 & 10.72 & 0 & 0 & 0 & 0 & 0.13 & 19.1 & $4 \%$ & & 0.0 & 0 & 1 & 0 & 0 & 1 \\
\hline 1 & 10.65 & 2 & 0 & 0 & 2 & 0.50 & 17.38 & $4 \%$ & & 0.2 & 1 & 1 & 0 & 0 & 1 \\
\hline 1 & 10.45 & 11 & 0 & 103 & 114 & 0.09 & 9.31 & $85 \%$ & & 130.6 & 4 & 2 & 0 & 0 & 0 \\
\hline 1 & 10.15 & 0 & 0 & 3 & 3 & 0.06 & 24.35 & $9 \%$ & & 2.0 & 1 & 1 & 0 & 0 & 1 \\
\hline 1 & 9 & 0 & 0 & & 0 & 0.25 & 15.41 & $4 \%$ & & 0.0 & 0 & 0 & 0 & 0 & 0 \\
\hline 1 & 8.8 & 2 & 0 & 7 & 9 & 0.21 & 29.21 & $83 \%$ & 6.06 & 1.5 & 1 & 0 & 1 & 2 & 0 \\
\hline 1 & 8.62 & 0 & 0 & 0 & 0 & 0.25 & 28.33 & $3 \%$ & & 0.0 & 0 & 0 & 0 & 1 & 0 \\
\hline 1 & 8.5 & 0 & 0 & 40 & 40 & 0.27 & 18.19 & $51 \%$ & 4.87 & 8.2 & 1 & 1 & 0 & 0 & 1 \\
\hline 1 & 8.19 & 2 & 0 & 3 & 5 & 0.22 & 24.54 & $93 \%$ & 5.36 & 0.9 & 1 & 1 & 1 & 2 & 0 \\
\hline 1 & 7.84 & 0 & 0 & 0 & 0 & 1.00 & 14.98 & $14 \%$ & & 0.0 & 0 & 1 & 0 & 1 & 1 \\
\hline 1 & 7.72 & 0 & 0 & 18 & 18 & 0.06 & 9.28 & $83 \%$ & & 31.0 & 2 & 2 & 0 & 0 & 0 \\
\hline 1 & 6.45 & 0 & 0 & 0 & 0 & 0.02 & 8.95 & $58 \%$ & & 0.0 & 0 & 1 & 0 & & 2 \\
\hline 1 & 6.3 & 0 & 0 & 2 & 2 & 0.26 & 18.47 & $64 \%$ & 4.82 & 0.4 & 1 & 1 & 0 & 0 & 2 \\
\hline 1 & 6.15 & 1 & 0 & 14 & 15 & 0.24 & 16.98 & $82 \%$ & 4.07 & 3.7 & 1 & 1 & 0 & 2 & 1 \\
\hline 2 & 14.37 & 0 & & 0 & 0 & 0.02 & 18.88 & $85 \%$ & & 0.0 & 0 & 1 & 0 & 1 & 0 \\
\hline 2 & 14.3 & 0 & & 0 & 0 & 0.25 & 16.93 & $4 \%$ & & 0.0 & 0 & 0 & 0 & 0 & 0 \\
\hline 2 & 14.14 & 3 & & 7 & 10 & 1.00 & 25.26 & $1 \%$ & & 0.4 & 1 & 1 & 0 & 0 & 1 \\
\hline 2 & 13.98 & 65 & & 0 & 65 & 1.00 & 23.67 & $12 \%$ & & 2.7 & 1 & 1 & 0 & 0 & 1 \\
\hline 2 & 13.77 & 107 & & 55 & 162 & 0.81 & 26.65 & $7 \%$ & & 7.5 & 1 & 2 & 1 & 0 & 1 \\
\hline 2 & 13.66 & 147 & & 19 & 166 & 0.06 & 31.06 & $13 \%$ & & 85.5 & 3 & 1 & 1 & 1 & 1 \\
\hline 2 & 13.5 & 0 & & 44 & 44 & 0.06 & 32.59 & $6 \%$ & & 21.6 & 2 & 2 & 0 & 0 & 1 \\
\hline 2 & 13.2 & 0 & & 19 & 19 & 0.03 & 30.56 & $15 \%$ & & 19.9 & 2 & 1 & 0 & 0 & 1 \\
\hline 2 & 13.12 & 0 & & 23 & 23 & 0.06 & 23.52 & $9 \%$ & & 15.6 & 2 & 1 & 0 & 0 & 1 \\
\hline 2 & 12.8 & 1 & & 6 & 7 & 0.13 & 27.73 & $4 \%$ & & 2.0 & 1 & 1 & 0 & 1 & 1 \\
\hline 2 & 12.7 & 2 & & 7 & 9 & 0.01 & 36.01 & $37 \%$ & & 32.0 & 2 & 1 & 0 & 0 & 0 \\
\hline 2 & 12.25 & 129 & & 10 & 139 & 0.50 & 20.13 & $2 \%$ & & 13.8 & 2 & 1 & 0 & 0 & 2 \\
\hline 2 & 11.9 & 13 & & 26 & 39 & 0.77 & 15.77 & $30 \%$ & 3.67 & 3.2 & 1 & 1 & 0 & 0 & 1 \\
\hline 2 & 11.6 & 13 & & 13 & 26 & 0.25 & 20.92 & $14 \%$ & & 5.0 & 1 & 1 & 0 & 0 & 1 \\
\hline 2 & 11.2 & 1 & & 56 & 57 & 0.59 & 17.31 & $31 \%$ & 3.27 & 5.6 & 1 & 1 & 0 & 0 & 2 \\
\hline 2 & 11.05 & 126 & & 26 & 152 & 0.09 & 30.32 & $10 \%$ & & 53.5 & 3 & 1 & 1 & 0 & 1 \\
\hline 2 & 10.95 & 0 & & 18 & 18 & 0.02 & 32.53 & $48 \%$ & & 35.4 & 1 & 1 & 0 & 0 & 0 \\
\hline 2 & 10.83 & 0 & & 62 & 62 & 0.02 & 24.79 & $45 \%$ & & 160.1 & 4 & 2 & 0 & 0 & 1 \\
\hline
\end{tabular}




\begin{tabular}{|c|c|c|c|c|c|c|c|c|c|c|c|c|c|c|c|}
\hline : & 氙 & 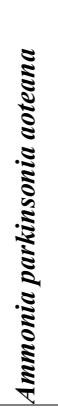 & 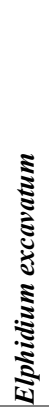 & 泀 & $\underset{\tilde{U}}{\tilde{\theta}}$ & 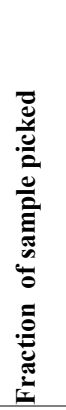 & 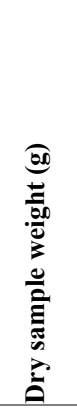 & 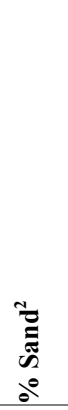 & 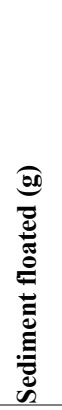 & 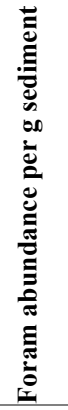 & 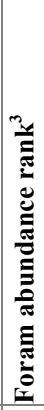 & 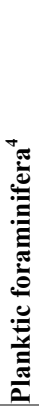 & 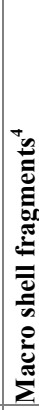 & 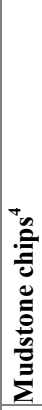 & 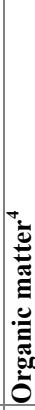 \\
\hline 2 & 10.7 & 0 & & 64 & 64 & 0.05 & 23.97 & $44 \%$ & & 57.0 & 3 & 2 & 0 & 0 & 1 \\
\hline 2 & 9.8 & 0 & & 0 & 0 & 0.25 & 17.5 & $5 \%$ & & 0.0 & 0 & 0 & 0 & 1 & 2 \\
\hline 2 & 9.73 & 0 & & 0 & 0 & 0.06 & 20.31 & $19 \%$ & & 0.0 & 0 & 0 & 0 & 0 & 1 \\
\hline 2 & 9.24 & 0 & & 1 & 1 & 0.06 & 30.19 & $35 \%$ & & 0.5 & 1 & 1 & 0 & 1 & 0 \\
\hline 2 & 9.19 & 0 & & 0 & 0 & 0.02 & 29.14 & $56 \%$ & & 0.0 & 0 & 0 & 0 & 1 & 0 \\
\hline 2 & 9.1 & 36 & & 2 & 38 & 1.00 & 31.12 & $6 \%$ & & 1.2 & 1 & 0 & 1 & 0 & 1 \\
\hline 2 & 8.95 & 33 & & 9 & 42 & 0.65 & 16.06 & $34 \%$ & 3.55 & 4.0 & 1 & 1 & 1 & 1 & 2 \\
\hline 2 & 8.65 & 30 & & 27 & 57 & 0.66 & 19.04 & $25 \%$ & 3.15 & 4.5 & 1 & 1 & 1 & 0 & 1 \\
\hline 2 & 8.45 & 0 & & 2 & 2 & 0.02 & 23.67 & $46 \%$ & & 5.4 & 1 & 1 & 0 & 1 & 0 \\
\hline 2 & 8.3 & 0 & & 1 & 1 & 0.02 & 43.44 & $34 \%$ & & 1.5 & 1 & 1 & 0 & 1 & 0 \\
\hline 2 & 8.18 & 3 & & 4 & 7 & 0.03 & 61.33 & $29 \%$ & & 3.7 & 1 & 1 & 1 & 0 & 0 \\
\hline 2 & 7.95 & 0 & & 0 & 0 & 0.13 & 14.55 & $45 \%$ & & 0.0 & 0 & 0 & 0 & 0 & 1 \\
\hline 2 & 7.7 & 0 & & 0 & 0 & 0.03 & 18.77 & $22 \%$ & & 0.0 & 0 & 1 & 0 & 0 & 2 \\
\hline 2 & 7.35 & 4 & & 7 & 11 & 0.06 & 27.06 & $31 \%$ & & 6.5 & 1 & 1 & 1 & 1 & 1 \\
\hline 3 & 14.15 & 0 & & 2 & 2 & 0.13 & 36.31 & $6 \%$ & & 0.4 & 1 & 1 & 0 & 0 & 1 \\
\hline 3 & 14.11 & 0 & & 0 & 0 & 0.02 & 29.84 & $44 \%$ & & 0.0 & 0 & 1 & 0 & 0 & 0 \\
\hline 3 & 14.08 & 0 & & 0 & 0 & 0.01 & 33.8 & $80 \%$ & & 0.0 & 0 & 1 & 0 & 0 & 0 \\
\hline 3 & 14.02 & 0 & & 1 & 1 & 0.01 & 40.51 & $68 \%$ & & 3.2 & 1 & 1 & 0 & 0 & 0 \\
\hline 3 & 13.92 & 1 & & 3 & 4 & 0.25 & 34.75 & $3 \%$ & & 0.5 & 1 & 1 & 0 & 0 & 1 \\
\hline 3 & 13.82 & 64 & & 29 & 93 & 0.50 & 13.49 & $19 \%$ & & 13.8 & 2 & 1 & 0 & 0 & 1 \\
\hline 3 & 13.74 & 4 & & 4 & 8 & 0.25 & 16.24 & $8 \%$ & & 2.0 & 1 & 1 & 0 & 0 & 1 \\
\hline 3 & 13.7 & 0 & & 0 & 0 & 0.13 & 13.27 & $7 \%$ & & 0.0 & 0 & 1 & 0 & 0 & 2 \\
\hline 3 & 13.55 & 122 & & 2 & 124 & 0.60 & 15.24 & $36 \%$ & 3.33 & 13.6 & 2 & 1 & 0 & 0 & 1 \\
\hline 3 & 13.4 & 0 & & 0 & 0 & 0.58 & 16.94 & $47 \%$ & 4.65 & 0.0 & 0 & 1 & 0 & 0 & 1 \\
\hline 3 & 13.2 & 21 & & 7 & 28 & 0.38 & 16.08 & $65 \%$ & 3.9 & 4.6 & 1 & 1 & 0 & 0 & 1 \\
\hline 3 & 13 & 38 & & 10 & 48 & 0.44 & 17.05 & $60 \%$ & 4.55 & 6.4 & 1 & 1 & 2 & 0 & 2 \\
\hline 3 & 12.93 & 13 & & 25 & 38 & 0.53 & 13.81 & $56 \%$ & 4.05 & 5.2 & 1 & 1 & 0 & 0 & 1 \\
\hline 3 & 12.8 & 0 & & 21 & 21 & 0.02 & 31.23 & $45 \%$ & & 43.0 & 3 & 2 & 0 & 0 & 1 \\
\hline 3 & 12.7 & 0 & & 35 & 35 & 0.06 & 34.13 & $26 \%$ & & 16.4 & 2 & 2 & 0 & 0 & 2 \\
\hline 3 & 12.67 & 0 & & 19 & 19 & 0.03 & 21.77 & $47 \%$ & & 27.9 & 2 & 2 & 0 & 0 & 2 \\
\hline 3 & 12.6 & 0 & & 12 & 12 & 0.03 & 23.4 & $62 \%$ & & 16.4 & 2 & 2 & 0 & 0 & 2 \\
\hline 3 & 12.56 & 0 & & 8 & 8 & 0.06 & 28.06 & $13 \%$ & & 4.6 & 1 & 1 & 1 & 0 & 2 \\
\hline 3 & 12.45 & 6 & & 61 & 67 & 0.06 & 42.28 & $81 \%$ & & 25.4 & 2 & 2 & 1 & 0 & 0 \\
\hline 3 & 12.26 & 1 & & 8 & 9 & 0.02 & 32.07 & $29 \%$ & & 18.0 & 2 & 2 & 0 & 0 & 1 \\
\hline 3 & 12.2 & 0 & & 4 & 4 & 0.01 & 29.89 & $27 \%$ & & 17.1 & 2 & 1 & 0 & 0 & 0 \\
\hline 3 & 12.1 & 0 & & 4 & 4 & 0.02 & 35.88 & $40 \%$ & & 7.1 & 1 & 2 & 0 & 0 & 1 \\
\hline 3 & 11.9 & 102 & & 13 & 115 & 0.13 & 17.26 & $20 \%$ & & 53.3 & 3 & 1 & 1 & 0 & 2 \\
\hline 3 & 11.5 & 6 & & 72 & 78 & 0.76 & 18.06 & $28 \%$ & 3.72 & 5.7 & 1 & 1 & 0 & 0 & 1 \\
\hline 3 & 11 & 16 & & 58 & 74 & 0.73 & 16.66 & $30 \%$ & 3.72 & 6.1 & 1 & 1 & 0 & 0 & 1 \\
\hline 3 & 10.8 & 0 & & 2 & 2 & 0.13 & 15.08 & $12 \%$ & & 1.1 & 1 & 1 & 0 & 0 & 1 \\
\hline
\end{tabular}




\begin{tabular}{|c|c|c|c|c|c|c|c|c|c|c|c|c|c|c|c|}
\hline : & 音 & 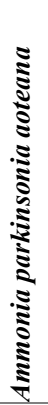 & 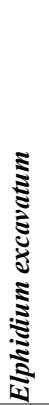 & 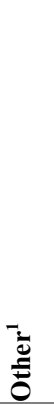 & $\stackrel{\vec{J}}{\stackrel{\Xi}{\theta}}$ & 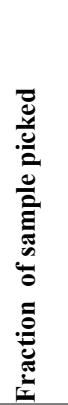 & 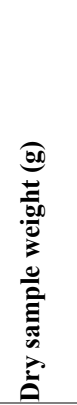 & 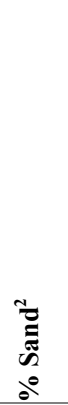 & 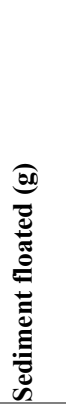 & 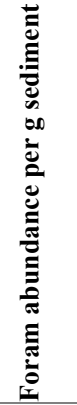 & 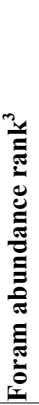 & 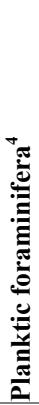 & 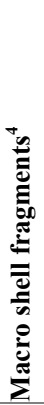 & 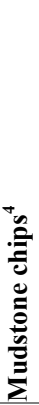 & 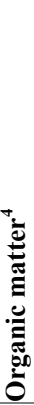 \\
\hline 4 & 19.35 & 0 & 0 & 62 & 62 & 0.06 & 10.77 & $94 \%$ & & 92.1 & 3 & 1 & 1 & 0 & 0 \\
\hline 4 & 18.95 & 54 & 0 & 54 & 108 & 0.06 & 44.57 & $86 \%$ & & 38.8 & 2 & 2 & 2 & 2 & 0 \\
\hline 4 & 18.45 & 15 & 0 & 47 & 62 & 0.13 & 6.91 & $92 \%$ & & 71.8 & 3 & 1 & 1 & 0 & 0 \\
\hline 4 & 18.1 & 0 & 0 & 2 & 2 & 0.03 & 7.1 & $91 \%$ & & 9.0 & 1 & 0 & 1 & 0 & 0 \\
\hline 4 & 17.72 & 0 & 0 & 0 & 0 & 0.06 & 14.13 & $21 \%$ & & 0.0 & 0 & 0 & 0 & 0 & 1 \\
\hline 4 & 17.55 & 0 & 0 & 0 & 0 & 0.03 & 15.39 & $30 \%$ & & 0.0 & 0 & 0 & 0 & 0 & 1 \\
\hline 4 & 17.36 & 0 & 0 & 0 & 0 & 0.06 & - & - & & - & 0 & 0 & 0 & 0 & 1 \\
\hline 4 & 17.02 & 0 & 0 & 0 & 0 & 0.03 & 10.26 & $65 \%$ & & 0.0 & 0 & 1 & 0 & 0 & 0 \\
\hline 4 & 16.66 & 0 & 0 & 0 & 0 & 0.03 & 10.76 & $70 \%$ & & 0.0 & 0 & 0 & 0 & 0 & 0 \\
\hline 4 & 16.4 & 0 & 0 & 1 & 1 & 0.02 & 14.29 & $75 \%$ & & 4.5 & 1 & 0 & 0 & 0 & 0 \\
\hline 4 & 16.02 & 0 & 0 & 0 & 0 & 0.03 & 18.76 & $22 \%$ & & 0.0 & 0 & 0 & 0 & 0 & 1 \\
\hline 4 & 15.65 & 0 & 0 & 0 & 0 & 0.25 & 18.86 & $3 \%$ & & 0.0 & 0 & 0 & 0 & 0 & 1 \\
\hline 4 & 15.31 & 0 & 0 & 0 & 0 & 0.03 & 18.37 & $20 \%$ & & 0.0 & 0 & 0 & 0 & 0 & 1 \\
\hline 4 & 14.73 & 0 & 0 & 0 & 0 & 0.03 & 13.73 & $31 \%$ & & 0.0 & 0 & 0 & 0 & 0 & 1 \\
\hline 4 & 14.25 & 0 & 0 & 0 & 0 & 0.03 & 13.5 & $32 \%$ & & 0.0 & 0 & 1 & 0 & 0 & 1 \\
\hline 4 & 13.44 & 2 & 0 & 24 & 26 & 0.06 & 10.17 & $51 \%$ & & 40.9 & 3 & 1 & 0 & 0 & 1 \\
\hline 4 & 12.96 & 1 & 0 & 13 & 14 & 0.06 & 15.8 & $17 \%$ & & 14.2 & 2 & 1 & 0 & 0 & 1 \\
\hline 5 & 23.1 & 0 & 0 & 0 & 0 & 0.03 & 14.63 & $97 \%$ & & 0.0 & 0 & 0 & 0 & 0 & 0 \\
\hline 5 & 21.25 & 10 & 0 & 35 & 45 & 0.03 & 19.18 & $95 \%$ & & 75.1 & 3 & 1 & 1 & 1 & 0 \\
\hline 5 & 20.3 & 13 & 0 & 99 & 112 & 0.08 & 17.25 & $99 \%$ & & 83.1 & 3 & 1 & 0 & 0 & 0 \\
\hline 5 & 18.5 & 46 & 0 & 60 & 106 & 0.44 & 16.9 & $87 \%$ & & 14.3 & 2 & 1 & 2 & 2 & 0 \\
\hline 5 & 18.16 & 14 & 0 & 87 & 101 & 1.00 & 15.83 & $11 \%$ & & 6.4 & 1 & 1 & 2 & 1 & 0 \\
\hline 5 & 18.12 & 16 & 0 & 97 & 113 & 0.06 & 15.7 & $87 \%$ & & 115.2 & 4 & 1 & 1 & 0 & 0 \\
\hline 5 & 18.03 & 16 & 11 & 47 & 74 & 0.22 & 18.67 & $29 \%$ & 4.11 & 18.0 & 2 & 1 & 2 & 0 & 0 \\
\hline 5 & 17.78 & 4 & 0 & 55 & 59 & 0.33 & 16.73 & $72 \%$ & 5.55 & 10.7 & 2 & 1 & 1 & 0 & 0 \\
\hline 5 & 17.56 & 0 & 0 & 20 & 20 & 0.02 & 16.69 & $82 \%$ & & 76.7 & 3 & 1 & 0 & 0 & 0 \\
\hline 5 & 17.55 & 0 & 0 & 15 & 15 & 0.02 & 20.17 & $86 \%$ & & 47.6 & 3 & 1 & 0 & 0 & 0 \\
\hline 5 & 17.45 & 33 & 1 & 72 & 106 & 0.38 & 14.83 & $80 \%$ & 5.61 & 18.9 & 2 & 1 & 0 & 0 & 0 \\
\hline 5 & 17.28 & 1 & 0 & 25 & 26 & 0.02 & 17.87 & $85 \%$ & & 93.1 & 3 & 1 & 0 & 0 & 0 \\
\hline 5 & 16.82 & 13 & 0 & 96 & 109 & 0.08 & 17.7 & $84 \%$ & & 78.8 & 3 & 1 & 0 & 0 & 0 \\
\hline 5 & 15.95 & 0 & 0 & 0 & 0 & 0.03 & 16.94 & $26 \%$ & & 0.0 & 0 & 1 & 0 & 0 & 0 \\
\hline 5 & 15.75 & 0 & 0 & 5 & 5 & 0.03 & 16.53 & $48 \%$ & & 9.7 & 1 & 1 & 0 & 0 & 0 \\
\hline 5 & 15.2 & 0 & 0 & 0 & 0 & 0.03 & 19.58 & $38 \%$ & & 0.0 & 0 & 1 & 0 & 0 & 0 \\
\hline 5 & 14.3 & 3 & 0 & 12 & 15 & 0.29 & 18.23 & $63 \%$ & 5.29 & 2.8 & 1 & 1 & 0 & 0 & 0 \\
\hline 5 & 13.16 & 0 & 0 & 2 & 2 & 0.03 & 13.35 & $27 \%$ & & 4.8 & 1 & 1 & 0 & 0 & 0 \\
\hline 5 & 11.7 & 0 & 0 & 2 & 2 & 0.06 & 19.8 & $30 \%$ & & 1.6 & 1 & 1 & 0 & 0 & 0 \\
\hline 5 & 11.1 & 0 & 0 & 0 & 0 & 0.06 & 12.33 & $36 \%$ & & 0.0 & 0 & 0 & 0 & 1 & 0 \\
\hline 5 & 10.4 & 3 & 0 & 25 & 28 & 0.24 & 18.34 & $35 \%$ & 4.4 & 6.4 & 1 & 1 & 0 & 0 & 0 \\
\hline 5 & 9 & 0 & 0 & 4 & 4 & 0.03 & 17.46 & $19 \%$ & & 7.3 & 1 & 1 & 0 & 0 & 0 \\
\hline 5 & 8.22 & 0 & 0 & 4 & 4 & 0.06 & 18.15 & $26 \%$ & & 3.5 & 1 & 1 & 0 & 0 & 1 \\
\hline
\end{tabular}




\begin{tabular}{|c|c|c|c|c|c|c|c|c|c|c|c|c|c|c|c|}
\hline : & 氙 & 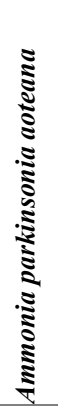 & 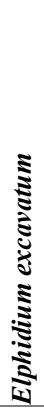 & 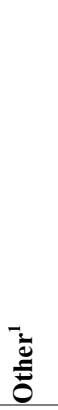 & $\stackrel{\text { సే }}{0}$ & 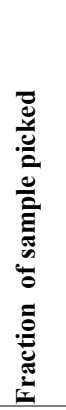 & 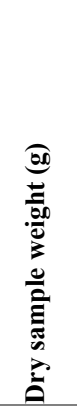 & 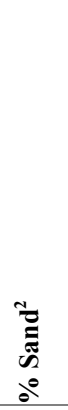 & 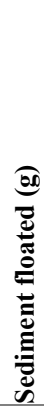 & 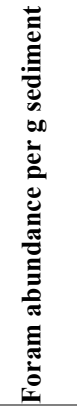 & 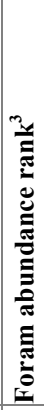 & 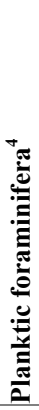 & 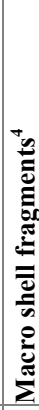 & 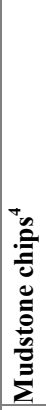 & 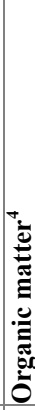 \\
\hline 5 & 7.45 & 0 & 0 & 2 & 2 & 0.03 & 20.61 & $40 \%$ & & 3.1 & 1 & 1 & 0 & 0 & 0 \\
\hline 5 & 7.05 & 0 & 0 & 1 & 1 & 0.03 & 20.65 & $42 \%$ & & 1.5 & 1 & 1 & 0 & 0 & 0 \\
\hline 5 & 6.02 & 1 & 0 & 5 & 6 & 0.02 & 20.48 & $58 \%$ & & 18.8 & 2 & 1 & 1 & 0 & 1 \\
\hline 5 & 6 & 1 & 0 & 17 & 18 & 0.03 & 19.16 & $50 \%$ & & 30.1 & 2 & 1 & 0 & 0 & 1 \\
\hline 5 & 5.5 & 0 & 0 & 3 & 3 & 0.03 & 18.7 & $19 \%$ & & 5.1 & 1 & 1 & 0 & 0 & 0 \\
\hline 5 & 5.2 & 1 & 0 & 23 & 24 & 0.13 & 22.17 & $75 \%$ & & 8.7 & 1 & 1 & 1 & 2 & 0 \\
\hline 6 & 8.4 & 0 & 0 & 0 & 0 & 0.02 & 18.18 & $30 \%$ & & 0.0 & 0 & 1 & 0 & 0 & 0 \\
\hline 6 & 7.5 & 0 & 0 & 0 & 0 & 0.03 & 10.36 & $97 \%$ & & 0.0 & 0 & 0 & 0 & 0 & 0 \\
\hline 6 & 5.9 & 0 & 0 & 0 & 0 & 0.02 & 15.52 & $75 \%$ & & 0.0 & 0 & 0 & 0 & 0 & 0 \\
\hline 6 & 5.7 & 0 & 0 & 0 & 0 & 0.02 & 18.57 & $44 \%$ & & 0.0 & 0 & 0 & 0 & 0 & 0 \\
\hline 6 & 5.65 & 121 & 0 & 3 & 124 & 0.50 & 18.13 & $8 \%$ & & 13.7 & 2 & 1 & 0 & 0 & 1 \\
\hline 6 & 5.5 & 0 & 0 & 0 & 0 & 0.03 & 17.79 & $70 \%$ & & 0.0 & 0 & 1 & 0 & 0 & 0 \\
\hline 6 & 5.05 & 0 & 0 & 0 & 0 & 0.02 & 19.85 & $58 \%$ & & 0.0 & 0 & 0 & 0 & 0 & 0 \\
\hline 7 & 21 & 22 & 0 & 85 & 107 & 0.13 & 8.41 & $94 \%$ & & 101.8 & 4 & 1 & 1 & 0 & 0 \\
\hline 7 & 19.38 & 21 & 0 & 65 & 86 & 0.13 & 8.82 & $84 \%$ & & 78.0 & 3 & 1 & 1 & 0 & 0 \\
\hline 7 & 18.6 & 25 & 0 & 75 & 100 & 0.34 & 27.06 & $72 \%$ & & 10.8 & 2 & 1 & 2 & 1 & 0 \\
\hline 7 & 17.91 & 4 & 0 & 79 & 83 & 0.09 & 7.82 & $70 \%$ & & 113.2 & 4 & 1 & 1 & 0 & 0 \\
\hline 7 & 17.6 & 1 & 2 & 8 & 11 & 0.06 & 14.61 & $41 \%$ & & 12.0 & 2 & 1 & 0 & 0 & 0 \\
\hline 7 & 17.18 & 6 & 0 & 87 & 93 & 0.13 & 23.82 & $32 \%$ & & 31.2 & 2 & 1 & 2 & 0 & 0 \\
\hline 7 & 17.08 & 8 & 0 & 107 & 115 & 0.25 & 9.95 & $79 \%$ & & 46.2 & 3 & 1 & 2 & 0 & 0 \\
\hline 7 & 16.9 & 0 & 0 & 2 & 2 & 0.25 & 12.93 & $30 \%$ & & 0.6 & 1 & 1 & 0 & 0 & 0 \\
\hline 7 & 16.5 & 0 & 0 & 0 & 0 & 0.06 & 10.8 & $34 \%$ & & 0.0 & 0 & 0 & 0 & 0 & 1 \\
\hline 7 & 15.53 & 0 & 0 & 0 & 0 & 0.06 & 12.98 & $26 \%$ & & 0.0 & 0 & 0 & 0 & 0 & 1 \\
\hline 7 & 14.36 & 0 & 0 & 0 & 0 & 0.06 & 13.83 & $19 \%$ & & 0.0 & 0 & 1 & 0 & 0 & 1 \\
\hline 7 & 12.42 & 0 & 0 & 0 & 0 & 0.06 & 8.05 & $42 \%$ & & 0.0 & 0 & 0 & 0 & 0 & 1 \\
\hline 7 & 10.72 & 0 & 0 & 0 & 0 & 0.06 & 11.42 & $29 \%$ & & 0.0 & 0 & 0 & 0 & 0 & 1 \\
\hline 7 & 10.1 & 0 & 0 & 0 & 0 & 0.06 & 7.56 & $33 \%$ & & 0.0 & 0 & 0 & 0 & 0 & 1 \\
\hline 7 & 9.4 & 0 & 0 & 0 & 0 & 0.13 & - & - & & - & 0 & 0 & 0 & 1 & 1 \\
\hline 7 & 8.4 & 1 & 0 & 15 & 16 & 0.13 & 9.32 & $30 \%$ & & 13.7 & 2 & 1 & 0 & 0 & 1 \\
\hline 7 & 8.03 & 0 & 0 & 0 & 0 & 0.06 & 10.69 & $23 \%$ & & 0.0 & 0 & 0 & 0 & 0 & 1 \\
\hline 7 & 7.9 & 0 & 0 & 4 & 4 & 0.06 & 9.14 & $22 \%$ & & 7.0 & 1 & 1 & 0 & 0 & 1 \\
\hline 7 & 7.6 & 0 & 0 & 0 & 0 & 0.03 & 11.03 & $49 \%$ & & 0.0 & 0 & 0 & 0 & 0 & 1 \\
\hline 7 & 7.42 & 0 & 0 & 0 & 0 & 0.06 & 7.77 & $83 \%$ & & 0.0 & 0 & 0 & 0 & 0 & 1 \\
\hline 7 & 7.05 & 0 & 0 & 0 & 0 & 0.06 & 4.71 & $91 \%$ & & 0.0 & 0 & 0 & 0 & 0 & 0 \\
\hline 7 & 6.31 & 0 & 0 & 0 & 0 & 0.03 & 5.39 & $84 \%$ & & 0.0 & 0 & 0 & 0 & 0 & 1 \\
\hline 7 & 5.65 & 0 & 0 & 0 & 0 & 0.13 & 6.24 & $66 \%$ & & 0.0 & 0 & 1 & 0 & 0 & 0 \\
\hline 7 & 5.35 & 0 & 0 & 0 & 0 & 0.50 & 10.28 & $3 \%$ & & 0.0 & 0 & 0 & 0 & 0 & 1 \\
\hline 7 & 5.25 & 0 & 0 & 9 & 9 & 0.06 & 121.6 & $31 \%$ & & 1.2 & 1 & 0 & 1 & 1 & 0 \\
\hline $8 a$ & 1.7 & 1 & 0 & 11 & 12 & 0.06 & 22.87 & $84 \%$ & & 8.4 & 1 & 1 & 0 & 2 & 0 \\
\hline $8 \mathrm{a}$ & 1.35 & 1 & 0 & 99 & 100 & 0.09 & 12.83 & $73 \%$ & & 83.1 & 3 & 1 & 0 & 1 & 0 \\
\hline
\end{tabular}




\begin{tabular}{|c|c|c|c|c|c|c|c|c|c|c|c|c|c|c|c|}
\hline : & 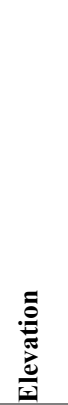 & 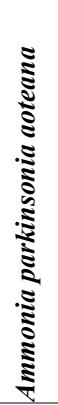 & 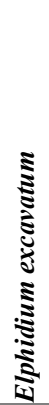 & 㐫 & हैّ & 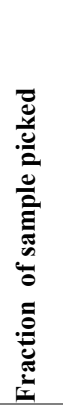 & 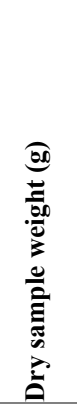 & 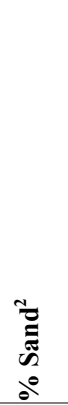 & 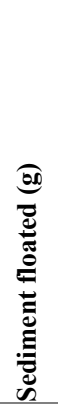 & 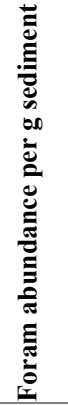 & 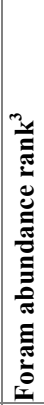 & 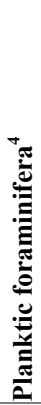 & 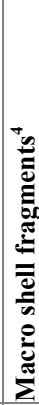 & 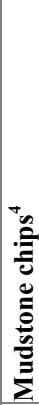 & 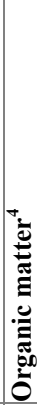 \\
\hline $8 a$ & 0.8 & 0 & 0 & 3 & 3 & 0.13 & 17.34 & $7 \%$ & & 1.4 & 1 & 1 & 0 & 0 & 1 \\
\hline $8 b$ & 2.75 & 155 & 0 & 2 & 157 & 0.38 & 28.59 & $5 \%$ & & 14.6 & 2 & 1 & 0 & 1 & 1 \\
\hline $8 \mathrm{c}$ & 3.52 & 1 & 0 & 60 & 61 & 0.21 & 20.44 & $29 \%$ & 4.31 & 14.2 & 2 & 1 & 0 & 0 & 0 \\
\hline $8 \mathrm{c}$ & 3.32 & 68 & 0 & 3 & 71 & 1.00 & 15.77 & $2 \%$ & & 4.5 & 1 & 1 & 0 & 0 & 0 \\
\hline $8 \mathrm{c}$ & 3.25 & 89 & 2 & 9 & 100 & 0.25 & 22.32 & $10 \%$ & & 17.9 & 2 & 1 & 0 & 0 & 0 \\
\hline $8 \mathrm{c}$ & 2.95 & 0 & 0 & 8 & 8 & 0.03 & 19.46 & $34 \%$ & & 13.2 & 2 & 1 & 0 & 0 & 0 \\
\hline $8 c$ & 2.7 & 0 & 0 & 4 & 4 & 0.03 & 16.18 & $62 \%$ & & 7.9 & 1 & 1 & 0 & 0 & 2 \\
\hline $8 d$ & 8.12 & 1 & 0 & 1 & 2 & 0.13 & 15.1 & $17 \%$ & & 1.1 & 1 & 1 & 0 & 0 & 0 \\
\hline $8 d$ & 7.62 & 0 & 0 & 0 & 0 & 0.06 & 5.19 & $97 \%$ & & 0.0 & 0 & 0 & 0 & 0 & 0 \\
\hline $8 d$ & 6.68 & 0 & 0 & 0 & 0 & 0.02 & 16.13 & $91 \%$ & & 0.0 & 0 & 1 & 0 & 0 & 0 \\
\hline $8 d$ & 5.22 & 0 & 0 & 0 & 0 & 0.03 & 16.48 & $54 \%$ & & 0.0 & 0 & 1 & 0 & 0 & 1 \\
\hline $8 \mathrm{e}$ & 4.45 & 0 & 0 & 4 & 4 & 0.06 & 19.11 & $28 \%$ & & 3.3 & 1 & 1 & 0 & 1 & 0 \\
\hline $8 \mathrm{e}$ & 3.7 & 0 & 0 & 18 & 18 & 0.03 & 19.19 & $51 \%$ & & 30.0 & 2 & 1 & 0 & 0 & 0 \\
\hline $8 \mathrm{e}$ & 3.1 & 0 & 0 & 3 & 3 & 0.03 & 15.37 & $38 \%$ & & 6.2 & 1 & 1 & 0 & 0 & 1 \\
\hline $8 \mathrm{e}$ & 2.25 & 0 & 0 & 9 & 9 & 0.25 & 20.05 & $6 \%$ & & 1.8 & 1 & 1 & 0 & 0 & 2 \\
\hline $8 \mathrm{e}$ & 1.75 & 0 & 0 & 16 & 16 & 0.03 & 20.99 & $36 \%$ & & 24.4 & 2 & 1 & 0 & 0 & 1 \\
\hline $8 \mathrm{e}$ & 1 & 0 & 0 & 7 & 7 & 0.13 & 19.17 & $9 \%$ & & 2.9 & 1 & 1 & 0 & 0 & 1 \\
\hline
\end{tabular}

\subsection{References}

Allen, G. P. and H. W. Posamentier (1993). "Sequence stratigraphy and facies model of an incised valley fill: the Gironde estuary, France." Journal of Sedimentary Petrology 63(3): 378-391.

Allen, G. P. and H. W. Posamentier (1994). Transgressive facies and sequence architecture in mixed tide- and wave-dominated incised valleys: example from the Gironde estuary, France. Incised-valley systems: origin and sedimentary sequences, SEPM Special Publication 51. Dalrymple, R. W., Boyd, R, and Zaitlin, B. A. (Eds), SEPM Tulsa, Oklahoma.: 225-241.

Anstey, R. L. and T. L. Chase (1974). Environments through time. Minneapolis, Burgess Publishing Ltd. Fig 3.1.2, p. 2.

Beavan, J. and J. Haines (2001). "Contemporary horizontal velocity and strain rate fields of the PacificAustralian plate boundary zone through New Zealand." Journal of Geophysical Research 106(B1): 741 770.

Berryman, K. R., Y. Ota and A. G. Hull (1989). "Holocene paleoseismicity in the fold and thrust belt of the Hikurangi subduction zone, eastern North Island, New Zealand." Tectonophysics 163: 185-195. 
Berryman, K. R., Y. Ota and A. G. Hull (1992). "Holocene evolution of an estuary on a tectonically rising coast: the Pakarae River locality, eastern North Island, New Zealand." Sedimentary Geology 80: 151-162.

Carter, L., B. Manighetti, M. Elliot, N. Trustrum and B. Gomez (2002). "Source, sea level and circulation effects on the sediment flux to the deep ocean over the past $15 \mathrm{ka}$ off eastern New Zealand." Global and Planetary Change 33: 339-355.

Chappell, J. (1993). "Contrasting sedimentary geologies of lower Daly River, northern Australia, and lower Sepik-Ramu, Papua New Guinea." Sedimentary Geology 83: 339-358.

Cochran, U., K. Berryman, D. Mildenhall, B. Hayward, K. Southall, C. Hollis, P. Barker, L. Wallace, B. Alloway and K. Wilson (2006). "Paleoecological insights into subduction zone earthquake occurrence, eastern North Island, New Zealand." Geological Society of America Bulletin, 118(9/10): 1051-1074.

Collot, J.-Y., J. Delteil, K. Lewis, B. Davy, G. Lamarche, J.-C. Andru, P. Barnes, F. Chanier, E. Chaumillon, S. Lallemand, B. M. De Lepinay, A. Orpin, B. Pelletier, M. Sosson, Toussaint and C. Uruski (1996). "From oblique subduction to intra-continental transpression: structures of the southern Kermadec-Hikurangi margin from multibeam bathymetry, side-scan sonar and seismic reflection." Marine Geophysical Researches 18(2-4): 357-381.

Dabrio, C. J., C. Zazo, J. L. Goy, F. J. Sierro, F. Borja, J. Lario, J. A. Gonzalez and J. A. Flores (2000). "Depositional history of estuarine infill during the last postglacial transgression (Gulf of Cadiz, Southern Spain)." Marine Geology 162: 381-404.

Dalrymple, R. W., B. A. Zaitlin and R. Boyd (1992). "Estuarine facies models: conceptual basis and stratigraphic implications." Journal of Sedimentary Petrology 62(6): 1130-1146.

Darienzo, M. E., C. D. Peterson and C. Clough (1994). "Stratigraphic evidence for great subductionzone earthquakes at four estuaries in Northern Oregon, U. S. A." Journal of Coastal Research 10: 820 876.

Dawson, S. and D. E. Smith (1997). "Holocene relative sea-level changes on the margin of a glacioisostatically uplifted area: an example from northern Caithness, Scotland." The Holocene 7(1): 59-77.

De Mets, C., R. G. Gordon, D. F. Argus and S. Stein (1994). "Effect of recent revisions to the geomagnetic reversal timescale on estimates of current plate motions." Geophysical Research Letters 21: 2191-2194.

Fletcher III, C. H., H. J. Knebel and J. C. Kraft (1990). "Holocene evolution of an estuarine coast and tidal wetlands." Geological Society of America Bulletin 102: 283-297.

Foster, G. and L. Carter (1997). "Mud sedimentation on the continental shelf at an accretionary margin - Poverty Bay, New Zealand." New Zealand Journal of Geology and Geophysics 40: 157-173.

Froggatt, P. C. and D. J. Lowe (1990). "A review of late Quaternary silicic and some other tephra formations from New Zealand: their stratigraphy, nomenclature, distribution, volume and age." New Zealand Journal of Geology and Geophysics 33: 89-109.

Froggatt, P. C. and G. M. Rogers (1990). "Tephrostratigraphy of high-altitude peat bogs along the axial ranges, North Island, New Zealand." New Zealand Journal of Geology and Geophysics 33: 111-124.

Gibb, J. G. (1986). “A New Zealand regional Holocene eustatic sea-level curve and its application to determination of vertical tectonic movements, A contribution to IGCP-Project 200". Recent Crustal Movements of the Pacific Region, Bulletin of the Royal Society of New Zealand. 24: 377-395.

Goff, J. R., H. L. Rouse, S. L. Jones, B. W. Hayward, U. Cochran, W. McLea, W. W. Dickinson and M. S. Morley (2000). "Evidence for an earthquake and tsunami about 3100-3400 yr ago, and other catastrophic saltwater inundations in a coastal lagoon, New Zealand." Marine Geology 170: 231-249. 
Guilbault, J.-P., J. J. Clague and M. Lapointe (1995). "Amount of subsidence during a late Holocene earthquake - evidence from fossil tidal marsh foraminifera at Vancouver Island, west coast of Canada." Palaeogeography, Palaeoclimatology, Palaeoecology 118: 49-71.

Hartley, B. (1996). An Atlas of British Diatoms, Biopress Ltd, Bristol.

Hayward, B. W., H. R. Grenfell, G. Cairns and A. Smith (1996). "Environmental controls on benthic foraminiferal and thecamoebian associations in a New Zealand tidal inlet." Journal of Foraminiferal Research 26: 150-171.

Hayward, B. W., H. R. Grenfell, C. Reid and K. Hayward (1999a). Recent New Zealand shallow-water benthic foraminifera: taxonomy, ecologic dstribution, biogeography, and use in paleoenvironmental assessment., Institute of Geological and Nuclear Sciences Monograph 21. 264 p. Lower Hutt, New Zealand: Institute of Geological and Nuclear Sciences Limited.

Hayward, B. W., H. R. Grenfell and D. B. Scott (1999b). "Tidal range of marsh foraminifera for determining former sea-level heights in New Zealand." New Zealand Journal of Geology and Geophysics 42: 395-413.

Hayward, B. W., C. J. Hollis and H. R. Grenfell (1997). Recent Elphidiidae (Foraminiferida) of the South-west Pacific and fossil Elphidiidae of New Zealand., Institute of Geological and Nuclear Sciences Monograph 16. 170 p. Lower Hutt, New Zealand: Institute of Geological and Nuclear Sciences Limited.

Hayward, B. W., G. H. Scott, H. R. Grenfell, R. Carter and J. H. Lipps (2004a). "Techniques for estimation of tidal elevation and confinement ( $\sim$ salinity) histories of sheltered harbours and estuaries using benthic foraminifera: examples from New Zealand." The Holocene 14(2): 218-232.

Hayward, B. W., U. Cochran, K. Southall, E. Wiggins, H. R. Grenfell, A. Sabaa, P. R. Shane and R. Gehrels (2004b). "Micropalaeontological evidence for the Holocene earthquake history of the eastern Bay of Plenty, New Zealand, and a new index for determining the land elevation record." Quaternary Science Reviews 23: 1651-1667.

Heap, A. D. and S. L. Nichol (1997). "The influence of limited accommodation space on the stratigraphy of an incised-valley succession: Weiti River estuary, New Zealand." Marine Geology 144(1-3): 229-252.

Heap, A. D., S. Bryce and D. A. Ryan (2004). "Facies evolution of Holocene estuaries and deptas: a large-sample statistical study from Australia." Sedimentary Geology 168: 1-17.

Hemphill-Haley, E. (1995). "Diatom evidence for earthquake-induced subsidence and tsunami $300 \mathrm{yr}$ ago in southern coastal Washington." Geological Society of America Bulletin 107: 367-378.

Hughen, K. A., M. G. L. Baillie, E. Bard, Beck, J. W. , C. J. H. Bertrand, P. G. Blackwell, C. E. Buck, G. S. Burr, K. B. Cutler, P. E. Damon, R. L. Edwards, R. G. Fairbanks, M. Friedrich, T. P. Guilderson, B. Kromer, G. McCormac, S. Manning, B. B. Ramsey, P. J. Reimer, R. W. Reimer, S. S. Remmele, J. R., M. Stuiver, S. Talamo, F. W. Taylor, J. van der Plicht and C. E. Weyhenmeyer (2004). "Marine04 Marine Radiocarbon Age Calibration, 0-26 Cal Kyr BP." Radiocarbon 46(3): 1059-1086.

Krammer, K. and H. Lange-Bertalot (1991). Bacillariophyceae: Achnanthaceae, Gustav Fischer Verlag, Stuttgart.

Krammer, K. and H. Lange-Bertalot (1999a). Bacillariophyceae: Bacillariaceae, Epithemiaceae, Surirellaceae, Specktrum Akademischer Verlag, Heidelberg.

Krammer, K. and H. Lange-Bertalot (1999b). Bacillariophyceae: Naviculaceae, Specktrum Akademischer Verlag, Heidelberg. 
Krammer, K. and H. Lange-Bertalot (2000a). Bacillariophyceae: Centrales, Fragilariaceae, Eunotiaceae, Spektrum Akademischer Verlag, Heidelberg.

Krammer, K. and H. Lange-Bertalot (2000b). Bacillariophyceae: English and French translation of the keys., Spektrum Akademischer Verlag, Heidelberg.

Lessa, G. C., S. R. Meyers and E. Marone (1998). "Holocene stratigraphy in the Paranagua Bay estuary, southern Brazil." Journal of Sedimentary Research 68(6): 1060-1076.

Long, A. J., J. B. Innes, J. R. Kirby, J. M. Lloyd, M. M. Rutherford, I. Shennan and M. J. Tooley (1998). "Holocene sea-level change and coastal evolution in the Humber estuary, eastern England: an assessment of rapid coastal change." The Holocene 8(2): 229-247.

Long, A. J. and I. Shennan (1998). "Models of rapid relative sea-level change in Washington and Oregon, USA." The Holocene 8(2): 129-142.

Lowe, D. J. (1988). "Late Quaternary volcanism in New Zealand: towards an integrated record using distal airfall tephras in lakes and bogs." Journal of Quaternary Science 3(2): 111-120.

Mazengarb, C. and I. G. Speden (Compilers) (2000). Geology of the Raukumara area, Institute of Geological \& Nuclear Sciences 1:250,000 Geological Map 6. Institute of Geological and Nuclear Sciences Limited, Lower Hutt, New Zealand.

McCormac, F. G., A. G. Hogg, P. G. Blackwell, C. E. Buck, T. F. G. Higham and P. J. Reimer (2004). "SHCal04 Southern Hemisphere calibration, 0 - 26 ka cal BP." Radiocarbon 46: 1087-1092.

McGlone, M. S., A. J. Anderson and R. N. Holdaway (1994). An ecological approach to the Polynesian settlement of New Zealand. The Origins of the First New Zealanders. D. G. Sutton, Auckland University Press: $136-163$.

Mildenhall, D. C. (1994). "Early to Mid Holocene pollen samples containing mangrove pollen from Sponge Bay, East Coast, North Island, New Zealand." Journal of the Royal Society of New Zealand 24(2): 219-230.

Moore, P. D. and J. A. Webb (1978). An illustrated guide to pollen analysis, Hodder and Stoughton, London.

Moore, P. D., J. A. Webb and M. E. Collinson (1991). Pollen analysis, Blackwell Scientific Publications, Oxford, Boston.

Morton, J. and M. Miller (1968). The New Zealand sea shore. Collins, London.

Nelson, A. R., A. E. Jennings and K. Kashima (1996). "An earthquake history derived from stratigraphic and microfossil evidence of relative sea-level change at Coos Bay, southern coastal Oregon." Geological Society of America Bulletin 108: 141-154.

Nichol, S. L., R. Boyd and S. Penland (1996). "Sequence stratigraphy of a coastal-plain incised valley estuary: Lake Calcasieu, Louisiana." Journal of Sedimentary Research 66(4): 847-857.

Orpin, A. (2004). "Holocene sediment deposition on the Poverty-slope margin by the muddy Waipaoa River, East Coast New Zealand." Marine Geology 209: 69-90.

Ota, Y., Ed. (1987). Holocene coastal tectonics of eastern North Island, New Zealand. A preliminary report on late Quaternary seismo-tectonic movement in the Circum Pacific area, 1st survey (1985/86).

Ota, Y., K. R. Berryman, A. G. Hull, T. Miyauchi and N. Iso (1988). "Age and height distribution of Holocene transgressive deposits in eastern North Island, New Zealand." Palaeogeography, Palaeoclimatology, Palaeoecology 68: 135-151. 
Ota, Y., A. G. Hull and K. R. Berryman (1991). "Coseismic uplift of Holocene marine terraces in the Pakarae River area, eastern North Island, New Zealand." Quaternary Research 35: 331-346.

Ota, Y., A. G. Hull, N. Iso, Y. Ikeda, I. Moriya and T. Yoshikawa (1992). "Holocene marine terraces on the northeast coast of North Island, New Zealand, and their tectonic significance." New Zealand Journal of Geology and Geophysics 35: 273-288.

Patterson, R. T., I. Hutchinson, J.-P. Guilbault and J. J. Clague (2000). "A comparison of the vertical zonation of diatom, foraminifera, and macrophhyte assemblages in a coastal marsh: implications for greater paleo-sea level resolution." Micropaleontology 46(3): 229-244.

Powers, M. C. (1953). "A new roundness scale for sedimentary particles." Journal of Sedimentary Petrology 23: 117-119.

Round, F. E., R. M. Crawford and D. G. Mann (1990). The Diatoms: Biology and Morphology of the Genera, Cambridge University Press, Cambridge.

Roy, P. S. (1984). New South Wales Estuaries: their origin and evolution. Coastal Geomorphology in Australia, Academic Press Australia: 99-121.

Roy, P. S., P. J. Cowell, M. A. Ferland and B. G. Thom (1994). Wave-dominated coasts. (Carter, R. W. G., Woodroffe, C. D., Editors). Coastal evolution: Late Quaternary shoreline morphodynamics. Cambridge, Cambridge University Press.

Sakai, T., O. Fujiwara and T. Kamataki (2006). "Incised-valley-fill succession affected by rapid tectonic uplifts: An example from the uppermost Pleistocene to Holocene of the Isumi River lowland, central Boso Peninsula, Japan." Sedimentary Geology 185: 21-39.

Shennan, I., A. J. Long, M. M. Rutherford, F. M. Green, J. B. Innes, J. M. Lloyd, Y. Zong and K. J. Walker (1996). "Tidal marsh stratigraphy, sea-level change and large earthquakes, I: A 5000 year record in Washington, U.S.A." Quaternary Science Reviews 15: 1023-1059.

Shennan, I., D. B. Scott, M. Rutherford and Y. Zong (1999). "Microfossil analysis of sediments representing the 1964 earthquake, exposed at Girdwood Flats, Alaska, USA." Quaternary International 60: $55-73$.

Sherrod, B. L., R. C. Bucknam and E. B. Leopold (2000). "Holocene relative sea level changes along the Seattle Fault at Restoration Point, Washington." Quaternary Research 54: 384-393.

Sloss, C. R., B. G. Jones, C. V. Murray-Wallace and C. E. McClennen (2005). "Holocene sea level fluctuations and the sedimentary evolution of a barrier estuary: Lake Illawarra, New South Wales, Australia." Journal of Coastal Research 21(5): 943-959.

Stokes, S. and D. J. Lowe (1988). "Discriminant function analysis of late Quaternary tephras from five volcanoes in New Zealand using glass shard major element chemistry." Quaternary Research 30: 270 283.

Stuiver, M. and H. A. Polach (1977). "Discussion; reporting of C-14 data." Radiocarbon 19(3): $355-$ 363.

van Dam, H., A. Mertens and J. Sinkeldam (1994). "A coded checklist and ecological indicator values of freshwater diatoms from the Netherlands." Netherlands Journal of Aquatic Ecology 28: 117-133.

Vucetich, C. G. and W. A. Pullar (1964). "Stratigraphy of Holocene ash in the Rotorua and Gisborne districts. Part 2." New Zealand Geological Survey Bulletin 73: 43-63.

Wilson, K. J., K. Berryman, U. Cochran and T. Little (Ch. 4). "Early Holocene paleoseismic history at the Pakarae locality, eastern North Island, New Zealand, inferred from transgressive marine sequence architecture and biostratigraphy." 
Wilson et al. (Ch. 2): Wilson, K. J., K. R. Berryman, N. J. Litchfield and T. A. Little (submitted). "A revision of Mid to Late Holocene marine terrace distribution and chronology at New Zealand's most tectonically active coastal location, Pakarae River, North Island, New Zealand." New Zealand Journal of Geology and Geophysics.

Witkowski, A., H. Lange-Bertalot and D. Metzeltin (2000). Diatom Flora of Marine Coasts I, A. R. G. Gantner Verlag K. G., Ruggell.

Woodroffe, C. D. (1996). Late Quaternary infill of macrotidal estuaries in northern Australia. Estuarine Shores: Evolution, Environmants and Human Alterations. Nordstrum, K. F., Roman, C. T (Editors). John Wiley \& Sons Ltd.: 89-114.

Woodroffe, C. D., M. E. Mulrennan and J. Chappell (1993). "Estuarine infill and coastal progradation, southern van Diemen Gulf, northern Australia." Sedimentary Geology 83: 257-275.

Yoshikawa, T. (1988). "Pattern and rate of tectonic movement and Late Quaternary geomorphic development in the Raukumara Peninsula, northeastern North Island, New Zealand." Bulletin of the Department of Geography University of Tokyo 20: 1-28. 


\title{
CHAPTER Four
}

\author{
EARly Holocene paleoseismic history at the PaKarae locality, \\ EASTERN NORTH ISLAND, NEW ZEALAND, INFERRED FROM TRANSGRESSIVE \\ MARINE SEQUENCE ARCHITECTURE.
}

\begin{abstract}
Early Holocene transgressive marine deposits infilling the Pakarae River paleo-valley, East Coast, North Island, New Zealand, are used to provide evidence of sudden, coseismic uplift events, thus extending the paleoseismic history of the Pakarae locality back in time prior to eustatic sea level (SL) stabilisation at $\sim 7,000$ cal. yrs B.P. The highest Holocene marine terrace at the Pakarae locality is underlain by a transgressive fluvio-estuarine sequence that documents infilling of the Pakarae River paleo-incised valley from $\sim 10,000-7,000 \mathrm{cal}$. yrs B.P. Using sedimentology and biostratigraphy, we elaborate on an incised valley infilling facies architecture developed for tectonically active coasts and reconstruct the paleoenvironmental evolution of the Pakarae River paleo-valley during this period. Two estuarine units display sudden vertical transitions to floodplain sediments, implying significant marine regressions. During this period eustatic SL was rapidly and continuously rising. The marine regressions and associated estuary abandonment are attributed to coseismic coastal uplift events at $\sim 9,000$ and $\sim 8,500$ cal. yrs B.P. A third uplift between 8,500 and $\sim 7,350$ cal. yrs B.P. is inferred from a significant difference between the amount of sediment preserved and the sediment thickness predicted from the eustatic SL curve. This study demonstrates the utility of analysis of transgressive deposits and their paleoenvironmental characteristics for neotectonic investigations on active coasts. The transgressive facies architecture technique allows us to extend paleoseismic histories of coastal sites prior to the time of eustatic SL rise culmination and also has the potential to be applied in locations where marine terraces have not been preserved.
\end{abstract}

\subsection{Introduction}

With rising awareness of the devastating effects of subduction zone earthquakes, long-term records ( $>200 \mathrm{yrs})$ of plate interface and upper plate paleoseismicity are becoming increasingly important. Coastal environments are commonly the only 
places that preserve a record of such events. For example, coseismic subsidence is often documented by drowning of tidal marsh sequences, and uplift is recorded by abandonment of marine terraces on parts of the coastline favourable for their preservation. The duration of these records is often limited by the time elapsed since stabilisation of post-glacial eustatic sea level (SL). This is because modern SL can be used as a datum against which to measure non-eustatic $(\approx$ tectonic $)$ effects. Here we extend the paleoseismic history at the Pakarae River mouth (henceforth called Pakarae locality), New Zealand's most tectonically active coastal location, back beyond the time of eustatic SL stabilisation at $~ 7,000$ cal. yrs B.P. (Gibb, 1986) by unravelling an event history in the transgressive fluvio-marine sequence.

Tectonic uplift since $\sim 7,000$ cal. yrs B.P., taking place at an average rate of $3.2 \pm 0.8$ $\mathrm{mm} / \mathrm{yr}$, is recorded at the Pakarae River mouth, North Island, New Zealand, by a flight of seven Holocene marine terraces. Prior to 7,000 cal. yrs B.P. the incised valley of the Pakarae River was infilled by a transgressive sedimentary sequence under conditions of rapidly rising eustatic SL (Berryman et al., 1992). Wilson (Ch. 3) demonstrated that tectonic uplift occurred during deposition of the sequence and was a major control on the facies distribution. Here we further investigate the paleogeographic evolution and tectonic history of the Pakarae River paleo-estuary. We apply two methods to identify the timing of tectonic uplift that has affected the transgressive estuarine sequence. One method is to compare the thickness of the estuarine section with that on a stable coast. On stable coasts the thickness of sediment should equal the amount of eustatic SL rise. If tectonic uplift occurs during transgression the total thickness of sediment will be less than the amount of eustatic SL rise, with the deficit approximately equalling the tectonic uplift component. The second, and more important, method employed is to use the paleoenvironmental facies architecture to detect sudden marine regressions that identify tectonic event horizons. We use the sedimentological and paleoenvironmental data reported by Wilson (Ch. 3) to constrain a paleogeographic model of the Pakarae locality coastal evolution during the early Holocene. We discuss evidence for the timing and magnitude of early Holocene uplift events at the Pakarae locality, thus extending the paleoseismic history of this significant location adjacent to the Hikurangi subduction zone. 

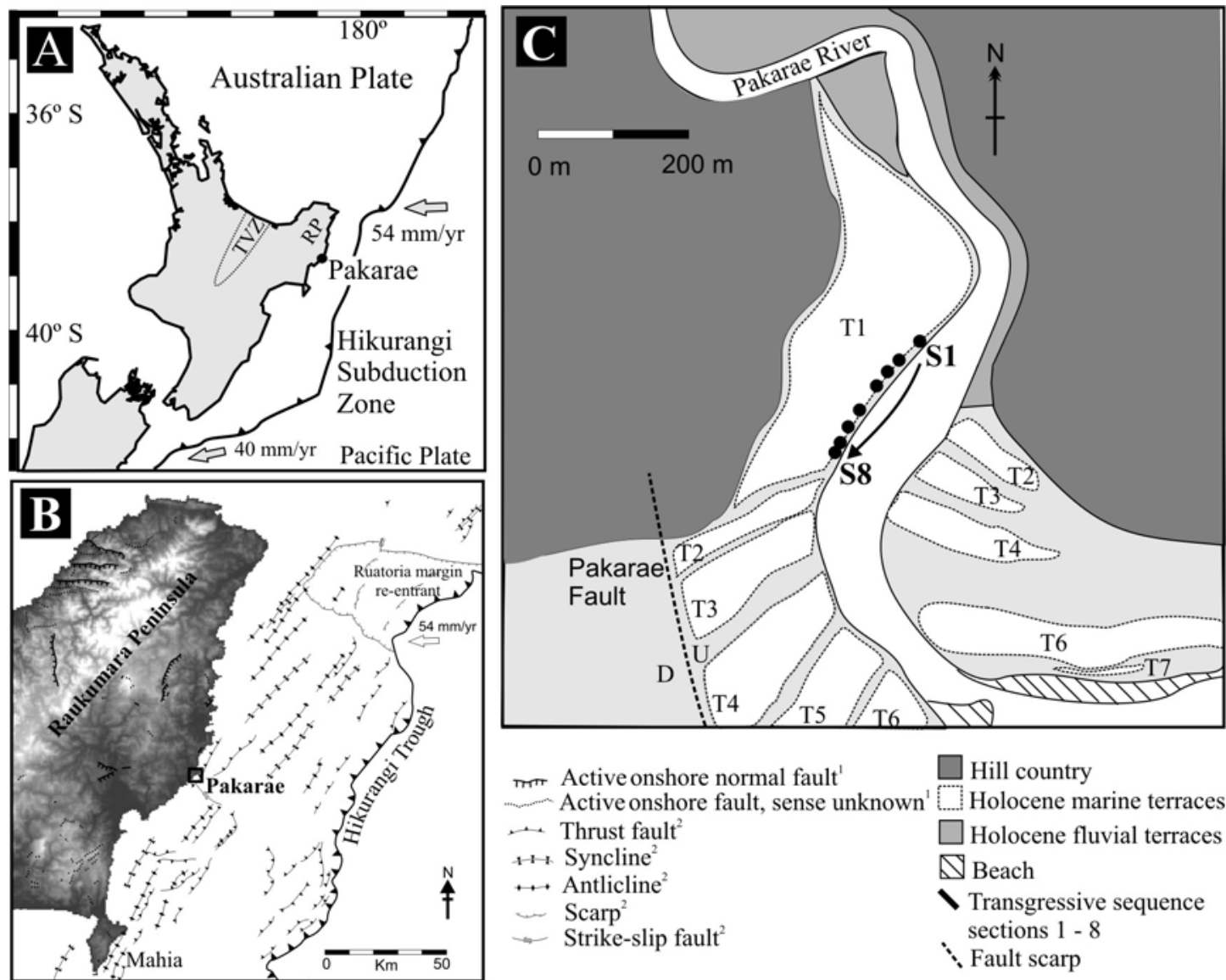

Active onshore normal fault ${ }^{1}$

Active onshore fault, sense unknown'

Hill country

‥ Thrust fault

$1 \rightarrow$ Syncline ${ }^{2}$

$\ldots$ Antlicline

- Scarp ${ }^{2}$

$\ldots$ Strike-slip fault ${ }^{2}$

Holocene marine terraces

$\square$ Holocene fluvial terraces

$\checkmark$ Beach

Transgressive sequence

sections $1-8$

$\because$ Fault scarp

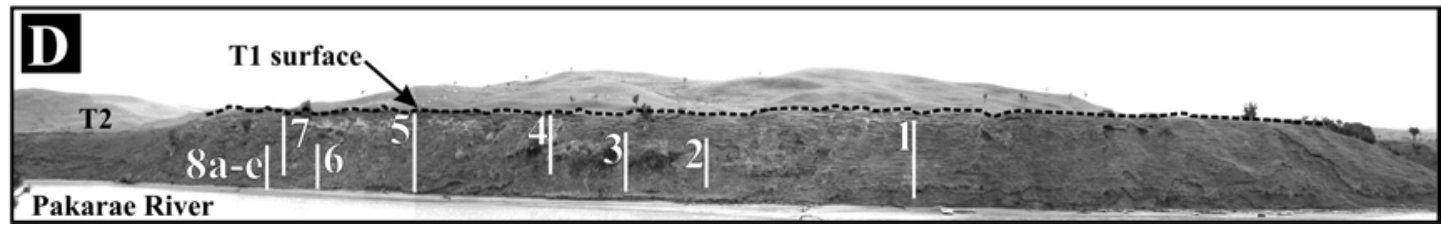

Figure 4.1. (A) North Island, New Zealand with major tectonic features. TVZ: Taupo volcanic zone, RP: Raukumara Peninsula. Pacific-Kermadec relative plate motions after Collot et al., 2001; Hikurangi subduction deformation front after Collot et al., 1996. (B) Topography and tectonic features of the Raukumara Peninsula. 1Onshore active faults from the GNS Science Active Faults Database (http://data.gns.cri.nz/af/). 2 Offshore structures from Lewis et al. (1997). (C) Pakarae River mouth with major geomorphic elements, marine terraces (after Wilson, Ch. 2) and stratigraphic section locations. (D) Pakarae River, transgressive exposures beneath TI (highest Holocene marine transgression surface) with Sections $1-8 \mathrm{e}$. Riverbank is $\sim 25 \mathrm{~m}$ high. 
The Pakarae locality is an important site along this sector of the margin because the Holocene record there can place constraints on the boundaries of various upper plate strain domains, and clarify where episodic (coseismic) versus aseismic tectonic processes may have operated along the Hikurangi margin. The Pakarae River mouth is situated on the southeastern Raukumara Peninsula, $\sim 65 \mathrm{~km}$ inboard of the Hikurangi subduction trough on the eastern coast of North Island, New Zealand (Fig. 4.1). No subduction earthquakes have occurred in historic times along this section of the margin. The presence of a stepped sequence of Holocene coseismic marine terraces at the Pakarae River mouth has been interpreted to record permanent uplift and is most likely a consequence of faulting in the upper plate of this subduction zone (Ota et al., 1991; Wilson, Ch. 2). Alternatively, sediment underplating inferred from seismic velocities that indicate a weak zone along the plate interface, has been suggested as a cause of long term uplift of Raukumara Peninsula (Walcott, 1987; Eberhart-Phillips and Reyners, 1999; Reyners et al., 1999; Litchfield et al., in press). Subducted seamounts, evident from margin indentations adjacent to the Raukumara Peninsula, have also been suggested as a cause of coastal uplift (Lewis et al., 2004). Normal faulting is persistent in the Raukumara Range but reverse faults are inferred in the coastal area and offshore (Mazengarb, 1984; Lewis et al., 1997; Mazengarb and Speden, 2000, Fig. 4.1B).

The Pakarae River mouth marine terraces were first mapped, correlated, and dated by Ota et al. (1991). Seven terraces were recognised and named T1-T7, from oldest to youngest. T1 was recognised as corresponding with the maximum Holocene marine transgression, which in the New Zealand region occurred 7 cal. ka BP (Gibb, 1986; Berryman et al., 1992). The age of uplift of each terrace was estimated from radiocarbon ages and tephra distribution by Ota et al. (1991). This chronology has been revised by Wilson (Ch. 2). Although the Pakarae Fault, a reactivated Tertiary normal fault near the Pakarae River mouth, was argued to have moved during terrace uplift events, it did not rupture with every terrace-forming event. Rather uplift was inferred to have been driven by slip on an active reverse fault located a few kilometres offshore of the Pakarae River mouth (Ota et al., 1991). Ota et al. (1988) presented radiocarbon dates from the sedimentary sequence underlying $\mathrm{T} 1$ and made summaries of the stratigraphy but no further interpretations were made. 
The Pakarae River mouth transgressive sequence was interpreted in more detail by Berryman et al. (1992). Stratigraphy, radiocarbon dates and tephrochronology were used to produce paleogeographic maps showing evolution from 9 to $1 \mathrm{ka} \mathrm{B}$. P. They also constructed a relative SL curve for the Pakarae locality from $11 \mathrm{ka} \mathrm{B}$. P. to present day. Berryman et al. (1992) showed there was a deficit in the amount of sediment preserved when compared to the amount of accommodation space created by eustatic SL rise. They attributed the deficit to tectonic uplift during deposition of the sequence, but specific events could not be identified on the basis of their data. Unconformities and weathering horizons within the sequence were mentioned and inferred to indicate of uplift events. Berryman et al. (1992) inferred a regression in the relative SL curve for the Pakarae locality at $\sim 10.5-9.5$ cal. yrs B.P. that they attributed to a eustatic SL fall rather than a sudden uplift event because of (1) correlation to similar-aged trees growing in and overwhelmed by estuarine deposits at several other sites along the East Coast, and (2) correlation with a change in the trend of the Gibb (1986) eustatic SL curve.

Wilson (Ch. 3) examined the Pakarae River mouth sedimentary sequence; they remeasured one section in common with the Berryman et al. (1992) study and described seven new riverbank sections spanning a $220 \mathrm{~m}$ stretch of the riverbank. Twelve new radiocarbon ages were presented. Sedimentology and benthic foraminifera assemblages were used to define four broad paleoenvironmental facies associations, the distribution of which was used to develop a facies architecture model for sediment infill of an incised valley in an uplifting tectonic setting. In this paper we combine all the available stratigraphic data and facies model results previously presented to (1) develop models of the paleogeographic evolution of the Pakarae River paleo-estuary, and (2) identify and date specific tectonic event horizons.

\subsection{Methodology}

\subsubsection{Reconstruction of the Pakarae locality paleoenvironments}

The facies architecture profile developed from the Pakarae riverbank sections (Wilson, Ch. 3) provides the basis for paleogeographic reconstructions (Fig. 4.2). 
Four paleoenvironmental facies associations are recorded in the Pakarae riverbank sequence, namely floodplain, estuary-head delta, estuarine, and barrier (Fig. 4.2). Interpretations of these are based on a combination of sedimentology and foraminifera data (Wilson, Ch. 3).

The paleogeographic models of the Pakarae River paleo-estuary are constructed sequentially with the stepwise addition of each successive sedimentary unit. We start with the basal floodplain deposit resting on a bedrock strath. For each facies or stratigraphic unit we develop an associated plan-view of the paleogeography of the Pakarae River valley that satisfies the preserved distribution of the facies. Each of our paleogeographic reconstructions of the Pakarae River valley represents our best-fit model, but they are not unique because of the limited exposure available in outcrop. For all paleoenvironmental facies within each time slice, we aimed to satisfy the following criteria, in no order of relative importance: (i) the predicted spatial relationships of the Pakarae River mouth paleoenvironments to one another, (ii) the temporal relationships between eustatic SL data and the radiocarbon ages within the Pakarae River mouth sedimentary sequence, (iii) the average timing and magnitude of uplift events at the Pakarae locality as inferred by the post-7,000 cal. yrs B.P. marine terraces. These criteria are discussed further below:

- The predicted spatial relationships of the Pakarae locality paleoenvironments:

Based on depositional models developed for Holocene infilling of incised valleys (Roy, 1984; Dalrymple et al., 1992; Allen and Posamentier, 1993), each of the four depositional environments identified within the Pakarae River mouth sedimentary sequence should have a predictable spatial relationship to one another. In a landward to seaward direction, the order of the facies should be: floodplain, estuary-head delta, estuary, and estuary mouth barrier. At the Pakarae River mouth the estuary head-delta facies may not always occur between the floodplain and estuarine facies because its distribution appears to be chiefly controlled by proximity to a local gravel supply (Wilson, Ch. 3). Therefore, in our models we generally show the floodplain facies merging directly into the estuarine facies. 


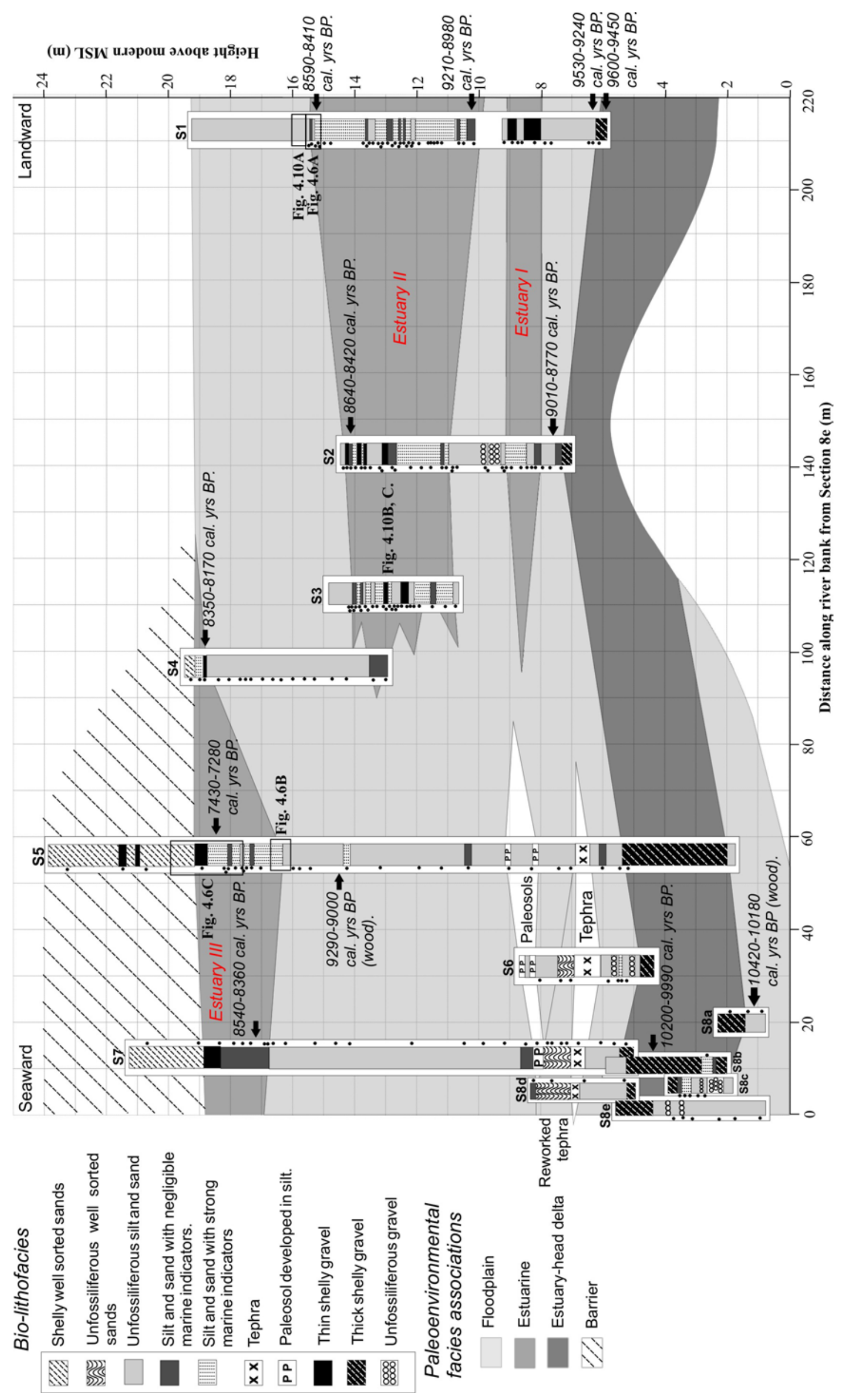


Figure 4.2. Bio-lithofacies and paleoenvironmental facies associations of the Pakarae River incised valley infill sedimentary sequence after Wilson (Ch. 3). Locations of section photos in proceeding figures shown.

- SL constraints imposed by the eustatic SL data of Gibb (1986) and the radiocarbon age control within the Pakarae locality sedimentary sequence:

The New Zealand eustatic SL curve provides an estimate of the amount of sediment that should be deposited between age control points. As eustatic SL rose, accommodation space within the paleo-valley was created. If sedimentation rates within the paleo-estuary approximately kept pace with the rate of accommodation space creation (as supported by the presence of intertidal microfauna throughout the sequence), the sediment thickness between two age control points should approximate the amount of eustatic SL that occurred during that time interval. In our paleoenvironmental reconstructions we compare the present elevations of the radiocarbon dated shells with the eustatic SL at the time of their deposition to assess whether the sediment thickness between the shells is consistent with the estimated amount of eustatic SL rise or if there is a significant difference. For each radiocarbon age we take the midpoint of the 2-sigma calibrated age range and project this across to the midpoint of the SL curve envelope, and use the eustatic SL at this midpoint as the estimate of eustatic SL at that time (Fig. 4.3). Taking the upper and lower bounds of the eustatic SL curve envelope produces a wide range of eustatic SL elevations; there can be up to $15 \mathrm{~m}$ of uncertainty where the curve is very steep. For consistency we take the mid-point eustatic SL and apply an uncertainty of $\pm 2 \mathrm{~m}$ at a $95 \%$ confidence interval to all paleo-SL estimates. We try to produce paleoenvironmental reconstructions where the eustatic SL change between each age control point is within $2 \mathrm{~m}$ of the change predicted by the eustatic SL curve.

When considering preserved sediment thicknesses and relationships to eustatic SL changes, we do not account for the affects of post-depositional sediment compaction. A study by Paul and Barras (1998) of a sequence of Holocene silty clays with shelly lenses, similar to the Pakarae River mouth sediments, found that over a $20 \mathrm{~m}$ thickness of sediment a maximum of $2.5 \mathrm{~m}$ of correction was required to account for 
the effects of compaction. This equates with a mid-section correction of $\sim 10 \%$ of the bed thickness (Paul and Barras, 1998). Therefore, it is likely that the Pakarae River mouth sediments have compacted slightly but the correction required to account for this is minor in comparison to the magnitudes of eustatic and tectonic relative SL changes that we will be discussing. Furthermore, the gravel layers within the Pakarae River mouth sequence probably undergo little to no post-depositional compaction.

- The average $<7,000 \mathrm{cal}$. yrs B.P. timing and magnitude of tectonic events at the Pakarae locality:

The marine terraces at the Pakarae River mouth record tectonic uplift subsequent to the stabilisation of SL at 7,000 cal. yrs B.P. During that time sudden uplift events have occurred at an average interval of $850 \pm 450$ yrs with an average coastal uplift magnitude of $2.7 \pm 1.1 \mathrm{~m}$ per event (Ota et al., 1991; Wilson, Ch. 2). It is unlikely that the characteristics of tectonic uplift at the Pakarae locality changed during the Holocene. Our paleoenvironmental models for the early Holocene attempt to stay within the uncertainties of the post-7,000 cal. yrs B.P. single uplift events.

\subsubsection{Age control}

Age control is provided by radiocarbon ages and the tephrochronology previously presented in Wilson (Ch. 3). Nine estuarine shell radiocarbon ages and three detrital wood radiocarbon ages were obtained from the Pakarae River valley infill sedimentary sequence (Fig. 4.3, Table 4.1). The tephra at $\sim 7 \mathrm{~m}$ AMSL in Sections 5 8 is identified as the Rotoma (9535 - 9465 cal. yrs B.P., Froggatt and Lowe, 1990). 
Table 4.1. Radiocarbon ages from the Pakarae River mouth incised-valley infill sedimentary sequence.

\begin{tabular}{|c|c|c|c|c|c|c|c|c|}
\hline : & 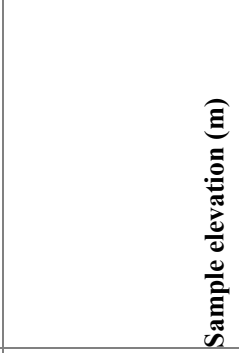 & 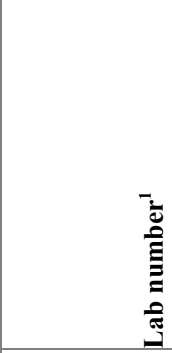 & 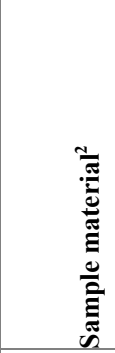 & 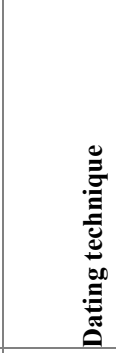 & $\underbrace{e}_{0}$ & 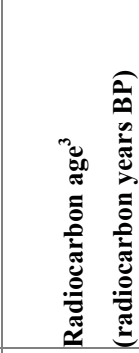 & 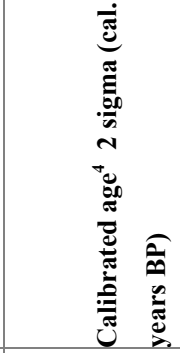 & 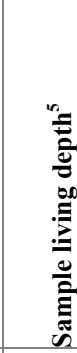 \\
\hline 1 & $15.2+/-0.22$ & NZA 21854 & A & AMS & -1.27 & $8056 \pm 30$ & $8590-8410$ & -0.2 \\
\hline 1 & $10.05+/-0.22$ & NZA 22529 & A & AMS & 1.05 & $8458 \pm 35$ & 9210-8980 & -0.2 \\
\hline 1 & $6.3+/-0.22$ & WK 16864 & Wood & Standard & -28.2 & $8420 \pm 59$ & 9530-9240 & $?$ \\
\hline 1 & $6+/-0.22$ & NZA 21961 & A & AMS & -0.91 & $8868 \pm 30$ & $9600-9450$ & -0.2 \\
\hline 2 & $14.15+/-0.22$ & NZA 22528 & A & AMS & 1.42 & $8082 \pm 35$ & $8640-8420$ & -0.2 \\
\hline 2 & $7.5+/-0.22$ & NZA 21852 & A, B & AMS & -3.71 & $8338 \pm 30$ & $9010-8770$ & -0.2 \\
\hline 4 & $18.9+/-0.22$ & NZA 22526 & A, B & AMS & 0.98 & $7791 \pm 35$ & $8350-8170$ & -0.2 \\
\hline 5 & $18.3-18.7+/-0.22$ & NZA 21851 & A, B. C & AMS & -0.49 & $6847 \pm 30$ & $7430-7280$ & -0.2 \\
\hline 5 & $14.5+/-0.22$ & Wk 16454 & Wood & Standard & -27.2 & $8219 \pm 52$ & 9290-9000 & ? \\
\hline 7 & $17.15+/-0.22$ & NZA 22527 & A & AMS & 0.39 & $7981 \pm 35$ & $8540-8360$ & -0.2 \\
\hline $8 \mathrm{a}$ & $1.1+/-0.31$ & Wk 16453 & Wood & Standard & -28 & $9158 \pm 52$ & $10420-10180$ & $?$ \\
\hline $8 \mathrm{~b}$ & $4.4+/-0.31$ & NZA 21853 & A & AMS & -2.9 & $9266 \pm 30$ & $10200-9990$ & -0.2 \\
\hline
\end{tabular}

${ }^{1}$ Wk: The University of Waikato Radiocarbon Dating Laboratory; NZA: Institute of Geological and Nuclear Sciences Rafter Radiocarbon Laboratory.

${ }^{2}$ Shell: A: Austrovenus stutchburyi, B: Paphies australis, C: Melagraphia aethiops.

${ }^{3}$ Conventional radiocarbon age before present (1950 AD) after Stuiver and Polach, 1977. Radiocarbon 19: 355-363.

${ }^{4}$ Calibrated age in calendar years. Wood ages calibrated using Southern Hemisphere atmospheric data of McCormac et al (2004), marine ages calibrated using data from Hughen et al (2004). Radiocarbon ages calibrated using OxCal v3.10.

${ }^{5}$ Estimated based on Austrovenus stutchburyi living at mean sea level and burrowing to a depth of $0.2 \mathrm{~m}$ below the sediment surface. 


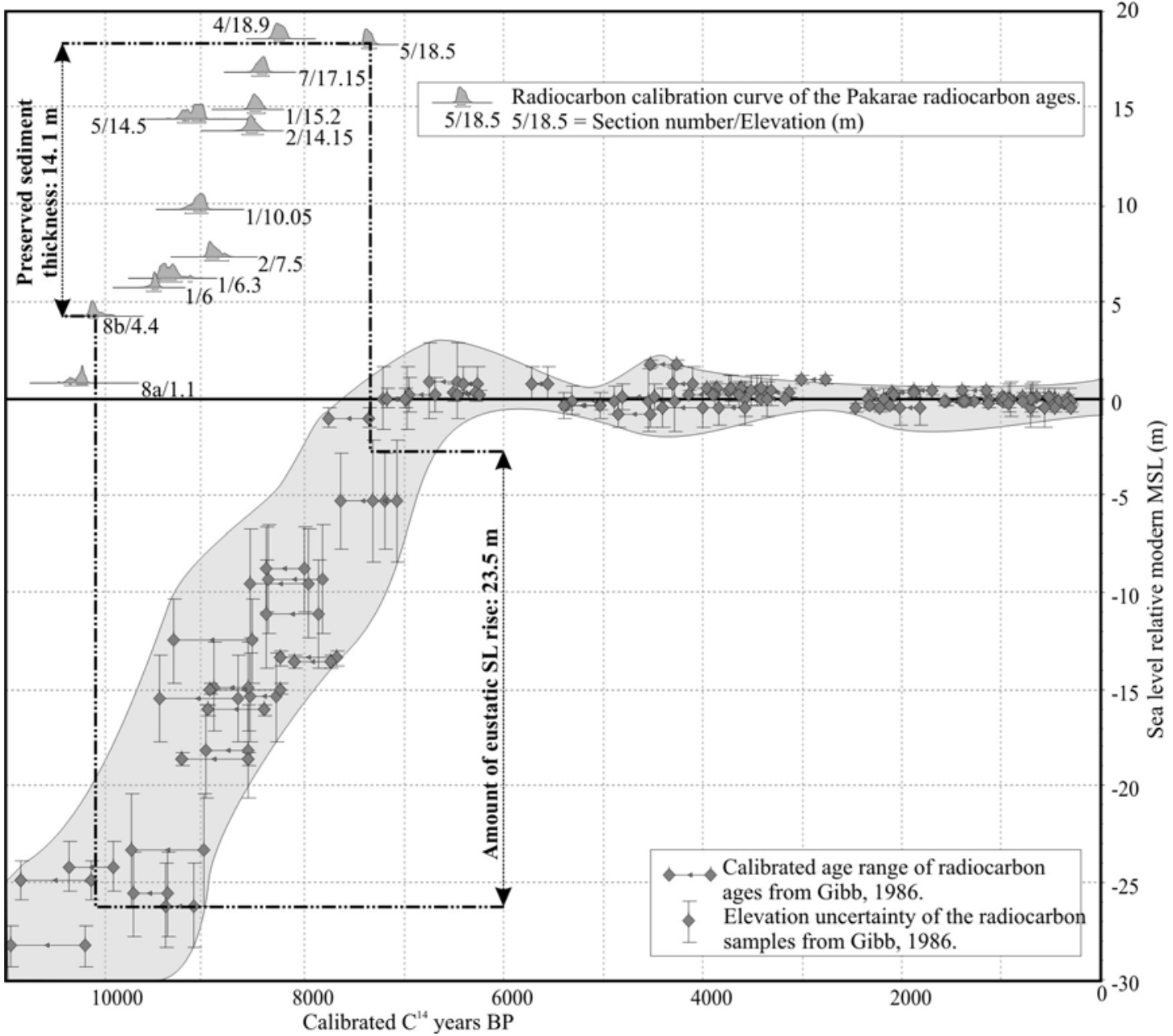

Figure 4.3. Pakarae transgressive sequence radiocarbon ages plotted at their modern elevation (m AMSL) and the data of Gibb, 1986, to envelope the New Zealand eustatic SL curve. Radiocarbon ages calibrated using OxCal v3.10 Bronk Ramsey (2005), marine samples calibrated using the calibration curve of Hughen et al (2004) and wood samples calibrated using Southern Hemisphere atmospheric data from McCormac et al (2004). Dashed lines and arrows show a comparison between the thickness of sediment preserved at Pakarae and the amount of eustatic SL rise that occurred from $\sim 10100$ cal. yrs B.P. to $\sim 7300$ cal. yrs B.P. The deficit between these two measurements approximates the net amount of tectonic uplift that occurred during that time interval. 


\subsection{Results: Paleogeographic evolution of the Pakarae locality paleo-estuary}

\subsubsection{Models of estuary evolution}

We identify eight stages of paleogeographic evolution of the Pakarae River mouth paleo-estuary (Fig. 4.4). There is evidence for at least two significant marine regressions that we suggest are tectonically driven coastal uplift events. A third uplift event is inferred from a significant accommodation space deficit.

\section{I. $\quad$ Marine transgression A: $\sim 10.25-9.5 \mathrm{ka}$.}

The oldest sedimentary unit is an alluvial unit that represents SL lowstand deposition. The floodplain facies, consisting of massive silt with occasional gravel beds, forms the basal strath upon which transgressive marine deposits subsequently accumulated. Detrital wood within the basal floodplain facies yielded a radiocarbon age of 1042010180 cal. yrs B. P. cal. yrs B.P. Estuary-head delta deposits overly the floodplain facies. These deltaic deposits are manifest as a laterally continuous unit of gravel. The poorly sorted nature and clast angularity implies a short transportation distance of the sediments. We infer that the gravel clasts were sourced from mudstone bedrock that outcrops at the base of Section 1 or from hillsides flanking the Pakarae River paleovalley. Prior to gravel deposition, at $\sim 10,300$ cal. yrs B.P., New Zealand eustatic SL was $\sim-24 \pm 2 \mathrm{~m}$ and rising at $\sim 7 \mathrm{~mm} / \mathrm{yr}$. The estuary-head delta sediments probably represent the first incursion of the marine environment into the incised valley that the Pakarae River had cut during the previous glacial lowstand. Two radiocarbon ages from estuarine shells within the estuary head deltaic gravels indicate the sedimentary unit decreases in age towards the north (Fig. 4.2), this is consistent with a transgressive marine sequence. Our paleogeographic reconstruction shows a transgressive estuary with gravel deposition around the bedrock high (Fig. 4.4.1).

\section{Marine transgression A continued: $~ 9.5-9 \mathrm{ka}$.}

Overlying the estuary head gravels are floodplain and estuarine sediments (Estuary I, Fig. 4.4.2). The non-marine sediments may have accumulated around a topographic high created above the basement outcrop at the base of Section 2. The Rotoma tephra was deposited and preferentially accumulated in the downstream sections (S5 - S8). 
1. Marine transgression $A$. $(\sim 10,250-9,500$ cal. yrs BP $)$

Enhanced gravel deposition around bedrock high.
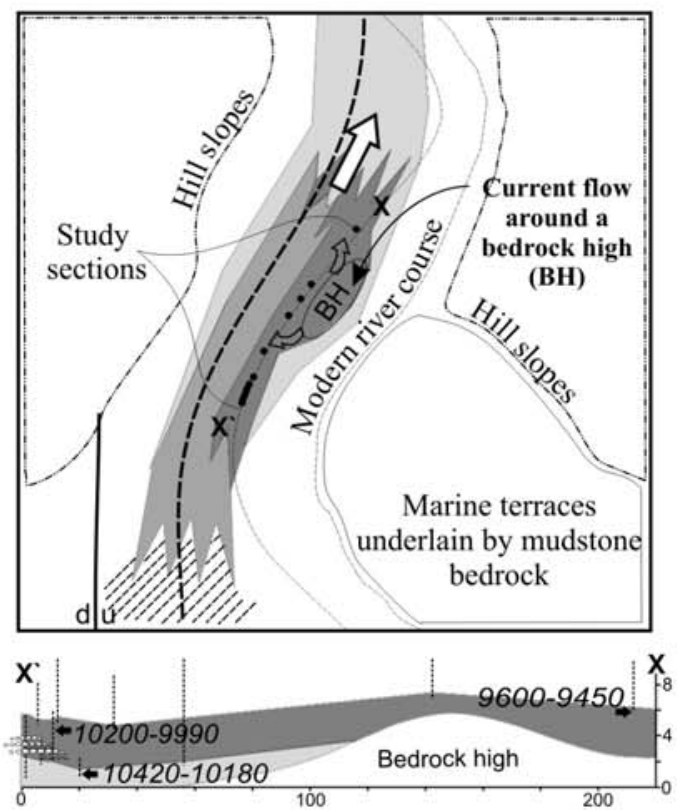

\section{Uplift event $A$}

\section{$(\sim 9,000$ cal. yrs BP $)$}

Marine regression, fluvial sedimentation and possible formation of a marine terrace with paleosols forming.
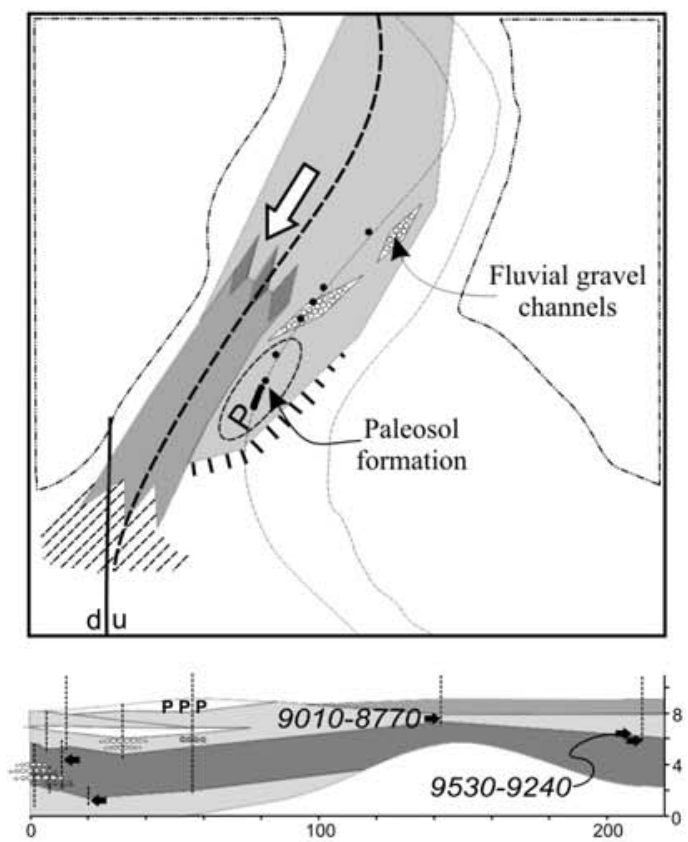

2. Marine transgression $\mathrm{A}$. cont. ( 9,500 - 9,000 cal. yrs BP)

Tephra deposition and reworking, tidal flat expansion.
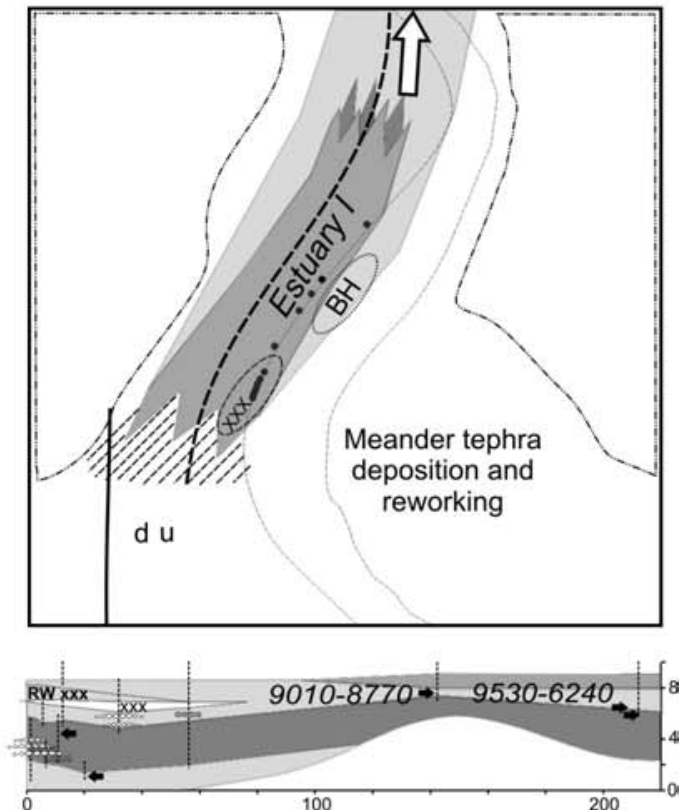

\section{Marine trangression $B$.}

(post $\sim 9,000$ cal. yrs BP)

Marine transgression along western side of the valley.
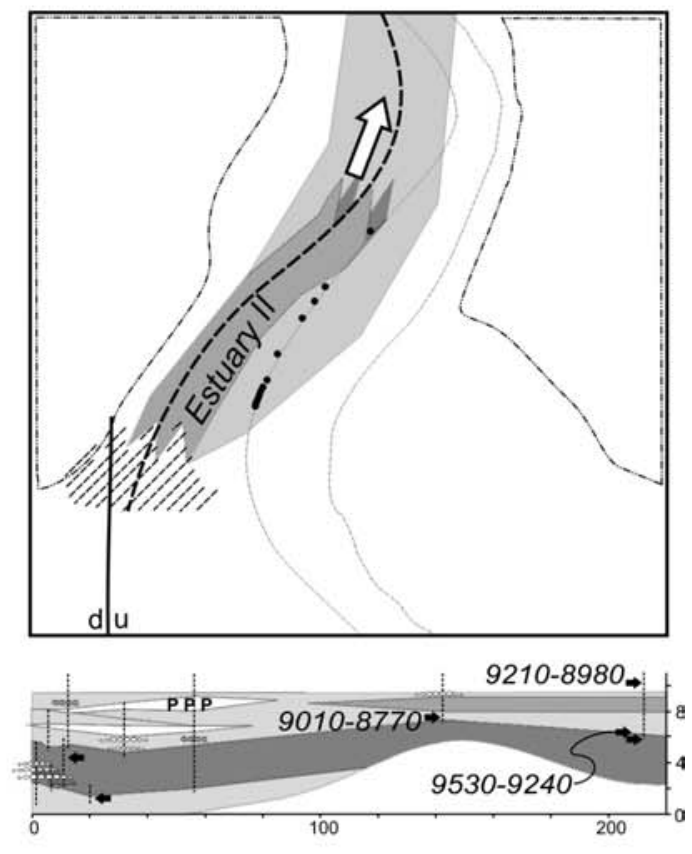

Fluvial lithofacies

Estuary-head delta lithofacies

$\cdots$, Studied section

- Modern Pakarae River course

with locations of studied sections

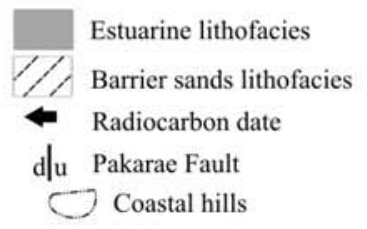

$\longrightarrow$ Direction of relative SL

*000000* Fluvial gravel layer

eeee Estuarine sediment layer

. Estimated former position of

Pakarae River

IIIT Terrace

RW xxx Reworked tephra

Figure 4.4. Continued on following page. 
5. Marine trangression $\mathrm{B}$. cont. $(\sim 9,000-8,500$ cal. yrs BP)

Marine transgression - main estuary basin infills synchronous with fluvio-tidal sedimentation in the southeast of the valley.
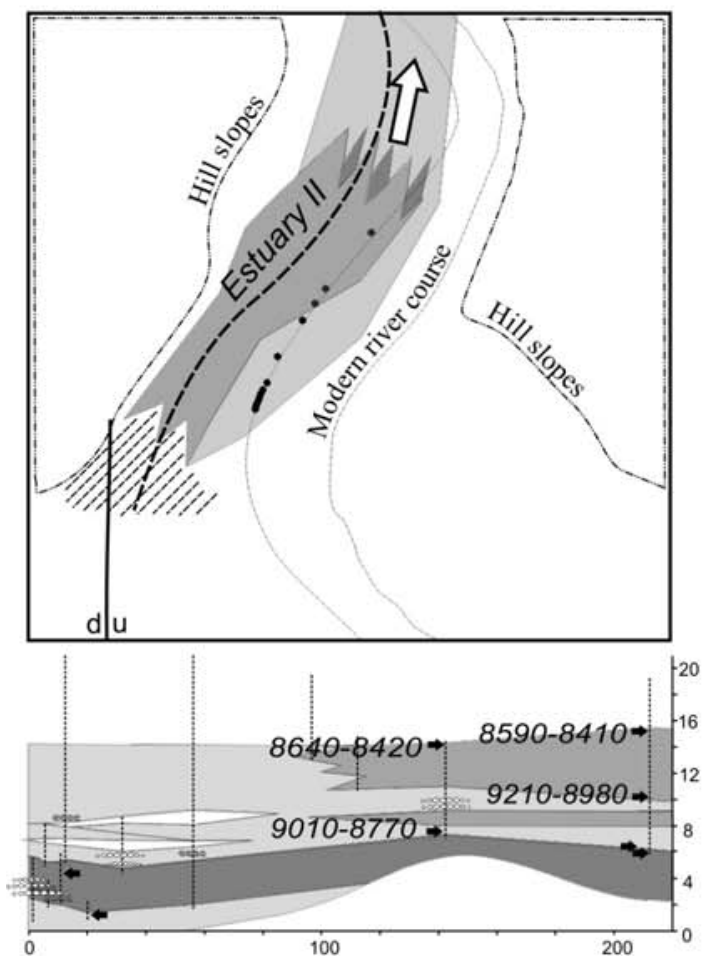

7. Marine trangression $\mathrm{C}$.

$(\sim 8,500-7,400$ cal. yrs BP)

Marine transgression - tidal channel cut into fluvial sediments.
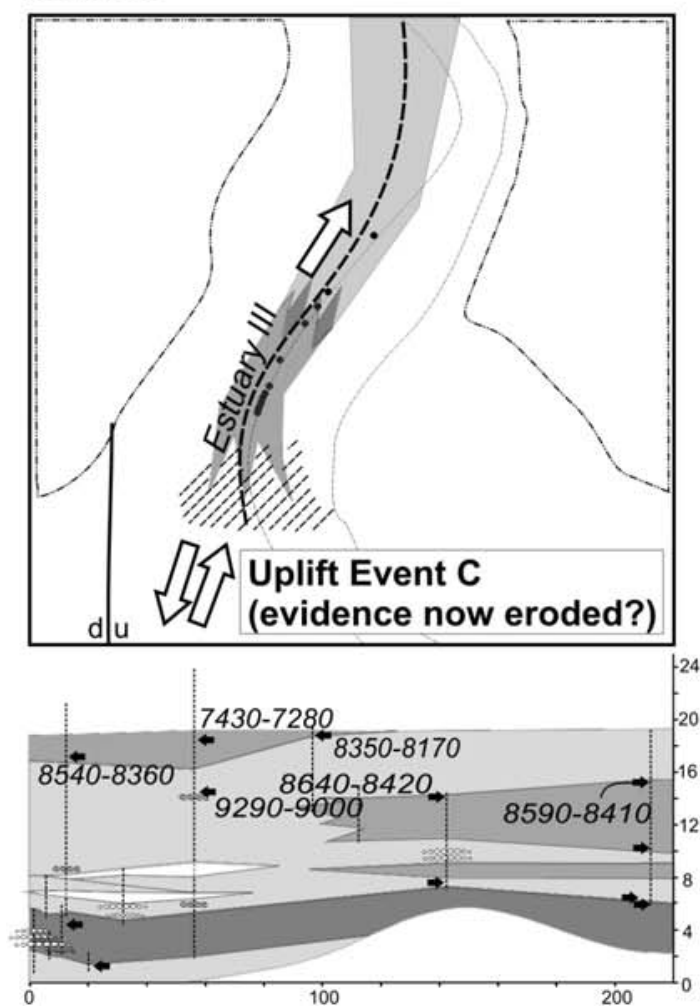

Figure 4.4. Paleogeographic evolution of the Pakarae River, reconstruction of preserved stratigraphy and relative SL changes from $\sim 10$ to $7 \mathrm{ka}$.

\section{Uplift Event B.}

$(\sim 8,500$ cal. yrs BP $)$

Marine regression, fluvial sedimentation pulse.

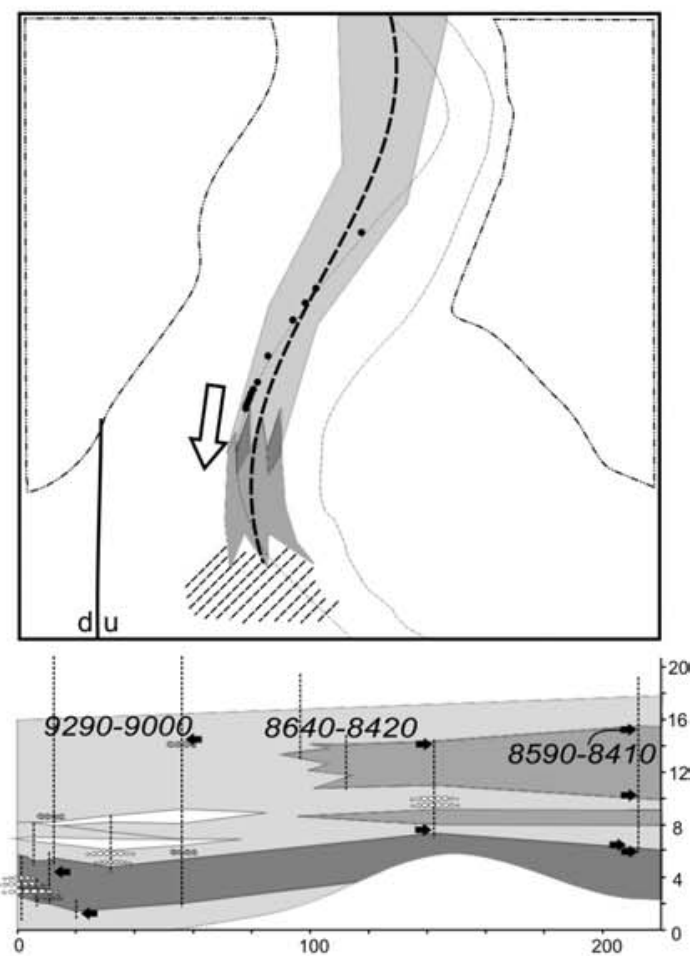

\section{Estuary infilling.}

\section{(post 7,400 cal. yrs BP)}

Beach barrier progrades into estuary from seaward side, fluvial sediments infill from the landward side.
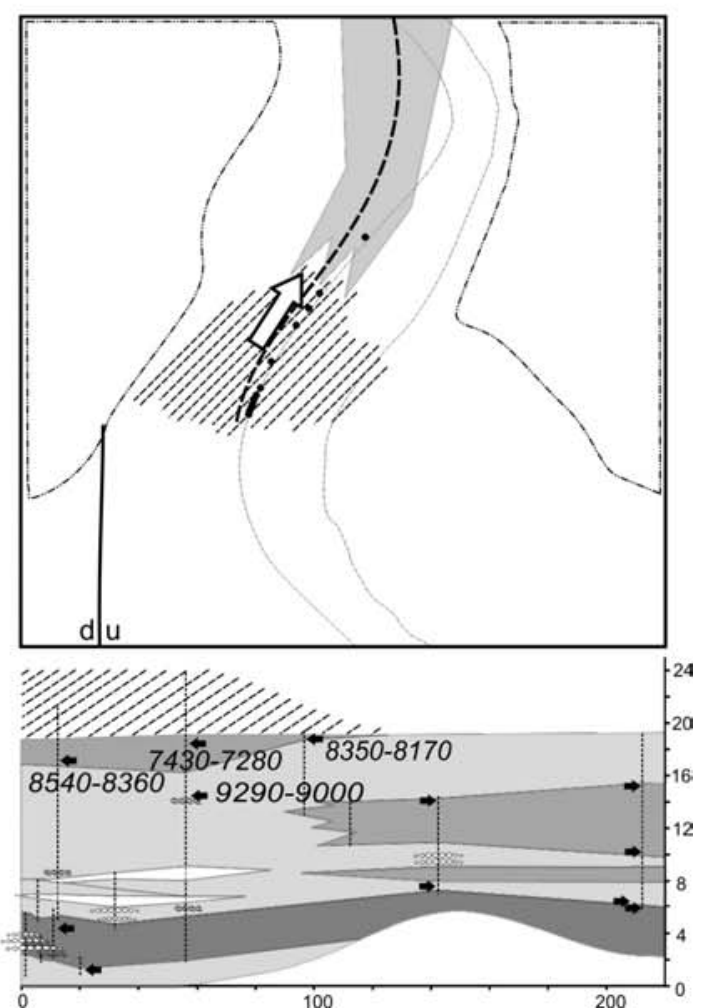

24 . . 
The overthickening and lenticular shape of the tephra probably represents infilling of an abandoned oxbow of the river, suggesting that the rivermouth was located further west than it is at present. Estuarine facies were deposited in sections S1 and S2 up to $\sim 9$ ka.

\section{Uplift Event A: $\sim 9 \mathrm{ka}$.}

At an elevation of $\sim 9$ m AMSL, Estuary I facies are overlain by floodplain sediments and, at equivalent elevations in the southern sections, a series of paleosols are present. Both of these transitions provide evidence of a significant, and sudden marine regression. Eustatic SL was rising during this period and estuarine facies might therefore be expected to be overlain, in a normal sedimentary order, by increasingly marine-influenced sediment. That Estuary $\mathrm{I}$ is instead overlain by non-marine floodplain sediments indicates either that there was a fall in SL due to tectonic uplift or that there was rapid fluvial progradation (Fig. 4.4.3). The paleosols in Sections 5 7 occur within floodplain silts. Paleosols represent a period of time when a surface did not receive sediment, and a soil was allowed to develop. Therefore, rapid fluvial progradation is unlikely to have occurred at this time. It is more likely that the river was subject to a fall in its base level, a change that lowered the elevation at which fluvial sediments were deposited. A fall in river base level is consistent with a marine regression. This could have been caused by eustatic SL fall, a change in fluvial discharge or tectonic uplift. The New Zealand eustatic SL curve of Gibb (1986) is not of sufficient resolution to discount a eustatic SL fall. Carter et al. (1986) used submerged shorelines in the southwest Pacific to infer the ages of several stillstands during Holocene SL rise and Larcombe et al. (1995) also present evidence from Australia of stillstands and minor falls in eustatic SL during the Holocene. The ages of the stillstands do not, however, coincide with the estimated $\sim 9$ ka environmental change at Pakarae, and a stillstand would not trigger fluvial incision into an already existing estuary. Assuming the Estuary I was close to the shoreline, a change in river discharge or decreased sediment supply would not have caused a significant (if any) incision due to the proximity to the base level. Furthermore, a change in fluvial discharge is most likely to climatically controlled, hence of regional extent. Eastern North Island offshore sediment cores do not display any significant changes in sediment flux at this time (Foster and Carter, 1997; Carter et al., 2002). 
Sharp changes from intertidal foraminifera assemblages to foraminifera-barren ones at the Estuary I-floodplain contact suggests that this base level fall was sudden (Wilson, Ch. 3). The paleogeographic reconstruction shows a southward shift in the marinefloodplain interface (Fig. 4.3). The floodplain environment moved over Sections $1-2$ and at Sections $5-7$ a fluvial terrace formed, upon which the paleosols developed. This terrace is analogous to the fluvio-tectonic terraces present at the modern Pakarae river mouth. Eustatic SL was rising during this period, therefore the most likely cause of a marine regression is tectonic uplift; we call this Uplift Event A. Uplift must have been sufficient to elevate the more southern sections (Sections $5-7$ ) above the depositional height of floodplain sediments (although we cannot quantify this amount) and to raise Estuary I out of intertidal range. Estuary I contains foraminifera assemblages dominated by $A$. aoteana, a species dominant at intertidal-subtidal elevations in brackish environments (Hayward et al., 1999), and fragments of $A$. stutchburyi, a common estuarine bivalve that lives between MSL and low tide elevations, Marsden and Pilkington, 1995; Morton, 2004). The occurrence of these two species together suggests that Estuary I sediment was deposited at or slightly below MSL. The Pakarae River mouth has a spring tidal range of $1.7 \mathrm{~m}$. Therefore the only firm constraint we can place on the magnitude of Uplift Event A is that it was probably $>0.85 \mathrm{~m}$. The amount of uplift can also be roughly estimated from the paleosols. If it takes approximately 200-300 years for a soil to develop on a fluvial terrace (based on a conservative estimate), and eustatic SL was rising at $\sim 7 \mathrm{~mm} \mathrm{yr}^{-1}$, then the terrace must have been uplifted by $>1.4-2.1 \mathrm{~m}$ to allow sufficient elevation before marine inundation resumed.

\section{Marine transgression B: post-9 ka.}

Floodplain sediments were deposited in all sections following the above inferred uplift event. As discussed, the southern sections must have been subaerial for sufficient periods of time to allow paleosols to form (Fig. 4.4.4). Two to three paleosol units can be distinguished. This shows there may have been intermittent flooding of the surface as the base level of the river increased in elevation with rising eustatic SL before it was completely overwhelmed by fluvial sedimentation. In the northern sequence (in Sections 1 and 2) 1-2 $\mathrm{m}$ of fluvial silt and gravel was deposited over the silty clay sediments of Estuary I. When eustatic SL became high enough, 
following Uplift Event A, an estuary was re-established in the northern sections, this is called Estuary II. A. stutchburyi shells from the base of Estuary II have a radiocarbon age of 9210-8980 cal. yrs B.P. This age overlaps (at the 2-sigma interval) with a shell age at the base of Estuary I (Fig. 4.4.4). We suggest that the shells at the base of Estuary II were reworked from deposits at the top of Estuary I. At the same time that Estuary II became established in Sections 1 and 2, non-marine sedimentation continued in the southern sections. This apparent anomaly of having non-marine sedimentation south, or in the possible seaward direction, of a marine environment is discussed further below.

\section{V. $\quad$ Marine transgression B continued: $9-8.5 \mathrm{ka}$.}

Estuary II was infilled during Marine Transgression B (Fig. 4.4.5). The thickness of the intertidal estuarine infill ranges from 3.5 to $5.5 \mathrm{~m}$ (decreasing thickness southward). Radiocarbon ages from the top of Estuary II range between 8640 and 8410 cal. yrs B.P. (Fig. 4.4). We therefore estimate that estuary infilling ceased at $8.5 \mathrm{ka}$. Infilling of Estuary II took place over $\sim 500$ years. During the time period of infilling, between $9-8.5 \mathrm{ka}$, there was $\sim 5-8 \mathrm{~m}$ of eustatic SL rise. Accounting for uplift in Event $\mathrm{A}$ of $\sim 2-3 \mathrm{~m}$ (= marine regression), $1 \mathrm{~m}$ of fluvial deposition and the $5.5 \mathrm{~m}$ of estuarine sediment in Section 1, the thickness of the Estuary II facies is consistent with the amount of eustatic SL rise during this time interval, within the uncertainty of the radiocarbon ages and the eustatic SL curve (Fig. 4.3).

Southward of Estuary II floodplain facies were deposited (Fig. 4.4.5). How nonmarine sediments could have accumulated apparently seaward of Estuary II is not fully resolved. We offer three possible paleogeographic scenarios: (A) Birds-foot fluvial delta. The southward non-marine sediments were deposited as lobes within an estuarine environment in which localised sedimentation rates were too high for marine fauna to survive or they are too heavily diluted to be detected; (B) Colluvial fans were depositing sediment above MSL in the southern sections or (C) Fluvial cut-and-fill: originally present estuarine sediments were removed from the southern sections by post-uplift incision to be replaced by younger floodplain sediments (Fig. 4.5). It is not well determined whether the floodplain facies of the southern sections was emplaced prior to, synchronously with, or after emplacement of Estuary II. A radiocarbon age of 9290-9000 cal. yrs B.P. on detrital wood fragment from the floodplain facies of 
Section 5 is older than estuarine shell ages from equivalent elevations in Sections 1 and 2 (radiocarbon ages of $8640-8420$ and $8590-8410$ cal. yrs B.P., Fig. 4.2). This result supports model A (birds foot delta) or model B (colluvial fan) as both of these scenarios require emplacement of the southern non-marine sediment prior to estuary establishment in the northern sections (Fig. 4.5). However, because the wood is detrital and could have been reworked, where as the shells are in-situ, the wood age is a less reliable indicator of sediment depositional age than the shells.

None of these scenarios are entirely consistent with the stratigraphic and age data of the Pakarae River mouth sequence. A combination of the above processes may be responsible. The width of the Pakarae River paleo-valley $(<200 \mathrm{~m})$ is relatively narrow and leaves little room for multiple, or migrating sediment deposition lobes. The birds-foot delta scenario unrealistically implies that sediment delivered to the estuary by the river bypassed Sections 1-3 without entraining any of the inhabitant marine fauna and preferentially settled seaward in Sections 5 and 7. To inhibit colonisation by marine fauna we have implied that sedimentation rates must have been very rapid. However Section 1 indicates sedimentation rates here were approximately equal to the rate of eustatic SL rise. By inference, rates in Sections 5 and 7 must have been greater than the rate of eustatic SL rise. Therefore sediment would have quickly built up above MSL. Colluvial fan deposition is inconsistent with the presence of horizontal sedimentary bedding structures seen throughout the nonmarine facies. Post-uplift fluvial cut-and-fill is possible, although there are no detectable unconformities evident of an incision horizon within the non-marine sediments of Sections 5 and 7.

\section{Uplift Event B: $\sim 8.5 \mathrm{ka}$.}

Abandonment of Estuary II occurred $\sim 8.5 \mathrm{ka}$. Like the abandonment of Estuary I, the regressive estuarine-floodplain transition is inconsistent with rising eustatic SL and could represent either tectonic uplift or fluvial progradation. The similarity in radiocarbon ages of the highest shells in Sections 1 and 2 indicate synchronous changes at these locations, consistent with sudden tectonic uplift. If fluvial progradation due to increased sediment supply or a SL stillstand caused estuary abandonment, then the shell ages at the top of the estuarine facies would be expected to become younger seaward. A layer of $P$. australis shells characteristically mark 
(A) Colluvial fans infilling the Pakarae estuary either prior to or synchronously with Estuary II infilling
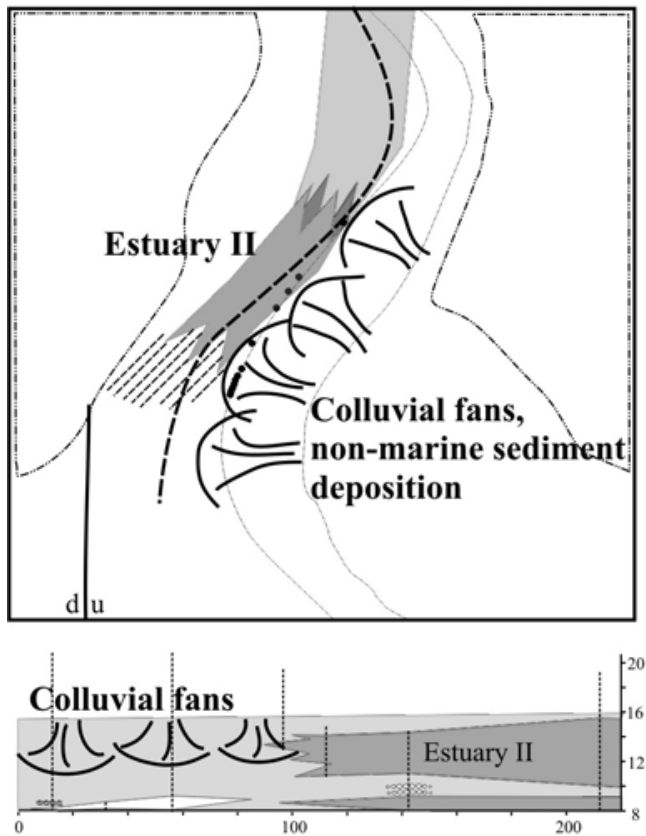

(C.i) Estuary II facies originally continuous in the seaward direction prior to uplift.

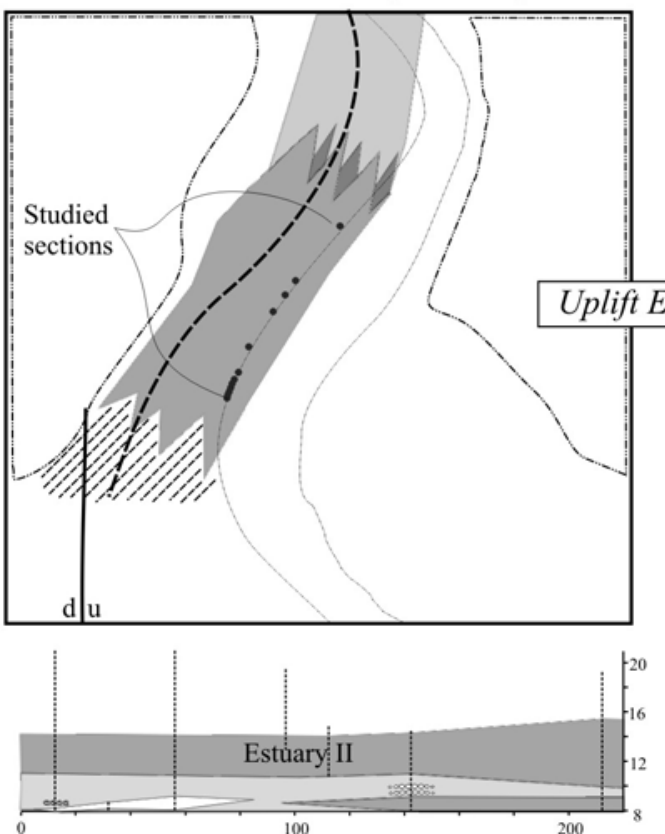

(B) Birds-foot fluvial delta infilling a bathymetrically complex paleo-Pakarae estuary
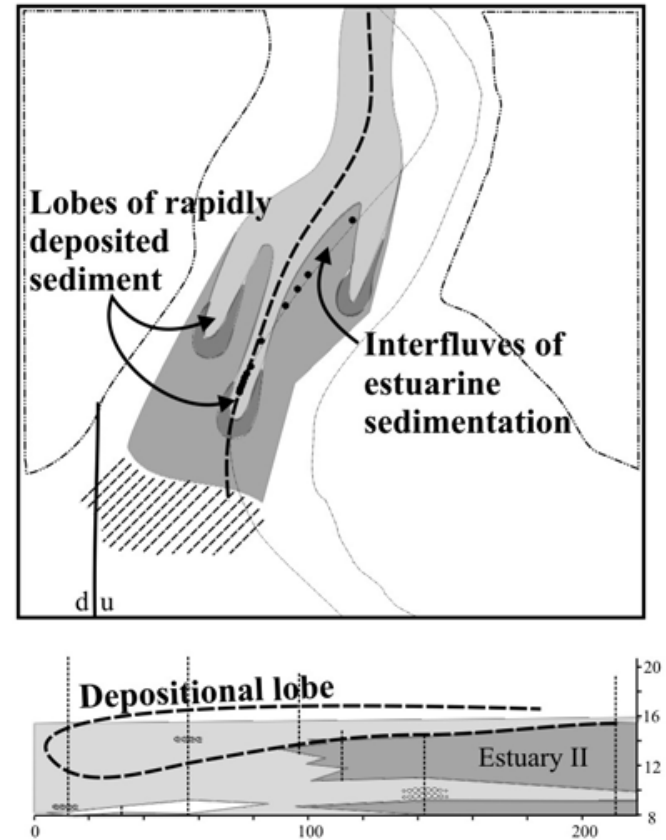

(C.ii) After Uplift Event B the seaward portion of Estuary II facies is removed by fluvial incision and later infilled by younger non-marine sediments.

Figure 4.5. Three scenarios to explain the juxtaposition of seaward barren sediments against landward estuarine sediments with a rich marine fauna in the Pakarae paleo-valley (see Fig. 4.4 for the map legend).

(A) Colluvial fans entering paleo-estuary.

(B) Birds-foot fluvial delta infilling the paleo-estuary.

(C.i and C.ii) Post-uplift fluvial incision removing seaward Estuary II facies. 
the contact between marine and floodplain sediments in Sections 1-3 (Fig. 4.6A). The abrupt changes in the foraminifera assemblages from intertidal to barren, and the presence of life assemblages of $P$. australis indicate that marine regression from this site was rapid. Life assemblages are those in which there are a range of shells from juvenile to adult. Hull (1987) infers sudden death from the preservation of life assemblages because if the environmental change was gradual then the smaller, and younger, species component of the assemblage would have moved to more suitable environments. Again, eustatic SL was rising during this period therefore, a tectonic uplift event is the most likely explanation for the marine regression, we call this Uplift Event B (Fig. 4.4.6).

\section{Marine transgression $C: 8.5-7.4 \mathrm{ka}$.}

The stratigraphically highest and youngest estuarine facies, correlated between Sections 4, 5 and 7, represents Estuary III (Fig. 4.4.7). This estuary evolved due to eustatic SL transgression. Three radiocarbon ages have been obtained from this facies. Two ages of poorly preserved shells at the base of the facies are 8350-8170 cal. yrs B.P. (Sections 4, $18.9 \mathrm{~m}$ ) and 8540-8360 cal. yrs B.P. (Section 7, $17.15 \mathrm{~m}$, Fig. 4.7). Well-preserved shells from near the top of the facies gave an age of 7430-7280 cal. yrs B.P. (Section 5, 18.3-18.7 m, Fig. 4.7). The large age differences and contrasts in shell preservation imply two shell populations within Estuary III. We suggest that the older, degraded shells were reworked from the uppermost sediments of Estuary II, or they were living in the seaward part of Estuary III when it was initially established seaward of its present location. The base of the estuarine facies is sharp and probably represents a transgressive surface (in the nomenclature of Dalrymple et al., 1992, and Allen and Posamentier, 1993; Fig. 4.6B).

If we assume the shell age of 7430-7280 cal. yrs B.P. is in place and representative of the age of infilling of Estuary III, an interval of $~ 1160$ yrs separates Estuary II and Estuary III. During this interval there was $\sim 10 \pm 2 \mathrm{~m}$ of eustatic SL rise (Fig. 4.3). The elevation difference between the in-place dated shells in Estuary II and Estuary III is $3.5 \mathrm{~m}$. The calculated accommodation space deficit (the difference between preserved sediment thickness and the amount accommodation space created by eustatic SL rise) is $\sim 6.5 \pm 2 \mathrm{~m}$ (Fig. 4.8). One uplift event horizon has been identified during this time 

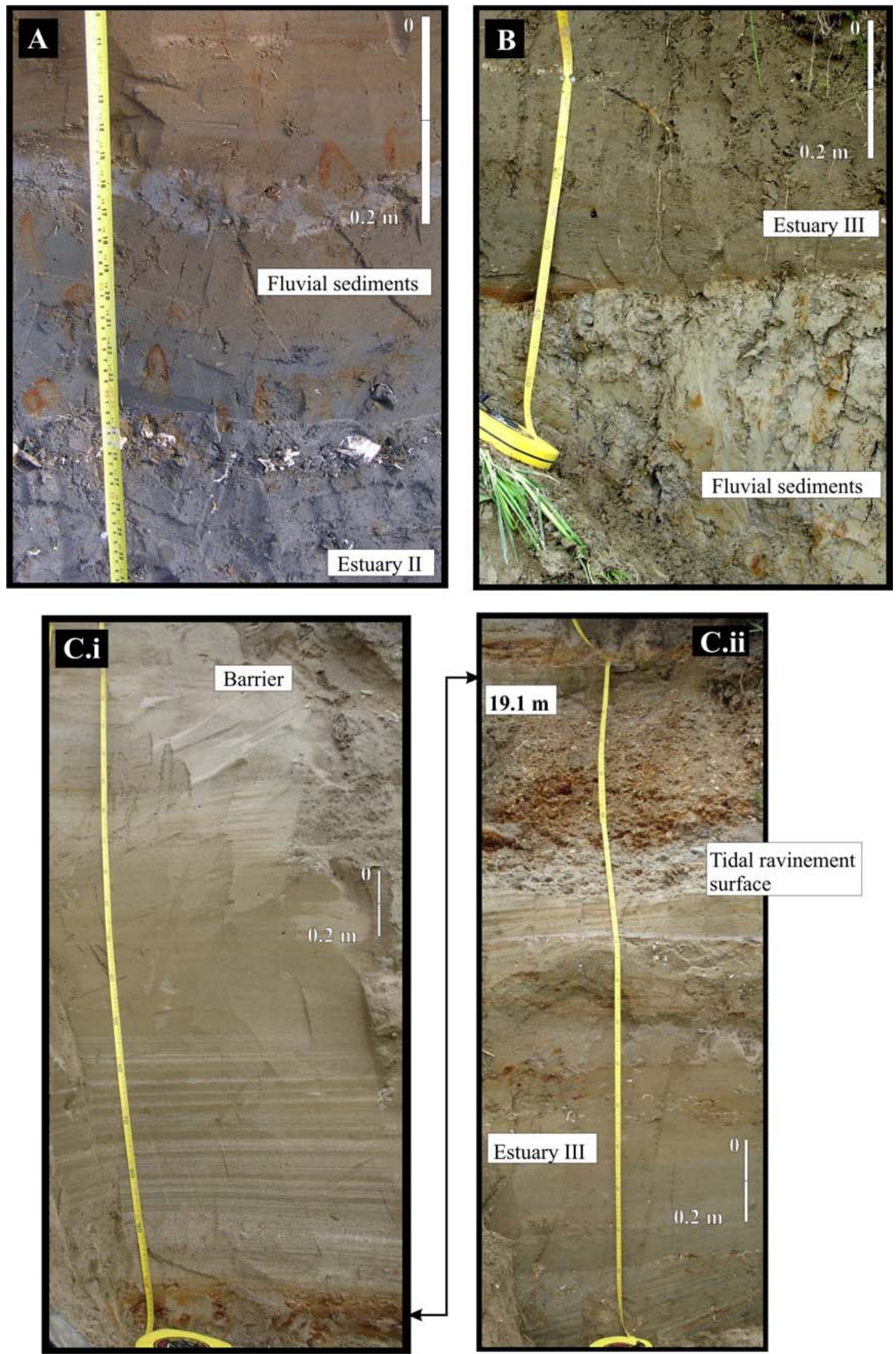

Figure 4.6. (A) Section 1, facies contact between Estuary II and fluvial sediments at $\sim 15.3 \mathrm{~m}$ AMSL. Shells are P. australis. (B) Sections 5, facies contact between fluvial sediments and the base of Estuary III, 16.2 m AMSL. (C) Section 5, facies contact between barrier sands and the top of Estuary III; C.i: $\sim 19$ - 20 m AMSL; C.ii: $\sim 19-17.5$ m AMSL. 

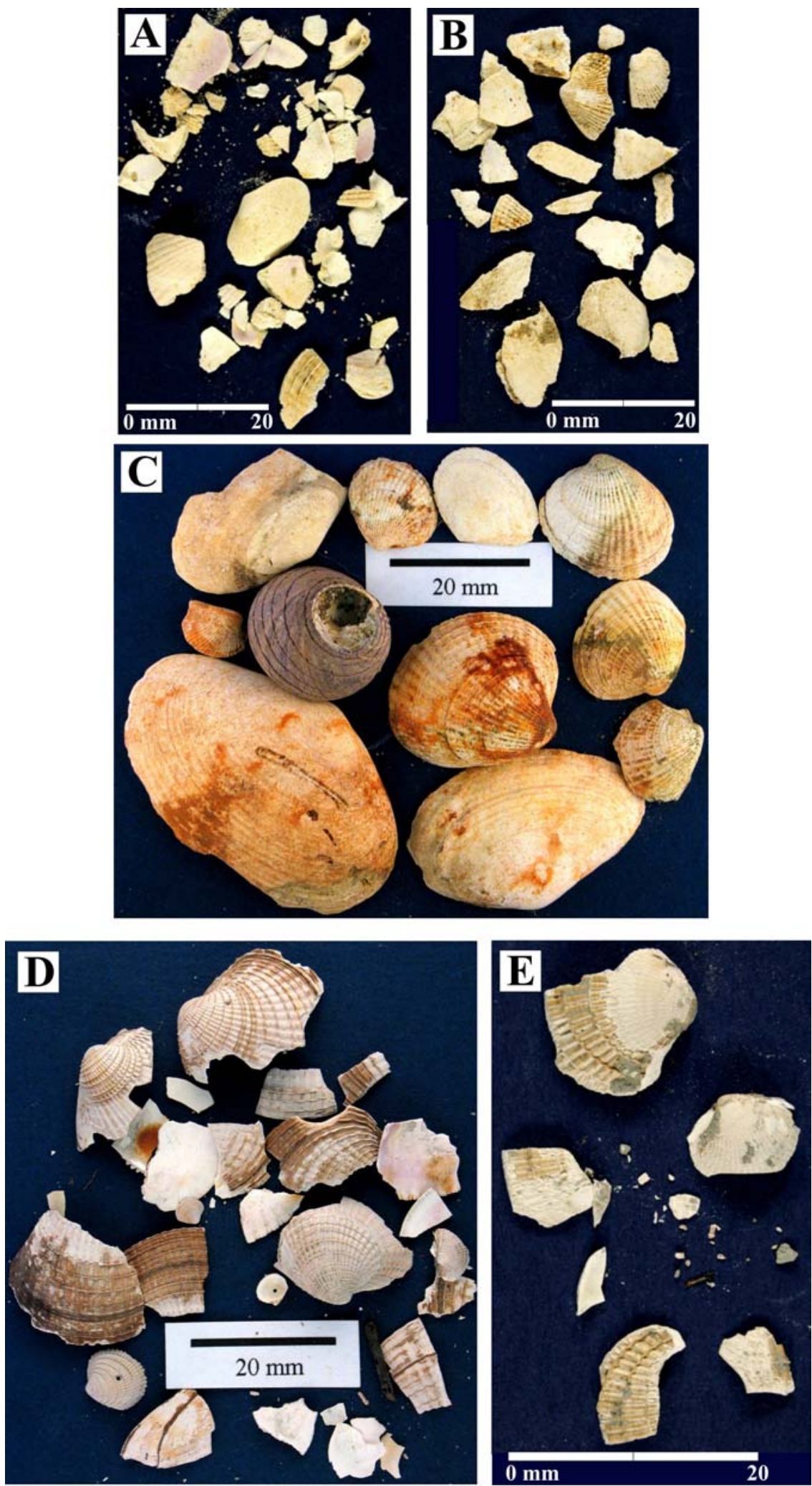

Figure 4.7. Radiocarbon shell samples collected from the Estuary III facies. (A) Section 4, $18.9 \mathrm{~m}$, 8350-8170 cal. yrs. B.P. (B) Section 7, 17.15 m, 8540-8360 cal. yrs. B.P. (C) Section 5, 18.3-18.7 m, 7430-7280 cal. yrs. B.P. (D) Section 1, 15.2 m, 8590-8410 cal. yrs B.P. (E) Section 2, 14.15 m, 8640 8420 cal. yrs B.P. 
period: that at the top of Estuary II, inferred to represent Uplift Event B. It is unlikely, however, that a single event could account for the entire accommodation space deficit of $\sim 6.5 \mathrm{~m}$. Average uplift magnitudes at the Pakarae locality are $2.7 \pm 1.1 \mathrm{~m}$ per event (Ota et al., 1991; Wilson, Ch. 2). The accommodation space deficit of $\sim 6.5 \mathrm{~m}$ probably represents at least two uplift events: Uplift Event B as well as an inferred Uplift Event C. This scenario would be broadly consistent with the uplift event frequency inferred from the marine terrace data. Marine terraces were formed at intervals of $850 \pm 450$ yrs (Wilson, Ch. 2), and the accommodation space deficit of $6.5 \mathrm{~m}$ accumulated over $\sim 1160$ yrs, therefore two uplift events within this time interval is feasible. Evidence for Uplift Event $\mathrm{C}$ was probably recorded in the sedimentary sequence seaward of Section 7. This part of the sequence has been eroded during marine terrace formation.

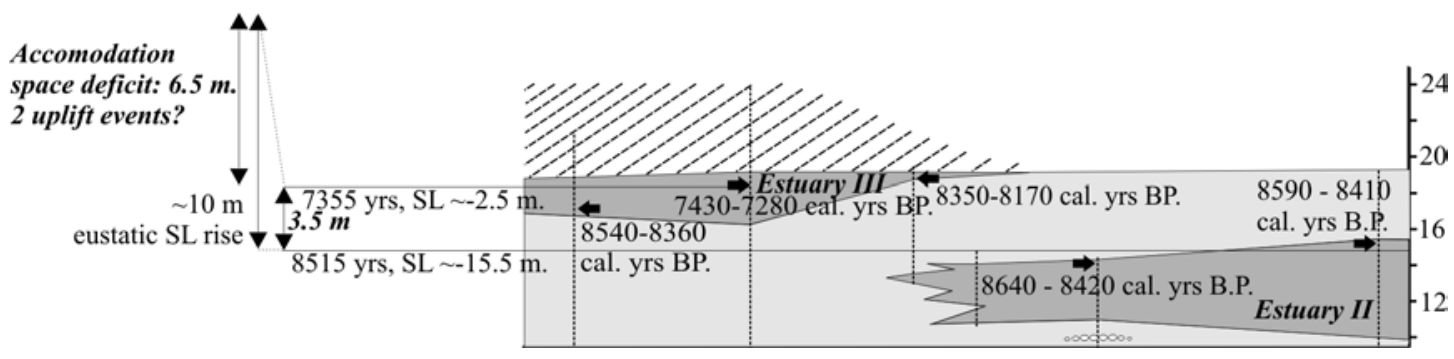

Figure 4.8. Relationships between preserved sediment thickness and amounts of eustatic SL rise for the time period between the deposition of Estuary II and Estuary III.

\section{Estuary infilling and marine regression: post $7.4 \mathrm{ka}$.}

The upper contact between Estuary III and the barrier sands is gradational (Fig. 4.6C). This unit represents infilling of the paleo-estuary during the last several hundred years of eustatic SL rise $(\sim 7,400-7,000$ cal. yrs B.P.; Fig. 4.4.8). Some scouring at the base of tidal channel gravels can be seen (Fig. 4.6C), consistent with a tidal ravinement surface (after Dalrymple et al., 1992). The barrier sands grade upward into aeolian sands. After $\sim 7,000$ cal. yrs B.P. marine regression continued due to repeated tectonic uplift events during the subsequent period of stable eustatic SL, as recorded by the flight of mid to late Holocene marine terraces. 


\subsection{Discussion}

\subsubsection{Chronology of relative SL change}

Our paleogeographic reconstructions have been used to identify three previously unrecognised uplift events in the Holocene: two event horizons are distinguished by abrupt regressions within the Pakarae River mouth sedimentary sequence (Uplift Events $\mathrm{A}$ and B) and a third, younger uplift event is inferred from a significant accommodation space deficit between 8500 - 7400 cal. yrs B.P..(Uplift Event C). The oldest event (Uplift Event A) occurred $29210-8770$ cal. yrs B.P. Its magnitude was $>0.85 \mathrm{~m}$ and was sufficient enough to cause the river to abandon its bed, creating a fluvial terrace and grade to a new lower base level. The time of the second event, Uplift Event B, is well-constrained by two radiocarbon ages dating the death of shells due to estuary abandonment at $8640-8410$ cal. yrs B.P. The third event, Uplift Event C, occurred in the time interval between Uplift Event B and 7430-7280 cal. yrs B.P. No magnitude constraints can be placed on the Uplift Events B and C. However, accommodation space deficits suggest a combined vertical movement of $6.5 \pm 2 \mathrm{~m}$. A new relative Holocene SL curve for the Pakarae locality has been constructed using data presented here and marine terrace data of Ota et al. (1991) and Wilson (Ch. 2; Fig. 4.9).

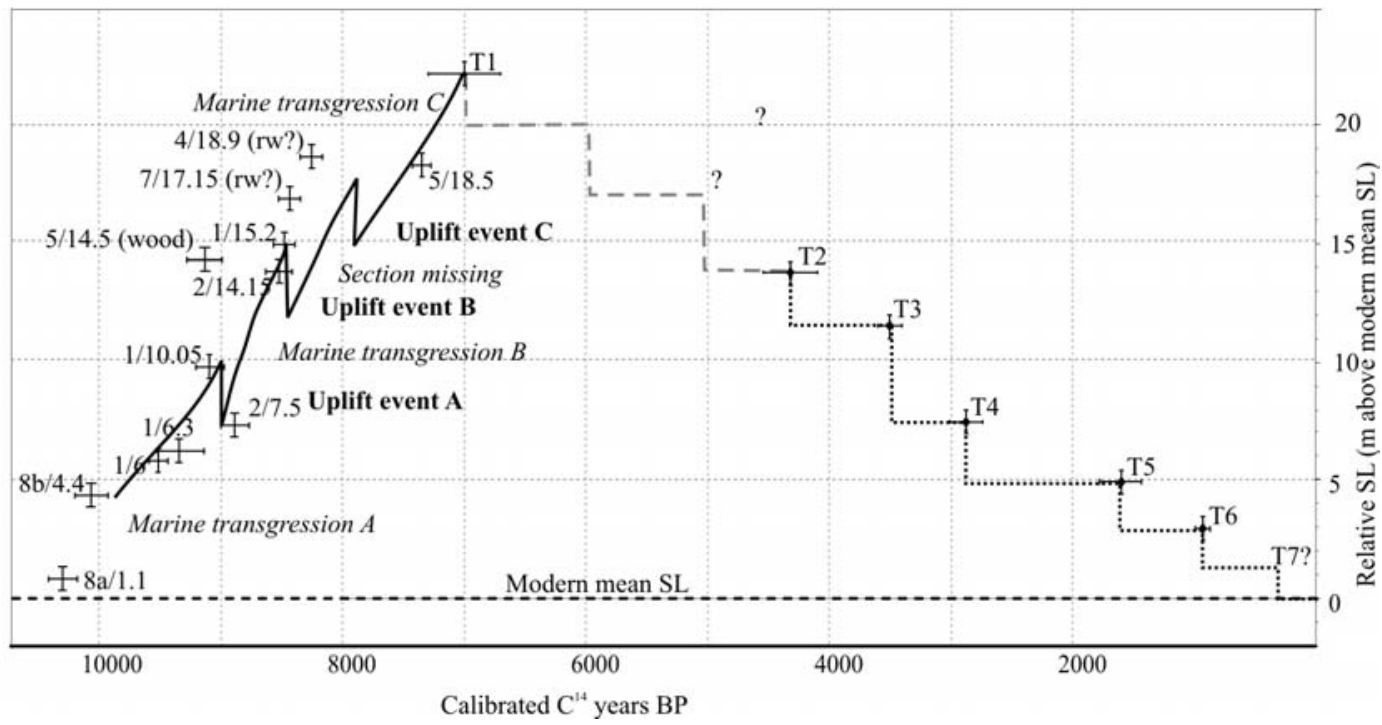

Figure 4.9. Pakarae locality Holocene relative SL curve. Transgressive sequence data presented in this study and the post- 7,000 cal. yrs B.P. marine terrace data presented in Wilson (Ch. 2). (rw?): probable reworked sample. 
The relative SL curve is a significant revision of the previous curve constructed for the Pakarae locality by Berryman et al. (1992). The Berryman et al. curve shows a similar trend but evidence of pre-7000 cal. yrs B.P. uplift was based only on accommodation space deficits, not on specific facies distributions, and individual events were not delineated. As previously discussed, Berryman et al. suggested a relative SL fall at $\sim 10500$ - 9500 cal. yrs B.P., which they inferred to have been a eustatic regression rather than tectonic one based partly on correlation to the eustatic SL curve. Recent calibration of the Gibb (1986) SL curve does not show the equivalent change in trend at $\sim 10500-9500$ cal. yrs B.P. Our data do not support an uplift event in this time period. However, if one did occur near 10500 cal. yrs B.P. the Pakarae River mouth sedimentary sequence would have been unlikely to preserve a record of it, as the sequence is younger than $\sim 10400$ cal. yrs B.P. and the location was probably undergoing terrestrial (floodplain) sedimentation at that time.

\subsubsection{Uplift rates}

The radiocarbon ages obtained from the Pakarae River mouth transgressive sequence, in combination with the Gibb (1986) eustatic SL data, can be used to calculate average uplift rates over time periods extending back to $\sim 10000$ cal. yrs B. P. (Table 4.2). We obtain an average uplift rate of $3.15 \pm 0.8 \mathrm{~mm} / \mathrm{yr}$ (excluding the wood radiocarbon ages as the depositional elevation of these samples relative to MSL is uncertain). This rate is the same as that calculated using the younger Pakarae River mouth marine terrace data (Wilson, Ch. 3) and indicates steady average uplift rates of the Pakarae locality since $\sim 10000$ cal. yrs B.P.

\subsubsection{Tsunami events}

With such a high frequency of sudden coastal uplift events, Pakarae River mouth is an obvious candidate for tsunami inundation. Tsunamigenic sources include an offshore thrust fault, the Pakarae normal fault, the Hikurangi subduction interface, trans-Pacific tsunamis (particularly from South America), submarine landslides, and other offshore faults such as the Lachlan Fault. Tsunami deposits can be recognised as anomalous high-energy influxes into low-energy environments (Goff et al., 2001; Cochran, 2002). There are many high-energy sedimentary layers in the Pakarae River mouth sequence that could be indicative of tsunamis. However, in general the sequence is too 
variable to be able to isolate anomalous deposits and unequivocally attribute them to tsunami. Our facies analysis has shown that this paleo-estuary was extremely dynamic. It would be difficult to distinguish tsunami-emplaced layers from other high-energy environments or events such as tidal channels, storm surges, and flood deposits. For example, Fig. 4.10B and 4.10C show two shell and gravel layers within laminated estuarine silts. These gravel layers could be tsunami deposits, suggesting a high frequency of events, or they could represent migrating tidal channel lags within the estuary. Mapping the extent of the deposits would be required to differentiate between channel and more extensive flood or tsunami deposits.

Table 4.2. Uplift rate calculations from the Pakarae River mouth incised valley infill sequence. Paleosea levels at time of sample deposition are estaimted using the Gibb (1986) eustatic SL curve with an uncertainty of $\pm 2 \mathrm{~m}$. All shell samples are estimated to have had a living depth of $-0.2 \mathrm{~m}$ relative to mean sea level at the time of their death.

\begin{tabular}{|c|c|c|c|c|c|c|c|}
\hline . & 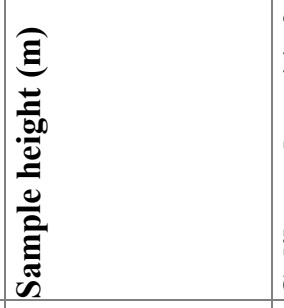 & 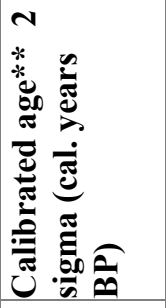 & 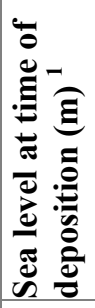 & 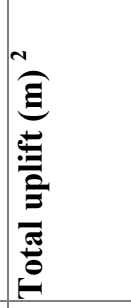 & 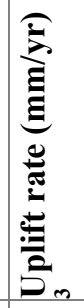 & 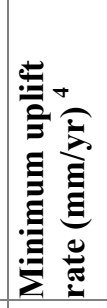 & 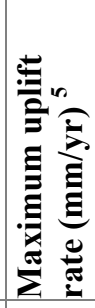 \\
\hline 1 & $15.2+/-0.22$ & $8590-8410$ & -12 & 27 & 3.2 & 2.9 & 3.4 \\
\hline 1 & $10.05+/-0.22$ & $9210-8980$ & -19 & 28.85 & 3.2 & 2.9 & 3.4 \\
\hline 1 & $6.3+/-0.22$ & $9530-9240$ & -20 & 26.1 & $2.8^{*}$ & 2.5 & 3.0 \\
\hline 1 & $6+/-0.22$ & $9600-9450$ & -22 & 27.8 & 2.9 & 2.7 & 3.2 \\
\hline 2 & $14.15+/-0.22$ & $8640-8420$ & -12.5 & 26.45 & 3.1 & 2.8 & 3.4 \\
\hline 2 & $7.5+/-0.22$ & $9010-8770$ & -18 & 25.3 & 2.8 & 2.6 & 3.1 \\
\hline 4 & $18.9+/-0.22$ & $8350-8170$ & -12.5 & 31.2 & 3.8 & 3.5 & 4.1 \\
\hline 5 & $\begin{array}{llll}18.3 & - & 18.7 & +/- \\
0.22 & & & \end{array}$ & $7430-7280$ & -2.5 & 20.8 & 2.8 & 2.5 & 3.1 \\
\hline 5 & $14.5+/-0.22$ & $9290-9000$ & -19.5 & 34 & $3.7 *$ & 3.4 & 4.0 \\
\hline 7 & $17.15+/-0.22$ & $8540-8360$ & -14.5 & 31.45 & 3.7 & 3.4 & 4.0 \\
\hline $8 \mathrm{a}$ & $1.1+/-0.31$ & $\begin{array}{l}10420- \\
10180\end{array}$ & -27 & 28.1 & $2.7^{*}$ & 2.5 & 3.0 \\
\hline $8 b$ & $4.4+/-0.31$ & $\begin{array}{l}10200- \\
9990\end{array}$ & -26 & 30.2 & 3.0 & 2.8 & 3.2 \\
\hline & & & & Average & 3.15 & & \\
\hline & & & & $2 \sigma$ & 0.8 & & \\
\hline
\end{tabular}




\footnotetext{
${ }^{1}$ Sea level estimated using Gibb (1986) New Zealand Holocene sea level curve, the mid-point of the $2 \sigma$ calibrated radiocarbon age is projected to the SL curve, we estimate an uncertainty of $\pm 2 \mathrm{~m}$ using this method.

${ }^{2}$ Total uplift $=$ modern sample elevation - eustatic SL at time of deposition.

${ }^{3}$ Uplift rate $=($ total uplift $) /$ (mid-point of the $2 \sigma$ calibrated radiocarbon age $)$

${ }^{4}$ Minimum uplift rate $=($ total uplift $-2 \mathrm{~m}) /($ maximum $2 \sigma$ calibrated age $)$

${ }^{5}$ Maximum uplift rate $=($ total uplift $+2 \mathrm{~m}) /($ minimum $2 \sigma$ calibrated age $)$

*Wood samples: may have been deposited above MSL therefore these are maximum uplift rates.
}

One unit that may be a tsunami deposit is a coarse sand layer within Section 1 at 15.5 m AMSL (Fig. 4.10A). The base of this unit is erosional and it contains entrained silt rip-up clasts; the sand displays unidirectional, high angle bedding. There are scattered shells even though the unit occurs within floodplain sediments. These features are all indicative of a tsunami deposit. However, the unit occurs $0.23 \mathrm{~m}$ above the horizon marking the abandonment of Estuary II, a horizon that has been identified as representing Uplift Event B. The unit cannot be correlated to Sections 2 and 3, which also display the uplift event horizon. If the coarse sand influx was a tsunami generated by the uplift event, we are uncertain what the intervening $0.23 \mathrm{~m}$ of silt sediment represents. It may be that sediment was deposited immediately following Uplift Event B, though it does not display any chaotic or colluvial-type structures. Alternatively the tsunami deposit may be unrelated to Uplift Event B, and from a different tsunamigenic source. This layer has a depositional age of $<8600$ cal. yrs B.P. A possible tsunami deposit dated at $\sim 8000$ cal. yrs B.P. has been identified within a paleo-estuary sequence at Hicks Bay, $100 \mathrm{~km}$ north of the Pakarae River mouth (Wilson, Ch. 5). The deposits may correlate and be indicative of a regional tsunamigenic source such as the Hikurangi subduction interface or a trans-Pacific Ocean tsunami. These examples demonstrate the complexity of distinguishing tsunami deposits within a dynamic estuary such as the Pakarae River mouth.

\subsubsection{The interpretation of transgressive sequences for paleoseismology}

We identify three major reasons why transgressive deposits are useful in coastal paleoseismic studies: (1) the ability to extend earthquake records prior to the time of eustatic SL stabilisation; (2) their potential for application on coastlines that do not preserve marine terraces; and (3) the ability to distinguish mechanisms of uplift on coastlines without historical occurrences of coseismic uplift. Each of these is discussed further: 

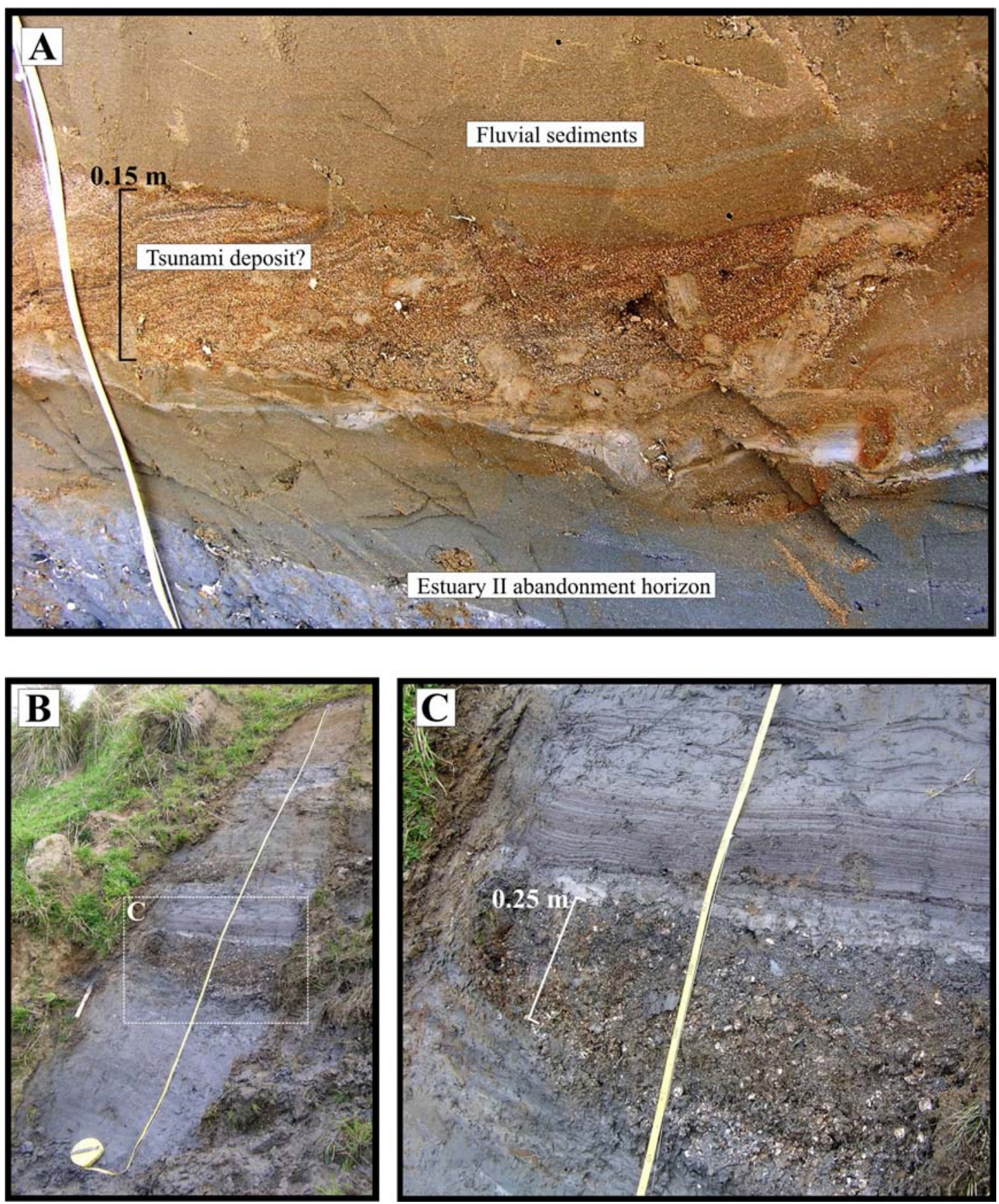

Figure 4.10. High-energy sedimentary units within low-energy paleoenvironments. (A) Section 1, 15 - 16 m AMSL. (B) Section 3, 11 - 15.8 m AMSL. (C) Section 3, 12 - 13 m AMSL. 
1. As previously stated, coastal neotectonic studies are frequently limited to the interval following eustatic SL stabilisation. This study has demonstrated that transgressive fluvio-marine deposits can record evidence of tectonic events prior to eustatic SL stabilisation. This technique may therefore be particularly valuable in regions with long recurrence intervals.

2. During post-glacial SL rise, estuaries were probably widespread along the New Zealand coastline. These are now largely infilled and the sequences may have untapped potential for coastal neotectonic studies. Many areas of the New Zealand coast are undergoing erosion, therefore where marine terraces are not well-formed or have not been preserved; in such areas transgressive sequences can be a tool for determining uplift rates and mechanisms.

3. On some coastlines there may be uncertainty over tectonic uplift mechanisms. Marine terraces are frequently assumed to be coseismic landforms, but terrace morphology can be created by other processes; on coastlines where there has been no historical coseismic uplift this is an important issue. For example, gradual uplift coupled with periods of storminess or varying sediment supply may create benched coastlines. Usually these scenarios can be tested by collecting a suite of radiocarbon samples from the same marine terrace to test their coherence (Ota et al., 1991; Berryman, 1993), and in rare cases by studying the ecological assemblages on the terrace straths (Hull, 1987). This study has shown that the style of uplift (sudden or gradual; i.e. coseismic or aseismic) can be estimated from the marine transgression fill deposits. The technique may provide a more accurate determination of uplift mechanisms than marine terraces. In the Pakarae River mouth sequence, the very sharp facies contacts at the top of Estuaries I and II are a reliable indicator of sudden uplift. The preservation of a life assemblage of $P$. australis at the top of Estuary II is a good indicator of sudden environmental change, as is the sharp transition from intertidal foraminifera assemblages to sediments barren of foraminifera. Transgressive deposits, if accessible, may be useful in resolving uncertainty about the uplift mechanism of marine terraces. 


\subsubsection{Practical limitations of neotectonic analysis of transgressive deposits}

While the use of transgressive deposits in detecting uplift events has been successful at the Pakarae locality, there are also several limitations. First, detailed local knowledge of post-glacial eustatic SL rise is essential, and in areas undergoing glacioisostatic rebound, tectonic uplift signals may be more difficult to isolate. Second, it is not always possible to quantify the amount of uplift that occurs with each event. Quantification is limited by the accuracy of the eustatic SL curve and by the paleoenvironmental bathymetric control. At the Pakarae River mouth paleoenvironmental control is relatively weak because only in-situ A. aoteana foraminifera are preserved. This is a common intertidal species, hence its presence provides relatively little control on the position of paleo-mean SL. Foraminifera with greater SL sensitivity can generally be found at estuary margins. Therefore, there is potential to place better constraints on the amount of uplift if the exposures are in the right location or if drill cores can reach marginal-estuarine locations. Third, a wide spatial distribution of exposures (or drill cores) is needed to detect each event. Correlation of events across an area is needed to understand the paleogeography of the valley. Even at the Pakarae River mouth, a relatively small paleo-valley, direct stratigraphic evidence of Uplift Event $\mathrm{C}$ is missing and was probably only recorded further seaward. Availability of age control also potentially limits the interpretation of uplift events from transgressive sequences. Only Uplift Event B has been accurately dated within the Pakarae River mouth sequence. There appears to be a high degree of shell reworking and this has limited the age constraints we can place on Uplift Event A. Sediment reworking is probably a common characteristic of uplifting transgressive estuaries, with rapid changes in sediment depocentres as a result of alternating eustatic SL rises, causing landward movement, and tectonic uplift, causing seaward retreat.

\subsection{Conclusions}

A fluvio-estuarine transgressive sequence has been used to identify tectonic uplift events that occurred during infilling of the Pakarae River mouth incised valley. Stratigraphic evidence suggests there was abandonment of two estuarine units at 9,000 and 8,600 cal. yrs B.P., and microfaunal evidence suggests the paleoenvironmental changes were sudden. We attribute the sudden changes to rupture of an offshore reverse fault producing coseismic coastal uplift. A third uplift event 
prior to $\sim 7,350$ cal. yrs B.P. is inferred on the basis of a significant accommodation space deficit.

This study has extended the paleoseismic history of the Pakarae locality to span the past 10,000 years. The long record has been obtained through the combined use of marine terraces that post-date the culmination of eustatic SL rise and transgressive marine facies architecture, which relies upon constantly rising eustatic SL. The use of biostratigraphy to document the sudden nature of paleoenvironmental change adds robustness to inferences based on the marine terraces that uplift on this part of the Hikurangi margin occurs by coseismic processes.

\subsection{References}

Allen, G. P. and H. W. Posamentier (1993). "Sequence stratigraphy and facies model of an incised valley fill: the Gironde estuary, France." Journal of Sedimentary Petrology 63(3): 378-391.

Berryman, K. R. (1993). "Age, height, and deformation of Holocene terraces at Mahia Peninsula, Hikurangi subduction margin, New Zealand. 1." Tectonics 12(6): 1347-1364.

Berryman, K. R., Y. Ota and A. G. Hull (1992). "Holocene evolution of an estuary on a tectonically rising coast: the Pakarae River locality, eastern North Island, New Zealand." Sedimentary Geology 80: 151-162.

Cochran, U. (2002). Detection of large Holocene earthquakes in the sedimentary record of Wellington, New Zealand using diatom analysis. Unpublished PhD thesis, Victoria University of Wellington, Wellington.

Collot, J.-Y., J. Delteil, K. Lewis, B. Davy, G. Lamarche, J.-C. Andru, P. Barnes, F. Chanier, E. Chaumillon, S. Lallemand, B. M. De Lepinay, A. Orpin, B. Pelletier, M. Sosson, Toussaint and C. Uruski (1996). "From oblique subduction to intra-continental transpression: structures of the southern Kermadec-Hikurangi margin from multibeam bathymetry, side-scan sonar and seismic reflection." Marine Geophysical Researches 18(2-4): 357-381.

Collot, J.-Y., K. Lewis, G. Lamarche and S. Lallemand (2001). "The giant Ruatoria debris avalanche on the northern Hikurangi margin, New Zealand; results of oblique seamount subduction." Journal of Geophysical Research 106B(9): 19271-19297.

Dalrymple, R. W., B. A. Zaitlin and R. Boyd (1992). "Estuarine facies models: conceptual basis and stratigraphic implications." Journal of Sedimentary Petrology 62(6): 1130-1146.

Eberhart-Phillips, D. and M. Reyners (1999). "Plate interface properties in the northeast Hikurangi subduction zone, New Zealand, from converted seismic waves." Geophysical Research Letters 26(16): $2565-2568$

Froggatt, P. C. and D. J. Lowe (1990). "A review of late Quaternary silicic and some other tephra formations from New Zealand: their stratigraphy, nomenclature, distribution, volume and age." New Zealand Journal of Geology and Geophysics 33: 89-109. 
Gibb, J. G. (1986). A New Zealand regional Holocene eustatic sea-level curve and its application to determination of vertical tectonic movements, A contribution to IGCP-Project 200. Recent Crustal Movements of the pacific Region, Bulletin of the Royal Society of New Zealand. 24: 377-395.

Goff, J. R., C. Chague-Goff and S. L. Nichol (2001). "Paleotsunami deposits: a New Zealand perspective." Sedimentary Geology 143: 1-6.

Hayward, B. W., H. R. Grenfell, C. Reid and K. Hayward (1999). Recent New Zealand shallow-water benthic foraminifera: taxonomy, ecologic dstribution, biogeography, and use in paleoenvironmental assessment. Institute of Geological and Nuclear Sciences Monograph 21. 264 p. Institute of Geological and Nuclear Sciences Limited, Lower Hutt, New Zealand.

Hughen, K. A., M. G. L. Baillie, E. Bard, Beck, J. W. , C. J. H. Bertrand, P. G. Blackwell, C. E. Buck, G. S. Burr, K. B. Cutler, P. E. Damon, R. L. Edwards, R. G. Fairbanks, M. Friedrich, T. P. Guilderson, B. Kromer, G. McCormac, S. Manning, B. B. Ramsey, P. J. Reimer, R. W. Reimer, S. S. Remmele, J. R., M. Stuiver, S. Talamo, F. W. Taylor, J. van der Plicht and C. E. Weyhenmeyer (2004). "Marine04 Marine Radiocarbon Age Calibration, 0-26 Cal Kyr BP." Radiocarbon 46(3): 1059-1086.

Hull, A. G. (1987). "A late Holocene marine terrace on the Kidnappers Coast, North Island, New Zealand: some implications for shore platform development processes and uplift mechanisms." Quaternary Research 28: 183-195.

Larcombe, P., R. M. Carter, J. Dye, M. K. Gagan and D. P. Johnson (1995). "New evidence for episodic post-glacial sea-level rise, central Great Barrier Reef, Australia." Marine Geology 127: 1-44.

Lewis, K. B., J.-Y. Collot, B. Davy, J. Delteil, S. Lallemand and C. Uruski (1997). "North Hikurangi GeodyNZ swath maps: depths, texture and geological interpretation 1: 500 000." National Institute for Water and Atmospheric Research miscellaneous series chart 72. Wellington.

Lewis, K., S. E. Lallemand and L. Carter (2004). "Collapse in a Quaternary shelf basin off East Cape, New Zealand: evidence for passage of a subducted seamount inboard of the Ruatoria giant avalanche." New Zealand Journal of Geology and Geophysics 47: 415-429.

Litchfield, N. J., S. Ellis, K. Berryman and A. Nicol (in press). "Subduction related uplift in the Hikurangi Margin, New Zealand." JGR, Earth Surface.

Marsden, I. D. and R. Pilkington (1995). "Spatial and temporal variations in the condition of Austrovenus stutchburyi Finlay, 1927 (Bivalvia: Veneridae) from the Avon-Heathcote estuary, Christchurch." New Zealand Natural Sciences 22: 57-67.

Mazengarb, C. (1984). "The Fernside Fault: an active normal fault, Raukumara Peninsula, New Zealand." New Zealand Geological Survey Record 3: 98-103.

Mazengarb, C. and I. G. Speden (compilers). (2000). Geology of the Raukumara area, Institute of Geological \& Nuclear Sciences 1:250,000 geological map 6. Institute of Geological and Nuclear Sciences Limited, Lower Hutt, New Zealand.

McCormac, F. G., A. G. Hogg, P. G. Blackwell, C. E. Buck, T. F. G. Higham and P. J. Reimer (2004). "SHCal04 Southern Hemisphere calibration, 0 - 26 ka cal BP." Radiocarbon 46: 1087-1092.

Morton, J. (2004). Seashore ecology of New Zealand and the Pacific, Hayward, B. W. (scientific editor), Bateman, Auckland.

Ota, Y., K. R. Berryman, A. G. Hull, T. Miyauchi and N. Iso (1988). "Age and height distribution of Holocene transgressive deposits in eastern North Island, New Zealand." Palaeogeography, Palaeoclimatology, Palaeoecology 68: 135-151.

Ota, Y., A. G. Hull and K. R. Berryman (1991). "Coseismic uplift of Holocene marine terraces in the Pakarae River area, eastern North Island, New Zealand." Quaternary Research 35: 331-346. 
Paul, M. A. and B. F. Barras (1998). "A geotechnical correction for post-depositional sediment compression: examples from the Forth valley, Scotland." Journal of Quaternary Science 13(2): 171176.

Reyners, M., D. Eberhart-Phillips and G. Stuart (1999). "A three-dimensional image of shallow subduction: crustal structure of the Raukumara Peninsula." Geophysical Journal International 137: 873890.

Roy, P. S. (1984). New South Wales estuaries: their origin and evolution. Coastal Geomorphology in Australia, Academic Press Australia: 99-121.

Stuiver, M. and H. A. Polach (1977). "Discussion; reporting of C-14 data." Radiocarbon 19(3): $355-$ 363.

Walcott, R. I. (1987). "Geodetic strain and the deformation history of the North Island, of New Zealand during the late Cainozoic." Philosophical Transactions of the Royal Society of London A 321: 163-181.

Wilson, K. (Ch. 5): Wilson, K., K. Berryman, U. Cochran and T. Little (in press). "Holocene coastal evolution and uplift mechanisms of the northeastern Raukumara Peninsula, North Island, New Zealand." Quaternary Science Reviews.

Wilson, K. (Ch. 3): Wilson, K. J., K. Berryman and U. Cochran (in press). "A facies architecture model for Holocene incised valley infill on a tectonically active coast: Pakarae River, New Zealand." Sedimentary Geology.

Wilson, K. (Ch. 2): Wilson, K. J., K. R. Berryman, N. J. Litchfield and T. A. Little (2006). "A revision of Mid to Late Holocene marine terrace distribution and chronology at New Zealand's most tectonically active coastal location, Pakarae River, North Island, New Zealand." New Zealand Journal of Geology and Geophysics, 49: 477-489 


\title{
ChAPTER Five
}

\section{Holocene coAstal EVOLUtion AND UPLIFT MECHANiSMS OF THE NORTHEASTERn RAUKumara PEninsula, NoRTh Island, NeW ZEALAND.}

\begin{abstract}
The coastal geomorphology of the northeastern Raukumara Peninsula, New Zealand, is examined with the aim of determining the mechanisms of Holocene coastal uplift. Elevation and coverbed stratigraphic data from previously interpreted coseismic marine terraces at Horoera and Waipapa indicate that, despite the surface morphology, there is no evidence that these terraces are of marine or coseismic origin. Early Holocene transgressive marine deposits at Hicks Bay indicate significant differences between the thickness of preserved intertidal infill sediments and the amount of space created by eustatic sea level rise, therefore uplift did occur during the early Holocene evolution of the estuary, but the paleoecology and stratigraphy of the sequence shows no evidence of sudden land elevation changes. Beach ridge sequences at Te Araroa slope gradually toward the present day coast with no evidence of steps resulting from sudden coseismic uplift events. The evolution of the beach ridges was probably controlled by sediment supply in the context of a background continuous uplift rate. No individual dataset uniquely resolves the uplift mechanism. However, from the integration of all available evidence we conclude that Holocene coastal uplift of this region has been driven by a gradual, aseismic mechanism. An important implication of this is that tectonic uplift mechanisms significantly vary along the subduction margin of the East Coast of the North Island. This contrasts with the conclusions of all previous studies, which have inferred Holocene coastal uplift along the length of the margin was achieved by coseismic events.
\end{abstract}

\subsection{Introduction}

The interpretation of Holocene coseismic uplift along the East Coast of the North Island, New Zealand, despite changes in upper plate structures and Hikurangi subduction zone dynamics is examined in this study. Early Holocene transgressive marine sediments and mid-late Holocene marine terraces occur extensively along the East Coast adjacent to the Hikurangi subduction zone (Ota, 1987; Ota et al., 1988; 1992). At several localities on the central and southern East Coast detailed studies 
have produced sound evidence of terrace formation by sudden, episodic uplift processes that are, by inference, coseismic (Berryman, 1993; Hull, 1987; Ota et al., 1991). Numerous other terraces along this margin with similar geomorphology have also been presumed to be coseismically uplifted.

This study focuses on the northeastern tip of the Raukumara Peninsula at the northern end of the onland Hikurangi margin (Fig. 5.1, inset). There, suites of 4 - 5 marine terraces were recorded by Ota et al. (1992). These terraces are geomorphically similar to those on the southern Hikurangi margin, suggesting an origin by a common uplift mechanism. However, in the Raukumara Peninsula region, upper plate compressional structures are absent or poorly expressed on land and there have been no large historical earthquakes. In contrast, in the central and southern Hikurangi margin upper plate reverse faults are common both on and offshore and coseismic coastal uplift has taken place there in historic time (for example, the 1931 Napier earthquake and 1855 Wairarapa earthquake).

We examine the marine terraces at Horoera and Waipapa (Fig. 5.1) to evaluate whether or not they were uplifted coseismically. We also undertake a geomorphic study of the late Holocene beach ridge sequence at Te Araroa (TA, Fig. 5.1) and a paleoenvironmental study of the early Holocene uplifted transgressive marine deposits in nearby Hicks Bay (HB, Fig. 5.1) to further assess rates and processes of Holocene tectonic uplift in the northeastern (NE) Raukumara Peninsula.

In this paper we present a summary of the regional geology, modern geomorphology and previous work related to the Horoera, Waipapa, HB and TA study sites. We then outline the methodology of this study and summarize the results at each location in turn. We interpret data from each site and then integrate the conclusions from each location to address the question of regional Holocene styles of uplift and its relationship to the geodynamics of the Hikurangi margin as a whole.

\subsection{Tectonic setting}

The Raukumara Peninsula is located at the northeastern end of the East Coast of the North Island. HB, TA and East Cape are located at the northeastern tip of the 


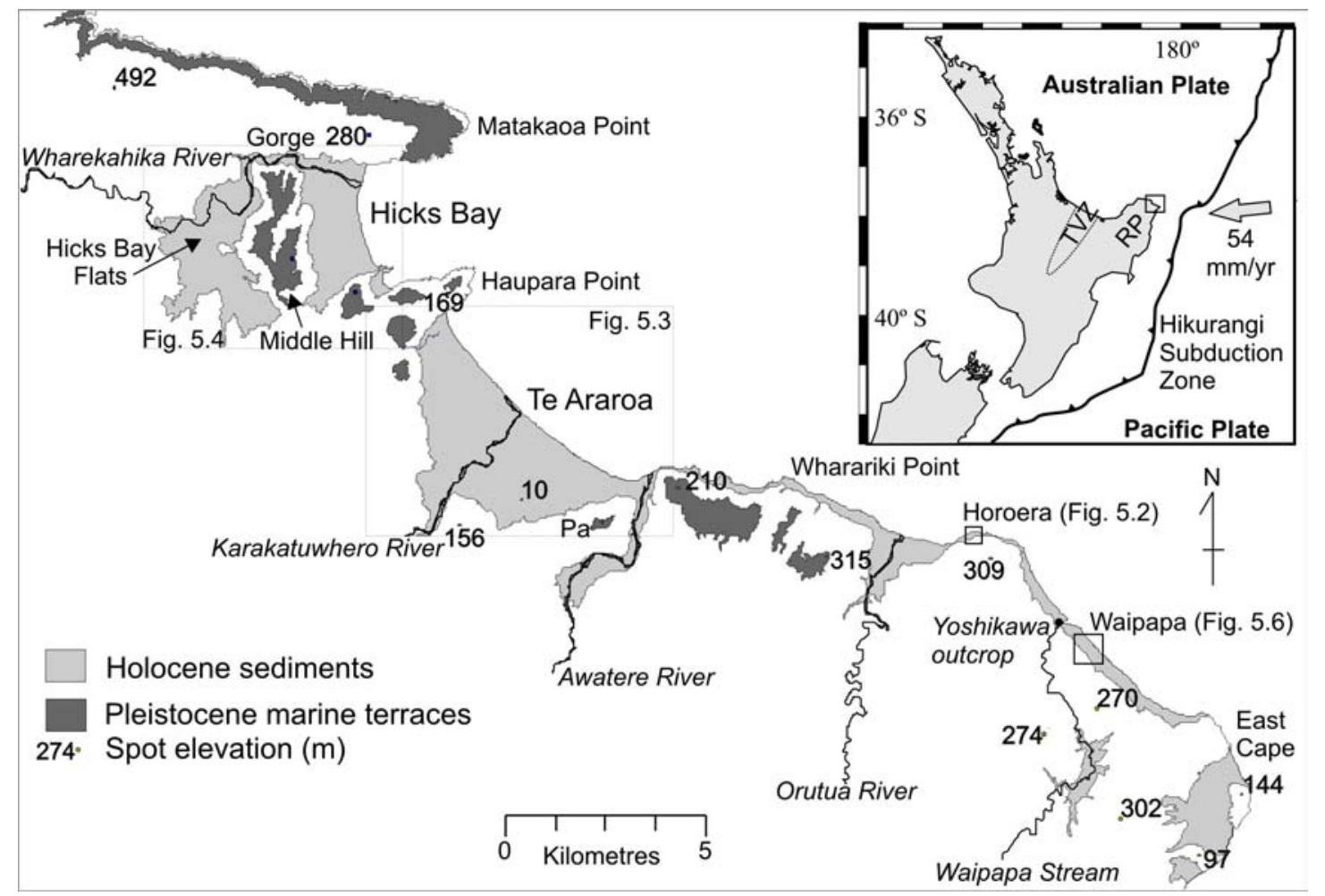

Figure 5.1. Location map of the northeastern Raukumara Peninsula region. Inset: Plate tectonic setting of the Raukumara Peninsula. Pacific-Kermadec plate motion after Collot et al. (2001). RP: Raukumara Peninsula, TVZ: Taupo Volcanic Zone. 
peninsula (Fig. 5.1). The Hikurangi Trough lies approximately $60 \mathrm{~km}$ offshore, east of HB-TA. Convergence between the Pacific Plate and the Kermadec Forearc occurs at $\sim 54 \mathrm{~mm} \mathrm{yr}^{-1}$ at an azimuth of $277^{\circ}$ (Collot et al., 2001). Bedrock near HB-TA consists of Pliocene forearc basin muddy sandstones of the Mangaheia Group and early Cretaceous to Eocene igneous rocks (Matakaoa Volcanics) of the East Coast Allocthon (Mazengarb and Speden, 2000).

In contrast to the central to southern parts of the Hikurangi margin, the Raukumara Peninsula contains few known active onshore faults. Mazengarb and Speden (2000) noted that mapped active fault segments are typically short and have a normal sense of slip (Ota et al., 1991; Mazengarb, 1984). Inactive faults on the Raukumara Peninsula generally strike northwest, approximately perpendicular to the emplacement direction of the East Coast Allocthon and are primarily early Miocene reverse faults (Mazengarb and Speden, 2000).

\subsection{Previous studies of NE Raukumara Peninsula Quaternary coastal geology}

Holocene deposits in the HB-TA region were first descibed by Henderson and Ongley (1920) and Ongley and MacPherson (1928). Garrick (1979) mapped beach ridges at TA and presented two topographic profiles from the southeastern side of the Karakatuwhero River (Fig. 5.1). Three radiocarbon ages of shells collected within 320 $\mathrm{m}$ of the modern beach shore yielded ages of $<1068$ cal. yrs B.P., establishing the Holocene age of the beach ridges. Projecting the average progradation rate, derived from the oldest of these radiocarbon ages, back to the highest beach ridge inland, Garrick (1979), calculated an average beach ridge uplift rate of $1.5 \mathrm{~mm} \mathrm{yr}^{-1}$. Garrick (1979) divided the beach ridges into four zones separated by intervening swamps that he called Coastal Revisions (CR1 - CR3). CR1 and CR2 were proposed to have formed during periods of coastal erosion; Garrick (1979) suggested the oldest zone (CR3) may have formed due to relatively fast coastal emergence. Ota et al. (1992) subsequently mapped the beach ridges at TA, dividing them into five zones, named I $-\mathrm{V}$. The zones were defined by the continuity of beach ridges. They recognised two, $2 \mathrm{~m}$ high, scarps between Zones III-IV and IV-V. The swamps between zones II - V coincide with the Coastal Revisions of Garrick (1979). Ota et al. (1992) did not discuss the formation of the TA beach ridges or mechanisms of their subsequent uplift. 
Yoshikawa et al. (1980) included the Holocene terraces of the HB-TA, East Cape and Whangaparoa, on the northwestern side of the Raukumara Peninsula, $25 \mathrm{~km}$ west of $\mathrm{HB}$, into a single landform, which they referred to as the Te Araroa terrace. They noted at least three to four sub-levels of terraces within this larger terrace and presented a profile across marine terraces at Waipapa Stream (Fig. 5.1). Maps of marine terraces from $\mathrm{HB}$ to East Cape, and 26 radiocarbon ages from Holocene deposits in the region were presented by Ota et al. (1992). These authors recognised three marine terraces at HB based on aerial photograph interpretation, with the lowest and highest terraces continuing inland behind Middle Hill. An exposure along the Wharekahika River called "Location A" (henceforth called Ota A) includes abundant Austrovenus stutchburyi shells, a common estuarine species. The highest elevation shell bed yielded a radiocarbon age of 7662-7429 cal. yrs B.P. Ota et al. (1992) further identified an overlying tephra as the Whakatane tephra $(\sim 5550$ cal. yrs B.P., Froggatt and Lowe, 1990). They mapped marine terraces almost continuously from the Awatere River mouth to East Cape, recognising up to five terraces at the Orutua River mouth and Horoera Point, and three at Waipapa Stream mouth (Fig. 5.1). All radiocarbon ages presented by these authors from shells within the terrace cover deposits were $<1240$ - 930 cal. yrs B.P. Ota et al. (1992) interpreted all of these late Holocene terraces as having been uplifted suddenly during earthquakes.

\subsection{Methods}

\subsubsection{Geomorphic analysis of the Horoera and Waipapa coastal terraces}

The coastal terraces at Horoera and Waipapa were surveyed using a real time kinematic GPS. One benchmark, four high tide points and two mid-tide sea level points were used as vertical geodetic control to calibrate the GPS. All elevations are relative to mean sea level (MSL) and have a $95 \%$ uncertainty of $\pm 0.22 \mathrm{~m}$. At Horoera nine topographic profiles were measured normal to the shoreline and strike of the terraces (Figs. 5.2, P1-P9); ten profiles parallel to the shoreline and the strike of the terraces were obtained at the front and rear of each terrace (Figs. 5.2, $1 \mathrm{~F}-5 \mathrm{~F}$ and $1 \mathrm{R}$ - 5R). At Waipapa three topographic profiles were obtained, all normal to the shoreline and to the strike of the terraces. Twenty auger holes were hand-drilled on the Horoera terraces and eight on the Waipapa terraces to examine the stratigraphy of their cover sediments. 


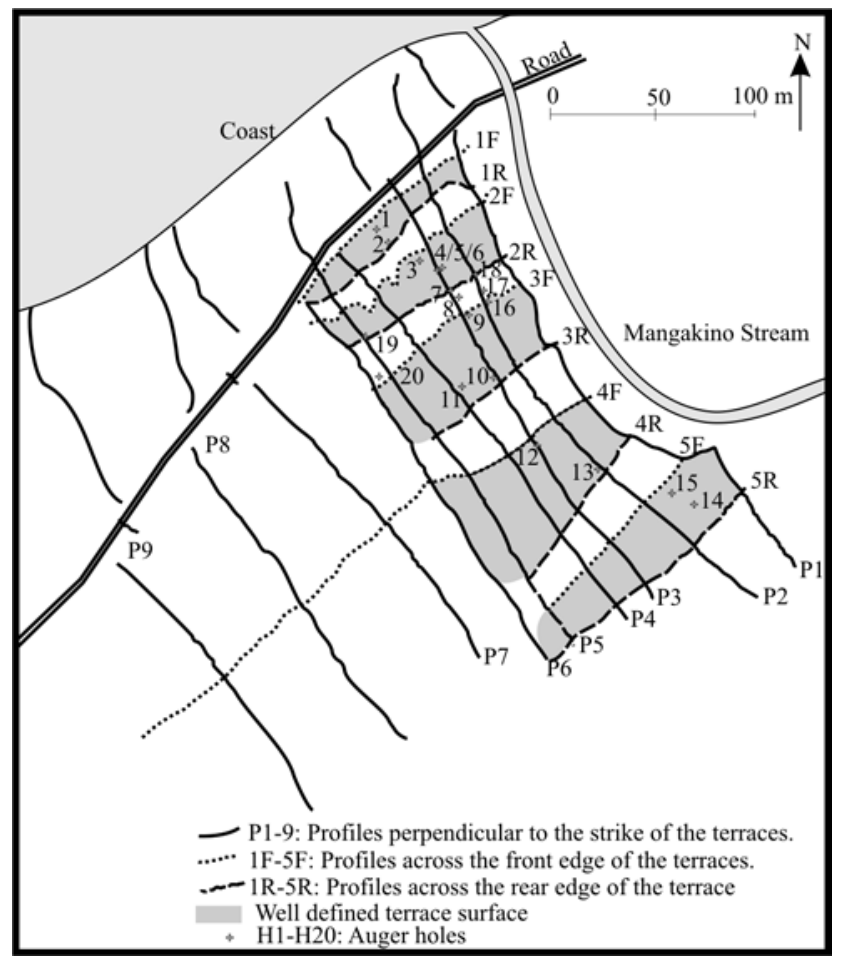

Figure 5.2. Location of elevation profiles and auger holes on the Horoera terraces.

\subsubsection{Geomorphic analysis of the Te Araroa Beach Ridges}

The TA beach ridges (Fig. 5.3) were examined for any steps in the sequence that may represent coseismic uplift. Previous work showed the sequence could be divided into zones of ridges separated by two, 2 m high, scarps (Garrick, 1979; Ota et al., 1992). We use detailed elevations surveys, stratigraphy, radiocarbon dating and tephrochronology to further investigate the evolution of the coastal plain and how the beach ridges relate to uplift processes.

Elevation profiles (TA North and TA South) were taken across the coastal plain on both sides of the Karakatuwhero River at TA using an RTK GPS (Fig. 5.3). GPS points were recorded every $2 \mathrm{~m}$. Where swamps could not be crossed, particularly on TA North, several short segments of profile have been joined together with the intervening distance left blank (Fig. 5.3). Elevation control was maintained by 
calibrating the GPS at three geodetic markers, three estimated high tide markers and two measurements of the tide level at certain times of the day. The elevation measurements have a $95 \%$ confidence interval of $\pm 0.42 \mathrm{~m}$.

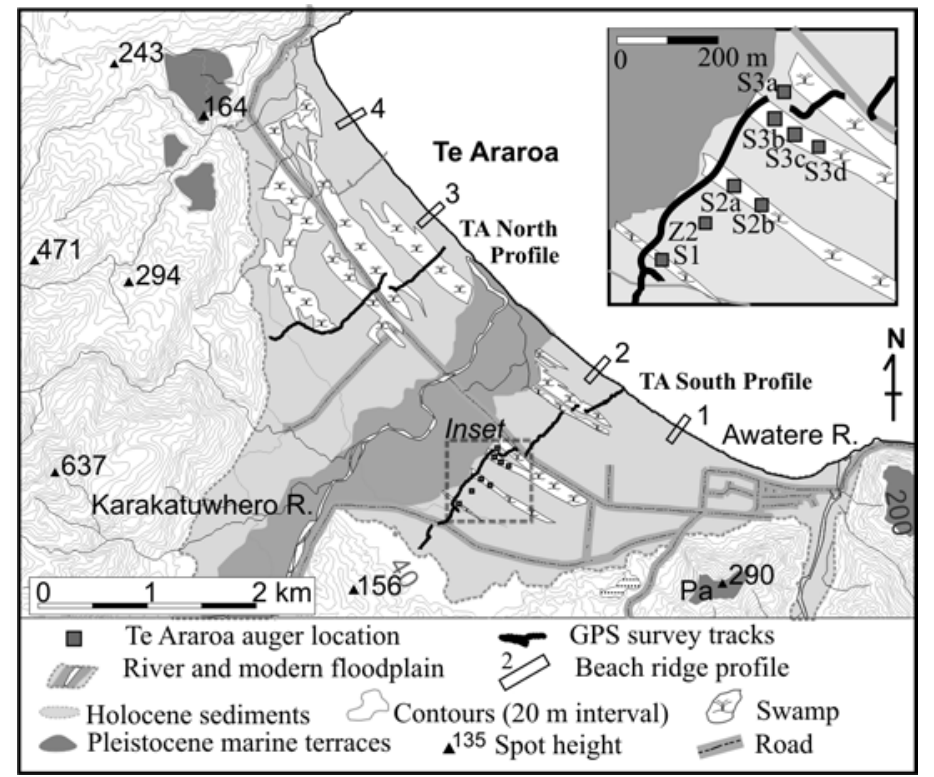

Figure 5.3. Topography of the Te Araroa area with locations of auger profiles, GPS survey tracks and locations of modern beach ridge profiles.

Seven hand augers were drilled on the Te Araroa plain (Fig. 5.3 inset, named S1 - S3a and Z2). The sedimentary characteristics were visually assessed and samples were taken at significant boundaries. Three samples were processed for diatom content using the same techniques as will be described for the Hicks Bay study. Two radiocarbon samples of wood were obtained from auger holes S1 and S3d. Radiocarbon ages are presented at the 2-sigma age range (95\% probability) and as calibrated radiocarbon years, unless otherwise stated.

The glass geochemistry of three tephra samples from auger holes S1 and S2a were analysed. Glass shards of $63-250 \mu \mathrm{m}$ size were mounted in epoxy blocks; these were polished and carbon coated. At least ten glass shards from the tephra were analysed with a JEOL-733 microprobe in the Analytical Facility of Victoria University of Wellington, using a $10-\mu \mathrm{m}$-diameter beam of $8 \mathrm{nA}$ at $15 \mathrm{kV}$ accelerating voltage. 


\subsubsection{Stratigraphic study of the Hicks Bay paleo-estuary}

Inland of the Middle Hill at HB is a broad, low-lying, swampy area through which the Wharekahika River and its tributaries meander (the HB Flats, Fig. 5.1). Shells exposed along the banks of the Wharekahika River attest to an early Holocene estuarine paleoenvironment in this area (Ota et al., 1992). This transgressive estuarine sequence was targeted for drilling and paleoenvironmental analysis.

Estuarine, salt marsh and tidal inlet sediments have been used at subduction zone margins globally to document land elevation changes associated with earthquakes (Atwater, 1987; Clague, 1997; Darienzo et al., 1994; Hayward et al., 2004a; Nelson et al., 1996; Shennan et al., 1996; Sherrod et al., 2000) and on passive coasts to document eustatic sea level (SL) changes and glacio-isostatic vertical land movements (Bratton et al., 2003; Dawson et al., 1998; Dawson and Smith, 1997; Shennan et al., 1994; 1995). The distribution of many species of tidal-wetland micro- and macrofauna and flora is related to tidal inundation and/or salinity and thus can be used as a proxy for the position of MSL (Hayward et al., 1999b; 2004b; Patterson et al., 2000). We use the transgressive sequence beneath the HB Flats to document the rate and style of tectonic uplift at this locality.

For our purposes an ideal place to drill is at the margins of the paleo-estuary where the micro-flora and -fauna have restricted salinity or inundation tolerances and are thus sensitive to changes in MSL. The Ota A riverbank section revealed marine sediments underlying the Hicks Bay flats in at least one location, and we assumed that they continue seaward of this point. At most locations inland of the Ota A river outcrop, gravels exposed in augered holes and penetrometer resistance data suggest a thick non-marine section not suitable for drilling (A1-A10, Fig. 5.4, Appendix 5.1, Appendix 5.2). Diatoms from A8 at $5.8 \mathrm{~m}$ below the surface indicated the enclosing silts were deposited in freshwater. This was a lower elevation than where estuarine sediments were found downstream at Ota A and A4. We inferred that the location of A8 is probably upstream of the head of the paleo-estuary. Therefore HB1 was drilled on the riverbank next to Ota A, and HB2 is located $\sim 100 \mathrm{~m}$ downstream.

An RTK GPS was used to measure the elevation of the drill hole and probe sites; four elevation calibration points were also measured. The elevation measurements have an 
uncertainty of $\pm 0.3 \mathrm{~m}$. HB1 was drilled at an elevation of $11.76 \mathrm{~m}$ above mean SL (AMSL) and reached a depth of $12 \mathrm{~m}$. HB2 was drilled at an elevation of $11.81 \mathrm{~m}$ AMSL and penetrated tp a depth of $10 \mathrm{~m}$. All positions within the cores are henceforth referred to by their elevations in metres above mean SL (m AMSL).

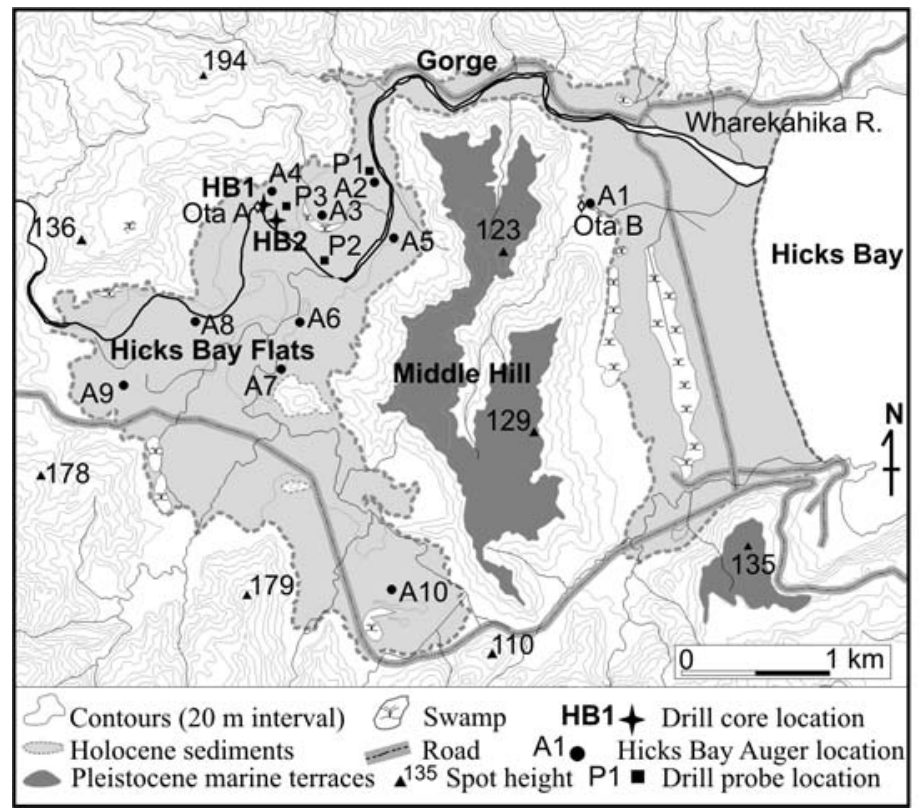

Figure 5.4. Topography of the Hicks Bay area with locations of core, probe and auger profiles.

A hydraulic, truck-mounted drill rig collected sediment cores HB1 and HB2 (Fig. 5.4). Hollow-stem augers with an inside diameter of $85 \mathrm{~mm}$ were used to simultaneously advance the hole and take undisturbed core samples. Core samples were taken in a thin-walled stainless steel liner at intervals of approximately $0.5 \mathrm{~m}$. The cores were extruded into PVC liners. All surfaces of the core were scraped to remove the outer $\sim 5 \mathrm{~mm}$ of sediment to reduce the chance of contamination by sediment smearing inside the core liner. In some sections, particularly near the top, there is some compression of the sediment so that when the core was extruded it had a length $<0.5 \mathrm{~m}$. The method of coring means that the whole sequence was captured, but we leave a blank space on the corelogs where compression occurred. There was no evidence of core disturbance during drilling. Cores were logged in the field by visually assessing sediment type, grainsize, colour and macrofossil content. Sampling 
was undertaken in the laboratory with $20 \mathrm{~mm}$ slices of sediment removed and the inner portion of the slices processed for microfossils and isotopes. All cores are archived in the coolstore at Victoria University of Wellington.

Five new radiocarbon ages have been obtained from Hicks Bay: four from the drill cores and one from an auger hole drilled at the riverbank exposure next to the HB1 drill site. All radiocarbon samples, except HB1/-0.26 m AMSL, were fragments of $A$. stutchburyi; HB1/-0.26 m AMSL was a small twig ( 30 mm long, $5 \mathrm{~mm}$ diameter). The AMS radiocarbon technique was used to date all samples. Well-preserved shells were preferentially selected for dating to minimise the possibility of reworking.

\subsubsection{Micropaleontology study of the Hicks Bay paleo-estuary sequence}

- Foraminifera: Ninety-one samples were selected from HB1 and HB2 for a foraminifera study. Samples were processed using the standard techniques of Hayward et al. (1999a). Where possible, 100 - 200 benthic foraminifera were picked, 100 tests being adequate for environmental assessment using brackish foraminifera (Hayward et al., 1996; 1999b). Only well-preserved foraminifera were identified. Identification was made with reference to Hayward et al. (1999a, 1997), and by personal communication with B. Hayward and A. Sabaa (Geomarine Research, May 2004). Amounts of macro shell fragments and wood or plant matter in each sample were estimated and noted as either absent, scattered or abundant. Planktic foraminifera were picked from each sample and counted; we did not identify them as they yield no information about the paleo-elevation of the sediment. For 21 samples with rare well-preserved benthic foraminifera, we used a floating technique to concentrate the tests. Approximately 5 grams of the $>0.063 \mathrm{~mm}$ sediment fraction was stirred into sodium polytungstate with a specific gravity of 1.6; the fraction that floated contained the concentrated foraminifera.

- Palynology: Nine samples from cores HB1 and HB2 (Table 5.1) were processed for spores and pollen to assess whether palynology could contribute useful information for paleoenvironmental reconstruction at the Hicks Bay sites. Processing followed the standard technique of Moore and Webb (1978) and Moore et al. (1991). Bill McLea (VUW) identified the pollen taxa. 
- Diatoms: Sixteen samples from HB1 and HB2, and five sampled from Ota A, A8 and A10 were analysed for diatom content (Table 5.2). Twelve of these samples were fully processed by a standard method described in Cochran et al. (2006). Diatom species were identified at X1600 magnification with reference to standard floras (eg, Krammer and Lange-Bertalot, 1991-2000; Hartley, 1996; Witkowski et al., 2000). Where possible the species were assessed for their salinity and habitat preferences taken from van Dam et al. (1994) and Round et al. (1990) and the above floras. The remaining nine samples were assessed by placing a wet smear of sediment on the slide and checking for the presence or absence of diatoms.

Table 5.1 Palynological results from Hicks Bay cores, HB1 and HB2.

\begin{tabular}{|c|c|c|c|c|c|c|c|c|c|c|c|c|c|c|c|}
\hline ঠ் & 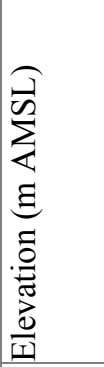 & 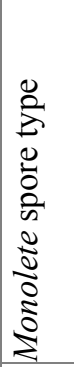 & 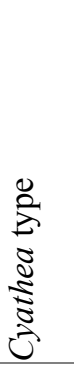 & 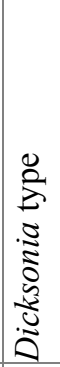 & 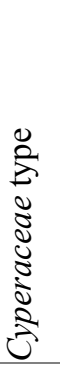 & 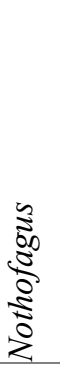 & 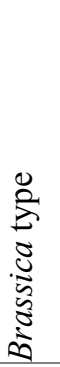 & 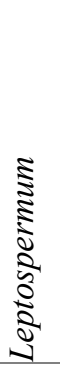 & $\begin{array}{l}\tilde{\Xi} \\
\mathbb{\Xi} \\
\Xi \\
\Omega\end{array}$ & 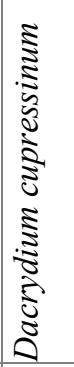 & 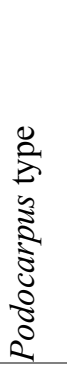 & 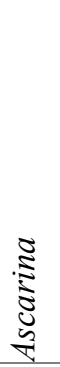 & 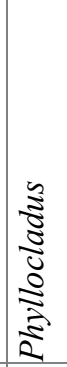 & 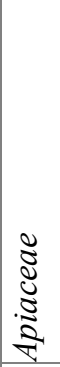 & $\frac{\check{\Xi}}{\tilde{0}}$ \\
\hline HB1 & 9.96 & & 18 & & & & 1 & & & 4 & & & & & \\
\hline HB1 & 9.86 & 18 & 32 & 3 & 5 & 4 & 1 & 2 & 2 & 22 & 13 & 3 & 2 & & \\
\hline HB1 & 9.36 & & 2 & & & & & & & & & & & & \\
\hline HB1 & 8.36 & & 11 & & & & & & & & & & & & \\
\hline HB1 & 7.96 & 5 & 25 & & & & & & & 8 & 2 & & & 2 & 1 \\
\hline HB2 & 8.82 & & & & & & & & & & & & & & \\
\hline HB2 & 6.02 & 1 & 20 & & & & 1 & & & & 1 & & & & \\
\hline HB2 & 5.68 & 5 & 6 & & & & & & & 1 & & & & & \\
\hline HB2 & 1.84 & 10 & 25 & & & 1 & & & & 6 & 4 & & & 1 & \\
\hline
\end{tabular}


Table 5.2 Diatom results from Hicks Bay cores HB1 and HB2.

\begin{tabular}{|c|c|c|c|c|c|}
\hline 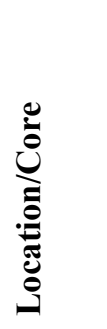 & 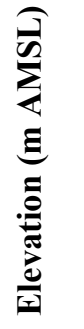 & 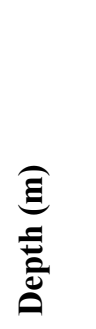 & 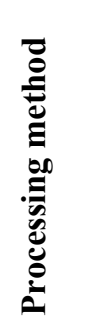 & 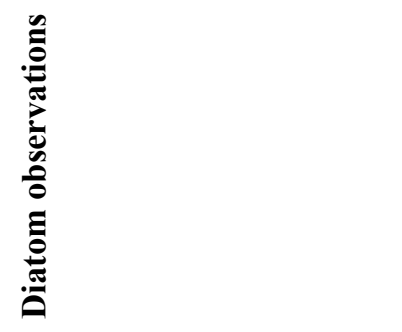 & 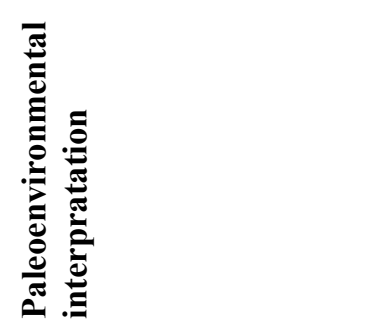 \\
\hline \multicolumn{6}{|c|}{ Hicks Bay } \\
\hline Ota A & 6.3 & & Smear & $\begin{array}{l}\text { Rare brackish marine } \\
\text { diatoms }\end{array}$ & Brackish-marine \\
\hline Ota A & 3.5 & & Smear & Barren & $\begin{array}{l}\text { Possibly overbank silts, or } \\
\text { diatoms not preserved }\end{array}$ \\
\hline HB1 & 9.96 & & Smear & Barren & “ \\
\hline HB1 & 9.36 & & Smear & Barren & “6 \\
\hline HB1 & 8.36 & & Full & $\begin{array}{l}\text { Sparse well-preserved } \\
\text { brackish marine diatoms }\end{array}$ & Brackish-marine \\
\hline HB1 & 7.96 & & Full & “ & Brackish-marine \\
\hline HB1 & 7.46 & & Full & “6 & Brackish-marine \\
\hline HB1 & 5.78 & & Full & “" & Brackish-marine \\
\hline HB1 & 3.62 & & Full & “" & Brackish-marine \\
\hline HB1 & -0.16 & & Full & “" & Brackish-marine \\
\hline HB1 & -0.26 & & Full & “" & Brackish-marine \\
\hline HB2 & 9.2 & & Smear & Barren & $\begin{array}{l}\text { Possibly overbank silts, or } \\
\text { diatoms not preserved }\end{array}$ \\
\hline HB2 & 8.82 & & Smear & Barren & “ \\
\hline HB2 & 8.11 & & Full & $\begin{array}{l}\text { Sparse well-preserved } \\
\text { brackish marine diatoms }\end{array}$ & Brackish-marine \\
\hline HB2 & 6.02 & & Full & “ & Brackish-marine \\
\hline HB2 & 5.66 & & Full & “6 & Brackish-marine \\
\hline HB2 & 4.84 & & Full & “" & Brackish-marine \\
\hline HB2 & 3.76 & & Full & “6 & Brackish-marine \\
\hline A8 & & -4.5 & Smear & $\begin{array}{l}\text { Abundant well-preserved } \\
\text { freshwater diatoms }\end{array}$ & $\begin{array}{l}\text { Freshwater, not overbank } \\
\text { silts }\end{array}$ \\
\hline A8 & & -5.8 & Smear & $\begin{array}{l}\text { Moderate concentrations of } \\
\text { well-preserved freshwater } \\
\text { diatoms }\end{array}$ & $\begin{array}{l}\text { Freshwater, not overbank } \\
\text { silts }\end{array}$ \\
\hline A10 & & -1.35 & Smear & $\begin{array}{l}\text { Fragments of fresh water } \\
\text { diatoms }\end{array}$ & Probably overbank silts \\
\hline \multicolumn{6}{|c|}{ Te Araroa Plain } \\
\hline S3b & & 0.98 & Smear & Barren & Probably overbank silts \\
\hline S3d & & 0.9 & Smear & Barren & Probably overbank silts \\
\hline $\mathrm{S} 2 \mathrm{~b}$ & & 0.67 & Smear & $\begin{array}{l}\text { Abundant freshwater } \\
\text { diatoms }\end{array}$ & $\begin{array}{l}\text { Wetland with some } \\
\text { ponded open water. }\end{array}$ \\
\hline
\end{tabular}




\subsubsection{Stable isotope study of the Hicks Bay paleo-estuary sequence}

Thirty-one samples from HB1 were selected for a stable isotope study to assess whether $\mathrm{C}$ and $\mathrm{N}$ isotopic values and ratios showed sensitivity to paleoenvironmental change in the core and if a more detailed study could assist in detecting small paleosalinity changes. We concluded that the stable isotope data did not add any higher paleoenvironmental resolution beyond that attained from the microfossils. Nevertheless, we present the methodology and detailed results in Appendix 5.3.

\subsection{Results}

\subsubsection{Horoera terrace stratigraphy and geomorphology}

Auger profiles on the Horoera terraces revealed a $\sim 0.2-0.3 \mathrm{~m}$ interval of sandy topsoil overlying orange-grey mottled silt on bedrock. All but four of the holes reached mudstone bedrock (Fig. 5.5A). Mudstone pebbles that could not be drilled through were encountered in Auger holes H1-H2 and H10-H11. Shell fragments were found at the base of H1-H2. Auger holes H18 and H20 contained a $<10 \mathrm{~mm}$ thick layer of finegrained white tephra.

The terrace risers become less pronouced to the west, away from the Mangakino Stream (Fig. 5.5C). Five terraces can be identified in profiles P1-P4, but the only riser that is continuously recognisable along P5 to P9 is that between terraces 3 and 4 (Fig. 5.5C). The elevations of the terraces decrease from east to west (Fig. 5.5D). The average height decrease, measured along the strike of the terrace risers, from east to west over a distance of $\sim 100 \mathrm{~m}$ is $\sim 0.5 \mathrm{~m}$ (Fig. 5.5D). The mudstone bedrock increases in elevation landward at approximately the same gradient as the terrace surfaces and the cover sediments are nearly constant in thickness. Repeated augering at sites bounding the $\sim 2 \mathrm{~m}$ riser between terraces 2 and 3 , however, shows that there is not an equivalent elevation change on the basement surface as there is at the surface (Fig. 5.5B). For example, in $\mathrm{P} 2$ there is a well-defined $2.5 \mathrm{~m}$ riser between terraces 2 and 3 , but the elevation of the mudstone bedrock on either side of the surface riser changes by only $0.5 \mathrm{~m}$ (Fig. 5.5B). 

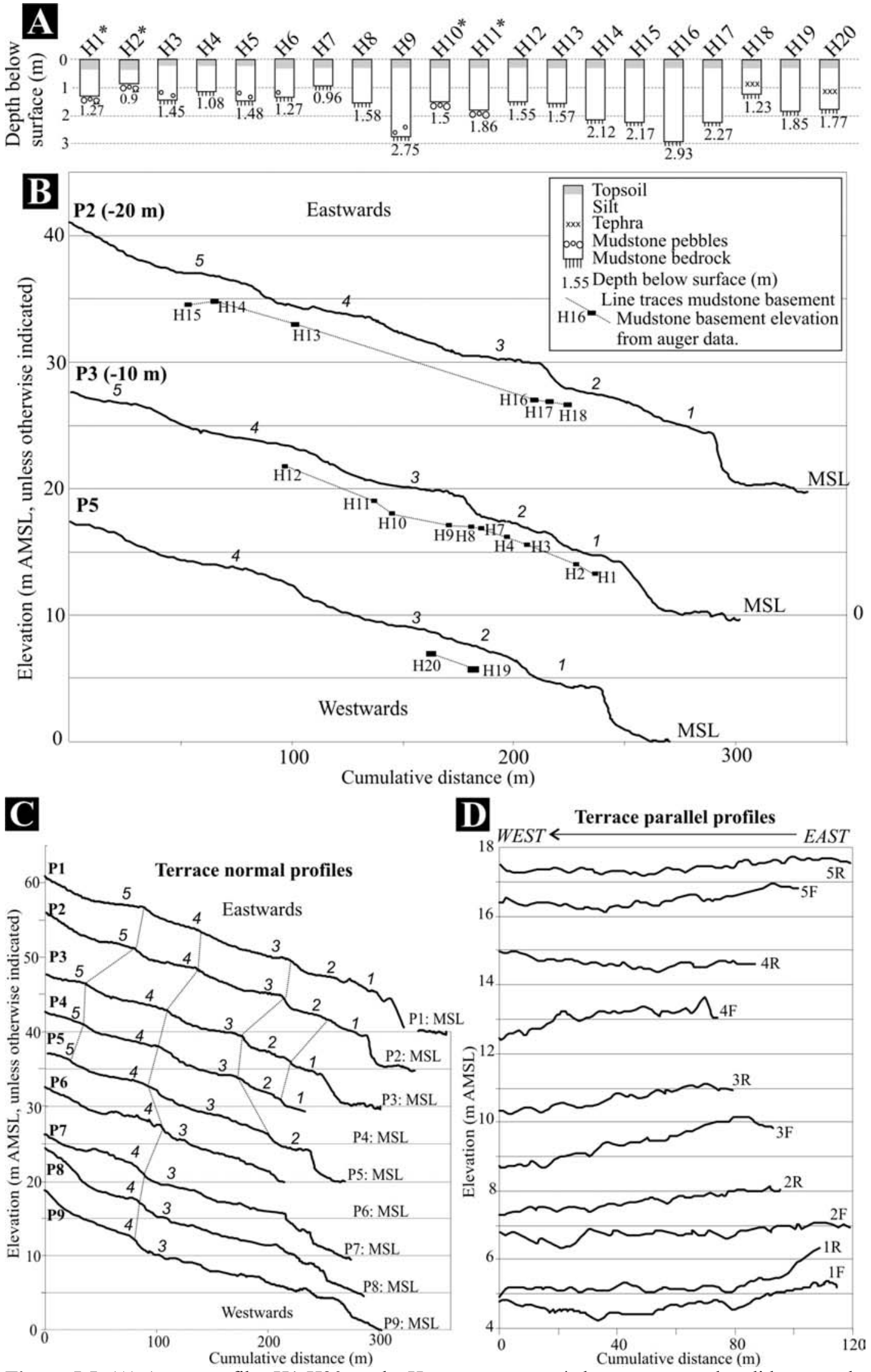

Figure 5.5. (A) Auger profiles $\mathrm{H} 1-\mathrm{H} 20$ on the Horoera terraces, * denotes augers that did not reach the mudstone bedrock. (B) Profiles 2,3 and 5 (crossing perpendicular to the strike of the terraces) with the bedrock elevations projected onto them. Terraces are numbered 1-5. (C) Profiles 1-9 with terraces 1-5 labeled, dotted lines trace the recognisable risers along the strike of the terraces. (D) Elevation profiles following the strike of the terraces along the front $(1 \mathrm{~F}-5 \mathrm{~F})$ and rear $(1 \mathrm{R}-5 \mathrm{R})$ of the terraces. 


\subsubsection{Waipapa terrace stratigraphy and morphology}

Only one auger hole at Waipapa reached mudstone bedrock at a depth of $4.6 \mathrm{~m}$ below the surface (W1a, Fig. 5.6B). All other auger holes were terminated at the water table, therefore the measurements record the minimum thickness of coverbed material on the terraces. All auger holes, except those on Terrace 2, were in homogenous finemedium well-sorted grey sand. Auger holes W2a and W2b were in grey-brown silt.

Terraces 3 and 4 are relatively narrow, with sharp risers and almost horizontal terrace surfaces (although the landward edge of Terrace 3 has been disturbed by the gravel road, Fig. 5.6A, C). Terrace 4 increases $1.5 \mathrm{~m}$ in height along strike towards the south over a distance of $100 \mathrm{~m}$. The riser between terraces 3 and 2 is very steep, increasing in height from $3 \mathrm{~m}$ in the north to $6 \mathrm{~m}$ in the south (Fig. 5.6C). Terrace 2 decreases in definition and elevation towards the south. Terrace 1 is wide with a gentle slope, and the riser between terrace 1 and 2 becomes less pronounced toward the south. A riser between terrace 1 and the modern beach cannot be distinguished either in the field or on the elevation profiles.

The thickness of cover sand or silt on the terraces is generally greater than the height of the adjacent seaward riser. For example, the thickness of sand on Terrace 4 is 4.6 $\mathrm{m}$, and the riser height between Terraces 4 and 3 is $3.5 \mathrm{~m}$. A minimum of $3.7 \mathrm{~m}$ of silt overlies Terrace 3, compared with the Terrace 3 to 2 riser height of $3 \mathrm{~m}$. Terrace 2 has a minimum of $3.5 \mathrm{~m}$ of sand cover, and the adjacent Terrace $2-1$ riser height is $3 \mathrm{~m}$ (Fig. 5.6). 


\section{A}
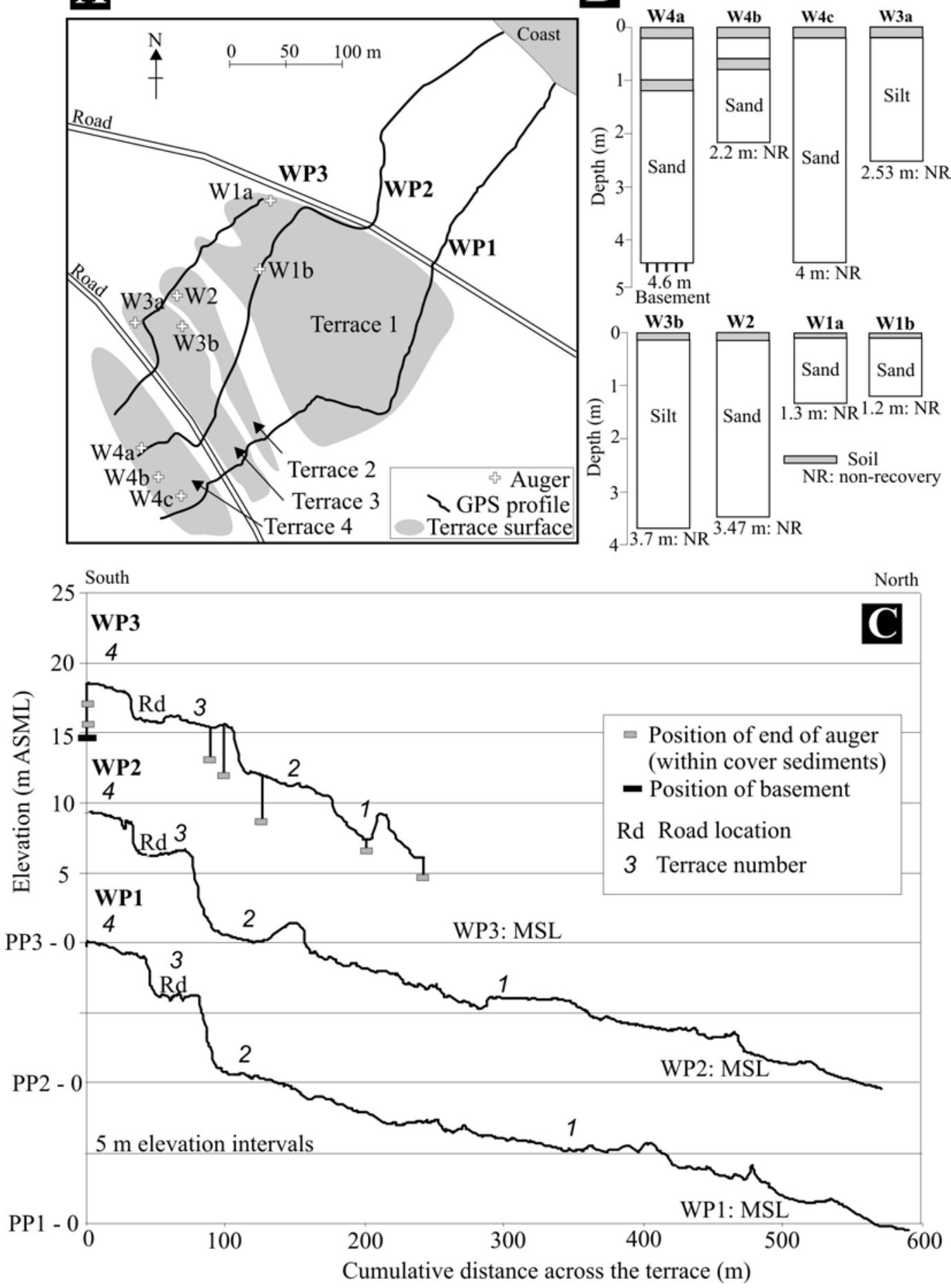

Figure 5.6. (A) Location map of the Waipapa terraces, profiles and auger holes; and approximate boundaries of the terraces are shown. (B) Auger hole stratigraphy. (C) Elevation profiles, WP1-WP3, with the auger hole depths projected to WP3. 


\subsubsection{Evolution of the Te Araroa beach ridges}

\subsubsection{Beach ridge morphology and stratigraphy}

The elevation profiles of TA North and TA South are similar to one another in the section extending from the beach to $\sim 400 \mathrm{~m}$ inland (Fig. 5.7B, C). Both display 6 well-defined beach ridges with heights of $\sim 0.5 \mathrm{~m}$. The average elevation of the ridges increases over the $400 \mathrm{~m}$ by $0.8 \mathrm{~m}$ in the TA South profile, and $1.2 \mathrm{~m}$ in the TA North profile (Fig. 5.7B, C). The modern storm ridge of TA North is $\sim 0.9 \mathrm{~m}$ lower than the equivalent storm ridge in TA South. We observed a gradual northward decrease of modern storm ridge elevation along the TA shoreline (Fig. 5.7D). The decrease is attributed to the locations of the dominant sediment source, the Awatere River, at the south end of the bay.

The two profiles are dissimilar from $\sim 400 \mathrm{~m}$ inland to the back of the coastal plain (to the edge of the colluvial fans at $2000 \mathrm{~m}$ inland). On the inland coastal plain, north of the river, there are numerous swampy areas and several sand dunes (Fig. 5.3). The beach ridges on the TA North profile are indistinct at $>750 \mathrm{~m}$ inland and steps of 1-2 $\mathrm{m}$ in the profile are evident around the road and sand dune (Fig. 5.7B). The TA South profile is preferred for geomorphic interpretation because it appears to have fewer swamps, suggesting less possible fluvial modifications to the beach ridges, and it has no sand dunes (Fig. 5.7C).

The TA South profile shows beach ridges up to $2100 \mathrm{~m}$ inland, although the ridge definition becomes poorer with increasing distance inland (Fig. 5.7C). Four swamps that can be seen on aerial photos can be distinguished on the elevation profiles (S1-S4, Fig. 5.7C). We identify five zones of beach ridges (Z1-Z5, Fig. 5.7C), these are the same zones as Ota et al. (1992) identified. However, we divide their Zone II into two separate zones (Z1 and Z2) and we do not identify anything equivalent to the Ota et al. (1992) Zone I, which they only locate on the northern side of the river. 
A TA Beach Ridge sequence auger profiles
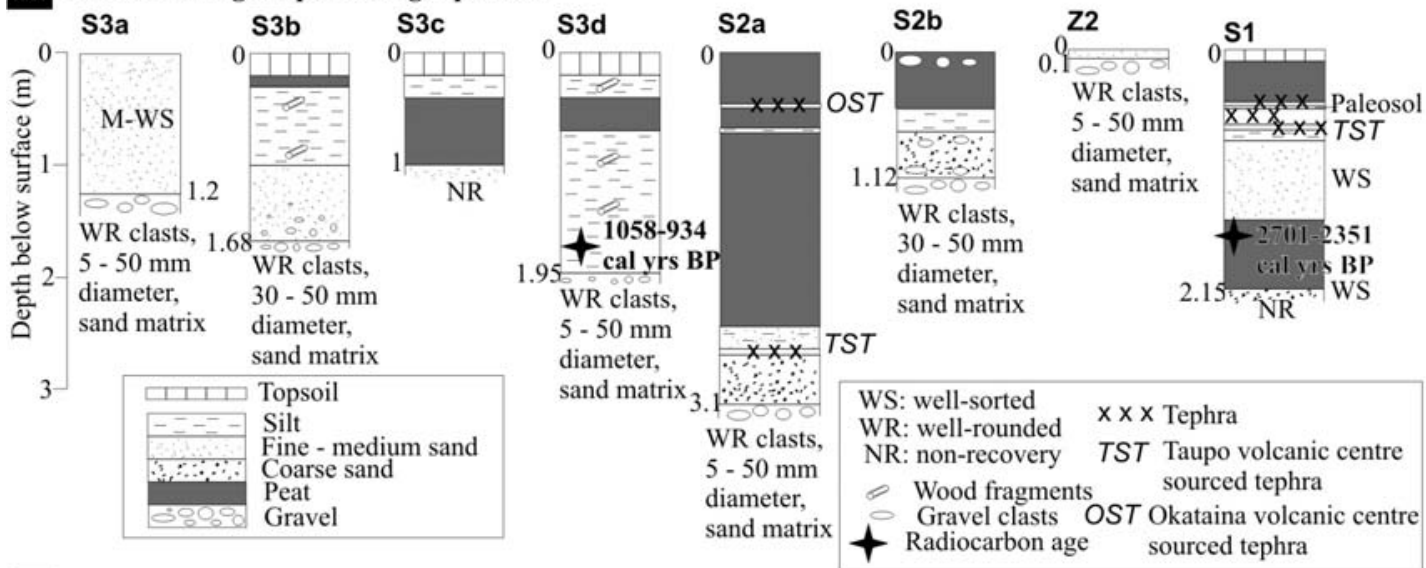

B TA North Profile

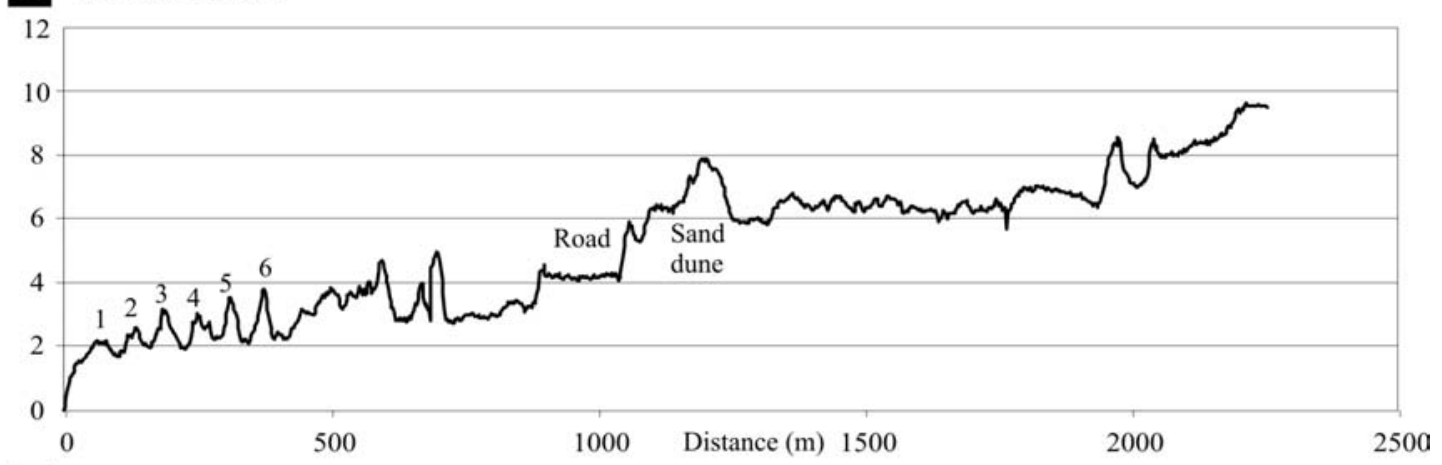

C TA South Profile

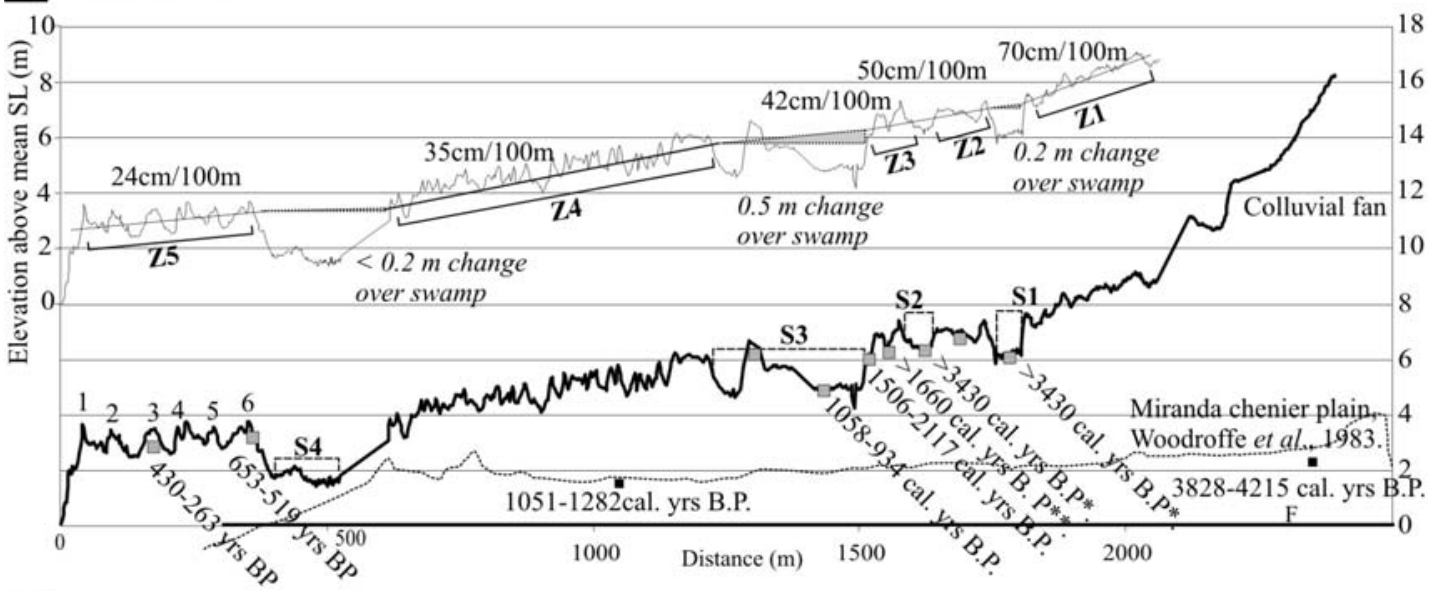

D TA Modern storm beach profiles

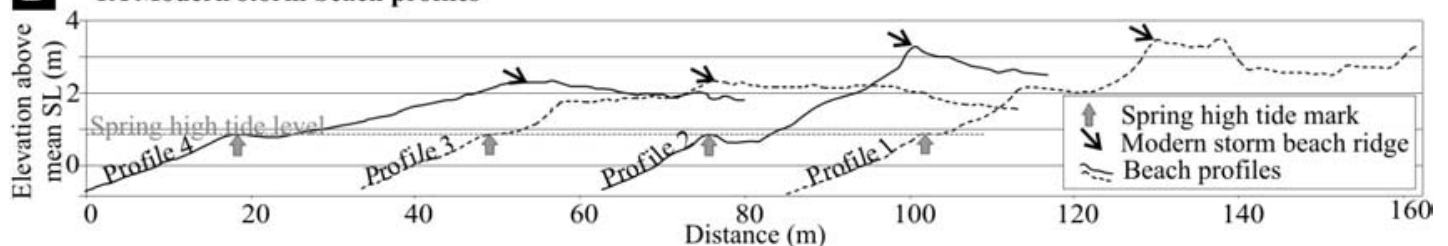

Figure 5.7. Te Araroa Beach Ridges (A) Auger stratigraphy (locations shown on Fig. 5.3). (B) TA North elevation profile. (C) TA South elevation profile. Top profile shows the names of the beach ridge zones (Z1 - Z5) and the gradient of each zone and the amount of elevation change across the swamps. The middle profile shows the names of each swamp zone (S1 - S4), and radiocarbon ages from this study and Garrick (1979), Ota et al. (1992) and this study. (D) Profiles from the intertidal wave zone to the crest of the modern storm beach ridge at four locations along the Te Araroa beach (Profiles 1 - 4, south to north respectively, see locations Fig. 5.3). Main sediment source is to the south. * Waimihia tephra, 3375 - 3485 cal. yrs B.P. (Froggatt and Lowe, 1990). ** Sea-rafted Taupo pumice identified by Ota et al., 1992, eruption age of 1720 - 1600 cal. yrs B.P. (Froggatt and Lowe, 1990). 
Lines projected through the midpoint of all the beach ridges of each zone of TA South show that the average beach ridge height increases landward. The gradients range from $0.24 \mathrm{~m} / 100 \mathrm{~m}$ to $0.7 \mathrm{~m} / 100 \mathrm{~m}$ (Fig. 5.7). Twenty-seven beach ridges have been identified on the TA South profile; the average elevation difference between the successive ridge crests is $0.17 \mathrm{~m}$.

The beach ridges are composed of well-rounded greywacke gravel clasts that are generally $10-50 \mathrm{~mm}$ in diameter. There is very little sand cover on the southern coastal plain; auger Z2, 1700m inland has only $0.1 \mathrm{~m}$ of cover sand (Fig. 5.7A). The intervening swamps are infilled with silt and peat (S3b-d, S2a-b, and S1, Fig. 5.7A). Three silt samples were analysed for diatoms (Table 5.2). The silt sample from S2b contained abundant, freshwater diatoms indicative of a freshwater, ponded wetland. The other two samples, from S3b and S3d were barren of diatoms; these are interpreted as overbank silts.

\subsubsection{Age control of the Te Araroa beach ridges}

Age control comes from previously reported radiocarbon ages and observations of tephra occurrences (Garrick, 1979; Ota et al., 1992), new radiocarbon ages presented here, and our tephra analyses. Two new radiocarbon samples were collected from the base of auger holes in swamps S1 and S3 (Table 5.3). Wood fragments within silt at the base of S3d yielded an age of 1058-934 cal. yrs B.P. (Table 5.3). A wood sample collected by Ota et al. (1992) from the landward side of this swamp gave a radiocarbon age of 1506-2117 cal. yrs B.P. Our radiocarbon age from the base of S3 is consistent with the previously collected data and with the absence of tephra in the swamp; it dates the start of infilling of the swamp and therefore is a minimum age for the beach ridges immediately landward in Zone 3. Ota et al. (1992) also observed searafted Taupo pumice on beach ridges within Zone 3, implying the beach ridges were formed prior to 1720 - 1600 cal. yrs B.P. (Froggatt and Lowe, 1990).

Peat from the base of S1 yielded a radiocarbon age of 2701-2351 cal. yrs B.P. (Table 5.3). The tephra lying approximately $1 \mathrm{~m}$ above the radiocarbon sample has a Taupo volcanic centre glass geochemical signature (Appendix 5.4). This tephra was $\sim 50 \mathrm{~mm}$ thick and composed of coarse lapilli. It is most likely to be the Waimihia tephra, 3375-3485 cal. yrs B.P (Froggatt and Lowe, 1990), which is typically the only coarse 
grained Taupo volcanic centre tephra found in the East Cape region. The alternative is the Taupo tephra (1720 - 1600 cal. yrs B.P., Froggatt and Lowe, 1990). The Taupo tephra is consistent with our radiocarbon age, however in this region the Taupo tephra is usually absent or very fine grained. We infer, based on the grain size characteristics, that the tephra in swamp S1 is the Waimihia. Either it has been redeposited or the radiocarbon age represents younger material (either younger tree roots growing down or contamination during sample collection).

Swamp S2 contains a tephra near the base of the sediment sequence at $-2.6 \mathrm{~m}$ depth (auger S2a, Fig. 5.7A). This is a Taupo volcanic centre sourced tephra (Appendix 5.4) and has a coarse lapilli texture. We infer it to be the Waimihia tephra, therefore giving a minimum age of 3375-3485 cal. yrs B.P. for the beach ridges in Zone 2. A shallower tephra in this swamp, at $-0.5 \mathrm{~m}$ depth, has Okataina volcanic centre glass geochemistry. We do not know which tephra it is; it may be reworked. Two shells samples collected by Garrick (1979) from the beach ridges within Zone 5 yielded ages of 420-263 and 653-519 cal. yrs B.P (Fig. 5.7C).

\subsubsection{Hicks Bay paleo-estuary}

\subsubsection{Hicks Bay Flats stratigraphy}

Sections from the Hicks Bay Flats (Appendix 5.1) show that at least the uppermost 4 $\mathrm{m}$ of sedimentary infill is a mixture of silt and gravel. The silt is generally massive, with rare wood fragments and some sandy layers. The gravel occurs in layers up to $0.2 \mathrm{~m}$ thick; clasts are typically pebble-sized $(10-40 \mathrm{~mm}$ diameter $)$ and supported in a matrix of silt or sand. Similarities in grain size and sorting between these sediments and modern river sediments imply that they are fluvial deposits: overbank (silt) and flood (gravel) deposits. A diatom sample from silts in A10 contained fragments of freshwater diatoms. The fragmented nature of the specimens supports an overbank fluvial depositional environment (Table 5.2).

Two exposures on terrace riser sections contained silt and gravel (A6 and A7, Fig. 5.1, Appendix 5.1). Previously mapped as the inland extension of the highest marine terrace (Ota et al., 1992) the sections indicate these terraces on the HB flats are probably fluvial. A peat layer occurs in three auger holes at depths of $-2.2-4.5 \mathrm{~m}$ 
below the surface. The peat layers are correlated as they are all directly overlain by a $50 \mathrm{~mm}$ thick tephra layer (Whakatane tephra, Ota et al., 1992).

\subsubsection{Cores $H B 1$ and $H B 2$}

The sedimentary record preserved in drill cores HB1 and HB2 was subjected to a high-resolution paleoenvironmental study. From the base of both cores $(-0.24 \mathrm{~m}$ AMSL in HB1 and $1.9 \mathrm{~m}$ AMSL in HB2) up to 3.3 and $4.1 \mathrm{~m}$ AMSL in HB1 and HB2 respectively, they are dominated by blue-grey silt with occasional $A$. stutchburyi shells and wood fragments. A. stutchburyi is a shallow-burrowing bivalve common at mid- to low-tide elevations in estuaries and sheltered sand flats (Marsden, 2004; Marsden and Pilkington, 1995; Morton and Miller, 1968). Many of the A. stutchburyi fragments retrieved in the cores may have formerly been whole shells that were broken during drilling or core extrusion. Observations of the adjacent riverbank section (Ota A) from $6.8 \mathrm{~m}-12 \mathrm{~m}$ AMSL are that all the A. stutchburyi shells within the section are articulated whole bivalves preserved in growth position.

A unit of medium-coarse grey sand bounded by sharp contacts is at $3.3-4.7 \mathrm{~m}$ AMSL in HB1 and 4.1 - 4.7 m AMSL in HB2 (Fig. 5.8). This sandy unit contains wood fragments, coarse shell grit and large A. stutchburyi fragments. Above the sand unit, to $7.2 \mathrm{~m}$ AMSL (HB1) and 5.2 m AMSL (HB2), is blue-grey silt with occasional A. stutchburyi shells and wood fragments. From $7.2 \mathrm{~m}$ AMSL (HB1) and $5.2 \mathrm{~m}$ AMSL (HB2) up to $8.3 \mathrm{~m}$ AMSL, both cores are composed of massive silt with occasional wood chips. At $\sim 8.3 \mathrm{~m}$ in both cores is a $0.2 \mathrm{~m}$ thick silty peat, which is overlain by a fine-grained $10 \mathrm{~mm}$ thick tephra. From the tephra up to $\sim 11.6 \mathrm{~m} \mathrm{AMSL}$ ( $0.5 \mathrm{~m}$ below the surface) is massive orange-brown silt. At $\sim 11.6 \mathrm{~m}$ AMSL there is a $50 \mathrm{~mm}$-thick coarse-grained orange tephra, which is directly overlain by topsoil. 


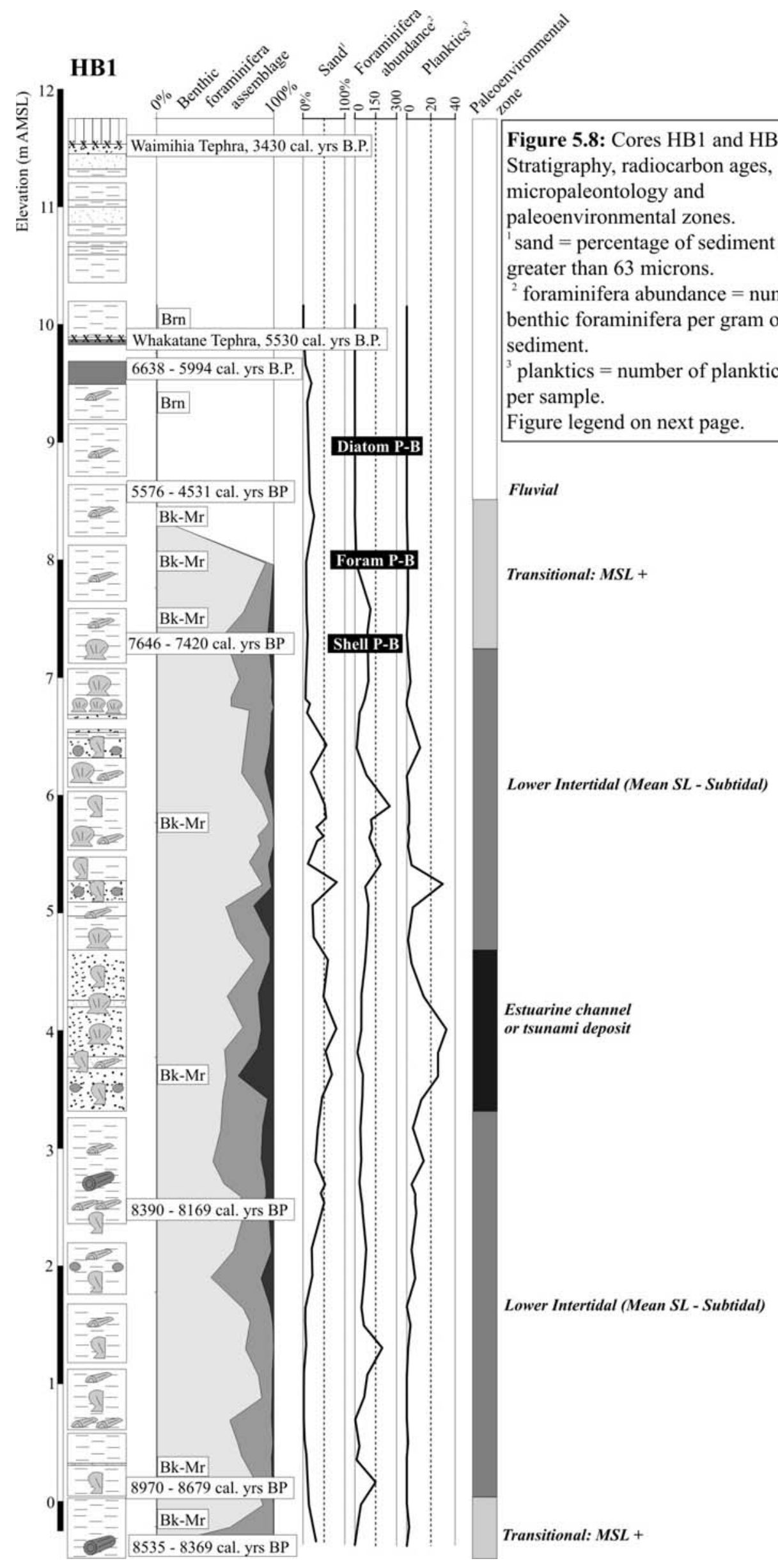




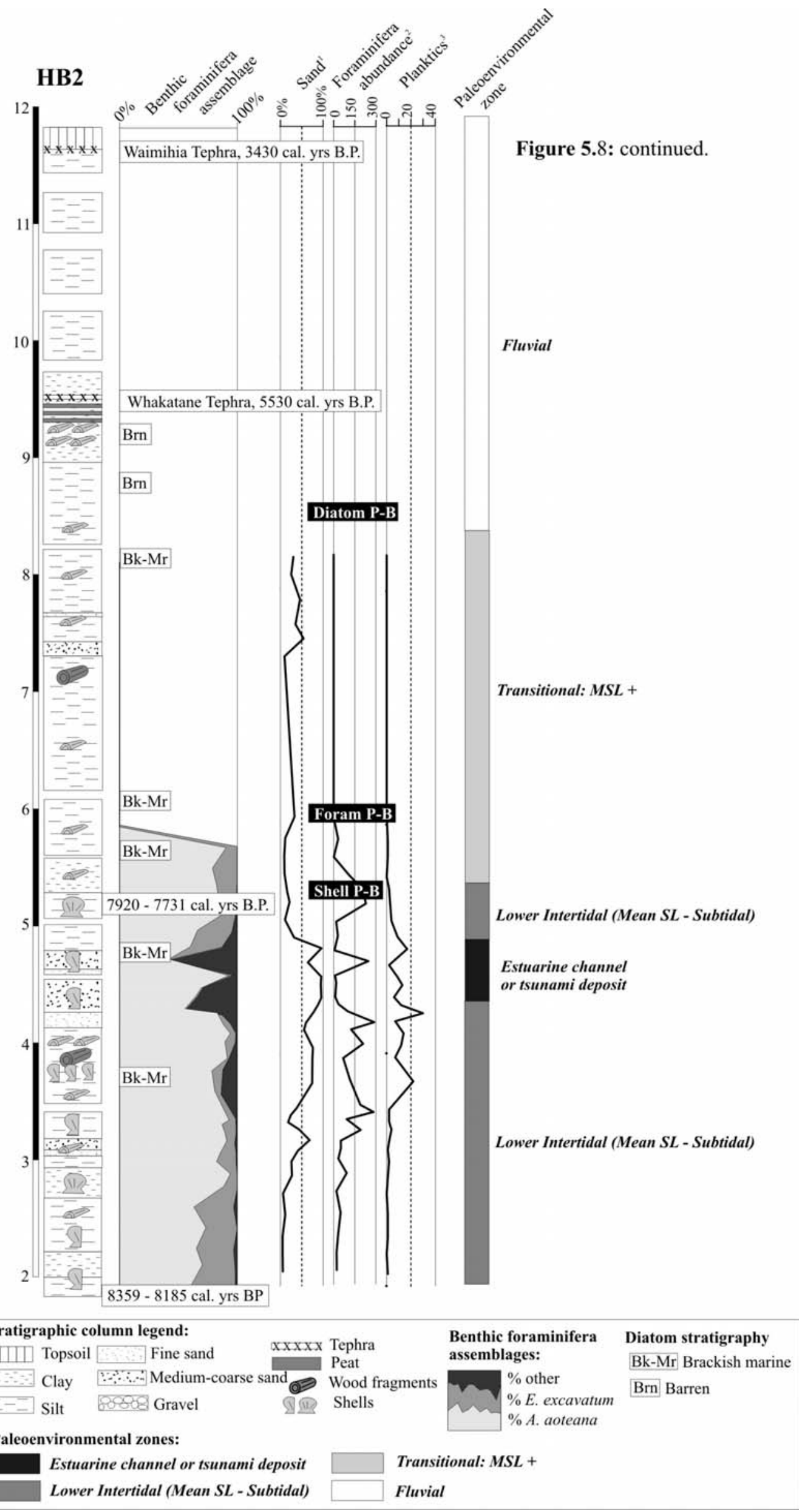


Fifty-one samples from HB1 were studied for foraminifera. The samples were selected between 10.54 and $-0.38 \mathrm{~m}$ AMSL, with an average sampling spacing of 1 per $0.21 \mathrm{~m}$ in this interval. Seven samples from above $7.96 \mathrm{~m}$ AMSL were barren of foraminifera, as was one sample below $-0.22 \mathrm{~m}$ AMSL. Forty samples were selected from HB2 between $8.12 \mathrm{~m}$ and $1.94 \mathrm{~m}$ AMSL, an average sampling spacing of one per $0.15 \mathrm{~m}$. Eight samples from above $5.68 \mathrm{~m}$ AMSL were barren. In both cores there is a transition from samples containing forams (forams present) to samples barren of forams. We call this the foram P-B (present-barren) transition. Foraminifera census data are presented in Appendix 5.5.

All samples from HB1 and HB2 containing foraminifera are dominated by Ammonia parkinsonia $f$. aoteana with secondary proportions of Elphidium excavatum $f$. excavatum, and minor amounts of "Other" benthic species (Fig. 5.8, GNS Data Repository). Common Other species include Haynesina depressula, Elphidium charlottense, Notorotalia species, and Bulimina species (Appendix 5.5). A. aoteana ranges from 46 to $95 \%$ of the assemblage in $\mathrm{HB} 1$ and $\mathrm{HB} 2$, with an average of $72 \%$ in HB1 and $79 \%$ in HB2. E. excavatum has a range of $1-43 \%$ and averages $23 \%$ in HB1 and 13\% in HB2. Others range from $1-57 \%$, with an average of $5 \%$ in HB1 and $8 \%$ in $\mathrm{HB} 2$.

A. aoteana is a common species in brackish to very slightly brackish environments. It is a dominant species in the intertidal and subtidal zones of the seaward parts of estuaries and mid to inner areas of enclosed harbours (Hayward et al., 1999a). E. excavatum is restricted to brackish environments; it usually lives at intertidal depths in the inner-mid zones of estuaries and in enclosed tidal inlets (Hayward et al., 1999a). $H$. depressula is an intertidal, brackish-marine species, and E. charlottense is a slightly more open-water species. E. charlottense occurs most commonly at intertidalsubtidal depths on sheltered sandy beaches (Hayward et al., 1999a). All the samples analysed for foraminifera assemblages are likely to be from the lower intertidal zone of a sheltered, slightly brackish, estuary, which is consistent with the presence of the estuarine $A$. stutchburyi shells in the cores.

Statistical correlations show a strong positive relationship between \% Sand ( $>63 \mu \mathrm{m})$ and the \% Other foraminifera (Appendix 5.6). This relationship is seen in Fig. 5.8, where there are peaks in \% Other at $\sim 4-5 \mathrm{~m}$ AMSL in HB1 and HB2; these peaks 
correspond with the medium-coarse sand layer described above. There is a strong peak in planktics in HB1 within the coarse sand layer. A corresponding increase in planktics also occurs in HB2, but it is not as distinctive as in HB1 (Fig. 5.8).

The change in foraminifera assemblage at the Foram P-B transition is sudden; there is no gradual decrease in foraminifera abundance approaching this transition (Fig. 5.8). This transition occurs at a higher elevation than the Shell P-B transition in both cores (0.75 m higher in HB1 and $0.5 \mathrm{~m}$ higher in HB2). No visual change in sedimentology is evident at the Shell or Foram P-B transitions. We interpret these transitions to be a gradual environmental change to a less saline or higher elevation setting. It was around this transition that we concentrated sampling for pollen, diatoms, and stable isotopes.

Palynology samples were selected from the HB1 and HB2 cores on both sides of the foraminifera P-B transition. One sample (HB1/9.86 m AMSL) was taken from a peat unit, and one sample (HB2/1.84 m AMSL) was taken from a unit with abundant $A$. stutchburyi fragments. All samples are dominated by Cyathea-type pollen with minor amounts of Podocarpus-type and Dacrydium cupressinum pollen (Table 5.1). The pollen indicates the regional forest was a lowland podocarp forest, but they yield no information about the environment in the immediate vicinity of the sample location. Pollen from plants such as rushes, sedges, saltwort and mangroves can be indicative of the local environment and have been used elsewhere as corroborative evidence of coastal waterbody and sea level change (Cochran et al., 2006, Goff et al., 2000, Shennan et al., 1994). We conclude that palynology is not suitable for paleoenvironmental interpretation of the $\mathrm{HB}$ cores, possibly because the core locations are too far from the estuary margins where saltmarsh plants were growing.

The highest diatom samples (HB1/9.96, 9.36 and HB2/9.2 and 8.82 m AMSL) are barren. A barren result from a smear slide means either that the diatoms have a very low abundance or they are not present. All samples from the Hicks Bay cores below HB1/8.36 m AMSL and HB2/8.11 m AMSL contain sparse well-preserved brackish marine diatom assemblages. Abundances were not high enough to warrant full census counts. The diatom assemblages do not change significantly above and below the foram P-B transition (Table 5.2). There are two reasons why this is could be so: (1) the foraminifera may not be present in the upper parts of the cores, above the P-B 
transition, because of dissolution or extremely low abundances, despite the paleoenvironment remaining the same across the barren-intertidal transition as the diatoms indicate, or (2) there was a small change in salinity across the foram P-B transition that inhibited intertidal foraminifera survival, even though the environment remained suitable for diatoms.

SEM images of the foraminifera do not provide any strong evidence for poor preservation closer to the foram P-B transition thus suggesting chemical dissolution or mechanical breakage was not been responsible for this transition (Appendix 5.7). This implies the foram P-B transition and the transition from intertidal-shells-present to barren-of-shells marks a real paleoenvironmental change.

(A) $\% \delta^{13} \mathrm{C}$

(B) $\mathrm{C} / \mathrm{N}$ ratio

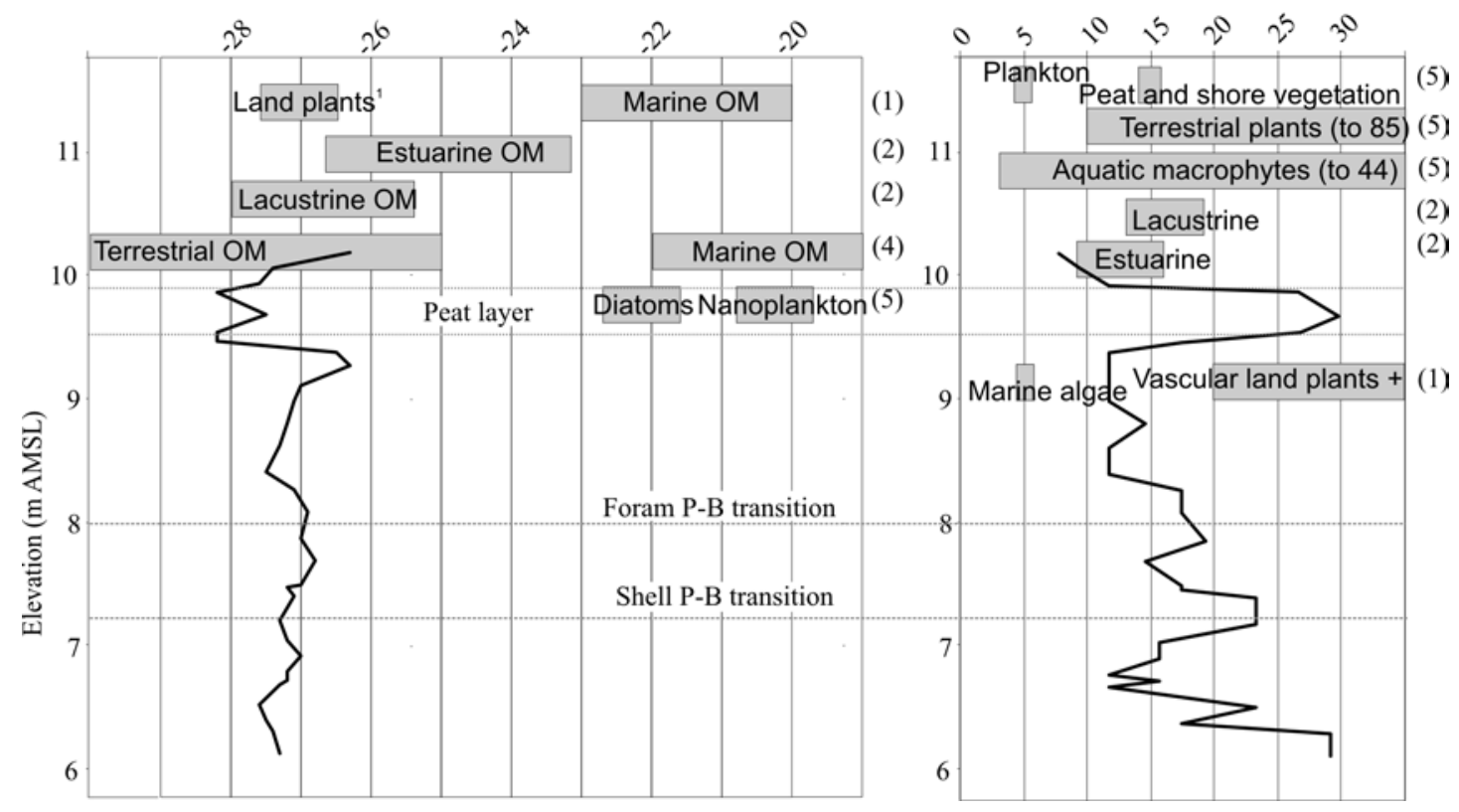

Figure 5.9. Stable isotope measurements from the upper $6 \mathrm{~m}$ of $\mathrm{HB} 1$ with major stratigraphic boundaries marked. (A) $\% \delta^{13} \mathrm{C}$ and (B) $\mathrm{C} / \mathrm{N}$ ratio of $\mathrm{HB} 1$ with superimposed value ranges for terrestrial, estuarine and marine organic matter from several publications. (1) Meyers (1994), (2) Thornton and McManus (1994), (3) Fontugne and Jouanneau (1987), (4) Gearing et al. (1984), (5) Muller and Voss (1999). ${ }^{1}$ Land plants with a C4 pathway. ${ }^{\S} \mathrm{C}: \mathrm{N}$ ratio is calculated by an atomic ratio where $\mathrm{C}: \mathrm{N}=\left(\% \mathrm{C}^{14}\right) /\left(\% \mathrm{~N}^{12}\right)$. 
Stable isotope analyses span the peat layer ( $\sim 9.76 \mathrm{~m}$ AMSL), the foram P-B transition at $7.96 \mathrm{~m} \mathrm{AMSL}$ and the first A. stutchburyi shells at 7.26 m AMSL (Fig. 5.8, Fig. 5.9). $\delta^{13} \mathrm{C}$ and the $\mathrm{C} / \mathrm{N}$ ratio have are useful parameters for distinguishing organic matter provenance (Meyers, 1994; Muller and Mathesius, 1999; Thornton and McManus, 1994). In $\mathrm{HB} 1 \delta^{13} \mathrm{C}$ and $\mathrm{C} / \mathrm{N}$ isotopic values of samples from the estuarine paleoenvironment do not show values within the range of typical marine organic matter (Fig. 5.9A, B), perhaps because HB was located in a sheltered intertidal inlet and received a high terrestrial sediment input. Further discussion of the results is presented in Appendix 5.3. We conclude that for the Hicks Bay cores this technique is not a viable tool for distinguishing freshwater and marine paleoenvironments.

\subsubsection{Age control for Cores HB1 and HB2}

Four new radiocarbon ages were obtained from the cores, two each from HB1 and HB2 (Table 5.3). One radiocarbon age was obtained from an auger hole at Ota A, and three ages previously reported by Ota et al. (1992) at Ota A have been recalibrated. These four ages from Ota A are directly correlated to their equivalent elevations in HB1 as this core was collected $<5 \mathrm{~m}$ away from the riverbank exposure. The Waimihia tephra (3485 - 3375 cal. yrs B.P.) is at $11.6 \mathrm{~m}$ AMSL in both cores and Whakatane tephra (5590 - 5465 cal. yrs B.P) is at $9.8 \mathrm{~m}$ AMSL in HB1 and $9.5 \mathrm{~m}$ AMSL in HB2, thus providing additional age control.

The radiocarbon dates occur in chronological order, decreasing upwards with increasing elevation, with two exceptions (Fig. 5.8, Table 5.3). A wood age (55764531 cal. yrs B.P) obtained by Ota et al. (1992) at Ota A/8.6 $\mathrm{m}$ is younger than the radiocarbon age from the peat $1.2 \mathrm{~m}$ above $(6638-5994 \mathrm{cal}$. yrs B.P.) The wood age partly overlaps with and is younger than the Whakatane tephra whereas the peat age is older than the tephra. Due to the overlap with the higher Whakatane tephra, we suggest that the wood age (Ota $\mathrm{A} / 8.6 \mathrm{~m})$ is unreliable and could be a tree root younger than its surrounding sediment. The wood age at HB1/-0.26 m (8535 - 8369 cal. yrs B.P.) is younger than the shell age $0.42 \mathrm{~m}$ above (HB1/0.16 m: $8970-8679$ cal. yrs B.P.). It overlaps by 21 years with the $2-\sigma$ age range of the shell $2.76 \mathrm{~m}$ higher at HB1/2.5 m: 8390 - 8169 cal. yrs B.P.). Both shell samples are likely to have been in life position but it is possible that the wood fragment was from a tree root. For the purposes of sedimentation rate calculations we prefer to use the shell ages because the 
samples probably had equivalent living depths relative to mean SL, whereas the paleoenvironmental position of the wood fragment is less certain.

Table 5.3 Radiocarbon ages from the Hicks Bay Flats and the Te Araroa beach ridge sequence.

\begin{tabular}{|c|c|c|c|c|c|c|}
\hline 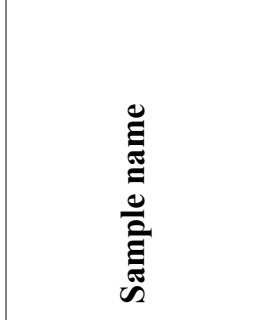 & 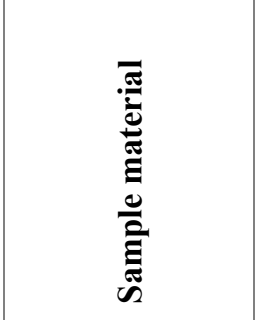 & 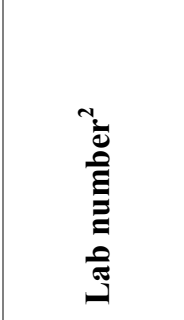 & 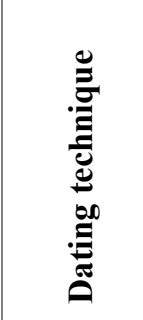 & $\underbrace{\partial}_{0}$ & 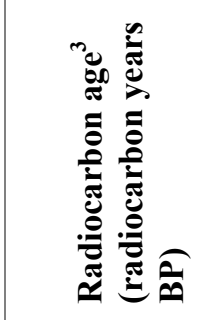 & 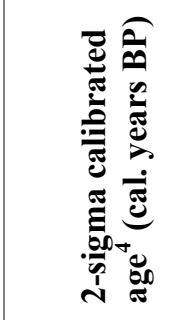 \\
\hline $\begin{array}{l}\mathrm{S} 3 \mathrm{~d} / 1.6-1.8 \mathrm{~m} \\
\text { depth }\end{array}$ & $\begin{array}{l}\text { Detrital organic } \\
\text { matter within silt }\end{array}$ & NZA 22393 & AMS & -26.85 & $1142 \pm 30$ & $1058-934$ \\
\hline $\mathrm{S} 1 / 1.59 \mathrm{~m}$ depth & Peat & NZA 22394 & AMS & -27.49 & $2485 \pm 30$ & 2701- 2351 \\
\hline $\begin{array}{l}\mathrm{HB} 1 / 0.16 \mathrm{~m} \\
\text { AMSL }\end{array}$ & A. stutchburyi & NZA 21087 & AMS & -1.04 & $8276 \pm 35$ & $8970-8679$ \\
\hline $\begin{array}{l}\mathrm{HB} 1 /-0.26 \mathrm{~m} \\
\text { AMSL }\end{array}$ & Wood & NZA 20754 & AMS & -28.66 & $7678+/-30$ & $8535-8369$ \\
\hline $\begin{array}{l}\mathrm{HB} 2 / 1.9 \mathrm{~m} \\
\text { AMSL }\end{array}$ & A. stutchburyi & NZA 22544 & AMS & 1.26 & $7812 \pm 35$ & $8359-8185$ \\
\hline $\begin{array}{l}\mathrm{HB} 2 / 5.2 \mathrm{~m} \\
\text { AMSL }\end{array}$ & A. stutchburyi & NZA 20910 & AMS & -0.48 & $7360+/-35$ & $7920-7731$ \\
\hline $\begin{array}{l}\text { Ota A } 2.5 \mathrm{~m} \\
\text { AMSL }^{1}\end{array}$ & A. stutchburyi & NZA 17348 & AMS & -0.06 & $7824+/-55$ & $8390-8169$ \\
\hline $\begin{array}{l}\text { Ota A } 7.2 \mathrm{~m} \\
\text { AMSL }^{1}\end{array}$ & A. stutchburyi & NZA 5461 & Standard & & $7046+/-66$ & $7646-7420$ \\
\hline $\begin{array}{l}\text { Ota A } 8.6 \mathrm{~m} \\
\text { AMSL }^{1}\end{array}$ & Wood & GaK 10474 & Standard & & $4470+/-180$ & $5576-4531$ \\
\hline $\begin{array}{l}\text { Ota A } 9.8 \mathrm{~m} \\
\text { AMSL }^{1}\end{array}$ & Peat & GaK 10473 & Standard & & $5590+/-140$ & $6638-5994$ \\
\hline
\end{tabular}

${ }^{1}$ Previously published in Ota et al. (1992).

${ }^{2}$ NZA: Rafter Radiocarbon Laboratory, GaK: Gakushuin University.

${ }^{3}$ Conventional radiocarbon age before present (1950 AD) after Stuiver and Polach, (1977).

${ }^{4}$ Marine dates calibrated using Hughen et al. (2004); terrestrial dates calibrated using McCormac et al. (2004).

\subsubsection{Hicks Bay core paleoenvironmental zones}

Cores HB1 and HB2 are the primary source of information on the early Holocene paleoenvironments of Hicks Bay. The best paleoenvironmental indicators obtained 
from the cores are their sedimentology and their foraminifera, shell, and diatom contents. We combine the information from these four indicators to define four paleoenvironmental zones: (1) estuarine channel (or tsunami), (2) lower intertidal estuarine, (3) fluvial, and (4) transitional (Fig. 5.8). We outline the distribution and characteristics of each zone and give the reasons for our paleoenvironmental interpretation below.

\section{Estuarine channel (or tsunami):}

This zone occurs in HB1 at 3.3 - 4.7 m AMSL and in HB2 at 4.1 - 4.7 m AMSL (Fig. 5.8). The unit comprises medium-coarse sand, fragmented shells, shell grit, and includes relatively high proportions of "Other" foraminifera and planktic species. The coarser sand and mechanical breakage of the shells indicate deposition in a higher energy environment than the surrounding silts. The high proportion of Other foraminifera were probably transported from the open bay, for example, several of the species, such as Zealfloris parri and Trifarina angulosa, live on open coasts. The planktic foraminifera also indicate transport from the open coast, as planktic species do not inhabit brackish environments. We interpret this unit as an estuarine channel deposit because of the inferred high energy (tidal currents) and increased open coast hydraulic exchange, though no sedimentary bedforms can be distinguished from the cores. This layer also displays several characteristics of a tsunami deposit. For example, it is an anomalously coarse sand bed within silt, the lower contact is sharp and possibly erosional, and it contains deeper water marine foraminifera and is relatively shell-rich ( $c f$. Goff et al., 2001, 2004; Nelson et al., 1996; Shennan et al., 1996). However, we have no data on the spatial extent of the sand layer to test the tsunami theory, for example tsunami deposits typically fine landward (Goff et al., 2001), and the narrow marine inlet of the HB gorge may restrict the entry of a tsunami into the HB Flats.

\section{Lower intertidal:}

This zone occurs in HB1 at $0-3.3 \mathrm{~m}$ and $4.7-7.2 \mathrm{~m}$ AMSL, and in HB2 at $1.9-4.2$ $\mathrm{m}$ and 4.7 - 5.2 $\mathrm{m}$ AMSL (Fig. 5.8). Sediments of this zone are homogenous bluegrey silts with scattered A. stutchburyi shells that were probably in-situ prior to drilling disturbance, and occasional small wood fragments. Foraminifera assemblages 
are dominated by A. aoteana and E. excavatum and diatom samples are characteristic of brackish marine environments. We interpret the environment to be lower intertidal estuarine because this is the preferred living environment of the foraminifera and shells. The fine sediment is consistent with deposition in the central part of an estuary where currents generated by both tidal and fluvial energy are minimal (Dalrymple et al., 1992).

\section{Fluvial:}

The fluvial zone occurs cores above 8.5 m AMSL in HB1 and 8.3 m AMSL in HB2 (Fig. 5.8). The sediments are dominated by orange-brown silt, this zone has scattered wood fragments, and both cores contain a $0.1-0.3 \mathrm{~m}$ thick peat, and two tephra layers. This zone is distinguished by a lack of marine indicators: no shells, foraminifera and marine diatoms. The peat layer indicates a fresh water environment existed at least some of the time. The absence of chemical corrosion of the foraminifera indicates that groundwater dissolution was not responsible for the absence of calcareous test higher in the core, thus decreased salinity is the most likely reason for their absence. The silts do not contain any sedimentary structures in the cores, but decimetre-thick horizontal layers with gradational contacts can be seen in the adjacent riverbank outcrop. The sediments are compatible with an overbank fluvial silt depositional environment.

\section{Transitional:}

The transitional zone occurs in HB1 between $-0.5-0 \mathrm{~m}$ and $7.2-8.5 \mathrm{~m}$ AMSL. It is thicker in HB2, where it occurs between 5.2 and 8.3 m AMSL (Fig. 5.8). Grey-brown silt dominates this zone; there are no shells or foraminifera. Diatoms indicate a brackish marine environment. We interpret this zone to be transitional between intertidal and fluvial environments. Salinity levels probably decreased below the threshold for foraminifera and shells, but diatoms persisted. Alternatively, the diatoms, which are more readily transported, could have been redeposited in this environment. We would expect to see a gradual change in the foraminifera with the change from intertidal to freshwater conditions, but this was not seen. Possibly the foraminifera were not preserved or were not detected during the picking. Alternatively the environmental change was abrupt. 


\subsubsection{Paleoenvironmental evolution of the Hicks Bay Flats}

The early Holocene evolution of the Hicks Bay Flats and its associated sedimentary infill is illustrated in Fig. 5.10. We divide the evolution into eight stages based upon the paleoenvironmental zones defined in cores HB1 and HB2.

1. Pre-9,000 cal. yrs B.P.: Fluvial Valley

No paleoenvironmental data are available to directly document the infill of the HB Flats prior to $\sim 9,000$ cal. yrs B.P but we infer it was a fluvial valley (Fig. 5.10.1). The small section of transitional sediments at the base of core HB1 (0 - -0.3 m AMSL) implies a change from non-marine to estuarine conditions that started prior to $\sim 8,900$ cal yrs B.P. The Wharekahika River would have previously incised and extended across the continental shelf to meet the glacial-age base level. Prior to $\sim 9,000$ cal. yrs B.P., the sea was transgressing across the continental shelf under postglacial eustatic SL rise. The probe profile put down next to HB1 shows a large increase in resistance at -0.5 to $-2 \mathrm{~m}$ in HB1, directly below the base of the HB1 core (Appendix 5.2). This increase in resistance may reflect the presence of fluvial gravels deposited during the glacial lowstand.

2. $\sim 8,900$ cal. yrs B.P.: Initial marine incursion.

The A. stutchburyi shell at $-0.16 \mathrm{~m}$ yields an age of $8970-8679$ cal. yrs B.P and dates the first incursion of marine-influenced sediments into the HB Flats (Fig. 5.10.2). Intertidal foraminifera, brackish-marine diatoms and estuarine shells start to appear at this time, marking the transgression of the sea into the HB Flats due to eustatic SL rise. There is no physical change in the sediments, except for the appearance of shells.

3. $8,900-8,000$ cal. yrs B.P.: Continued marine transgression.

Sediments of this time period in HB1 and HB2 record deposition at lower intertidal elevations. The estuarine environment was probably transgressing landward and deepening within the HB Flats (Fig. 5.10.3). Age constraint comes from $A$. stutchburyi shells in HB1 and HB2 (Fig. 5.8). 
5.10.1. Pre 8970 cal. yrs B.P.

Fluvial valley at glacial lowstand.

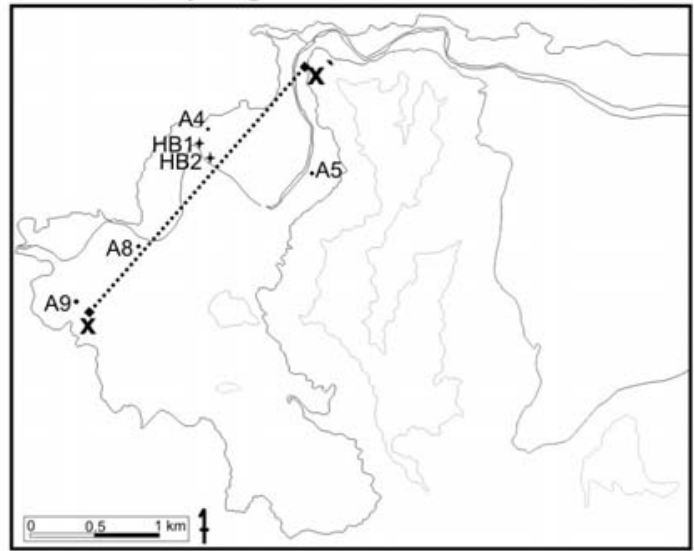

${ }_{12} \mathbf{x}$

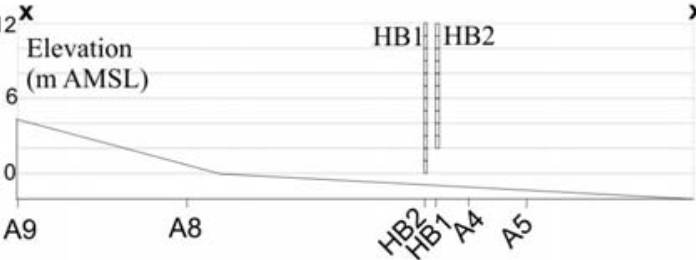

5.10.3. 8900 - 8000 cal. yrs B.P.:

Continuing marine transgression in HB Flats.

Estuary deepening to MSL-Subtidal.

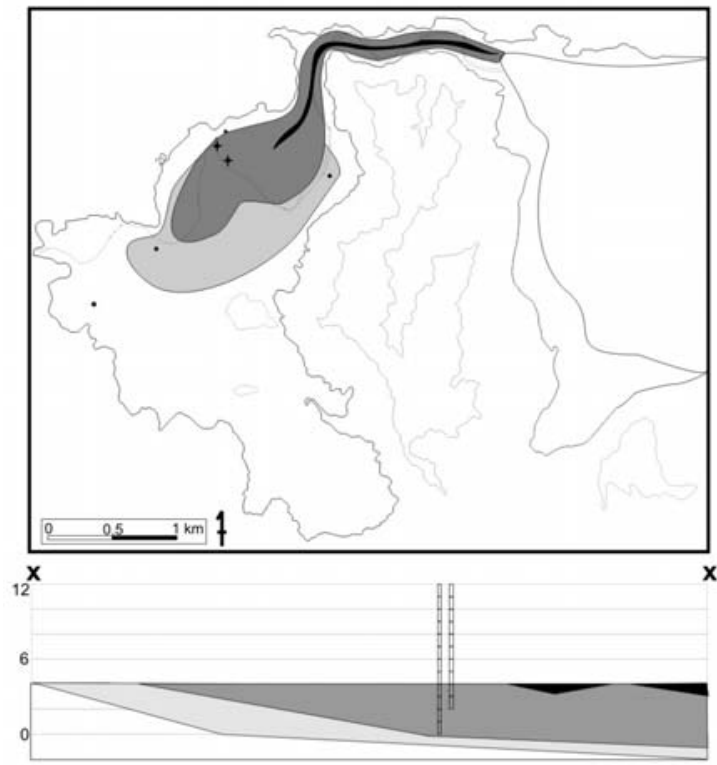

5.10.2. 8900 cal. yrs B.P.

Beginning of marine transgression into HB Flats.
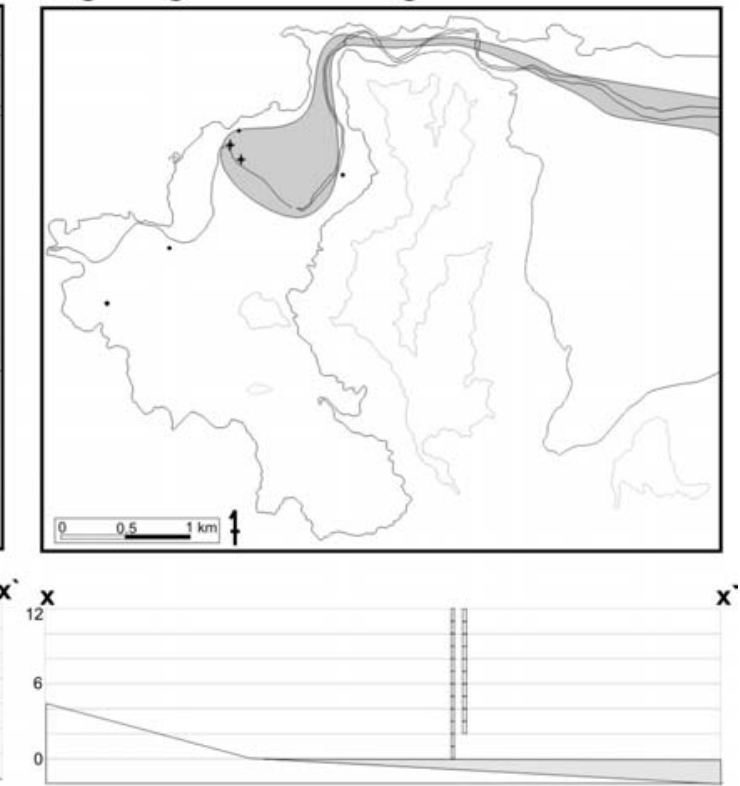

5.10.4. 8000 cal. yrs B.P.:

Probable maximum extent and depth of $\mathrm{HB}$ paleo-estuary, subtidal channel expansion or tsunami inundation.

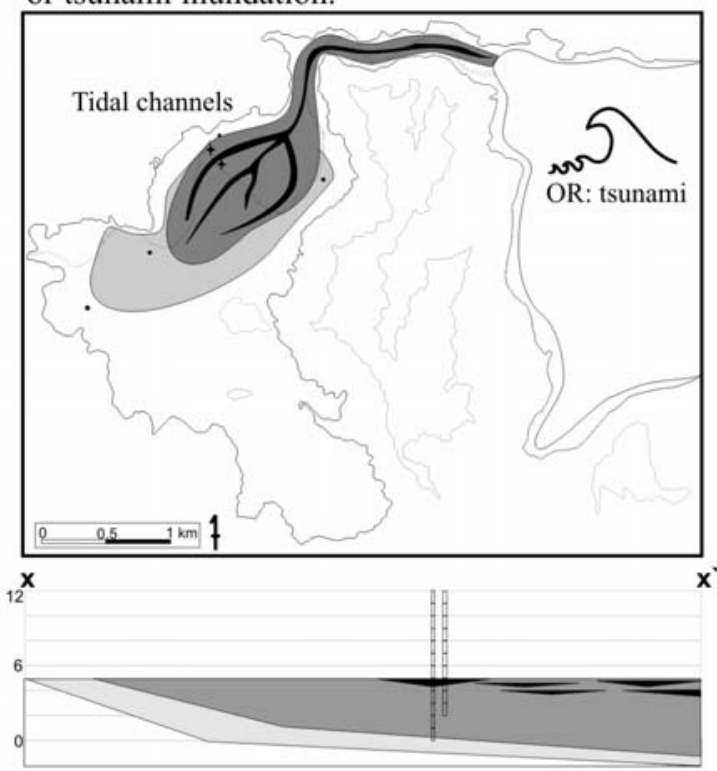

Estuarine channel

Lower intertidal (mean SL - subtidal)

Transitional: MSL +

Fluvial

Figure 5.10 (1 - 4). Paleogeographic evolution of the Hicks Bay Flats in plan and stratigraphic profile view. 
5.10.5. 8,000 - 7,000 cal. yrs B.P.

Complete infilling of the HB paleo-estuary,

SL stabilisation.

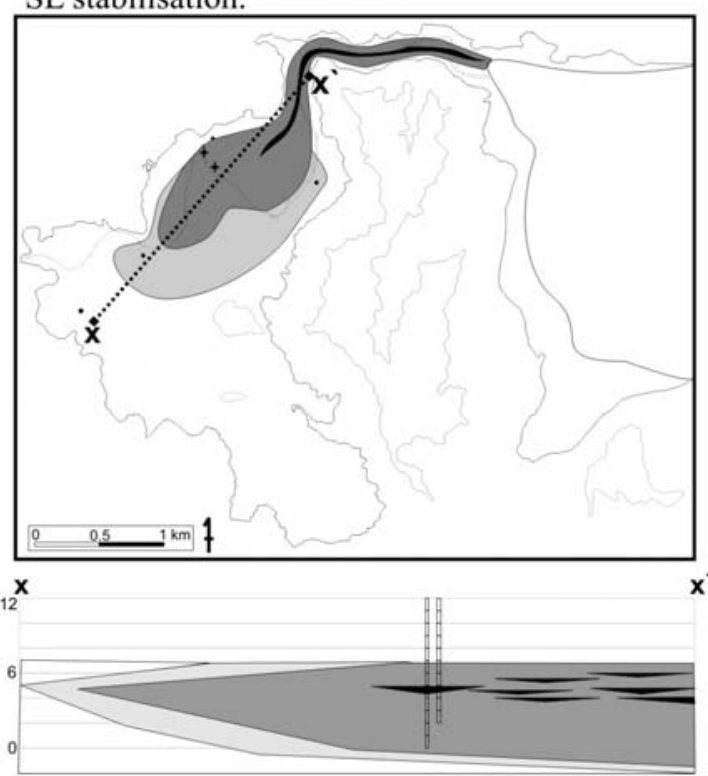

5.10.7. 6000 cal. yrs B.P.:

Fluvial deposition. Possible blocking of river mouth causing poor drainage on the HB flats and widespread development of peat.

Marine regression continues.
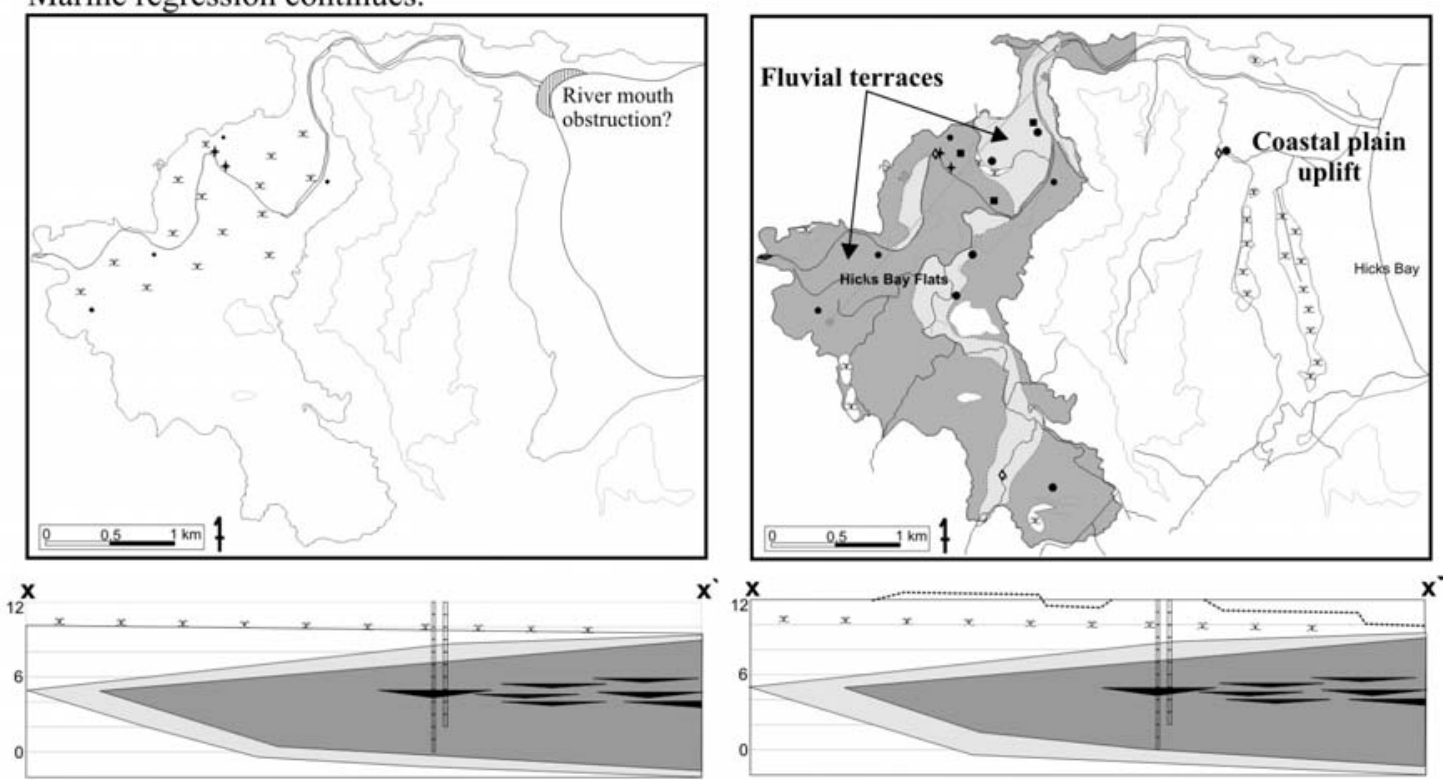

Estuarine channel

Lower intertidal (mean SL - subtidal)

Transitional: MSL +

Fluvial
Marine regression. Uplift of HB flats, incision of meandering streams and river. Fluvial terraces cut.

Figure 5.10 (5-8). Paleogeographic evolution of the Hicks Bay Flats in plan and stratigraphic profile view (continued). 
4. $\sim 8,000$ cal. yrs B.P.: Maximum marine transgression (or tsunami).

At approximately $\sim 8,000$ cal. yrs B.P. subtidal estuarine channels reached cores HB1 and HB2 (Fig. 5.10.4). This zone contains the only significant grain size change in the cores. Coarse sand was deposited under relatively strong tidal currents. The subtidal paleoenvironment represents the deepest the HB Flats paleo-estuary reached, and by inference the marine environment probably reached its maximum landward extent at this time (Fig. 5.10.4). Bounding ages of 8390-8169 cal. yrs B.P. at HB1/2.5 m AMSL and 7920-7731 cal. yrs B.P. at HB2/5.2 m AMSL (Fig. 5.8) provide age constraints. As previously discussed, the coarse sand layer may be a tsunami deposit. Future work could establish if this is more likely by determining the extent of the sand layer on the HB Flats and correlating the deposit at nearby coastal locations. To date no tsunami deposits of $\sim 8 \mathrm{ka}$ age have been identified in the region, but few studies have been undertaken. If the sand is a tsunami deposit, it is not associated with a change in paleo-elevation of the HB Flats, as the environment remains lower intertidal after deposition of the sand.

5. $\sim 8,000-7,000$ cal. yrs B.P.: Infilling of estuary and marine regression.

During this period the depositional environment changed from subtidal to lower intertidal and then to a transitional estuarine-fluvial environment. This sequence indicates progressive infilling of the paleo-estuary and a consequential shallowing of the depositional elevation that represents a marine regression (Fig. 5.10.5).

6. 7,000 cal. yrs B.P.: Complete marine withdrawal from Hicks Bay Flats.

The transition to a fluvial environment in HB1 and HB2 signifies the complete withdrawal of any marine influence from the HB Flats (Fig. 5.10.6). Age control on this transition is poor. The highest shell sample (at HB1/7.2 m AMSL) yielded an age of 7646-7420 cal. yrs B.P. Intertidal foraminifera and brackish-marine diatoms persist $\sim 1 \mathrm{~m}$ higher than the dated shell therefore the marine regression was complete after 7646-7420 cal. yrs B.P, but before the deposition of the peat, which has a radiocarbon age of 6638-5994 cal. yrs B.P. An estimate of $\sim 7 \mathrm{ka}$ for marine withdrawal from the HB Flats is consistent with the bounding radiocarbon ages and with stabilisation of eustatic SL in the New Zealand region (Gibb, 1986). 
7. $\sim 7,000-6,000$ cal. yrs B.P.: Fluvial deposition and peat development.

Fluvial sedimentation followed marine withdrawal from the HB Flats and SL stabilisation (Fig. 5.10.7). In both HB1 and HB2 $1 \mathrm{~m}$ of fluvial silt was deposited during the time between marine withdrawal and peat deposition. The peat layer occurs at five sites in the HB Flats, indicating it is not a localised deposit. It may record a period when the entire HB Flats was either (a) starved of sediment, thus organic matter was concentrated; or (b) the Wharekahika River mouth was blocked, causing poor drainage of the HB Flats and development of widespread swamps.

8. $\sim 6,000$ cal. yrs B.P. - Modern: Uplift of Hicks Bay Flats, fluvial incision and marine regression.

Following deposition of the Whakatane tephra $(\sim 5530$ cal. yrs B.P), fluvial sedimentation continued on the HB Flats (Fig. 5.10.8). Fluvial silts, probably overbank flood deposits, were deposited at HB1, HB2 and A4. The silts are conformably overlain by the Waimihia tephra ( 3430 cal. yrs B.P.), which lies below the topsoil. The auger cores at A8 and A9 have homogeneous fluvial silt between the peat and the topsoil, but they do not contain the Waimihia tephra. At all other locations on the HB Flats (A1-A3, A5-A7 and A10), thin gravel layers occur at depths of $0.6-2.5 \mathrm{~m}$ below the surface. As discussed above, the gravls are probably fluvial cut-and-fill deposits. None of these auger cores or sections contained the Waimihia tephra, possibly implying that deposition of these sequences occurred after $\sim 3430$ cal. yrs B.P.

Since SL stabilisation, the Hicks Bay Flats area has been uplifted, as illustrated by the modern elevation of the shells in HB1 and HB2. This uplift has been accompanied by incision of the sedimentary fill by the Wharekahika River and the formation of river terraces. Evidence for tectonic uplift includes the sloping, $\sim 1 \mathrm{~km}$ wide Holocene coastal plain at Hicks Bay and a series of uplifted beach ridges (Ota et al., 1992). Uplift rates, based on radiocarbon ages on five shell samples in HB1, HB2 and the riverbank exposure next to HB1, range from $1.2-2 \mathrm{~mm} \mathrm{yr}^{-1}$, with an average of 1.7 $\mathrm{mm} \mathrm{yr}^{-1}$ (Table 5.4). We base the uplift rate only on radiocarbon ages from $A$. stutchburyi shells, because there is more certainty that these have not been redeposited, compared to the wood samples. A. stutchburyi have a restricted living 
depth range of mid- to low-tide elevations (the spring tidal range at $\mathrm{HB}$ is $1.7 \mathrm{~m}$, therefore mid-low tide elevations are $0--0.85 \mathrm{~m}$ AMSL). In calculating uplift rates we use a living depth of $-0.2 \mathrm{~m}$ for the $A$. stutchburyi, which accounts for the shells living at mid-tide and burrowing down to $0.2 \mathrm{~m}$ depth below the surface.

Table 5.4 Tectonic uplift rate calculations from Hicks Bay. To calculate these uplift rates we estimate the amount of vertical motion, relative to mean SL, that each radiocarbon dated sample has been through since its deposition. We use a living depth of $-0.2 \mathrm{~m}$ above mean MSL for the living depth of the $A$. stutchburyi (this assumes the shells are in-situ). The Gibb (1986) New Zealand eustatic SL curve is used to the position of eustatic SL at the time of sample deposition.

\begin{tabular}{|c|c|c|c|c|c|c|c|}
\hline 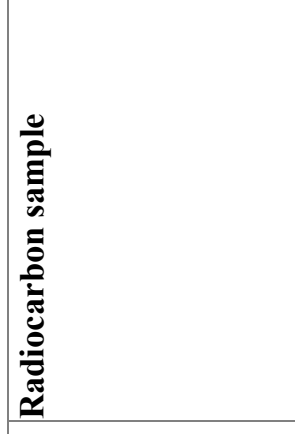 & 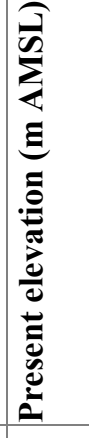 & 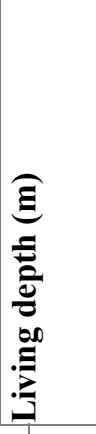 & 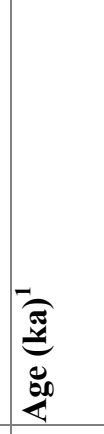 & 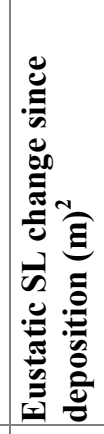 & 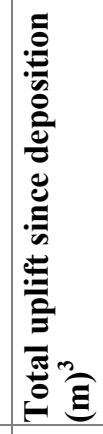 & 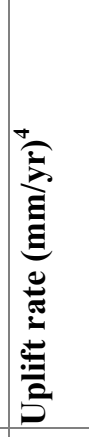 & 疍 \\
\hline Ota A/7.2 m & 7.2 & -0.2 & 7.533 & 2.1 & 9.1 & 1.21 & $0.93-1.5$ \\
\hline Ota A/2.5 m & 2.5 & -0.2 & 8.28 & 14.1 & 16.4 & 1.98 & $1.72-2.25$ \\
\hline $\mathrm{HB} 1 / 0.16 \mathrm{~m}$ AMSL & 0.16 & -0.2 & 8.825 & 17.5 & 17.46 & 1.98 & $1.72-2.24$ \\
\hline $\mathrm{HB} 2 / 5.2 \mathrm{~m}$ AMSL & 5.2 & -0.2 & 7.826 & 6 & 11 & 1.41 & $1.14-1.69$ \\
\hline HB2/1.9 m AMSL & 1.9 & -0.2 & 8.272 & 14.1 & 15.8 & 1.91 & $1.65-2.18$ \\
\hline
\end{tabular}

\footnotetext{
${ }^{1}$ Mid point of the 2-sigma calibrated radiocarbon age (see Table 5.3).

${ }^{2}$ Estimated from the Gibb, 1986, eustatic SL curve using the midpoint of the 2-sigma calibrated age and projecting this to the middle of the eustatic SL points (see Fig. 12). We estimate an uncertainty of \pm $2 \mathrm{~m}$ for estimates of the past eustatic SL using this Holocene SL curve.

${ }^{3}$ Total uplift $=($ present elevation + eustatic SL change $)-$ living depth

${ }^{4}$ Uplift rate $=$ total uplift/age

${ }^{5}$ Uncertainty $=[($ total uplift $+2 \mathrm{~m}) /$ youngest radiocarbon age $]-[($ total uplift $-2 \mathrm{~m}) /$ oldest radiocarbon age)].
} 


\subsection{Discussion: Uplift mechanisms of the northeastern Raukumara Peninsula}

\subsubsection{Horoera terrace formation}

The terraces at Horoera were described as marine terraces by Ota et al. (1992), who inferred that their flat surfaces and parallelism with the coast implied wave-cut platforms. Based on our data, we interpret the Horoera terraces to be non-marine in origin. Except for the base of Terrace 1, we found no marine deposits beneath any of the terraces. Terraces 2-5 have coverbeds composed exclusively of silt. Marine terraces are typically covered in marine deposits such as well-sorted sands, gravels, shells and/or shell hash. The modern beach at Horoera displays a mixture of exposed mudstone platform with abundant rock-boring shells and coarse shelly sands. We infer that the silt cover on the Horoera terraces is not of marine origin because (a) it has no modern analogue on the Horoera coastline, (b) it is poorly sorted and finegrained, not characteristic of wave deposited sediments, and (c) there are no shells within the silt.

We interpret Horoera terrace flight to be an alluvial fan that has been modified by flooding on the Mangakino Stream (Fig. 5.2) to cut the apparent terrace morphology. The terrace risers appear to be superficial features that do not involve bedrock incision. Across the most distinctive terrace riser, that between terraces $3-2$, there is no accompanying step in the bedrock below it. The silt coverbeds on the terraces may be overbank flood deposits. The observation that the terraces increase in elevation eastward toward the current position of the Mangakino Stream is consistent with an alluvial fan origin, but not a marine one.

Auger holes $\mathrm{H} 1$ and $\mathrm{H} 2$, and exposures along the beach and in the stream show that Terrace 1 has $\sim 0.5 \mathrm{~m}$ of mudstone gravel with rare whole shells on the bedrock strath. It is from this terrace that a shell radiocarbon age of $<250$ yrs B.P. was obtained by Ota et al. (1992). A marine environment may have covered the bedrock there at some time, though the bedrock strath was not necessarily wave cut. Moreover, the shells there could be anthropogenic deposits. The Raukumara Peninsula region was settled by Maori 800 - 500 yrs B.P (McGlone et al., 1994). Numerous pas (fortified places) 
along the coastline attest to Maori occupation of the Horoera area, thus the shells on Terrace 1 could be midden material.

This re-evaluation of the Horoera terraces strongly suggests that they are not of marine origin and therefore cannot be used to calculate an uplift rate. They do not provide evidence for coseismic uplift in this part of the Raukumara Peninsula, as was inferred by Ota et al. (1992).

\subsubsection{Waipapa terrace formation}

The Waipapa terraces are probably depositional landforms associated with sand dunes that have been shaped into a terrace-like forms by either anthropogenic alterations (the site is close to a Maori pa, these are commonly terraced as part of the fortifications or for cultivation) or fluvial processes. Like those at Horoera, the terraces at the Waipapa stream mouth are unlikely to be of marine origin because (1) their geomorphology is not characteristic of marine terraces, (2) the bedrock strath, where it was recorded at W4a (Fig. 5.6), is not overlain by beach deposits, and (3) the surface topography of the terraces is not strongly controlled by the underlying bedrock morphology. We elaborate on each of these points in turn:

(1) The surface of Terrace 4 decreases in height towards the north, whereas the surface of terrace 3 increases in height towards the north (Fig. 5.6). Some along-strike tilt on terraces could be anticipated if uplift of the terraces was controlled by a nearby fault, causing differential uplift, or if there was preferential sediment deposition at one end of a terrace due to longshore drift or prevailing winds. However, opposing directions of tilt on different terraces is difficult to account for. The very sharp risers between terraces 4,3 and 2 are also uncharacteristic of marine terraces, as the steps are almost vertical. If these were produced by coseismic uplift this morphology implies no adjustments, or scarp degradation in the dynamic foreshore area following the uplift.

(2) Auger W4a reached the bedrock platform. The coverbed sediments are entirely medium-fine grained, well-sorted sand, most likely dune sands. By contrast, the modern beach face consists of medium-coarse sand with scattered shells. If the 
bedrock platform underlying Terrace 4 was wave-cut then, as explained above, coarse sands and shells would be expected on this strath surface.

(3) On terraces 4, 3 and 2 the thickness of cover sediments is greater than the terrace riser height. This implies that as each successively lower terrace was being formed, the terrace strath cut into the cover deposits of the older terrace. The height difference between the terraces should not be used as an estimate of the amount of coseismic uplift due to the uncertainty of where the terrace straths are located. The relatively large thickness of terrace coverbeds and the unconsolidated nature of the sands suggest the terrace surface morphology is not controlled by the basement morphology.

As at Horoera, this re-evaluation of the Waipapa terraces indicates that they are not of marine origin and, as such, do not provide evidence of coseismic coastal uplift. Nonetheless, a radiocarbon age on a wood sample, collected by Yoshikawa et al. (1980) from a riverbank exposure along the Waipapa Stream (labelled "Yoshikawa outcrop", Fig. 5.1), indicates this area has a high coastal uplift rate. The sample yeilded an age of 9900-9400 cal. yrs B.P. and was collected from silt containing marine and estuarine diatoms at $7 \mathrm{~m}$ AMSL. This equates with an uplift rate of $2.7-$ $3.3 \mathrm{~mm} \mathrm{yr}^{-1}$ (using $22 \pm 2 \mathrm{~m}$ of eustatic SL rise, Gibb, 1986). The lack of marine terraces indicates that this rapid coastal uplift is either not being accommodated by coseismic movements, or slope and fluvial processes have removed the marine terraces

\subsubsection{Te Araroa beach ridges}

The Te Araroa coastal plain is characterised by an overall seaward slope, upon which zones of beach ridges $\sim 0.5-1 \mathrm{~m}$ in height are separated by swamps (Fig. 5.7C). It is likely that the TA beach ridges have accreted since SL stabilisation at $\sim 7 \mathrm{ka}$. This means any excess elevation of the relict beach ridges must be the product of tectonic uplift. Age control on the oldest beach ridges is poor, though they must be $>3375$ 3485 cal. yrs B.P, the age of Waimihia tephra found in swamp S1. Maximum uplift rates can be calculated using the Waimihia tephra as the minimum age of the beach ridges at the front edge of Zones 1 and 2 (Table 5.5). Uplift rates can also be calculated using the radiocarbon ages of Garrick (1979) and Ota et al. (1992) for Zones 3 and 5 . We use the modern elevation of the crest of the beach ridge and 
subtract the elevation of the modern storm beach ridge $(4 \mathrm{~m})$ to get a total amount of uplift. The calculated uplift rates range between 0.5 and $2 \mathrm{~mm} \mathrm{yr}^{-1}$ (Table 5.5).

Table 5.5 Uplift rates calculated from the Te Araroa beach ridges sequence.

\begin{tabular}{|c|c|c|c|c|c|c|}
\hline لَّ & 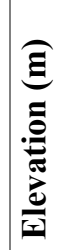 & 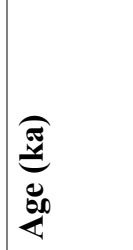 & 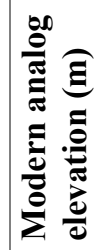 & 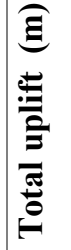 & 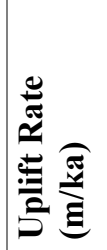 & 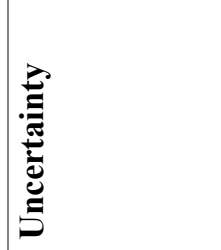 \\
\hline Front edge Z1 & 8.4 & $>3.43$ & 4 & 4.4 & 1.3 & Maximum rate \\
\hline Front edge Z2 & 8 & $>3.43$ & 4 & 4 & 1.2 & Maximum rate \\
\hline Front edge Z3 & 7.6 & $1.8115^{1}$ & 4 & 3.6 & 2.0 & $(1.7-2.4)^{3}$ \\
\hline Back edge Z5 & 4.3 & $0.586^{2}$ & 4 & 0.3 & 0.51 & $(0.46-0.58)^{3}$ \\
\hline
\end{tabular}

${ }^{1}$ Radiocarbon age of Ota et al., 1992. Midpoint of the $2 \sigma$ calibrated age B.P.

${ }^{2}$ Radiocarbon age of Garrick, 1979. Midpoint of the $2 \sigma$ calibrated age B.P.

${ }^{3}$ Maximum uplift rate $=$ calculated using the minimum age of the $2 \sigma$ calibrated age range; minimum uplift rate: calculated using the maximum age of the $2 \sigma$ calibrated age range.

If uplift was sudden and coseismic steps would form in the beach ridge sequence (Fig. 5.11A). The height of the step would approximately equal the amount of coastal uplift. If uplift occurred by a constant process then the ridges would develop a seaward slope (Fig. 5.11B). Each new ridge would probably form when the previous ridge reached a threshold height above MSL. A ridge crest may reach this threshold height either by natural accretion or by tectonic uplift. Either mechanism builds new beach ridges at successively lower initial elevations. (A) Beach ridge progradation
involving coseismic coastal uplift.

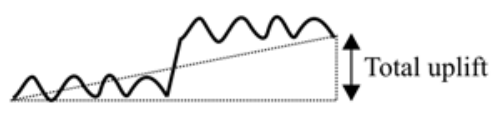

(B) Beach ridge progradation involving continuous, gradual uplift.

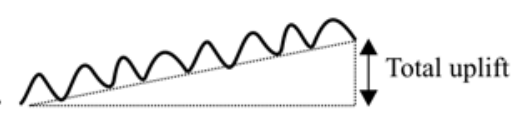

Figure 5.11. Cartoon of beach ridge progradation under (A) intermittent, sudden uplift, and (B) continuous gradual uplift. 
The TA beach ridges have a seaward slope, which is compatible with the constant uplift scenario (Fig. 5.11B). Ota et al. (1992) observed two $2 \mathrm{~m}$ scarps at the seaward edge of beach ridge Zones 3 and 4. Their profile was in the same location as our TA South profile. While the equivalent scarps can be seen in the TA South profile, they do not actually equate with a $2 \mathrm{~m}$ step in the overall elevation of the beach ridges. Across the width of the swamps adjacent to these scarps (S3 and S4), there is only a slight change in beach ridge elevation $(0.5 \mathrm{~m}$ across $\mathrm{S} 3$ and $<0.2 \mathrm{~m}$ across $\mathrm{S} 4$, Fig. 5.7C). Importantly, the negligible change in beach ridge elevation across the swamps also argues against the swamps representing periods of SL regression caused by coseismic uplift. We interpret the swamps to represent periods of decreased sediment supply to the coast or southward deflections of the Karakatuwhero River mouth.

We note several changes in the mean slope of the beach ridge zones. The gradients range from $0.24 \mathrm{~m}$ to $0.7 \mathrm{~m}$ per $100 \mathrm{~m}$ (Fig. 5.7C). Such changes in slope could be due to (1) varying uplift rates through time, or (2) varying sediment supply through time. Zone 5 has the lowest gradient of $0.24 \mathrm{~m} / 100 \mathrm{~m}$ and radiocarbon ages suggest this zone is $<650$ cal. yrs B.P. This age is approximately coincident or slightly post-dates the arrival of Maori in the region (McGlone et al., 1994; Wilmshurst, 1997). Sedimentation pulses have been recorded in several lake cores from the eastern North Island associated with the arrival of Maori and land clearance by fires (Eden and Page, 1998; Wilmshurst, 1997). The rapid development of beach ridge Zone 5 at TA could be a response to enhanced sediment supply due to land burning and clearance by the Maori settlers. The association of probable increased sediment supply and a lower gradient beach ridge zone suggests that sediment supply is the dominant control on the steepness of the beach ridge zones, rather than varying uplift rates.

In summary, the TA beach ridges show no evidence of any steps that can be attributed to coseismic uplift. Furthermore, the large number of ridges $(>27$ in the TA South profile) argues against tectonic uplift being the cause of abandonment of each ridge. We suggest that the beach ridges have formed by abundant sediment supply coupled with continuous gradual tectonic uplift and that both factors have promoted the seaward progradation of the coastal plain. 


\subsubsection{Hicks Bay paleo-estuary}

Results from the HB cores show infilling of the HB flats was controlled by rising eustatic SL. However, the modern elevation of the radiocarbon samples indicates that uplift of the area has occurred either during or after sediment deposition (Table 5.4, Fig. 5.12). We use the sedimentary sequence to evaluate, firstly, whether uplift occurred during deposition of the sequence, and secondly, to make inferences about the rate and style of this uplift. We can do this by comparing the thickness of sediment preserved with the amount of accommodation space created by eustatic SL rise during the period of deposition (the accommodation space concept is illustrated in Fig. 5.13). If no uplift occurred during deposition of the sequence then the thickness of intertidal sediment should approximately equal the amount of space created in the estuary by eustatic SL rise, assuming sedimentation kept pace with SL rise. HB1 contains $8.5 \mathrm{~m}$ of intertidal sediment deposited between $\sim 9,000-7,000$ cal. yrs B.P (Fig. 5.8). During this period eustatic SL rose $\sim 17.5 \mathrm{~m}$ (Fig. 5.12). There is a deficit of $\sim 9 \mathrm{~m}$. Similarly, in HB2 there is $6.3 \mathrm{~m}$ of intertidal sediment that spans $\sim 8,300-7,000$ cal. yrs B.P. With $\sim 14 \mathrm{~m}$ of eustatic SL rise in this period, there is an accommodation space deficit of $\sim 7.3 \mathrm{~m}$ (Fig. 5.14). These large deficits imply uplift did occur during deposition of the sedimentary sequence as there is less sediment preserved than the amount of space created by SL rise.

The large uncertainties associated with the eustatic SL curve, and to a lesser degree, with radiocarbon ages, mean that calculating the exact amount of sediment "missing" within each core is subject to large uncertainties. Despite this limitation, the available data suggests a consistent accommodation space deficit of $\sim 30-60 \%$, over varying time periods (Fig. 5.14). We have not taken into account post-depositional sediment compaction when calculating the accommodation space deficits, as we consider this to be minor compared with the magnitude of the deficits in question. Paul and Barras (1998) studied a sequence of Holocene silty clays with shelly lenses, similar to the Hicks Bay core sediments and found that over a $20 \mathrm{~m}$ thickness of sediment a maximum of $2.5 \mathrm{~m}$ of correction was required to approximately recalibrate the sediment depths for the effects of compaction. This equates with a mid-section correction of $\sim 10 \%$ of the bed thickness (Paul and Barras, 1998). Therefore, our accommodation space deficit estimates may be overestimated by $\sim 10 \%$, but given the 
$30-60 \%$ deficits that we infer (Fig. 5.14), tectonic uplift probably plays a more important role in the preserved sedimentary bed thickness than post-depositional compaction.

If this uplift was caused by coseismic uplift, we predict the events would be recorded by: (1) a sudden paleoenvironmental change reflecting an increase in land elevation, e.g. a change from subtidal to MSL elevation or higher, and a freshening of the aquatic environment; or (2) an unconformity if the uplifted sediments were exposed subaerially and eroded. Eustatic SL was rising during deposition of the early Holocene Hicks Bay Flats sequence. An uplift event would therefore be recorded as a negative sea level tendency (a marine regression) within a sequence predominantly displaying a positive sea level tendency (a marine transgressive sequence, Fig. 5.13).

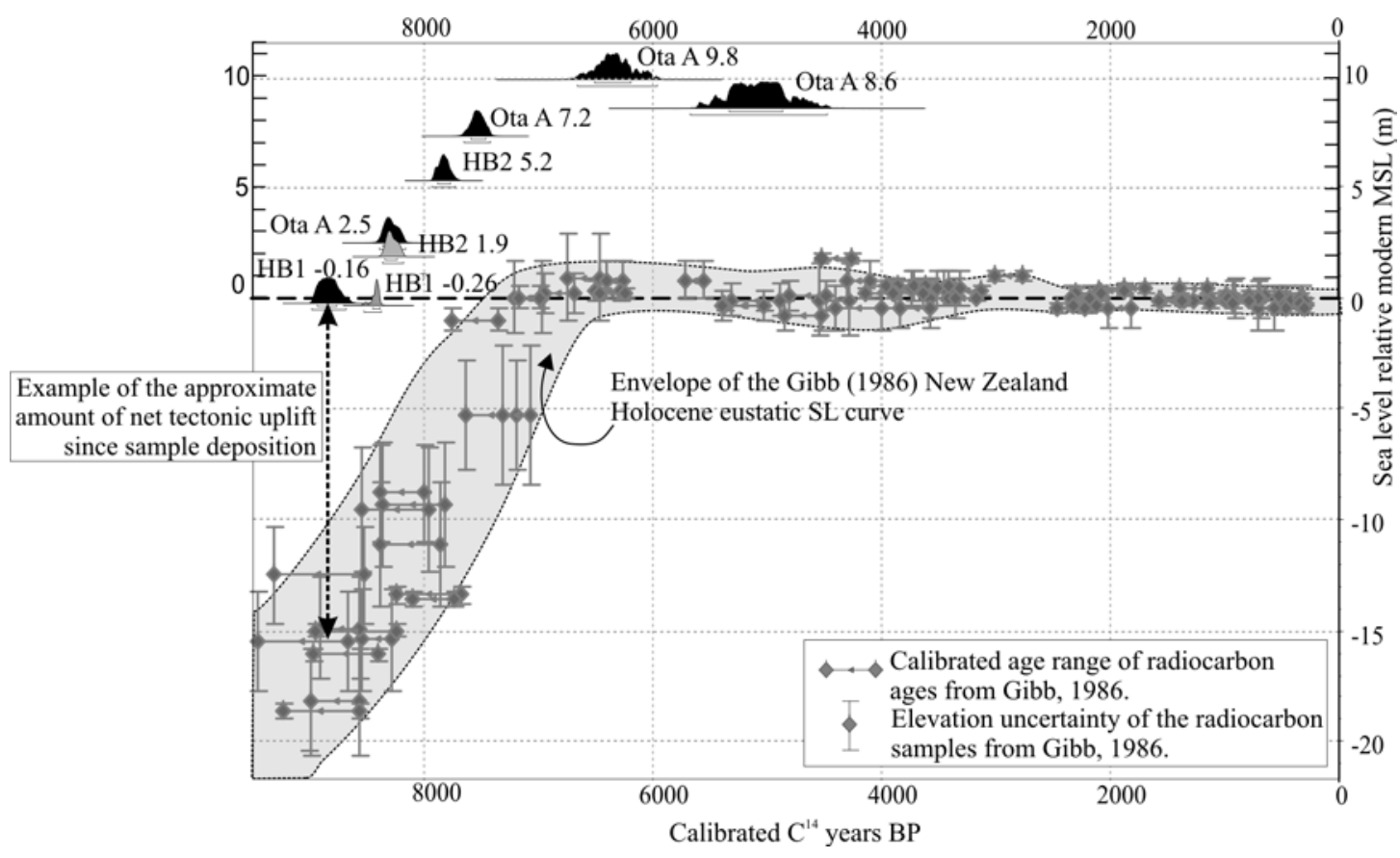

Figure 5.12. New Zealand Holocene sea level curve, from Gibb (1986). Hicks Bay Flats radiocarbon ages are plotted at the modern elevation of the sample. Radiocarbon ages plotted using OxCal v3.10 Bronk Ramsey (2005), wood samples calibrated using Southern Hemisphere Atmospheric data from McCormac et al (2004) and shell samples calibrated using Marine data from Hughen et al (2004). 
If we refer back to the record of paleoenvironmental change from the HB cores and examine the sequence in terms of possible uplift events, only one significant sharp contact is evident: between lower intertidal sediments and the subtidal estuarine channel (the coarse sand layer at $\sim 4$ m AMSL in HB1 and HB2, Fig. 5.8). This sharp sedimentary contact is discounted as recording a sudden uplift event because (a) the inferred paleoenvironment goes from lower intertidal to subtidal - a positive sea level tendency consistent with rising eustatic SL; and (b) the sharp contact is consistent with scouring at the base of a tidal channel or tsunami entrainment. All other paleoenvironmental zone contacts are gradational.

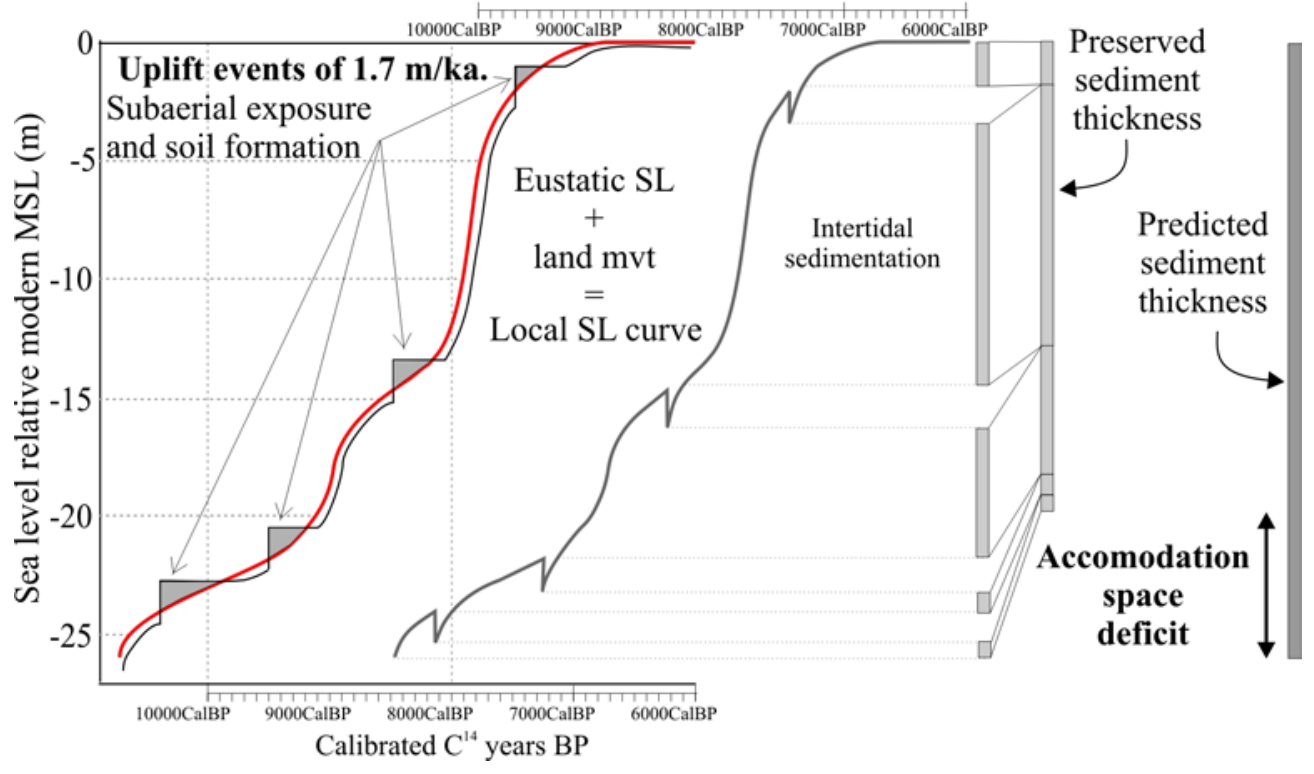

Figure 5.13. Cartoon depicting the hypothetical development of a relative SL curve for a site undergoing coseismic uplift during eustatic SL rise. This is based on an uplift rate of $1.7 \mathrm{~mm} \mathrm{yr}^{-1}$, equating with one uplift event of $1.7 \mathrm{~m}$ per ka. It assumes all uplift is accommodated by coseismic movement with no interseismic vertical movement, and that there is no post-uplift erosion of the sequence. The cartoon shows how the relative SL curve would have a dominantly positive SL tendency, punctuated by sudden, and short-lived SL falls. If sedimentation kept pace with SL rise then this would result in a lesser thickness of sediment deposited relative to the amount of space created by eustatic SL rise - termed the "accommodation space deficit". 


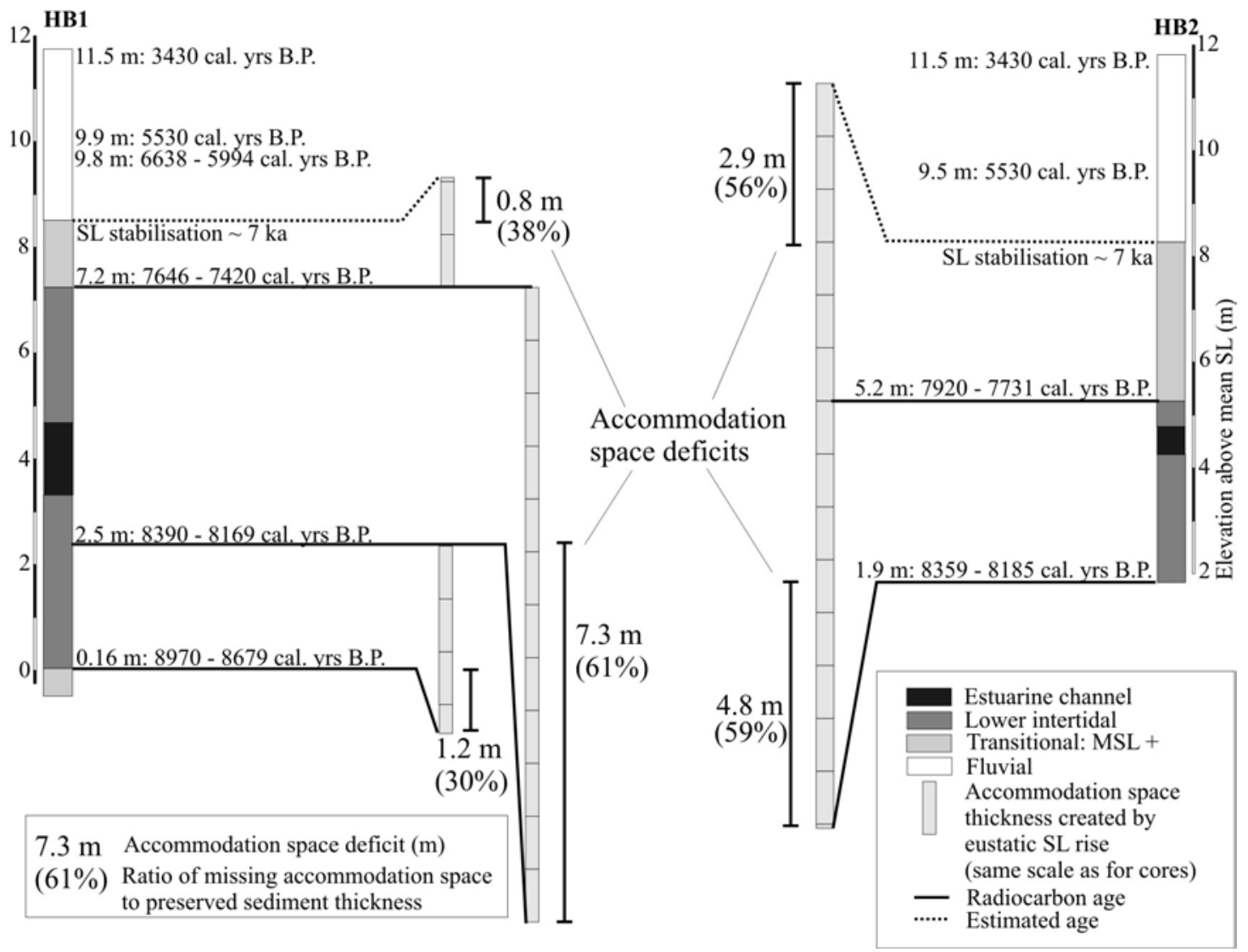

Figure 5.14. Thickness of intertidal sediment in HB1 and HB2 compared with the thickness of accommodation space created by rising eustatic SL during the same time period. Estimates of past eustatic SL have an uncertainty of $+/-2 \mathrm{~m}$ and are from the Gibb (1986) New Zealand SL curve, shown in Fig. 5.12. 
In the absence of sharp contacts and unconformities in cores HB1 and HB2 we assess whether there are any marine regressions that might indicate uplift events. Only one gradational contact occurs during the period of rising SL where a negative SL tendency is inferred from the paleoenvironmental data. At $\sim 8-7 \mathrm{ka}$ the environment changes from subtidal to lower intertidal (Stage 5, Fig. 5.10.5). This transition is sustained and therefore it was unlikely to record a sudden uplift event, which would cause a relatively short-lived sea level regression. The sustained and gradual nature of the paleoenvironmental transition is more likely to reflect infilling of the estuary, as sedimentation rates catch up with and then exceed the rates of eustatic SL rise. That the subtidal-intertidal transition is followed by a gradual change to a fluvial environment, coincident with the stabilisation of SL, supports estuary infilling as the cause for the marine regression.

Although there are no obvious stratigraphic changes that one might attribute to sudden uplift, we need to consider what the minimum amount of uplift is that would be resolvable with the available data. Most of the sediment in the HB1 and HB2 cores is from a lower intertidal environment. The spring tidal range of $\mathrm{HB}$ is $1.7 \mathrm{~m}$ and therefore, most of the sediment was deposited between 0 and -0.85 m relative to MSL. Assuming no post-uplift erosion, $>0.85 \mathrm{~m}$ of uplift would be needed to completely raise this paleoenvironmental zone to an elevation greater than MSL. However, our paleoecological proxies do not resolve a MSL - high tide foraminiferal assemblage. If uplift did raise the paleoenvironment to above MSL, it would probably be recognisable as a section barren of foraminifera within the lower intertidal sequence. Our sampling resolution is sufficiently dense that we do not think we have missed such an event. An uplift event of $>1.7 \mathrm{~m}$ would have elevated the sequence above the high spring tide level. An unconformity, a paleosol or a foraminifera-barren section would probably record subaerial exposure.

Our results demonstrate that uplift of the Hicks Bay Flats has been accommodated either by constant, gradual uplift, or by intermittent sudden uplift events of less than $1.7 \mathrm{~m}$, and probably $<0.85 \mathrm{~m}$ presuming we could recognise a paleoenvironmental change from lower intertidal to MSL-high tide. The time over which the uplift occurred is between 270 - 970 years (the minimum and maximum time periods, Fig. 5.14). Future work using drill cores at more marginal locations on the Hicks Bay Flats 
might capture tidal-wetland microfaunal assemblages more sensitive to the rates of sea level changes and thus might provide further resolution to any coseismic uplift that did occur. Three marine terraces on the Hicks Bay coastal plain were mapped by Ota et al. (1992) based on steps identified in aerial photographs. We revisited a profile through the highest terrace at HB (Ota B/A1, Fig. 5.4, Appendix 5.1) and the sediments appear to be fluvial silts and colluvial gravels, therefore implying that at least the oldest terrace is not marine. We did not survey the HB terraces because they span the same time period as the TA beach ridges. By comparisons to TA, we infer the steps recognised by Ota et al. (1992) are those at the landward edge of swamps and there is probably no significant net elevation change across the swamp.

\subsubsection{Global examples of aseismic tectonic uplift and seismic hazard implications.}

There are few global examples of coastal tectonic uplift driven by gradual or aseismic mechanisms. Glacio-isostatic adjustments at high-latitude locations can produce uplift at rates similar to or higher than, the uplift recorded in the NE Raukumara Peninsula (for example; Berglund, 2005; Ekman and Makinen, 1996; Forman et al., 2004; James et al., 2000; Larsen et al., 2004; Miettinen, 2004). Aseismic and coseismic uplift mechanisms have contributed to coastal uplift at rates of up to $10 \mathrm{~mm} \mathrm{yr}^{-1}$ at Isla Mocha, Chile (Nelson and Manley, 1992). Both mechanisms of uplift were attributed to rupture and creep on an inferred offshore imbricate thrust fault. Aseismic coastal uplift at $\sim 1 \mathrm{~mm} \mathrm{yr}^{-1}$ has been recorded at eastern Kyushu, Japan, where it has been related to subduction of a buoyant body, the Kyushu-Palau Ridge (Nakada et al., 2002, and references therein). Similar to Kyushu, aseismic uplift of the NE Raukumara Peninsula is probably related to subduction of a buoyant body, namely the Hikurangi Plateau and associated sediment underplating. The geodynamic significance of this is to be explored further in a following paper (Wilson, Ch. 6).

The recognition of aseismic processes accommodating uplift in the NE Raukumara Peninsula region contributes to an understanding of the seismic hazard of this area. With no large to great subduction zone earthquakes in historical times, the Hikurangi subduction zone interface is a significant source of uncertainty in national seismic hazard assessments (Stirling et al., 2002). This study shows there have been no coseismic coastal uplift events in at least the past $\sim 8,500$ cal. yrs B.P., therefore implying no large to great earthquakes have been generated either on the subduction 
interface or on offshore upper plate faults during the Holocene along this sector of the Hikurangi margin.

\subsection{Conclusions}

Our interpretation of the Horoera and Waipapa terraces is that they do not have a marine origin and thus do not provide evidence of coseismic coastal uplift. How then, is the rapid uplift (at rates of $0.5-3.3 \mathrm{~mm} \mathrm{yr}^{-1}$ ) achieved? The Te Araroa beach ridge sequence does not display any steps indicative of significant coseismic uplift events. Rather, the gradient of the beach ridge zones is approximately constant with small differences probably related to changes in sediment supply superimposed on a background uplift rate. The paleoecology of the Hicks Bay transgressive sequence shows no evidence of coseismic uplift events $>0.85 \mathrm{~m}$; all paleoenvironmental transitions appear to be gradational. Accommodation space deficits at varying time intervals indicate that uplift occurred throughout deposition of the Hicks Bay Flats sedimentary infill sequence.

This combination of different methodologies applied to varying time periods at four different coastal locations leads us to conclude that a continuous, aseismic process has driven Holocene coastal uplift of the NE Raukumara Peninsula. This outcome is important for two reasons. Firstly, it is a rare example of aseismic tectonic mechanisms driving coastal uplift. Secondly, we have shown that Holocene coastal uplift mechanisms do vary along the East Coast of the North Island. This implies that similar coastal geomorphology, for example, raised terraces, wide coastal plains and uplifted estuaries, can be produced by different tectonic processes. This recognition brings some reconciliation to the former inconsistency of similar Holocene coastal tectonic processes along the Hikurangi margin, despite the apparent contrasts in upper plate structures. 
Appendix 5.1. Stratigraphic columns of exposures and augers on the Hicks Bay Flats. Locations shown on Fig. 5.4.
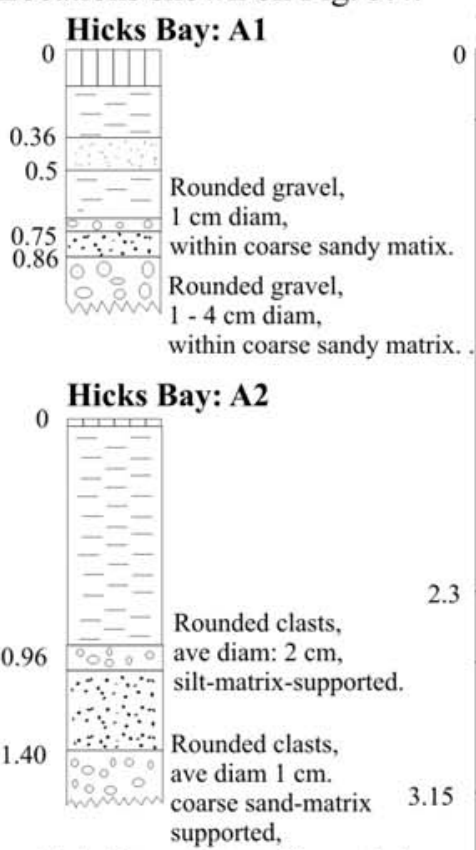

End of auger, water table reached. non-recovery of coarse sand.

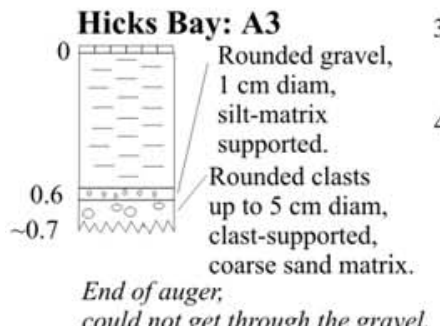

Hicks Bay: A5

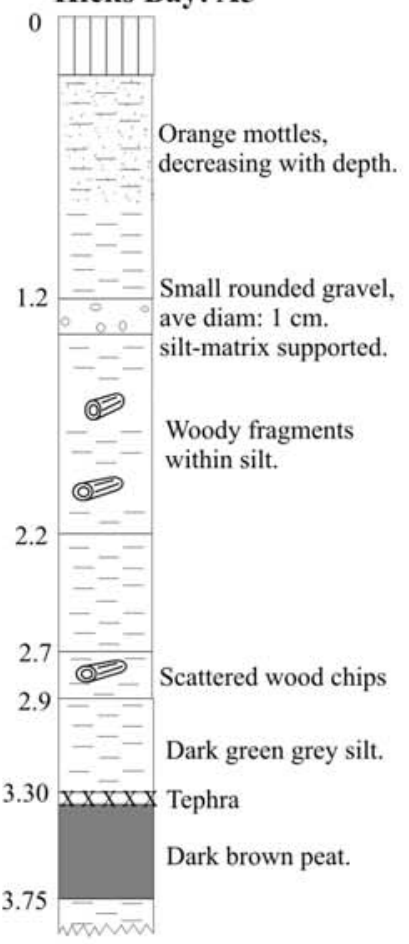

Hicks Bay: A6

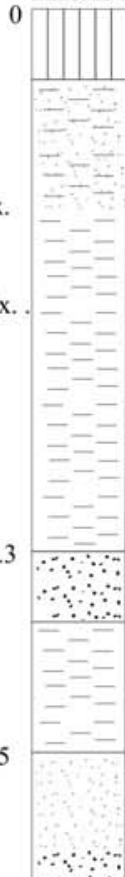

Rounded gravel, ave diam: $2 \mathrm{~cm}$, coarse sandmatrix supported

3.8

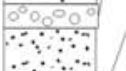

Rounded gravel, ave diam: $1 \mathrm{~cm}$, $\because \because$ coarse sand-

4.2

Water table reached. no recovery in sands.

Hicks Bay: A4

.

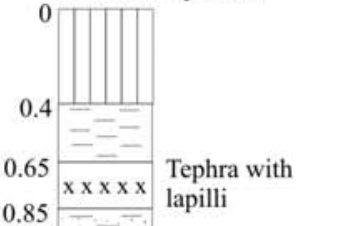

$0.85 \stackrel{\mathrm{x} \times \mathrm{x \times x}}{-}$ lapilli
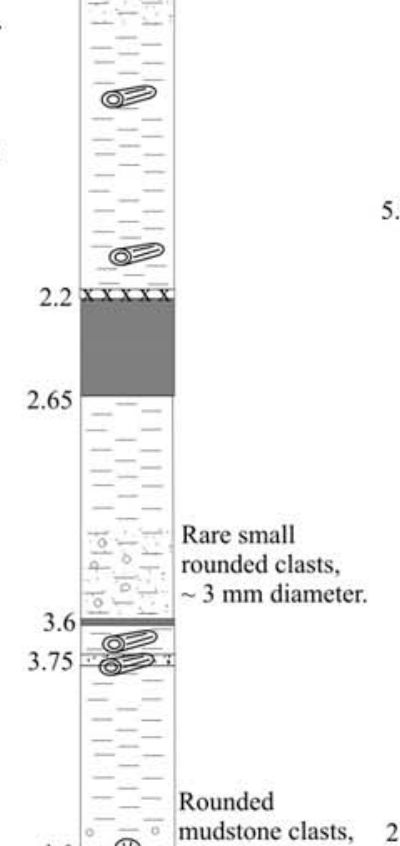

$4.6 \circ-1 \mathrm{~cm}$ diameter. $\sim 1$ cm diameter.
Hicks Bay: A8
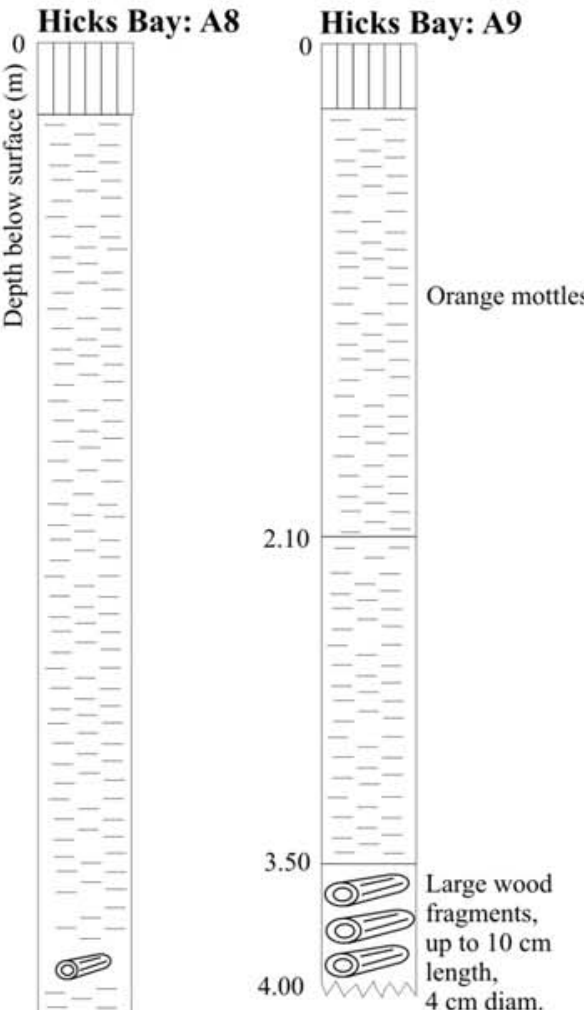

Hicks Bay: A10

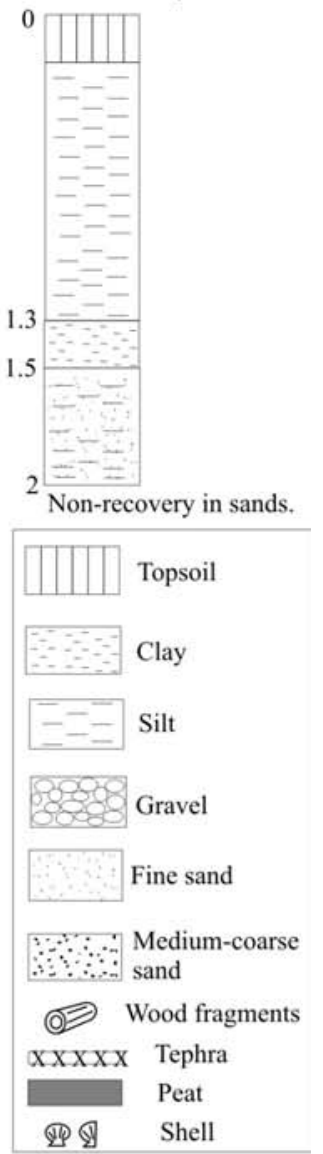

Well rounded gravel, clast-supported, clast diam up to $8 \mathrm{~cm}$ diam, 


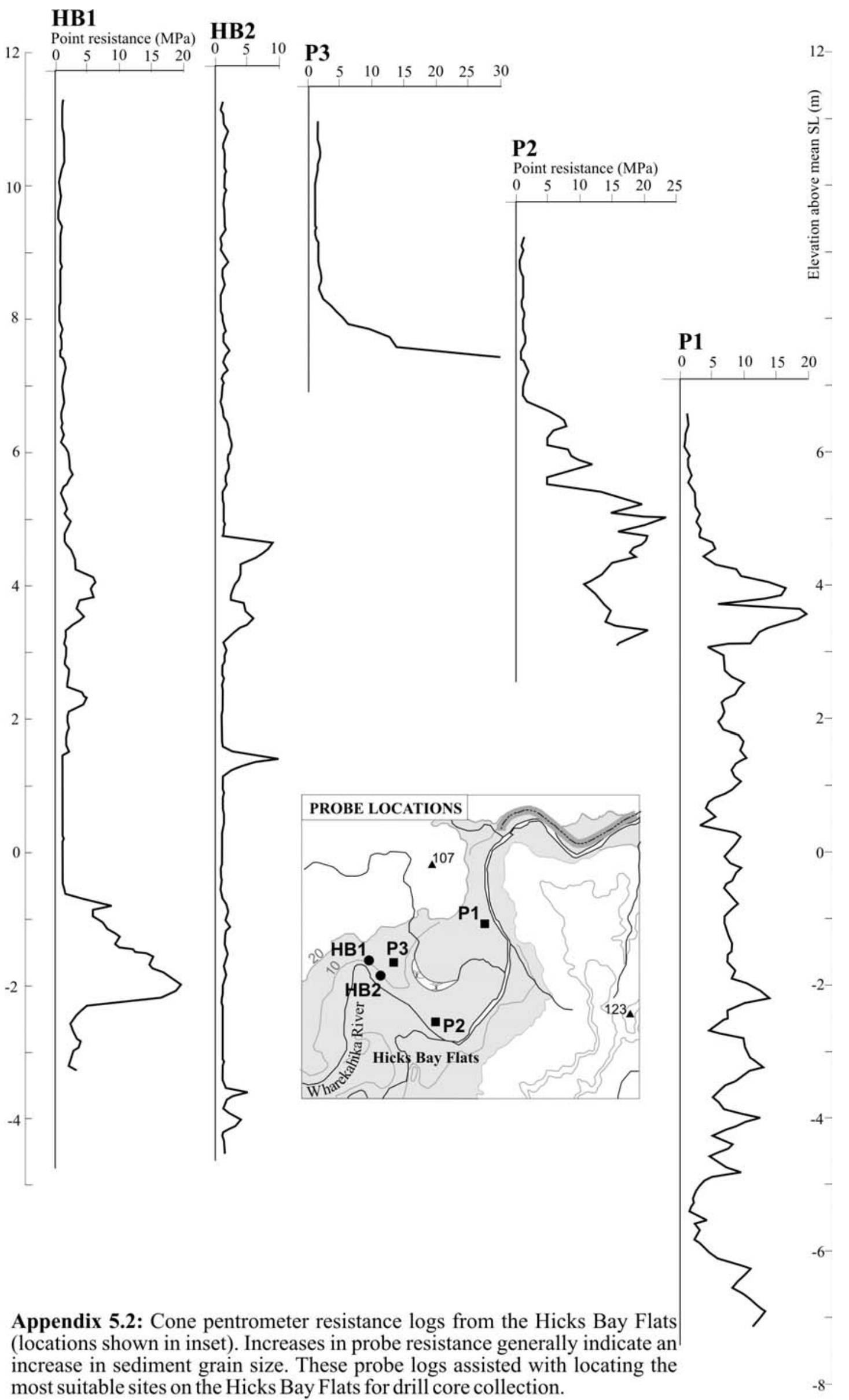


Appendix 5.3: Hicks Bay cores stable isotope study.

\section{Appendix 5.3: Objectives}

Thirty-one samples from HB1 were selected for a stable isotope study to assess whether C and $\mathrm{N}$ isotopic values and ratios showed sensitivity to paleoenvironmental change in the core and if a more detailed study could assist with detecting small paleo-salinity changes.

\section{Appendix 5.3: Methods}

The samples were chosen from $10.3 \mathrm{~m}$ to $6.2 \mathrm{~m}$ AMSL. The samples span transitions from fluvial to peat and fluvial to estuarine (as identified from the shells and foraminifera). Sediment samples of $\sim 10 \mathrm{~g}$ were finely ground and homogenised with a mortar and pestle. Samples were run on a Europa Geo 20-20 mass spectrometer in continuous flow with an ANCA (automatic N and C analyser) elemental analyser at the Rafter Stable Isotope Laboratory. Whole sediment samples were run for total carbon and nitrogen content $(\% \mathrm{C}$ and $\% \mathrm{~N})$, and carbon and nitrogen isotopes $\left(\delta^{13} \mathrm{C}\right.$ and $\left.\delta^{15} \mathrm{~N}\right)$. A split of the whole sample was treated with $1 \mathrm{~N} \mathrm{HCl}$ overnight to demineralise the sediment. The split was run on the ANCA again to get total organic carbon and nitrogen content (\%TOC and \%TON). Inorganic carbon $\left(\% \mathrm{CaCO}_{3}\right)$ contribution was calculated from $\% \mathrm{C}$ (total) - \% TOC (organic).

\section{Appendix 5.3: Results}

Stable isotope analyses span the peat layer ( $\sim 9.76 \mathrm{~m}$ AMSL), the foram P-B transition at 7.96 m AMSL and the start of the A. stutchburyi shells at $7.26 \mathrm{~m}$ AMSL (Fig. B). Most of the samples are dominated by silt, though there are some sand samples between $6.8-5.8 \mathrm{~m}$ AMSL. Variation in sand content does not appear to correlate with any significant isotopic excursion in the sandy regions.

Both carbon and nitrogen isotopic values show a variation for samples within the peat layer $(\sim-2 \mathrm{~m})$. Nitrogen isotopes show an increase in $\delta^{15} \mathrm{~N}$ (Fig. B-C), while carbon isotopes show an isotopic decrease (Fig. B-A). \% C (total), \% TOC (organic) and $\mathrm{C} / \mathrm{N}$ all increase during this interval to maximas around $9.8 \mathrm{~m}$ (Fig. B-B, D). Carbonate shells and foraminifera tests are composed of inorganic $\mathrm{C}$, however the plot does not show an increase in $\% \mathrm{C}$ (total) when the foraminifera tests and shells become present in the core (Fig. B-D). $\delta^{15} \mathrm{~N}$ also shows little variation below the peat layer (Fig. B-C). All the $\delta^{15} \mathrm{~N}$ values typically fall within the range of terrestrial organic matter $(0-2 \%$ ) as marine organic matter has higher values of $>2.6 \%$ (Fig. 
7, Peters et al., 1978; Schoeninger and DeNiro, 1984, and references therein; Thornton and McManus, 1994).

$\delta^{13} \mathrm{C}$ and the $\mathrm{C} / \mathrm{N}$ ratio have previously been the most useful parameters for distinguishing organic matter provenance (Meyers, 1994; Thornton and McManus, 1994; Muller and Mathesius, 1999). The $\delta^{13} \mathrm{C}$ plot shows a slight trend toward more negative values below 7.8 $\mathrm{m}$ AMSL. Published observations of freshwater and marine $\delta^{13} \mathrm{C}$ values vary slightly, but all agree that marine $\delta^{13} \mathrm{C}$ values are higher than freshwater values (Fig. 7A). The $\mathrm{C} / \mathrm{N}$ ratio values are variable beneath the peat (perhaps due to the small scale introduction of mixed organic material from cyclic flooding) but show a trend toward higher values with increasing depth; again, published values indicate higher $\mathrm{C} / \mathrm{N}$ values are indicative of terrestrial organic matter (Fig. 7B).

In both of the plots $\left(\delta^{13} \mathrm{C}\right.$ and $\left.\mathrm{C} / \mathrm{N}\right)$ we see the values are not within the range of typical marine organic matter (Fig. 7A, B). We conclude that for the Hicks Bay cores this technique is not a viable tool for distinguishing freshwater and marine paleoenvironments. This is probably because the marine environment at $\mathrm{HB}$ was a sheltered intertidal inlet and received a high terrestrial sediment input. We emphasise that this was a test of the technique. Consequently, we have not considered the extent to which the $\mathrm{C}$ and $\mathrm{N}$ isotopes are affected by factors such as Preservation of organic material, transportation, microbial activity, water depth and temperature, water currents, unusual weather events (drought, flood, wind etc). The sharp peaks in all isotopic values at the peat layer indicate that the stable isotopes do reflect significant increases in organic matter. However this is clearly visible in the cores and in this study a quantification of the amount of C (total) is not especially helpful for environmental interpretation, the stable isotopes do not add to our other microfossil studies. 


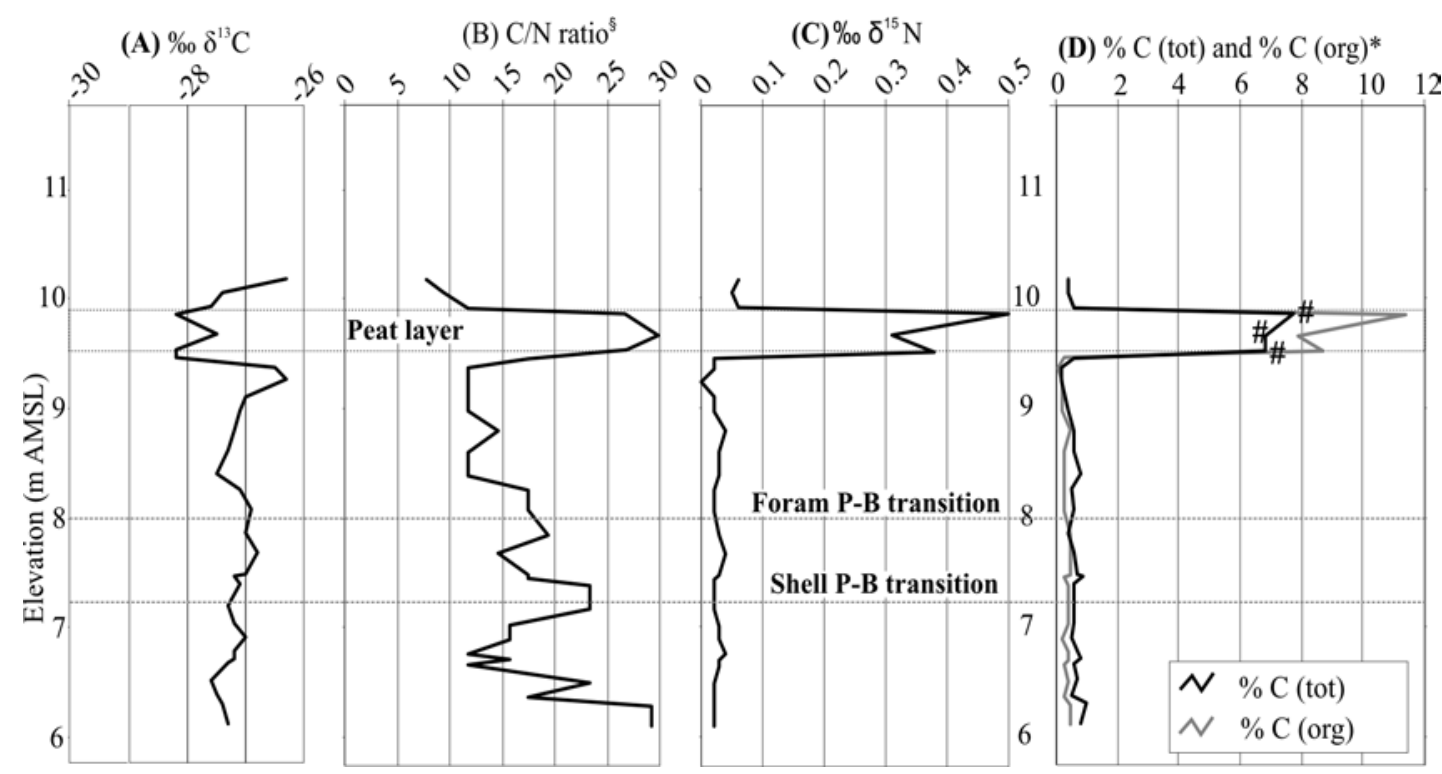

Appendix 5.3, Figure. A: Stable isotope measurements HB1/6 - 10.2 m AMSL. Major stratigraphic boundaries marked.

(A) $\%$ o $\delta^{13} \mathrm{C}$; (B) $\mathrm{C} / \mathrm{N}$ ratio $\S,(\mathrm{C}) \% \delta^{15} \mathrm{~N}$; (D) $\% \mathrm{C}$ (tot) and $\% \mathrm{C}$ (org) ${ }^{*}$.

$\S \mathrm{C}: \mathrm{N}$ ratio is calculated by an atomic ratio where $\mathrm{C}: \mathrm{N}=\left(\% \mathrm{C}^{14}\right) /\left(\% \mathrm{~N}^{12}\right)$.

* \%C (tot) is the total amount of carbon in the samples before demineralisation, $\% \mathrm{C}$ (org) is the total amount of organic carbon in the sample after demineralisation.

\# Samples have lower than expected carbon due to over saturation of detector during the measurement.

Appendix 5.4: Major element glass geochemistry of tephra from the Te Araroa coastal plain ( $\mathrm{n}=$ number of glass shards analysed).

\begin{tabular}{|l|l|l|l|l|l|l|l|l|l|l|l|}
\hline \multicolumn{9}{|l|}{ Element } \\
\hline Sample & $\mathrm{SiO}_{2}$ & $\mathrm{Al}_{2} \mathrm{O}_{3}$ & $\mathrm{TiO}_{2}$ & $\mathrm{FeO}$ & $\mathrm{MnO}$ & $\mathrm{MgO}$ & $\mathrm{CaO}$ & $\mathrm{Na}_{2} \mathrm{O}$ & $\mathrm{K} 2 \mathrm{O}$ & $\mathrm{Cl}$ & $n$ \\
\hline S1, -0.65 m & & & & & & & & & & & \\
\hline Average & 74.8 & 14.3 & 0.2 & 1.7 & 0.1 & 0.2 & 1.9 & 4.0 & 2.6 & 0.1 & 14 \\
\hline $1 \sigma$ & 3.7 & 2.6 & 0.1 & 0.4 & 0.1 & 0.1 & 1.3 & 0.9 & 0.6 & 0.1 & \\
\hline S2a, -2.75 m & & & & & & & & & & & \\
\hline Average & 76.0 & 13.3 & 0.3 & 2.0 & 0.1 & 0.2 & 1.5 & 3.6 & 2.8 & 0.2 & 10 \\
\hline $\mathbf{1 \sigma}$ & 0.4 & 0.2 & 0.0 & 0.2 & 0.0 & 0.0 & 0.1 & 0.3 & 0.1 & 0.0 & \\
\hline S2a. -0.5 m & & & & & & & & & & & \\
\hline Average & 78.1 & 12.3 & 0.1 & 0.9 & 0.1 & 0.1 & 0.6 & 3.7 & 3.9 & 0.2 & 11 \\
\hline $1 \sigma$ & 0.3 & 0.2 & 0.0 & 0.1 & 0.0 & 0.0 & 0.2 & 0.1 & 0.3 & 0.1 & \\
\hline
\end{tabular}


Appendix 5.5: Foraminifera census data from the Hicks Bay cores, HB1 and HB2.

* 0: barren; 1 : scattered; 2 : abundant. ** JF: juvenile fragments, SS: shell sand.

\begin{tabular}{|c|c|c|c|c|c|c|c|c|c|c|c|c|c|c|c|c|c|c|c|c|c|c|c|c|c|}
\hline 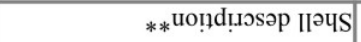 & & & & & & & & & & & & & & & & & & & & & & & & & \\
\hline 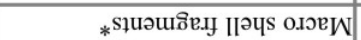 & 0 & 0 & 0 & 0 & 0 & 0 & 0 & 0 & - & 0 & 0 & - & $\mathrm{N}$ & 0 & - & $\mathrm{N}$ & 0 & 0 & 0 & 0 & $\mathrm{~N}$ & - & -1 & - & $\alpha$ \\
\hline 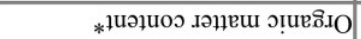 & - & $\mathrm{N}$ & $\mathrm{N}$ & - & -7 & - & - & - & - & 0 & - & 0 & 0 & 0 & $\mathrm{~N}$ & - & 0 & 0 & 0 & 0 & 0 & 0 & 0 & - & 0 \\
\hline * słsejo әuоңspnW & 0 & 0 & 0 & 0 & 0 & 0 & 0 & 0 & 0 & 0 & 0 & 0 & 0 & o & 0 & 0 & 0 & 0 & 0 & 0 & 0 & - & - & 0 & 0 \\
\hline spoəx.дso јо .әquи $\mathrm{N}$ & & & & & & & & & $\mathrm{N}$ & ส & $\Xi$ & i & i & 6 & ¿े & & $\theta$ & \pm & $\stackrel{\infty}{\infty}$ & $\frac{4}{4}$ & 㥹 & $\begin{array}{l}\infty \\
+ \\
+\infty\end{array}$ & ल & लै & $\bar{r}$ \\
\hline 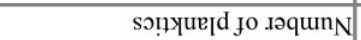 & & & & & & & & - & - & & $m$ & & & - & $=$ & & $\mathrm{N}$ & $\mathrm{N}$ & - & $\mathrm{N}$ & - & $\theta$ & - & $n$ & - \\
\hline 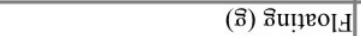 & & & & & & & & & & & & & & & i & & & & & & & & & & \\
\hline 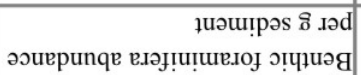 & $\stackrel{\circ}{\circ}$ & $\therefore$ & $\stackrel{\circ}{\circ}$ & $\stackrel{\circ}{\circ}$ & $\because$ & $\begin{array}{l}\infty \\
\infty \\
\infty\end{array}$ & $\because$ & $\stackrel{+}{=}$ & $\stackrel{\mathfrak{m}}{\mathfrak{I}}$ & $\stackrel{\infty}{-\infty}$ & $\begin{array}{c}\dot{t} \\
\dot{s}\end{array}$ & $\stackrel{\infty}{i}$ & $\overrightarrow{\dot{q}}$ & $\stackrel{m}{\mathrm{~m}}$ & $\stackrel{m}{2}$ & 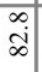 & $\frac{n}{n}$ & $\stackrel{n}{=}$ & $\stackrel{\text { I }}{ \pm}$ & $\begin{array}{ll}\infty \\
\oplus \\
\oplus\end{array}$ & \begin{tabular}{l}
+ \\
\hdashline \\
$=$
\end{tabular} & \begin{tabular}{l}
3 \\
$\infty$ \\
$\infty$ \\
\hdashline
\end{tabular} & $\begin{array}{ll}m \\
n \\
n\end{array}$ & 宛 & $\begin{array}{l}\stackrel{0}{\infty} \\
\infty \\
\infty\end{array}$ \\
\hline (suo.ọu $\varepsilon 9<\%$ ) purs \% & $\therefore$ & $\therefore$ & :ं० & ڤ్సి & @े & ذి & ¿ें & $亠^{\circ}$ & $\stackrel{\circ}{\infty}$ & $\stackrel{\circ}{=}$ & $\check{2}^{\circ}$ & :ें & : & ذి & ठें & ఏे & ஸें & ถั่ & ஸें & ذें & ¿ें & さे & $\frac{0}{\infty}$ & लें & iें \\
\hline 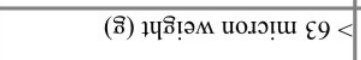 & ?. & ?. & 9 & ָุ. & $\begin{array}{l}\overrightarrow{+} \\
\dot{+}\end{array}$ & ?ִ & $\bar{a}$ & $\begin{array}{l}0 \\
\text { in }\end{array}$ & 宫 & $\overrightarrow{6}$ & $\vec{i}$ & i. & $\begin{array}{l}\infty \\
\dot{n}\end{array}$ & $m$ & $\overline{0}$ & $\underset{\infty}{N}$ & $\stackrel{\Delta}{\Xi}$ & ì & $\stackrel{\text { I }}{=}$ & $\begin{array}{l}\infty \\
\stackrel{a}{a}\end{array}$ & $\stackrel{?}{ \pm}$ & ?) & $\begin{array}{l}\text { ma. } \\
\dot{q}\end{array}$ & $\begin{array}{l}0 \\
\subseteq\end{array}$ & $\stackrel{n}{n}$ \\
\hline 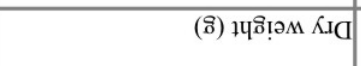 & लें & ले. & mi & $\begin{array}{cc}\dot{y} \\
\dot{q} \\
\dot{q}\end{array}$ & $\begin{array}{c}\dot{f} \\
\dot{f}\end{array}$ & $\widehat{\hat{q}}$ & $\begin{array}{ll}n \\
\tilde{m} \\
\end{array}$ & $\stackrel{\circ}{+}$ & $\begin{array}{ll}n \\
\tilde{q} \\
\tilde{q}\end{array}$ & 官 & $\overline{\mathrm{q}}$ & $\begin{array}{ll}n \\
q \\
q\end{array}$ & m. & $\stackrel{\circ}{+}$ & ஸे & $\stackrel{n}{y}$ & mें & $\begin{array}{ll}\infty \\
\text { लें }\end{array}$ & 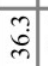 & $\overrightarrow{\dot{q}}$ & $\begin{array}{l}\text { İ } \\
\text { f }\end{array}$ & $\vec{y}$ & $\begin{array}{l}\circ \\
\dot{\leftrightarrow} \\
\text { in }\end{array}$ & ?̧ & $\stackrel{n}{n}$ \\
\hline рәуоч & $\stackrel{8}{-}$ & 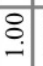 & $\frac{m}{0}$ & ְ̊. & $\begin{array}{l}\tilde{3} \\
\stackrel{2}{0}\end{array}$ & $\hat{O}$ & $\begin{array}{l}0 \\
0 \\
0\end{array}$ & $\bar{?}$ & $\begin{array}{l}0 \\
\stackrel{2}{0} \\
0\end{array}$ & $\tilde{O}$ & $\begin{array}{l}\tilde{O} \\
0 \\
0\end{array}$ & $\tilde{O}$ & $\stackrel{1}{\circ}$ & o. & $\frac{\infty}{0}$ & $\stackrel{n}{2}$ & 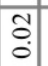 & $\begin{array}{l}\mathrm{S} \\
0 \\
0\end{array}$ & 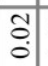 & $\tilde{O}$ & $\stackrel{\tilde{O}}{\circ}$ & $\begin{array}{l}\tilde{3} \\
0 \\
0\end{array}$ & $\begin{array}{l}\text { tu } \\
\text { Oे }\end{array}$ & $\stackrel{3}{0}$ & $\stackrel{+}{\circ}$ \\
\hline 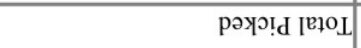 & 0 & 0 & 0 & 0 & 0 & - & 0 & $\overline{\mathrm{I}}$ & $\stackrel{\overbrace{}}{2}$ & $\tilde{n}$ & $\underset{\mathbb{N}}{\mathbb{N}}$ & $\Xi$ & 8 & $\hat{0}$ & సे & $\tilde{\varepsilon}$ & 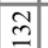 & $\stackrel{\infty}{\varrho}$ & 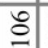 & 尺े & กี & $\overrightarrow{\mathrm{c}}$ & 守 & $\bar{\Xi}$ & $\hat{\Xi}$ \\
\hline .әчюО & 0 & o & 0 & o & o & - & 0 & 0 & 0 & - & 0 & 4 & 0 & 0 & $m$ & $m$ & $\mathrm{a}$ & 0 & 0 & 0 & 0 & - & 0 & $\theta$ & - \\
\hline dds puin! & 0 & o & 0 & o & o & 0 & 0 & 0 & 0 & 0 & 0 & o & 0 & 0 & 0 & 0 & 0 & 0 & 0 & 0 & 0 & - & o & $\mathrm{a}$ & 0 \\
\hline 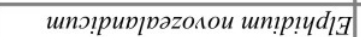 & 0 & o & o & o & 0 & 0 & 0 & 0 & 0 & 0 & 0 & o & 0 & o & 0 & 0 & o & 0 & 0 & 0 & 0 & - & 0 & 0 & 0 \\
\hline dds vu!u! $\mid$ ng & 0 & 0 & 0 & 0 & 0 & 0 & 0 & 0 & 0 & 0 & 0 & 0 & 0 & 0 & 0 & 0 & 0 & 0 & 0 & 0 & 0 & 0 & - & 0 & - \\
\hline ораи ри!юо & 0 & 0 & 0 & 0 & o & 0 & 0 & 0 & 0 & 0 & 0 & o & 0 & 0 & 0 & 0 & 0 & 0 & 0 & 0 & 0 & 0 & 0 & 0 & 0 \\
\hline dds p! & 0 & 0 & o & 0 & 0 & 0 & 0 & 0 & 0 & 0 & 0 & o & 0 & 0 & 0 & 0 & 0 & 0 & 0 & 0 & 0 & - & o & 0 & 0 \\
\hline әsиәпор.ирчо ип!р!ч & 0 & 0 & 0 & 0 & 0 & 0 & 0 & 0 & 0 & - & 0 & 0 & 0 & o & 0 & 0 & 0 & 0 & 0 & 0 & 0 & 0 & - & 0 & 0 \\
\hline рұпичи ри!! & 0 & 0 & 0 & o & 0 & 0 & 0 & 0 & 0 & 0 & 0 & o & 0 & 0 & 0 & 0 & 0 & 0 & 0 & 0 & 0 & 0 & 0 & 0 & 0 \\
\hline 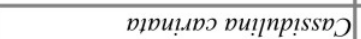 & 0 & 0 & 0 & o & 0 & 0 & 0 & 0 & 0 & 0 & 0 & o & 0 & 0 & 0 & 0 & 0 & 0 & 0 & 0 & 0 & 0 & - & 0 & 0 \\
\hline s.ıpds!p səp!ฺ!q!D & 0 & 0 & 0 & 0 & 0 & 0 & 0 & 0 & o & 0 & 0 & 0 & 0 & 0 & 0 & 0 & 0 & 0 & 0 & 0 & 0 & 0 & o & 0 & 0 \\
\hline 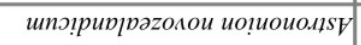 & 0 & 0 & 0 & 0 & 0 & 0 & 0 & 0 & 0 & 0 & 0 & 0 & 0 & 0 & 0 & 0 & 0 & 0 & $\circ$ & 0 & 0 & 0 & 0 & 0 & 0 \\
\hline 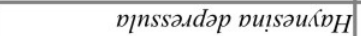 & 0 & 0 & 0 & 0 & 0 & 0 & 0 & 0 & $a$ & 6 & $\mathrm{~N}$ & 0 & 0 & 0 & - & $a$ & 0 & 0 & 0 & 0 & 0 & 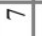 & 0 & 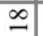 & 0 \\
\hline ипџрАвวхх ип!р!ч $d_{l G}$ & 0 & 0 & 0 & 0 & 0 & 0 & 0 & $a$ & $?$ & in & i & ले & q & $\overline{\mathrm{N}}$ & $\infty$ & मे & $=$ & $n$ & r & $\infty$ & $\simeq$ & Z & $\simeq$ & के & m \\
\hline рирәюо ричочич & 0 & 0 & 0 & 0 & 0 & 0 & 0 & $\cong$ & సి & \& & \& & $?$ & 8 & $\infty$ & ร & $\stackrel{\vartheta}{\beth}$ & $\stackrel{9}{=}$ & $\tilde{\varrho}$ & ন & $\cong$ & $\stackrel{ \pm}{m}$ & ఫ్రి & & $\infty$ & $\infty$ \\
\hline 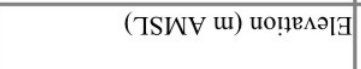 & $\begin{array}{l}0 \\
0 \\
0\end{array}$ & $\hat{\alpha}$ & $\begin{array}{l}\text { ț } \\
\text { a }\end{array}$ & $a$ & ఫे & $\begin{array}{l}\mathscr{n}^{2} \\
\infty\end{array}$ & $\begin{array}{l}0 \\
\infty \\
\infty \\
\infty\end{array}$ & $\stackrel{\circ}{\circ}$ & ?ִ & $\stackrel{n}{?}$ & $\begin{array}{l}\infty \\
\stackrel{2}{0}\end{array}$ & $\begin{array}{l}\bar{\infty} \\
\dot{\phi}\end{array}$ & $\begin{array}{l}n \\
\hat{\sigma}\end{array}$ & $\hat{\sigma}$ & $\begin{array}{l}7 \\
\dot{b}\end{array}$ & $\frac{\infty}{6}$ & $\begin{array}{l}\delta \\
\text { nे }\end{array}$ & $\begin{array}{l}\infty \\
\stackrel{\infty}{r} \\
\dot{n}\end{array}$ & $\begin{array}{l}\mathbb{A} \\
\dot{n}\end{array}$ & $\begin{array}{l}t+ \\
\dot{b}\end{array}$ & $\begin{array}{l}\infty \\
n \\
n \\
n\end{array}$ & $\begin{array}{l}\overline{7} \\
\dot{n}\end{array}$ & $\begin{array}{l}\text { กิ } \\
\text { n. }\end{array}$ & $\begin{array}{l}8 \\
\text { in }\end{array}$ & 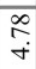 \\
\hline & $\bar{q}$ & & $\overline{\underline{m}}$ & & $\underline{\underline{m}}$ & & $\overline{\underline{m}}$ & & $\bar{\infty}$ & & $\bar{m}$ & & $\overline{\underline{⿴ 囗}}$ & $\overline{\underline{M}}$ & $\overline{\underline{\theta}}$ & $\overline{\underline{9}}$ & $\overline{\underline{\theta}}$ & $\overline{\underline{9}}$ & $\overline{\underline{x}}$ & $\overline{\underline{x}}$ & $\overline{\underline{9}}$ & $\overline{\underline{9}}$ & & $\overline{\underline{\theta}}$ & \\
\hline
\end{tabular}




\begin{tabular}{|c|c|c|c|c|c|c|c|c|c|c|c|c|c|c|c|c|c|c|c|c|c|c|c|c|c|}
\hline 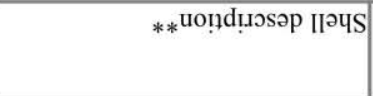 & 生 & & & & & 生 & & & 红 & 红 & & & & & & & & 里 & & & 红 & 生 & & & \\
\hline 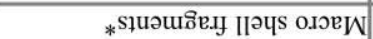 & - & 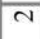 & - & 0 & 0 & - & - & 0 & - & - & 0 & - & - & - & 0 & 0 & 0 & - & 0 & 0 & - & $\mathrm{N}$ & - & c & 0 \\
\hline 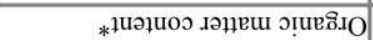 & - & - & 0 & 0 & 0 & 0 & - & - & 0 & - & 0 & - & - & - & - & - & - & $\pi$ & $N$ & N & 0 & $N$ & 0 & - & 0 \\
\hline * Słsej0 әuоłspnW & 0 & 0 & 0 & 0 & 0 & - & 0 & 0 & 0 & 0 & 0 & 0 & 0 & 0 & 0 & 0 & 0 & 0 & 0 & 0 & 0 & 0 & 0 & c & 0 \\
\hline 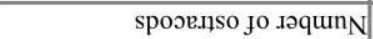 & กี & $\overline{7}$ & $\underline{n}$ & $\simeq$ & I & ஸे & 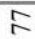 & 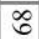 & 兄 & $n$ & gे & ㄱ. & ஓे & กี & 0 & n & \& & 0 & g & $\stackrel{\infty}{+}$ & $\frac{4}{4}$ & $\bar{a}$ & $m$ & - & \\
\hline so!lyue[d fo .ə⿱亠䒑) & $\nabla$ & $\Xi$ & $m$ & $\underset{N}{\sim}$ & $\stackrel{\sim}{\sim}$ & $\simeq$ & $n$ & \pm & $\nabla$ & $\pi$ & $r$ & $\infty$ & t & $r$ & 0 & m & - & 0 & 0 & 0 & - & 0 & & & $n$ \\
\hline 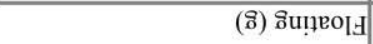 & & & $\hat{a}$ & $\overline{0}$ & & & & & & & & & & & & & & & & & & & & & \\
\hline 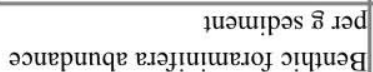 & $\stackrel{\nabla}{r}$ & $\frac{1}{i}$ & ช্ & $\stackrel{m}{\infty}$ & $\begin{array}{l}\infty \\
\infty \\
\infty\end{array}$ & $\stackrel{n}{n}$ & $\stackrel{m}{m}$ & 官 & ஸे & $\stackrel{0}{+}$ & $\vec{n}$ & $\stackrel{0}{i}$ & $\stackrel{\infty}{\infty}$ & ri & $\begin{array}{l}0 \\
\infty \\
+\end{array}$ & $\stackrel{m}{7}$ & ?ำ & $\stackrel{+}{\circ}$ & $\frac{2}{6}$ & i & $\underset{m}{m}$ & $\stackrel{-}{i}$ & $\dot{g}$ & m & $\stackrel{+}{+}$ \\
\hline (suoıo!̣u $\varepsilon 9<\%$ ) pues $\%$ & ठृं & ஓ̊ & $\grave{\infty}^{\circ}$ & iे & ठั & $\dot{i}_{0}^{\circ}$ & iे & $\grave{j}^{\circ}$ & $\dot{i n}^{0}$ & $\stackrel{\text { ஜे }}{\vartheta}$ & $\frac{\partial^{\circ}}{n}$ & $\dot{i}^{\circ}$ & $\frac{\partial}{2}$ & ֻें & $8^{\circ}$ & in & $\grave{\infty}^{\circ}$ & $\stackrel{\circ}{\circ}$ & $\stackrel{\circ}{\circ}$ & $\stackrel{\circ}{\circ}$ & $\stackrel{+}{\circ}^{\circ}$ & $\grave{\infty}^{\circ}$ & $\stackrel{\circ}{ٍ}$ & $\stackrel{\partial}{I}$ & ํํํ \\
\hline 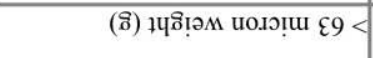 & กุ. & 咅 & 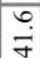 & $\stackrel{9}{2}$ & $\frac{n}{n}$ & $\frac{\text { d }}{2}$ & $\stackrel{\circ}{\circ}$ & $\stackrel{ \pm}{\Xi}$ & $\stackrel{n}{\simeq}$ & $\underset{0}{\infty}$ & $\stackrel{\infty}{a}$ & $\stackrel{0}{9}$ & $\stackrel{?}{=}$ & $\vec{g}$ & $\hat{\imath}$ & $\stackrel{\infty}{-}$ & $\stackrel{+}{i}$ & $\stackrel{\simeq}{-}$ & o. & $\stackrel{\infty}{\infty}$ & $\stackrel{?}{=}$ & $\stackrel{\infty}{i}$ & mे & $\hat{\imath}$ & 2 \\
\hline (ฮ) $)$ & $\underset{\mathfrak{y}}{\stackrel{\sim}{f}}$ & 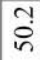 & $\overrightarrow{i n}$ & m & ते & ชู & $\begin{array}{l}\nabla \\
i n\end{array}$ & $\begin{array}{l}0 \\
\dot{\infty} \\
m\end{array}$ & $\vec{m}$ & $\stackrel{m}{m}$ & $\vec{a}$ & $\begin{array}{l}\infty \\
\dot{\gamma} \\
\dot{q}\end{array}$ & $\begin{array}{l}0 \\
\text { nn }\end{array}$ & $\begin{array}{l}0 \\
\infty \\
\infty\end{array}$ & $\overrightarrow{\mathrm{m}}$ & I & $\frac{\infty}{m}$ & $\frac{2}{n}$ & $\stackrel{m}{\infty}$ & $\stackrel{\infty}{\mathfrak{j}}$ & $\underset{m}{\infty}$ & $\underset{m}{\infty}$ & $\underset{⿱ 亠}{+}$ & $\exists$ & $\begin{array}{l}\sigma \\
y \\
y\end{array}$ \\
\hline 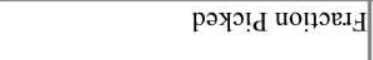 & $\begin{array}{l}\dot{J} \\
\dot{0}\end{array}$ & $\stackrel{1}{0}$ & $\frac{ \pm}{0}$ & $\stackrel{\infty}{\sim}$ & $\stackrel{3}{0}$ & $\begin{array}{l}n \\
0\end{array}$ & $\stackrel{\circ}{\circ}$ & $\begin{array}{l}\circ \\
0 \\
0\end{array}$ & $\overline{0}$ & $\stackrel{0}{\circ}$ & $=$ & $\stackrel{n}{0}$ & $\stackrel{\text { @o }}{0}$ & $\stackrel{0}{0}$ & $\stackrel{0}{0}$ & 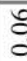 & $\stackrel{0}{0}$ & $\stackrel{0}{\varrho}$ & $\stackrel{0}{\circ}$ & 8 & $\frac{m}{0}$ & กิ & $\stackrel{\overbrace{}}{0}$ & 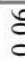 & กิ \\
\hline 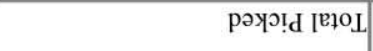 & ิㅡ & $\cong$ & $\stackrel{m}{m}$ & $\underline{6}$ & $\infty$ & $\equiv$ & $\dddot{n}$ & $\stackrel{ }{=}$ & $\stackrel{0}{=}$ & $\stackrel{\infty}{\circ}$ & $\Xi$ & $\stackrel{0}{=}$ & $\mathfrak{n}$ & $\stackrel{\infty}{=}$ & $\stackrel{\infty}{=}$ & g & 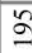 & $\stackrel{\infty}{\sim}$ & $\stackrel{n}{\sim}$ & 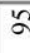 & $\Xi$ & $\stackrel{\infty}{\circ}$ & $\underline{-}$ & $\cong$ & $\stackrel{\infty}{\infty}$ \\
\hline ЈәчнО & $m$ & 0 & $=$ & 0 & $n$ & $N$ & $\mathrm{~N}$ & $m$ & 一 & $m$ & $\infty$ & - & 0 & $\mathrm{~N}$ & - & 0 & 0 & o & 0 & $N$ & 0 & 0 & $\mathrm{~N}$ & ce & o \\
\hline dds vu!ı!log & 0 & 0 & - & 0 & 0 & 0 & 0 & 0 & 0 & 0 & 0 & 0 & 0 & - & 0 & o & 0 & o & 0 & 0 & 0 & 0 & 0 & c & 0 \\
\hline ипю!рир|рәzолои ип!р!чd] & 0 & 0 & - & 0 & 0 & 0 & 0 & 0 & 0 & 0 & 0 & 0 & 0 & 0 & 0 & o & 0 & 0 & 0 & 0 & 0 & 0 & 0 & cor & 0 \\
\hline dds рuпи! $n g$ & 0 & 0 & a & $a$ & 0 & 0 & $N$ & - & 0 & - & - & 0 & 0 & $N$ & 0 & o & 0 & o & 0 & 0 & 0 & 0 & 0 & $c$ & 0 \\
\hline ораи ви! & 0 & - & 0 & - & 0 & 0 & 0 & 0 & 0 & 0 & 0 & 0 & 0 & 0 & 0 & 0 & 0 & 0 & 0 & 0 & 0 & 0 & 0 & $c$ & 0 \\
\hline dds p! pıоноо $N$ & 0 & $N$ & $N$ & $N$ & $N$ & 0 & 0 & 0 & - & - & - & $N$ & 0 & 二 & 0 & 0 & 0 & 0 & 0 & 0 & 0 & 0 & 0 & c & 0 \\
\hline әsиәпо..ıур ип!р!чd]马 & 0 & 0 & $N$ & 0 & $m$ & 0 & 0 & - & 0 & 0 & 0 & 0 & 0 & 0 & 0 & 0 & o & 0 & 0 & 0 & 0 & 0 & 0 & $c$ & 0 \\
\hline рұпи!и ри!пр!ssрวоqоро & 0 & 0 & 0 & 0 & - & 0 & 0 & 0 & 0 & 0 & 0 & 0 & 0 & 0 & 0 & o & 0 & 0 & 0 & 0 & 0 & 0 & 0 & $c$ & 0 \\
\hline 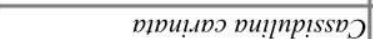 & 0 & $\theta$ & 0 & $\mathrm{~N}$ & - & 0 & $m$ & 0 & $m$ & $\mathrm{~N}$ & 0 & - & 0 & - & - & 0 & 0 & 0 & 0 & 0 & 0 & 0 & 0 & $c$ & 0 \\
\hline s.ıpds!p sap!ฺ!q!ว & 0 & - & $\alpha$ & 0 & $\pi$ & 0 & 0 & 0 & 0 & 0 & 0 & 0 & 0 & 0 & 0 & o & 0 & 0 & 0 & 0 & 0 & 0 & 0 & 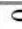 & 0 \\
\hline 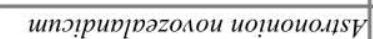 & 0 & 0 & 0 & 0 & 0 & 0 & 0 & 0 & 0 & 0 & 0 & 0 & 0 & 0 & 0 & 0 & 0 & o & 0 & 0 & 0 & 0 & 0 & ce & 0 \\
\hline рцпssдидар ричsәикри & 0 & - & 0 & 0 & 0 & $m$ & in & 0 & 0 & 0 & $N$ & 0 & - & $n$ & - & - & 0 & $m$ & $m$ & 0 & 0 & $\mathrm{~N}$ & 0 & 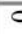 & 0 \\
\hline ипџрирวха ип!р!чd!马 & $\Xi$ & in & 点 & g & $\underline{0}$ & io & g & $\begin{array}{l}\text { d } \\
0\end{array}$ & $\stackrel{m}{\forall}$ & $\tilde{\sim}$ & $\stackrel{\infty}{\sim}$ & $\stackrel{+}{\Delta}$ & \& & $\bar{n}$ & ה & $\stackrel{\infty}{\sim}$ & $\underset{+}{+}$ & d & 2 & m & $\stackrel{m}{q}$ & $\stackrel{\sim}{\sim}$ & $\stackrel{\sim}{\sim}$ & $=$ & $\tilde{6}$ \\
\hline рирәюо р!иочии & 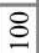 & $\hat{6}$ & $\stackrel{\infty}{\sim}$ & $\stackrel{\infty}{\circ}$ & in & ஜ & 咅 & $n$ & $\infty$ & $\stackrel{\infty}{\infty}$ & $\bar{R}$ & $\infty$ & \& & $n$ & $\infty$ & $\equiv$ & 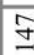 & $\sqrt{2}$ & $\mathscr{\infty}$ & in & $\infty$ & $\stackrel{\infty}{\sim}$ & 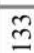 & g & $\tilde{c}$ \\
\hline ( TSWV u) ио!ฺє & $\begin{array}{l}\infty \\
\stackrel{v}{+}\end{array}$ & خे & $\begin{array}{l}\bar{\sigma} \\
\dot{\gamma}\end{array}$ & $\begin{array}{l}\mathscr{N} \\
\text { ri }\end{array}$ & $\underset{\sim}{\sigma}$ & $\underset{\sim}{\stackrel{\sim}{+}}$ & $\frac{\circ}{m}$ & $\begin{array}{l}\infty \\
\infty \\
i\end{array}$ & $\begin{array}{l}\hat{b} \\
\text { i }\end{array}$ & in & กี & $\stackrel{n}{\stackrel{n}{*}}$ & $\frac{d}{d}$ & $\stackrel{\infty}{\infty}$ & $\mathbb{J}$ & $n$ & ปิ & 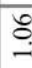 & $\begin{array}{l}\infty \\
\infty \\
0\end{array}$ & o & $\stackrel{\infty}{+}$ & గొ & $\frac{5}{0}$ & c & $\begin{array}{l}2 \\
\text { 尺े }\end{array}$ \\
\hline & $\underline{\underline{x}}$ & $\overline{\underline{\theta}}$ & $\overline{\underline{m}}$ & $\underline{\underline{\underline{I}}}$ & $\underline{\underline{\underline{I}}}$ & $\overline{\underline{\theta}}$ & $\underline{\underline{\theta}}$ & $\underline{\underline{x}}$ & $\bar{\vartheta}$ & $\overline{\underline{m}}$ & $\overrightarrow{\underline{\theta}}$ & $\bar{\vartheta}$ & $\bar{\emptyset}$ & $\bar{\vartheta}$ & $\underline{m}$ & $\underline{m}$ & $\underline{m}$ & $\bar{q}$ & $\bar{m}$ & $\bar{q}$ & $\bar{\oplus}$ & $\overrightarrow{\underline{x}}$ & $\overrightarrow{\underline{\theta}}$ & 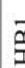 & $\overline{\underline{\theta}}$ \\
\hline
\end{tabular}




\begin{tabular}{|c|c|c|c|c|c|c|c|c|c|c|c|c|c|c|c|c|c|c|c|c|c|c|c|c|c|}
\hline **uo!̣d!̣ısəp IIәपS & & & & & & & & & & & & & & & & $\infty$ & 生 & $\infty$ & $\infty$ & n & in & $\begin{array}{l}\frac{\omega}{\infty} \\
\frac{1}{n}\end{array}$ & & & \\
\hline 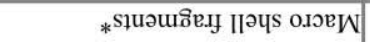 & 0 & 0 & 0 & 0 & 0 & 0 & 0 & 0 & 0 & 0 & 0 & 0 & $N$ & - & 0 & - & - & - & - & - & - & - & - & - & - \\
\hline 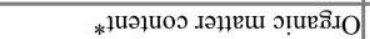 & $N$ & 0 & 0 & 0 & 0 & 0 & 0 & 0 & 0 & - & $N$ & $N$ & - & - & $N$ & - & 0 & - & 0 & 0 & 0 & 0 & 0 & 0 & 0 \\
\hline * S1sejo әuоıspnW & 0 & & & & & & & & & & & & & & & & & & & & & & & & \\
\hline 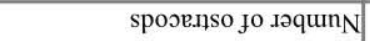 & - & & & & & & & & & - & & & & $\nabla$ & $\infty$ & $N$ & $a$ & $\Xi$ & $n$ & $m$ & 0 & 6 & $\hat{\sim}$ & $\infty$ & $\stackrel{\sim}{\sim}$ \\
\hline 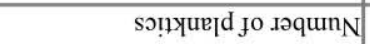 & & & & & & & & & & - & - & & $N$ & $m$ & $\nabla$ & $a$ & I & N & $a$ & $\underline{m}$ & 0 & $I$ & లి & $r$ & \pm \\
\hline 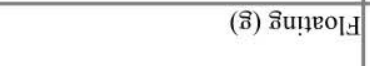 & $\begin{array}{l}\hat{0} \\
\dot{n}\end{array}$ & $\stackrel{\infty}{\stackrel{\sim}{+}}$ & $\stackrel{n}{\forall}$ & $\begin{array}{l}\tilde{\sigma} \\
\dot{\sigma}\end{array}$ & mे & $\stackrel{+}{\stackrel{+}{+}}$ & $\stackrel{8}{8}$ & $\underset{+}{\tilde{\sigma}}$ & $\begin{array}{l}\infty \\
\stackrel{0}{+} \\
+\end{array}$ & & & & & & & & 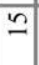 & & O̦ & $\frac{1}{6}$ & $=$ & 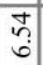 & $\underset{+}{\infty}$ & & \\
\hline 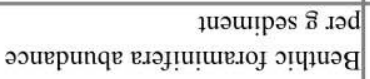 & ஸ̃ & $\stackrel{\circ}{\circ}$ & $\stackrel{0}{0}$ & $\stackrel{\circ}{0}$ & $\stackrel{\circ}{\circ}$ & $\stackrel{0}{0}$ & $\stackrel{\circ}{\circ}$ & $\stackrel{\circ}{\circ}$ & $\stackrel{\circ}{\circ}$ & $\frac{n}{m}$ & $\stackrel{0}{-}$ & $\stackrel{\infty}{5}$ & $\stackrel{n}{\tilde{n}}$ & ते & $\ddot{\infty}$ & กे & กู & 守 & กั & $\stackrel{0}{\infty}$ & $\stackrel{n}{=}$ & $\stackrel{\circ}{\dot{+}}$ & $\stackrel{+}{8}$ & $\vec{\infty}$ & $\begin{array}{l}\infty \\
\text { N } \\
-1\end{array}$ \\
\hline (suo.ı!̣u $\varepsilon 9<\%$ ) pues \% & $\frac{\partial^{\circ}}{m}$ & 官 & i̊ & bे & iे & 离 & தீ & ठें & ले & $\stackrel{\partial^{\circ}}{=}$ & ڤ̊ & $\stackrel{\circ}{\circ}$ & i̊ & $\frac{\partial^{0}}{\sim}$ & $\stackrel{\circ}{\circ}$ & ஸे & ๖̊ँ & ఫัర & ถัㅇํ & $\stackrel{\circ}{\square}$ & ฉั & $\begin{array}{l}\stackrel{0}{0} \\
\infty \\
\infty\end{array}$ & $\stackrel{\circ}{\stackrel{2}{人}}$ & ठ̊ํ & in \\
\hline 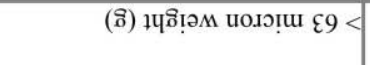 & I & $\stackrel{\infty}{\stackrel{\sim}{J}}$ & $\stackrel{9}{=}$ & ᄋ्். & ปี & $\begin{array}{l}0 \\
\text { ì }\end{array}$ & $\stackrel{n}{*}$ & $\begin{array}{l}0 \\
\dot{2}\end{array}$ & $\stackrel{\infty}{\dot{\Xi}}$ & ì & $\vec{m}$ & $\stackrel{\Upsilon}{\forall}$ & $\stackrel{?}{r}$ & $\stackrel{\infty}{a}$ & $\stackrel{\infty}{+}$ & $\stackrel{ \pm}{\stackrel{\Xi}{二}}$ & $\frac{\emptyset}{\bar{y}}$ & ָั & $\begin{array}{l}9 \\
\infty \\
\infty \\
m\end{array}$ & $\frac{0}{\dot{\gamma}}$ & mi & กิ่ & $\underset{m}{N}$ & $\frac{\pi}{\pi}$ & m \\
\hline 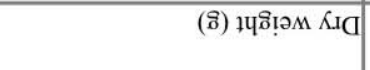 & $\begin{array}{l}\infty \\
\dot{0} \\
\wp\end{array}$ & $\hat{\mathrm{H}}$ & $\stackrel{テ}{\dot{\gamma}}$ & $\begin{array}{l}\dot{\gamma} \\
\dot{\gamma}\end{array}$ & $\begin{array}{l}\infty \\
\dot{j} \\
\text { ले }\end{array}$ & $\begin{array}{l}0 \\
\dot{f}\end{array}$ & vे & $\frac{0}{n}$ & $\overline{7}$ & $\stackrel{m}{\infty}$ & ஸे & $\begin{array}{l}\dot{v} \\
\dot{\gamma}\end{array}$ & $\frac{N}{\gamma}$ & $\vec{b}$ & ڤे & $\begin{array}{l}\stackrel{0}{0} \\
\dot{n}\end{array}$ & 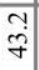 & $\begin{array}{l}0 \\
\dot{\sigma} \\
\nabla\end{array}$ & $\grave{\dot{q}}$ & $\stackrel{n}{\xi}$ & $\mid \begin{array}{l}\infty \\
\dot{0} \\
m\end{array}$ & $\stackrel{m}{m}$ & $\begin{array}{l}0 \\
\dot{\infty}\end{array}$ & $\begin{array}{l}\vec{b} \\
\dot{\sigma}\end{array}$ & $\stackrel{\vartheta}{\vartheta}$ \\
\hline 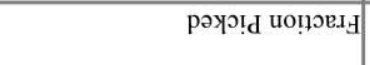 & $\stackrel{8}{\circ}$ & 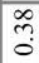 & $\begin{array}{l}\infty \\
\text { ma } \\
0\end{array}$ & 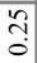 & సิ & กิ & กै & ָे & $\stackrel{m}{0}$ & $\begin{array}{l}\circ \\
0\end{array}$ & 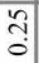 & $\stackrel{3}{0}$ & 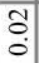 & 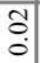 & $\frac{m}{0}$ & $\begin{array}{l}0 \\
\circ\end{array}$ & ?ొ & $\begin{array}{l}\overline{0} \\
0\end{array}$ & $\frac{m}{0}$ & $\frac{ \pm}{0}$ & $\frac{1}{0}$ & $\frac{I}{0}$ & $\frac{0}{0}$ & ¿. & రి \\
\hline рәуэч [в]оL & - & 0 & 0 & 0 & 0 & 0 & 0 & 0 & 0 & $\approx$ & $\Xi$ & 寺 & 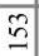 & $\underline{6}$ & $\hat{\circ}$ & 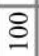 & 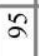 & กิ & กี & $\stackrel{m}{=}$ & 웅 & $\overline{\mathrm{N}}$ & $\underset{\sim}{\infty}$ & $\stackrel{+}{n}$ & $\stackrel{\sim}{\sim}$ \\
\hline .ІәчमО & 0 & 0 & 0 & 0 & 0 & 0 & 0 & 0 & 0 & 0 & 0 & 0 & 0 & - & 0 & 0 & $\hat{m}$ & $m$ & $\underline{2}$ & $\underset{\sim}{\infty}$ & 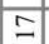 & 0 & 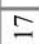 & - & $N$ \\
\hline dds рu!ฺ!log & 0 & 0 & 0 & 0 & 0 & 0 & 0 & 0 & 0 & 0 & 0 & 0 & 0 & 0 & 0 & 0 & 0 & 0 & 0 & 0 & 0 & $\simeq$ & 0 & 0 & 0 \\
\hline 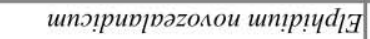 & 0 & 0 & 0 & 0 & 0 & 0 & 0 & 0 & 0 & 0 & 0 & 0 & 0 & 0 & 0 & 0 & 0 & 0 & 0 & 0 & 0 & 0 & 0 & 0 & 0 \\
\hline dds pu!̣u!̣ng & 0 & 0 & 0 & 0 & 0 & 0 & 0 & 0 & 0 & 0 & 0 & 0 & - & - & 0 & $\mathrm{~N}$ & $\cong$ & 0 & $\mathrm{~N}$ & 6 & $\infty$ & 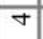 & $\infty$ & 0 & 0 \\
\hline орәи ричроО & 0 & 0 & 0 & 0 & 0 & 0 & 0 & 0 & 0 & 0 & 0 & 0 & 0 & 0 & 0 & 0 & 0 & 0 & 0 & 0 & 0 & 0 & 0 & 0 & 0 \\
\hline dds р! рұонооо & 0 & 0 & 0 & 0 & 0 & 0 & 0 & 0 & 0 & 0 & 0 & 0 & 0 & 0 & - & $N$ & $m$ & 0 & 0 & $\nabla$ & $\theta$ & $n$ & - & - & 0 \\
\hline 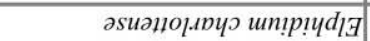 & 0 & 0 & 0 & 0 & 0 & 0 & 0 & 0 & 0 & 0 & 0 & 0 & 0 & 0 & 0 & $m$ & - & 0 & 0 & 0 & - & $N$ & 0 & 0 & 0 \\
\hline 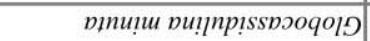 & 0 & 0 & 0 & 0 & 0 & 0 & 0 & 0 & 0 & 0 & 0 & 0 & 0 & 0 & 0 & 0 & 0 & 0 & 0 & 0 & 0 & 0 & 0 & 0 & 0 \\
\hline 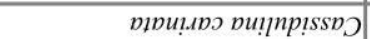 & 0 & 0 & 0 & 0 & 0 & 0 & 0 & 0 & 0 & 0 & 0 & 0 & 0 & 0 & 0 & 0 & 0 & 0 & 0 & 0 & 0 & 0 & 0 & 0 & 0 \\
\hline s.upds!p sap!)!q!ว & 0 & 0 & 0 & 0 & 0 & 0 & 0 & 0 & 0 & 0 & 0 & 0 & 0 & 0 & - & 0 & 0 & 0 & 0 & 0 & 0 & 0 & 0 & 0 & 0 \\
\hline ипэ!рирірәzолои иопиоиоия & 0 & 0 & 0 & 0 & 0 & 0 & 0 & 0 & 0 & 0 & 0 & 0 & 0 & 0 & - & 0 & $\theta$ & 0 & 0 & 0 & 0 & $\mathrm{~N}$ & 0 & 0 & 0 \\
\hline 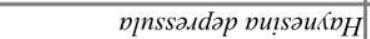 & 0 & 0 & 0 & 0 & 0 & 0 & 0 & 0 & 0 & 0 & 0 & 0 & 0 & 0 & $\mathrm{~N}$ & 0 & 0 & - & 0 & 0 & 0 & 0 & 0 & 0 & 0 \\
\hline ипџрムрวхә ип!р!чd & - & 0 & 0 & 0 & 0 & 0 & 0 & 0 & 0 & $a$ & $m$ & $\stackrel{\sim}{2}$ & $\stackrel{\Delta}{\sim}$ & $\Xi$ & $\vec{m}$ & $\hat{\sim}$ & - & 0 & - & $N$ & - & 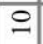 & $\bar{m}$ & $r$ & $\mathcal{N}$ \\
\hline рирәоор річочии & 0 & 0 & 0 & 0 & 0 & 0 & 0 & 0 & 0 & 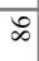 & $=$ & $\bar{\beth}$ & $\stackrel{\infty}{\simeq}$ & I & $\bar{\nabla}$ & 8 & 안 & ปี & $\stackrel{\sim}{\circ}$ & $\Re$ & ले & $\tilde{\infty}$ & $\stackrel{\mathscr{I}}{\mathrm{f}}$ & 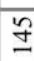 & $\stackrel{\infty}{=}$ \\
\hline (TSWV ш) иоџ̣е & $\begin{array}{c}\infty \\
? \\
i \\
i\end{array}$ & $\stackrel{\mathcal{I}}{\infty}$ & $\hat{a}$ & $\frac{⿱ 亠 䒑}{N}$ & 节 & $\stackrel{+}{\sim}$ & $\stackrel{ \pm}{N}$ & $\underset{\sigma}{\delta}$ & $\begin{array}{l}\infty \\
\dot{\infty}\end{array}$ & $\begin{array}{l}\infty \\
\dot{0} \\
i\end{array}$ & $\begin{array}{l}\text { กิ } \\
\text { ஸे }\end{array}$ & m. & $\underset{i}{\stackrel{i}{n}}$ & $\frac{\sim}{i}$ & $\hat{\sigma}$ & $\begin{array}{l}\dot{D} \\
\dot{\nabla}\end{array}$ & $\begin{array}{l}\mathbb{N} \\
\dot{+}\end{array}$ & $\begin{array}{l}0 \\
\dot{\nabla}\end{array}$ & $\begin{array}{l}\stackrel{g}{+} \\
\dot{f}\end{array}$ & $\begin{array}{l}\stackrel{Y}{+} \\
+\end{array}$ & กิ & 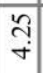 & $\stackrel{F}{\dot{T}}$ & $\bar{t}$ & \begin{tabular}{l}
$\delta$ \\
\multirow{+}{*}{}
\end{tabular} \\
\hline & $\underline{\underline{x}}$ & થิ & થิ & થิ & થิ & થิ & 㒸 & થิ & થิ & 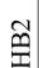 & શૈ & શૈ & શิ & $\tilde{\vartheta}$ & થิ & શૈ & $\stackrel{\cong}{\cong}$ & $\stackrel{\vartheta}{\Xi}$ & થิ & ભิ & 凤ี & $\stackrel{\cong}{\underline{I}}$ & થิ & 凤ี & થิ \\
\hline
\end{tabular}




\begin{tabular}{|c|c|c|c|c|c|c|c|c|c|c|c|c|c|c|c|c|}
\hline **uọ̣d!̣osəp I[ә्पS & & & & & 告 & & & & 㝳 & & & & 告 & & & \\
\hline 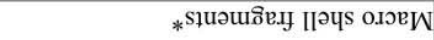 & 0 & - & 一 & - & - & - & 0 & 0 & - & - & - & - & $\sim$ & - & 0 & 0 \\
\hline 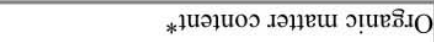 & - & - & 一 & 0 & 0 & - & 0 & - & - & - & - & $N$ & - & 0 & 0 & $N$ \\
\hline *S!SE[0 әuolspnW & & & & & & & & - & & & & & & & & \\
\hline spoor.tpso fo .raqun $\mathrm{N}$ & $=$ & i & $\underline{-2}$ & $\because$ & $\underline{0}$ & $\approx$ & ิㅡ & $\cong$ & 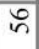 & ิ & $\bar{F}$ & ळे & 3 & $\infty$ & 고 & $n$ \\
\hline 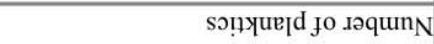 & 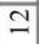 & $r$ & ป & $N$ & $N$ & $N$ & + & $N$ & - & $N$ & - & & - & - & 0 & - \\
\hline 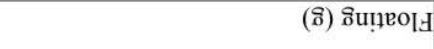 & & & & & & & & ڤ & ठे & & & & & & & \\
\hline 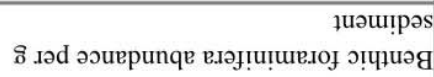 & $\stackrel{\text { ก̊ }}{\stackrel{2}{1}}$ & $\vec{\infty}$ & $\begin{array}{l}0 \\
\underline{1}\end{array}$ & $\begin{array}{l}9 \\
\infty \\
\infty\end{array}$ & $\underset{\sim}{\infty}$ & ๙ู & $\stackrel{?}{2}$ & $\stackrel{\circ}{\circ}$ & $\frac{N}{n}$ & กิ & নু & ָָ' & $\begin{array}{l}0 \\
\stackrel{q}{q}\end{array}$ & $\frac{\infty}{m}$ & $\frac{\sim}{\sim}$ & $\tilde{\mathrm{n}}$ \\
\hline (suo.sọu $\varepsilon 9<\%$ ) pues $\%$ & ํํํ & i̊ & 웜 & $\stackrel{\circ}{\infty}$ & $\stackrel{\stackrel{\circ}{+}}{\circ}$ & $\stackrel{\infty}{\infty}$ & $\stackrel{\circ}{\dot{y}}$ & $\grave{\delta}_{0}^{\circ}$ & $\frac{\partial^{0}}{\gamma}$ & : & $\stackrel{\circ}{\stackrel{2}{N}}$ & ठ̊ํ & $\stackrel{\varrho^{\circ}}{=}$ & ì & in & $8^{\circ}$ \\
\hline 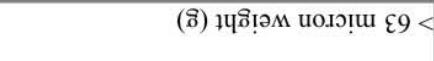 & ํ. & $\frac{N}{m}$ & $\overrightarrow{\mathrm{m}}$ & $\frac{N}{N}$ & $\stackrel{n}{\simeq}$ & $\hat{\infty}$ & ते & $\hat{\emptyset}$ & $\stackrel{\infty}{\infty}$ & $\stackrel{N}{=}$ & $\stackrel{n}{=}$ & $\begin{array}{l}0 \\
i\end{array}$ & $\vec{n}$ & nุ & กู & $\stackrel{\infty}{i}$ \\
\hline 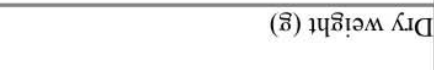 & 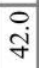 & $\frac{\bullet}{\gamma}$ & $\begin{array}{l}\dot{\theta} \\
\dot{q}\end{array}$ & 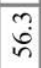 & $\begin{array}{c}\text { ㅇ. } \\
\text { nิ }\end{array}$ & $\stackrel{\circ}{g}$ & $\stackrel{\sim}{\circ}$ & 官 & $\begin{array}{l}0 \\
\dot{0} \\
\dot{\sigma}\end{array}$ & $\overrightarrow{⿱ 宀}$ & 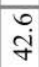 & $\begin{array}{l}\infty \\
\dot{q}\end{array}$ & $\begin{array}{l}\infty \\
\dot{\gamma} \\
\dot{\gamma}\end{array}$ & $\underset{\sim}{\infty}$ & $\ddot{m}$ & $\underset{g}{\dot{q}}$ \\
\hline рәуј! иоџ̣ю... & $\begin{array}{l}\overline{0} \\
\dot{0}\end{array}$ & @o & రి & $\stackrel{1}{0}$ & ö & 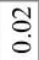 & ర్ & $\stackrel{8}{8}$ & $\stackrel{0}{\stackrel{0}{0}}$ & $\begin{array}{l}\infty \\
0 \\
0 \\
0\end{array}$ & $\hat{0}$ & $\stackrel{m}{0}$ & 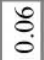 & $\stackrel{1}{0}$ & $\frac{m}{0}$ & $\frac{m}{0}$ \\
\hline рәуэ! [етоL & $\hat{\varrho}$ & $\hat{m}$ & $\stackrel{ }{=}$ & $\because$ & $\cong$ & ○ & $\stackrel{n}{n}$ & กิ & 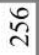 & $\Xi$ & $\tilde{I}$ & $\stackrel{3}{0}$ & $\stackrel{2}{ \pm}$ & 2 & $\cong$ & ले \\
\hline Іәч1О & 6 & 으 & $\stackrel{0}{-}$ & 0 & 0 & 一 & $m$ & - & - & 0 & 0 & $N$ & 0 & 0 & 0 & 0 \\
\hline dds pu!̣ı!log & 0 & 0 & 0 & 0 & 0 & 0 & 0 & 0 & 0 & 0 & 0 & 0 & 0 & 0 & 0 & 0 \\
\hline ипэ!риррраzояои ип!р!ч $d_{l \rightrightarrows}$ & 0 & 0 & 0 & 0 & 0 & 0 & 0 & 0 & 0 & 0 & 0 & 0 & 0 & 0 & 0 & 0 \\
\hline dds pu!nu! ng & 0 & 一 & $\nabla$ & 0 & 0 & 0 & 0 & 0 & 0 & 0 & 0 & - & 0 & 0 & 0 & 0 \\
\hline ораи ри! оо & 0 & 0 & 0 & 0 & 0 & 0 & 0 & 0 & 0 & 0 & 0 & 0 & 0 & 0 & 0 & 0 \\
\hline dds p! pıоцоцо N & 0 & $\theta$ & 0 & - & 0 & 0 & 0 & 0 & 0 & 0 & 0 & 0 & 0 & 0 & 0 & 0 \\
\hline әsиวнор.ичо ип!р!чd & - & - & - & - & 0 & 0 & 0 & 0 & 0 & 0 & 0 & 0 & 0 & 0 & - & 0 \\
\hline 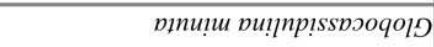 & 0 & 0 & 0 & 0 & 0 & 0 & 0 & 0 & 0 & 0 & 0 & 0 & 0 & 0 & 0 & 0 \\
\hline 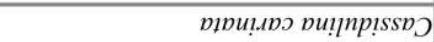 & 0 & 0 & 0 & 0 & 0 & 0 & 0 & 0 & 0 & 0 & 0 & 0 & 0 & 0 & 0 & 0 \\
\hline s.Inds!p sap!ว!q!ว & 0 & 0 & 0 & 0 & 0 & 0 & 0 & 0 & 0 & 0 & 0 & 0 & 0 & 0 & 0 & 0 \\
\hline ипэ!рираравонои ио!иоиомь & 0 & 0 & 0 & 0 & 0 & 0 & 0 & 0 & 0 & 0 & 0 & 0 & 0 & 0 & 0 & 0 \\
\hline ріпssалдар ри!sәикр & 0 & 0 & 0 & 0 & - & 0 & 0 & - & - & 0 & 0 & o & 0 & $m$ & - & $N$ \\
\hline ипџрАрэха ип!р!ч & $N$ & $\cong$ & 6 & 으 & \pm & 으 & $=$ & $\tilde{m}$ & $\stackrel{\Re}{q}$ & $r$ & $\Xi$ & $\tilde{m}$ & $\stackrel{\infty}{m}$ & is & ก & n \\
\hline рирдюор р!иочии & む & I & के & $\stackrel{+}{2}$ & 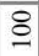 & $\curvearrowleft$ & 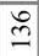 & $\frac{m}{2}$ & $\overline{\bar{N}}$ & $\stackrel{\Xi}{O}$ & ᄋ & $\tilde{6}$ & $\stackrel{\Xi}{\Xi}$ & ชี & $\bar{\infty}$ & $\dot{\infty}$ \\
\hline (TSWV ш) иоџенәә & $\begin{array}{l}2 \\
\infty \\
\text { ले }\end{array}$ & $\underset{\sim}{\stackrel{\infty}{r}}$ & $\begin{array}{l}\infty \\
\stackrel{n}{m} \\
m\end{array}$ & 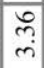 & $m$ & $\underset{\sim}{\stackrel{+}{N}}$ & $\frac{I}{m}$ & $\hat{\mathrm{c}}$ & $\stackrel{\partial}{i}$ & حิ & $\hat{i}$ & $\begin{array}{l}\text { तु } \\
\text { i }\end{array}$ & $\underset{i}{\mathbb{Z}}$ & $\begin{array}{c} \pm \\
\text { i }\end{array}$ & $\vec{i}$ & $\stackrel{+}{-}$ \\
\hline & $\stackrel{\vartheta}{\underline{\mid}}$ & ڤิ) & 㒸 & $\stackrel{\Re}{\Theta}$ & થิ & થี & 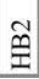 & થิ & શૈ & $\stackrel{\oplus}{\underline{\Xi}}$ & ભ & થิ & $\stackrel{\vartheta}{\Theta}$ & $\tilde{\Theta}$ & થิ & $\stackrel{થ}{\underline{I}}$ \\
\hline
\end{tabular}


Appendix 5.6: Hicks Bay core foraminifera data statistical correlation analysis.

Appendix 5.6.1: HB1 statistical correlations between foraminifera assemblages composition and physical properties of the sample.

\begin{tabular}{|l|r|r|r|r|r|r|}
\hline HB1 statistical correlations & & & & \\
\hline & \% A. aoteana & \% E. excavatum & \% all other & Abundance* & \% Sand \\
\hline \% A. aoteana & & 0.94 & 0.06 & $\mathbf{0 . 0 0}$ & 0.11 \\
\hline \% E. excavatum & -0.01 & & 0.43 & 0.63 & 0.87 \\
\hline \% all other & -0.27 & -0.11 & & 0.27 & 0.41 \\
\hline Abundance* & $\mathbf{0 . 5 9}$ & -0.07 & -0.16 & & 0.51 \\
\hline \% Sand & 0.22 & 0.02 & 0.12 & 0.09 & \\
\hline
\end{tabular}

Statistically significant correlation: increased $\%$ A. aoteana with increased foraminifera abundance.

Appendix 5.6.2: HB2 statistical correlations between foraminifera assemblages composition and physical properties of the sample.

\begin{tabular}{|l|r|r|r|r|r|r|}
\hline HB2 statistical correlations & & & & & \\
\hline & $\%$ A. aoteana & \% E. excavatum & \% all other & Abundance* & \% Sand \\
\hline \% A. aoteana & & 0.03 & 0.97 & $\mathbf{0 . 0 0}$ & 0.57 \\
\hline$\%$ E. excavatum & 0.35 & & 0.15 & 0.71 & $\mathbf{0 . 0 0}$ \\
\hline \% all other & 0.01 & -0.23 & & 0.20 & $\mathbf{0 . 0 0}$ \\
\hline Abundance* & $\mathbf{0 . 6 1}$ & -0.06 & -0.21 & & 0.69 \\
\hline$\%$ Sand & 0.09 & $\mathbf{- 0 . 5 8}$ & $\mathbf{0 . 7 0}$ & 0.07 & \\
\hline
\end{tabular}

Statistically significant correlation: increased \% Other with increased sand.

Statistically significant correlation: decreased \% E. excavatum with increased sand.

${ }^{1}$ Lower left corner values: Pearson's $r$, this describes the strength of correlation between two variables and whether the relationship is negative or positive. Upper right values: $\mathrm{P}$ value indicates the probability that the two variables are uncorrelated, correlations with $\mathrm{P}=>0.05$ are discounted from analysis, as there is an increased likelihood that the correlation is due to random effects.

* Abundance: number of benthic foraminifera per gram of dry sediment. 
Appendix 5.7: Scanning electron microscope images of representative foraminifera from Hicks Bay cores, HB1 and HB2. Species are identified where possible. The white bar in each image is a 100 micron scale.
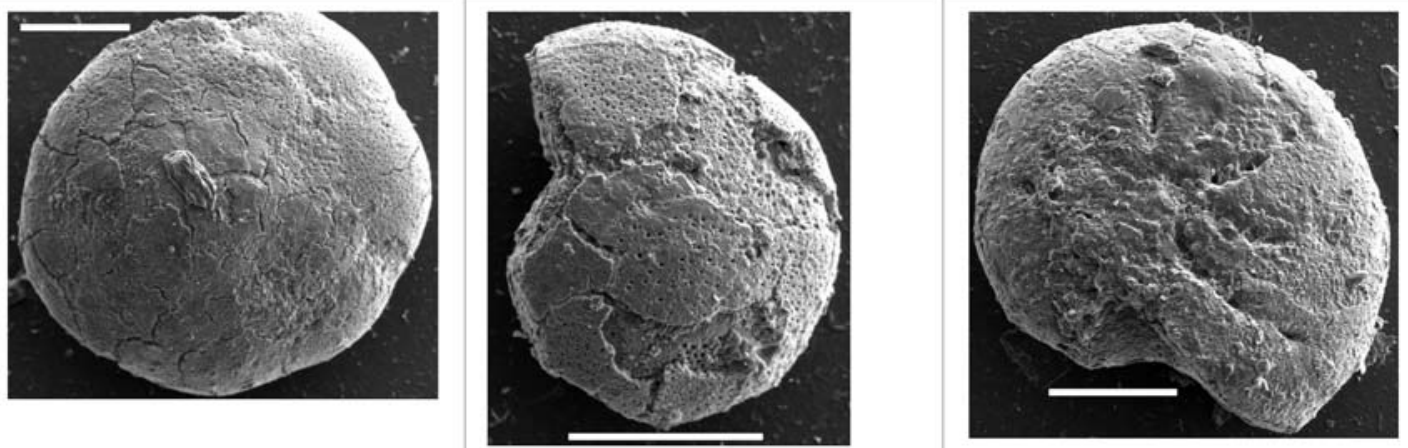

HB1/-0.22 m AMSL

A. aoetana $\mathrm{HB} 1 /-0.22 \mathrm{~m}$ AMSL

A. aoetana $\mathrm{HB} 1 /-0.22 \mathrm{~m}$ AMSL

A. aoetana
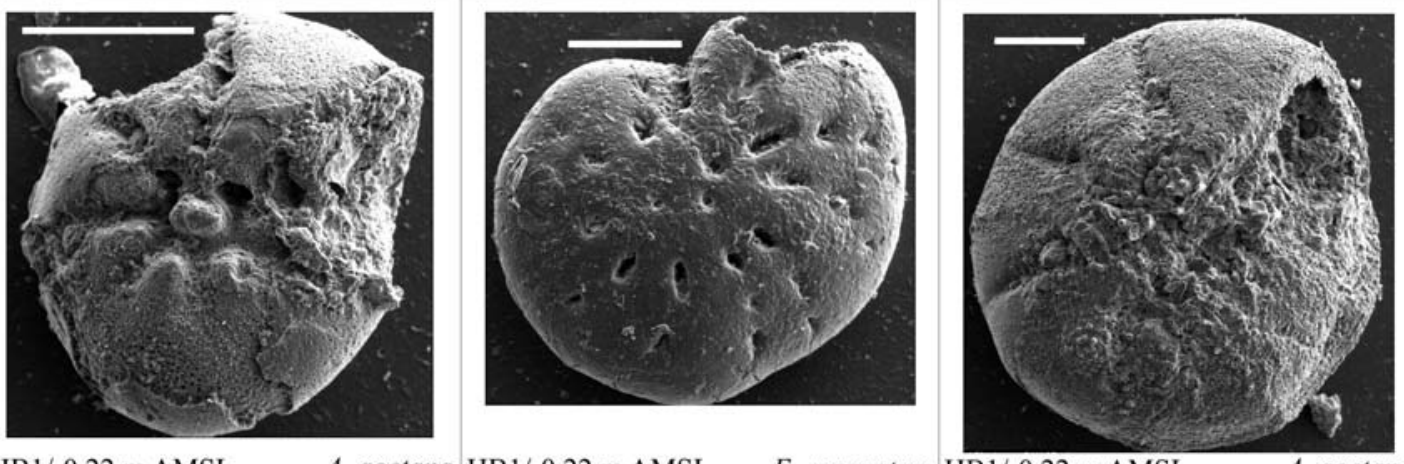

HB1/-0.22 m AMSL

A. aoetana $\mathrm{HB} 1 /-0.22 \mathrm{~m}$ AMSL

E. excavatum $\mathrm{HB1} /-0.22 \mathrm{~m}$ AMSL

A. aoetana
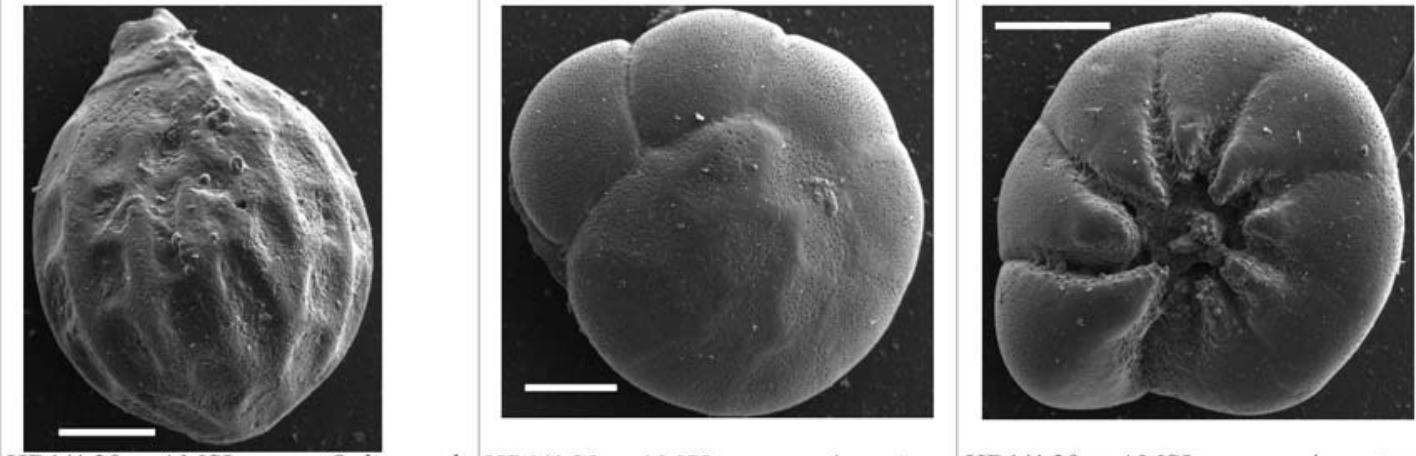

HB1/4.29 m AMSL

Oolina melo $\mathrm{HB} 1 / 4.29 \mathrm{~m}$ AMSL

A. aoetana $\mathrm{HB} 1 / 4.29 \mathrm{~m}$ AMSL

A. aoetana
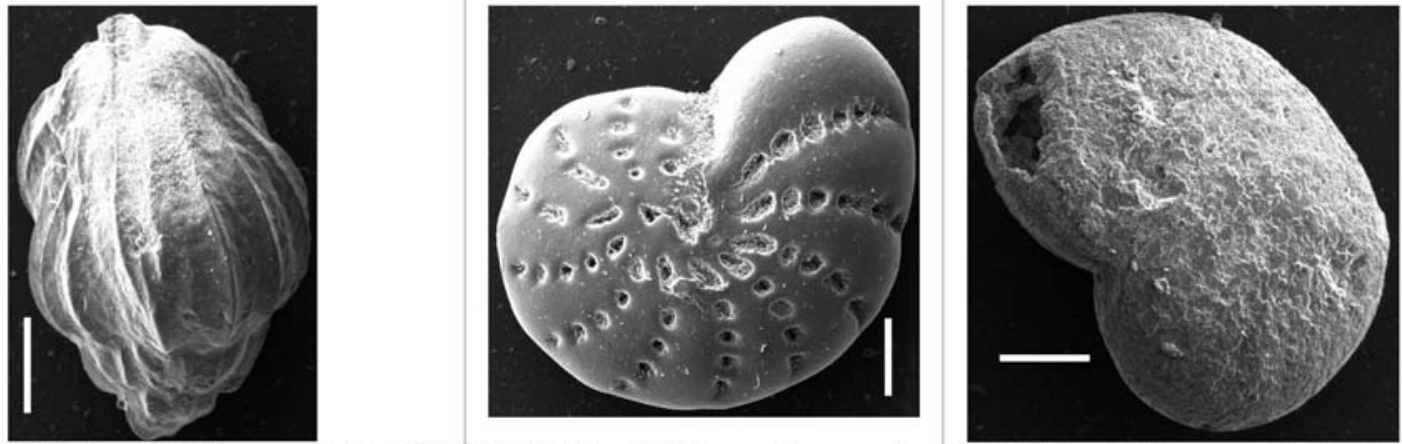

HB1/4.29 $m$ AMSL

Unidentified $\mathrm{HB} 1 / 4.29 \mathrm{~m}$ AMSL

E. excavatum $\mathrm{HB} 1 / 4.29 \mathrm{~m}$ AMSL

Unidentfied 


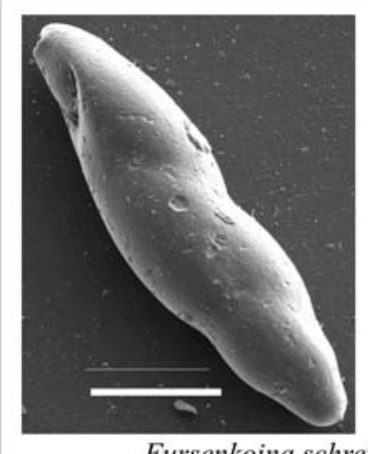

Fursenkoina schreibersiana HB1/5.06 m AMSL

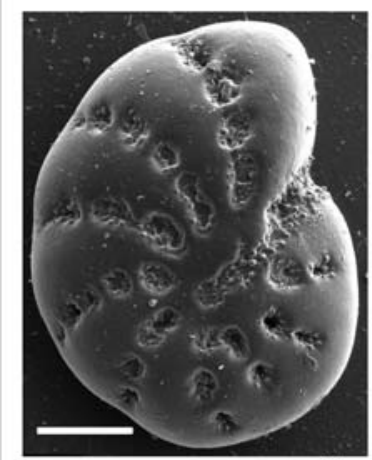

HB1/5.06 m AMSL

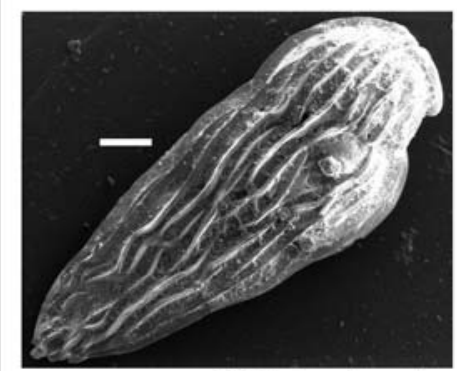

Saidovina karreriana

HB1/5.06 m AMSL

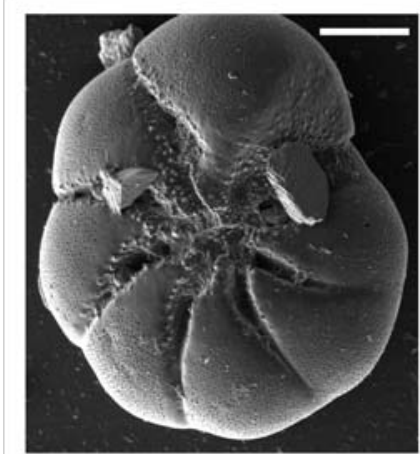

$\mathrm{HB} 1 / 5.78 \mathrm{~m}$ AMSL

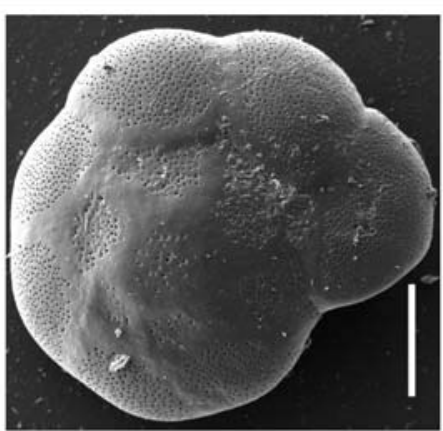

HB1/5.06 m AMSL

A. aoetana $\mathrm{HB} 1 / 5.06 \mathrm{~m}$ AMSL

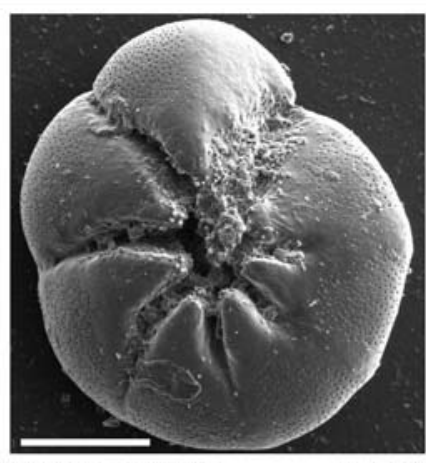

A. aoetana
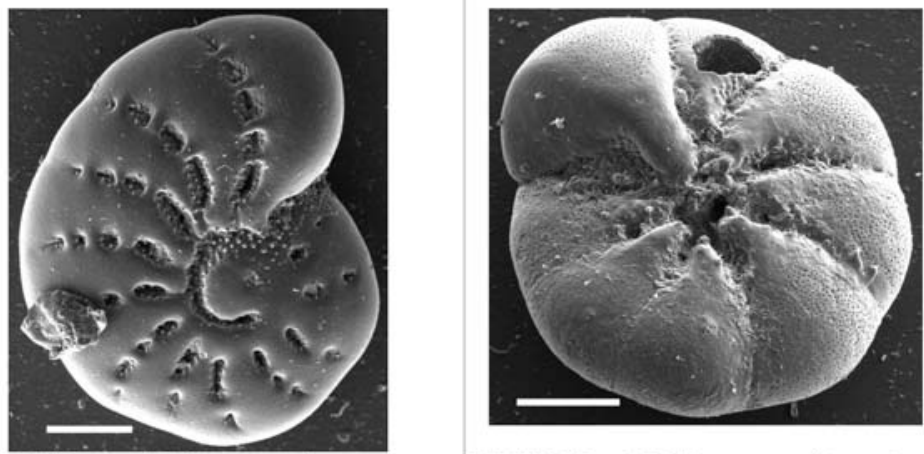

E. excavatum $\mathrm{HB} 1 / 5.06 \mathrm{~m}$ AMSL

A. aoetana

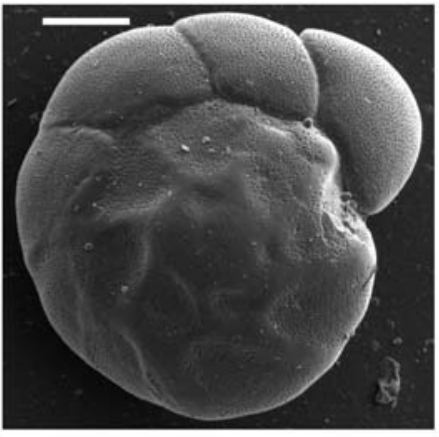

A. aoetana $\mathrm{HB} 1 / 5.78 \mathrm{~m} \mathrm{AMSL}$

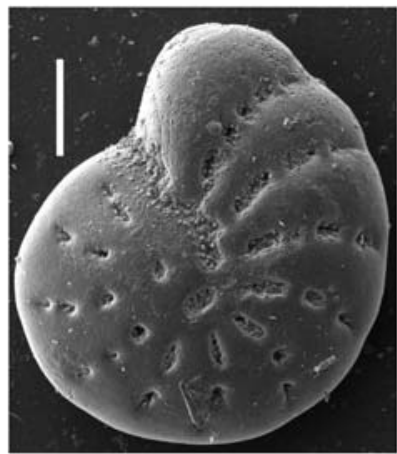

HB1/5.78 m AMSL

E. excavatum
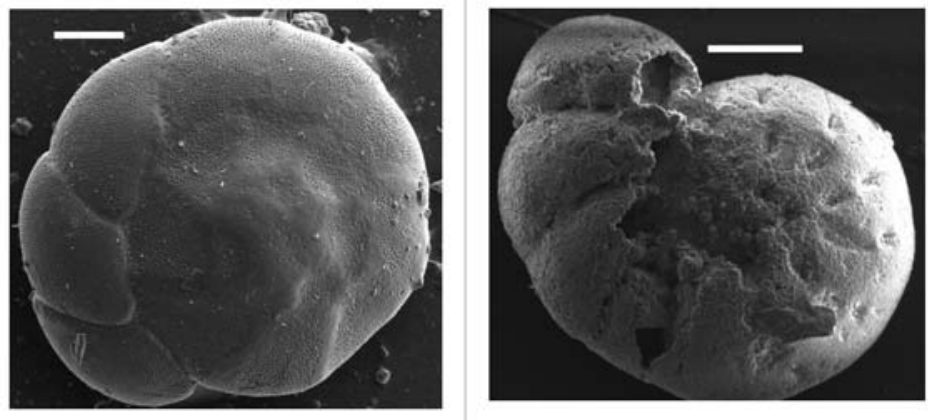

A. aoetana $\mathrm{HB} 1 / 7.96 \mathrm{~m}$ AMSL 

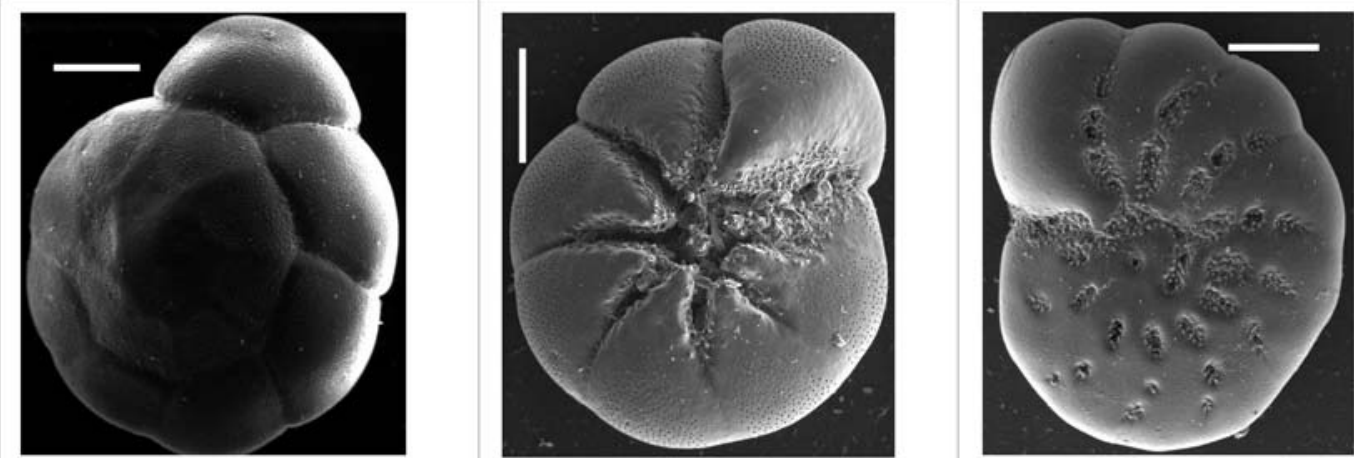

HB2/1.94 m AMSL

A. aoetana $\mathrm{HB} 2 / 1.94 \mathrm{~m}$ AMSL

A. aoetana $\mathrm{HB} 2 / 1.94 \mathrm{~m}$ AMSL

E. excavatum
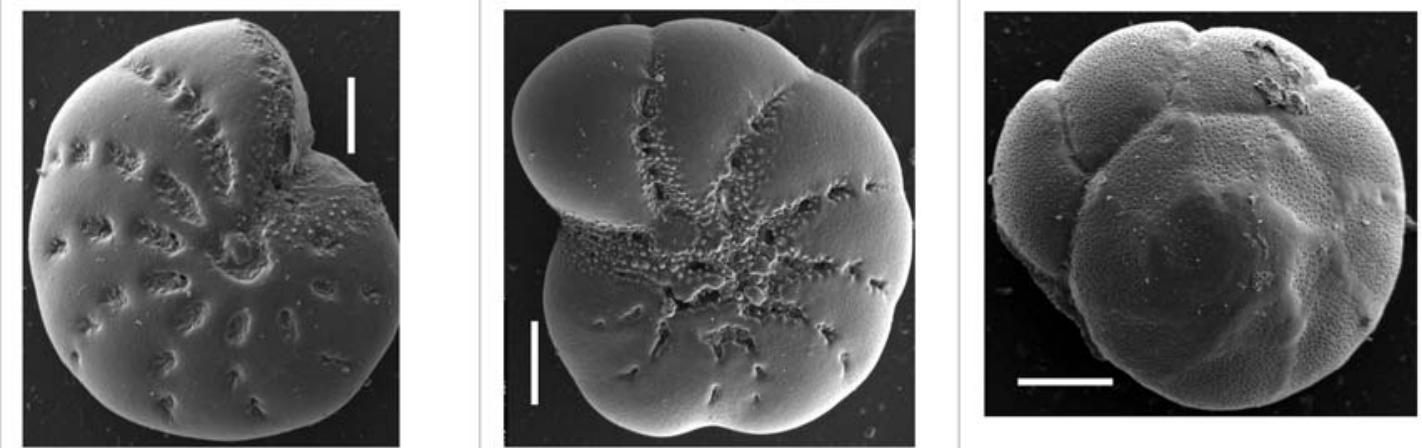

$\mathrm{HB} 2 / 1.94 \mathrm{~m}$ AMSL $\quad$ E. excavatum $\mathrm{HB} 2 / 2.62 \mathrm{~m}$ AMSL

A. aoetana $\mathrm{HB} 2 / 2.62 \mathrm{~m}$ AMSL

A. aoetana
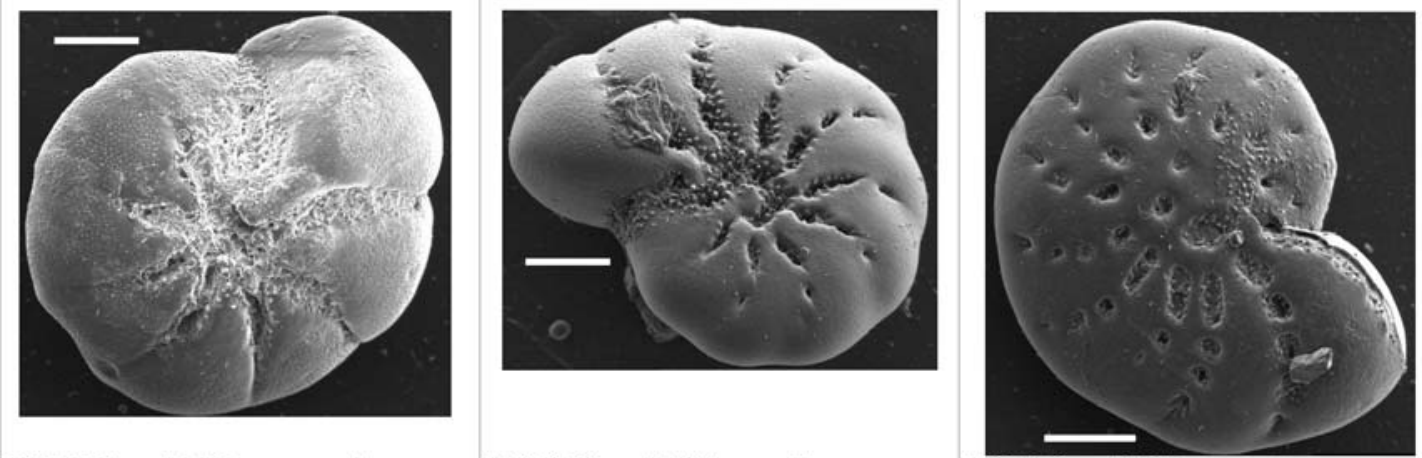

HB2/2.62 m AMSL

A. aoetana $\mathrm{HB} 2 / 2.62 \mathrm{~m}$ AMSL

E. excavatum $\mathrm{HB} 2 / 3.3 \mathrm{~m}$ AMSL

E. excavatum
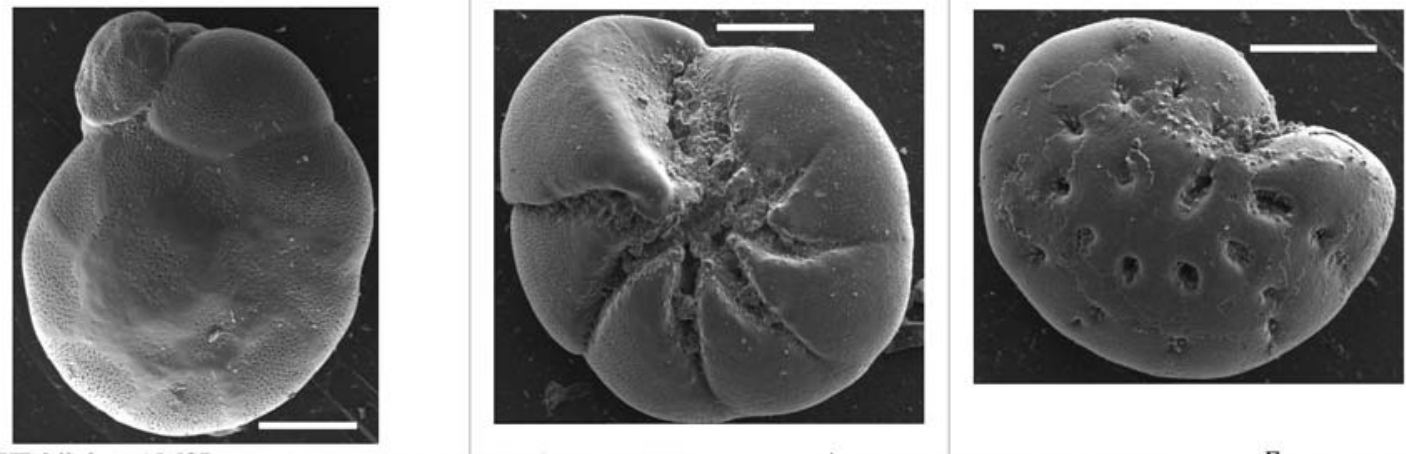

$\mathrm{HB} 2 / 3.3 \mathrm{~m}$ AMSL

A. aoetana $\mathrm{HB} 2 / 3.3 \mathrm{~m}$ AMSL

A. aoetana $\mathrm{HB} 2 / 3.3 \mathrm{~m}$ AMSL

E. excavatum 

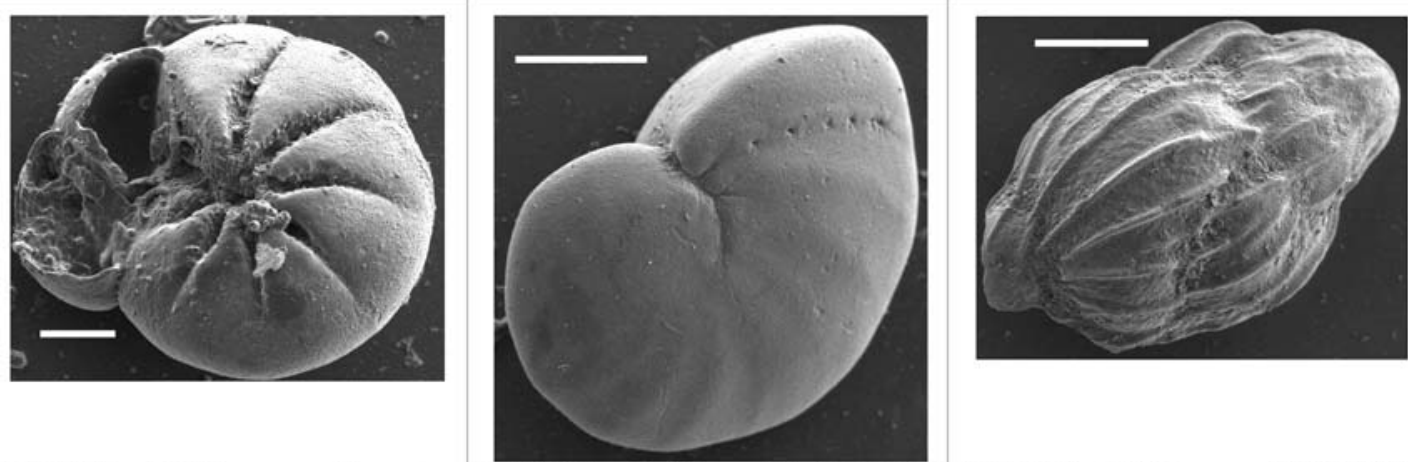

HB2/4.72 m AMSL A. aoetana $\mathrm{HB} 2 / 4.72 \mathrm{~m}$ AMS

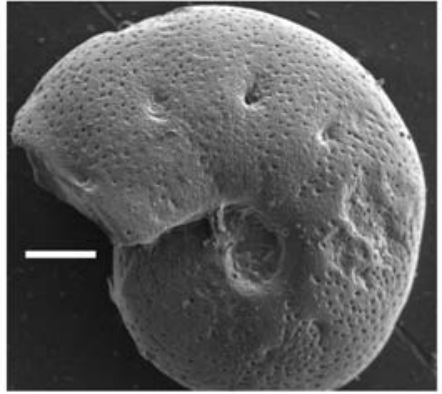

Astrononion novozealandicum HB2/4.72 m AMSL

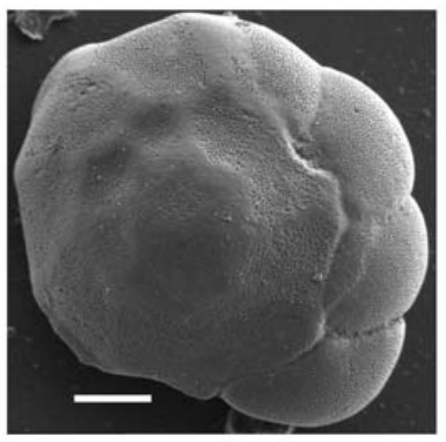

HB2/4.72 m AMSL

A. aoetana $\mathrm{HB} 2 / 4.72 \mathrm{~m}$

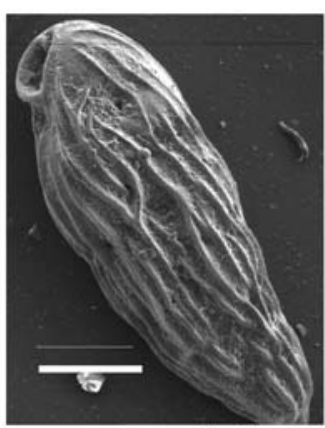

Saidovina karreriana

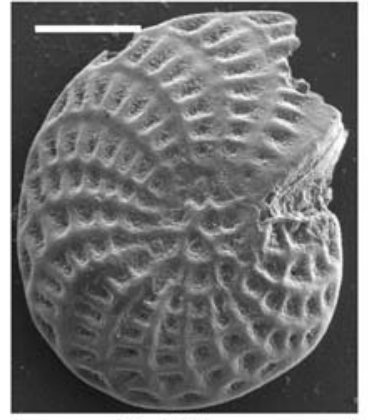

Elphidium novozealandicum HB2/4.72 m AMSL

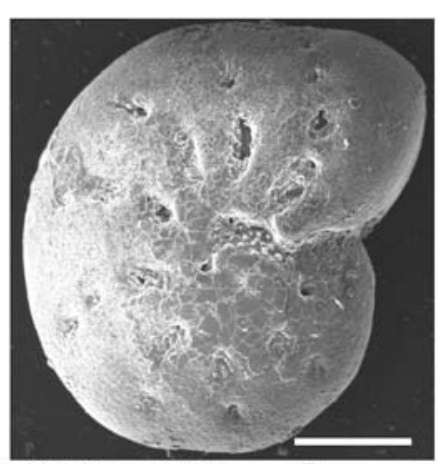

IB2/4.72 m AMSL Unidentified

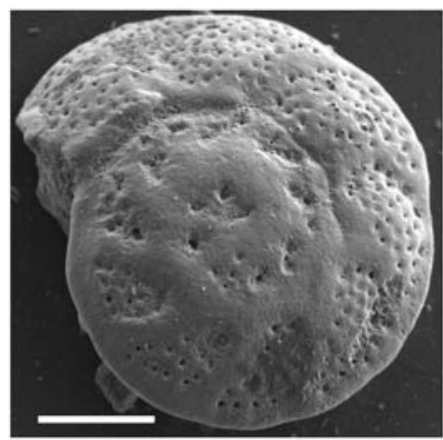

HB2/4.72 m AMSL

Unidentified

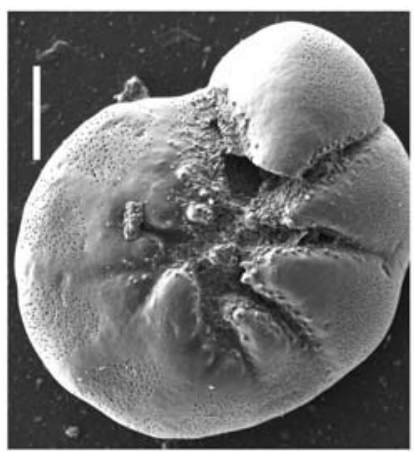

HB2/5.12 m AMSL

A. aoetana

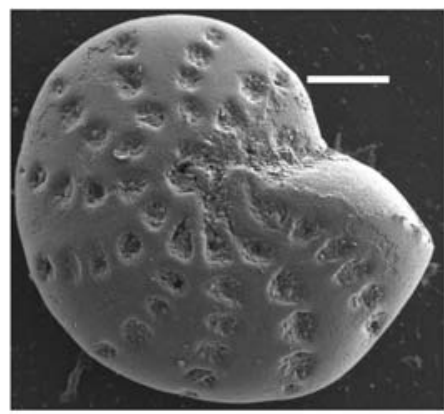

E. excavatum 

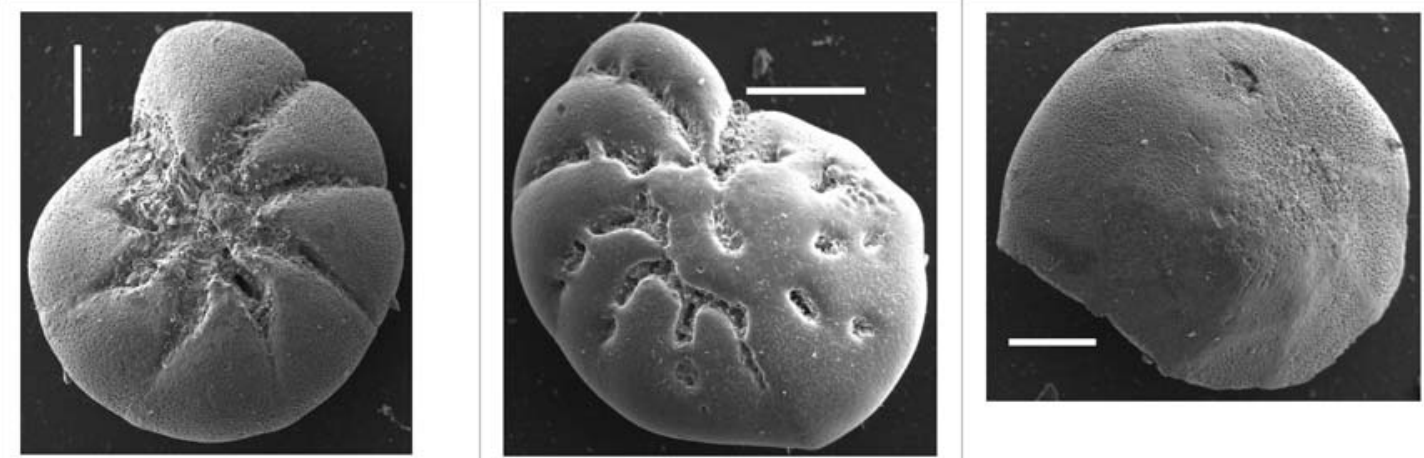

$\mathrm{HB} 2 / 5.24 \mathrm{~m}$ AMSL

A. aoetana HB2/5.24 m AMSL

Unidentified HB2/5.24 m AMSL

A. aoetana
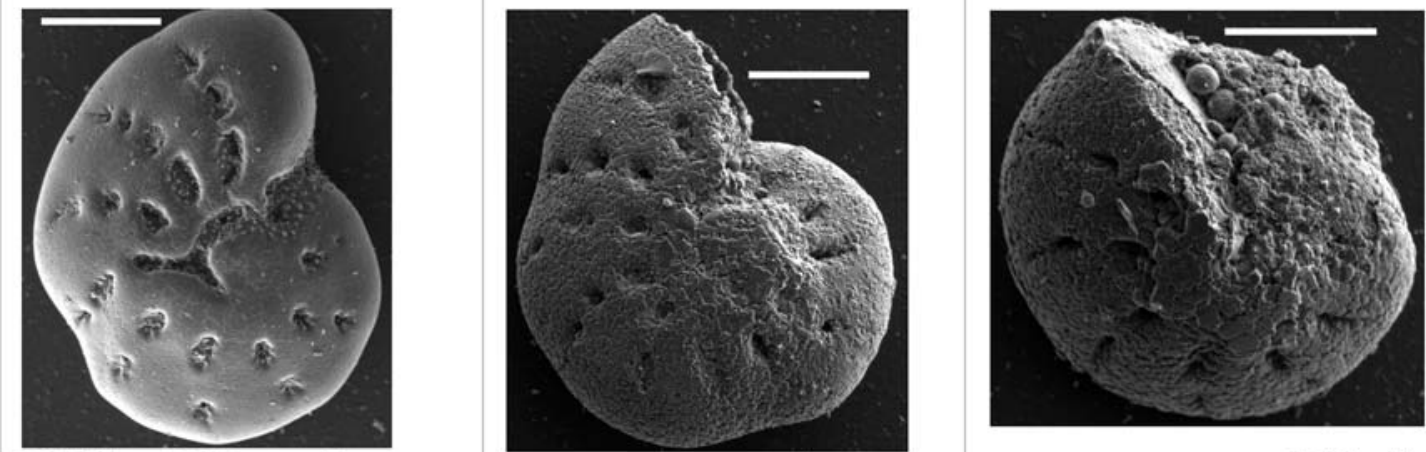

HB2/5.24 m AMSL

E. excavatum $\mathrm{HB} 2 / 5.37 \mathrm{~m}$ AMSL

E. excavatum $\mathrm{HB} 2 / 5.37 \mathrm{~m}$ AMSL

Unidentified
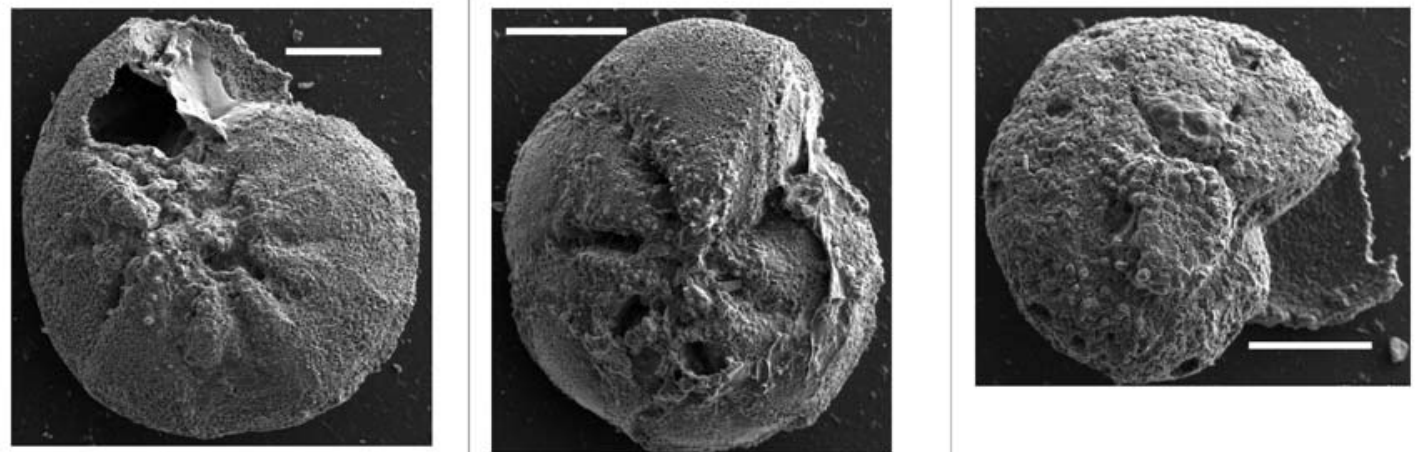

HB2/5.37 m AMSL A. aoetana $\mathrm{HB} 2 / 5.52 \mathrm{~m}$ AMSL

A. aoetana $\mathrm{HB} 2 / 5.52 \mathrm{~m}$ AMSL

Unidentified
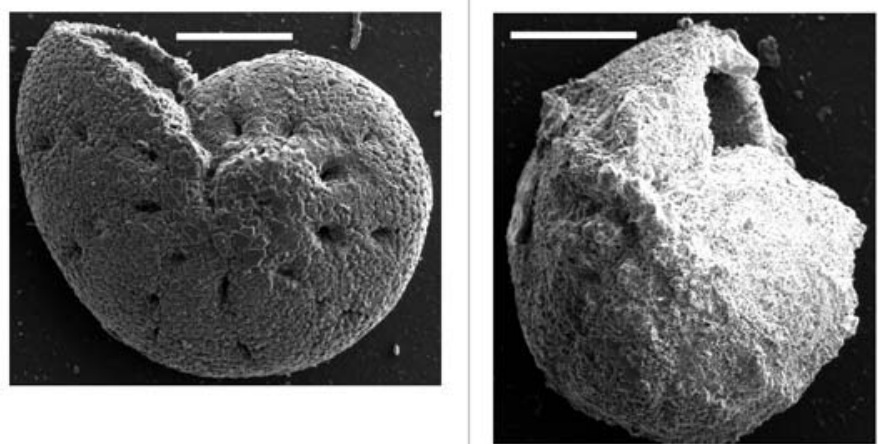

HB2/5.52 m AMSL

E. excavatum $\mathrm{HB} 2 / 5.68 \mathrm{~m}$ AMSL

A. aoetana 


\subsection{References}

Atwater, B. F. (1987). "Evidence for great Holocene earthquakes along the outer coast of Washington State." Science 236: 942-944.

Berglund, M. (2005). "The Holocene shore displacement of Gastrikland, eastern Sweden: a contribution to the knowledge of Scandinavian glacio-isostatic uplift." Journal of Quaternary Science 20(6): 519-531.

Berryman, K. R. (1993). "Age, height, and deformation of Holocene terraces at Mahia Peninsula, Hikurangi subduction margin, New Zealand. 1." Tectonics 12(6): 1347-1364.

Bratton, J. F., S. M. Colman, E. R. Thieler and R. R. Seal II (2003). "Birth of the modern Chesapeake Bay estuary between 7.4 and $8.2 \mathrm{ka}$ and implications for global sea level rise." Geo-Marine Letters 22: 188-197.

Clague, J. J. (1997). "Evidence for large earthquakes at the Cascadia subduction zone." Reviews of Geophysics 35(4): 439-460.

Cochran, U., K. Berryman, D. Mildenhall, B. Hayward, K. Southall, C. Hollis, P. Barker, L. Wallace, B. Alloway and K. Wilson (2006). "Paleoecological insights into subduction zone earthquake occurrence, eastern North Island, New Zealand." Geological Society of America Bulletin, 118(9/10): 1051-1074.

Collot, J.-Y., K. Lewis, G. Lamarche and S. Lallemand (2001). "The giant Ruatoria debris avalanche on the northern Hikurangi margin, New Zealand; results of oblique seamount subduction." Journal of Geophysical Research 106B(9): 19271-19297.

Dalrymple, R. W., B. A. Zaitlin and R. Boyd (1992). "Estuarine facies models: conceptual basis and stratigraphic implications." Journal of Sedimentary Petrology 62(6): 1130-1146.

Darienzo, M. E., C. D. Peterson and C. Clough (1994). "Stratigraphic evidence for great subductionzone earthquakes at four estuaries in Northern Oregon, U. S. A." Journal of Coastal Research 10: 820876.

Dawson, S. and D. E. Smith (1997). "Holocene relative sea-level changes on the margin of a glacioisostatically uplifted area: an example from northern Caithness, Scotland." The Holocene 7(1): 59-77.

Dawson, S., A. G. Dawson and K. J. Edwards (1998). "Rapid Holocene relative sea-level changes in Gruinart, Isle of Islay, Scottish Inner Hebrides." The Holocene 8(2): 183-195.

Eden, D. N. and M. J. Page (1998). "Palaeoclimatic implications of a storm erosion record from late Holocene lake sediments, North Island, New Zealand." Palaeogeography, Palaeoclimatology, Palaeoecology 139(37-58).

Ekman, M. and J. Makinen (1996). "Recent postgalcial rebound, gravity change and mantle flow in Fennoscandia." Geophysical Journal International 126(1): 229-234.

Fontugne, M. R., and Jouanneau, J.-M. (1987). Modulation of particulate organic carbon flux to the ocean by a macrotidal estuary: evidence from measurements of carbon isotopes on organic matter from the Gironde system. Estuarine, Coastal and Shelf Science 24, 377-387.

Forman, S. L., D. J. Lubinski, O. Ingolfsson, J. J. Zeeberg, J. A. Snyder, M. J. Siegert and G. G. Matishov (2004). "A review of postglacial emergence on Svalbard, Franz Josef Land and Novaya Zemlya, northern Eurasia." Quaternary Science Reviews 23: 1391-1434.

Froggatt, P. C. and D. J. Lowe (1990). "A review of late Quaternary silicic and some other tephra formations from New Zealand: their stratigraphy, nomenclature, distribution, volume and age." New Zealand Journal of Geology and Geophysics 33: 89-109. 
Garrick, R. A. (1979). "Late Holocene uplift at Te Araroa, East Cape, North Island, New Zealand." New Zealand Journal of Geology and Geophysics 22(1): 131-139.

Gearing, J. N., Gearing, P. J., Rudnick, D. T., Requejo, A. G., and Hutchins, M. J. (1984). Isotopic variability of organic carbon in a phytoplankton-based, temperate estuary. Geochimica et Cosmochimica Acta 48, 1089-1098.

Gibb, J. G. (1986). A New Zealand regional Holocene eustatic sea-level curve and its application to determination of vertical tectonic movements, A contribution to IGCP-Project 200. Recent Crustal Movements of the pacific Region., Bulletin of the Royal Society of New Zealand. 24: 377-395.

Goff, J. R., C. Chague-Goff and S. L. Nichol (2001). "Paleotsunami deposits: a New Zealand perspective." Sedimentary Geology 143: 1-6.

Goff, J. R., B. G. McFadgen and C. Chague-Goff (2004). "Sedimentary differences between the 2002 Easter Storm and the 15th-century Okoropunga tsunami, southeastern North Island, New Zealand." Marine Geology 204: 235-250.

Goff, J. R., H. L. Rouse, S. L. Jones, B. W. Hayward, U. Cochran, W. McLea, W. W. Dickinson and M. S. Morley (2000). "Evidence for an earthquake and tsunami about 3100-3400 yr ago, and other catastrophic saltwater inundations in a coastal lagoon, New Zealand." Marine Geology 170: 231-249.

Hartley, B. (1996). An Atlas of British Diatoms, Biopress Ltd, Bristol.

Hayward, B. W., U. Cochran, K. Southall, E. Wiggins, H. R. Grenfell, A. Sabaa, P. R. Shane and R. Gehrels (2004a). "Micropalaeontological evidence for the Holocene earthquake history of the eastern Bay of Plenty, New Zealand, and a new index for determining the land elevation record." Quaternary Science Reviews 23: 1651-1667.

Hayward, B. W., H. R. Grenfell, C. Reid and K. Hayward (1999a). Recent New Zealand shallow-water benthic foraminifera: taxonomy, ecologic dstribution, biogeography, and use in paleoenvironmental assessment., Institute of Geological and Nuclear Sciences Monograph 21. 264 p. Lower Hutt, New Zealand: Institute of Geological and Nuclear Sciences Limited.

Hayward, B. W., H. R. Grenfell and D. B. Scott (1999b). "Tidal range of marsh foraminifera for determining former sea-level heights in New Zealand." New Zealand Journal of Geology and Geophysics 42: 395-413.

Hayward, B. W., G. H. Scott, H. R. Grenfell, R. Carter and J. H. Lipps (2004b). "Techniques for estimation of tidal elevation and confinement ( $\sim$ salinity) histories of sheltered harbours and estuaries using benthic foraminifera: examples from New Zealand." The Holocene 14(2): 218-232.

Henderson, J. and M. Ongley (1920). "The geology of the Gisborne and Whatatutu Subdivisions, Raukumara Division." New Zealand Geological Survey Bulletin 21.

Hughen, K. A., M. G. L. Baillie, E. Bard, Beck, J. W. , C. J. H. Bertrand, P. G. Blackwell, C. E. Buck, G. S. Burr, K. B. Cutler, P. E. Damon, R. L. Edwards, R. G. Fairbanks, M. Friedrich, T. P. Guilderson, B. Kromer, G. McCormac, S. Manning, B. B. Ramsey, P. J. Reimer, R. W. Reimer, S. S. Remmele, J. R., M. Stuiver, S. Talamo, F. W. Taylor, J. van der Plicht and C. E. Weyhenmeyer (2004). "Marine04 Marine Radiocarbon Age Calibration, 0-26 Cal Kyr BP." Radiocarbon 46(3): 1059-1086.

Hull, A. G. (1987). "A late Holocene marine terrace on the Kidnappers Coast, North Island, New Zealand: some implications for shore platform development processes and uplift mechanisms." Quaternary Research 28: 183-195.

James, T. S., J. J. Clague, K. Wang and I. Hutchinson (2000). "Postglacial rebound at the northern Cascadia subduction zone." Quaternary Science Reviews 19: 1527-1541. 
Krammer, K. and H. Lange-Bertalot (1991). Bacillariophyceae: Achnanthaceae, Gustav Fischer Verlag, Stuttgart.

Krammer, K. and H. Lange-Bertalot (1999a). Bacillariophyceae: Bacillariaceae, Epithemiaceae, Surirellaceae, Specktrum Akademischer Verlag, Heidelberg.

Krammer, K. and H. Lange-Bertalot (1999b). Bacillariophyceae: Naviculaceae, Specktrum Akademischer Verlag, Heidelberg.

Krammer, K. and H. Lange-Bertalot (2000a). Bacillariophyceae: Centrales, Fragilariaceae, Eunotiaceae, Spektrum Akademischer Verlag, Heidelberg.

Krammer, K. and H. Lange-Bertalot (2000b). Bacillariophyceae: English and French translation of the keys., Spektrum Akademischer Verlag, Heidelberg.

Larsen, C. F., R. J. Motyka, J. T. Freymueller, K. A. Echelmayer and E. R. Ivins (2004). "Rapid uplift of southern Alaska caused by recent ice loss." Geophysical Journal International 158: 1118-1133.

Marsden, I. D. (2004). "Effects of reduced salinity and seston availability on growth of the New Zealand little-neck clam Austrovenus stutchburyi." Marine Ecology Progress Series 266(157-171).

Marsden, I. D. and R. Pilkington (1995). "Spatial and temporal variations in the condition of Austrovenus stutchburyi Finlay, 1927 (Bivalvia: Veneridae) from the Avon-Heathcote estuary, Christchurch." New Zealand Natural Sciences 22: 57-67.

Mazengarb, C. (1984). "The Fernside Fault: an active normal fault, Raukumara Peninsula, New Zealand." New Zealand Geological Survey Record 3: 98-103.

Mazengarb, C. and I. G. Speden (compilers), (2000). Geology of the Raukumara area, Institute of Geological \& Nuclear Sciences 1:250,000 geological map 6. Institute of Geological and Nuclear Sciences Limited, Lower Hutt, New Zealand.

McCormac, F. G., A. G. Hogg, P. G. Blackwell, C. E. Buck, T. F. G. Higham and P. J. Reimer (2004). "SHCal04 Southern Hemisphere Calibration, 0 - 26 ka cal BP." Radiocarbon 46: 1087-1092.

McGlone, M. S., A. J. Anderson and R. N. Holdaway (1994). An ecological approach to the Polynesian settlement of New Zealand. The Origins of the First New Zealanders. D. G. Sutton, Auckland University Press: $136-163$.

Meyers, P. A. (1994). "Preservation of elemental and isotopic source identification of sedimentary organic matter." Chemical Geology 114: 289-302.

Miettinen, A. (2004). "Holocene sea-level changes and glacio-isostasy in teh Gulf of Finland, Baltic Sea." Quaternary International 120: 91-104.

Moore, P. D. and J. A. Webb (1978). An illustrated guide to pollen analysis, Hodder and Stoughton, London.

Moore, P. D., J. A. Webb and M. E. Collinson (1991). Pollen analysis, Blackwell Scientific Publications, Oxford, Boston.

Morton, J. and M. Miller (1968). The New Zealand sea shore. Collins, London.

Muller, A. and U. Mathesius (1999). "The paleoenvironments of coastal lagoons in the southern Baltic Sea, I. The application of sedimentary $\mathrm{C}_{\text {org }} / \mathrm{N}$ ratios as source indicators." Palaeogeography, Palaeoclimatology, Palaeoecology 145: 1-16.

Muller, A., and Voss, M. (1999). The paleoenvironments of coastal lagoons in the southern Baltic Sea, II. $\mathrm{d}^{13} \mathrm{C}$ and $\mathrm{d}^{15} \mathrm{~N}$ ratios of organic matter - sources and sediments. Palaeogeography, Palaeoclimatology, Palaeoecology 145, 17-32 
Nakada, M., M. Tahara, H. Shimizu, S. Nagaoka, K. Uehira and S. Suzuki (2002). "Late Pleistocene crustal uplift and gravity anomaly in the eastern part of Kyushu, japan, and its geophysical implications." Tectonophysics 351: 263-283.

Nelson, A. R. and W. F. Manley (1992). "Holocene coseismic and aseismic uplift of Isla Mocha, South-Central Chile." Quaternary International 15/16: 61-76.

Nelson, A. R., I. Shennan and A. J. Long (1996). " Identifying coseismic subsidence in tidal-wetland stratigraphic sequences at the Cascadia subduction zone of western North America." Journal of Geophysical Research 101: 6115-6135.

Ongley, M. and E. O. MacPherson (1928). "The geology of the Waiapu Subdivision, Raukumara Division." New Zealand Geological Survey Bulletin 30.

Ota, Y., Ed. (1987). Holocene coastal tectonics of eastern North Island, New Zealand. A preliminary report on late Quaternary seismo-tectonic movement in the Circum Pacific area, 1st survey (1985/86).

Ota, Y., K. R. Berryman, A. G. Hull, T. Miyauchi and N. Iso (1988). "Age and height distribution of Holocene transgressive deposits in eastern North Island, New Zealand." Palaeogeography, Palaeoclimatology, Palaeoecology 68: 135-151.

Ota, Y., A. G. Hull and K. R. Berryman (1991). "Coseismic uplift of Holocene marine terraces in the Pakarae River area, eastern North Island, New Zealand." Quaternary Research 35: 331-346.

Ota, Y., A. G. Hull, N. Iso, Y. Ikeda, I. Moriya and T. Yoshikawa (1992). "Holocene marine terraces on the northeast coast of North Island, New Zealand, and their tectonic significance." New Zealand Journal of Geology and Geophysics 35: 273-288.

Patterson, R. T., I. Hutchinson, J.-P. Guilbault and J. J. Clague (2000). "A comparison of the vertical zonation of diatom, foraminifera, and macrophhyte assemblages in a coastal marsh: implications for greater paleo-sea level resolution." Micropaleontology 46(3): 229-244.

Paul, M. A. and B. F. Barras (1998). "A geotechnical correction for post-depositional sediment compression: examples from the Forth valley, Scotland." Journal of Quaternary Science 13(2): 171176.

Peters, K. E., Sweeney, R. E., and Kaplan, I. R. (1978). Correlation of carbon and nitrogen stable isotope ratios in sedimentary organic matter. Limnology and Oceanography 23, 598-604.

Round, F. E., R. M. Crawford and D. G. Mann (1990). The Diatoms: Biology and Morphology of the Genera, Cambridge University Press, Cambridge.

Schoeninger, M. J., and DeNiro, M. J. (1984). Nitrogen and carbon isotope composition of bine collagen from marine and terrestrial animals. Geochimica et Cosmochimica Acta 48, 625-639.

Shennan, I., J. B. Innes, A. J. Long and Y. Zong (1994). "Late Devensian and Holocene relative sealevel changes at Loch nan Eala, near Arisaig, northwest Scotland." Journal of Quaternary Science 9(3): 261-283.

Shennan, I., J. B. Innes, A. J. Long and Y. Zong (1995). "Late Devensian and Holocene relative sealevel changes in Northwestern Scotland: new data to test existing models." Quaternary International 26: 97-123.

Shennan, I., A. J. Long, M. M. Rutherford, F. M. Green, J. B. Innes, J. M. Lloyd, Y. Zong and K. J. Walker (1996). "Tidal marsh stratigraphy, sea-level change and large earthquakes, I: A 5000 year record in Washington, U.S.A." Quaternary Science Reviews 15: 1023-1059.

Sherrod, B. L., R. C. Bucknam and E. B. Leopold (2000). "Holocene relative sea level changes along the Seattle Fault at Restoration Point, Washington." Quaternary Research 54: 384-393. 
Stirling, M. W., McVerry, G., and Berryman, K. R. (2002). A new seismic hazard model for New Zealand. Bulletin of the Seismological Society of America 92, 1878-1903.

Stuiver, M., and Polach, H. A. (1977). Discussion; reporting of C-14 data. Radiocarbon 19, 355-363.

Thornton, S. F. and J. McManus (1994). "Application of organic carbon and nitrogen stable isotope and $\mathrm{C} / \mathrm{N}$ ratios as source indicators of organic matter provenance in estuarine systems: evidence from the Tay estuary, Scotland." Estuarine, Coastal and Shelf Science 38: 219-233.

van Dam, H., A. Mertens and J. Sinkeldam (1994). "A coded checklist and ecological indicator values of freshwater diatoms from the Netherlands." Netherlands Journal of Aquatic Ecology 28: 117-133.

Wilmshurst, J. M. (1997). "The impact of human settlement on vegetation and soil stability in Hawke's Bay, New Zealand." New Zealand Journal of Botany 35: 97-111.

Wilson, K. (Ch. 6). Relationship between coastal geomorphology and subduction geodynamics in the Raukumara sector of the Hikurangi subduction zone.

Witkowski, A., H. Lange-Bertalot and D. Metzeltin (2000). Diatom Flora of Marine Coasts I, A. R. G. Gantner Verlag K. G., Ruggell.

Yoshikawa, T., Y. Ota, N. Yonekura, A. Okada and N. Iso (1980). "Marine terraces and their tectonic deformation on the northeast coast of the North Island, New Zealand." Geographical Review of Japan 53(4): 238-262. 


\title{
CHAPTER SIX
}

\section{Distribution, AGE AND UPLIFT PATTERNS OF PLEISTOCENE MARINE \\ TERRACES OF THE NORTHERN RAUKUMARA PENINSUla, NORTH ISLAND, NEW ZEALAND.}

\begin{abstract}
The distribution and age of Pleistocene marine terraces fringing the northern Raukumara Peninsula, North Island, New Zealand, are revised. Two terraces, the higher Otamaroa Terrace and the lower Te Papa Terrace, are present from Whitianga Bay, eastern Bay of Plenty, to Te Araroa, near East Cape. Six optically stimulated luminescence (OSL) ages obtained from the terrace deposits and coverbeds represent the first radiometric ages on these terraces. Loess from the Te Papa Terrace has an age of $62.6 \pm 6$ ka B.P. and the underlying sand has an age of $58.3 \pm 4.1 \mathrm{ka}$ B.P. Four OSL ages obtained from sand resting on the bedrock strath of the higher Otamaroa Terrace range from $64.5 \pm 4.7$ to $79.2 \pm 5.5 \mathrm{ka}$ B.P. These OSL ages suggest that the Te Papa Terrace formed during early Marine Isotope Stage (MIS) 3 and the Otamaroa Terrace formed during MIS 5a. However the loess on the Te Papa Terrace could also correlate with the widespread lower North Island Porewan loess that was deposited during MIS 4. In this case the Te Papa Terrace must have formed in MIS 5a and the Otamaroa Terrace must be older than MIS 5a. This alternative scenario implies that all the OSL ages derived from marine terrace sands are significant underestimations of their actual depositional age. We compare uplift rates at four locations where both terraces occur adjacent to one another. If constant terrace uplift to present day is assumed, the most likely terrace chronology is MIS 5e for the Otamaroa Terrace and MIS 5c for the Te Papa Terrace. The MIS 3 and 5a terrace chronology indicated from the OSL ages implies that uplift rates must have increased through time and are greater than previously thought. The terraces display a strong northwestward tilt, and the absence of any known onshore of nearshore active faults implies uplift is accommodated by a lower crustal doming related to processes operating along Hikurangi subduction zone.
\end{abstract}

\subsection{Introduction}

This study reviews the distribution and chronology of a set of Pleistocene marine terraces that fringe the west and northeast coasts of the Raukumara Peninsula (Fig. 
6.1). The geometry and rate of uplift of these terraces contribute to constraining uplift process boundaries operating across the Raukumara Peninsula and adjacent to the Hikurangi subduction margin. We present the first absolute ages obtained from these terraces and use global positioning system (GPS) elevation measurements along with cover bed stratigraphy to produce more accurate maps of the terrace surfaces and their uplift patterns. The terraces have previously been studied by Yoshikawa et al. (1980), Iso et al. (1982), Yoshikawa (1988) and Manning (1995). Therefore, we will not redescribe the details of the covered stratigraphy, origin or distribution of these terraces. Rather we focus here on updating these studies by using modern dating techniques in an effort to better resolve the age of the terraces and place the deformation in a regional geodynamic context.

The most extensive terrace, named the Otamaroa Terrace (Yoshikawa et al., 1980), has been inferred to have formed in Marine Isotope Stage (MIS) 5e (Chapman-Smith and Grant-Mackie, 1971; Yoshikawa et al., 1980). The lower Te Papa Terrace has been assigned to MIS 5a (Chapman-Smith and Grant-Mackie, 1971; Yoshikawa et al., 1980). The highest terrace, named the Matakaoa Terrace, has a very limited distribution (Yoshikawa et al., 1980). It is though to have formed in MIS 7 and has been mapped only at Matakaoa Point and has fragmentary occurrence south of Whitianga Bay. Deposits on the terraces have not previously been directly dated. Rather, age control has been achieved only through correlation with global eustatic sea level records and tephrochronology. Tephrochronology is of limited use in this region as the oldest widespread tephra is the Rotoehu Tephra. It has an age of $\sim 50 \mathrm{ka}$ and is present on all Pleistocene marine terraces in the region.

The Raukumara Peninsula is situated inboard of the Hikurangi subduction zone (Fig. 6.1A, D). Mapped Pleistocene marine terraces extend from a distance of c. $150 \mathrm{~km}$ normal to the Hikurangi Trough, to within c. $90 \mathrm{~km}$ normal to the Hikurangi Trough and are distributed on both sides of the northeastern projection of the crest of the Raukumara Ranges, a major axial range extending approximately parallel to the Hikurangi margin (Fig. 6.1D). The marine terraces are therefore in a unique location to yield information about uplift rates and processes over a wide area perpendicular to a subduction zone and around the perimeter of a major axial mountain range. Yoshikawa et al. (1980) projected the heights of the terraces to a plane normal to the 


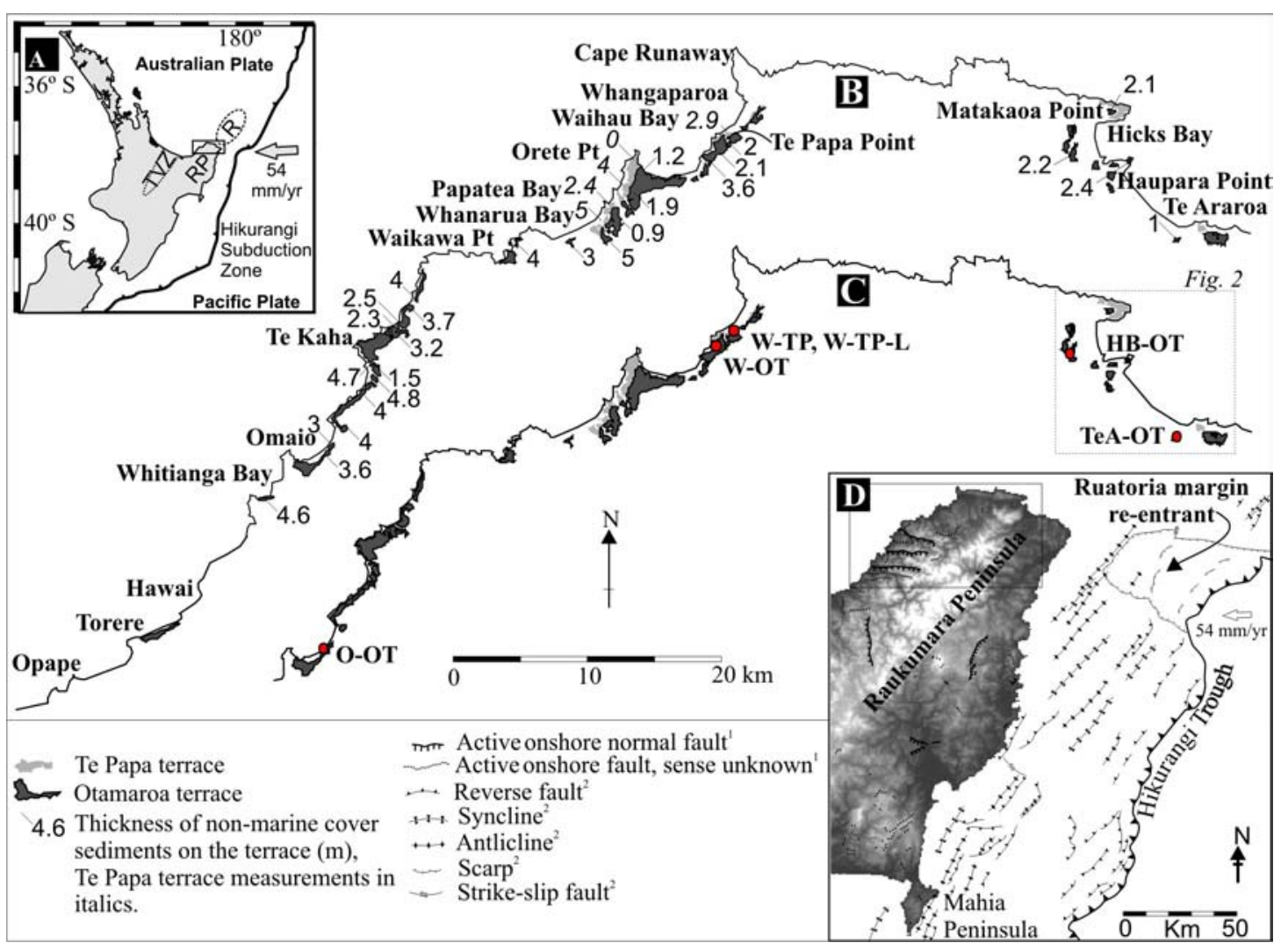

Figure 6.1. (A) North Island, New Zealand with major tectonic features. TVZ: Taupo volcanic zone, RP: Raukumara Peninsula, R: Raukumara Plain. Pacific-Kermadec plate motion after Collot et al. (2001); Hikurangi subduction deformation front after Collot et al. (1996). (B) Western and northern coastline of the Raukumara Peninsula with the distribution of the Otamaroa and Te Papa terraces, location names and the sites where non-marine terrace coverbed thicknesses were measured. (C) OSL sample locations. (D) Topography and tectonic features of the Raukumara Peninsula. 1 Onshore active faults from the GNS Science Active Faults Database (http://data.gns.cri.nz/af/). 2 Offshore structures from Lewis et al. (1997). 
trend of the East Coast and showed that the terraces have been uplifted and tilted to the northwest. They inferred that terrace uplift was associated with major earthquakes in the inner Kermadec Trench. We use GPS elevations to obtain a more accurate image of terrace geometry and assess the controlling structure in light of recent active fault data.

\subsection{Methodology}

\subsubsection{Terrace stratigraphy and distribution}

Terrace coverbed descriptions were made from natural exposures at 26 locations (Fig. 6.1B, Appendix 6.1). We follow the marine terrace terminology of Pillans (1990) and define all sediments on the terrace strath as coverbeds. The coverbeds are subdivided into marine and non-marine, or terrestrial, coverbeds. We measured the thickness of the topmost non-marine coverbeds sediments at 6 additional locations where we did not record an accompanying stratigraphic description. We used aerial photographs together with our stratigraphic studies to map the marine terraces.

\subsubsection{Terrace elevations}

Terrace surface elevations were measured using a real-time kinematic (RTK) GPS. Control points, including benchmarks, survey beacons and local sea level, were used to calibrate the vertical elevations measured by the GPS. Elevation uncertainties varied between regions depending on the number and uncertainty of the control points measured. The uncertainties for each region are as follows: Hicks Bay area: $\pm 0.07 \mathrm{~m}$, Waihau Bay area: $\pm 0.55 \mathrm{~m}$, Te Kaha area: $\pm 0.77 \mathrm{~m}$, Hawai area: $\pm 0.11 \mathrm{~m}$.

At most locations, an elevation was measured at approximately the middle of the terrace surface. Where possible we took points from the rear, middle and front of terraces (for example, at Te Kaha and Waihau Bay where the terrace surface was greater than $1 \mathrm{~km}$ wide). It is best practice to measure the elevation of a marine terrace at the strandline, the most landward part of the terrace surface (Pillans, 1990). Commonly, however, the terraces were too narrow for multiple points to be surveyed and colluvial fans covered the strandlines. Sixty elevation measurements were made on the Otamaroa Terrace, the highest and most extensive surface; fifteen were made on the lower Te Papa Terrace. At three locations in Te Araroa we could not access the 
terrace surface with the GPS. We estimated the elevations of these terraces from topographic maps with a contour interval of $20 \mathrm{~m}$. We estimate that the uncertainty of these elevations is $\pm 10 \mathrm{~m}$.

To calculate terrace uplift rates, we used the elevation of the top of the marine deposits on the terraces. At many locations GPS locations we made measurements of the coverbed stratigraphy. Using these data, the thickness of the non-marine coverbeds was subtracted from the terrace surface elevation to obtain a measurement of the elevation of the top of the marine deposits. Where our terrace surface elevation locations did not coincide with a corresponding stratigraphic column, we subtracted the thickness of non-marine coverbeds, as measured at the nearest location, from the surface elevation. Where we had several stratigraphic columns close together $(<0.5$ $\mathrm{km}$ apart), the thickness of non-marine deposits did not generally differ more than 2 $\mathrm{m}$. We estimate an uncertainty of $\pm 1 \mathrm{~m}$ in elevation measurements of the top of the marine deposits. Contour maps of the top of the marine deposit were created from a grided version of the data using the Golden Software Surfer surface mapping system.

\subsubsection{Age control}

We used optically stimulated luminescence (OSL) dating of bulk samples of silt-sized quartz and feldspar grains from the terrace sand and loess cover beds to estimate the age of the terraces. Six OSL samples were collected (Fig. 6.2, Table 6.1), four from the Otamaroa Terrace (samples denoted by OT) and two from the Te Papa Terrace (samples denoted by TP). All the Otamaroa Terrace samples and one sample from the Te Papa Terrace were selected from sediment interpreted to be beach deposits: coarse sands, or sand within gravel. Sampling was undertaken immediately above the bedrock strath so as to date the timing of strath cutting and avoid younger coverbeds (Fig. 6.2). One loess OSL sample was collected at Waihau Bay from the Te Papa Terrace (W-TP-L). It was collected from a loess layer overlying the sand from which the W-TP sand sample was obtained. The OSL dating was carried out at the Luminescence Dating Laboratory, Victoria University of Wellington. The technical details of the luminescence dating methodology for these samples is described in Rieser $(2005,2006)$. Excerpts from these technical reports are presented in Appendix 6.2 . 
Table 6.1: OSL sampling locations, modern elevations and stratigraphic context of the samples.

\begin{tabular}{|c|c|c|c|c|c|}
\hline 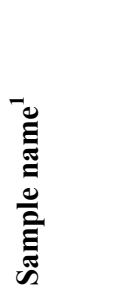 & 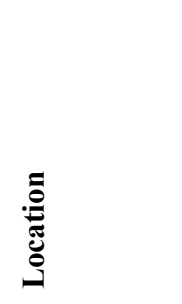 & 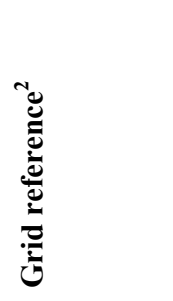 & 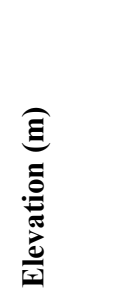 & 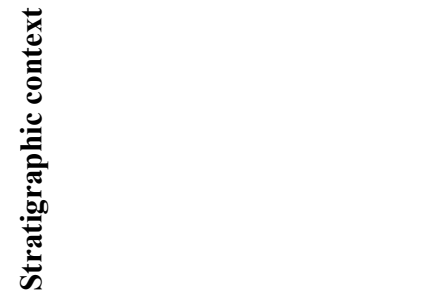 & 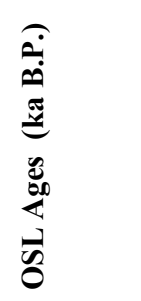 \\
\hline W-TP & Waihau Bay & Y14/496891 & 22.8 & Sand $0.5 \mathrm{~m}$ above bedrock strath & $58.3 \pm 4.1$ \\
\hline W-TP-L & Waihau Bay & Y14/496891 & 25 & $\begin{array}{l}\text { Loess overlying the sand of } \\
\text { sample W-TP, underlying } \\
\text { Rotoehu Tephra. }\end{array}$ & $62.6 \pm 6$ \\
\hline $\mathrm{O}-\mathrm{OT}$ & Omaio Bay & $\mathrm{X} 15 / 213684$ & 12 & $\begin{array}{l}\text { Sand lense within gravel, near } \\
\text { undulating bedrock strath. }\end{array}$ & $64.5 \pm 4.7$ \\
\hline W-OT & Waihau Bay & Y14/489881 & 62.4 & Sand overlying bedrock strath. & $78 \pm 5.9$ \\
\hline HB-OT & Hicks Bay & $\mathrm{Z} 14 / 753877$ & 131.25 & Sand overlying bedrock strath. & $68.7 \pm 5.6$ \\
\hline TeA-OT & Te Araroa & $\mathrm{Z14} / 834816$ & $279 \pm 5$ & $\begin{array}{l}\text { Sand lense within gravel } \\
\text { overlying bedrock strath. }\end{array}$ & $79.2 \pm 5.5$ \\
\hline
\end{tabular}

${ }^{1}$ TP: Te Papa Terrace, OT: Otamaroa Terrace, L: loess sample, TeA = Te Araroa, HB = Hicks Bay, O = Omaio, $\mathrm{W}=$ Waihau Bay.

${ }^{2}$ New Zealand Map Grid coordinates.

\subsection{Results}

\subsubsection{Terrace distribution}

Our terrace distribution is similar to that of Yoshikawa et al. (1980) and Manning (1995) on the western side of the Raukumara Peninsula coastline between Whangaparoa and Whitianga Bay (Fig. 6.1B). There are clearly two terraces from Whangaparoa to Papatea Bay, the Otamaroa (higher) and the Te Papa (lower). From Papatea Bay to Omaio Bay, only the Otamaroa Terrace is present (Fig. 6.1).

We did not include any terrace elevations southwest of Whitianga Bay in our analysis due to uncertainty about their origins and correlations. Yoshikawa et al. (1980) and Manning (1995), however, mapped the Otamaroa Terrace all the way south to Opape. South of Whitianga Bay the elevation of this terrace decreases to $<20 \mathrm{~m}$, and we found marine and fluvial terraces increasingly difficult to distinguish on the basis of geomorphology alone. The terrace stratigraphy also becomes increasingly ambiguous. 


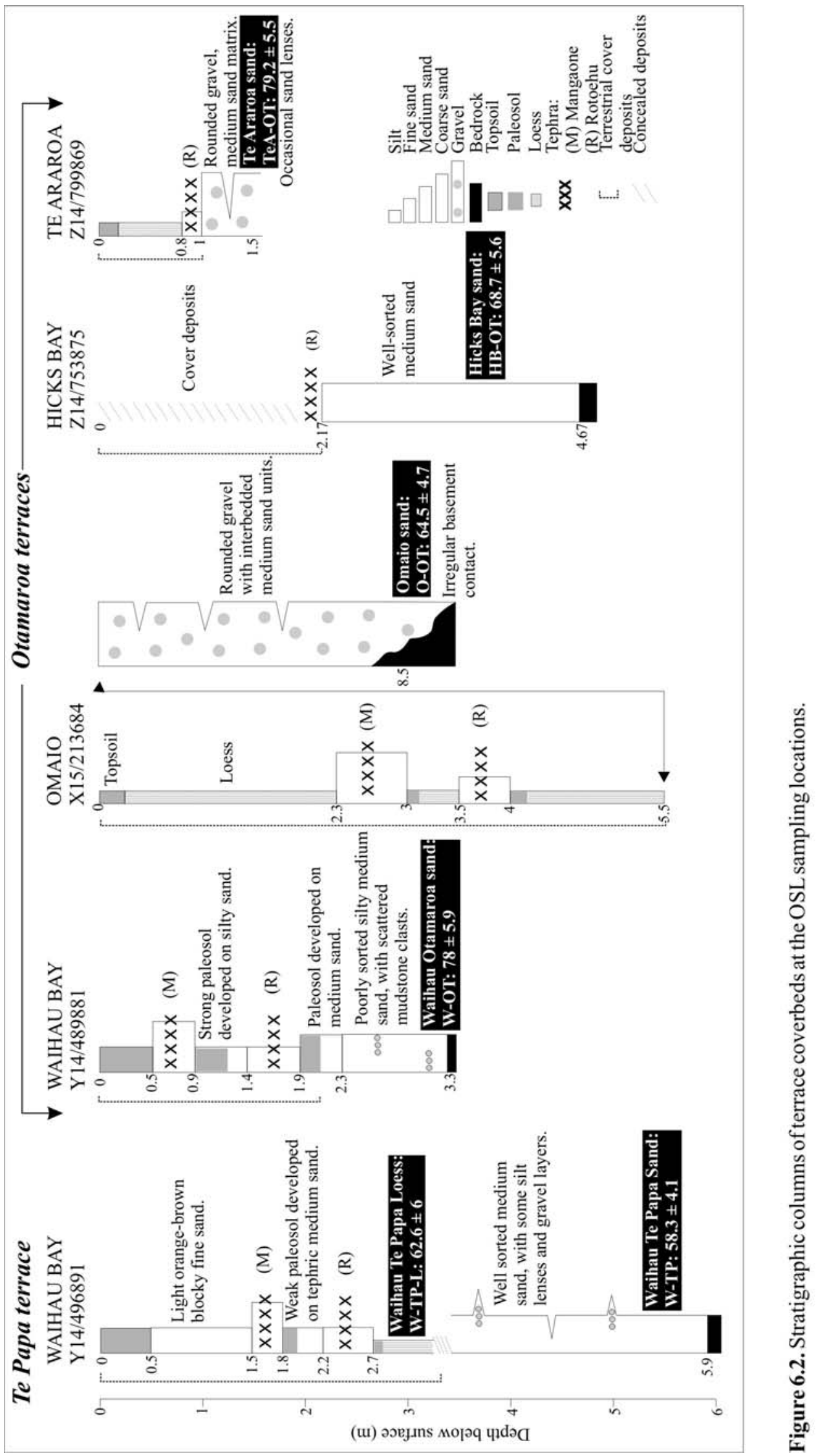


For example, at Torere cover deposits consist of $\sim 3 \mathrm{~m}$ of organic-rich silts overlying gravels. Organic silt is also recorded on terraces at Opape. Manning (1995) identified the Torere tephra, $\sim 285-325 \mathrm{ka}$, on the Otamaroa Terrace at Torere. Given the unusual presence of organic silt on the terrace and anomalous tephra coverbed age, it is questionable whether these terraces are of marine origin. Due to the lower uplift rates there has probably been reworking of terrace sediments by fluvial processes and possibly re-occupation of the terrace. For example, a continuous terrace at Hawai Bay has an obvious southwest tilt in a direction away from a river mouth at the northern end of the bay, indicating it is probably of fluvial origin. We also did not map terraces on the northern Raukumara Peninsula coastline between Cape Runaway and Matakaoa Point, though Yoshikawa et al. (1980) did map them there. We judged from our field visits that while there is a marine terrace along most of the coastline it has a steep surface gradient due to colluvial fan deposition. The terrace strath was difficult to locate, therefore we did not collect elevation measurements on it.

Our terrace distribution on the east side of the Peninsula, at Hicks Bay and Te Araroa agrees with that of Yoshikawa et al. (1980). However, our terrace correlations differ. The highest terrace on Matakaoa Point was defined by Yoshikawa et al. (1980) as the Matakaoa Terrace, and the lower terrace was correlated with the Otamaroa. The terrace capping the middle hill in central Hicks Bay was defined as the Otamaroa because it is the most extensive terrace. Based on our new elevation data, however, we correlate the highest terrace on Matakaoa Point with the mid-Hicks Bay terrace (Fig. 6.3), which implies that the lower terrace on Matakaoa Point is a younger terrace, probably the Te Papa Terrace.

\subsubsection{Terrace Stratigraphy}

Typical terrace coverbeds consist of gravels and sands overlying a wave cut strath on bedrock (Fig. 6.2). These gravels and sand are overlain by loess that is capped by a paleosol, then tephra. Overlying the tephra is another loess unit capped by a paleosol, then another tephra, which is overlain by silt. The entire sequence is capped by topsoil (Fig. 6.2). There are considerable differences in the thickness of these cover deposits, from 1.5-9+ m (Fig. 6.2, Appendix 6.1). 

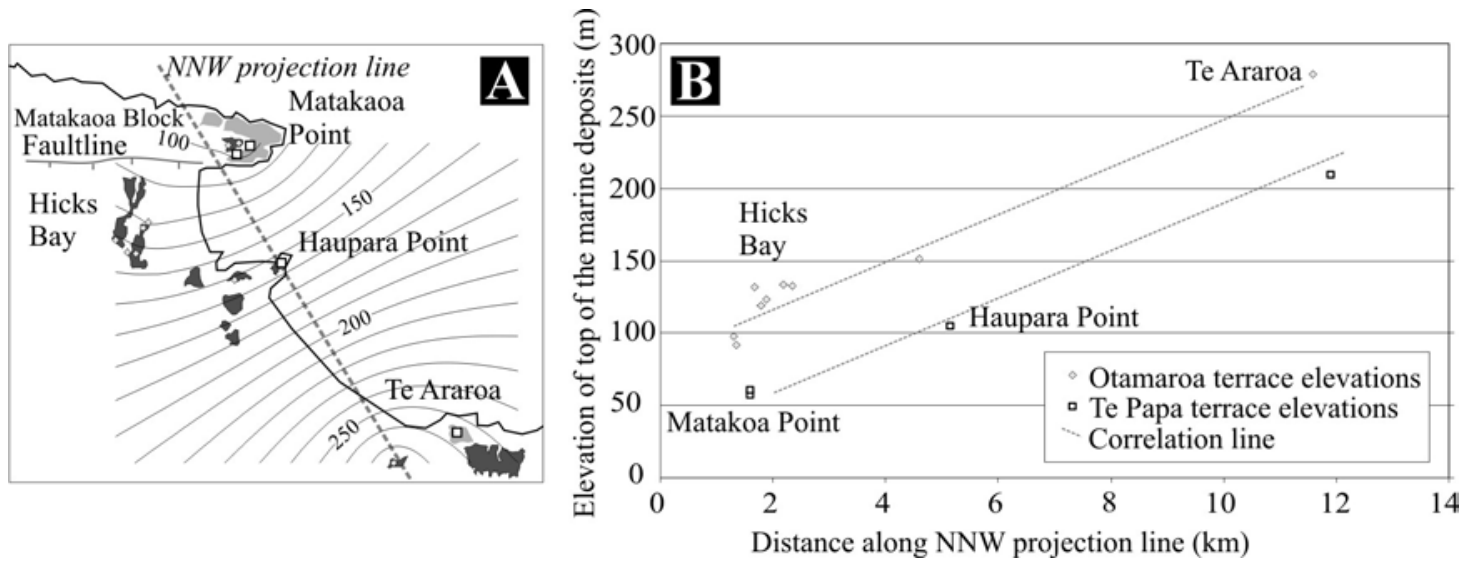

Figure 6.3. (A) Pleistocene terrace distribution at Matakaoa Point, Hicks Bay and Te Araroa and locations where the terrace elevation was measured. All points were measured with an RTK GPS except the two locations at Te Araroa, which were estimated from a 1:25000 topographic map. Contour lines show $10 \mathrm{~m}$ intervals on the highest terrace. The normal fault trace along the southern side of the Matakaoa Peninsula is shown. (B) Elevation of the Otamaroa and Te Papa Terraces projected to a NNE trend line. This graph shows how the two terraces at Matakaoa Point correlate with the Otamaroa and Te Papa Terraces. There is no downthrow to the south of the terraces across the normal fault bounding the east-west trending Matakaoa block.

We estimated the boundary between marine and non-marine deposits using sedimentology (Appendix 6.1). Silt, loess, paleosols, colluvium, poorly sorted gravels, and the interbedded tephras were judged to be non-marine deposits. Well-sorted sands and gravels directly on the terrace strath were judged to be beach deposits.

The identification of beach sands was important for OSL sampling because we aimed to collect sand deposited synchronously with marine terrace incision. The sands sampled for OSL dating did not display any direct evidence of a beach depositional environment, for example, shells. The well-sorted nature of the sand and well-rounded gravels support wave sorting. Alternative mechanisms for sand and gravel emplacement are colluvial, aeolian or fluvial deposition. Colluvial sediments were identified by the characteristics of silt matrix-supported angular gravel clasts and irregular bedding. We were careful not to select OSL samples from colluvial sediments. Sands sampled for OSL dating at Waihau Bay, Omaio and Te Araroa occur in close association with gravel, therefore an aeolian depositional mechanism is unlikely. At Hicks Bay the sampled sand was well-sorted and did not occur in association with gravel; it is possible it is dune sand. Fluvial deposition of gravels and 
sands was discounted at most locations because there are no nearby fluvial sources. Only the OSL sampling sites at Omaio Bay and Te Araroa are near rivers that could have occupied the terrace strath in the past. Therefore, it is possible, that streams deposited the sampled sands after terrace incision, rather than beach processes.

Loess was identified by characteristics such as a massive, homogenous nature, uniform silt grain size and blocky texture when dry. Loess units in the study region typically displayed paleosols developed at the top of them, indicative of weathering during warm climatic conditions following loess deposition (Palmer and Pillans, 1996).

Two tephras occur within the non-marine terrace coverbed sequence: a coarsegrained, dark orange tephra, and a fine to medium-grained, pale white tephra. They are the Mangaone (c. 28 ka B.P., Froggatt and Lowe, 1990) and Rotoehu tephras. The Rotoehu tephra has an estimated age of $50 \mathrm{ka} \mathrm{B}$. P., however, age estimates range from 45 - 65 ka B.P. Berryman (1992) estimates $52 \pm 7$ ka B.P. based on marine terrace correlation; Wilson et al. (1992) estimate $64 \pm 4$ ka B.P. based on radiometric dating of bracketing lavas, and Lian and Shane, 2000 estimate $44 \pm 3$ ka B.P. based on OSL dating of bracketing loess. Identification of the tephras was made with reference to the tephra descriptions presented in Iso et al. (1982) and Manning $(1995,1996)$.

\subsubsection{OSL results}

The OSL results are shown in Table 6.2. The four sand samples from the Otamaroa Terrace yielded ages of $64.5 \pm 4.7$ ka B.P., $68.7 \pm 5.6$ ka B.P., $78 \pm 5.9$ ka B.P. and $79.2 \pm 5.5$ ka B.P. Sample O-OT, from the Otamaroa Terrace at Omaio yielded an age of $64.5 \pm 4.7 \mathrm{ka} \mathrm{B.P.}$, although the sample was near saturation and cold be older. The curve fitting procedures are not robust for nearly saturated samples (Rieser, 2005, 2006). The sand sample immediately above the bedrock strath of the Te Papa Terrace (W-TP) yielded an age of $58.3 \pm 4.1$ ka B.P. The overlying loess (W-TP-L) yielded an age of $62.6 \pm 6$ ka B.P. 
Table 6.2: OSL results: Radionuclide and water contents, measured a-value and equivalent dose, doserate and luminescence age. $\mathrm{Te} A=\mathrm{Te}$ Araroa, $\mathrm{HB}=$ Hicks Bay, $\mathrm{O}=$ Omaio, $\mathrm{W}=$ Waihau Bay, $\mathrm{TP}$ $=$ Te Papa terrace, $\mathrm{OT}=$ Otamaroa Terrace.

\begin{tabular}{|c|c|c|c|c|c|c|c|c|c|c|c|c|}
\hline 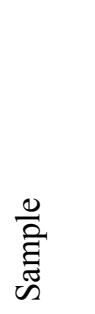 & 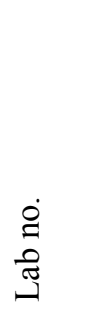 & 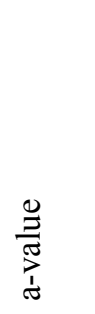 & 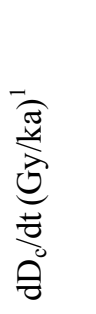 & $\underbrace{\sqrt[3]{0}}$ & 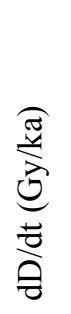 & 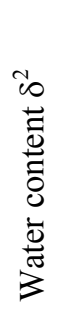 & 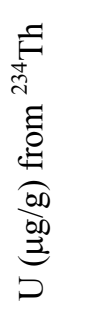 & 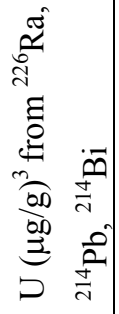 & 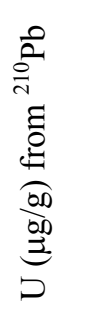 & 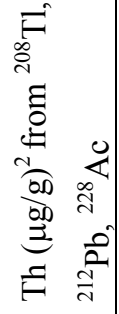 & $\frac{2}{\sqrt{e}}$ & 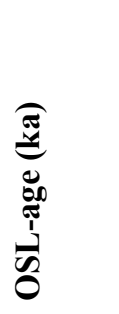 \\
\hline W-TP & $\begin{array}{c}\text { WLL4 } \\
27\end{array}$ & $\begin{array}{c}0.055 \pm \\
0.008\end{array}$ & $\begin{array}{r}0.1398 \\
\pm 0.007\end{array}$ & $\begin{array}{l}101 . \\
5 \pm 5\end{array}$ & $\begin{array}{c}1.74 \\
\pm 0.0 \\
9\end{array}$ & $\begin{array}{c}1.13 \\
8\end{array}$ & $\begin{array}{c}0.91 \pm 0 . \\
15\end{array}$ & $\begin{array}{c}0.89 \pm 0 . \\
09\end{array}$ & $\begin{array}{c}1.08 \pm 0 \\
16\end{array}$ & $\begin{array}{c}3.33 \pm 0 \\
06\end{array}$ & $\begin{array}{c}1.07 \pm 0 \\
02\end{array}$ & $58.3 \pm 4.1$ \\
\hline $\begin{array}{c}\text { W- } \\
\text { TP-L }\end{array}$ & $\begin{array}{c}\text { WLL5 } \\
07\end{array}$ & $\begin{array}{c}0.054 \pm \\
0.003\end{array}$ & $\begin{array}{c}0.1434 \\
\pm 0.007 \\
2\end{array}$ & $\begin{array}{c}112 . \\
6 \pm 4 . \\
8\end{array}$ & $\begin{array}{c}1.80 \\
\pm 0.1 \\
5\end{array}$ & $\begin{array}{c}1.33 \\
4\end{array}$ & $\begin{array}{c}2.15 \pm 0 \\
14\end{array}$ & $\begin{array}{c}1.90 \pm 0 . \\
09\end{array}$ & $\begin{array}{c}1.41 \pm 0 \\
11\end{array}$ & $\begin{array}{c}5.69 \pm 0 . \\
07\end{array}$ & $\begin{array}{c}0.90 \pm 0 \\
02\end{array}$ & $62.6 \pm 6.0$ \\
\hline $\mathrm{O}-\mathrm{OT}$ & $\begin{array}{c}\text { WLL5 } \\
05\end{array}$ & $\begin{array}{c}0.074 \pm \\
0.007\end{array}$ & $\begin{array}{c}0.1594 \\
\pm 0.008 \\
0\end{array}$ & $\begin{array}{c}245 . \\
9 \pm 1 \\
3.2\end{array}$ & $\begin{array}{c}3.81 \\
\pm 0.1 \\
9\end{array}$ & $\begin{array}{c}1.13 \\
5\end{array}$ & $\begin{array}{c}2.12 \pm 0 \\
20\end{array}$ & $\begin{array}{c}1.77 \pm 0 \\
13\end{array}$ & $\begin{array}{c}1.61 \pm 0 \\
18\end{array}$ & $\begin{array}{c}7.60 \pm 0 \\
10\end{array}$ & $\begin{array}{c}2.36 \pm 0 \\
05\end{array}$ & $64.5 \pm 4.7$ \\
\hline W-OT & $\begin{array}{c}\text { WLL4 } \\
28\end{array}$ & $\begin{array}{c}0.043 \pm \\
0.005\end{array}$ & $\begin{array}{r}0.1594 \\
\pm 0.008\end{array}$ & $\begin{array}{c}173 . \\
4 \pm 7 . \\
2\end{array}$ & $\begin{array}{l}2.2 \pm \\
0.14\end{array}$ & $\begin{array}{c}1.18 \\
6\end{array}$ & $\begin{array}{c}1.34 \pm 0 \\
18\end{array}$ & $\begin{array}{c}1.41 \pm 0 \\
1\end{array}$ & $\begin{array}{c}1.4 \pm 0.1 \\
9\end{array}$ & $\begin{array}{c}3.88 \pm 0 \\
06\end{array}$ & $\begin{array}{c}1.47 \pm 0 \\
03\end{array}$ & $78.9 \pm 5.9$ \\
\hline $\begin{array}{l}\text { HB- } \\
\text { OT }\end{array}$ & $\begin{array}{c}\text { WWL4 } \\
29\end{array}$ & $\begin{array}{c}0.029 \pm \\
0.004\end{array}$ & $\begin{array}{c}0.1706 \\
\pm 0.008 \\
5\end{array}$ & $\begin{array}{l}135 . \\
4 \pm 6\end{array}$ & $\begin{array}{c}1.97 \\
\pm 0.1 \\
3\end{array}$ & 1.21 & $\begin{array}{c}1.75 \pm 0 \\
2\end{array}$ & $\begin{array}{c}1.35 \pm 0 \\
11\end{array}$ & $\begin{array}{c}1.34 \pm 0 \\
2\end{array}$ & $\begin{array}{c}4.51 \pm 0 . \\
07\end{array}$ & $\begin{array}{c}1.28 \pm 0 \\
03\end{array}$ & $68.7 \pm 5.6$ \\
\hline $\begin{array}{l}\text { TeA- } \\
\text { OT }\end{array}$ & $\begin{array}{c}\text { WLL5 } \\
06\end{array}$ & $\begin{array}{c}0.074 \pm \\
0.013\end{array}$ & $\begin{array}{c}0.1706 \\
\pm 0.008 \\
5\end{array}$ & $\begin{array}{c}181 . \\
3 \pm 8 . \\
0\end{array}$ & $\begin{array}{c}2.29 \\
\pm 0.1 \\
2\end{array}$ & $\begin{array}{c}1.13 \\
6\end{array}$ & $\begin{array}{c}1.75 \pm 0 \\
15\end{array}$ & $\begin{array}{c}1.36 \pm 0 \\
10\end{array}$ & $\begin{array}{c}1.24 \pm 0 \\
13\end{array}$ & $\begin{array}{c}5.27 \pm 0 \\
07\end{array}$ & $\begin{array}{c}1.14 \pm 0 . \\
03\end{array}$ & $79.2 \pm 5.5$ \\
\hline
\end{tabular}

${ }^{1}$ Contribution of cosmic radiation to the total doserate, calculated as proposed by Prescott and Hutton (1994).

${ }^{2}$ Ratio wet sample to dry sample weight. Errors assumed $50 \%$ of $(\delta-1)$.

${ }^{3} \mathrm{U}$ and Th-contents are calculated from the error weighted mean of the isotope equivalent contents.

\subsection{Discussion}

\subsubsection{Ages of the Raukumara Peninsula Pleistocene marine terraces.}

OSL ages from marine terrace sands have been successfully used to estimate marine terrace ages in Japan, Korea and New Zealand (Tanaka et al., 1997; Choi et al., 2003; Litchfield and Lian, 2004). With an absence of shell material on the Raukumara Peninsula marine terraces, OSL is a useful method to date the terrace deposits directly. The OSL technique measures the time elapsed since the sediments were last exposed to light, and provided that the sediments were exposed during the transport 
process prior to deposition and not subsequently, they effectively date the age of sediment deposition.

The study of Pleistocene marine terraces globally has shown some general relationships exist between climate, sea level, terrace formation, and terrace cover deposits. Marine terrace straths are cut during relative SL highstands, therefore they represent warm climatic periods such as interglacials or interstadials. Beach deposits such as sand and gravel on the strath surface are assumed to be approximately equivalent in age with incision of the terrace strath. Following marine regression from the terrace, non-marine cover sediments are deposited on the terrace surface. These can be aeolian, fluvial or colluvial in origin. In New Zealand loess units are an ubiquitous non-marine deposit on marine terraces (for example, Berryman, 1993, Pillans, 1994, and Rees-Jones et al., 2000). Loess units typically record cold climatic conditions of glacials and stadial periods (Palmer and Pillans, 1996). Given the wellestablished loess chronology in New Zealand, the number of loesses on fluvial and marine terraces can be used as a correlation tool, particularly when interspersed with tephra units (Milne and Smalley, 1979, Palmer et al., 1989, Ota et al., 1996, Formento-Trigilio et al., 2003, and Litchfield and Rieser, 2005).

The sand sample from the Te Papa Terrace at Waihau Bay, yielded an OSL age of $58.3 \pm 4.1$ ka B.P. This result suggests a depositional age of early MIS 3 (Fig. 6.4). The overlying loess sample collected at the same location yielded an age of $62.6 \pm 6$ ka B.P. This loess age is slightly older than the underlying sand age, however, the samples are within the 1-sigma uncertainty range of one another (Fig. 6.4). We are confident the OSL sediment sample was loess, it displayed typical loess characteristics, including homogenous silt, blocky texture and a paleosol developed at the top of the unit. North Island loess stratigraphy would suggest that the Waihau Bay loess sample may correlate with a widespread MIS 4 loess, also known in the central and lower North Island as the Porewan loess (Milne and Smalley, 1979; Kennedy, 1988, 1994, Fig. 6.4). However, within the uncertainty limits of the OSL, it could also be an early MIS 3 loess deposit. The Waihau Bay loess unit is overlain by the Rotoehu Tephra ( 50 ka, Froggatt and Lowe, 1990). Therefore, it cannot correlate with younger, regionally identified loess units such as the lower North Island Rata loess, 32 - 40 ka B.P. (Milne and Smalley, 1979, Fig. 6.4). The lack of a correlative 
New Zealand early MIS 3 loess implies the Waihau Bay loess would have to be a localised unit. This is surprising because units similar to the sampled Waihau Bay loess are present on the marine terraces of the Raukumara Peninsula coastline from Torere to Haupara Point (Appendix 6.1). We would tentatively correlate all loess units directly underlying the Rotoehu Tephra based on the stratigraphic characteristics, but we have no OSL dates from elsewhere to confirm this. The loess age is therefore stratigraphically and chronologically consistent with a MIS 4 deposit correlative to the Porewan loess. If, as the OSL age implies, this is an early MIS 3 loess then is may be a localised deposit as there are no known correlative loess units of this age in New Zealand. If the loess is a MIS 4 deposit, this implies the Te Papa Terrace must be a MIS 5a or older terrace. The implication of this scenario is that the age of the sand, obtained from below the loess, must be too young. If the OSL age is correct and the loess is an early MIS 3 age then the marine terrace must have formed during the very earliest part of MIS 3.

Ages obtained from the Otamaroa Terrace cluster around the MIS 5a eustatic SL highstand at $80 \mathrm{ka}$ (Fig. 6.4). Samples from Te Araroa and Waihau Bay coincide with this age at $79.2 \pm 5.5 \mathrm{ka} \mathrm{B.P}$ and $78 \pm 5.9 \mathrm{ka}$ respectively. The sample from Hicks Bay is younger; the depositional age of $68.7 \pm 5.6 \mathrm{ka}$ B.P. falls within MIS 4, a stadial. However within the uncertainty of the OSL age, this sample spans the end of MIS 5a and the start of MIS 3 (Fig. 6.4). The sample from the Otamaroa Terrace at Omaio also falls within MIS 4 at $64.5 \pm 4.7 \mathrm{ka}$ B.P. but this sample probably has an underestimated age (Rieser, 2006).

Two possible scenarios emerge from the different interpretations of the OSL dating results. The first is that the OSL ages are all correct and the Otamaroa Terrace formed during MIS 5a and that the Te Papa Terrace formed during early MIS 3. The second scenario is that the loess unit pon the Te Papa Terrace correlates with the Porewan loess, a MIS 4 glacial deposit, thus implying both terraces are older than MIS 4 . An implication of this second scenario is that all the sand OSL ages from both terraces are consistently too young. We discuss both of these scenarios in turn and then present a model to test them. 


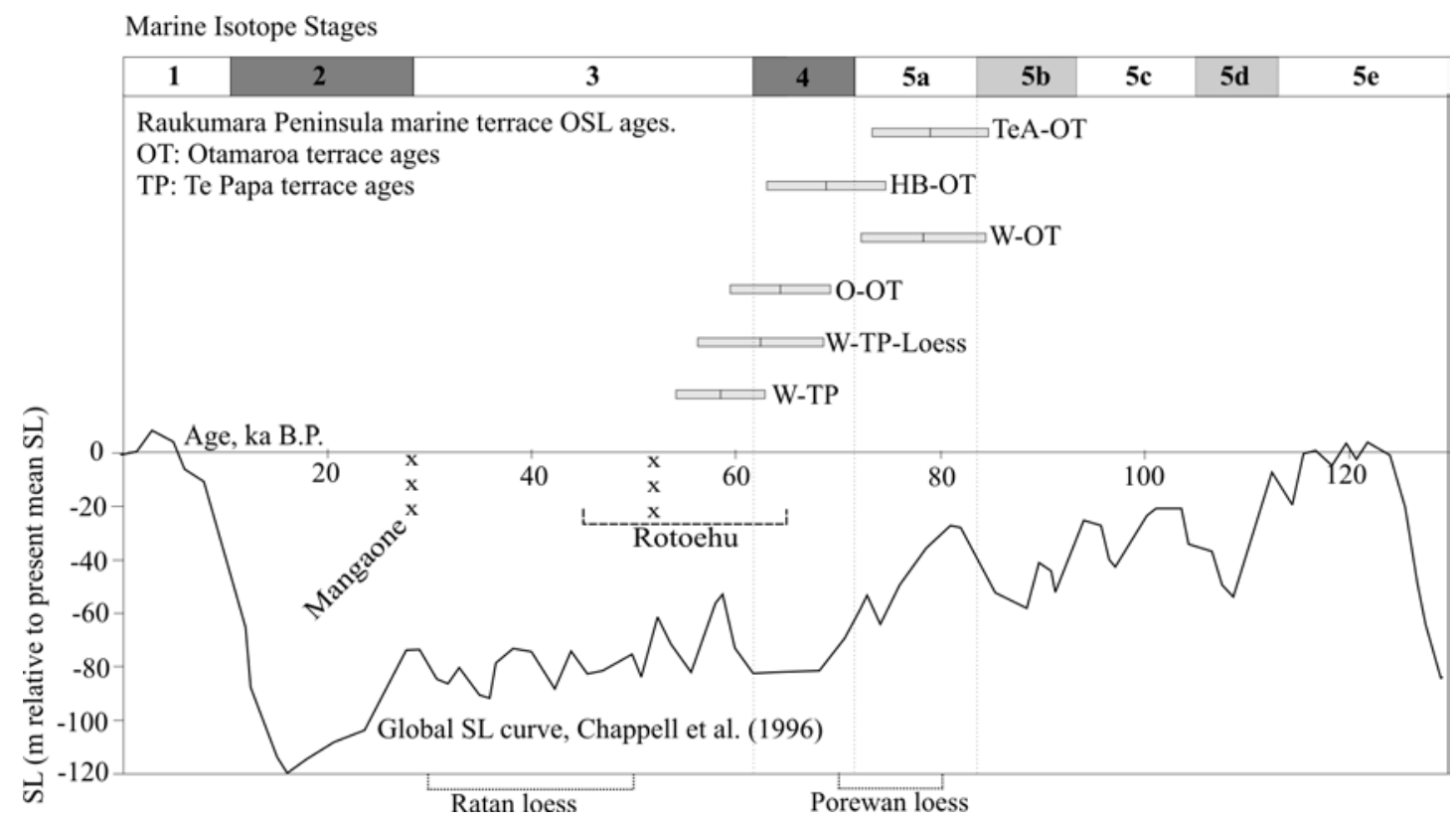

Figure 6.4. OSL ages from the Raukumara Peninsula Pleistocene terraces, samples with suffix "OT" are from the Otamaroa Terrace; suffix "TP" denotes from the Te Papa Terrace. Also shown are the marine isotope stage boundaries and the eustatic sea level curve of Chappell et al. (1996). Porewan and Ratan loess ages after Pillans (1994). TeA = Te Araroa, HB = Hicks Bay, O = Omaio, W = Waihau Bay.

- Scenario 1: Te Papa and Otamaroa Terraces formed during MIS 3 and $5 a$ respectively.

A MIS 3 and 5a chronology for the Te Papa and Otamaroa Terraces consistent with all the OSL ages. These results indicate faster uplift rates of the Raukumara Peninsula than previously thought (Yoshikawa et al., 1980; Yoshikawa, 1988). We identify three issues with this terrace chronology. Firstly, it implies the Waihau Bay loess is a MIS 3 deposit. Loess was deposited in the North Island during mid- to late-MIS 3, however, as discussed above, there are no known loess units on the North Island that were deposited prior to the Rotoehu Tephra within MIS 3. Furthermore, the loess on the Te Papa Terrace has a paleosol developed on it, suggesting a period of warm climatic conditions prior to the Rotoehu Tephra. If the upper age estimate of the Rotoehu Tephra of $64 \pm 4$ ka B.P. are correct (Wilson et al., 1992), and the loess is a MIS 3 deposit, there is a very small interval during which a paleosol could develop (Fig. $6.4)$. 
Secondly, if marine terraces formed during the MIS 3 and 5a eustatic SL highstands, where are the MIS 5c and 5e terraces? The eustatic SL highstands of MID 5c and 5e were higher than the highstands of the MIS 3 and 5a (Chappell et al., 1996, Fig. 6.4). Given a consistent or, even slower, uplift rate dating back to $\sim 125 \mathrm{ka}$, the MIS $5 \mathrm{e}$ and $5 \mathrm{c}$ terraces should have formed in this region and should be present higher in the landscape. No higher terraces occur in the region from Whitianga Bay to Te Araroa. One explanation is that the MIS 5c and 5e terraces did form but have subsequently been uplifted so high that they are now completely eroded. The tilted nature of the terraces implies the higher terraces would be preserved at least where the uplift rates are lowest, which they are not.

Thirdly, two of the Otamaroa Terrace OSL samples imply sand deposition on the marine terrace while eustatic SL was falling. On an uplifting coastline such as the Raukumara Peninsula, marine terrace incision is predicted to start when the rates of eustatic SL rise equal or exceed that rate of land uplift ( $c f$. Fig. 4 of Pillans, 1990). Terrace incision will cease when eustatic SL rates decrease below the land uplift rate. The OSL ages of HB-OT (68.7 \pm 5.6 ka B.P.) and O-OT (64.5 \pm 4.7 ka B.P.) imply sand deposition after the peak of MIS 5a, when eustatic SL was falling and terrace formation was unlikely (Fig. 6.4).

- Scenario 2: Te Papa and Otamaroa Terraces are older than MIS 4.

The OSL age of the loess unit on the Te Papa Terrace at Waihau Bay has a 1-sigma uncertainty range extending into MIS 4 (Fig. 6.4). If this loess unit correlates with the Porewan loess of the lower North Island (Milne and Smalley, 1979; Litchfield and Rieser, 2005), the marine terrace upon which it rests could have been formed prior to MIS 4, during MIS 5a or an older period. This correlation would imply that the sand OSL age from the Te Papa Terrace and the four OSL ages from sands on the Otamaroa Terrace are too young. We offer several reasons to explain why the sand OSL results might conceivably underestimate the age of the terrace:

\section{The sampled sands were not deposited at the time of with terrace cutting} but rather sometime afterwards. The Otamaroa Terrace may have been cut by marine abrasion, then stripped of its original cover deposits, and then later overlain by dune sand or colluvial or fluvial sediments. As previously 
discussed, we are confident that colluvial sediments were not sampled. The sand sampled at Hicks Bay may be dune sand. However, there are no rivers near the Waihau Bay sampling locations to produce fluvial sediments. The Waihau Bay sands are interbedded with gravel, therefore, aeolian or colluvial deposition seems unlikely for deposition of the OSL-dated Otamaroa and Te Papa Terrace sand samples. The sand within gravel sampled at Te Araroa and Omaio could be a fluvial deposits as there are presently rivers near the terraces. However, comparisons between the terrace elevations and eustatic sea levels at the time of sand deposition, as indicated by the OSL ages, suggests that the former base levels of the rivers would have been below present SL, therefore below the elevation of the terraces.

2. There was a time lag between deposition and final covering of the sand samples. Luminescence dating estimates the time since sediment was last exposed to light. The sand samples we collected from the Otamaroa Terrace may have been deposited synchronously with terrace formation but cover sediment either was not deposited until MIS 5a or 4 or cover sediment was stripped off and the sand ages reset before final covering. If so, the chain of events was the same across the entire region which seems unlikely.

3. An inherent issue with the OSL technique for dating marine terrace sands. It appears that all the sand OSL ages may be too young. If the explanations discussed above were the cause of age underestimation, it is surprising that all the terrace sands have been affected by the same problem, particularly given their wide geographical spread and differing uplift rates. If there was an issue with the OSL technique that results in an underestimation of marine terrace sand depositional ages then this might explain why all four samples on the Otamaroa Terrace have been affected. This also accounts for why the sand from the Te Papa Terrace at Waihau Bay is slightly younger, though within uncertainty, of the overlying loess, an issue that neither the first two explanations satisfy. Perhaps the grain size fraction of the sediment samples that is used for dating needs to be re-examined. For example, the silt grain size fraction of all samples was used for the OSL dating in this study. Perhaps this fine grain size fraction has filtered into the sand from the overlying, younger sediments. Anomalous fading of OSL samples can also cause age underestimation. The laboratory checks for anomalous fading by 
keeping the samples in storage for a month and then checking the rate of electron loss, no samples were found to show any sign of anomalous fading (Appendix 6.2). We are currently working with the Luminescence Daring Laboratory at Victoria University of Wellington to resolve the possible underestimation of marine terrace sand ages that we have suggested. Some samples may be dated again using the feldspar sand grain fraction of the samples instead of the silt fraction.

We cannot conclude why all the sand depositional ages possibly underestimate the age of the marine terraces. It may be a combination of all three points discussed above. If the OSL ages are underestimated, it means the terrace ages could be consistent with North Island loess stratigraphy and it explains why there are no higher terraces in the landscape. However, it would suggest that all the OSL ages of terrace sands are much too young.

\subsubsection{Modelling of possible terrace chronology combinations.}

We have presented two alternative scenarios of the terrace chronology. We test these scenarios by comparing the implied uplift rates at four locations where both the Te Papa and Otamaroa Terraces occur (Fig. 6.5). For this process we use the elevation of the top of the marine deposits at Orete Point, Waihau Bay, Matakaoa Point and Te Araroa. With the exception of Te Araroa, all of these were measured using the RTK GPS. Four models are presented that use different age assignments and uplift rates (Fig. 6.5). Similar calculated uplift rates for the two terraces are taken as support for the age assignments. This method assumes that terrace uplift rates have remained constant over the past $\sim 125 \mathrm{ka}$ and that the eustatic SL curve of Chappell et al. (1996) is correct. Conservative uncertainties are applied to the uplift rate calculations: $\pm 5 \mathrm{~m}$ for the eustatic sea level measurements and $\pm 5 \mathrm{ka}$ for the age of peak eustatic sea level for each period, as estimated by Chappell et al. (1996).

The model that yields the most constant and internally consistent uplift rates is a MIS $5 \mathrm{c}$ and $5 \mathrm{e}$ combination for the Te Papa and Otamaroa Terraces respectively (Fig. 6.5D). Of slightly poorer fit is a MIS 5a and 5c combination (Fig. 6.5B). The combination of MIS 3 and 5a, as suggested by the OSL ages presented in this study, implies uplift rates have varied significantly through time (Fig. 6.5A). 


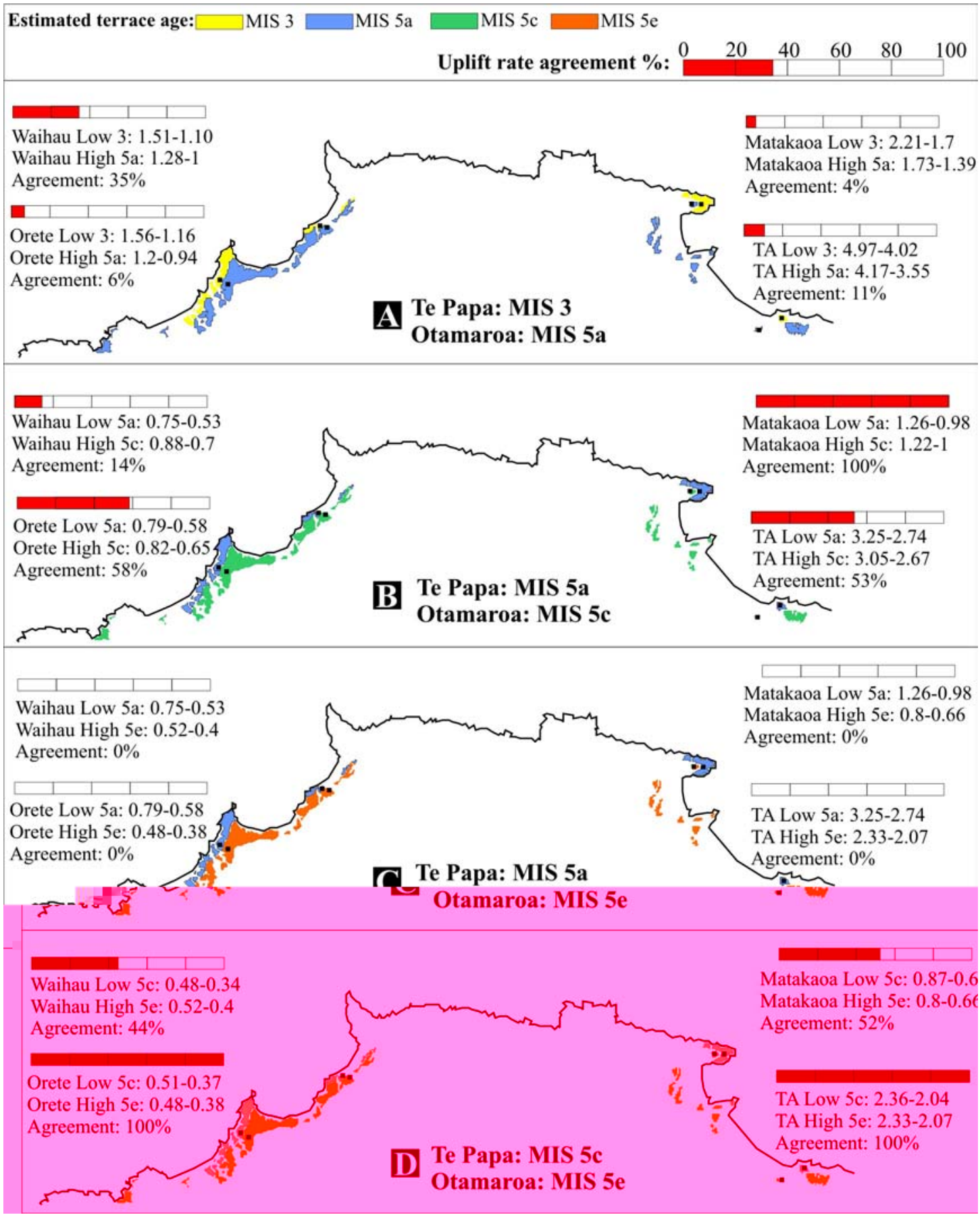

Figure 6.5. Comparison of uplift rates at four locations where the two terraces are adjacent to each other, to test four scenarios of terrace chronology: (A) Te Papa: MIS 3, Otamaroa: MIS 5a; (B) Te Papa: MIS 5a, Otamaroa: MIS 5c; (C) Te Papa: MIS 5a, Otamaroa: MIS 5e; (D) Te Papa: MIS 5c, Otamaroa: MIS 5e. The uplift rate for each terrace at each location is shown. The amount that the uplift rate ranges overlap is shown by the bar graph (we take the amount of overlap between the two uplift rate ranges at each location and divide this by the total range of the uplift rate values, yielding an agreement \%). Uplift rates are calculated based on the Chappell et al. (1996) sea level curve with: MIS 3 at $59 \pm 5 \mathrm{ka} \mathrm{B.P.} \mathrm{when} \mathrm{SL} \mathrm{was} 53 \pm 5 \mathrm{~m}$; MIS 5a at $80 \pm 5 \mathrm{ka} \mathrm{B.P.} \mathrm{when} \mathrm{SL} \mathrm{was} 28 \pm 5 \mathrm{~m}$; MIS 5c at $105 \pm 5 \mathrm{ka}$ B.P. when SL was $20 \pm 5 \mathrm{~m}$; MIS 5e at $125 \pm 5 \mathrm{ka}$ B.P. when SL was $5 \pm 5 \mathrm{~m}$. 
The best-fit model of MIS 5c and 5e and the MIS 5a and 5c model are consistent with our Scenario 2, described above, where both terraces are older than MIS 4 (Fig. 6.5D, B). The MIS 3 and 5a model is our Scenario 1 (Fig. 6.5A), which if correct implies that uplift rates increased by $13-26 \%$ between MIS 5a and MIS 3 (from $\sim 80$ to $59 \mathrm{ka}$ B.P.). The percentage increase is based on the average uplift rate and uses a MIS 3a age of $59 \mathrm{ka}$ with SL at $-53 \mathrm{~m}$ and a MIS 5a age of $80 \mathrm{ka}$ with SL at $-28 \mathrm{~m}$ (Chappell et al., 1996). Although it is possible that uplift rates have accelerated, we have no mechanism of testing this theory. No known major tectonic perturbations in the region occurred during the period from $\sim 80$ to $59 \mathrm{ka}$ B.P that may have triggered increased uplift rates. However, other than marine terraces there are few methods of detecting uplift rate variations through time.

The analysis also shows poor compatibility with a MIS 5a and 5e terrace combination, which is the terrace chronology previously suggested by Yoshikawa et al. (1980). The only way a MIS 5a and 5e terrace combination is feasible is if (1) uplift rates accelerated between $125 \mathrm{ka}$ and $80 \mathrm{ka}$ B.P. or (2) eustatic sea level during MIS 5a was higher than estimated by Chappell et al. (1996). Again, uplift rate acceleration through time is possible but cannot be tested. A possible cause of accelerated uplift during this period (125 to 80 ka B.P.) is the subduction of a seamount, which created the Ruatoria margin re-entrant (Fig. 6.1D), at the Hikurangi Trench $\sim 80 \mathrm{~km}$ southeast of Te Araroa at $170 \pm 40 \mathrm{ka}$ (Collot et al., 2001). Finite element models suggest that uplift caused by this seamount would be localised and occur in the accretionary wedge and forearc part of the margin, but not as inboard as the west coast of the Raukumara Peninsula (Litchfield et al., in press). The Raukumara Peninsula was not glaciated during the Pleistocene so isostatic adjustments cannot be a cause of changing uplift rates through time, as has been suggested to explain elevated MIS 5a corals on the US Atlantic coastal plain (Wehmiller et al., 2004).

Another source of uncertainty when modelling uplift rates is the eustatic SL curve. The Chappell et al. (1996) eustatic sea level curve estimates sea level during MIS 5a to have been $28 \mathrm{~m}$ below present sea level and Pillans et al. (1998) estimate $-24 \mathrm{~m}$. However, there have been suggestions that sea level was actually closer to the modern datum during MIS 5a (Vacher and Hearty, 1989; Ludwig et al., 1996). If sea level were higher than $-23 \mathrm{~m}$ in MIS 5a (the highest sea level we use in our uplift rate 
calculations), the uplift rates for a MIS 5a (Te Papa) and 5e (Otamaroa) configuration would be more compatible, with less of a requirement for uplift rates to have varied through time. More specifically, the best fit for a uniform uplift rate for a MIS 5a-5e configuration is achieved if eustatic SL during MIS 5a was $-10 \mathrm{~m}$, as opposed to the $28 \mathrm{~m}$ of the Chappell et al. (1996) SL curve. However, we could find no evidence elsewhere in New Zealand or globally to support a eustatic SL of -10 m during MIS 5a. In the New Zealand region, a higher MIS 5a sea level than the Chappell et al. (1996) estimate has been proposed by Rees-Jones et al. (2000) based on an OSL age of $71 \pm 14 \mathrm{ka}$ from a marine terrace sand at an elevation of $6 \mathrm{~m}$ on the south Otago coast. Tectonic uplift rates in the region are not thought to have been sufficient to have raised the terrace from the estimated MIS 5a eustatic sea level of $-18 \mathrm{~m}$ to $+6 \mathrm{~m}$, therefore the authors proposed that eustatic sea level in MIS 5a was closer to modern sea level. However, subsequent OSL dating of the same stratigraphy indicated that the OSL age of $71 \pm 14 \mathrm{ka}$ age is probably too young. Two OSL ages from the same beach sand unit yielded ages of $117 \pm 13 \mathrm{ka}$ and $117 \pm 12 \mathrm{ka}$, implying a terrace correlation with MIS 5e (Litchfield and Lian, 2004).

If the OSL ages from the Otamaroa Terrace are correct the most likely terrace chronology is MIS 3 for the Te Papa and MIS 5a for the Otamaroa Terrace. This terrace chronology implies that uplift rates increased in the period between $\sim 80$ and $59 \mathrm{ka}$ B.P. It also means that the MIS 5c and 5e terraces are missing from the terrace flight.

Based on our terrace chronology compatibility models (Fig. 6.5) and the welldocumented global extensiveness of the MIS 5e terrace (for example, Bloom et al., 1974; Hsu, 1992; Kelsey and Bockheim, 1994; Pillans, 1994; Murray-Wallace, 2002; DeDiego-Forbis et al., 2004; Marquardt et al., 2004), it seems likely that the Otamaroa Terrace was formed during MIS 5e, as originally suggested by Yoshikawa et al., 1980. Our constant uplift rate model favours an MIS 5C age for the Te Papa Terrace, not $5 \mathrm{a}$ as previously thought. Unless uplift rates have varied through time or eustatic sea level was higher during MIS 5a than is currently accepted, a MIS 5c Te Papa Terrace age is more compatible with the present elevation of the MIS 5e Otamaroa Terrace. The most significant issue with this chronology is that it requires that our OSL ages are all too young. 


\subsubsection{Deformation of the marine terraces in the context of Hikurangi subduction margin tectonics}

The Pleistocene marine terraces can be confidently correlated around the Raukumara Peninsula Regardless of their ages, the terrace surfaces were originally horizontal and their subsequent deformation reflects the spatial pattern of tectonic processes. The Otamaroa Terrace has a distinctive northwest tilt (Fig. 6.6). The contour map shows some compression of the contours at Te Kaha and Orete Point because the Otamaroa Terrace is wide at these locations and we were able to acquire terrace elevations at its the front, middle and rear, therefore the contours reflect the seaward slope of the terrace. The Te Papa Terrace more limited spatial extent, but also shows the same morphology and northwest tilt (Fig. 6.6). The tilt of the Te Papa Terrace is not as steep as that of the older Otamaroa Terrace. The similarity in geometry and progressive tilting though time indicates that the same mechanism has operated to lift both terraces. The tilt vector of the terraces is approximately normal to the strike of the Raukumara Peninsula and the Hikurangi Trench (Fig. 6.7), suggesting that uplift is related to Hikurangi subduction zone processes. The lack of mapped active faults implies that an upper plate fault is not causing the uplift. Rather, deeper, lower-crust to upper-mantle processes likely controlling the uplift pattern.

The terrace tilt is very steep and has a more northerly orientation on the east side of the Peninsula from Matakaoa Point to Te Araroa (Figs. 6.3, 6.7). It should be noted, however, that the terrace elevations in Fig. 6.7 have been projected on to a westnorthwest line, which is approximately parallel to the tilt direction of most of the terraces, with the exception of those in the Hicks Bay - Te Araroa region that are inclined to the north-northwest. Therefore the terrace tilt in Fig. 6.7 is artificially oversteepened. If the projection line had been in a more northerly direction, the terrace tilt would be slightly less (cf. Fig. 6.3). There are no known onshore or nearoffshore active faults that can account for this geometry of the steep north-northwest tilt of the terraces from Matakaoa Point to Te Araroa (Fig. 6.1D, Collot et al., 1996; Lewis et al., 1997; Mazengarb and Speden, 2000). The more northerly tilt direction of the terraces in the Hicks Bay - Te Araroa region may be related to the offshore transition into the Raukumara Plain, a long-lived deep forearc basin immediately north of Matakaoa Point (Fig. 6.1A, Gillies and Davey, 1986; Davey et al., 1997). 


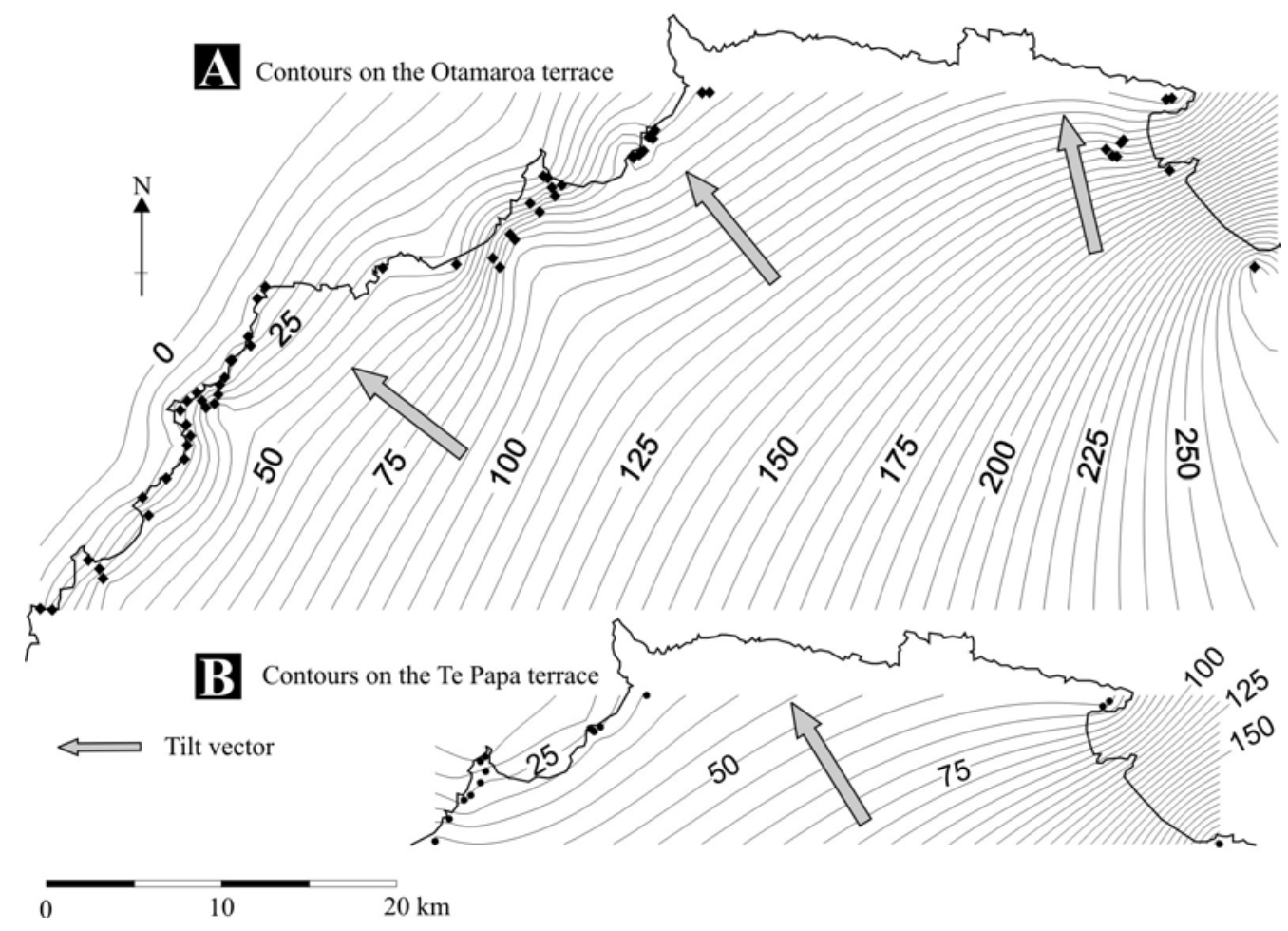

Figure 6.6. Contours of the Otamaroa Terrace surface (A) and Te Papa Terrace (B). Heights are based on the elevation of the top of the marine sediments on the terrace. Contour interval is $5 \mathrm{~m}$.

If the Otamaroa Terrace formed during MIS 5e, uplift rates show a general increase from $\sim 0.1 \mathrm{~mm} \mathrm{yr}^{-1}$ at Omaio and Te Kaha to $\sim 2.2 \mathrm{~mm} \mathrm{yr}^{-1}$ at Te Araroa (Fig. 6.7). If the Otamaroa Terrace formed during MIS 5a, then uplift rates are substantially higher, ranging from $\sim 0.6 \mathrm{~mm} \mathrm{yr}^{-1}$ at Omaio to $\sim 3.8 \mathrm{~mm} \mathrm{yr}^{-1}$ at Te Kaha (Fig. 6.7). These uplift rates are significantly different and indicate that further investigation of the age of these terraces is warranted. 


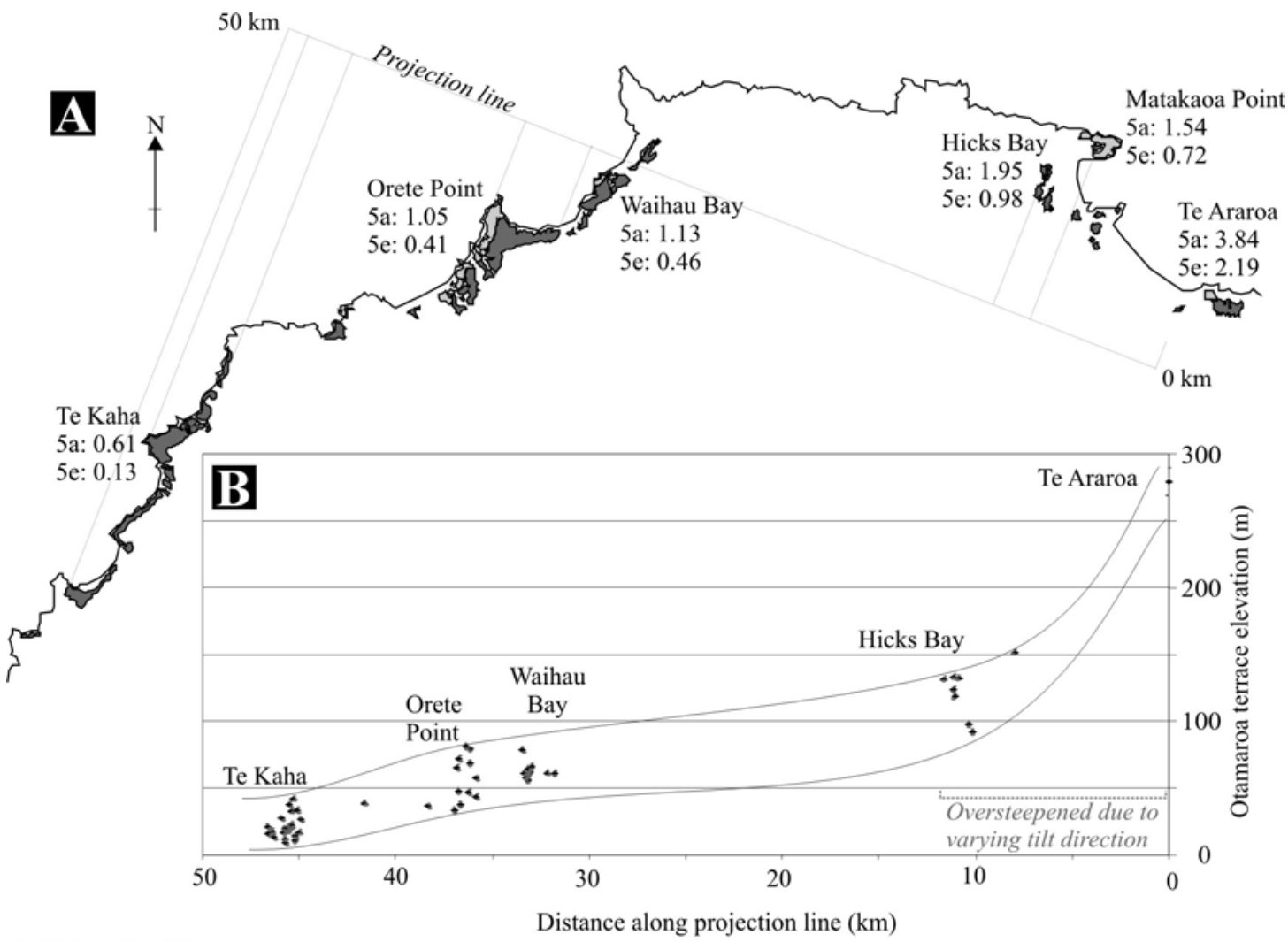

Te Kaha $=$ locality

5a: $0.61=$ predicted terrace formation stage and average uplift rate $(\mathrm{mm} / \mathrm{yr})$ for that locality (based on a MIS 5a eustatic SL of $-28 \mathrm{~m}$ at $80 \mathrm{ka}$ B.P.).

5e: $0.13=$ predicted terrace formation stage and average uplift rate $(\mathrm{mm} / \mathrm{yr})$ for that locality (based on a MIS 5e eustatic SL of $5 \mathrm{~m}$ at $125 \mathrm{ka}$ B.P.).

Figure 6.7. (A) Uplift rates of the Pleistocene marine terraces around the Raukumara Peninsula, based upon the Otamaroa Terrace being MIS 5e and the Te Papa Terrace being MIS 5c. Elevations used are the top of the marine deposits on the terrace. We used the Chappell et al. (1996) eustatic sea level estimates of: MIS 5c at 105 B.P. when SL was $20 \mathrm{~m}$; MIS 5e at $125 \mathrm{ka}$ B.P. when SL was $5 \mathrm{~m}$. Projection line is the trend that we projected the uplift rates onto to produce (B). (B) Otamaroa terrace elevations with distance from Te Araroa projected to a west-northwest trend. We note however, that the dominant tilt direction in the Matakaoa Point to Te Araroa region is to the north-northwest therefore the projected tilt for this region shown in the graph is artificially oversteepened. Black dots are the uplift rate estimates at each location and the grey dots show the uncertainty range of these uplift rates, based on $\mathrm{a} \pm 5 \mathrm{~m}$ uncertainty in the Chappell et al., 1996) past SL estimates and a $\pm 5 \mathrm{ka}$ age uncertainty for the age of the MIS 5e and 5c SL peaks. 


\subsection{Conclusions}

This study presents the first absolute ages for the Raukumara Peninsula Pleistocene terraces. Six OSL ages suggest that the Otamaroa Terrace formed during MIS 5a and the Te Papa Terrace formed during MIS 3. One loess age from the Te Papa Terraces suggests a correlation with the Porewan loess, a MIS 4 deposit. We present two terrace chronology scenarios:

- Scenario 1, which accepts the OSL ages, has a MIS 3 and 5a terrace chronology.

- Scenario 2, which places greater importance is on regional loess stratigraphy and global marine terrace correlation, has both terraces older then MIS 4.

Modelling of terrace uplift rates suggests that the terraces most likely formed during MIS 5c and 5e assuming uplift rates have been constant through time. This modelling thus supports Scenario 2. However by inference, all five OSL ages from the terrace sands must be significantly underestimated and we cannot resolve why this is so. Scenario 1 is possible, but it implies a $13-26 \%$ increase in terrace uplift rates between MIS 5a and 3 (between $~ 80-60$ ka B.P.), and also begs the question of where the MIS 5c and 5e terraces are in the landscape. The modelling also shows that the terrace chronology of MIS 5a and 5e (Yoshikawa et al., 1980; Yoshikawa, 1988) is unlikely unless uplift rates have increased through time or eustatic sea level during MIS 5a was within $\sim 10 \mathrm{~m}$ of the present levels. The terraces have a strong northwest tilt that cannot be explained by any known active faults in the region. We suggest that upper mantle and lower crust processes related to the Hikurangi subduction zone control the geometry and uplift of the terraces. 
Appendix 6.1: Stratigraphic columns of Pleistocene marine terraces cover sequences. Below is a map showing column locations and the following two pages show the stratigraphy. The heavy dashed line beside each column denotes the non-marine cover sediments.

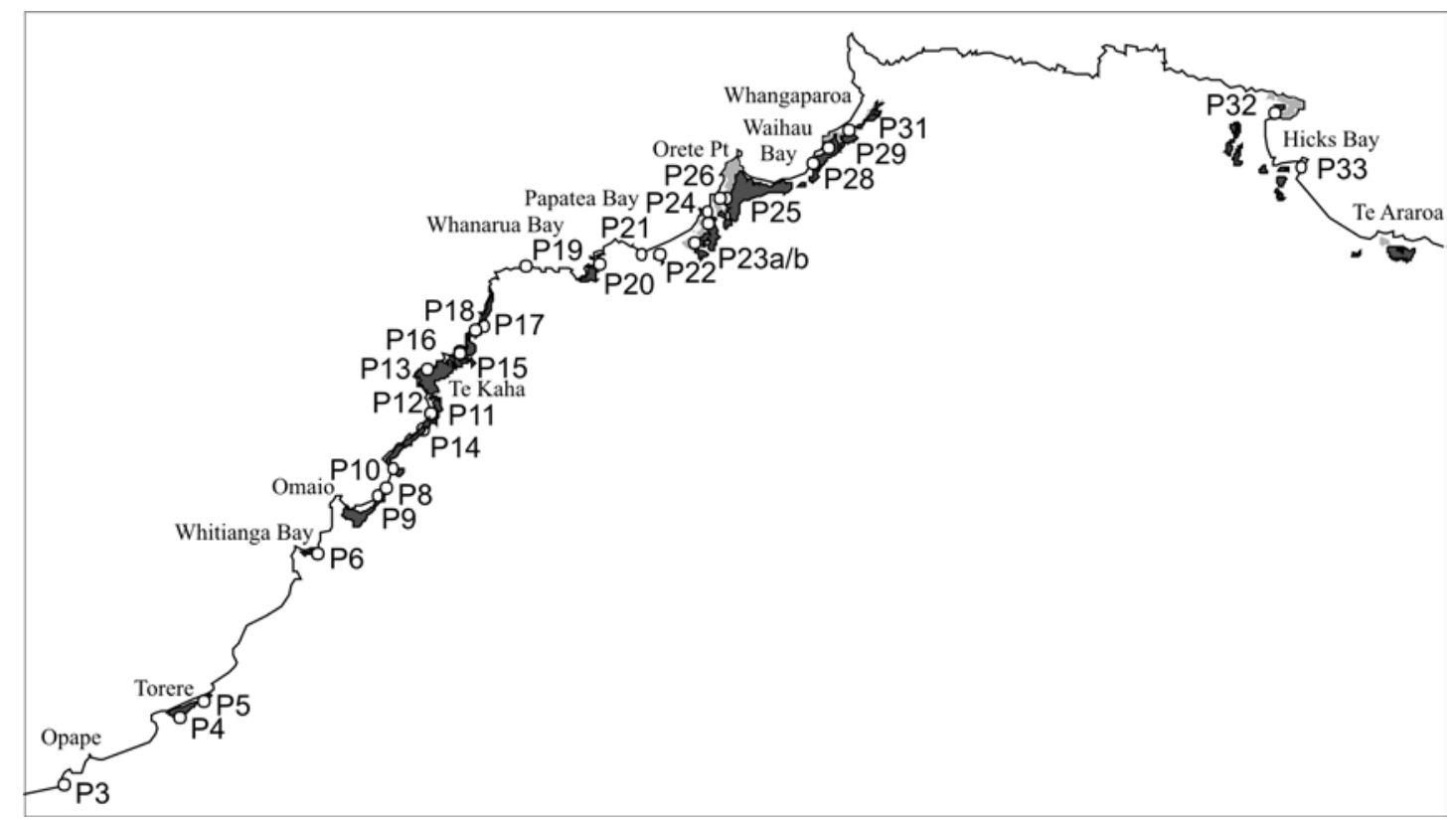

Appendix 6.1 Figure A: Locations where coverbed sequence stratigraphic columns were recorded. 

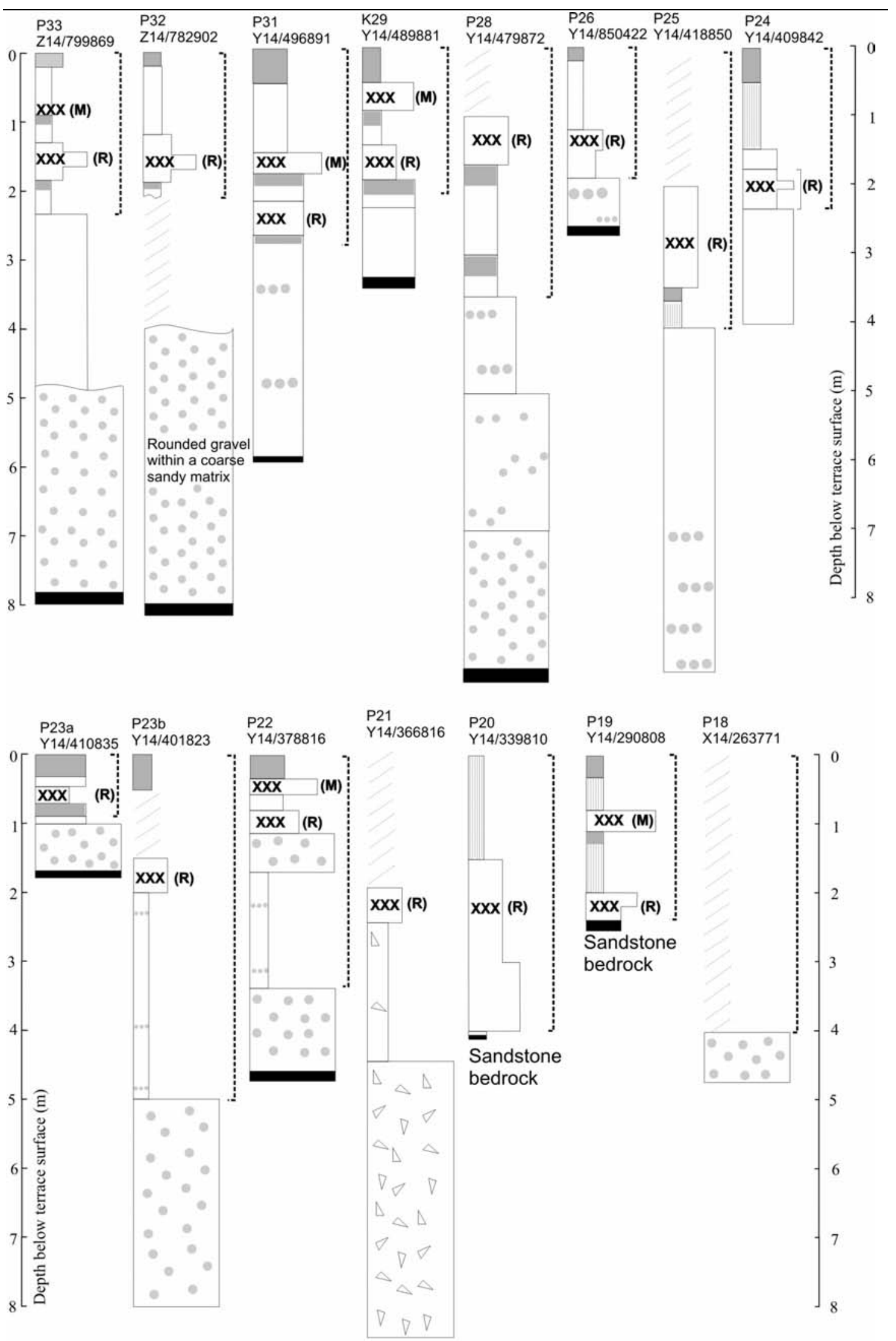

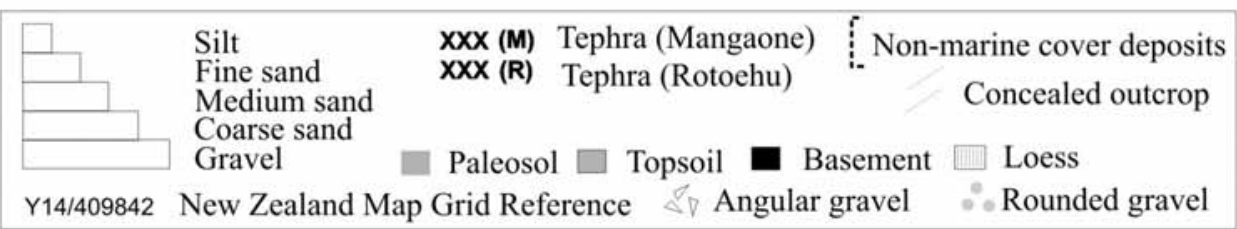




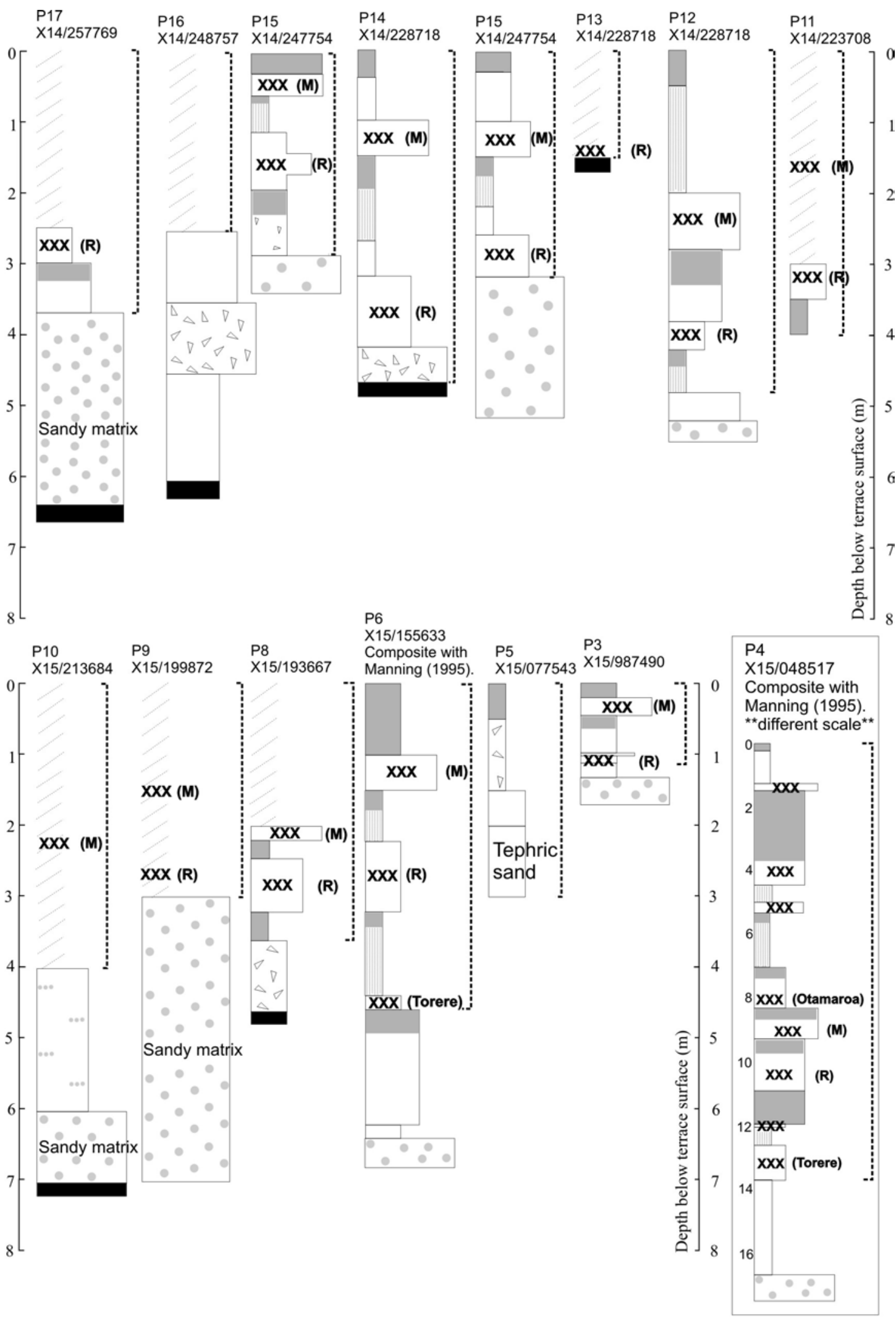

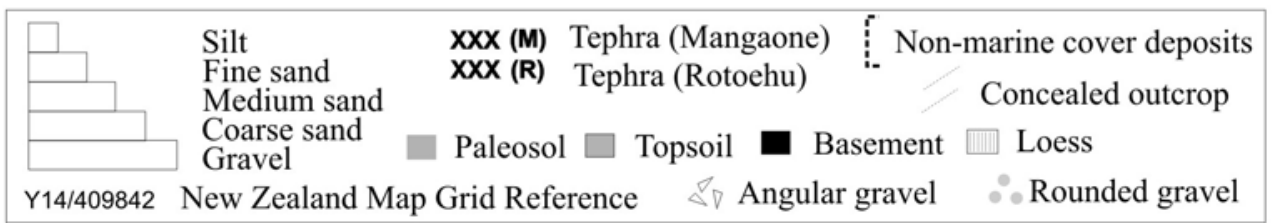


Appendix 6.2: Laboratory procedures of optically stimulated luminescence measurements. Excerpts are taken directly from the Technical Reports of Uwe Resier $(2005,2006)$.

\section{Summary}

Six samples (laboratory codes WLL427-429 and WLL505-507) were submitted for Luminescence Dating by Kate Wilson (VUW). The deposition ages have been determined for all samples using the silt fraction. The palaeodose, i.e. the radiation dose accumulated in the sample after the last light exposure (assumed at deposition), was determined by measuring the blue luminescence output during infrared optical stimulation (which selectively stimulates the feldspar fraction). The doserate was estimated on the basis of a low level gammaspectrometry measurement. All measurements were done in Victoria Universities Dating Laboratory.

\section{Procedure / Luminescence measurements}

Sample preparation was done under extremely subdued safe orange light in a darkroom. Outer surfaces, which may have seen light during sampling, were removed and discarded. The actual water content and the saturation content were measured using 'fresh' inside material.

The samples were treated with $10 \% \mathrm{HCl}$ to remove carbonates until the reaction stopped, then carefully rinsed with distilled water. Thereafter, all organic matter was destroyed with $10 \% \mathrm{H}_{2} \mathrm{O}_{2}$ until the reaction stopped, then carefully rinsed with distilled water. By treatment with a solution of sodium citrate, sodium bicarbonate and sodium dithionate iron oxide coatings were removed from the mineral grains and then the sample was carefully rinsed again.

The grain size $4-11 \mu \mathrm{m}$ was extracted from the samples in a water-filled (with added dispersing agent to deflocculate clay) measuring cylinder using Stokes' Law. The other fractions were discarded. The samples then are brought into suspension in pure acetone and deposited evenly in a thin layer on 70 aluminum discs (1 $\mathrm{cm}$ diameter).

Luminescence measurements were done using a standard Riso TL-DA15 measurement system, equipped with Kopp 5-58 and Schott BG39 optical filters to select the luminescence blue band. Stimulation was done $\mathrm{cw}$ at about $30 \mathrm{~mW} / \mathrm{cm}^{2}$ with infrared diodes at $880 \Delta 80 \mathrm{~nm}$. $\beta$-irradiations were done on a Daybreak $801 \mathrm{E}{ }^{90} \mathrm{Sr},{ }^{90} \mathrm{Y} \beta$-irradiator, calibrated against SFU, Vancouver, Canada to about 3\% accuracy. $\alpha$-irradiations were done on a ${ }^{241} \mathrm{Am}$ irradiator supplied and calibrated by ELSEC, Littlemore, UK. 
The Paleodoses were estimated by use of the multiple aliquot additive-dose method (with late-light subtraction). After an initial test-measurement, 30 aliquots were $\beta$-irradiated in six groups up to six times of the dose result taken from the test. 9 aliquots were $\alpha$-irradiated in three groups up to three times of the dose result taken from the test. These 39 disks were stored in the dark for four weeks to relax the crystal lattice after irradiation.

After storage, these 39 disks and 9 unirradiated disks were preheated for $5 \mathrm{~min}$ at $220 \mathrm{C}$ to remove unstable signal components, and then measured for $100 \mathrm{sec}$ each, resulting in 39 shinedown curves. These curves were then normalized for their luminescence response, using $0.1 \mathrm{~s}$ shortshine measurements taken before irradiation from all aliquots.

The luminescence growth curve ( $\beta$-induced luminescence intensity vs added dose) is then constructed by using the initial 10 seconds of the shine down curves and subtracting the average of the last $20 \mathrm{sec}$, the so called late light which is thought to be a mixture of background and hardly bleachable components. The shine plateau was checked to be flat after this manipulation. Extrapolation of this growth curve to the dose-axis gives the equivalent dose $D_{e}$, which is used as an estimate of the Paleodose.

A similar plot for the alpha-irradiated discs allows an estimate of the $\alpha$-efficiency, the a-value (Luminescence/dose generated by the $\alpha$-source divided by the luminescence/dose generated by the $\beta$-source).

\section{Fading test}

Samples containing feldspars in rare cases show an effect called anomalous fading. This effect inhibits accurate dating of the sample, as the electron traps in the crystal lattice of these feldspars are unable to store the age information over longer periods of time. None of the samples gave an indication of this problem.

\section{Procedure / Gamma spectrometry}

The dry, ground and homogenised soil samples were encapsuled in airtight perspex containers and stored for at least 4 weeks. This procedure minimizes the loss of the short-lived noble gas ${ }^{222} \mathrm{Rn}$ and allows ${ }^{226} \mathrm{Ra}$ to reach equilibrium with its daughters ${ }^{214} \mathrm{~Pb}$ and ${ }^{214} \mathrm{Bi}$.

The samples were counted using high resolution gamma spectrometry with a broad energy Ge detector for a minimum time of $24 \mathrm{~h}$. The spectra were analysed using GENIE2000 software. 
The doserate calculation is based on the activity concentration of the nuclides ${ }^{40} \mathrm{~K},{ }^{208} \mathrm{Tl},{ }^{212} \mathrm{~Pb}$, ${ }^{228} \mathrm{Ac},{ }^{214} \mathrm{Bi},{ }^{214} \mathrm{~Pb},{ }^{226} \mathrm{Ra}$.

\subsection{References}

Berryman, K. (1992). "A stratigraphic age of Rotoehu ash and late Pleistocene climate interpretation based on marine terrace chronology, Mahia Peninsula, North Island, New Zealand." New Zealand Journal of Geology and Geophysics 35(1): 1-7.

Berryman, K. R. (1993). "Distribution, age, and deformation of Late Pleistocene marine terraces at Mahia peninsula, Hikurangi subduction margin, New Zealand." Tectonics 12(6): 1365-1379.

Bloom, A. L., W. S. Broecker, J. Chappell, R. K. Matthews and K. J. Mesolella (1974). "Quaternary sea level fluctuations on a tectonic coast: new $230 \mathrm{Th} / 234 \mathrm{U}$ dates from the Huon Peninsula, New Guinea." Quaternary Research 4: 185-205.

Chapman-Smith, M. and J. A. Grant-Mackie (1971). "Geology of the Whangaparoa area, eastern Bay of Plenty." New Zealand Journal of Geology and Geophysics 14(1): 3-38.

Chappell, J., A. Omura, T. Esat, M. McCulloch, J. Pandolfi, Y. Ota and B. Pillans (1996). "Reconciliation of later Quaternary sea levels derived from coral terraces at Huon Peninsula with deep sea oxygen isotope records." Earth and Planetary Science Letters 141: 227-236.

Choi, J. H., A. S. Murray, M. Jain, C. S. Cheong and H. W. Chang (2003). "Luminescense dating of well-sorted marine terrace sediments on the southeastern coast of Korea." Quaternary Science Reviews 22: 407-421.

Collot, J.-Y., J. Delteil, K. Lewis, B. Davy, G. Lamarche, J.-C. Andru, P. Barnes, F. Chanier, E. Chaumillon, S. Lallemand, B. M. De Lepinay, A. Orpin, B. Pelletier, M. Sosson, Toussaint and C. Uruski (1996). "From oblique subduction to intra-continental transpression: structures of the southern Kermadec-Hikurangi margin from multibeam bathymetry, side-scan sonar and seismic reflection." Marine Geophysical Researches 18(2-4): 357-381.

Collot, J.-Y., K. Lewis, G. Lamarche and S. Lallemand (2001). "The giant Ruatoria debris avalanche on the northern Hikurangi margin, New Zealand; results of oblique seamount subduction." Journal of Geophysical Research 106B(9): 19271-19297.

Davey, F. J., S. Henrys and E. Lodolo (1997). "A seismic crustal section across East Cape convergent margin, New Zealand." Tectonophysics 269: 199-215.

De Mets, C., R. G. Gordon, D. F. Argus and S. Stein (1994). "Effect of recent revisions to the geomagnetic reversal timescale on estimates of current plate motions." Geophysical Research Letters 21: 2191-2194.

DeDiego-Forbis, T., R. Douglas, D. Gorsline, E. Nava-Sanchez, L. Mack and J. Banner (2004). "Late Pleistocene (last interglacial) terrace deposits, Bahia Coyote, Baja California Sur, Mexico." Quaternary International 120: 29-40.

Formento-Trigilio, M. L., D. W. Burbank, A. Nicol, J. Shulmeister and U. Rieser (2003). "River response to an active fold-and-thrust belt in a convergent margin setting, North Island, New Zealand." Geomorphology 49(1-2): 125-152.

Froggatt, P. C. and D. J. Lowe (1990). "A review of late Quaternary silicic and some other tephra formations from New Zealand: their stratigraphy, nomenclature, distribution, volume and age." New Zealand Journal of Geology and Geophysics 33: 89-109. 
Gillies, P. N. and F. J. Davey (1986). "Seiemic reflection and refraction studies of the Raukumara forearc basin, New Zealand." New Zealand Journal of Geology and Geophysics 29: 391-403.

Hsu, J. T. (1992). "Quaternary uplift of the Peruvian coast related to the subduction of the Nazca Ridge: 13.5 to 15.6 degrees latitude." Quaternary International 15/16: 87-97.

Iso, N., A. Okada, Y. Ota and T. Yoshikawa (1982). "Fission-track ages of late Pleistocene tephras on the Bay of Plenty coast, North Island, New Zealand." New Zealand Journal of Geology and Geophysics 25: 295-303.

Kelsey, H. M. and J. G. Bockheim (1994). "Coastal landscape evolution as a function of eustasy and surface uplift rate, Cascadia margin, southern Oregon." Geological Society of America Bulletin 106: 840-854.

Kennedy, N. (1988). Late Quaternary loess associated with the Mamaku Plateau, North Island, New Zealand. Loess: its distribution, geology and soils. D. N. Eden and R. J. Furkert. Rotterdam, A A Balkema: 71-80.

Kennedy, N. (1994). "New Zealand tephro-chronology as a tool in geomorphic history of the c. 140 ka Mamaku Ignimbrite Plateau and in relating oxygen isotope stages." Geomorphology 9: 97-115.

Lewis, K. B., J.-Y. Collot, B. Davy, J. Delteil, S. Lallemand and C. Uruski (1997). "North Hikurangi GeodyNZ swath maps: depths, texture and geological interpretation 1: 500 000." National Institute for Water and Atmospheric Research miscellaneous series chart 72. Wellington.

Lian, O. B. and P. Shane (2000). "Optical dating of Paleosols bracketing the widespread Rotoehu Tephra, North Island, New Zealand." Quaternary Science Reviews 19(16): 1649-1662.

Litchfield, N. and O. B. Lian (2004). "Luminescence age estimates of Pleistocene marine terrace and alluvial fan sediments associated with tectonic activity along coastal Otago, New Zealand." New Zealand Journal of Geology and Geophysics 47: 29-37.

Litchfield, N. and U. Rieser (2005). "Optically stimulated luminescence age constraints for fluvial aggradation terraces and loess in the eastern North Island, New Zealand." New Zealand Journal of Geology and Geophysics 48: 581-589.

Litchfield, N. J., S. Ellis, K. Berryman and A. Nicol (in press). "Subduction related uplift in the Hikurangi Margin, New Zealand." JGR, Earth Surface.

Ludwig, K. R., D. R. Muhs, K. R. Simmons, R. B. Halley and E. A. Shinn (1996). "Sea level records at $\sim 80$ ka from tectonically stable platforms: Florida and Bermuda." Geology 24(3): 211-214.

Manning, D. A. (1995). Late Pleistocene tephrostratigraphy of the eastern Bay of Plenty region, New Zealand., Unpublished $\mathrm{PhD}$ thesis, Victoria University of Wellington.

Manning, D. A. (1996). "Middle-late Pleistocene tephrostratigraphy of the eastern Bay of Plenty, New Zealand." Quaternary International 34-36: 3-12.

Marquardt, C., A. Lavenu, L. Ortleib, E. Godoy and D. Comte (2004). "Coastal neotectonics in Southern Contral Andes: uplift and deformation of marine terraces in Northern Chile (27 degrees south)." Tectonophysics 394: 193-219.

Mazengarb, C. and I. G. Speden (2000). Geology of the Raukumara area, Institute of Geological \& Nuclear Sciences 1:250,000 Geological Map 6.

Milne, J. D. G. and I. J. Smalley (1979). "Loess deposits in the southern part of the North Island of New Zealand: an outline stratigraphy." Acta Geologica Academiae Sientiarum Hungaricae, Tomus 22: 197-204. 
Murray-Wallace, C. V. (2002). "Pleistocene coastal stratigraphy, sea-level highstands and neotectonism of the southern Australian passive continental margin - a review." Journal of Quaternary Science 17(56): 469-489.

Ota, Y., B. Pillans, K. Berryman, A. Beu, T. Fujimori, T. Miyauchi, G. Berger, A. Beu and F. Climo (1996). "Pleistocene coastal terraces of Kaikoura Peninsula and the Marlborough Coast, South Island, New Zealand." New Zealand Journal of Geology and Geophysics 39(1): 51-73.

Palmer, A., C. G. Vucetich, M. S. McGlone and M. A. Harper (1989). "Late Glacial loess and early Last Glacial vegetation history of Wairarapa valley, New Zealand." New Zealand Journal of Geology and Geophysics 32: 499-513.

Palmer, A. and B. Pillans (1996). "Record of climatic fluctuations from ca. 500 ka loess deposits and paleosols near Wanganui, New Zealand." Quaternary International 34-36: 155-162.

Pillans, B. (1990). "Pleistocene marine terraces in New Zealand: a review." New Zealand Journal of Geology and Geophysics 33: 219-231.

Pillans, B. (1994). "Direct marine-terrestrial correlations, Wanganui Basin, New Zealand: the last 1 million years." Quaternary Science Reviews 13: 189-200.

Pillans, B., J. Chappell and T. Naish (1998). "A review of the Milankovich climate beat: template for Plio-Pleistocene sea-level changes and sequence stratigraphy." Sedimentary Geology 122: 5-21.

Rees-Jones, J., W. J. Rink, R. J. Norris and N. J. Litchfield (2000). "Optical luminescence dating of uplifted marine terraces along the Akatore Fault near Dunedin, South Island, New Zealand." New Zealand Journal of Geology and Geophysics 43: 419-424.

Rieser, U. (2005). "Determination of sediment deposition ages by luminescence dating." Victoria University of Wellington Technical Report 05/11.

Rieser, U. (2006). "Determination of sediment deposition ages by luminescence dating." Victoria University of Wellington Technical Report

Tanaka, K., R. Hataya, N. A. Spooner, D. G. Questiaux, Y. Saito and T. Hashimoto (1997). "Dating of marine terrace sediments by ESR, TL and OSL methods and their applicabilities." Quaternary Science Reviews 16: 257-264.

Vacher, H. L. and P. Hearty (1989). "History of Stage 5 sea level in Bermuda: review with new evidence of a brief rise to present sea level during substage 5a." Quaternary Science Reviews 8: 159168.

Wehmiller, J. F., K. R. Simmons, H. Cheng, L. Edwards, J. Martin-McNaughton, L. L. York, D. E. Krantz and C.-C. Shen (2004). "Uranium-series coral ages from the US Atlantic Coastal Plain - the "80-ka" problem revisited." Quaternary International 120: 3-14.

Wilson, C. J. N., B. F. Houghton, M. A. Lanphere and S. D. Weaver (1992). "A new radiometric age estimate for the Rotoehu Ash from Mayor Island volcano, New Zealand." New Zealand Journal of Geology and Geophysics 35: 371-374.

Yoshikawa, T. (1988). "Pattern and rate of tectonic movement and Late Quaternary geomorphic development in the Raukumara Peninsula, northeastern North Island, New Zealand." Bulletin of the Department of Geography University of Tokyo 20: 1-28.

Yoshikawa, T., Y. Ota, N. Yonekura, A. Okada and N. Iso (1980). "Marine terraces and their tectonic deformation on the northeast coast of the North Island, New Zealand." Geographical Review of Japan 53(4): 238-262. 


\title{
CHAPTER SEVEN
}

\section{RELATIONSHIPS BETWEEN LATE QUATERNARY COASTAL GEOMORPHOLOGY AND SUBDUCTION ZONE GEODYNAMICS OF THE RAUKUMARA SECTOR OF THE HIKURANGI MARGIN.}

\begin{abstract}
Subduction zone geodynamics and seismic hazard of the Raukumara sector of the Hikurangi margin forearc, eastern North Island, New Zealand, are poorly understood. Here we assess the coastal neotectonic record of the Raukumara Peninsula, in order to elucidate forearc deformation processes across a margin-normal width of $100 \mathrm{~km}$. We consider how these processes relate to the subduction zone and the implications for the seismic hazard of this sector of the margin. Late Quaternary coastal uplift mechanisms of the Raukumara sector vary between localised zones of coseismic uplift and broader zones of aseismic uplift. Evidence for uplift mechanisms was obtained from detailed studies of Holocene and Pleistocene marine terrace geomorphology and from the stratigraphy of early Holocene transgressive marine sequences at three coastal regions on the Raukumara Peninsula. We propose that the main parameter controlling the spatial distribution of uplift mechanisms is the proximity of the forearc to the Hikurangi Trough and, by inference, the depth to the plate interface below. Three zones of forearc uplift mechanisms are identified: (1) a zone of coseismic uplift on upper plate contractional faults within $20-80 \mathrm{~km}$ of the trough, (2) a passive inner forearc zone at $\sim 80-120 \mathrm{~km}$ from the trough, vertical tectonic movement within this zone is controlled by distal upper plate structures or plate interface paleoseismicity, and (3) a zone of aseismic uplift driven by sediment underplating located $\sim 120-180 \mathrm{~km}$ of the trough. Changes in the thickness of the upper plate crust and plate coupling along the strike of the Raukumara sector are inferred to be less important in controlling uplift mechanism distribution than changes normal to the margin. The coseismic and aseismic uplift zones have little potential for recording a subduction earthquake history. We identify the passive forearc zone as the most likely region to contain a coastal paleoseismic history of subduction earthquakes because it is less affected by upper plate deformation and displays the general pattern of vertical tectonics predicted to occur during plate interface events. This study demonstrates the utility of studying uplift mechanisms across a broad zone perpendicular to subduction zones. Variances in forearc deformation processes have been documented; these are related to subduction zone geodynamics and are critical in regional-scale seismic hazard assessment.
\end{abstract}




\subsection{Introduction}

The Raukumara sector of the Hikurangi margin, East Coast, North Island, New Zealand (Fig. 7.1A), possesses perhaps some of the least well-understood subduction zone geology of the Hikurangi margin. There are no significant active faults in the onshore forearc (Mazengarb and Speden, 2000), and geophysical studies suggest the forearc is undergoing margin-normal extension (Darby and Meertens, 1995; Arnadottir et al., 1999; Reyners and McGinty, 1999). These observations suggest that the coastline should be subsiding, which is seen at some locations. However, the Raukumara Peninsula also shows some of the highest coastal uplift rates along the Hikurangi margin (Berryman et al., 1989; Ota et al., 1992. Furthermore, the mechanism of these high coastal uplift rates varies spatially between aseismic and coseismic (Berryman, 1993a; Wilson, Ch. 5, Ch. 3). Sediment underplating has been suggested as a cause of forearc uplift (Walcott, 1987; Thornley, 1996), yet the localised zones of coseismic coastal uplift along the Raukumara Peninsula do not reconcile with the broad crustal warping one would expect above ponded sediment in the lower crust. In addition, there have been no large or great earthquakes on the Raukumara Peninsula in historic time and the risk of a plate interface rupture event is poorly constrained (Stirling et al., 2002; Cochran et al., 2006). In the absence of historic events neotectonic interpretation of coastal geomorphology and stratigraphy provides the only record of subduction zone paleoseismology available on active margins, yet the relationship between coastal tectonics of the Raukumara Peninsula and the plate interface is poorly understood for this margin sector.

In this study we review the late Quaternary coastal geomorphology of the Raukumara Peninsula with the aim of understanding some of the geodynamic processes operating on this segment of the Hikurangi margin. We seek to understand what type of structures accommodate coastal uplift on the Raukumara Peninsula, whether these structures have a predictable spatial relationship to the Hikurangi subduction zone, and whether these relationships can be integrated with other geophysical and geologic studies of the Raukumara sector. Essentially, can the coastal neotectonic record be used to shed light on the processes of forearc deformation and what can this tell us about seismic hazard in the region? 

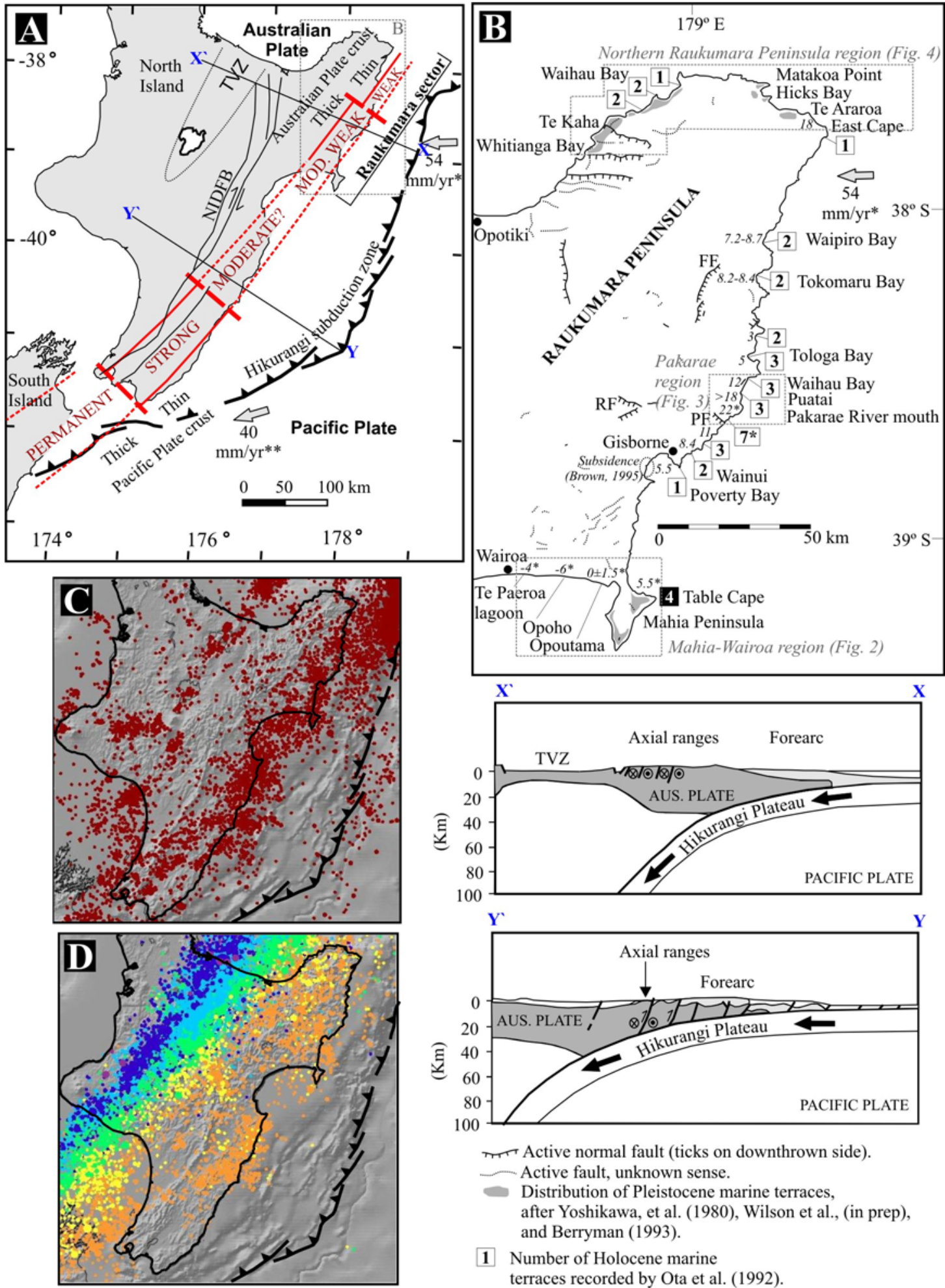

100

Active normal fault (ticks on downthrown side).

Active fault, unknown sense.

Distribution of Pleistocene marine terraces, after Yoshikawa, et al. (1980), Wilson et al., (in prep), and Berryman (1993).

1 Number of Holocene marine terraces recorded by Ota et al. (1992)

* also recorded by Wilson et al. (2006)

4 Number of Holocene marine

terraces recorded by Berryman (1993).

5.5 Elevation of the Holocene marine transgression surface recorded by Ota et al. (1992).

* Pakarae: also recorded by Wilson et al. (2006),

Mahia recorded by Berryman (1993) and

Opoho-Opoutama recorded by Cochran et al. (2006). 
Figure 7.1. (A) Location map of the Raukumara Peninsula, North Island, New Zealand, and the adjacent Hikurangi subduction zone (TVZ: Taupo Volcanic Zone, NIDFB: North Island dextral fault belt). Red lines show the width of the interseismically locked portion of the plate interface, text indicates the strength of plate coupling, after Reyners (1998). Cross-sections X-X' and Y-Y are adopted from Beanland (1995). *Pacific-Kermadec plate motion after Collot et al. (2001), **PacificAustralia plate motion after De Mets et al. (1994). (B) Localities, coastal tectonics and active onshore faults of the Raukumara Peninsula. Shown is the distribution of Pleistocene marine terraces (grey shade), the number of Holocene marine terraces (boxed numbers) and the elevation of the maximum Holocene marine transgression surface. Only the faults that have had detailed studies undertaken on them are named (PF: Pakarae Fault, FF: Fernside Fault, RF: Repongaere Fault). Data sources are listed in the legend. Dashed grey boxes outline the regions where thorough coastal geomorphic studies have been undertaken, and which are discussed in detail in the text. *Pacific-Kermadec plate motion after Collot et al. (2001). (C) Recent seismicity of the Hikurangi margin at depths shallower than $40 \mathrm{~km}$, 1990 - present day, events > M 3. (D) Recent seismicity of the Hikurangi margin at depths shallower greater than $40 \mathrm{~km}, 1990$ - present day, events > M 3. Maps C and D sourced from www.geonet.org.nz.

\subsection{Previous work}

The Hikurangi Trough lies offshore of the East Coast of the North Island and this is the surface manifestation of convergence between the Pacific and Australian Plates (Lewis, 1980; Lewis and Pettinga, 1993, Fig. 7.1A). The onshore region of the North Island from Cape Palliser in the south to Matakaoa Point in the northeast is known as the Hikurangi margin. Plate convergence rates vary from $54-40 \mathrm{~mm} \mathrm{yr}^{-1}$, the rate of convergence decreases, and obliquity of convergence increases towards the south (Collot et al., 2001; De Mets et al., 1994). Presently, and for approximately the past 7 Ma, the Hikurangi Plateau, has been subducting along the Hikurangi margin (Reyners et al., 2006). This oceanic crustal Plateau is a Cretaceous large igneous province that is approximately $12-15 \mathrm{~km}$ thick (Davy and Wood, 1994). A major tectonic feature of the southern and central Hikurangi margin sectors is the North Island dextral fault belt (NIDFB, Fig. 7.1A). This series of dextral strike slip faults strikes northeast along the eastern side of the axial ranges, at approximately $39^{\circ} \mathrm{S}$ they strike northward and traverse across the axial ranges to the Bay of Plenty and eastern edge of the TVZ. This major fault system therefore bypasses the Raukumara Peninsula and there is a distinctive absence of active faulting within the onshore forearc of the Raukumara sector.

Interpretations of geodetic data, shallow seismicity and the few active onshore faults in the region suggest the Raukumara Peninsula is currently undergoing margin-normal extension (Darby and Meertens, 1995; Thornley, 1996; Webb and Anderson, 1998; 
Arnadottir et al., 1999; Reyners and McGinty, 1999). Reyners and McGinty (1999) note that extensional earthquake focal mechanisms occur in the upper $9.5 \mathrm{~km}$ of the Raukumara Peninsula crust and compressional thrust faulting occurs below this (Fig. 7.1C,D). Geodetic measurements by Darby and Meertens (1995), Thornley (1996) and Arnadottir et al. (1999) suggest trenchward extension of the central and eastern Raukumara Peninsula. Few active normal faults have been mapped on the central and eastern Raukumara Peninsula. The three most well-documented faults are the Fernside fault, the Pakarae fault and the Repongaere Fault (Fig. 7.1B, Mazengarb, 1984; Ota et al., 1991; Wilson, Ch. 2; New Zealand Active Faults Database: http://data.gns.cri.nz/af/index.jsp). These three faults have been active during the Holocene and are short $(<20 \mathrm{~km}$ in length) normal faults. Faults such as the Fernside are consistent with the trenchward slumping and extension suggested by Thornley (1996), Arnadottir et al. (1999) and Reyners and McGinty (1999).

Given the absence of active faulting it has long been a question of how the Raukumara Peninsula is uplifting? Sediment underplating was first suggested as a cause of Raukumara Peninsula uplift by Walcott (1987). This theory was largely based on an estimated sediment accretion budget whereby Walcott (1987) compared the amount of sediment estimated to have entered the Hikurangi Trough with the amount of sediment accreted to the forearc. The lack of a modern accretionary wedge adjacent to the Raukumara Peninsula led Walcott (1987) to conclude that sediment entering the subduction zone was ponding beneath the Raukumara Ranges and driving the broad uplift of the Pleistocene marine terraces. Thornley (1996) studied the structural geology, seismicity, geodesy of the Raukumara Peninsula and concluded that the Raukumara Peninsula is undergoing broad antiformal uplift and trenchward extension. Critical wedge models were used to demonstrate that extension is probably due to surficial sliding of Neogene sediments above a detachment layer composed of Paleogene smectite. He inferred the sliding is driven by gravity and maintained by continuous axial range uplift driven by sediment underplating.

Later studies using velocity models, constructed using earthquake arrival time inversions, and seismic attenuation models of the upper plate and subduction interface beneath the Raukumara Peninsula indicated a zone of low velocity and high attenuation directly above the plate interface. This zone is inferred to represent 
ponded sediment (Eberhart-Phillips and Reyners, 1999; Reyners et al., 1999; Eberhart-Phillips and Chadwick, 2002). The ponded sediment is located deeper than $20 \mathrm{~km}$; it is estimated to be up to $20 \mathrm{~km}$ thick and directly underlies the axis of the Raukumara Ranges (Reyners et al., 1999). A channel of subducting sediment $\sim 1-2$ $\mathrm{km}$ thick is inferred on the plate interface along the whole strike of the Raukumara sector (Eberhart-Phillips and Reyners, 1999). Tectonic erosion at the Hikurangi Trough along this portion of the margin provides a sediment source for underplating as the sediment cover on the subducting Plateau is relatively thin at $1-1.5 \mathrm{~km}$ (Collot et al., 1996). The thickness of the low-velocity zone underlying the Raukumara Peninsula decreases south of a line running approximately between Opotiki and Tologa Bay (Fig. 7.1A, B), leading Reyners et al. (1999) to infer that the thickness of underplated sediment beneath the Raukumara Peninsula decreases southwestward. They suggest this decrease is related to a change in crustal thickness. Specifically the crust of the northeastern Raukumara Peninsula is $\sim 20 \mathrm{~km}$ thick and subducted sediment ponds against a relatively strong mantle backstop. In the southwestern Raukumara Peninsula the thickness of the crust increases to $\sim 38 \mathrm{~km}$, and the lower crust is relatively weak, allowing sediment subduction to greater depths (Reyners et al., 1999). The body of underplated sediment is not included by Reyners et al. (1999) as part of the Australian plate crust, hence the crustal thickness increases southward despite a substantial thickness $(\sim 20 \mathrm{~km})$ of underplated sediment beneath the northern Raukumara Peninsula.

Two recent studies by Upton et al. (2003) and Litchfield et al. (in press) use finite element modelling of a subduction margin to understand the effects that underplated sediment has upon forearc uplift rates. 3D finite-difference modelling by Upton et al. (2003) indicates that an antiformal region of uplift can develop directly above a zone of weaker material in the upper plate. Rates of uplift up to $4 \mathrm{~mm} \mathrm{yr}^{-1}$ were modelled when a block of weaker material, based on the ponded sediment dimensions of Reyners et al. (1999), was used in the model. The Litchfield et al. (in press) study uses 2D finite element models to test several possible mechanisms of forearc uplift. They demonstrate that sediment underplating could produce uplift of the Raukumara Ranges, although rates of uplift are poorly constrained because the modelling technique dictates that underplated sediment could only be simulated by inducing tectonic erosion at the trough. The study also suggests that subduction of the 
Hikurangi Plateau may be the cause of widespread low uplift rates $\left(<1 \mathrm{~mm} \mathrm{yr}^{-1}\right)$ across the Hikurangi margin and seamount subduction may cause uplift at rates up to $0.7 \mathrm{~mm} \mathrm{yr}^{-1}$ in localised zones of $20-80 \mathrm{~km}$ in diameter (Litchfield et al., in press).

There appears to be less upper plate seismicity on the Raukumara Peninsula relative to the southern Hikurangi margin according to the cumulative number of events greater than or equal to M 4 at depths between $0-20 \mathrm{~km}$ (Stirling et al., 2002). However, the $b$-value (a parameter that compares the earthquake size distribution of a region to the Gutenberg-Richter relationship) of the Raukumara Peninsula is $\sim 0.9$ (Stirling et al., 2002). This value is typically suggests either a reverse faulting province or an incomplete seismic record in which smaller magnitude earthquakes are underestimated in the catalogue. Because the Raukumara Peninsula is a promontory region it is more likely that the distribution of seismic network has resulted in an underestimation of small earthquakes in this region. Therefore the $b$-value indicates that the apparent decrease in upper plate seismicity on the Raukumara Peninsula is therefore probably an artefact of the seismic network distribution rather than a real tectonic signal.

The Raukumara sector plate interface is inferred to be presently weakly coupled relative to the southern sectors of the margin. Plate coupling has been estimated primarily by two methods: firstly by the distribution and nature of earthquake focal mechanisms along the plate interface (Reyners et al., 1998; Reyners and McGinty, 1999) and secondly by modelling GPS velocities (Wallace et al., 2004). These methods provide different ways of estimating plate coupling. The Reyners (1998) study estimates the margin-normal width of the plate interface that is seismically locked (Fig. 7.1A), whereas the Wallace et al. (2004) study estimates the slip rate deficit between plate convergence and interface movement and uses this to produce a coupling coefficient. Both of these are a measure of the current interseismic coupling state of the interface. Reyners (1998) estimates the width of the locked zone beneath the Raukumara Peninsula to be $20-40 \mathrm{~km}$ beneath the onshore forearc in the southwest but largely offshore in the northeastern part of the Raukumara Peninsula (Fig. 7.1A). The Wallace et al. (2004) model shows a relatively uniform coupling coefficient across the Raukumara Peninsula, with only a patch of slightly higher coupling in the Gisborne to Tologa Bay area. Both studies of plate coupling show a 
gradient in coupling along the strike of the margin, from strongly coupled in the southwest to weakly coupled in the northeast, beneath the Raukumara Peninsula. They suggest there is a correlative decrease in the maximum size of subduction earthquakes that may be generated by plate interface rupture along the margin from southwest to northeast.

The above studies suggest that the Raukumara Peninsula is in a state of marginnormal extension and that the forearc overlies a plate interface that possibly does not generate large to great subduction earthquakes. However moderate to high coastal uplift rates (2-5 $\mathrm{mm} \mathrm{yr}^{-1}$ ) have been recorded at many coastal localities along the peninsula (Ota et al., 1988; 1992). Elsewhere along the margin uplift rates of these magnitudes have been attributed to compressional structures, typically reverse faults listric to the plate interface. This study uses coastal uplift data to make inferences about the geodynamics of the subduction zone, and we will try to address inconsistencies between geophysical and geological methods of studying forearc deformation.

\subsection{Raukumara Peninsula coastal geomorphology and uplift mechanisms}

The late Quaternary coastal geomorphology of the Raukumara Peninsula has been studied at a reconnaissance level by Ota et al. $(1988 ; 1992)$ and Brown (1995). These studies documented the occurrence and elevation of the highest Holocene marine transgressive sediments, and the number of Holocene marine terraces (Fig. 7.1B). Eustatic SL in the New Zealand region stabilised at $\sim 7 \mathrm{ka}$ (Gibb, 1986). The surface created when sediments infilled valleys up to the stable SL position is known as the maximum Holocene marine transgression surface (Ota et al., 1988) and it can be used as a marker horizon to estimate the sense and amount of vertical tectonic movement since $\sim 7$ ka B.P. Ota et al. (1988) measured the maximum Holocene marine transgression surface at elevations between -4 and $22 \mathrm{~m}$ along the Raukumara Peninsula coast (Fig. 7.1B). Holocene marine terraces represent coastal uplift that has occurred since the time of eustatic SL stabilisation (post-7 ka B.P., Gibb (1986). Between one and seven marine terraces were measured and described by Ota et al. (1988) at 22 locations. However, seven of these locations on the northeastern Raukumara Peninsula have been revised by Wilson (Ch. 5). 
The late Quaternary coastal tectonic geomorphology of three regions of the Raukumara Peninsula has been studied in detail: (1) the coastline from Whitianga Bay to East Cape, an area we refer to as the northern Raukumara Peninsula region, (2) the Pakarae region, and (3) Wairoa to Mahia Peninsula region (Fig. 7.1B). We summarise the results of studies in each of these regions with emphasis on the mechanisms of vertical tectonic movement.

\subsubsection{Mahia-Wairoa region}

The Holocene coastal geomorphology and stratigraphy of the coastline between Wairoa and Mahia Peninsula has been studied by Ota et al. (1989), Berryman (1993a, b) and Cochran et al. (2006) (Fig. 7.2). Mid to late Holocene uplift of the Mahia Peninsula is evidenced by a flight of by 4 to 5 marine terraces (Berryman, 1993a). Sediment cores of mid to late Holocene marginal marine sediments collected at Opoutama show equivocal evidence for vertical movement. Sediment cores at Te Paeroa lagoon and Opoho show the maximum Holocene marine transgression surface presently lying at 4 and $6 \mathrm{~m}$ below modern mean SL, this indicates net tectonic subsidence since the time of eustatic SL stabilisation (Cochran et al., 2006).

The Holocene marine terraces at Table Cape and Auroa Point, Mahia Peninsula, display topography, coverbed stratigraphy and radiocarbon age clustering all indicative of uplift by a sudden coseismic mechanism (Berryman, 1993a). Average Holocene uplift rates vary along the coast and range from $2.5 \mathrm{~mm} \mathrm{yr}^{-1}$ to $0.7 \mathrm{~mm} \mathrm{yr}^{-1}$. The structure accommodating uplift is probably the Lachlan Fault, a thrust fault located offshore 5-10 km eastward of Mahia Peninsula (Fig. 7.2, Barnes et al., 2002). This fault and the associated anticlinal Lachlan Ridge structure are well imaged by hydrocarbon exploration seismic data (Barnes et al., 2002). It is fortuitous that seismic lines can be placed across the southern tip of Mahia Peninsula thus enabling imaging of a cross-section of the Lachlan Ridge structure. The Lachlan Fault dips westward at $55^{\circ}-70^{\circ}$, but the gradient decreases with depth to become listric to the subduction interface at $\sim 20 \mathrm{~km}$ depth (Barnes et al., 2002). This position is approximately within the middle of that part of the plate interface estimated to be interseismically locked by Reyners (2000, Fig. 7.1A), but it is not strongly coupled according to the GPSdetermined slip deficit (Wallace et al., 2004). A suite of seven Pleistocene marine terraces at Mahia Peninsula attest to coastal uplift dating back to $\sim 210$ ka (Fig. 7.2). 
These terraces display a west-northwest tilt, consistent with uplift on the flank of the Lachlan anticline (Berryman, 1993b).

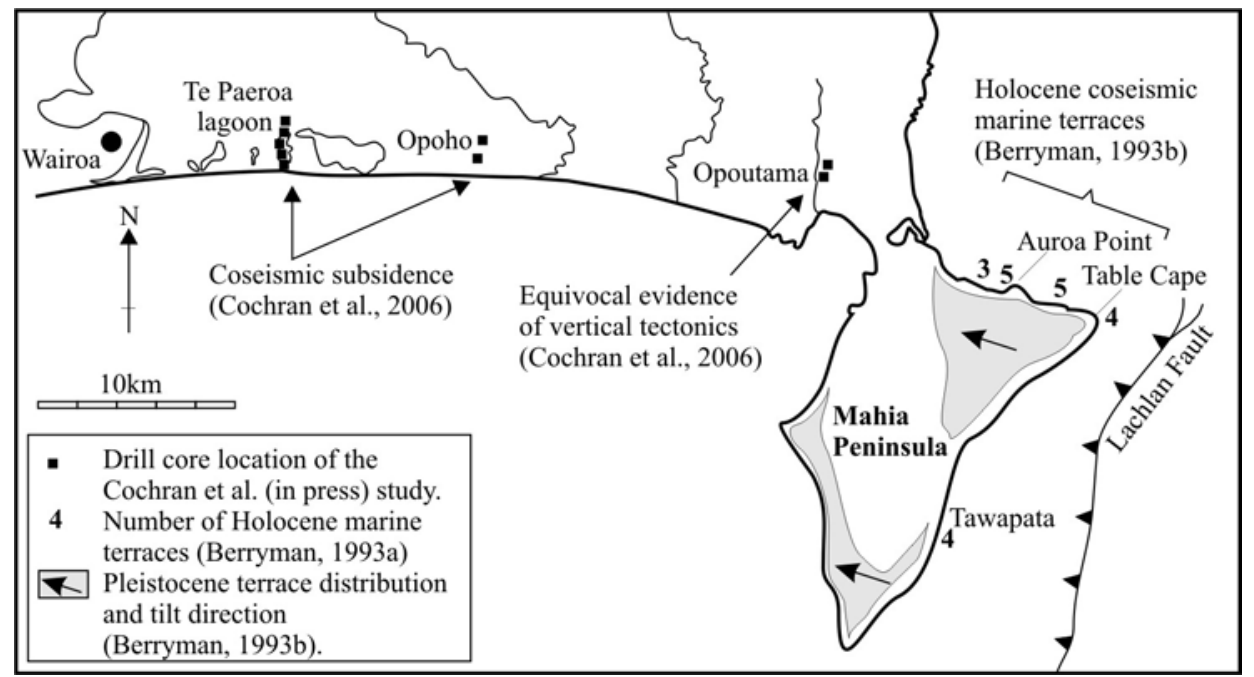

Figure 7.2. Location map and summary of the coastal neotectonics in the Mahia-Wairoa region. Position of the Lachlan Fault after Barnes et al. (2002). Location of Holocene marine terraces and the distribution of Pleistocene marine terraces are shown.

Two subsidence event horizons have been identified within sediment cores collected from Te Paeroa lagoon and Opoho. The events are identified by rapid paleoenvironmental changes and coincide with probable tsunami deposits; thus a sudden coseismic mechanism is inferred (Cochran et al., 2006). Thus far the subsidence events at Te Paeroa lagoon and Opoho have not been correlated to terrace uplift events at Mahia Peninsula, the age ranges of these two data sets do not coincide. Forward elastic dislocation models indicate the observed pattern of vertical movement recorded at Te Paeroa lagoon, Opoho and Opoutama could be generated by rupture of the subduction interface or the Lachlan fault or by simultaneous rupture of both (Cochran et al., 2006).

\subsubsection{Pakarae region}

Ota et al. (1991) and Wilson (Ch. 2) have studied the mid to late Holocene marine terraces at the Pakarae River mouth (Fig. 7.3A, B). The morphology, coverbed 
stratigraphy and radiocarbon ages of the terraces are consistent with coseismic events causing uplift and abandonment of marine abrasion surfaces. Seven marines terraces record uplift since $\sim 7 \mathrm{ka}$ B.P at intervals of $850 \pm 450 \mathrm{yrs}$ with an average magnitude of $2.7 \pm 1.1 \mathrm{~m}$ per event (Fig. 7.3B, C). The average uplift rate is $3.2 \pm 0.8 \mathrm{~mm} \mathrm{yr}^{-1}$. A sequence of early Holocene transgressive marine sediments underlying the highest terrace at the Pakarae River mouth has been studied by Berryman et al. (1992) and Wilson (Ch. 3, Ch 4). These studies demonstrated that the infill sequence is thinner than expected given eustatic SL change, implying uplift during deposition. Wilson (Ch. 4) used paleoenvironmental facies architecture to identify three uplift events that occurred during infilling of the Pakarae River paleo-valley in the early Holocene. Significantly, this study used biostratigraphy to demonstrate that changes from estuarine to floodplain paleoenvironments were sudden, verifying that uplift at the Pakarae River mouth occurs by coseismic mechanisms.

At Puatai Beach and Waihau Bay, 9 and $15 \mathrm{~km}$ northeast of the Pakarae River mouth respectively, uplift rates of similar magnitudes to the Pakarae River mouth have been estimated from marine terraces (Fig. 7.3A). This region from Waihau Bay will henceforth be referred to as the Pakarae region (Fig. 7.3A). Puatai Beach appears to have the highest uplift rates of the three locations and has been suggested to represent the crest of a coast-parallel ellipsoid dome structure. Coseismic uplift of the three locations is thought to be driven by a near-shore reverse fault striking approximately north-notheast (Fig. 7.3A, Ota et al., 1991; Litchfield and Wilson, 2005; Wilson, Ch. 2). It is likely that this fault lies within $5 \mathrm{~km}$ of the coastline. The existence of the fault has not been verified by seismic imaging because available seismic data do not reach this close to the shoreline. Bathymetric data support the existence of active structures offshore of the Pakarae region; Ariel Bank, a north-northeast-striking bathymetric high, approximately $20 \mathrm{~km}$ southeast of the Pakarae River mouth is an example (Lewis et al., 1997). A reverse fault directly offshore of the Pakarae region has been mapped by Lewis et al. (1997), though this was based upon the inferences of Ota et al. (1991), rather than seismic or bathymetric data. Recent seismic data collected by the Ministry of Economic Development may help to map the offshore region in greater detail (Ministry of Economic Development Petroleum Report Series PR3136, 2005). 

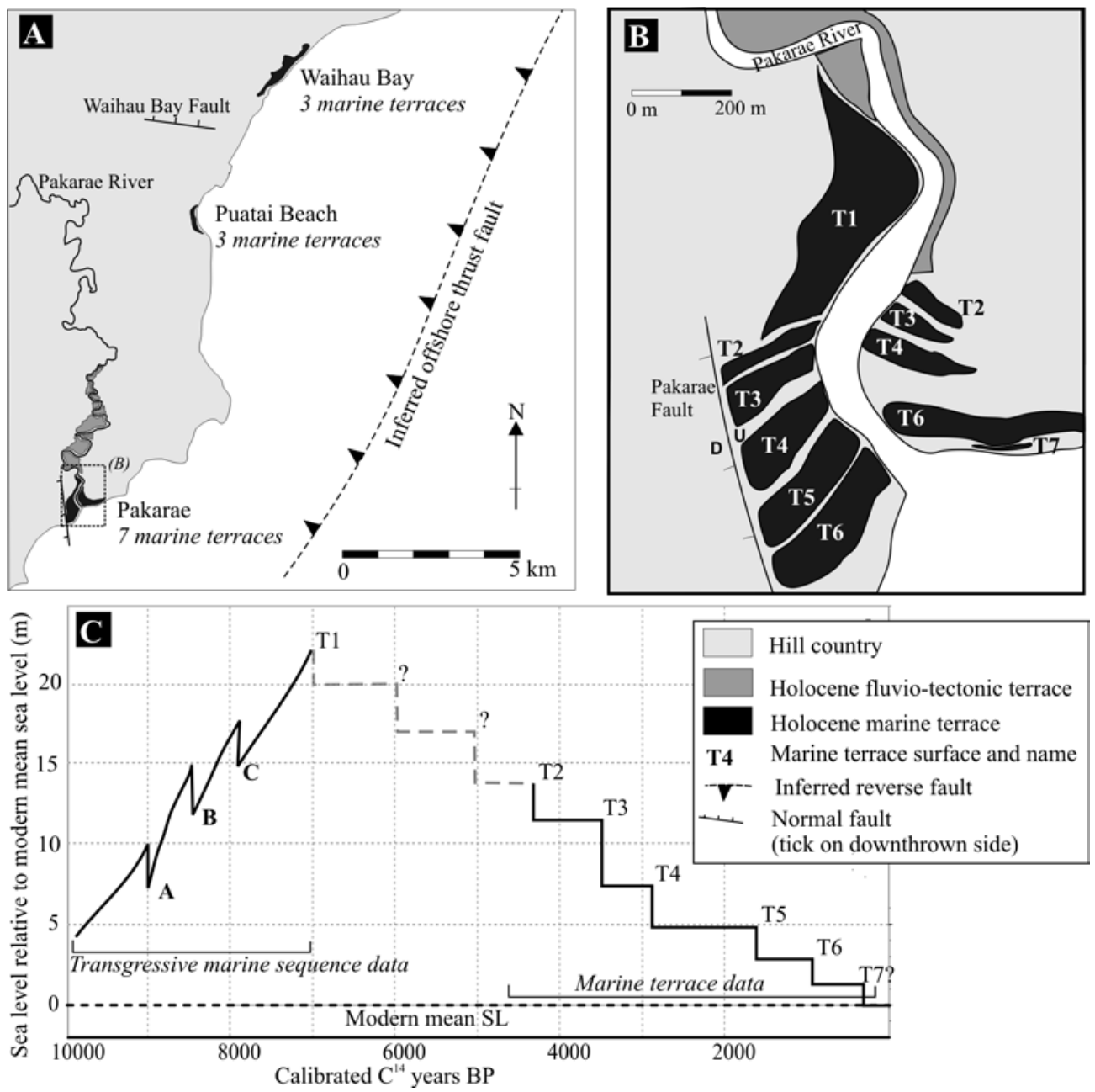

Figure 7.3 (A) Location map, neotectonics and coastal geology of the Pakarae region. Terrace numbers and inferred offshore fault location after Ota et al. (1991). (B) Marine terrace distribution at the Pakarae River mouth, after Wilson, Ch. 2. (C) A relative Holocene sea level curve for the Pakarae River mouth locality from Wilson, Ch. 4. Steps within the curve represent sudden relative sea level falls due to coseismic land uplift.

Litchfield and Wilson (2005) studied the surface geometry of late Holocene fluvial terraces along the Pakarae River that grade to the marine terraces. These fluviotectonic terraces have a landward tilt and display a fan-like geometry that implies uplift of the terraces was greatest at the coast. The Holocene marine terraces at the Pakarae River mouth also display a landward tilt of $0.24^{\circ}$ (Wilson, Ch. 2). Evidence of landward tilt is consistent with uplift along a nearshore reverse fault. Preliminary elastic dislocation modelling using the geometry of the fluvio-tectonic terraces and marine terrace uplift rates indicates that the offshore reverse fault is likely to be very 
steep and may or may not be listric to the plate interface. No dislocation models could exactly replicate the pattern of uplift created by the Pakarae River mouth-PuataiWaihau Bay data points. Invoking slip on both the plate interface and the upper plate reverse fault did not help to resolve the model (L. Wallace, pers.comm., Litchfield and Wilson, 2005).

\subsubsection{Northern Raukumara Peninsula region}

Aspects of the Holocene coastal geomorphology of the northern Raukumara Peninsula, from Hicks Bay to East Cape, have been examined by Garrick (1979), Ota et al. (1992) and Wilson (Ch. 5). Ota et al. (1992) described up to five marine terraces on the coastline east of Te Araroa at Waipapa and Horoera. They inferred from the geomorphology that the terraces were uplifted by coseismic events. Wilson (Ch. 5) undertook detailed topographic surveys and an examination of the cover sediment sequences of the terraces and concluded the terraces did not have a marine origin and therefore yielded no evidence of coseismic uplift events. Wilson (Ch. 5) examined the biostratigraphy and chronology of a transgressive marine sequence infilling the Hicks Bay valley (Fig. 7.4A). Significant differences between the preserved thickness of intertidal valley infill and the amount of eustatic SL rise during the equivalent time periods indicated the uplift occurred synchronously with deposition of the trangressive sequence. Paleoecological constraints indicate this uplift was probably gradual, though it may have occurred by frequent coseismic events causing $<0.85 \mathrm{~m}$ of uplift per event. The seaward slope of an uplifted beach ridge sequence at Te Araroa also supports gradual uplift (Fig. 7.4A). The Wilson (Ch. 5) study concluded that most Holocene uplift in this region was aseismic.

An average Holocene uplift rate of $1.7 \pm 0.4 \mathrm{~mm} \mathrm{yr}^{-1}$ was calculated from the Hicks Bay transgressive marine sequence data. At Te Araroa the Holocene uplift rates are poorly constrained and range between 0.5 and $2 \mathrm{~mm} \mathrm{yr}^{-1}$. Yoshikawa et al. (1980) collected a wood sample from a riverbank exposure of silt containing marine and estuarine diatoms at $7 \mathrm{~m}$ AMSL along the Waipapa Stream (labelled "Yoshikawa outcrop", Fig. 7.4A). It yielded a radiocarbon age of 9900-9400 cal. yrs B.P., equating with an uplift rate of $2.7-3.3 \mathrm{~mm} \mathrm{yr}^{-1}$ (using $22 \pm 2 \mathrm{~m}$ of eustatic SL rise since its 


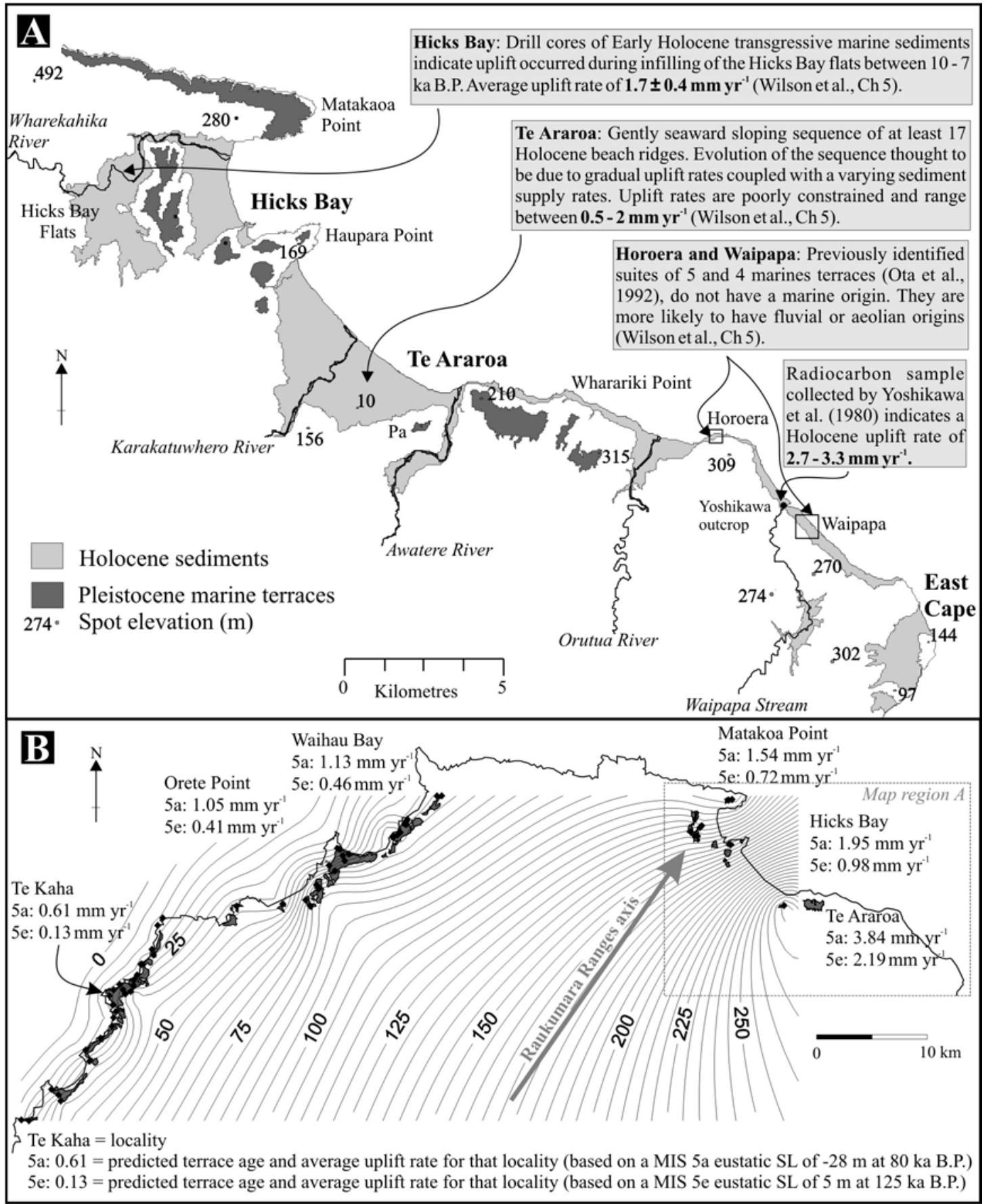

Figure 7.4 (A) A summary of the Holocene coastal geomorphology of the northern Raukumara Peninsula region from Hicks Bay to East Cape. (B) Distribution of the Otamaroa Pleistocene marine terrace along the northern Raukumara Peninsula coastline. Contour lines represent the smoothed elevation of the surface at the top of marine deposits on the terrace strath ( $5 \mathrm{~m}$ contour interval). As discussed in the text, it is currently uncertain whether this is a Stage 5a ( 80 ka) or 5e $(\sim 125 \mathrm{ka})$ terrace; uplift rates for both cases are shown. Map source: Wilson (Ch. 6). 
deposition, Gibb, 1986). These few measurements of Holocene uplift indicate that uplift rates in this region increase southeastward towards East Cape.

The Pleistocene marine terrace distribution and chronology of the northern Raukumara Peninsula have been studied by Chapman-Smith and Grant-Mackie (1971), Yoshikawa et al. (1980), Yoshikawa (1988) and Wilson (Ch. 6). Two terraces, the higher Otamaroa terrace and the lower Te Papa terrace, almost continuously fringe the northern Raukumara Peninsula coastline from Whitianga Bay to Te Araroa (Fig. 7.1B, Fig. 7.4B). The terrace surfaces tilt to the northwest, approximately normal to the trend of the Hikurangi Trough. The tilt vector becomes more northerly towards Te Araroa (Fig. 7.4B). The age of these terraces is uncertain. Wilson (Ch. 6) presented six OSL ages from terrace cover sediments that suggest the terraces formed during marine isotope stages (MIS) 3 and 5a, in which case the present day elevation differentials between the two terraces imply uplift rates have increased through time. However loess chronology and uplift models, which assume uplift rates have been constant, suggest that the terraces formed during MIS 5c and 5e (Wilson, Ch. 6). The Otamaroa terrace is present in the middle of Hicks Bay, adjacent to the location where drill cores of the Holocene transgressive marine sediments were collected. If the Otamaroa terrace formed during MIS 5a, the average uplift rate for the past $\sim 80 \mathrm{ka}$ is $2 \pm 0.2 \mathrm{~mm} \mathrm{yr}^{-1}$ for the Hicks Bay locality. This is within the uncertainty range of the Holocene uplift rate of 0.9-2.2 $\mathrm{mm} \mathrm{yr}^{-1}$, estimated from the uplifted Holocene transgressive marine sediments (Wilson, Ch. 5). If the Otamaroa terrace formed

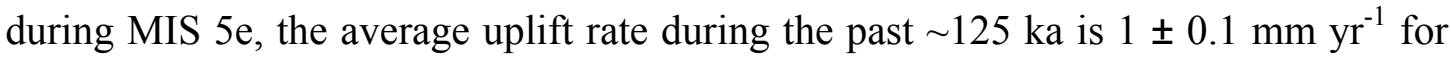
the Hicks Bay locality, which is less than the Holocene uplift rate (Wilson, Ch. 6).

Several east-west trending normal faults have been mapped on the western side of the Raukumara Peninsula (Fig. 7.1B). However the hanging walls are downthrown in the same direction as the terrace tilt, thus it is difficult to resolve offset given the relatively coarse terrace elevation data (Wilson, Ch. 6). These faults, if active, are not sufficient to drive the uplift and tilting of the Pleistocene terraces as far east as $\mathrm{Te}$ Araroa.

We assume here that the aseismic uplift process that is responsible for Holocene uplift at Hicks Bay and Te Araroa (Wilson, Ch. 6) is the same process that has driven uplift of the Pleistocene terraces. Evidence for this includes of (1) possible similarity in 
Holocene and Pleistocene uplift rates at Hicks Bay; (2) Holocene uplift rates on the eastern side of the Raukumara Peninsula increase toward the southeast, in the same direction as the rise in the Pleistocene terraces; and (3) uplifted Holocene sediments are recorded only in regions where the Pleistocene terraces are higher than $\sim 60 \mathrm{~m}$ (Fig. 7.1B, Fig. 7.4B), implying that the same uplift process controls the distribution of Holocene and Pleistocene terraces.

Crustal doming above a zone of buoyant underplated sediment adjacent to the Hikurangi subduction zone is the most likely driver of aseismic coastal uplift of the northern Raukumara Peninsula region. This mechanism was first suggested by Walcott (1987), though it was largely based on an estimated sediment accretion budget for the Raukumara Peninsula. Here we present several additional lines of evidence that support the theory that sediment underplating is driving uplift of the northern peninsula.

Firstly, the uplifted Pleistocene terraces span a margin-normal width of $\sim 60 \mathrm{~km}$ and a margin-parallel length of $\sim 60 \mathrm{~km}$ (Fig. 7.4B). Fault scaling relationships imply that if a single fault accommodated uplift of these terraces, the fault would necessarily have a high slip rate (in excess of the maximum terrace uplift rate of 2.2 or $3.8 \mathrm{~mm} \mathrm{yr}^{-1}$ ) and would have to be longer than $60 \mathrm{~km}$ in length. There are no known active faults onland near East Cape that could produce the uplift geometry of the Otamaroa Pleistocene terraces (Fig. 7.1B). A normal fault, downthrown to the southeast, has been mapped near East Cape by Mazengarb and Speden (2000), but there is no evidence it has been active during the Quaternary. In any case, the Pleistocene marine terraces are located in the footwall of this fault and the majority of absolute movement during slip on normal faults occurs through subsidence of the hanging wall (Jackson et al., 1988). There are also no known active faults immediately offshore of the northern Raukumara Peninsula that can explain Pleistocene marine terrace uplift (Fig. 7.5A, Davey et al., 1997; Lewis et al., 1997; 2004). However, nearshore active faults can be difficult to identify because scarps are eroded by the waves. A recent seismic survey traversing from the head of the Ruatoria margin re-entrant scarp across the northern tip of the Raukumara Peninsula showed no evidence of a reverse fault similar to the Lachlan fault (C. Uruski and D. Barker, pers. comm., Ministry of Economic Development Petroleum Report Series PR3136, 2005). Some anticlinal structures 
have been mapped offshore of East Cape, but they are more than $30 \mathrm{~km}$ offshore and less than $40 \mathrm{~km}$ in length (Collot et al., 1996; Lewis et al., 1997; 2004).

Sediment underplating is a viable explanation for northern Raukumara Peninsula uplift because a zone of ponded sediment located above the plate interface has been inferred using velocity and seismic attenuation models models (Eberhart-Phillips and Reyners, 1999; Reyners et al., 1999; Eberhart-Phillips and Chadwick, 2002). Numerical modelling by Upton et al. (2003) and Litchfield et al. (in press) also supports sediment underplating as a mechanism of upper plate uplift along the Hikurangi margin. Surface uplift rates of up to $4 \mathrm{~mm} \mathrm{yr}^{-1}$ over a zone of weaker material, input to a 3D finite-difference model to simulate ponded sediment, were estimated by Upton et al. (2003). These rates are similar or slightly higher than the Pleistocene terrace uplift rates at Te Araroa (Wilson, Ch. 6). 2D finite element modelling of the northern Hikurangi margin by Litchfield et al. (in press) concluded sediment underplating, caused by tectonic erosion, is the most likely mechanism of axial range uplift in the northern Hikurangi margin. Their model of sediment underplating showed a broad zone of uplift extending a margin-normal distance of $\sim 180 \mathrm{~km}$ from the trough.

\subsection{A model of Raukumara Peninsula uplift: subduction margin-parallel uplift mechanism zones.}

Evidence presented thus far shows that coastal uplift mechanisms of the Raukumara Peninsula are spatially variable. We suggest the most important parameter controlling forearc uplift is the distance from the subduction zone, and by inference, the increasing depth to the underlying plate interface. We propose three margin-parallel tectonic zones operating across the Raukumara sector of the Hikurangi margin (Fig. 7.5B).

The most outboard zone lies within a margin- normal distance of $\sim 20-80 \mathrm{~km}$ of the Hikurangi Trough, this is the coseismic uplift zone. A central zone, termed the passive inner forearc, lies between a margin normal distance of $\sim 80-120 \mathrm{~km}$ from the trough. The most inboard zone, called the aseismic uplift zone, lies at a distance of greater than $\sim 120 \mathrm{~km}$, and extends to $\sim 180 \mathrm{~km}$ though its westward limit is poorly constrained. The region within $10-20 \mathrm{~km}$ of the trough is one of tectonic erosion or, 


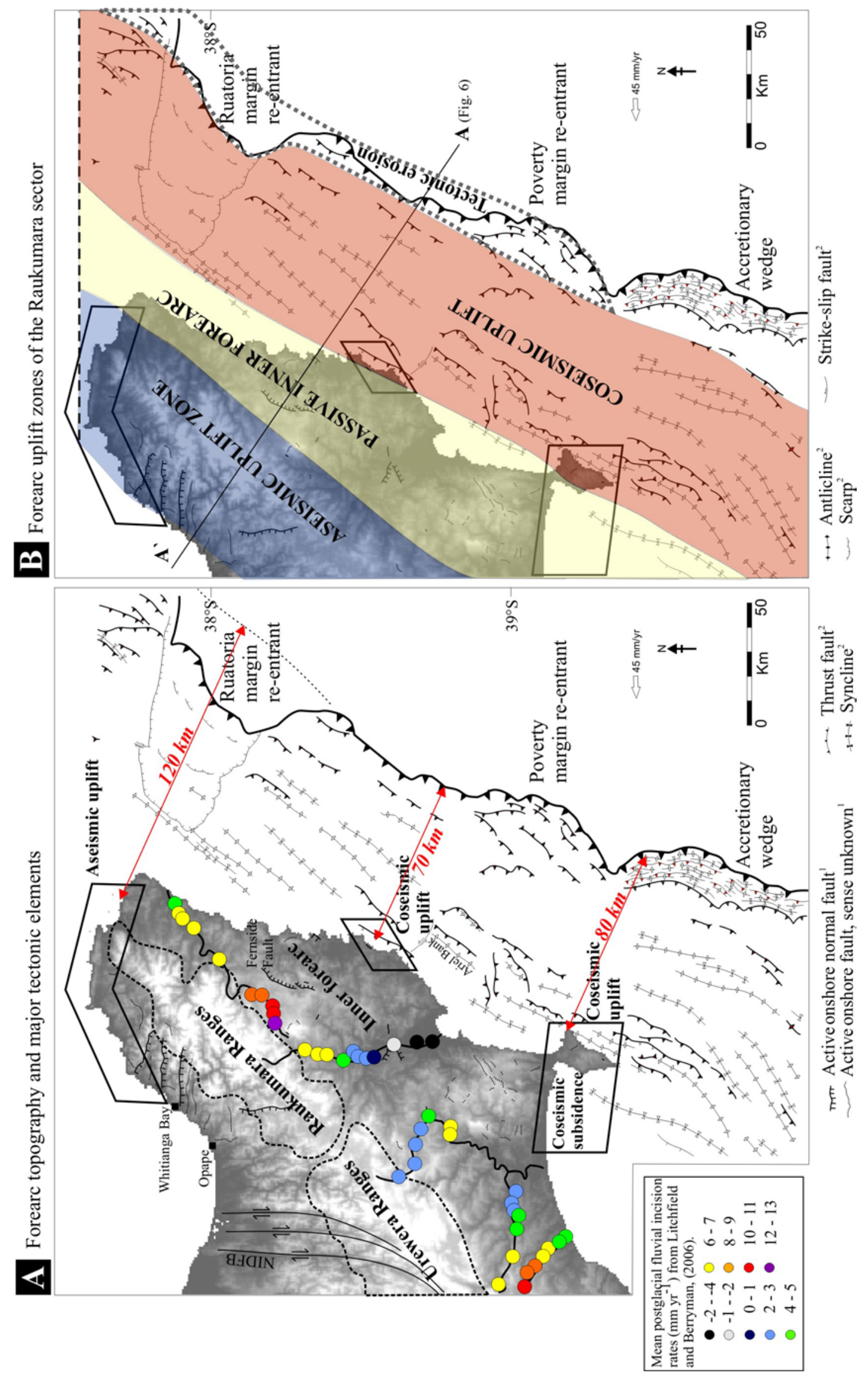


Figure 7.5 (A) Topography, major geomorphic elements and offshore structures of the Raukumara Peninsula. Coloured circles show postglacial fluvial incision rates, which are used as a proxy for rock uplift rates, after Litchfield and Berryman (2006). Offshore structures after Lewis et al. (1997). NIDFB: North Island dextral fault belt. Red arrows and numbers measure the margin-normal distance of the coastal regions from the Hikurangi Trough. (B) A model of Raukumara sector forearc uplift mechanism zones. Area within the grey dotted line represents the deformation front of the Hikurangi Trough; structures within this zone are not included within this model.

south of $\sim 39^{\circ} 30^{\prime}$, an area of accretion. These latter regions, directly adjacent to the Hikurangi Trough, are not included within our model; their detailed structure is discussed in Collot et al. (1996). Here we outline the evidence for each of the three vertical tectonic zones we have delineated, and the vertical tectonic processes operating within them.

\subsubsection{Coseismic uplift zone}

Deformation within this zone is characterised by permanent deformation of the upper plate with locally high rates of uplift along margin-parallel compressional structures these are probably dominantly short $(<50 \mathrm{~km}$ length) listric, reverse faults. The plate interface lies at a depth of 0-18 km (Fig. 7.6). The primary evidence for this zone is the well-documented Holocene coseismic uplift in the Pakarae region and at Mahia Peninsula (Ota et al., 1991; Berryman, 1993a; Wilson, Ch. 4.). These regions are located at the most southeasterly promontories of the Raukumara Peninsula and are the closest land to the Hikurangi Trough. Mahia Peninsula is $\sim 80 \mathrm{~km}$ from the trough and the $15 \mathrm{~km}$ stretch of coastline of the Pakarae region is approximately $70-75 \mathrm{~km}$ from the trough.

Estimates of the interseismic locked portion of the plate interface based on seismicity data place the trenchward edge of the locked zone directly below the Pakarae region and directly below Opoutama (Reyners, 1998). By implication, if the faults driving coastal uplift are listric to the plate interface, they intersect it within the interseismic locked portion. Current knowledge of structures offshore of the Raukumara sector indicate there are margin parallel reverse faults, synclines and anticlines (Fig. 7.5B, Lewis et al., 1997). These structures appear to form a zone with an arcward edge approximately in line with Mahia Peninsula and the Pakarae region. The nature and age of these structures are currently poorly known. We have made some preliminary 


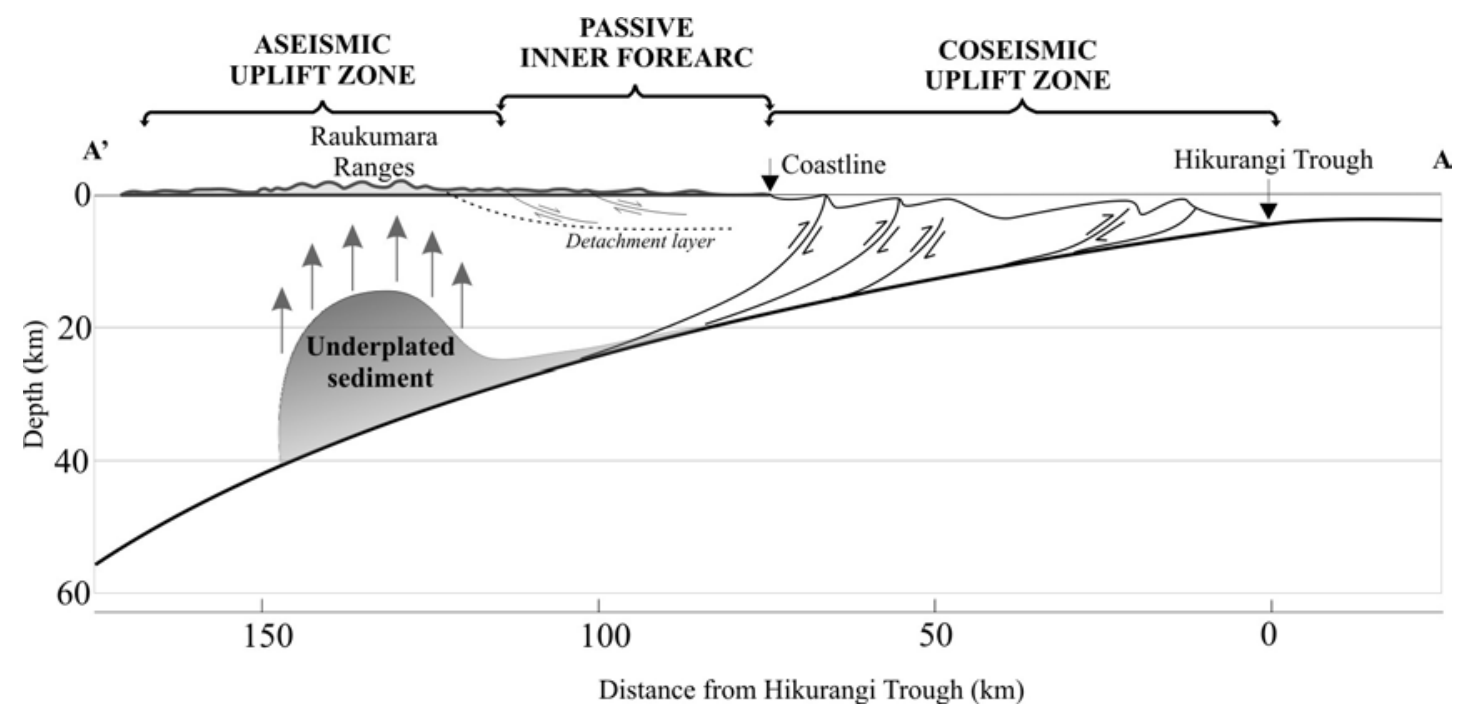

Figure 7.6. Schematic cross-section of the structures accommodating uplift across the Raukumara Peninsula. Geometry of the plate interface and ponded sediment body after Reyners et al. (1999). The nature of the offshore faults and the position of the detachment layer is an approximation and not based upon any seismic data. The forearc uplift zones from our model are shown above for reference.

interpretations of structure on a recently collected seismic line from the continental shelf approximately $20 \mathrm{~km}$ northeast of the Pakarae River mouth (Fig. 7.7). We presently have no age control on the units imaged in this seismic line but a nearshore fault offsets the seafloor, suggesting it has been active recently. Additional faults on the mid and outer shelf attest to the presence of numerous structures offshore of the Raukumara Peninsula, consistent with our suggestion of a compressional deformation zone. However, we emphasize these are preliminary interpretations and further interpretations of the 05CM 2D Seismic Survey collected in 2005 will provide a test of our model (Ministry of Economic Development Petroleum Report Series PR3136, 2005).

\subsubsection{Passive inner forearc}

This zone encompasses most of the eastern Raukumara Peninsula, excluding the southeastern coastal promontories of the Pakarae region and Mahia Peninsula. The zone consists dominantly of Neogene forearc basin sedimentary rocks and parts of the East Coast Allochthon. The plate interface lies at a depth of $\sim 18-25 \mathrm{~km}$ (Fig. 7.5B, Fig. 7.6). This zone encompasses most of the onland portion of the inner forearc and 


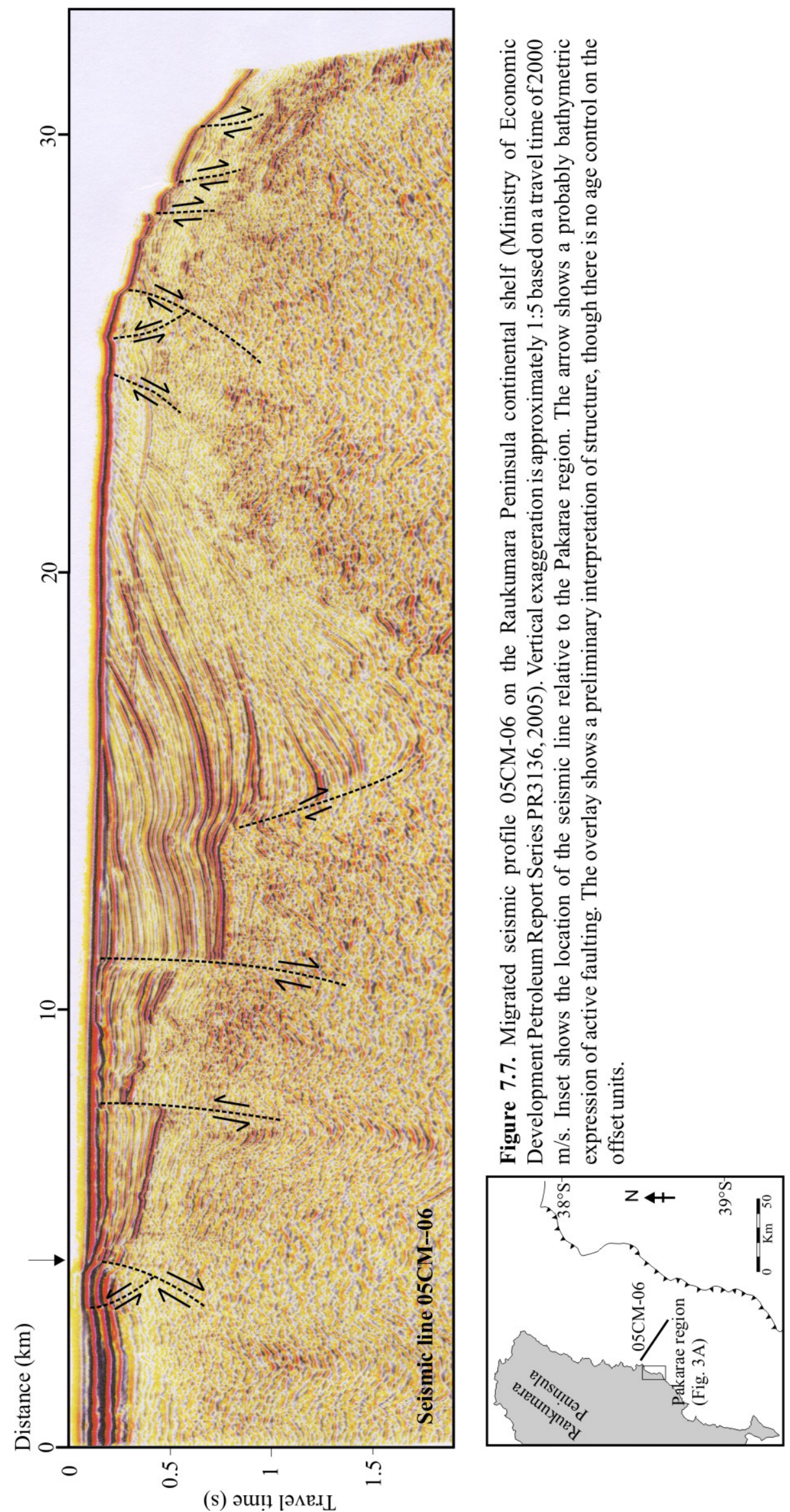


approximately $20-30 \mathrm{~km}$ of the continental shelf north of $\sim 38^{\circ} 30^{\prime} \mathrm{S}$. The distinguishing characteristics of the zone are a comparative lack of active faults, subdued topography and low to moderate vertical movement rates along the coast.

This zone is termed the passive inner forearc because we suggest vertical movements within the area occur in response to movement on distant structures. There are no structures within the upper plate of the passive inner forearc zone that drive vertical surface movements. Rather, uplift or subsidence is driven by structures either located trenchward in the coseismic uplift zone, in the arcward aseismic uplift zone, or by plate interface seismicity. An example is in the Mahia-Wairoa region where subsidence at Te Paeroa lagoon and Opoho has probably been driven by either the Lachlan Fault, $\sim 45 \mathrm{~km}$ away, or by rupture of the underlying plate interface (Cochran et al., 2006). Likewise, moderate uplift rates have been recorded at several locations along the coastline between the Pakarae region and East Cape (Ota et al., 1988; 1992) though no faults have been mapped in this area (Fig. 7.5A, Lewis et al., 1997; Mazengarb and Speden, 2000). Along this portion of the coastline it is not well resolved whether these moderate uplift rates are achieved by coseismic or aseismic mechanisms. While two or three marine terraces were recorded at four locations by Ota et al. (1992, Fig. 7.1B) that study was undertaken at a reconnaissance level. The study of terraces at Waipapa and Horoera by Wilson (Ch. 5) demonstrated that terrace geomorphology does not unambiguously equate with coseismic coastal uplift. Therefore we suggest further work to resolve the uplift mechanism may be justified along this portion of the coast with moderate uplift rates.

\subsubsection{Aseismic uplift zone}

Uplift within this zone is caused by a zone of underplated buoyant sediment. The most easterly localities of the northern Raukumara Peninsula region where aseismic uplift is inferred, namely Te Araroa, Waipapa and Horoera, are $>120 \mathrm{~km}$ from the Hikurangi Trough (or rather, from the trend of Hikurangi trough because at this location the margin is indented by the head scar of the Ruatoria debris avalanche (Fig. 7.5B, Collot et al., 2001; Lewis et al., 2004). The plate interface is at a depth of $25-$ $50 \mathrm{~km}$ and is overlain by an estimated $20 \mathrm{~km}$ of ponded underplated sediment (Fig. 7.6, Reyners et al., 1999). The edges of this zone are poorly constrained and currently are placed at the extent of the well-preserved Pleistocene marine terraces fringing the 
northern Raukumara Peninsula (Fig. 7.5B, Yoshikawa et al., 1980; Wilson, Ch. 6). However, the western coastline of the Raukumara Peninsula is approximately parallel to the Hikurangi Trough, suggesting that subduction processes control the formation of this whole coastline. Westward from Opape, faulting associated with the boundary of the Taupo volcanic zone dominates the tectonic structure (Wright, 1990; Taylor et al., 2004).

The trenchward boundary of the aseismic zone is located at Waipapa, the most eastern location where Holocene coastal uplift has been unequivocally recorded (Yoshikawa et al., 1980, Wilson, Ch. 5). However, the boundary of this zone could be further east and, in fact, could encompass East Cape, but we have little control on uplift rates or mechanisms east of Waipapa. We locate the southwest boundary of the aseismic uplift zone at the edge of the Raukumara Ranges (Fig. 7.5B). This boundary coincides with an increase in uplift rates as determined from fluvial terrace incision rates (Litchfield and Berryman, 2006).

\subsection{Discussion}

\subsubsection{Relationships between Pleistocene marine terrace geometry, sediment} underplating, and Raukumara Ranges uplift within the aseismic uplift zone.

We have demonstrated that sediment underplating is probably the cause of aseismic uplift of the Pleistocene marine terraces of the northern Raukumara Peninsula. These terraces extend across the northern projection of the axis of the Raukumara Ranges. It is implicit in our interpretation that sediment underplating also drives uplift of the Raukumara Ranges (Fig. 7.5B), as suggested by Walcott (1987), Reyners et al. (1999), Upton et al. (2003) and Litchfield et al. (in press). These studies have generally assumed that the axis of the Raukumara Range is the zone of maximum uplift (for example, uplift maps by Walcott, 1987; Pillans, 1986 and Litchfield et al., in press). However, differences between the geometry of the marine terraces and the Raukumara Ranges suggest this may not be the case (Fig. 7.8). 


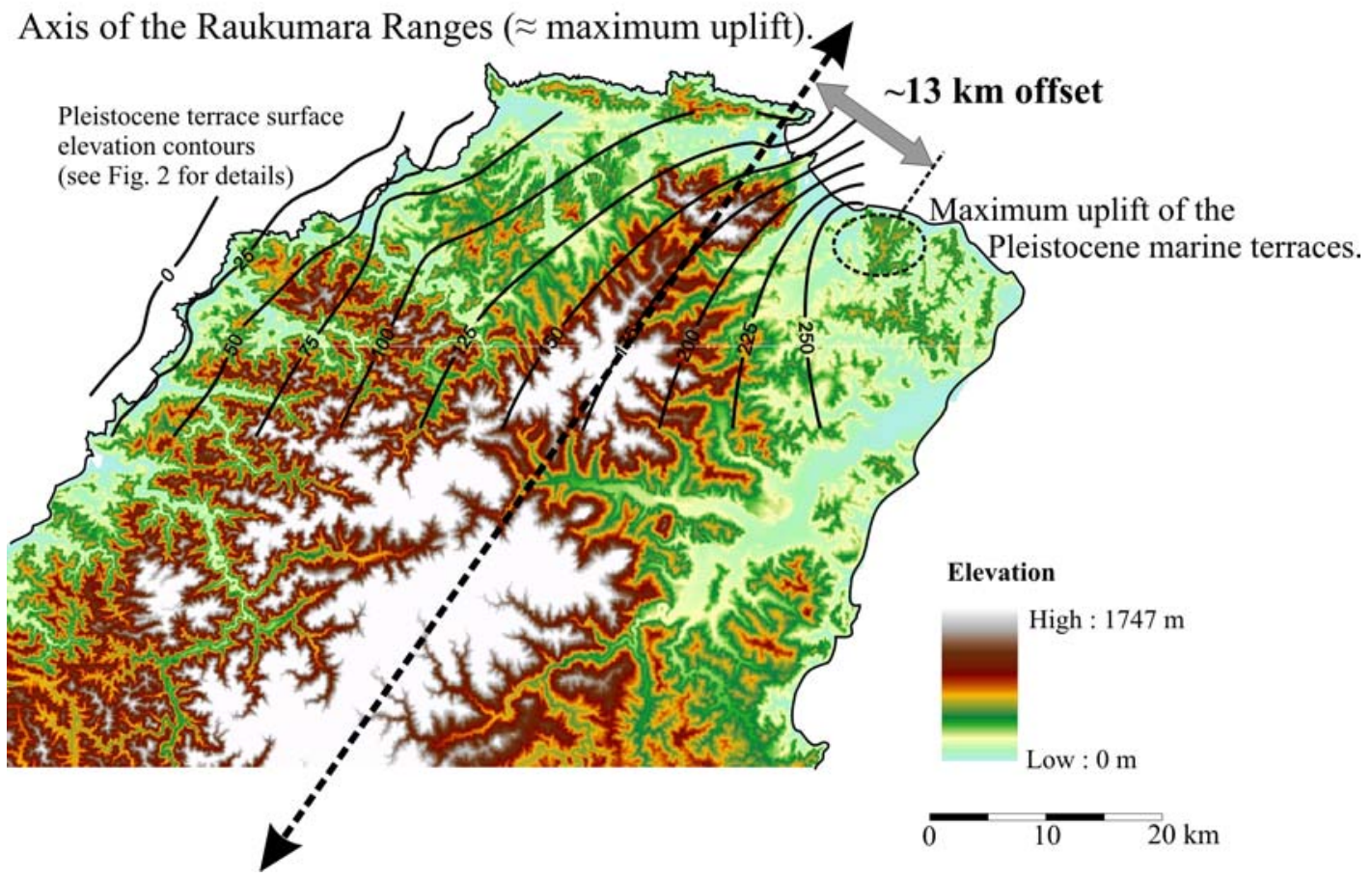

Figure 7.8. Map depicting the spatial offset between the zones of maximum aseismic uplift as estimated from the Raukumara Ranges and the Pleistocene marine terraces. Thick dashed line is an approximate trace of the crest of the Raukumara Ranges, inferred to represent the region of highest long-term uplift. $25 \mathrm{~m}$ contour lines on the Otamaroa Pleistocene marine terrace surface are shown for reference. The zone of highest Pleistocene terrace elevation is circled. The thick grey arrow indicates the spatial offset between the zones of highest uplift.

The point of maximum marine terrace uplift is offset $\sim 13 \mathrm{~km}$ east of the approximate along-strike projection of the Raukumara Range axis (Fig. 7.8). Furthermore, the marine terraces, tilting uniformly northwest, do not display approximately symmetrical antiformal geometry like the Raukumara Ranges (Fig. 7.8). Do these dissimilarities imply that sediment underplating is not the only uplift process involved in marine terrace uplift? Or, given that the Pleistocene marine terraces are a younger landform than the Ranges, is there temporal variation in the zone of maximum uplift? Or, alternatively, are the crests of the Raukumara Ranges not actually the zone of maximum uplift?

Firstly, we are confident that both the Pleistocene marine terraces and the Raukumara Ranges have formed predominantly by the same uplift mechanism. Evidence to 
support this includes the absence of active onland faults or candidate offshore faults, imaging of ponded sediment beneath the ranges (Reyners et al., 1999) and modelling of sediment underplating (Upton et al., 2003; Litchfield et al., in press).

Regarding temporal variations in the uplift pattern, apatite fission track data from basement rocks of the Raukumara Ranges indicate that the present phase of uplift began in the mid-Miocene (Kamp, 1999). The Pleistocene terraces record uplift only since $\sim 125 \mathrm{ka}$. It is possible that the region of high marine terrace uplift east of Te Araroa reflects a late Quaternary change or aberration to the uplift pattern of the Raukumara Peninsula. A candidate late Quaternary event that may have triggered accelerated uplift near Te Araroa is the subduction of a seamount. Collot et al. (2001) and Lewis et al. (2004) suggest that seamount subduction created the Ruatoria margin re-entrant at the Hikurangi Trough $\sim 80 \mathrm{~km}$ southeast of Te Araroa (Fig. 7.5A) and that collapse of the margin occurred at $170 \pm 40$ ka based on offshore Quaternary unconformities and sedimentation rates from core samples. Lewis et al. (2004) suggest that the seamount would currently be located near East Cape due to tentative correlation with the coastal uplift rates presented by Ota et al. (1992). Modelling of seamount subduction beneath the Hikurangi margin by Litchfield et al. (in press) suggests uplift over seamounts would occur in localised zones $\sim 20-80 \mathrm{~km}$ diameter and would create uplift of $\sim 0.7 \mathrm{~mm} \mathrm{yr}^{-1}$. This value is lower than the observed uplift rate at Te Araroa, implying seamount-related uplift would only contribute up to approximately one-third of the total uplift rate of the terraces east of Te Araroa.

An alternative explanation for the offset in maximum uplift between the marine terraces and the axial ranges is that the differential erosional resistance of the forearc rocks play a key role in Raukumara Ranges topography. The crests of the Raukumara Ranges, within Torlesse greywacke, may not represent maximum uplift; instead this zone could actually be further to the east within lower elevation hills composed of Miocene sedimentary rocks or the varied lithologies of the East Coast Allochthon. Topographic profiles across the Raukumara Peninsula indicate a strong correlation between elevation and lithology (Fig. 7.9). Average elevations sharply decrease over the transition from Torlesse greywacke, or Allochthon sediments to Neogene sedimentary rocks (Fig. 7.9). This correlation suggests that the locations of the crests of the Raukumara Ranges are controlled by a combination of uplift rate and bedrock 
erodibility. The less coherent Neogene sedimentary rocks may be uplifting at an equally fast or higher rate than the crest of the Torlesse ranges but comparable elevations are not achieved due to more rapid erosion of the neogene rocks. The eastern part of the Raukumara Peninsula may also have relatively low elevations as a result of trenchward sliding or slumping of its weak Neogene sedimentary cover, as suggested by Thornley (1996). The axis of maximum uplift may be located further east of the range crest and more in line with the maximum elevation of the Pleistocene marine terraces (Fig. 7.8). This scenario potentially aligns the regions of maximum aseismic uplift of the Raukumara Peninsula. However, it may be an oversimplification because the presence of allochthonous units or Neogene sedimentary sequences in itself may imply long-term uplift rates on the eastern Raukumara Peninsula are lower than within the Torlesse part of the Raukumara Ranges. This is because the East Coast Allochthon and the Neogene cover sequences probably formerly overlay the Torlesse greywacke (Kamp, 1999), thus exposure of the Torlesse testifies to higher uplift rates compared to regions where allochthonous and Neogene sedimentary sequences remain.

Finite element modelling of sediment underplating along the Hikurangi subduction zone by Upton et al. (2003) and Litchfield et al. (in press) suggests surface deformation above the ponded sediment would occur in a broad antiform. This deformation pattern contrasts with the broad northwest-tilting asymmetry of the Pleistocene marine terraces. These differences could be due to incomplete information on the geometry of the marine terraces, because there are no preserved terraces more than $5 \mathrm{~km}$ east of Te Araroa. However, the finite element models both assume the crust to be of uniform rheology, therefore they do not account for variable lithology and erosion rates at the surface, nor do they account for small-scale faults and folds in the upper plate. Furthermore, the constraints placed on the shape of the underplated sediment body in the models are weak. Upton et al. (2003) input an rectangular block of sediment directly on the plate interface spanning the approximate margin-normal width of the plate interface as inferred by Reyners et al. (1999). The Litchfield et al. (in press) model generates underplated sediment by imposing tectonic erosion at the trench. Without a upper plate backstop, however, the dimensions and position of the underplated sediment are unlikely to replicate the sediment body beneath the Raukumara Peninsula. The models of Raukumara Peninsula uplift produced to date 


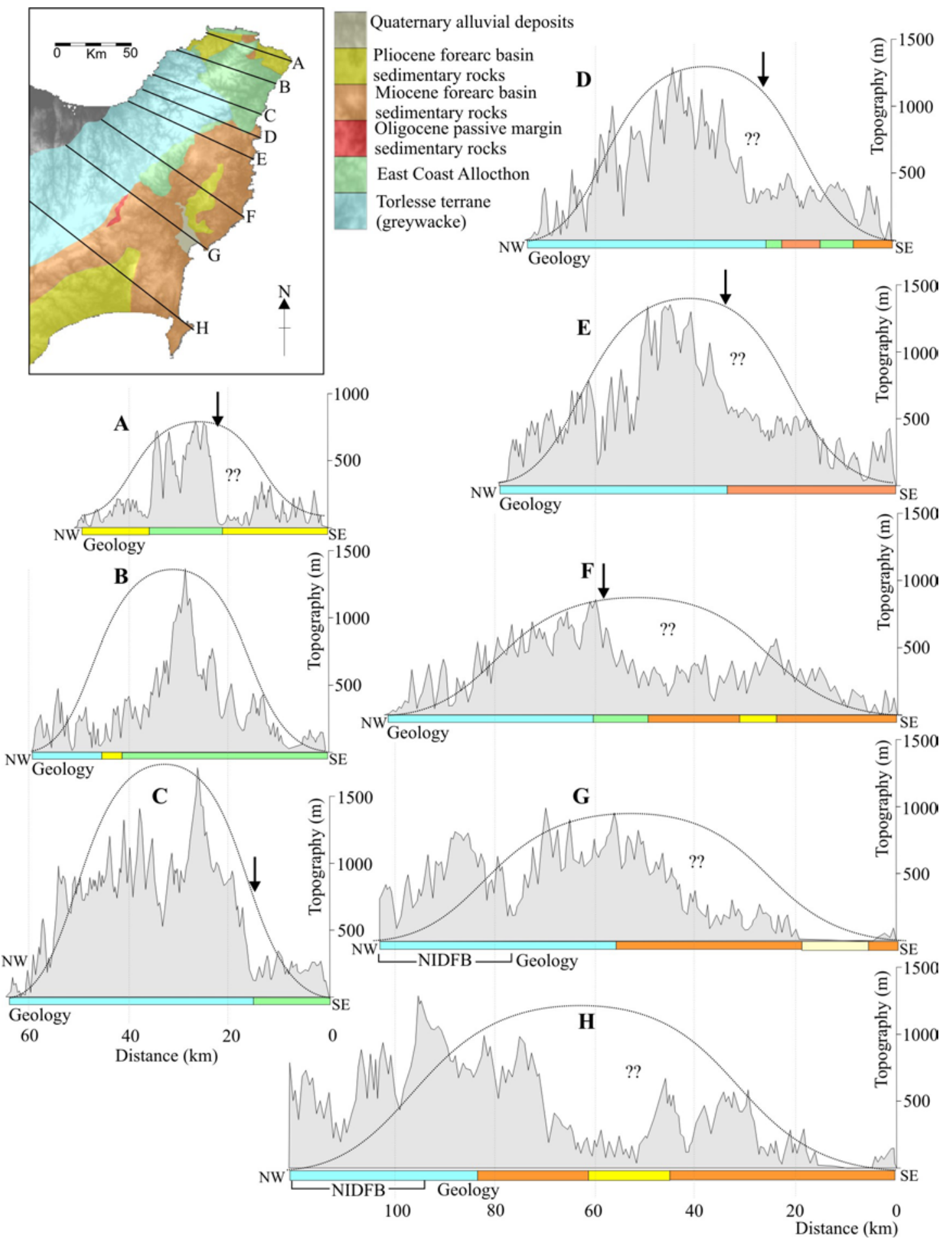

Figure 7.9. Summary of the Raukumara Peninsula geology (after Mazengarb and Speden, 2000) and topographic profiles across the Raukumara sector forearc with the geology shown below for reference. In most profiles the shape of the Raukumara Ranges departs from a typical antiformal shape. Regions of lower elevation correspond to Neogene sedimentary. The dashed lines represent a symmetrical antiformal shape. The small arrows highlight locations where there are sharp topographic changes across geologic contacts. The question marks highlight areas of lower elevations within Neogene sedimentary rocks. NIDFB: North Island dextral fault belt. 
are useful in demonstrating that sediment underplating is a likely mechanism of generating uplift of the Raukumara Ranges but they are too simplistic to be used to explain the surface geometry of the Pleistocene marine terraces. A model is needed that uses the Pleistocene terrace data to estimate the geometry of the underplated sediment beneath. This model could then be compared with the seismic velocity and attenuation models of the plate interface to better understand the relationships between the shape of the underplated sediment and surface geomorphology.

\subsubsection{Uplift mechanism distribution in relation to geodynamic changes along the strike of the Raukumara Peninsula.}

Our model of Raukumara Peninsula uplift mechanisms has focussed on changes normal to the subduction zone because distances from the subduction trench and depth to the plate interface are the most obvious parameters that change between regions with different uplift mechanisms. However, there are also some changes along the strike of the Raukumara Peninsula that should be considered when seeking to understand controls on uplift mechanisms. Firstly, there are changes in the thickness of the upper plate that, in turn are associated with differences in the thickness of underplated sediment (Reyners et al., 1999). Secondly, there are differences in the degree of plate coupling along the margin (Reyners, 1998; Wallace et al., 2004).

Reyners et al. (1999) infer that the thickness of the crust of the Australian Plate increases in the southern Raukumara Peninsula with an associated decrease in the volume of underplated sediment. If there is less or no ponded sediment southeast of the Tologa Bay-Opotiki line at $\sim 38^{\circ} 30^{\prime} \mathrm{S}$, our aseismic uplift zone, driven by sediment underplating, should not extend beyond this line. However, there is no significant change in axial range topography across this transition (Fig. 7.5A) nor is there any change in the occurrence of active faults within or adjacent to the ranges until $39^{\circ} \mathrm{S}$ where the faults of the North Island Dextral Fault Belt cut through the axial ranges (Fig. 7.5A). Uplift rate maps based on fluvial incision rates show an area of localised high uplift north of the Tologa Bay-Opotiki line (Litchfield and Berryman, 2006). Decreased fluvial incision rates within the axial ranges south of this line suggest the lesser thickness of underplated sediment southward has an influence on surface uplift (Fig. 7.5A). Even as far south as the Kaimanawa Ranges (Fig. 7.10C), accumulations of underplated sediment have been inferred from velocity models and 
are there suggested to be contributing the uplift the axial ranges (Reyners et al., 2006). Therefore, although there may be a change in uplift rates controlled by differences in crustal thickness southeastward along the Raukumara Peninsula, the mechanisms of uplift is not necessarily different.

The other notable change along the strike of the Raukumara Peninsula is in plate coupling. Reyners (1998) and Reyners and McGinty (1999) estimate a decrease in the width of the interseismically locked portion of the interface north of the Tologa BayOpotiki line (Fig. 7.1A). They relate this decrease to the change in crustal thickness and, as discussed above, there does not appear to be a change in uplift mechanisms. The Wallace et al. (2004) model of geodetically measured interseismic plate coupling shows a patch of slightly higher plate coupling beneath the Pakarae region (Fig. 7.10B). They suggest this patch may be due to an asperity on the plate interface related to seamount subduction. A similar patch of higher plate coupling is not evident in the Mahia region where coseismic uplift also occurs, suggesting a weak or no correlation between the contemporary plate interface slip rate deficit and coastal uplift mechanisms in the coseismic uplift zone. Notably, higher plate coupling has not been detected beneath the East Cape locality where a subducted seamount may be located (Lewis et al., 2004; Wallace et al., 2004).

\subsubsection{Raukumara Peninsula forearc deformation and plate interface dynamics.}

The risk of subduction earthquakes generated by rupture of the Hikurangi plate interface adjacent to and beneath the Raukumara Peninsula is poorly known (Stirling et al., 2002; Cochran et al., 2006). Paleoseismic records from coastal locations often provide the only records of subduction zone earthquakes (for example, Matsuda et al., 1978; Atwater, 1987; Nelson et al., 1996; Clague, 1997; Zachariasen et al., 1999; Ramirez-Herrera et al., 2004). We consider here the contribution that coastal tectonics discussed can make to resolving the subduction earthquake hazard along the Raukumara sector.

Firstly, coastal tectonic data within the aseismic uplift zone do not yield easily interpretable information about subduction earthquakes, as there is no evidence of coseismic events in that zone. The accumulation of ponded sediment beneath this zone is driving uplift in a gradual and continuous process, indicating that the plate 
interface directly below is moving in a state of stable sliding. Stable sliding of the plate interface is probably promoted by elevated fluid pressures in subducted sediment (Eberhart-Phillips and Reyners, 1999; Reyners et al., 1999).

Secondly, we have shown that coastal movements in the zone of coseismic coastal uplift occur primarily by slip on nearby reverse faults that may merge listrically with the plate interface. If these upper plate faults do intersect the plate interface, movement them does not necessarily require rupture of that interface. It is clear that coastal uplift at these locations represents permanent deformation of the upper plate. In contrast, elastic dislocation theory implies that coseismic vertical movement produced by subduction interface events will be recovered over time by elastic relaxation during the interseismic period (Savage, 1983; Okada, 1985; Thatcher, 1986). This theory has been supported by studies of postseismic deformation following historic earthquakes along the Nankai and Alaskan subduction zones (Thatcher, 1984; Savage, 1995; Savage et al., 1998). However, upper plate deformation related to subduction earthquakes is likely to be complex, and not all of the vertical deformation may be recovered after large earthquakes. Upper plate faults may accommodate a component of permanent coseismic deformation (McNeill et al., 1998; Kelsey et al., 2002). As there have been no historical subduction earthquakes off Raukumara Peninsula, it is unknown how the buoyancy of the Hikurangi Plateau may affect preservation of the subduction earthquake record along the Hikurangi margin.

Figure 7.10. Major tectonic features of the Hikurangi margin. (A) Gravity map of the Hikurangi margin. Offshore data are the free air gravity anomaly derived from satellite altimetry data (Sandwell and Smith, 1997), onshore data are the gridded Bouguer gravity anomaly calculated from the GNS gravity database. (B) Current interseismic plate coupling coefficient along the Hikurangi margin as estimated from the GPS-determined plate motion slip rate deficit on the plate interface by Wallace et al. (2004). 1 = stronger coupling, $0=$ weak coupling. (C) Significant geomorphic features and active faults of the Hikurangi margin. The boundaries of the Raukumara sector forearc uplift mechanism zones are shown for reference. Locations and numbers of Holocene marine terraces in the central and southern sectors are shown (after Berryman et al., 1989). Simplified offshore geology after Lewis and Pettinga (1993) and Barnes and Mercier de Lepinay (1997). Note the presence of the modern accretionary wedge south of the Raukumara sector. Major offshore features north and west of the Raukumara Peninsula are also indicated. 


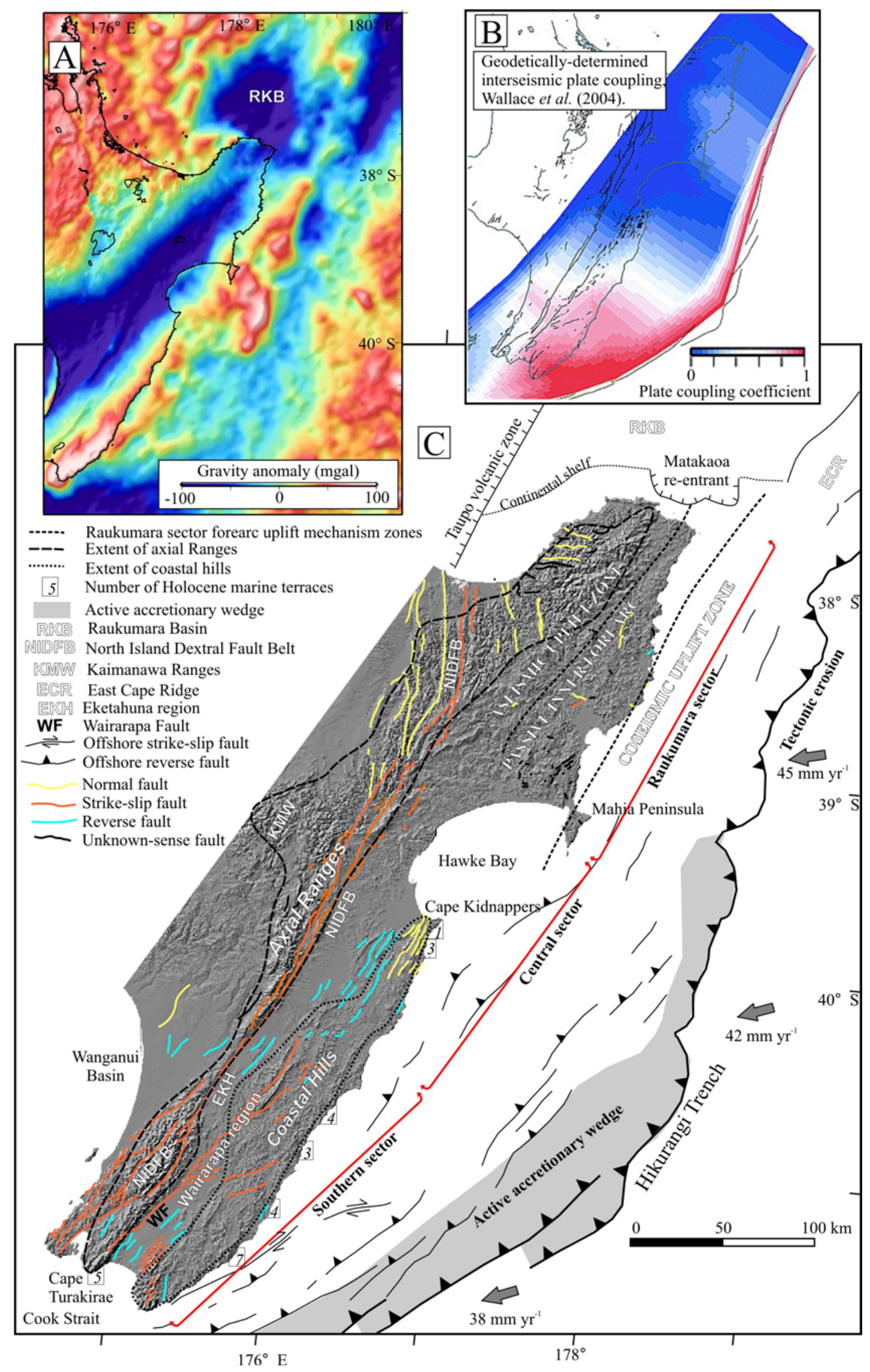


It is unknown whether there has been interseismic relaxation and recovery of uplift at the Pakarae region or at Mahia Peninsula that would indicate plate interface involvement. The biostratigraphy of uplifted fluvio-estuarine sequences at the Pakarae River mouth is not of sufficiently high resolution, or within suitable fossiliferous sediments, to enable resolution of interseismic movement (Wilson, Ch. 4.). Similarly, the biostratigraphy of subsided coastal waterbody sequences at Te Paeroa lagoon and Opoho do not contain evidence of interseismic subsidence (Cochran et al., 2006). Nevertheless, it is reasonable to assume on the basis of the geological record of longterm uplift that most coseismic uplift at these locations is permanent and has not been recovered by interseismic relaxation. It is probable, therefore, that the uplift events of the Pakarae region and at Mahia Peninsula involved slip on upper plate faults. If so no events can be interpreted as the result of a simple subduction interface rupture. Geological evidence from the Pakarae and Mahia regions does not allow us to distinguish the effects of upper plate faulting from synchronous interface and upper plate faulting.

A possible method of detecting events involving plate interface rupture is to look for synchroneity of events along the margin. Scaling relationships of plate interface events by Abe (1975) imply that the length of a interface rupture for a large to great subduction earthquake would probably be longer than the rupture lengths of upper plate faults. Therefore interface rupture events could potentially be recorded at many widely separated sites along the margin, whereas deformation involving slip on upper plate reverse faults may be more localised and discontinuous. The $7 \mathrm{ka}$ B.P. records of coseismic marine terraces at the Pakarae River mouth and Mahia Peninsula (involving 5 terraces at Mahia and 7 at the Pakarae River mouth, Berryman, 1993a and Wilson, Ch. 2) show different event ages that do not overlap at the 2-sigma uncertainty level, which suggests that plate interface rupture was not responsible for uplift at both sites. This analysis assumes that a plate interface rupture event would propagate across both locations, which are $65 \mathrm{~km}$ apart; with no available data to constrain rupture segments of the interface, this assumption is not necessarily correct.

Given the complication of upper plate faulting in the coseismic uplift zone, it is possible that coastal deformation within the passive inner forearc zone could potentially be a better indicator of subduction interface seismicity than deformation in 
the coseismic uplift region. The inner forearc zone has few or no active upper plate faults. However, the greater distance from the Hikurangi Trough and the greater depth to the interface may offset this benefit. As previously mentioned, further investigation of the mechanism of uplift within this zone is warranted, and searching for synchronous events could also be a research target.

An elastic dislocation model of surface deformation resulting from rupture of the current interseismically coupled portion of the interface along the entire length of the Hikurangi margin predicts that part of the coastal portion of the Raukumara Peninsula passive forearc zone will be uplifted and part will subside (Fig. 7.11, L. Wallace, pers. comm.). The dislocation model shown in Fig. 7.11 is based on current plate coupling estimated from GPS-measured plate motion slip rate deficits (Fig. 7.10B, Wallace et al., 2004) and assumes no significant spatial variation in coupling through time. A 100 -year return time event is modelled. The predicted vertical displacements increase linearly with longer recurrence intervals. Interestingly, the model shows that for the coastline covered by our passive forearc zone the predicted deformation pattern is broadly similar to current information about coastal tectonics of this zone. For example, the model predicts subsidence in the Wairoa and western Poverty Bay regions, fitting with the subsidence documented by Brown (1995) and Cochran et al. (2006). Uplift is predicted for the coastline from the Pakarae region northward to Waipiro Bay at $>0.1 \mathrm{~m}$ for a 100 year event (Fig. 7.11). Moderate uplift rates have been documented along this portion of the coast (Fig. 7.1B). No uplifted coastal features have yet been identified along the stretch of coastline from Waipiro Bay to East Cape where $<0.1 \mathrm{~m}$ of uplift per $100 \mathrm{yrs}$ is predicted by the model (Fig. 7.11), though fluvial terraces in this region indicate moderate rates of fluvial incision inland (Fig. 7.5A).

Areas where the dislocation model yields results inconsistent with the coastal geology are Mahia Peninsula and the northwestern coast of the Raukumara Peninsula; in both areas the model predicts minor subsidence while Pleistocene marine terraces clearly attest to uplift (Fig. 7.11). Also of note is that the regions with particularly high late Quaternary uplift rates - the Pakarae River mouth and Te Araroa - are not distinguishable by correlative high uplift patches in the elastic dislocation model. These areas of poor correspondence between the model and known coastal geology 


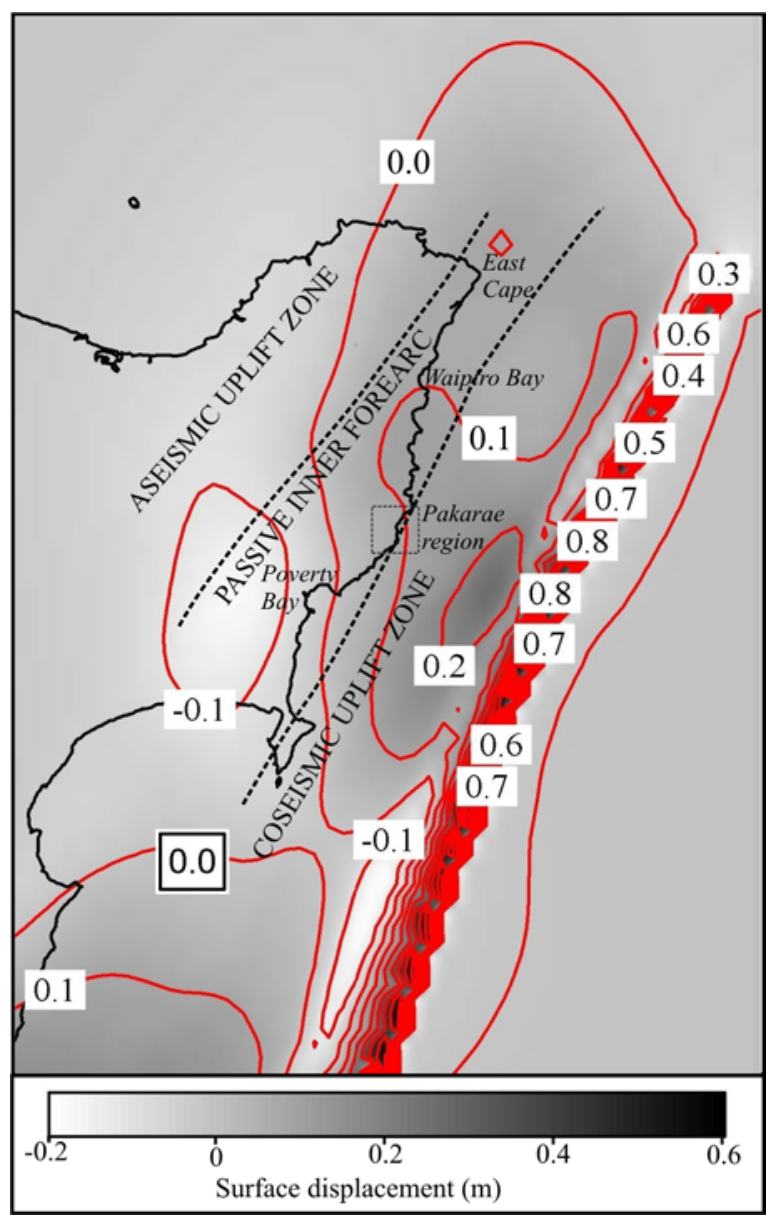

Figure 7.11. Elastic dislocation model of coseismic surface displacements during a 1 per 100-year plate interface rupture event (source: L. Wallace, pers. comm.). The model is based on rupture of the entire Hikurangi margin plate interface and uses GPS-derived estimates of interseismic plate coupling (Wallace et al., 2004). Surface displacements increase linearly with longer recurrence intervals. Also shown are some localities discussed in the text and the location of the forearc uplift mechanism zones for reference.

are within the coseismic uplift zone or the aseismic uplift zone. The general similarity between predicted coseismic displacement and coastal neotectonics within the passive forearc zone supports the suggestion that this zone may have more direct geodynamic relationship with the subduction interface and be a better recorder of subduction earthquakes than the neighbouring coseismic and aseismic uplift zones. However, elastic dislocation theory predicts that coseismic upper plate displacement caused by interface rupture modelled in Fig. 7.11 is recovered interseismically. Therefore, if the correlation between the model and the geology passive forearc zone is a true reflection of subduction earthquake deformation, not all of the coseismic displacement has been elastically recovered. 
Wells et al. (2003) suggested that a correlation exists between the spatial distribution of gravity lows and plate interface rupture asperities. They found that most historical plate interface rupture events occurred beneath forearc basins, which were distinguishable as pronounced negative gravity anomalies. They suggested, therefore, that forearc basins could be indicators of long-term plate interface seismic moment release. There does not appear to be such a correlation on the Hikurangi margin. The present interseismically locked portion of the interface along the Hikurangi margin (Reyners, 1998) coincides with positive gravity anomalies from the Wairarapa to the Raukumara Peninsula (cf. Fig. 7.1A and Fig. 7.10A). However, there have been no historical earthquakes to test this theory along the Hikurangi margin.

To summarise, we cannot presently use the coastal neotectonic record of the Raukumara Peninsula to unequivocally constrain the nature, timing or extent of subduction earthquakes along this part of the Hikurangi margin. This remains a significant research target, particularly given the potentially widespread effects that could result from such an event. However, we can use our uplift mechanism model to identify priority areas of study. Priorities include: (1) attaining a better understanding of how upper plate faults within the coseismic uplift zone interact with the plate interface; (2) searching for evidence of interseismic recovery following coseismic events; (3) correlating events along the margin as a method of constraining the spatial extent of rupture; and (4) determining the mechanism of coastal uplift within the passive forearc region because it has a higher likelihood of being related to a subduction earthquake than records from the aseismic or coseismic uplift zones.

\subsubsection{Seismic hazard implications for the Raukumara sector of the Hikurangi margin}

Seismic hazard of the Raukumara Peninsula is currently poorly constrained, largely due to the absence of historical subduction interface events, a possibly incomplete historical seismicity catalogue and little paleoseismic data to estimate the frequencies and magnitudes of such events (Stirling et al., 2002; Cochran et al., 2006). We have shown that our model of Raukumara Peninsula forearc uplift mechanisms yields little new data regarding the subduction zone paleoseismology of this margin sector. However, the general correlation we identified between modelled forearc deformation from a subduction zone event (Fig. 7.11) and Holocene coastal uplift data does 
suggest that rupture of the subduction interface has previously occurred and may be responsible for some of the deformation observed in the forearc of the Raukumara Peninsula.

Our model of forearc uplift mechanisms justifies a reassessment of the hazard of the upper plate faults of the Raukumara Peninsula. Ota et al. (1992) suggested the Holocene marine terraces in the Hicks Bay to East Cape region were uplifted during earthquakes, thereby implying a significant hazard in this area from offshore earthquakes. Wilson (Ch. 5reinterpreted the marine terraces, presenting evidence of aseismic coastal uplift processes related to sediment underplating. Therefore, the hazard of earthquakes on nearshore upper plate faults in the northeastern Raukumara Peninsula is less than previously thought.

The identification of a $60-70 \mathrm{~km}$ wide zone of coseismic uplift off the eastern coast of the Raukumara Peninsula implies a significant hazard to coastal regions of the Peninsula. The paleoseismic record from Mahia Peninsula has been accounted for by including the Lachlan Fault in the New Zealand seismic hazard model by Stirling et al. (2002). The record from the Pakarae region, however, has not been included in the model. Our preliminary interpretation of a recently acquired seismic line from the Raukumara Peninsula continental shelf suggests there are active faults in the offshore region (Fig. 7.7). The active upper plate faults within the coseismic uplift zone appear to be relatively short $(20-40 \mathrm{~km}$ long, Fig. $7.5 \mathrm{~A})$, therefore probably generate lesser magnitude earthquakes than the subduction interface. However, relatively short recurrence intervals are suggested for Mahia Peninsula (1060 \pm 560 yrs, Berryman, 1993a) and the Pakarae River mouth (850 \pm 450 yrs, Wilson, Ch. 2). By using the Lachlan fault as an analogy, a $\mathrm{M}_{\mathrm{W}} 7.6-8.0$ earthquake is estimated to account for marine terrace uplift if a 60-70 km long upper plate fault ruptured to the depth of the plate interface (Berryman, 1993a; Barnes et al., 2002). Faults within the offshore coseismic uplift zone, therefore, present a significant and high frequency seismic hazard. Being of short length, they have a more localised effect than a subduction interface event. However, they could conceivably rupture at the same time as the plate interface (for example, slip on the upper plate Patton Bay Fault synchronous with the 1964 Alaska earthquake, Plafker, 1972). These offshore faults also represent a large 
tsunami hazard to the coastal communities of the eastern Raukumara Peninsula and warning times would be short, probably less than 30 minutes.

\subsubsection{Onshore forearc deformation and offshore geology}

Our model of Raukumara Peninsula uplift mechanisms includes the eastern offshore region out to the Hikurangi Trough. Here we examine how this model relates to offshore geology west and north of the Peninsula, where there are transitions into different geodynamic regimes.

There is a transition from the aseismic uplift zone across the northward extensions of the strike slip faults of the NIDFB and into the backarc extensional regime of the offshore extension of the Taupo volcanic zone (TVZ, Fig. 7.10C) west and northwest of the Raukumara Peninsula. Active normal faulting has been well-documented in the Bay of Plenty and occurs mainly within the Whakatane Graben, which is $35-50 \mathrm{~km}$ west off the western Raukumara Peninsula coastline (Fig. 7.10C, Wright, 1990; Taylor et al., 2004). Subsidence rates within the Whakatane graben average $2-2.5$

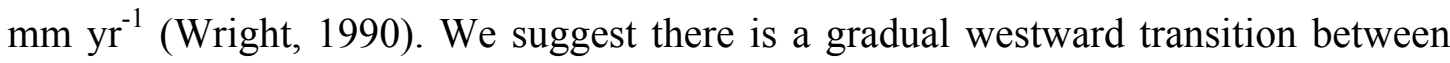
the aseismic uplift regime, which controls the position of the western Raukumara Peninsula coastline, across the NIDFB, and into the margins of the TVZ, where backarc coseismic extension and subsidence dominate.

The northern coast of the Raukumara Peninsula is flanked by a narrow section of continental shelf, a steep indented continental margin, and then the Raukumara Basin, which is a deep long-lived forearc basin developed on oceanic crust (Fig. 7.10A, C). Plate tectonic reconstructions by Davey et al. (1997) suggest that the northern Raukumara Peninsula continental margin was a subduction margin during the early Miocene. This former subduction zone, now identified as the Vening Meinesz fracture zone, was succeeded by the Hikurangi subduction zone in its present location during the mid-Miocene (Davey et al., 1997). The continental shelf is $15-20 \mathrm{~km}$ wide and is indented by the head scar of the Matakaoa Slide (Fig. 7.10C). While not yet fully understood (Carter, 1998; Joanne et al., 2005), the Matakaoa Slide may be related to strong northward tilt produced across the transition from the uplifting Raukumara Peninsula to the subsiding Raukumara Basin. The Raukumara Basin is a forearc basin lying at a depth of $\sim 2.5 \mathrm{~km}$, distinguished by a pronounced gravity low and infilled by 
$4-6.5 \mathrm{~km}$ of Cenozoic sediments (Gillies and Davey, 1986; Davey et al., 1997, Fig. 7.10A). The East Cape Ridge forms the eastern boundary of the basin (Fig. 7.10C). The western margin of the basin is formed by the offshore extension of the TVZ. The presence of the subsiding Raukumara Basin is clear evidence that forearc geodynamic processes abruptly change off the northern Raukumara Peninsula coastline. This change is probably related to the major crustal boundary of the Vening Meinesz fracture zone and the change to upper plate oceanic crust. Offshore structures closer to the Hikurangi Trough, such as the East Cape Ridge, have complex morphologies and tectonic histories involving transpression, uplift and extension (Collot et al., 1996; Collot and Davy, 1998). Perhaps our identified coseismic uplift zone extends further northeastward along the strike of the margin to encompass the region of the East Cape Ridge and trenchward structures. However, the aseismic uplift zone related to sediment underplating undoubtedly terminates at the present northern Raukumara Peninsula coastline.

\subsubsection{Comparisons of the uplift mechanism model with results of other tectonic studies of the Raukumara Peninsula}

This study has focussed on the use of coastal tectonics to infer the mechanisms of vertical forearc deformation in relation to subduction geodynamics. Here we discuss how our model of forearc uplift compares with and relates to previous studies of Raukumara Peninsula deformation using different methodologies.

Thornley (1996) suggested the Neogene sediments of the forearc are sliding trenchward on a detachment layer. This model is consistent with the coastal tectonics we see within the aseismic uplift zone and the passive forearc zone. Because this extension and sliding is essentially a surface process, it is largely geodynamically decoupled from the processes of forearc uplift that we discuss, which are more directly related to subduction zone processes. Regions that do not fit with the extensional and sliding model are those with high coastal uplift rates, excluding Mahia Peninsula which is not included in the Thornley (1996) study area. Thornley (1996) suggests areas of high coastal uplift, particularly Te Araroa and the Pakarae region, are the result of block rotation between active faults, primarily normal faults. We have shown that active faulting is unlikely in the Te Araroa area and that aseismic uplift is probably the dominant uplift mechanism in this region (Wilson, Ch. 5). 
Regarding the Pakarae region Thornley (1996) acknowledges the suggestion by Ota et al. (1991) that uplift is driven by a nearshore reverse fault, though figures produced by Thornley (1996) imply uplift at the Pakarae River mouth is driven by block rotation between onshore normal faults. Thus there is some disagreement between our model of uplift mechanisms in the Pakarae region and model of forearc deformation by Thornley (1996). Wilson (Ch. 2) shows that uplift at the Pakarae River mouth is unlikely to be related to uplift in the hanging wall of a normal fault. Other studies in the Pakarae region, building on the preliminary study by Litchfield and Wilson (2005) of fluvio-tectonic terraces along the Pakarae River, may assist in resolving the structure responsible for uplift.

Other significant studies of Raukumara Peninsula deformation have been based on geodesy (Walcott, 1978; Reilly, 1990; Darby and Meertens, 1995; Arnadottir et al., 1999) and seismicity (Webb and Anderson, 1998; Reyners et al., 1999; Reyners and McGinty, 1999; McGinty et al., 2000). Data from both sources support surficial trenchward extension of the Raukumara Peninsula. All studies agree that extension is probably related to gravitational collapse of the upper part of the forearc crust. Many of these studies mention the high coastal uplift rates along the Raukumara Peninsula coastline and reference the inference by Ota et al. (1991) that reverse faulting drives uplift of the Pakarae region. Few, however, provide discussions of how the uplift reconciles with the widespread extensional regime they document. Many of the studies appear to view the Pakarae region as an isolated and anomalous area. It is only by correlating coseismic uplift mechanisms between the Pakarae region and Mahia Peninsula and by examining the distribution of offshore structures that it becomes clear that a continuous and pervasive zone of compressional tectonics may exist trenchward of the eastern part of the onshore forearc. Because most of this zone lies offshore, it is not surprising that landbased techniques such as seismic deployments and GPS surveys have not documented deformation within the offshore area. One location where GPS data could test our uplift mechanism model is Matakaoa Point where a continuous GPS station has been installed. We predict that uplift is occurring continuously and aseismically at this location. Presently this station has only been in operation for 4 years and at least 5 years of data are required to obtain confident estimates of vertical deformation, longer if the deformation rates are low (Laura Wallace, pers. comm.). 


\subsubsection{Geodynamic changes along the strike of the Hikurangi margin}

Significant changes are in onshore upper plate topography and neotectonics, and offshore structure and bathymetry occur along the strike of the Hikurangi margin (Fig. 7.10C). The Coastal Hills and NIDFB are significant tectonic geomorphic features of the central and southern Hikurangi margin sectors (Fig. 7.10C). The prevalence of active compressional faulting within the Coastal Hills indicates most, or all, of the uplift is achieved by coseismic upper plate deformation (Lamarche et al., 1995; Kelsey et al., 1998; Chanier et al., 1999; Nicol et al., 2002; Pettinga, 2004). Directly east of Mahia Peninsula, an active accretionary wedge begins to form. The wedge this increases in width southward offshore of the central and southern sector before pinching out near Cook Strait (Collot et al., 1996; Barnes et al., 1998). Uplifted marine terraces have been documented at many sites along the southern and eastern coastlines of Wairarapa and Wellington and near Hawke Bay (Fig. 7.10C, Wellman, 1971a, 1971b; Hull, 1987; Ota et al., 1988; Berryman et al., 1989; Miyauchi et al., 1989; Ota et al., 1990; Pillans and Huber, 1995). Historical coseismic coastal uplift events $\left(M_{\mathrm{W}} 7.61931\right.$ Napier earthquake, Hull, 1990; and the $\mathrm{M}_{\mathrm{W}} 8.21855$ Wairarapa earthquake, Grapes, 1989) and the prevalence of active nearshore reverse faults (Barnes and Mercier de Lepinay, 1997; Barnes et al., 1998; Barnes and Audru, 1999) suggest coastal uplift of the central and southern Hikurangi margin sectors occurs by coseismic mechanisms. These observations generally suggest the outer forearc uplift of the central and southern Hikurangi margin is mostly, or entirely, accommodated by permanent deformation on upper plate structures.

The characteristics of zones of forearc uplift mechanisms seen on the Raukumara Peninsula change in the central and southern sectors of the Hikurangi margin. We discuss how each uplift mechanism zone changes southward. Firstly, the aseismic uplift zone probably decreases in width southward. Sediment underplating may play a role in uplift of the central axial ranges (.eg., the Kaimanawas, Reyners et al., 2006) but mantle upwelling is also an important uplift process here (Pulford and Stern, 2004), and both the central and southern axial ranges are deformed by major upper plate strike slip faults. Secondly, the passive forearc zone is probably manifest in the southern Hawkes Bay and Wairarapa regions as the low-lying areas of the inner forearc, between the Coastal Hills and the axial ranges (Fig. 7.10C). These forearc 
basins have undergone relatively little deformation (Cashman et al., 1992), except in the Eketahuna region where there is a zone of strike slip and reverse faulting (Kelsey et al., 1995; Lamarche et al., 1995, Fig. 7.10C). Thirdly, the southward continuation of the Raukumara Peninsula coseismic uplift zone is probably manifest as the compressional faulting on the continental shelf and within the Coastal Hills. Essentially the same coseismic uplift processes are operating in the central and southern sectors. However the zone appears to be much wider, extending up to 200 $\mathrm{km}$ from the Hikurangi Trough, and it probably accommodates a higher proportion of margin-normal deformation relative to the Raukumara Peninsula sector.

In summary, there are significant changes in forearc deformation along the strike of the margin. Like Litchfield et al. (submitted) we also ask the question why mechanisms of forearc deformation differ along strike of the Hikurangi margin and what parameters control or influence these changes.

Changes in the rate and obliquity of plate convergence along the margin affect the degree of slip partitioning (Beanland, 1995; Beanland and Haines, 1998; Nicol and Beavan, 2003). Several studies have inferred that margin-parallel motion is accommodated along the Raukumara sector by rotation of the Peninsula, rather than by strike slip faults as seen in the southern and central margin sectors (Beanland and Haines, 1998; Wallace et al., 2004). This change contributes to the absence of active faults in the Raukumara forearc. Margin-normal slip does not appear to significantly change along the margin; it is accommodated in all sectors by slip on the plate interface and on upper plate reverse faults (Reyners, 1998; Webb and Anderson, 1998). On the Raukumara Peninsula, however, the zone of reverse faulting is mainly offshore, whereas to the south it is wider and extends onshore.

An obvious factor that may have an effect on upper plate deformation is the character of the subducting plate and the Hikurangi Plateau. There are no significant changes in the thickness of the Hikurangi Plateau along the margin (Davy and Wood, 1994, Davy, pers. comm.), and recent seismicity does not show evidence of subducting slab segmentation (Ansell and Bannister, 1996; Reyners, 1998; Webb and Anderson, 1998). The only significant change appears to be an increase in the radius of subducted plate curvature along the southern Hikurangi margin (Ansell and Bannister, 1996). This increase arises because the subducted slab is slightly shallower with 
increasing distance from the trench in comparison to the northern Hikurangi margin. Several studies also indicate that the subducted slab extends to a greater depth in the northern Hikurangi margin relative to the south (Walcott, 1987; Beanland, 1995; Webb and Anderson, 1998). It is unknown how the geometry of the subducted slab affects the forearc deformation mechanisms, though Beanland (1995) suggests that the different depths of slab penetration along the margin have a major effect on the dynamic coupling between the plates. Dynamic coupling is a measurement of the forces acting pon the plate interface (Beanland, 1995, Scholz and Campos, 1995). Decreased dynamic coupling across the plate interface of the Raukumara sector means less margin-normal stress is transferred to the upper plate than is the case farther south. This difference helps to account for why the coseismic uplift zone of the Raukumara sector is narrower than farther south.

Alternative measurements of plate coupling also show strong differences along the strike of the margin. Current interseismic plate coupling, measured by the width of the plate interface locked zone as estimated from seismicity (Reyners, 1998, Fig. 7.1A) and measured by GPS-determined plate motion slip rate deficits (Wallace et al., 2004), decreases northward (Fig. 7.10B). We have discussed previously that the differences in plate coupling along the Raukumara sector do not appear to correlate with changing uplift mechanisms normal to the Hikurangi margin. However, the much greater amplitude changes in plate coupling along the whole margin does show a general correlation with the amount of coseismic compressional deformation, as reflected by the increasing margin-normal width of the coseismic uplift zone southwards.

Many other factors contribute to forearc deformation, aside from the morphology of the subducting plate. Two further factors that we consider are sediment thickness on the subducting plate and roughness of the subducting plate. There is less sediment infill of the Hikurangi Trough adjacent to the Raukumara Peninsula sector, mostly due to eastward deflection of the Hikurangi channel $[c f .2-4 \mathrm{~km}$ of sediment in the central and southern Hikurangi Trough (Lewis and Pettinga, 1993) and $1-1.5 \mathrm{~km}$ of sediment in the Raukumara sector trough (Collot et al., 1996)]. Less sediment thus is available for offscraping and construction of an accretionary wedge. Seamounts on the subducting Hikurangi Plateau increase northwards (Wood and Davy, 1994). 
Seamounts increase plate roughness, a factor elsewhere observed to increase forearc deformation (Fisher et al., 1998; Sak et al., 2004). Both the decrease in trench sediment and increase in seamounts contribute tectonic erosion at the Hikurangi Trough adjacent to the Raukumara sector. Tectonic erosion, in turn, causes offscraping of the base of the upper plate, entrained sediment is subducted beneath the margin and underplated at depth. However, as noted by Litchfield et al. (in press) diversion of the Hikurangi channel occurred relatively recently $(2-0.5 \mathrm{Ma}$, Lewis et al., 1998), and their modelling suggests the effects of decreased sediment supply will take $\sim 7 \mathrm{Ma}$ to become manifest in the axial ranges. Therefore, seamount impacts are suggested as the more important cause of tectonic erosion.

In summary, significant changes in forearc uplift mechanisms occur along the strike of the margin. The causes of these changes are probably related to the geometry of the subducting plate, plate coupling, and sediment cover and seamount abundance on the Hikurangi Plateau. The Raukumara Peninsula sector and the southern Hikurangi margin sector probably represent two end members of a spectrum of plate coupling, and this is manifest by the along-strike changes in forearc uplift mechanisms.

\subsubsection{Comparison of Raukumara Peninsula forearc uplift to global subduction zones}

We question whether the Raukumara Peninsula sector of the Hikurangi margin is comparable to any global examples of forearc deformation in an effort to further understand the geodynamics of the Hikurangi subduction zone. In particular, are there any global analogies that possess subduction earthquake histories? Our dataset from the Raukumara Peninsula is unique because we are able to trace uplift mechanisms around the east, north and northwest coasts of the peninsula, a margin normal distance of almost $120 \mathrm{~km}$. There are few subductions zones worldwide where such a setting exists. Most studies of spatial variation in forearc coastal uplift focus on changes in uplift rates along the strike of the margin, rather than normal to it (for example, Hsu, 1992; Kelsey and Bockheim, 1994; Personius, 1995). Studies of coastal uplift rates and mechanisms have been undertaken along margin-normal profiles at the Peninsula de Nicoya, Costa Rica, but only along a $\sim 20 \mathrm{~km}$ distance (Marshall and Anderson, 1995; Gardner et al., 2001), and also in the Antofagasta region of northern Chile, across a width of $\sim 50 \mathrm{~km}$ (Delouis et al., 1998). 
Nakada et al. (2002) suggested that aseismic uplift associated with the buoyancy of a

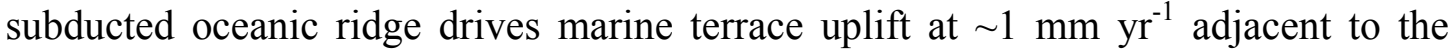
Nankai subduction zone. This setting is similar to the Raukumara Peninsula in that the marine terraces are located $\sim 150 \mathrm{~km}$ from the trench and the subducted ridge is in some ways analogous to the Hikurangi Plateau beneath the Raukumara Peninsula. The estimated maximum magnitude of subduction earthquakes offshore of the Kyushu coastline is less than along the neighbouring segments that display coseismic uplifted coastal terraces ( $c f . \mathrm{M}_{\mathrm{W}}<7.5$ for the Kyushu segment, $\mathrm{M}_{\mathrm{W}}>8$ for the neighbouring Shikoku segment). The decreased hazard of subduction earthquakes along the Kyushu segment is related to a decrease in plate coupling, probably caused by the subducted ridge (Nakada et al., 2002). The model is similar to that of Reyners (1998), indicating that the Raukumara sector has lesser magnitude subduction earthquakes than the southern margin. A trenchward zone of active faulting occurs offshore of Kyushu, a further similarity to the situation off the Raukumara Peninsula.

The northern Chilean forearc has perhaps the most similar forearc tectonics to the Raukumara Peninsula. Different faulting styles, inclusing extensional, transtensional, and compressional, occur in margin-parallel zones (Delouis et al., 1998; Adam and Reuther, 2000; Hartley et al., 2000). The outer forearc, extending from the trench $\sim 120 \mathrm{~km}$ arcward and including the continental shelf and land, is undergoing synchronous uplift and trenchward extension. Uplift is thought to be driven by sediment underplating and forearc extension is related to gravitational collapse of the oversteepened forearc. The adjacent trench is sediment starved, and tectonic erosion is believed to be contributing to forearc oversteepening and is providing subducted sediment for arcward underplating (Adam and Reuther, 2000; Hartley et al., 2000). However, unlike the Raukumara Peninsula subduction zone, the northern Chilean subduction interface is believed to be strongly coupled and great earthquakes $\left(>\mathrm{M}_{\mathrm{W}}\right.$ 8.5) have occurred historically on neighbouring interface segments (Delouis et al., 1996). The forearc block above the underplated sediment zone is bounded by faults, and a $\mathrm{M}_{\mathrm{W}} 8$ subduction earthquake caused surficial extensional faulting in the Antofagasta region (Delouis et al., 1998). Therefore, while tectonic erosion, underplated sediment and forearc extension in Chile and New Zealand are similar, coseismic deformation above the underplated sediment zone is not. The dissimilarities 
may be related to the contrast between the typical oceanic crust of the Nazca plate and the overthickened oceanic crust of the Hikurangi Plateau.

Margin-parallel zones with different forearc deformation styles have also been documented along the Aleutian arc. Von Huene and Klaeschen (1999) documented a permanent strain zone within $30 \mathrm{~km}$ of the trench and an arcward elastic strain zone where subduction earthquake coseismic deformation was largely recovered interseismically. This situation differs from the Raukumara Peninsula, particularly as the forearc landmass is located $>200 \mathrm{~km}$ from the trench. Again these differences may reflect the subduction of normal oceanic crust at the strongly coupled interface of the Aleutian margin.

\subsection{Conclusions}

We have reviewed late Quaternary coastal uplift mechanisms of the Raukumara sector of the Hikurangi margin. The main factor controlling the spatial distribution of uplift mechanisms is the distance of the forearc from the trough and, by inference, the depth to the plate interface below. Three margin-parallel zones of forearc deformation are proposed: a trenchward coseismic uplift zone, an arcward aseismic uplift zone, and a passive inner forearc zone between the two. The boundary between the aseismic uplift zone and the passive forearc is the least well constrained though further study of the coastal geology of the Te Araroa to East Cape region may help to resolve this. The two onshore locations where coseismic uplift occurs, Mahia Peninsula and the Pakarae region, correlate along margin-strike with presently mapped offshore structures, though there is little data available regarding the nature and age of these structures. Preliminary interpretation of a recently acquired offshore seismic line supports our suggestion that this is a region dominated by active listric reverse faults, though more thorough investigation of more offshore data will provide a test of our interpretations.

Our model of forearc uplift mechanisms for the Raukumara Peninsula indicates that most of the upper plate deformation is not a direct consequence of plate interface seismicity. The coseismic uplift zone represents permanent strain on upper plate faults. These faults probably merge downwards with the plate interface, though we do not know if they rupture synchronously with, or independently of the plate interface. 
The passive forearc zone may have the greatest potential for preserving a record of subduction earthquakes due to the absence of nearby upper plate faults, Also the pattern of coastal uplift and subsidence within this zone best fits models of subduction earthquake displacements.

Previous models of seismic hazard have underestimated the potential for earthquake events on near- and offshore reverse faults, with major implications for tsunami hazard. Forearc deformation differs significantly along the Hikurangi margin, but the tripartite division of Raukumara sector forearc deformation appears to continue southward along the Hikurangi margin, although there is some change in the characteristics and widths of the deformation zones. Changes in forearc dynamics along the strike of the entire margin are probably due to changes in subducting plate geometry and morphology, and a related strong gradient in plate coupling.

While along-strike changes in forearc deformation of the Hikurangi margin are important for understanding the large scale tectonic evolution of the subduction zone and possible subduction earthquake segmentation boundaries, we have shown there are significant tectonic changes normal to subduction zones. On a regional scale these changes have important seismic hazard implications.

\subsection{References}

Abe, K. (1975). "Reliable estimation of the seismic moment of large earthquakes." Journal of the Physics of the Earth 23: 381-390.

Adam, J. and C.-D. Reuther (2000). "Crustal dynamics and active fault mechanics during subduction erosion. Application of frictional wedge analysis on to the North Chilean Forearc." Tectonophysics 321: 297-325.

Ansell, J., H. and S. C. Bannister (1996). "Shallow morphology of the subducted Pacific plate along the Hikurangi margin, New Zealand." Physics of the Earth and Planetary Interiors 93: 3-20.

Arnadottir, T., S. Thornley, F. Pollitz, F. and D. J. Darby (1999). "Spatial and temporal strain rate variations at the northern Hikurangi margin, New Zealand." Journal of Geophysical Research 104(B3): 4931-4944.

Atwater, B. F. (1987). "Evidence for great Holocene earthquakes along the outer coast of Washington State." Science 236: 942-944.

Barnes, P. M. and J.-C. Audru (1999). "Quaternary faulting in the offshore Flaxbourne and Wairarapa Basins, southern Cook Strait, New Zealand." New Zealand Journal of Geology and Geophysics 42: 349-367. 
Barnes, P. M. and B. Mercier de Lepinay (1997). "Rates and mechanics of rapid frontal accretion along the very obliquely convergent southern Hikurangi margin, New Zealand." Journal of Geophysical Research 102(B11): 24931-24952.

Barnes, P. M., B. Mercier de Lepinay, J.-Y. Collot, J. Delteil and J.-C. Audru (1998). "Strain partitioning in the transition area between oblique subduction and continental collision, Hikurangi margin, New Zealand." Tectonics 17(4): 534 - 557.

Barnes, P. M., A. Nicol and T. Harrison (2002). "Late Cenozoic evolution and earthquake potential of an active listric thrust complex above the Hikurangi subduction zone, New Zealand." Geological Society of America Bulletin 114(11): 1379-1405.

Beanland, S. (1995). The North Island Dextral Fault Belt, Hikurangi Subduction Margin, New Zealand. Unpublished PhD thesis, School of Earth Sciences, Victoria University of Wellington, New Zealand.

Beanland, S. and J. Haines (1998). "The kinematics of active deformation in the North Island, New Zealand, determined from geologic strain rates." New Zealand Journal of Geology and Geophysics 41(311-323).

Berryman, K. R. (1993a). "Age, height, and deformation of Holocene terraces at Mahia Peninsula, Hikurangi subduction margin, New Zealand. 1." Tectonics 12(6): 1347-1364.

Berryman, K. R. (1993b). "Distribution, age, and deformation of Late Pleistocene marine terraces at Mahia peninsula, Hikurangi subduction margin, New Zealand." Tectonics 12(6): 1365-1379.

Berryman, K. R., Y. Ota and A. G. Hull (1989). "Holocene paleoseismicity in the fold and thrust belt of the Hikurangi subduction zone, eastern North Island, New Zealand." Tectonophysics 163: 185-195.

Berryman, K. R., Y. Ota and A. G. Hull (1992). "Holocene evolution of an estuary on a tectonically rising coast: the Pakarae River locality, eastern North Island, New Zealand." Sedimentary Geology 80: 151-162.

Brown, L. J. (1995). "Holocene shoreline processes at Poverty Bay, a tectonically active area, northeastern North Island, New Zealand." Quaternary International 26: 21-33.

Carter, L. (1998). "Matakoa debris flow - a giant, Quaternary mass failure of the East Cape continental margin." Basset, K. N. and Nobes, D. C. (eds.) Programme and abstracts, Geological Society of New Zealand Annual Conference, Christchurch, New Zealand. Geological Society of New Zealand Miscellaneous Publication 101A: 63.

Cashman, S. M., H. M. Kelsey, C. F. Erdman, H. N. C. Cutten and K. R. Berryman (1992). "Strain partitioning between structural domains in the forearc of the Hikurangi subduction zone, New Zealand." Tectonics 11(2): 242-257.

Chanier, F., J. Ferriere and J. Angelier (1999). "Extensional deformation across an active margin, relations with subsidence, uplift and rotations: the Hikurangi subduction, New Zealand." Tectonics 18(5): 862-876.

Chapman-Smith, M. and J. A. Grant-Mackie (1971). "Geology of the Whangaparoa area, eastern Bay of Plenty." New Zealand Journal of Geology and Geophysics 14(1): 3-38.

Clague, J. J. (1997). "Evidence for large earthquakes at the Cascadia subduction zone." Reviews of Geophysics 35(4): 439-460.

Cochran, U., K. Berryman, D. Mildenhall, B. Hayward, K. Southall, C. Hollis, P. Barker, L. Wallace, B. Alloway and K. Wilson (2006). "Paleoecological insights into subduction zone earthquake occurrence, eastern North Island, New Zealand." Geological Society of America Bulletin, 118(9/10): 1051-1074. 
Collot, J.-Y. and B. Davy (1998). "Forearc structures and tectonic regimes at the oblique subduction zone between the Hikurangi Plateau and the southern Kermadec margin." Journal of Geophysical Research 103(B1): 623-650.

Collot, J.-Y., J. Delteil, K. Lewis, B. Davy, G. Lamarche, J.-C. Andru, P. Barnes, F. Chanier, E. Chaumillon, S. Lallemand, B. M. De Lepinay, A. Orpin, B. Pelletier, M. Sosson, Toussaint and C. Uruski (1996). "From oblique subduction to intra-continental transpression: structures of the southern Kermadec-Hikurangi margin from multibeam bathymetry, side-scan sonar and seismic reflection." Marine Geophysical Researches 18(2-4): 357-381.

Collot, J.-Y., K. Lewis, G. Lamarche and S. Lallemand (2001). "The giant Ruatoria debris avalanche on the northern Hikurangi margin, New Zealand; results of oblique seamount subduction." Journal of Geophysical Research 106B(9): 19271-19297.

Darby, D. J. and C. M. Meertens (1995). "Terrestrial and GPS measurements across the taupo backarc and Hikurangi forearc in New Zealand." Journal of Geophysical Research 100(B5): 8221-8232.

Davey, F. J., S. Henrys and E. Lodolo (1997). "A seismic crustal section across East Cape convergent margin, New Zealand." Tectonophysics 269: 199-215.

Davy, B. and R. Wood (1994). "Gravity and megnetic modelling of the Hikurangu Plateau." Marine Geology 118: 139-151.

De Mets, C., R. G. Gordon, D. F. Argus and S. Stein (1994). "Effect of recent revisions to the geomagnetic reversal timescale on estimates of current plate motions." Geophysical Research Letters 21: $2191-2194$

Delouis, B., A. Cisternas, L. Dorbath, L. Rivera and E. Kausel (1996). "The Andean subduction zone between 22 and 25 degrees $\mathrm{S}$ (northern Chile): precise geometry and state of stress." Tectonophysics 259: $81-100$.

Delouis, B., H. Philip, L. Dorbath and A. Cisternas (1998). "Recent crustal deformation in the Antofagasta region (northern Chile) and the subduction process." Geophysical Journal International 132: $302-338$.

Eberhart-Phillips, D. and M. Chadwick (2002). "Three-dimensional attenuation model of the shallow Hikurangi subduction zone in the Raukumara Peninsula, New Zealand." Journal of Geophysical Research 107(B2): ESE 3-1 - 3-15.

Eberhart-Phillips, D. and M. Reyners (1999). "Plate interface properties in the northeast Hikurangi subduction zone, New Zealand, from converted seismic waves." Geophysical Research Letters 26(16): $2565-2568$

Fisher, D., T. Gardner, J. S. Marshall, P. Sak and M. Protti (1998). "Effect of subducting sea-floor roughness on fore-arc kinematics, Pacific coast, Costa Rica." Geology 26(5): 467-470.

Gardner, T., J. S. Marshall, D. Merritts, B. Bee, R. Burgette, E. Burton, J. Cooke, N. Kehrwald, M. Protti, D. Fisher and P. Sak (2001). "Holocene forearc block rotation in response to seamount subduction, southeastern Peninsula de Nicoya, Costa Rica." Geology 29(2): 151-154.

Garrick, R. A. (1979). "Late Holocene uplift at Te Araroa, East Cape, North Island, New Zealand." New Zealand Journal of Geology and Geophysics 22(1): 131-139.

Gibb, J. G. (1986). A New Zealand regional Holocene eustatic sea-level curve and its application to determination of vertical tectonic movements, A contribution to IGCP-Project 200. Recent Crustal Movements of the pacific Region., Bulletin of the Royal Society of New Zealand. 24: 377-395.

Gillies, P. N. and F. J. Davey (1986). "Seiemic reflection and refraction studies of the Raukumara forearc basin, New Zealand." New Zealand Journal of Geology and Geophysics 29: 391-403. 
Grapes, R. (1989). "The Wairarapa Fault: displacements and paleoseismicity." Bulletin of the New Zealand National Society for Earthquake Engineering 22(1): 13-16.

Hartley, A. J., G. May, G. Chong, P. Turner, S. J. Kape and E. J. Jolley (2000). "Development of a continental forearc: A Cenozioc example from the Central Andes, northern Chile." Geology 28(4): 331334.

Hsu, J. T. (1992). "Quaternary uplift of the Peruvian coast related to the subduction of the Nazca Ridge: 13.5 to 15.6 degrees latitude." Quaternary International 15/16: 87-97.

Hull, A. G. (1987). "A late Holocene marine terrace on the Kidnappers Coast, North Island, New Zealand: some implications for shore platform development processes and uplift mechanisms." Quaternary Research 28: 183-195.

Hull, A. G. (1990). "Tectonics of the 1931 Hawke's Bay earthquake." New Zealand Journal of Geology and Geophysics 33: 309-320.

Jackson, J. A., N. J. White, Z. Garfunkel and H. Anderson (1988). "Relations between normal-fault geometry, tilting and vertical motions in extensional terrains: an example from the southern Gulf of Suez." Journal of Structural Geology 10(2): 155-170.

Joanne, C., T. Lebourg, G. Lamarche, J.-Y. Collot and S. Migeon (2005). "Mechanical parameters and sediment rheology in the submarine Matakoa avalanches, East Cape region." Pettinga, J. R. and Wandres, A. M. (eds.) Programme and abstracts, Geological Society of New Zealand 50th Annual Conference, Kaikoura, New Zealand. Geological Society of New Zealand Miscellaneous Publication 119A: 39

Kamp, P. J. J. (1999). "Tracking crustal processes by FT thermochronology in a forearc high (Hikurangi margin, New Zealand) involving Cretaceous subduction termination and mid-Cenozoic subduction initiation." Tectonophysics 307: 313-343.

Kelsey, H. M. and J. G. Bockheim (1994). "Coastal landscape evolution as a function of eustasy and surface uplift rate, Cascadia margin, southern Oregon." Geological Society of Americe Bulletin 106: 840-854.

Kelsey, H. M., S. M. Cashman, S. Beanland and K. R. Berryman (1995). "Structural evolution along the inner forearc of the obliquely convergent Hikurangi margin." Tectonics 14(1): 1-18.

Kelsey, H. M., A. G. Hull, S. M. Cashman, K. R. Berryman, P. Cashman, J. H. Trexler Jr and J. G. Begg (1998). "Paleoseismology of an active fault in a forearc setting: the Poukawa fault zone, Hikurangi forearc, New Zealand." Geological Society of America Bulletin 110(9): 1123-1148.

Kelsey, H. M., R. C. Witter and E. Hemphill-Haley (2002). "Plate-boundary earthquakes and tsunamis of the past $5500 \mathrm{yr}$, Sixes River estuary, sothern Oregon." Geological Society of America Bulletin 114(3): 298-314.

Lamarche, G., S. Beanland and J. Ravens (1995). "Deformation styles and history of the Eketahuna region, Hikurangi forearc, New Zealand, from shallow seismic reflection data." New Zealand Journal of Geology and Geophysics 38: 105-115.

Lewis, K. (1980). "Quaternary sedimentation on the Hikurangi oblique subduction and transform margin, New Zealand." Special Publication of the Institute of Professional Sedimentologists 4: 171189.

Lewis, K. B. and J. R. Pettinga (1993). The emerging, imbricate frontal wedge of the Hikurangi Margin. Ballance, P. F. (Ed.). South Pacific Sedimentary Basins, Elsevier. Sedimentary Basins of the World 2: 225-250.

Lewis, K., J.-Y. Collot and S. Lallemand (1998). "The damned Hikurangi Trough: a channel-fed trench blocked by subducting seamounts and their wake avalanches (New Zealand-France GeodyNZ Project)." Basin Research 10(4): 441-468. 
Lewis, K., S. E. Lallemand and L. Carter (2004). "Collapse in a Quaternary shelf basin off East Cape, New Zealand: evidence for passage of a subducted seamount inboard of the Ruatoria giant avalanche." New Zealand Journal of Geology and Geophysics 47: 415-429.

Lewis, K. B. and J. R. Pettinga (1993). The emerging, imbricate frontal wedge of the Hikurangi Margin. Ballance, P. F. (Eds). South Pacific Sedimentary Basins, Elsevier. Sedimentary Basins of the World 2: 225-250.

Lewis, K. B., J.-Y. Collot, B. Davy, J. Delteil, S. Lallemand and C. Uruski (1997). "North Hikurangi GeodyNZ swath maps: depths, texture and geological interpretation 1: 500 000." National Institute for Water and Atmospheric Research miscellaneous series chart 72. Wellington.

Litchfield, N. and K. Wilson (2005). "Holocene tectonic fluvial terraces at Pakarae River mouth, Gisborne region." Pettinga, J. R. and Wandres, A. M. (eds.) Programme and abstracts, Geological Society of New Zealand 50th Annual Conference, Kaikoura, New Zealand. Geological Society of New Zealand Miscellaneous Publication 119A: 45-46.

Litchfield, N. J. and K. Berryman (2006). "Relations between postglacial fluvial incision rates and uplift rates in the North Island, New Zealand." Journal of Geophysical Research 111(FO2007): doi:10.1029/2005JF000374.

Litchfield, N. J., S. Ellis, K. Berryman and A. Nicol (in press). "Subduction related uplift in the Hikurangi Margin, New Zealand." Journal of Geophysical Research, Earth Surface.

Marshall, J. S. and R. S. Anderson (1995). "Quaternary uplift and seismic cycle deformation, Peninsula de Nicoya, Costa Rica." Geological Society of America Bulletin 107(4): 463-473.

Matsuda, T., Y. Ota, M. Ando and N. Yonekura (1978). "Fault mechanism and recurrence time of major earthquakes in southern Kanto district, Japan, as deduced from coastal terrace data." Geological Society of America Bulletin 89: 1610 - 1618.

Mazengarb, C. (1984). "The Fernside Fault: an active normal fault, Raukumara Peninsula, New Zealand." New Zealand Geological Survey Record 3: 98-103.

Mazengarb, C. and I. G. c. Speden (2000). Geology of the Raukumara area, Institute of Geological \& Nuclear Sciences 1:250,000 Geological Map 6.

McGinty, P., M. Reyners and R. Robinson (2000). "Stress directions in the shallow part of the Hikurangi subduction zone, New Zealand, from the inversion of earthquake first motions." Geophysical Journal International 142: 339-350.

McNeill, L. C., C. Goldfinger, R. Yeats and L. Kulm (1998). The effects of upper plate deformation on records of prehistoric Cascadia subduction zone earthquakes. Coastal Tectonics, Geological Society. 146: 321-324.

Ministry of Economic Development Petroleum Report Series PR3136 (2005). 05CM 2D Seismic Survey, Offshore East Coast -North Island: 280 pp.

Miyauchi, T., Y. Ota and A. G. Hull (1989). "Holocene marine terraces and tectonic uplift in the Waimarama coastal plain, eastern North Island, New Zealand." New Zealand Journal of Geology and Geophysics 32: 437-442.

Nakada, M., M. Tahara, H. Shimizu, S. Nagaoka, K. Uehira and S. Suzuki (2002). "Late Pleistocene crustal uplift and gravity anomaly in the eastern part of Kyushu, japan, and its geophysical implications." Tectonophysics 351: 263-283.

Nelson, A. R., I. Shennan and A. J. Long (1996). " Identifying coseismic subsidence in tidal-wetland stratigraphic sequences at the Cascadia subduction zone of western North America." Journal of Geophysical Research 101: 6115-6135. 
Nicol, A. and J. Beavan (2003). "Shortening of an overriding plate and its implications for slip on a subduction thrust, central Hikurangi margin, New Zealand." Tectonics 22 (6): 1070, doi:10.1029/2003TC001521.

Nicol, A., R. Van Dissen, P. Vella, B. Alloway and A. Melhuish (2002). "Growth of contractional structures during the last 10 m.y. at the southern end of the emergent Hikurangi forearc basin, New Zealand." New Zealand Journal of Geology and Geophysics 45: 365-385.

Okada, Y. (1985). "Surface deformation due to shear and tensile faults in a half-space." Bulletin of the Seismological Society of America 75(4): 1135-1154.

Ota, Y., K. R. Berryman, A. G. Hull, T. Miyauchi and N. Iso (1988). "Age and height distribution of Holocene transgressive deposits in eastern North Island, New Zealand." Palaeogeography, Palaeoclimatology, Palaeoecology 68: 135-151.

Ota, Y., K. R. Berryman, L. J. Brown and K. Kashima (1989). "Holocene sediments and vertical tectonic downwarping near Wairoa, Northern Hawkes Bay, New Zealand." New Zealand Journal of Geology and Geophysics 32: 333-341.

Ota, Y., A. G. Hull and K. R. Berryman (1991). "Coseismic uplift of Holocene marine terraces in the Pakarae River area, eastern North Island, New Zealand." Quaternary Research 35: 331-346.

Ota, Y., A. G. Hull, N. Iso, Y. Ikeda, I. Moriya and T. Yoshikawa (1992). "Holocene marine terraces on the northeast coast of North Island, New Zealand, and their tectonic significance." New Zealand Journal of Geology and Geophysics 35: 273-288.

Ota, Y., T. Miyauchi and A. G. Hull (1990). "Holocene marine terraces at Aramoana and Pourerere." New Zealand Journal of Geology and Geophysics 33: 541-546.

Personius, S. F. (1995). "Late Quaternary stream incision and uplift in the forearc of the Cascadia subduction zone, western Oregon." Journal of Geophysical Research 100(B10): 20193-20210.

Pettinga, J. R. (2004). "Three-stage massive gravitational collapse of the emergent imbricate frontal wedge, Hikurangi Subduction Zone, New Zealand." New Zealand Journal of Geology and Geophysics 47: 399-414.

Pillans, B. (1986). A late Quaternary uplift map for the North Island, New Zealand. Recent Crustal Movements of the Pacific Region., Bulletin of the Royal Society of New Zealand. 24: 409-418.

Pillans, B. and P. Huber (1995). "Interpreting coseismic deformation using Holocene coastal deposits, Wellington, New Zealand." Quaternary International 26: 87-95.

Plafker, G. (1972). "Alaskan earthquake of 1964 and Chilean earthquake of 1960: implications for arcc tectonics." Journal of Geophysical Research 77(901-925).

Pulford, A. and T. Stern (2004). "Pliocene exhumations and landscape evolution of central North Island, New Zealand: the role of the upper mantle." Journal of Geophysical Research 109(FO1016): doi:10.1029/2003JF000046.

Ramirez-Herrera, M. T., V. Kostoglodov and J. Urrutia-Fucugauchi (2004). "Holocene-emerged notches and tectonic uplift along the Jalisco coast, Southwest Mexico." Geomorphology 58: 291-304.

Reilly, W. I. (1990). "Horizontal crustal deformation on the Hikurangi margin." New Zealand Journal of Geology and Geophysics 33(393-400).

Reyners, M. (1998). "Plate coupling and the hazard of large subduction thrust earthquakes at the Hikurangi subduction zone, New Zealand." New Zealand Journal of Geology and Geophysics 4: 343 354. 
Reyners, M., P. McGinty and K. Gledhill (1998). "The Ormond, New Zealand, earthquake of 1993 August 10: rupture in the mantle of the subducted Pacific plate." New Zealand Journal of Geology and Geophysics 41(2): 179-185.

Reyners, M., D. Eberhart-Phillips and G. Stuart (1999). "A three-dimensional image of shallow subduction: crustal structure of the Raukumara Peninsula." Geophysical Journal International 137: 873890.

Reyners, M. and P. McGinty (1999). "Shallow subduction tectonics in the Raukumara Peninsula, New Zealand, as illuminated by earthquake focal mechanisms." Journal of Geophysical Research 104(B2): 3025-3034.

Reyners, M. (2000). "Quantifying the hazard of large subduction thrust earthquakes in Hawke's Bay." Bulletin of the New Zealand Society for Earthquake Engineering 33(4): 477-483.

Reyners, M., D. Eberhart-Phillips, G. Stuart and Y. Nishimura (2006). "Imaging subduction from the trench to $300 \mathrm{~km}$ depth beneath the central North Island, New Zealand, with Vp and Vp/Vs." Geophysical Journal International 165: 565-583.

Sak, P., D. Fisher and T. Gardner (2004). "Effects of seafloor roughness on the upper plate vertical tectonism: Osa Peninsula, Costa Rica." Tectonics 23(TC1017): doi:10.1029/2002TC001474.

Sandwell, D. T. and W. H. F. Smith (1997). "Marine gravity anomaly from Geosat and ERS 1 satellite altimetry." Journal of Geophysical Research 105(B5): 10,039-10,054.

Savage, J. C. (1983). "A dislocation model of strain accumulation and release at a subduction zone." Journal of Geophysical Research 88(B6): 4984-4996.

Savage, J. C. (1995). "Interseismic uplift at the Nankai subduction zone, southwest Japan, 1951-1990." Journal of Geophysical Research 100(B4): 6339-6350.

Savage, J. C., J. L. Svarc, W. H. Prescott and W. K. Gross (1998). "Deformation across the rupture zone of the 1964 Alaska earthquake, 1993-1997." Journal of Geophysical Research 103(B9): 21275 21283.

Scholz, C. H. and J. Campos (1995). "On the mechanisms of seismic decoupling and back arc spreading at subduction zones." Journal of Geophysical Research 100(B11): 22103 - 22115.

Stirling, M. W., G. McVerry and K. R. Berryman (2002). "A new seismic hazard model for New Zealand." Bulletin of the Seismological Society of America 92(5): 1878-1903.

Taylor, S. K., J. M. Bull, G. Lamarche and P. Barnes (2004). "Normal fault growth and linkage in the Whakatane Graben, new Zealand, during the last 1.3 Myr." Journal of Geophysical Research (Solid Earth) 109(BO2408): doi:10.1029/2003JB002412.

Thatcher, W. (1984). "The earthquake deformation cycle at the Nankai Trough, Southwest Japan." Journal of Geophysical Research 89(B5): 3087-3101.

Thatcher, W. (1986). "Cyclic deformation related to great earthquakes at plate boundaries." Royal Society of New Zealand Bulletin 24: 245 - 273.

Thornley, S. (1996). "Neogene tectonics of Raukumara Peninsula, Northern Hikurangi margin, New Zealand." Victoria University of Wellington Unpublished PhD thesis.

Upton, P., P. Koons and D. Eberhart-Phillips (2003). "Extension and partitioning in an oblique subduction zone, New Zealand: constraints from three-dimensional numerical modeling." Tectonics 22(6): doi:10.1029/2002TC001431. 
von Huene, R. and D. Klaeschen (1999). "Opposing gradients of permanent strain in the aseismic zone and elastic strain across the seismogenic zone of the Kodiak shelf and slope, Alaska." Tectonics 18(2): 248-262.

Walcott, R. I. (1978). "Geodetic strains and large earthquakes in the axial tectonic belt of North Island, New Zealand." Journal of Geophysical Research 85(B9): 4419-4429.

Walcott, R. I. (1987). "Geodetic strain and the deformation history of the North Island, of New Zealand during the late Cainozoic." Philosophical Transactions of the Royal Society of London A 321: 163-181.

Wallace, L. M., J. Beavan, R. McCaffrey and D. Darby (2004). "Subduction zone coupling and tectonic block rotations in the North Island, New Zealand." Journal of Geophysical Research 109(B12406): doi:10.1029/2004JB003241.

Webb, T. and H. Anderson (1998). "Focal mechanisms of large earthquakes in the North Island of New Zealand: slip partitioning at an oblique active margin." Geophysical Journal International 134: 40-86.

Wellman, H. W. (1971a). "Holocene tilting and uplift on the White Rocks Coast, Wairarapa, New Zealand." Recent Crustal Movements, Royal Society of New Zealand Bulletin 9: 211-215.

Wellman, H. W. (1971b). "Holocene tilting and uplift on the Glenburn Coast, Wairarapa, New Zealand." Recent Crustal Movements, Royal Society of New Zealand Bulletin 9: 221-223.

Wells, R. E., R. J. Blakely, Y. Sugiyama, D. W. Scholl and P. A. Dinterman (2003). "Basin-centered asperities in great subduction zone earthquakes: a link between slip, subsidence, and subduction erosion?" Journal of Geophysical Research 108(B10): 2507, doi:10.1029/2002JB002072.

Wilson, K. J. (Ch. 2). "A revision of Mid to Late Holocene marine terrace distribution and chronology at New Zealand's most tectonically active coastal location, Pakarae River, North Island, New Zealand."

Wilson, K. J. (Ch. 3). "A facies architecture model for Holocene incised valley infill on a tectonically active coast: Pakarae River, New Zealand."

Wilson, K. J. (Ch. 4.). "Early Holocene paleoseismic history at the Pakarae locality, eastern North Island, New Zealand, inferred from transgressive marine sequence architecture and biostratigraphy."

Wilson, K. J. (Ch. 5). "Holocene coastal evolution and uplift mechanisms of the northeastern Raukumara Peninsula, North Island, New Zealand."

Wilson, K. J. (Ch. 6). "Distribution, age and uplift patterns of Pleistocene marine terraces of the northwaestern Raukumara Peninsula, North Island, New Zealand."

Wood, R. and B. Davy (1994). "The Hikurangi Plateau." Marine Geology 118(153-173).

Wright, I. C. (1990). "Late Quaternary faulting of the offshore Whakatane Graben, Taupo Volcanic Zone, New Zealand." New Zealand Journal of Geology and Geophysics 33: 245-256.

Yoshikawa, T. (1988). "Pattern and rate of tectonic movement and Late Quaternary geomorphic development in the Raukumara Peninsula, northeastern North Island, New Zealand." Bulletin of the Department of Geography University of Tokyo 20: 1-28.

Yoshikawa, T., Y. Ota, N. Yonekura, A. Okada and N. Iso (1980). "Marine terraces and their tectonic deformation on the northeast coast of the North Island, New Zealand." Geographical Review of Japan 53(4): 238-262.

Zachariasen, J., K. Sieh, F. W. Taylor, R. L. Edwards and W. S. Hantoro (1999). "Submergence and uplift associated with the giant 1833 Sumatran subduction zone earthquake: evidence from coral microatolls." Journal of Geophysical Research 104(B1): 895-919. 


\section{Chapter Eight}

\section{CONCLUSIONS}

The primary conclusion of this thesis is that forearc uplift mechanisms of the Raukumara Peninsula are spatially variable and the main parameter controlling the distribution of aseismic and coseismic uplift is distance from the Hikurangi trench and depth to the plate interface beneath the forearc. This outcome has been reached by using several methodologies applied to coastal geomorphic features, which represent deformation over varying late Quaternary time periods.

At the Pakarae River mouth the late Holocene terrace morphology and coverbed stratigraphy is consistent with coseismic uplift driven by slip on an offshore reverse fault cutting through the upper plate of the Hikurangi margin. Similar geomorphology occurs as terrace sequences at the Waipapa and Horoera localities on the northeastern Raukumara Peninsula. However, at these localities the coverbed sediments and strath elevations suggested a terrestrial origin for the terraces. Therefore, we found that different processes can produce quite similar terrace flights on active coasts. Despite the geomorphic similarities, different processes formed the Pakarae River mouth and Waipapa and Horoera locality terraces. Only the terraces at the Pakarae River mouth indicate a coseismic coastal uplift mechanism.

The fluvio-estuarine sequences exposed beneath the highest marine terrace at the Pakarae River mouth, and along the Wharekahika River bank at Hicks Bay are both superb examples of tectonically-modified valley infill sequences. Three early Holocene uplift events have been identified in the 10,000 - 7,000 cal. yrs B.P. sequence of the Pakarae River mouth. Paleoenvironmetal reconstructions using biostratigraphy suggest that these were sudden, coseismic events. The Hicks Bay sediments are characteristic of a typical valley infill sequence stratigraphy but consistent accommodation space deficits and the present elevation of the sequence above mean sea level imply tectonic uplift during and since deposition of the sediments. The similarity of paleoenvironmental facies transitions of the Hicks Bay sequence to stable coast models provides a stark contrast to the Pakarae sequence and 
implies there were no significant and sudden uplift events during infilling of the Hicks Bay paleo-valley. These two studies demonstrate that paleoenvironmental facies analysis of valley infill sequences can provide valuable data concerning paleoseismicity in the coastal zone. The infill sequence analysis technique requires knowledge of the regional eustatic sea level curve and benefits from good biostratigraphic control. However, we have shown that it can extend the record of coastal paleoseismicity well back into the early Holocene, and it has the potential to be applied to coastlines that are otherwise unfavourable to the preservation of marine terraces. The facies architecture model for actively uplifting coasts that we developed from the Pakarae River mouth valley infill sequence can be used as an analogue when further incised valley sequences are investigated along the Hikurangi margin. On a global scale this model provides a valuable comparison with stable coast models, which dominate the literature on valley infilling.

Holocene coseismic uplift of the Pakarae River mouth, on the southeastern Raukumara Peninsula, is well documented by the combined study of its marine terraces and transgressive valley infill sequence. An aseismic uplift mechanism of the northeastern Raukumara Peninsula coastal region through the Holocene is indicated by the gradually sloping beach ridge sequence at Te Araroa, the absence of marine terraces along the East Cape coastline and the gradually uplifted valley infill sequence of Hicks Bay. By integrating the Holocene aseismic uplift data from the northeastern Raukumara Peninsula region with the longer term, and more spatially extensive Pleistocene marine terraces, and with known tectonic data from the Raukumara Peninsula and offshore we can see that the structure accommodating uplift is not any discrete upper plate fault. Rather, a more deep-seated process of sediment underplating probably drives aseismic uplift of the northern Raukumara Peninsula region and the Raukumara Ranges. Correlation of coseismic uplift at the Pakarae region to a similar tectonic setting at Mahia Peninsula also allows the identification of a margin-parallel zone of coseismic uplift driven by offshore reverse faults. Although understanding the role that plate interface rupture plays in forearc deformation processes remains a significant challenge, the regional changes in uplift mechanisms we have identified have important implications for the seismic hazard of the Raukumara Peninsula. 
Our initial proposition that similar coastal geomorphology along the Hikurangi margin should be controlled by the same tectonic processes has proven to be false. The detailed studies presented in this thesis have shown that there are significant and recognisable changes in coastal geomorphology and stratigraphy between different tectonic regimes. Somewhat surprising is that these changes in geomorphology and stratigraphy occur at regional scales within the confines of the Raukumara Peninsula itself, rather than at the scale of the entire Hikurangi margin. This is the first recognition of zones of different uplift mechanisms across the Hikurangi forearc and it has been achieved because the northern coastline of the Raukumara Peninsula uniquely provides a cross section through the forearc. The coseismic uplift and passive forearc zones appear to continue to along strike to the southern sectors of the margin although there are some changes in the width of the zones. We have shown that sediment underplating probably drives uplift of the Raukumara Ranges and an important implication of this study is that an aseismic process has evidently been capable of building an axial range with significant topography. This suggests that, although there are active faults within the axial ranges of the central and southern Hikurangi margin, uplift of these ranges may also be in part aseismic and therefore more closely linked with deep-seated subduction processes than previously appreciated. 